\title{
Uwarunkowania partnerstwa publiczno-prywatnego w finansowaniu inwestycji jednostek samorządu terytorialnego
}




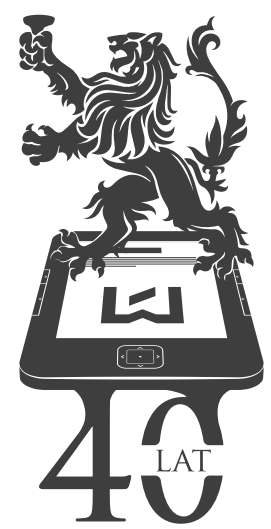

WYDAWNICTWA

UNIWERSYTETU ŁODZKIEGO 


\section{DAGMARA MARIA HAJDYS}

\section{Uwarunkowania partnerstwa publiczno-prywatnego w finansowaniu inwestycji jednostek samorządu terytorialnego}

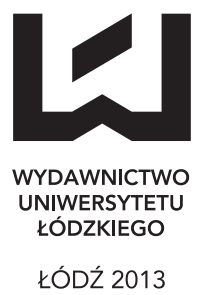


Dagmara Maria Hajdys - Katedra Finansów Publicznych, Instytut Finansów Wydział Ekonomiczno-Socjologiczny, Uniwersytet Łódzki, 90-255 Łódź, ul. POW nr 3/5

\author{
RECENZENT \\ Beata Zofia Filipiak \\ REDAKTOR WYDAWNICTWA UŁ \\ Bogustaw Pielat \\ SKŁAD KOMPUTEROWY \\ Leonora Wojciechowska \\ PROJEKT OKŁADKI \\ Joanna Skopińska
}

Wydrukowano z gotowych materiałów dostarczonych do Wydawnictwa UŁ

(C) Copyright by Uniwersytet Łódzki, Łódź 2013

\author{
Wydane przez Wydawnictwo Uniwersytetu Łódzkiego \\ Wydanie I. W.06233.13.0.H
}

ISBN 978-83-7525-876-9
Wydawnictwo Uniwersytetu Łódzkiego
90-131 Łódź, ul. Lindleya 8
www.wydawnictwo.uni.lodz.pl
e-mail: ksiegarnia@uni.lodz.pl
tel. (42) 6655863 , faks (42) 6655862


Najbliższym 



\section{SPIS TREŚCI}

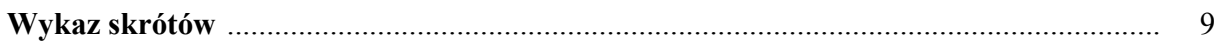

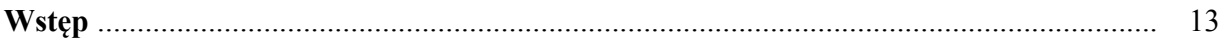

1. Partnerstwo publiczno-prywatne jako formula realizacji przedsięwzięć inwestycyj-

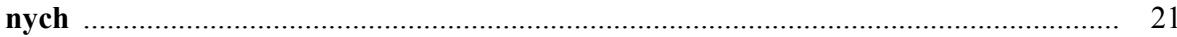

1.1. Ewolucja idei partnerstwa publiczno-prywatnego w Europie i na świecie .................. 21

1.2. Pojęcie partnerstwa publiczno-prywatnego i jego cechy .......................................... 28

1.2.1. Pojęcie partnerstwa publiczno-prywatnego w uregulowaniach organizacji międzynarodowych ........................................................................ 28

1.2.2. Pojęcie partnerstwa publiczno-prywatnego w literaturze ............................... 36

1.3. Aktualne regulacje prawne w zakresie partnerstwa publiczno-prywatnego w Unii Europejskiej i w Polsce ................................................................................... 45

1.3.1. Instytucja partnerstwa publiczno-prywatnego w regulacjach Unii Europejskiej ........ 45

1.3.2. Partnerstwo publiczno-prywatne w ustawodawstwie polskim ......................... 51

1.4. Modele i formy realizacji przedsięwzięć partnerstwa publiczno-prywatnego ............. 60

1.4.1. Modele partnerstwa publiczno-prywatnego ............................................... 60

1.4.2. Formy organizacyjne występujące w formule partnerstwa publiczno-prywatnego ....................................................................................... 64

1.4.3. Partnerstwo publiczno-prywatne a prywatyzacja .......................................... 73

2. Ekonomiczne, prawne i organizacyjne uwarunkowania wdrażania formuły partnerstwa publiczno-prywatnego …........................................................................... 83

2.1. Procedura przygotowania formuły partnerstwa publiczno-prywatnego ……............. 83

2.2. Fazy przedsięwzięcia partnerstwa publiczno-prywatnego …..................................... 87

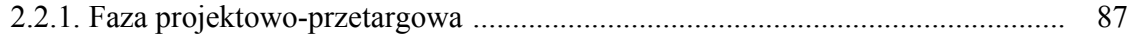

2.2.2. Faza inwestycyjno-eksploatacyjna .......................................................... 110

2.3. Uczestnicy przedsięwzięcia partnerstwa publiczno-prywatnego ................................ 112

2.4. Umowa jako podstawa prawna realizacji przedsięwzięcia partnerstwa publiczno-

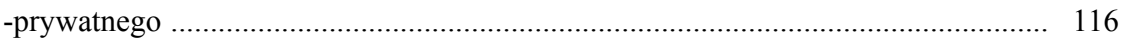

3. Finansowe uwarunkowania inwestycji jednostek samorządu terytorialnego $\quad$............... 125

3.1. Specyfika inwestycji jednostek samorządu terytorialnego ....................................... 125

3.2. Pomiar efektywności inwestycji jednostek samorządu terytorialnego $\quad$....................... 140

3.2.1. Efektywność inwestycji jednostek samorządu terytorialnego ......................... 140

3.2.2. Metody oceny efektywności inwestycji jednostek samorządu terytorialnego ... 145

3.3. Potencjał inwestycyjny jednostek samorządu terytorialnego ................................... 157

3.4. Źródła finansowania inwestycji jednostek samorządu terytorialnego ........................ 169

3.4.1. Systematyka źródeł finansowania inwestycji jednostek samorządu terytorialnego ........................................................................................... 169

3.4.2. Wewnętrzne źródła finansowania inwestycji jednostek samorządu terytorialnego …......................................................................................... 173 
3.4.3. Zewnętrzne źródła finansowania inwestycji jednostek samorządu terytorialnego

3.4.4. Alternatywne źródła finansowania inwestycji jednostek samorządu terytorialnego

4. Partnerstwo publiczno-prywatne jako źródło finansowania inwestycji jednostek samorządu terytorialnego

4.1. Działalność inwestycyjna a deficyt budżetowy i dług publiczny jednostek samorządu terytorialnego

4.2. Partnerstwo publiczno-prywatne a deficyt i dhug publiczny ...................................... 202

4.3. Ekonomiczno-techniczna analiza przedsięwzięć partnerstwa publiczno-prywatnego ........... 207

4.3.1. Zakres i obowiązek sporządzania analiz przedsięwzięcia partnerstwa publiczno-prywatnego

4.3.2. Analiza wstępna przedsięwzięć partnerstwa publiczno-prywatnego ................. 210

4.3.3. Analiza techniczna przedsięwzięć partnerstwa publiczno-prywatnego ............ 214

4.3.4. Analiza ekonomiczno-finansowa przedsięwzięcia partnerstwa publiczno-prywatnego ............................................................................... 215

4.3.5. Analiza prawno-organizacyjna przedsięwzięcia partnerstwa publiczno-prywatnego

4.3.6. Analiza ryzyka przedsięwzięcia partnerstwa publiczno-prywatnego ................ 222

4.3.7. Ubezpieczenie ryzyka w partnerstwie publiczno-prywatnym ......................... 246

4.3.8. Analiza środowiskowa $\mathrm{w}$ przedsięwzięciach partnerstwa publiczno-prywatnego ..........................................................................................

4.4. Value for Money jako kryterium efektywności inwestycji partnerstwa publiczno-prywatnego.

5. Analiza rynku samorządowych przedsięwzięć partnerstwa publiczno-prywatnego w Polsce w latach 2009-2011

5.1. Metodyka badań

5.2. Struktura podmiotowa partnerstwa publiczno-prywatnego w Polsce w latach 20092011

5.3. Struktura przedmiotowa partnerstwa publiczno-prywatnego w latach 2009-2011 ..... 277

5.4. Wartość rynku partnerstwa publiczno-prywatnego w Polsce w latach 2009-2011 .... 280

5.5. Analiza umów o partnerstwo publiczno-prywatne zawartych przez jednostki samorządu terytorialnego w latach 2009-2011 .......................................................... 283

5.5.1. Model współpracy wynikający z umowy o partnerstwie publiczno-prywatnym........ 283

5.5.2. Czas trwania umowy o partnerstwo publiczno-prywatne ................................ 285

5.5.3. Podział zadań i ryzyk w umowie o partnerstwo publiczno-prywatne w latach 2009-2011

5.6. Formuła partnerstwa publiczno-prywatnego w opinii ankietowanych jednostek samorządu terytorialnego

5.7. Planowane przedsięwzięcia partnerstwa publiczno-prywatnego $\mathrm{w}$ badanych jednostkach samorządu terytorialnego

5.8. Instytucje wspierające przedsięwzięcia partnerstwa publiczno-prywatnego w Polsce w latach 2009-2011

5.9. Potencjał inwestycyjny i dług samorządowy jako determinanty przedsięwzięć partnerstwa publiczno-prywatnego

5.9.1. Potencjał inwestycyjny a partnerstwo publiczno-prywatne ............................ 324

5.9.2. Poziom zadłużenia a partnerstwo publiczno-prywatne ................................. 331 
6. Teoretyczny model partnerstwa publiczno-prywatnego jako imperatyw dla finansowania inwestycji jednostek samorządu terytorialnego

6.1. Założenia teoretycznego modelu partnerstwa publiczno-prywatnego

6.2. Model partnerstwa publiczno-prywatnego w sektorze finansów samorządowych ...... 344

6.3. Zweryfikowany model PPP w obszarze inwestycji jednostek samorządu terytorialnego

6.4. Zakłócenia modelu partnerstwa publiczno-prywatnego w jednostkach samorządu terytorialnego

Zakończenie 359

Bibliografia

Spis map, schematów, tabel i wykresów 385

Aneks 1 - Ankieta 389

Od Redakcji 399 



\section{WYKAZ SKRÓTÓW}

\section{1. Źródla prawa}

PZP - Prawo zamówień publicznych (Ustawa z dnia 29 stycznia $2004 \mathrm{r}$. Prawo zamówień publicznych, DzU, 2004, nr 19, poz. 177 ze zm.)

TED - Tenders Electronic Daily („Europejski Dziennik Zamówień Publicznych")

Ustawa o PPP z 2005 - Ustawa z dnia 28 lipca 2005 r. o partnerstwie publiczno-prywatnym, DzU, 2005, nr 169, poz. 1420

Ustawa o PPP z 2008 - Ustawa z dnia 19 grudnia 2008 r. o partnerstwie publiczno-prywatnym, DzU, 2009, nr 19, poz. 100 ze zm.

\section{Inne skróty}

$$
\begin{array}{ll}
\text { art. } & - \text { artykuł } \\
\text { BIP } & - \text {,Biuletyn Informacji Publicznej” } \\
\text { BBO } & - \text { Buy- Build - Operate (kupuj - buduj - eksploatuj) } \\
\text { BDO } & \text { - Buy - Develop - Operate (kupuj - rozwijaj - eksploatuj) } \\
\text { BLOT } & - \text { Build - Lease - Operate - Transfer (buduj - leasinguj - ek- } \\
& \text { sploatuj - przekaż) } \\
\text { BOO } & - \text { Build - Own - Operate (buduj - bądź właścicielem - eksploatuj) } \\
\text { BOOT } & \text { - Build - Own - Operate - Transfer (buduj - bądź właścicielem - } \\
& \text { eksploatuj - przekaż) } \\
\text { BOT } & - \text { Build - Operate - Transfer (buduj - eksploatuj - przekaż) } \\
\text { BRTO } & - \text { Build - Rent - Transfer - Operate (buduj - wydzierżaw - } \\
& \text { eksploatuj - przekaż) } \\
\text { BT } & - \text { Build - Transfer (buduj - przekaż) } \\
\text { BTO } & - \text { Build - Transfer - Operate (buduj - przekaż - eksploatuj) } \\
\text { BZP } & - \text {,Biuletyn Zamówień Publicznych” } \\
\text { CAMP } & - \text { Capital Asset Pricing Model (model wyceny aktywów kapitało- } \\
& \text { wych) } \\
\text { CBA } & - \text { cost-benefit analysis (analiza kosztów i korzyści) } \\
\text { CEA } & - \text { cost-effectiveness analysis (metoda efektywności kosztowej) } \\
\text { DB } & - \text { Design - Build - (projektuj - buduj) } \\
\text { DBFO } & - \text { Design - Build - Finance - Operate (projektuj - buduj - finansuj } \\
& - \text { eksploatuj) }
\end{array}
$$




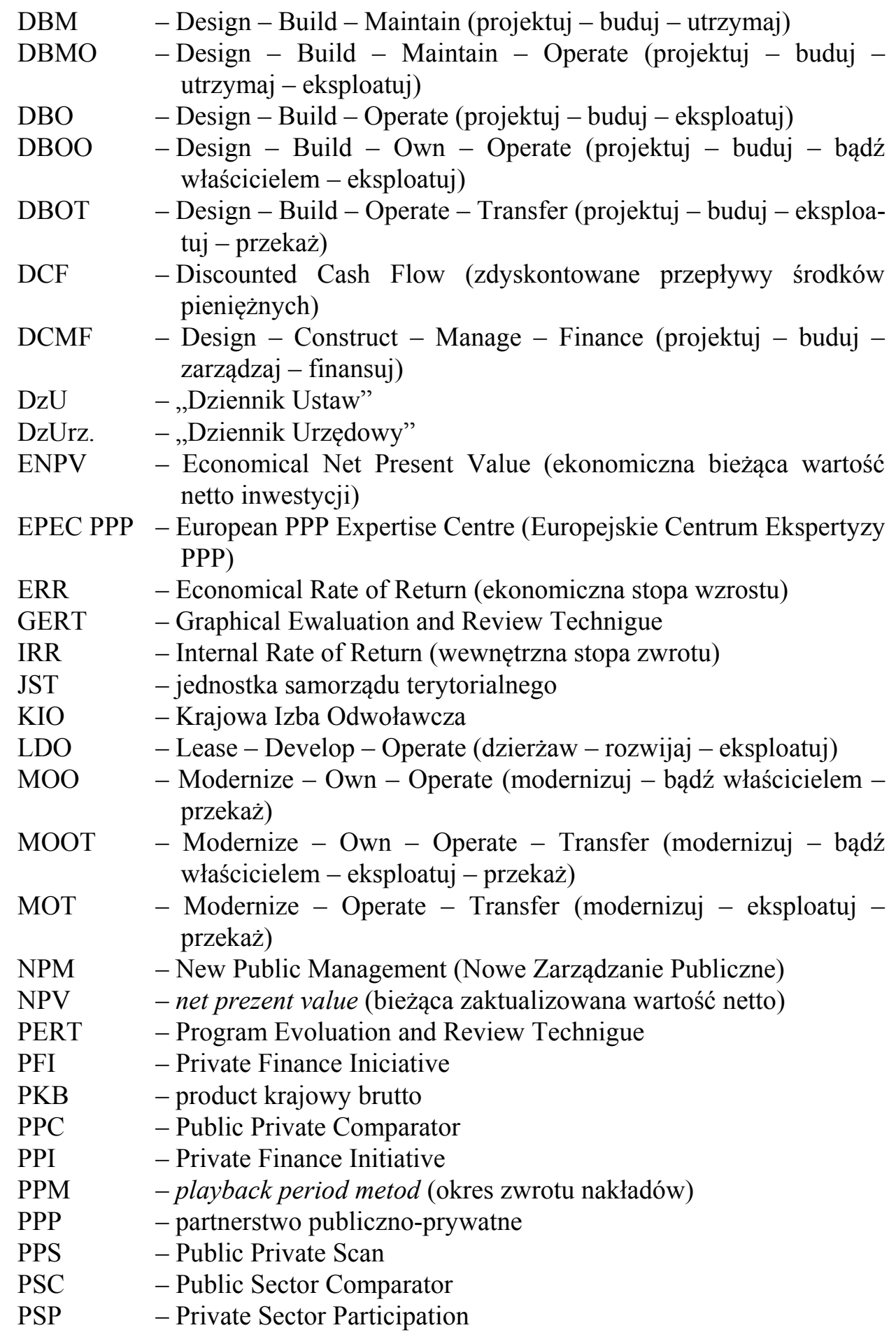


ROO - Renew - Own - Operate (odnawiaj - bądź właścicielem eksploatuj)

ROT $\quad-$ Renew - Operate - Transfer (odnawiaj - eksploatuj - przekaż)

SIWZ - specyfikacja istotnych warunków zamówienia

SPV - special purpose vehicle (spółka specjalnego przeznaczenia)

ze zm. $\quad-$ ze zmianami 



\section{WSTEP}

Skala zapoczątkowanych w Polsce w 1989 r. przemian politycznych, gospodarczych i społecznych, które w ostatniej dekadzie ewoluują dzięki przystąpieniu do struktur Unii Europejskiej, powoduje, że administracja publiczna, w tym przede wszystkim samorządowa, staje przed koniecznością realizacji systematycznie rosnącej liczby zadań publicznych. Spowolnienie gospodarcze, będące rezultatem globalnego kryzysu finansowo-gospodarczego, pogłębiający się deficyt budżetu państwa i jednostek samorządu terytorialnego generują dług publiczny zbliżający się do ustawowych granic. Podmioty publiczne, z uwagi na systematyczny wzrost wydatków związanych z rosnącymi potrzebami społecznymi oraz ograniczonymi zasobami ekonomicznymi, technicznymi i organizacyjnymi, w celu zahamowania rosnącego poziomu zadłużenia podejmują próby poszukiwania nowych form realizacji zadań publicznych. Doświadczenia różnych państw wskazują, że zadania publiczne mogą być pomyślnie wykonywane przy współpracy z sektorem prywatnym w ramach koncepcji partnerstwa publiczno-prywatnego (PPP).

Rozważając współpracę z sektorem prywatnym władze publiczne powinny mieć na uwadze, że formuła PPP nie jest celem samym w sobie, ale jedynie metodą efektywniejszej realizacji zadań publicznych. Władze publiczne coraz częściej poszukują nie tylko dodatkowych funduszy na realizację niezbędnych inwestycji, ale także wsparcia organizacyjno-technologicznego ze strony sektora prywatnego. Finansowanie rozwoju infrastruktury przy wykorzystaniu PPP zachodzi zarówno na szczeblu centralnym, jak i lokalnym. W dużym stopniu zakres tego finansowania zależy od możliwości budżetowych władz danego szczebla. Przedsięwzięcia PPP obejmują nie tylko budowę lub modernizację obiektów infrastrukturalnych, ale mogą dotyczyć także przejęcia przez sektor prywatny świadczenia określonych usług, tradycyjnie znajdujących się w gestii sektora publicznego (np. usługi wodno-kanalizacyjne, transport lokalny, oczyszczanie miast). Podmiot prywatny zaangażowany zostaje do wytworzenia inwestycji infrastrukturalnych, z reguły kapitałochłonnych, a następnie eksploatuje tę infrastrukturę, jednocześnie świadcząc usługi użyteczności publicznej. Warunkiem zaangażowania sektora prywatnego jest uzyskanie wynagrodzenia, które może pochodzić bezpośrednio z opłat od odbiorców usług, z budżetu podmiotu publicznego lub z obu tych źródeł jednocześnie.

Pojęcie partnerstwa publiczno-prywatnego pojawiło się w latach 70. minionego stulecia w Stanach Zjednoczonych, jednak historia realizacji infrastruktury 
użyteczności publicznej i świadczenia usług publicznych przez prywatnych inwestorów sięga czasów starożytnych. Ten sposób wykonywania zadań publicznych koncentrował się na przedsięwzięciach w zakresie dystrybucji wody, budowy dróg, mostów. Przeprowadzenie takich inwestycji, a następnie świadczenie usług odbywało się w formie koncesji. W XIX w. w tej formie powstały drogi i koleje w Wielkiej Brytanii, Francji, Stanach Zjednoczonych, Holandii. Wiek XIX i początki wieku XX charakteryzują się zwiększeniem interwencjonizmu państwowego $\mathrm{w}$ zakresie rozbudowy i zarządzania infrastrukturą służącą celom publicznym. Przyznawanie koncesji podmiotom prywatnym zostało zredukowane do minimum, a koszty eksploatacji i utrzymania przejmowały na siebie władze publiczne. W latach 70 . XX w. okazało się, że w wielu krajach występują poważne niedobory fiskalne uniemożliwiające dalsze inwestycje oraz modernizacje już istniejącej infrastruktury. Dodatkowo kryzysy paliwowe zmusiły rządzących w wielu krajach do redukcji kosztów. Powoli, ale systematycznie zaczęto zmieniać politykę odnośnie utrzymania i finansowania infrastruktury publicznej polegającej na włączaniu w proces zarządzania podmioty prywatne.

W drugiej połowie wieku XX w całej Europie Zachodniej postulowano zmiany $\mathrm{w}$ zakresie zarządzania administracją publiczną. W efekcie czego przekształcenia przebiegały dwukierunkowo. Po pierwsze działania administracji powoli zmieniały orientację na klienta, kładąc nacisk na jakość świadczonych usług oraz zasady skutecznej organizacji pracy. Po drugie, powszechnie głoszono tzw. menedżeryzm - koncepcję polegającą na adaptowaniu przez sektor publiczny reguł sektora prywatnego. Pojawiła się idea nowego zarządzania sektorem publicznym powszechnie określana mianem New Public Management (NPM). Zasadniczym przesłaniem reform sektora publicznego stała się idea przekazania $\mathrm{w}$ ręce profesjonalnych menedżerów zarządzania sektorem publicznym. Zwolennikami NPM stali się w Wielkiej Brytanii Margaret Thatcher i w Stanach Zjednoczonych Ronald Regan. Rdzeniem reform było odejście od weberowskiego modelu biurokratycznego „rozkazuj i kontroluj” do rynkowych zachęt i efektywnego zarządzania środkami publicznymi (NPM). Reformy miały na celu wprowadzenie:

- w ramach sektora publicznego stylu zarządzania typowego dla sektora prywatnego, co miało służyć modernizacji procesu dostarczania usług, stworzenia efektywnych struktur organizacyjnych,

- jasnych i wyraźnie zdefiniowanych reguł oraz standardów oceny efektywności działania sektora publicznego,

- zdyscyplinowanie działań sektora publicznego w celu oszczędności posiadanych zasobów, oraz

- orientację na klienta jako ostatecznego odbiorcy dostarczanych usług publicznych. 
Do kluczowych powodów zaangażowania sektora prywatnego w inwestycje publiczne należy zaliczyć:

- rosnące potrzeby inwestycyjne zwłaszcza w obszarze infrastruktury wynikające ze wzrostu gospodarczego i tempa zmian technologicznych,

- niezadowolenie dotychczasowych użytkowników z pełnienia funkcji inwestora i zarządcy mienia infrastrukturalnego przez państwo i jego agendy,

- ograniczone możliwości finansowe budżetu państwa i jednostek samorządu terytorialnego w stosunku do kosztów projektów inwestycyjnych,

- rosnący poziom zadłużenia, ograniczający dostęp do instrumentów zwrotnych.

Sektor prywatny powszechnie sprowadzany jest do roli wykonawcy usług na rzecz sektora publicznego. Rozwój formuły PPP pozwala spojrzeć na podmioty prywatne nie tylko przez pryzmat wykonawców, ale także realizatorów inwestycji i głównych dostarczycieli kapitału i usług. Wykorzystanie kapitału prywatnego pozwala gospodarce całego kraju na zwiększenie jego konkurencyjności poprzez nowe inwestycje. W okresach spowolnienia gospodarczego, czy kryzysu może stanowić bodziec powrotu na drogę zrównoważonego rozwoju.

Partnerstwo publiczno-prywatne przyjmuje najczęściej formułę długoterminowych umów zawartych pomiędzy podmiotem publicznym a prywatnym, której przedmiotem jest realizacja zadań publicznych umożliwiających optymalizację korzyści (Value for Money). Właściwe stosowanie formuły przynosi korzyści dla interesu publicznego przewyższające te osiągane za pomocą tradycyjnych metod. Źródłem tych korzyści jest wykorzystanie umiejętności, doświadczenia, metod, technologii i kapitału wniesionego przez stronę prywatną. Zaangażowanie prywatnych partnerów okazuje się skutecznym sposobem na wykonanie podejmowanych przedsięwzięć inwestycyjnych zgodnie z harmonogramem i planem finansowym, które to działania realizowane samodzielnie przez stronę publiczną niejednokrotnie są źródłem opóźnień i komplikacji.

Udane partnerstwo staje się dostawcą nowoczesnej infrastruktury i usług o wysokim standardzie i jakości. Zaoszczędzone środki budżetowe sektor publiczny może wykorzystać na inne cele. Za podstawową zaletę inwestycji realizowanych $\mathrm{w}$ formule partnerstwa publiczno-prywatnego wskazuje się możliwość przezwyciężenia ograniczeń budżetowych w zakresie inwestycji. Dostęp do kapitału prywatnego nabiera szczególnego znaczenia w warunkach trudności budżetowych w sektorze finansów publicznych, zwłaszcza przy nadmiernie rosnącym długu publicznym.

Formuła partnerstwa publiczno-prywatnego może być stosowana praktycznie w każdym państwie. Dla jej upowszechnienia niezbędna jednak wydaje się odpowiednia postawa administracji publicznej, umożliwiająca stworzenie 
dogodnych warunków i klimatu wokół formuły PPP. Wskazuje się ${ }^{1}$, że nie tylko unormowania prawne są bodźcem uruchamiającym nawiązywanie współpracy, ale bodźcem takim są też pozytywne przykłady ze strony władz centralnych, które stanowią zachętę do podejmowania działań na szczeblu samorządowym. Bez aktywnej pomocy państwa $\mathrm{w}$ obszarze instytucjonalnym, prawnym, społecznym i psychologicznym wypromowanie partnerstwa publiczno-prywatnego wydaje się niemożliwe.

Pomimo wielu zalet i korzyści, jakie wiążą się z partnerstwem publicznoprywatnym nie można pominąć jego wad i zagrożeń. Przedsięwzięcia partnerskie wykonywane niewłaściwie mogą stwarzać warunki do nadużyć prowadzących do generowania przez podmioty prywatne nieuzasadnionych zysków. Zjawisku temu towarzyszy na ogół brak odpowiedniego zabezpieczenia interesu publicznego. Odbywa się to ze szkodą dla sektora publicznego, który traci na wiarygodności jako nadzorca usług publicznych. Wśród głównych przyczyn niepowodzeń wymienia się także nieodpowiednie oszacowanie ryzyk inwestycyjnych, nadmierną ingerencję władz publicznych oraz zerwanie przez stronę publiczną umów zawartych z sektorem prywatnym. W celu uniknięcia takich sytuacji należy wypracować stosowne procedury współpracy, zadbać o należyte skonstruowanie umowy, a także przestrzegać tzw. dobrych praktyk. Doświadczenie w zakresie partnerstwa publiczno-prywatnego zdobyte dotychczas w różnych krajach napawa optymizmem i powinno stanowić impuls dla państw, które do tej pory nie zastosowały tejże formuły do realizacji zadań publicznych bądź podjęte w nich działania nie przyniosły oczekiwanego rezultatu.

Problematyka partnerstwa publiczno-prywatnego jest zagadnieniem szeroko opisywanym w literaturze zagranicznej i stanowi przedmiot rozwiązań instytucjonalnych zarówno na szczeblu Unii Europejskiej, jak i międzynarodowych instytucji finansowych. W Polsce od końca lat 90. minionego stulecia w kręgach naukowych oraz wśród praktyków toczy się ożywiona dyskusja nad sposobem implementacji reguł PPP do praktyki. Szczególną uwagę skoncentrowano na zagadnieniach formalno-prawnych zastosowania partnerstwa publiczno-prywatnego i dostosowania procedur do potrzeb i możliwości podmiotów publicznych. Efektem tych działań są odrębne akty prawne regulujące współpracę sektorów publicznego i prywatnego w formule partnerstwa publiczno-prywat-

\footnotetext{
${ }^{1}$ K. Brzozowska, Partnerstwo publiczno-prywatne w Europie, cele, uwarunkowania, efekty, Wydawnictwo Fachowe CeDeWu, Warszawa 2010; A. Cenkier, Partnerstwo publiczno-prywatne jako metoda wykonywania zadań publicznych, Szkoła Główna Handlowa w Warszawie, Warszawa 2009; B. Korbus, M. Strawiński, Partnerstwo publiczno-prywatne. Nowa forma realizacji zadań publicznych, Wydawnictwo Prawnicze LexisNexis, Warszawa 2006; M. Flinders, Splintered logic and political debate, [w:] International Handbook on Public Private Partnership, ed. by G. A. Hodge, C. Greve, A. E. Bordman, Edgar Elger: a Family Business in International Publishing, UK 2012.
} 
nego. Są to ustawa o partnerstwie publiczno-prywatnym z 19 grudnia $2008 \mathrm{r}^{2}$ i ustawa o koncesji na roboty budowlane lub usługi z 9 stycznia 2009 r. $^{3}$

$\mathrm{W}$ istniejącym dorobku badawczym (OECD, Bank Światowy, European PPP Expertise Centre, Instytut PPP, Centrum PPP, PARP) wiele uwagi poświęca się obszarom, w których partnerska współpraca może być wykorzystana. Dostępne na polskim rynku opracowania i raporty ukazują strukturę rynku PPP oraz wskazują na bariery ograniczające jego rynek. Inicjatorem współpracy i jej faktycznym wykonawcą $\mathrm{w}$ przeważającej mierze są jednostki samorządu terytorialnego (JST). W dotychczasowych badaniach brakuje wnikliwej analizy samorządowego rynku partnerstwa publiczno-prywatnego oraz identyfikacji współzależności między sytuacją finansową jednostki samorządu terytorialnego a skłonnością do realizowania partnerskich przedsięwzięć (zawierania umów o PPP). W okresie spowolnienia gospodarczego oraz ograniczonych możliwości zwiększania zadłużenia przez samorządy, partnerstwo publiczno-prywatne postrzegane jest jako jedno ze źródeł finansowania zadań publicznych, które przy prawidłowej konstrukcji nie będzie kreować nowego zadłużenia. Utrzymanie dotychczasowego tempa rozwoju i ograniczanie zadłużenia wymaga świadomego kształtowania polityki w zakresie doboru źródeł finansowania zadań publicznych, w tym inwestycji. Stąd potrzeba podjęcia próby stworzenia rozwiązań dotyczących współdziałania podsektora samorządowego i prywatnego.

Podstawowym celem niniejszej pracy jest identyfikacja uwarunkowań prawno-finansowych, sprzyjajacych partnerskiej wspótpracy oraz opracowanie modelu partnerstwa publiczno-prywatnego uwzględniajacego filary prawny, finansowy i administracyjno-organizacyjny, warunkujące prawidtowe wspótdzialanie sektora publicznego i prywatnego.

By osiągnąć cel podstawowy skoncentrowano się na celach szczegółowych, takich jak:

1) analiza uwarunkowań prawnych niezbędnych do realizacji przedsięwzięć w formule partnerstwa publiczno-prywatnego,

2) ocena poziomu potencjału inwestycyjnego jednostek samorządu terytorialnego $\mathrm{w}$ odniesieniu do skłonności poszukiwania niekonwencjonalnych form finansowania, w tym zastosowania partnerstwa publiczno-prywatnego,

3) ocena poziomu zadłużenia jednostek samorządu terytorialnego w kontekście skłonności do zawierania umów o PPP,

4) wskazanie sektorów gospodarki komunalnej, w której partnerstwo publiczno-prywatne znajduje zastosowanie,

5) ocena zakresu wsparcia instytucjonalnego we wdrażaniu procedur związanych z przygotowaniem postępowań o wybór partnera prywatnego dla PPP.

\footnotetext{
${ }^{2}$ Ustawa z dnia 19 grudnia 2008 r. o partnerstwie publiczno-prywatnym, DzU, 2008, nr 19, poz. $100 \mathrm{ze}$ zm.

${ }^{3}$ Ustawa z dnia 9 stycznia 2009 r. o koncesji na roboty budowlane lub ustugi, DzU. 2009, nr 19, poz. $101 \mathrm{ze}$ zm.
} 
Rozważaniom merytorycznym i empirycznym towarzyszyła hipoteza główna zakładająca, że poziom zadłużenia oraz niski poziom potencjału inwestycyjnego determinuja wladze jednostek samorzadu terytorialnego do realizowania inwestycji w formule partnerstwa publiczno-prywatnego.

Układ pracy podporządkowany został celowi głównemu i celom szczegółowym oraz weryfikacji przyjętej hipotezy. Praca składa się ze wstępu, sześciu rozdziałów podzielonych na podrozdziały oraz zakończenia.

W rozdziale pierwszym przedstawiono problematykę funkcjonowania partnerstwa publiczno-prywatnego na świecie i w Polsce. Zaprezentowano genezę współpracy międzysektorowej oraz ewolucję form realizacji zadań publicznych. Brak jednolitej definicji partnerstwa publiczno-prywatnego był przesłanką do ukazania różnorodności pojęć PPP funkcjonujących w międzynarodowych gremiach finansowych, instytucjach Unii Europejskiej oraz w państwach, w których formuła partnerstwa publiczno-prywatnego znalazła praktyczne zastosowanie. W tej części pracy przedstawiono także stanowisko Unii Europejskiej w kwestii zastosowania PPP oraz zakres regulacji prawnych obowiązujących w tym obszarze w Polsce. Rozwiązania prawne są istotnym czynnikiem przesądzającym o dynamice rozwoju rynku PPP i stanowią podłoże do kreowania polityki w zakresie PPP w państwach, w których formuła ta znajduje się dopiero w początkowej fazie wdrażania. Ponadto zwrócono uwage na różnice pomiędzy partnerstwem publiczno-prywatnym a prywatyzacją. Zastosowanie partnerstwa publiczno-prywatnego nie oznacza zmiany własności zaangażowanego majątku, co zachodzi w przypadku prywatyzacji. Społeczny odbiór każdej $\mathrm{z}$ tych form jest odmienny.

Rozdzial drugi zawiera charakterystykę procesu wdrażania formuły partnerstwa publiczno-prywatnego. Wiele uwagi poświęcono fazom realizacji przedsięwzięcia inwestycyjnego, wskazując na konsekwencje wyboru konkretnego rozwiązania prawnego. Realizacja formuły PPP w Polsce, przy obecnie przyjętych regulacjach, skutkuje dwutorowym, odrębnym postępowaniem w zakresie wyboru partnera prywatnego, a w konsekwencji różnorodną strukturą PPP. W sposób szczegółowy przedstawiono uczestników PPP oraz kształt i zakres umowy o PPP, która wieńczy proces projektowo-przetargowy.

Specyfika inwestycji samorządowych stanowi główny przedmiot rozważań trzeciego rozdzialu. Wskazano w nim na cechy odróżniające inwestycje sektora samorządowego od inwestycji prywatnych. Przedstawiono problem efektywności inwestycji samorządowych oraz metody jej oceny. Zakres i poziom inwestycji jednostek samorządu terytorialnego uzależniony jest od ich możliwości inwestycyjnych. W celu ich oceny została scharakteryzowana metodologia określenia potencjału inwestycyjnego dla JST. Proces inwestycyjny wymaga zagwarantowania kapitału. Dokonano więc przeglądu źródeł finansowania w podziale na wewnętrzne, zewnętrzne i alternatywne. Wskazano na istotną rolę 
środków pochodzących z Unii Europejskiej oraz źródeł pozyskiwanych z rynku finansowego.

Rozdzial czwarty poświęcony został prezentacji partnerstwa publicznoprywatnego jako źródła finansowania inwestycji samorządowych. Przedstawiono w nim związek pomiędzy poziomem zadłużenia a poziomem inwestycji. Analizie poddano wpływ umów o PPP na poziom długu publicznego. Zaprezentowano stanowiska Komisji Europejskiej i Eurostatu dotyczące wpływu umów o PPP na dług publiczny, odnosząc się jednocześnie do rozwiązań polskich $\mathrm{w}$ tym obszarze. W sposób szczegółowy ustosunkowano się do zagadnień ekonomicznych PPP. Przedstawiono zakres analiz sporządzanych w celu wykazania zasadności zastosowania PPP do realizacji zadania publicznego oraz zasad podziału zadań i ryzyk. Podstawę rozważań stanowiła problematyka ryzyka, jego klasyfikacja, identyfikacja i alokacja. Przyjęta przez strony umowy PPP polityka alokacji ryzyka w partnerskich projektach decyduje o wpływie na poziom długu publicznego i deficyt sektora finansów publicznych. Zaprezentowano także, rzadko podejmowany w kontekście PPP, problem ubezpieczenia ryzyk w umowach PPP.

Piaty rozdzial to studium analityczno-badawcze. Przedstawiono w nim wyniki badania ankietowego służące identyfikacji i ocenie uwarunkowań kształtujących rynek samorządowych przedsięwzięć partnerstwa publiczno-prywatnego. Opierając się na uzyskanych wynikach ukazano strukturę podmiotowo-przedmiotową samorządowego rynku PPP w Polsce. Wskazano na czynniki umożliwiające współpracę sektora publicznego i podmiotów publicznych, a także określono czynniki, których wystąpienie nie sprzyja tejże współpracy.

$W$ rozdziale szóstym zaprezentowano Teoretyczny Model PPP uwzględniający wzorcowe uwarunkowania prawne, finansowe i administracyjno-organizacyjne, określone filarami, sprzyjające zawieraniu umów o PPP przez podmioty publiczne, w tym jednostki samorządu terytorialnego. W każdym filarze wyróżniono części składowe i przyznano im wartości w skali 0-1 oceniające wystąpienie składnika. Pozwoliło to na określenie trzystopniowej skali skłonności podmiotu publicznego do zawierania umów o PPP. Teoretyczny Model PPP poddano weryfikacji, prezentując uwarunkowania sprzyjające i ograniczające zawarcie umowy o PPP w latach 2009-2011 przez jednostki samorządu terytorialnego. $\mathrm{W}$ podrozdziale 6.3. wskazano na czynniki, których wystąpienie w praktyce może doprowadzić do zakłóceń w działaniu Teoretycznego Modelu PPP.

Do hipotezy oraz celów pracy dostosowane zostały metody i narzędzia badawcze. W czterech pierwszych rozdziałach wykorzystano wnioskowanie dedukcyjne, w którym na podstawie analizy opisowej i porównawczej literatury zagranicznej oraz polskiej przedmiotu, zidentyfikowano uwarunkowania charakterystyczne dla formuly partnerstwa publiczno-prywatnego, które stanowiły podstawę do badania i sformułowania wniosków w kolejnych rozdziałach. 
W rozdziale piątym pracy, dotyczącym analizy rynku samorządowych przedsięwzięć partnerstwa publiczno-prywatnego, posłużono się analizą przyczynowoskutkową wykorzystując następujące techniki badawcze: badanie ankietowe, analizę dostępnych na polskim rynku raportów poświęconych PPP. Zastosowano też metodę statystyki opisowej w celu prezentacji pozyskanych danych.

Podstawowym narzędziem badawczym był kwestionariusz ankiety wysłany drogą mailową do 130 jednostek samorządu terytorialnego. Okres badawczy obejmował lata 2009-2011 i został podyktowany wejściem w życie nowych regulacji prawnych w zakresie zasad zawierania umów o partnerstwo publiczno-prywatne. Od lutego 2009 r. zaczęły obowiązywać nowa ustawa o partnerstwie publiczno-prywatnym z dnia 19 grudnia $2008 \mathrm{r}$. oraz ustawa $\mathrm{z}$ dnia 9 stycznia 2009 r. o koncesji na roboty budowlane lub usługi. Badane jednostki samorządu terytorialnego zostały pogrupowane $\mathrm{w}$ trzy próby badawcze. W pierwszej próbie badawczej (próba I) znalazły się wszystkie samorządy, które w latach 20092011 zamieściły w „Biuletynie Zamówień Publicznych” lub w „Suplemencie do Europejskiego Dziennika Unii Europejskiej” ogłoszenie o wybór partnera prywatnego lub koncesjonariusza dla przedsięwzięć PPP. W tej próbie zidentyfikowano kluczowe dla badania jednostki samorządu terytorialnego, tj. 16 samorządów, które zawarły umowy o PPP. W celu weryfikacji stopnia znajomości problematyki partnerstwa publiczno-prywatnego oraz skłonności do realizacji zadań publicznych w formule PPP celowo poszerzono próbę badawczą o 18 miast będących siedzibami organów stanowiących oraz/lub zarządów województw (określona w pracy jako próba II) oraz 42 gminy miejskie województwa łódzkiego (w pracy próba III). Badanie realizowane było od lutego do maja $2012 \mathrm{r}$.

W rozdziale szóstym, na podstawie zidentyfikowanych w poprzednich rozdziałach uwarunkowań, opracowano wzorcowy Teoretyczny Model PPP. Posługując się analizą przyczynowo-skutkową oraz opisową wskazano na części składowe filarów: prawnego, finansowego oraz administracyjno-organizacyjnego, których występowanie w praktyce warunkuje funkcjonowanie formuly partnerstwa publiczno-prywatnego.

W pracy oparto się na polskiej i zagranicznej literaturze przedmiotu, w szczególności wykorzystano zwarte publikacje z dziedziny finansów, finansów publicznych, finansów samorządowych, finansów przedsiębiorstw, prawa. Źródłem informacji były dokumenty i raporty Komisji Europejskiej, Banku Światowego, European PPP Expertise Centre oraz dostępne na rynku polskim raporty poświęcone rynkowi PPP. Cennym źródłem informacji było badanie ankietowe o rynku samorządowych przedsięwzięć partnerstwa publiczno-prywatnego.

Rozprawa jest wynikiem kilkuletnich badań własnych nad zagadnieniami związanymi z funkcjonowaniem partnerstwa publiczno-prywatnego oraz roli formuły PPP w finansowaniu działalności inwestycyjnej jednostek samorządu terytorialnego. 


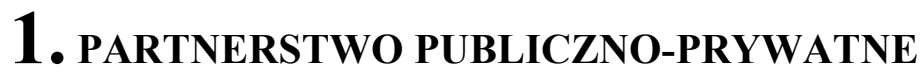 JAKO FORMULA REALIZACJI PRZEDSIĘWZIĘĆ INWESTYCYJNYCH}

\subsection{Ewolucja idei partnerstwa publiczno-prywatnego w Europie i na świecie}

Pierwsze wzmianki o podmiotach prywatnych zaangażowanych w realizację zadań publicznych pochodzą z czasów starożytnych. Najwcześniej odnotowana współpraca datuje się na IV w. p.n.e., a doszło do niej na greckiej wyspie Eubei, gdzie inżynier Chairephanes uzyskał dziesięcioletnią koncesję na meliorację jeziora Dystos. W zamian uzyskał prawo do uprawy odwodnionych terenów i zwolnienie $\mathrm{z}$ podatków z tytułu sprzedaży płodów rolnych. Konstrukcję ówczesnej współpracy przyrównuje się do dzisiejszej formy BOT (BuildOperate-Transfer) ${ }^{1}$.

W starożytnym Rzymie za transport poczty odpowiadał sam cesarz, natomiast budynki pocztowe podlegały wspólnotom lokalnym, które - najczęściej w drodze przetargu - wyłaniały prywatnego zarządcę. Zarządca podpisywał pięcioletnią umowę, na mocy której odpowiadał za wybudowanie, utrzymanie i funkcjonowanie obiektu. Formuła koncesji była wówczas wykorzystywana również przy budowie portów, dróg, term ${ }^{2}$.

W czasach nowożytnych prywatni przedsiębiorcy bardzo często angażowali się w świadczenie różnorodnych usług publicznych, o czym świadczą opisane w literaturze przykłady. Wskazuje się na wyprawę hiszpańskiego przedsiębiorcy, który dzięki zawartej z monarchą Hiszpanii umowie popłynął do Nowego Świata. W Stanach Zjednoczonych w 1652 r. Water Works Company z Bostonu podpisała umowę na wyłączność dostaw wody pitnej dla mieszkańców miasta. Firma Pony Express świadczyła usługi pocztowe przewożąc pocztę na zachodni

\footnotetext{
${ }^{1}$ Por. A. Sarnacka, Partnerstwo publiczno-prywatne - niewykorzystana szansa na rozwój infrastruktury, [w:] Realizacja zadań publicznych przez jednostki samorzadu terytorialnego we wspótpracy z sektorem prywatnym, red. E. Kornberger-Sokołowska, Uniwersytet Warszawski, Centrum Studiów Samorządu Terytorialnego i Rozwoju Lokalnego, Warszawa 2008, s. 128.

${ }^{2}$ A. Cenkier, Partnerstwo publiczno-prywatne jako metoda wykonywania zadań publicznych, Szkoła Główna Handlowa w Warszawie, Warszawa 2009, s. 33.
} 
brzeg rzeki Mississipi dzięki umowie zawartej pomiędzy przedstawicielami firmy a rządem federalnym Stanów Zjednoczonych ${ }^{3}$. Za prekursorów PPP w Europie uważa się braci Perrier, którzy w 1782 r. założyli spółkę zajmującą się dystrybucją wody w Paryżu.

Ważną inwestycją była budowa Kanału Sueskiego. Prace nad projektem połączenia Morza Śródziemnego z Morzem Czerwonym rozpoczęły się w 1847 r. W roku 1854 rząd egipski podpisał 99-letnią koncesję na budowę i eksploatację Kanału Sueskiego z prywatną spółką Suez Canal Company. Władze Egiptu przekazały $\mathrm{w}$ formie dotacji grunty pod budowę kanału oraz zwolniły z podatków nabywane materiały i sprzęt budowlany. Spółka uzyskała pełnomocnictwo na wybudowanie kanału, jego eksploatację oraz pobieranie opłat za korzystanie $\mathrm{z}$ niego ${ }^{4}$. Inwestycja, uznana za udaną i zyskowną zakończona została w $1868 \mathrm{r}$. Kanał oddano do użytku w 1869 r. i pozostawał on w rękach prywatnych przez prawie dziewięćdziesiąt lat, do momentu jego znacjonalizowania przez władze Egiptu ${ }^{5}$.

W okresie rewolucji przemysłowej przedsiębiorstwa użyteczności publicznej, zwłaszcza sieciowe, w przeważającej części należały do prywatnych właścicieli. Kapitał prywatny skoncentrowany był w rękach grupy ludzi, którzy byli w stanie w krótkim czasie zgromadzić potrzebne fundusze na wiele przedsięwzięć inwestycyjnych. W sytuacji, gdy środki własne przedsiębiorców okazywały się niewystarczające, byli oni w stanie ubiegać się o pożyczki. $\mathrm{Z}$ uwagi na pozycję społeczną i wiarygodność kredytową prywatnych przedsiębiorców uzyskanie przez nich kredytów nie stanowiło problemu.

Wiek XIX to „wiek inwestycji”, który obfitował w przedsięwzięcia kolejowe i drogowe. Wielka Brytania, Francja, Austria, Stany Zjednoczone, Szwajcaria, Niemcy intensywnie inwestowały w rozwój sieci kolejowych finansowanych przez prywatnych inwestorów. Rozwój kolei przyczynił się do ożywienia gospodarczego terenów, przez które przebiegały linie kolejowe. Zapotrzebowanie na przewozy przerosło oczekiwania inwestorów co przełożyło się na wymierne efekty finansowe spółek - zarządców.

Koniec wieku XIX przyniósł zmianę w podejściu do formy własności dostarczania usług użyteczności publicznej. Władze państwowe coraz rzadziej przyznawały prywatnym przedsiębiorcom koncesje na realizację infrastruktury, jednocześnie rozpoczęty został proces nacjonalizacji inwestycji już istniejących ${ }^{6}$.

${ }^{3}$ M. Moszoro, Partnerstwo publiczno-prywatne $w$ monopolach naturalnych $w$ sferze użyteczności publicznej, Szkoła Główna Handlowa w Warszawie, Warszawa 2005, s. 26.

${ }^{4}$ Więcej: K. Brzozowska, Partnerstwo publiczno-prywatne. Przesłanki, możliwości, bariery, Wydawnictwa Fachowe CeDeWu.pl, Warszawa 2006, s. 10-11.

${ }^{5}$ D. Hajdys, Możliwości i formy zaangażowania sektora prywatnego $w$ realizację inwestycji komunalnych w Polsce, [w:] Realizacja zadań publicznych przez jednostki samorzadu terytorialnego..., s. 76.

${ }^{6}$ Więcej: K. Brzozowska, Partnerstwo publiczno-prywatne..., s. 12-14. 
Proces ten był następstwem przemian jakim podlegały poglądy na rolę podmiotów z sektora publicznego w gospodarce i zaspokajaniu potrzeb publicznych.

W Wielkiej Brytanii kluczowe znaczenie miało przyjęcie ustaw Gas and Water Facilities Act w 1870 r. oraz Public Health Act z 1875 r., które nałożyły na władze lokalne obowiązek świadczenia usług publicznych ${ }^{7}$.

Kryzys lat trzydziestych XX w. i upowszechnienie koncepcji J. Keynesa doprowadziły do rosnącego zaangażowania państwa w gospodarkę, a w inwestycje infrastrukturalne i usługi użyteczności publicznej w pierwszej kolejności. W efekcie w krajach Europy Zachodniej do połowy lat siedemdziesiątych państwo było praktycznie jedynym inwestorem w sferze infrastruktury publicznej. Władze państwowe odgrywały główną rolę w określaniu kierunków rozwoju, decydując o liczbie, rodzaju i miejscu inwestycji. Głównym źródłem finansowania nowej infrastruktury były środki budżetowe oraz środki o charakterze pożyczkowym zaciągane $\mathrm{w}$ postaci emisji papierów wartościowych i pożyczek z międzynarodowych instytucji finansowych, tj. Banku Światowego czy Międzynarodowego Funduszu Walutowego ${ }^{8}$.

Dokonujące się przemiany społeczne, ekonomiczne i polityczne sprzyjały umocnieniu pozycji sektora publicznego jako głównego dostarczyciela usług publicznych. Sektor ten stał się niemal wyłącznym inwestorem w obszarze inwestycji infrastrukturalnych. Na początku lat siedemdziesiątych XX w. rządy poszczególnych państw napotkały barierę $\mathrm{w}$ postaci ograniczonych środków publicznych służących finansowaniu dalszej rozbudowy i modernizacji infrastruktury publicznej. Pojawienie się napięć fiskalnych (fiscal stress) i tzw. syndromu dużych miast (big city factor) ${ }^{9}$ oraz kryzysy naftowe (1973 i 1979 r.) obnażyły słabość państwa i stanowiły inspirację do podjęcia dyskusji nad fundamentalnymi aspektami ideologicznej i filozoficznej roli państwa w gospodarce. Problemy gospodarcze, wywołane kryzysami naftowymi, inflacją, ograniczeniami budżetowymi, osłabiły zdolność większości państw w zakresie działalności inwestycyjnej, co przełożyło się na pogorszenie stanu infrastruktury i jakości świadczonych inwestycji. Zaniedbania $\mathrm{w}$ tej dziedzinie, określane mianem „luki infrastrukturalnej”, wywołały potrzebę możliwie szybkiego znalezienia antidotum na powstałą sytuację. W takim klimacie zrodziła się koncepcja ponownego zainteresowania prywatnych inwestorów inwestycjami

${ }^{7}$ D. M. Newbery, Privatization, Restructuring and Regulation of Network Utilities, The Walras-Pareto Lectures, The MIT press, Cambridge, MA. 2000, s. 19.

${ }^{8}$ Por. K. Brzozowska, Partnerstwo publiczno-prywatne..., s. 12-14; M. Moszoro, Partnerstwo publiczno-prywatne w monopolach naturalnych..., s. 27.

${ }^{9}$ Zjawisko napięć fiskalnych polega na tym, że koszty realizacji zadań publicznych rosną szybciej niż dochody publiczne. Wzrost kosztów wynika z postępu technologicznego i tzw. syndromu dużych miast, w których koszty dostarczania podstawowych usług publicznych są wyższe niż w mniejszych miejscowościach. S. Bailey, Local government economics, principles and practice, Mac Millan, 1999, s. 109. 
publicznymi. Prywatny kapitał, zaawansowane technologie oraz doświadczenie wydawały się najlepszą kombinacją czynników, które można było wykorzystać do realizacji zadań publicznych ${ }^{10}$. Koncepcja partnerstwa publiczno-prywatnego wpisywała się także w szerszy kontekst reform administracji publicznej (New Public Management), które w poszukiwaniu poprawy efektywności działania sektora publicznego starały się go poddać ocenie rynkowej. W efekcie ponownie, po długim okresie przerwy, dopuszczono podmioty prywatne do konkurowania o możliwość wykonywania zadań publicznych. Kryzys fiskalny stał się bezpośrednim bodźcem do ukształtowania i wykorzystania formuły partnerstwa publiczno-prywatnego.

Postawa konserwatywnych rządów Margaret Thatcher i Ronalda Reagana, prowadząca do ograniczenia fiskalizmu i dominującej roli państwa w gospodarce, a także konieczność do podnoszenia nakładów na inwestycje infrastrukturalne doprowadziły do wzmożonych działań nakierowanych na współpracę z sektorem prywatnym, inicjując rozwój partnerstwa publiczno-prywatnego. Formuła partnerstwa publiczno-prywatnego okazała się atrakcyjnym rozwiązaniem w obszarach, które dotąd stanowiły domenę sektora publicznego.

Partnerstwo publiczno-prywatne zaczęto postrzegać jako tzw. trzecią drogę w sytuacji, gdy zawodzi model świadczenia usług zarówno przez państwo, jak i rynek. Państwo nie zapewnia efektywności działań, reguły gospodarki rynkowej nie gwarantują zaś „sprawiedliwości społecznej”"11. Zdaniem D. Osborna i T. Gaeblera rządzący stanęli przed koniecznością „znalezienia innej, nowej drogi - czegoś pośredniego pomiędzy rynkiem a biurokracją publiczną". Tak naprawdę nie było wiadome, czego należy poszukiwać i jakie rozwiązania przyjąć za właściwe. Postawa polityków i urzędników, w wielu przypadkach nakierowana na własny interes, prestiż i dochód prowadziła do zbytnich rozpiętości budżetowych i rozrostu administracji. Nie sprzyjało to poprawie efektywności ekonomicznej, a wręcz przeciwnie, tłamsiło efektywność, obniżało jakość świadczonych usług. Konieczne było poszukiwanie nowych rozwiązań, uwzględniających wykorzystanie kapitału prywatnego.

Wielka Brytania, która uznawana jest za kolebkę koncepcji partnerstwa publiczno-prywatnego, jako pierwsza podjęła się realizacji idei „mniej państwa a więcej rynku" " przyjął rozwiązanie pod nazwą Private Finance Iniciative (PFI), którego celem było uprawomocnienie współpracy sektora publicznego z sektorem prywatnym. Struktury PFI miały zapewnić transfer ryzyka związanego ze świadczeniem

${ }^{10}$ Por. A. Cenkier, Partnerstwo publiczno-prywatne..., s. 36-37.

${ }^{11}$ Por. W. Zaremba, Partnerstwo publiczno-prywatne. Nowe możliwości zarzadzania ustugami publicznymi, [w:] Partnerskie wspóldziałanie w sektorze publicznym i prywatnym, red. B. Plawgo, W. Zaremba, Fundacja Współczesne Zarządzanie, Białystok 2005, s. 40.

${ }^{12}$ D. Osborne, T. Gaebler, Rządzić inaczej. Jak duch przedsiębiorczości przenika i przeksztatca administrację publiczna, Media Rodzina, Poznań 1992, s. 432. 
usług publicznych na stronę prywatną oraz przyczynić się do wzrostu zadowolenia społecznego z jakości świadczonych usług. Wraz z wprowadzonymi regulacjami powołano do życia specjalną agendę rządową (przy Ministerstwie Finansów utworzono Treasury Taskforce), której celem było wspieranie koncepcji PPP oraz tworzenie bazy dobrych praktyk. Prace agendy skoncentrowane były na koordynacji działań na szczeblach rządowym i lokalnym, stworzeniu wytycznych dla przedsięwzięć pilotażowych oraz bazy wiedzy i doświadczeń w zakresie PPP ${ }^{13}$. W 1997 r. do władzy doszła Partia Pracy, która nadal realizowała koncepcję PFI, z tą różnicą, że zaczęto używać określenia Public Private Partnerships (PPP). Zmiana terminologii miała na celu zwrócenie uwagi nie tylko na charakter współpracy pomiędzy sektorami, znaczenie czynnika innowacyjności, ale przede wszystkim chodziło o uwypuklenie kwestii pozostawienia odpowiedzialności za świadczone usługi w rękach sektora publicznego ${ }^{14}$.

Wzorce przyjęte w Wielkiej Brytanii znalazły naśladowców w innych państwach. $Z$ reguły powoływano specjalne instytucje zajmujące się propagowaniem działań wchodzących w zakres PPP. Dla przykładu w Irlandii działa przy Ministerstwie Finansów Central PPP Unit, w Kanadzie istnieje specjalna prywatno-publiczna instytucja The Canadian Council for Public-Private Partnerships, w Danii funkcjonuje grupa robocza składająca się z przedstawicieli Ministerstw: Finansów, Transportu, Gospodarki i Infrastruktury. Podobne rozwiązanie instytucjonalne przyjęto na Węgrzech, gdzie nad wdrożeniem PPP czuwa międzyresortowy Komitet ds. PPP złożony z przedstawicieli Ministerstwa Gospodarki i Transportu, Finansów, Sprawiedliwości, Urzędu Premiera i Urzędu Statystycznego. W Polsce działają Centrum PPP jako niezależna instytucja obywatelska i Instytut PPP (instytucja pozarządowa o charakterze non-profit). W działania promocyjne zaangażowały się także instytucje rządowe: Ministerstwo Gospodarki tworząc bazę PPP oraz Ministerstwo Rozwoju Regionalnego z platformą PPP. Celem internetowych baz jest promowanie działań i wiedzy w zakresie partnerstwa. Przytoczone przykłady świadczą, że dla efektywnego funkcjonowania PPP niezbędne jest przygotowanie właściwego środowiska prawno-instytucjonalnego. Na uwagę zasługuje fakt, że tworzenie regulacji prawnych nie jest jedynym i najważniejszym warunkiem rozwoju partnerstwa. Istotniejsze jest budowanie właściwego klimatu, powszechnej akceptacji i przyzwolenia zarówno wśród przedstawicieli władz publicznych, jak i społeczeństwa. Konieczność wsparcia wynika z faktu, iż partnerstwo publicznoprywatne jest procesem skomplikowanym, nie dającym się określić w sztywnych ramach przy wykorzystaniu standardowego schematu postępowa-

${ }^{13}$ Zob. D. Hajdys, Możliwości i formy zaangażowania ..., s. 77.

${ }^{14}$ A. Lisek, Rozwiazania z zakresu partnerstwa publiczno-prywatnego w krajach Unii Europejskiej i Stanach Zjednoczonych, [w:] Partnerstwo publiczno-prywatne, Wrocławska Agencja Rozwoju Regionalnego, Wrocław, Kudowa-Zdrój 2002. 
nia ${ }^{15}$. Zakres i charakter wsparcia były i są różne w poszczególnych państwach, co przełożyło się na różnorodny charakter koncepcji.

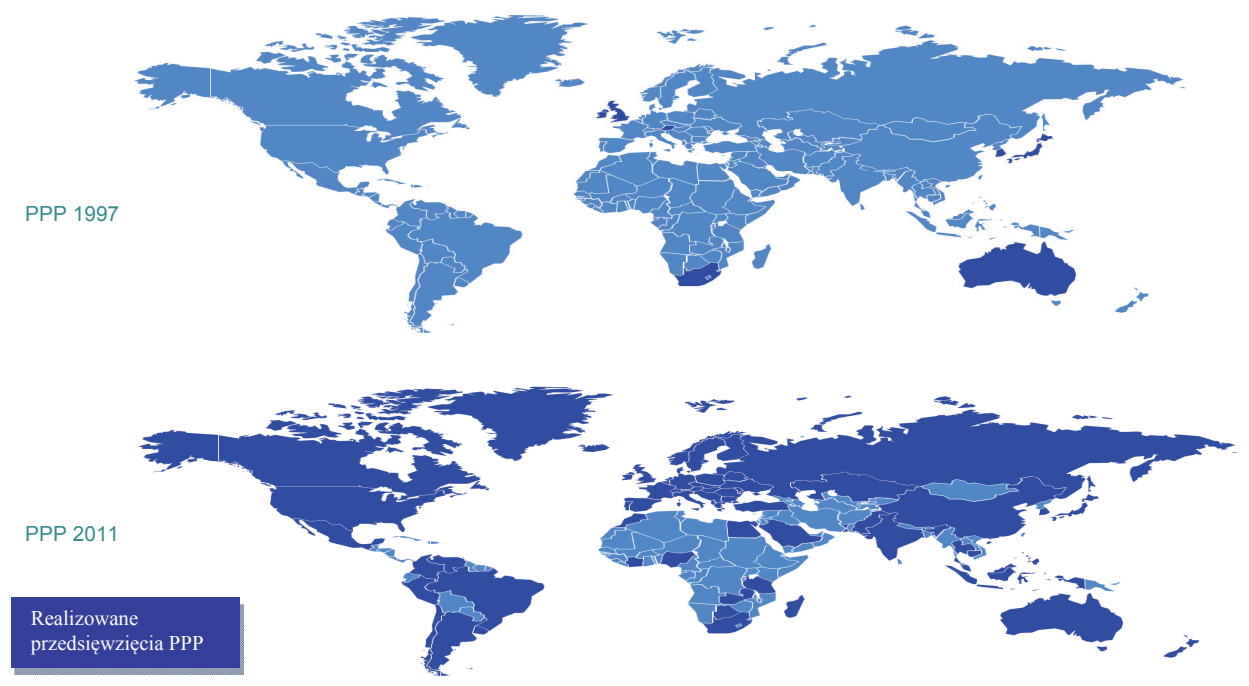

Mapa 1.1. Rozwój PPP na świecie w latach 1994-2011

Źródło: oprac. własne na podstawie danych European PPP Expertise Centre, www.eib.org/epec/

Za najbardziej dojrzałe PPP, zbliżone do funkcjonujących w Wielkiej Brytanii uznaje się rozwiązania występujące w Australii i Irlandii. We wcześniejszych fazach rozwoju znajdują się Francja, Hiszpania, Niemcy. Kraje Europy Środkowowschodniej należy uznać za kraje znajdujące się na początku ścieżki wdrażania $\mathrm{PPP}^{16}$. Według dostępnych statystyk w latach 1994-2011 na świecie zrealizowano prawie 1200 przedsięwzięć PPP o łącznej wartości 345 mld Euro $^{17}$. Terytorialne zmiany związane $z$ rozwojem rynków PPP na świecie przedstawia mapa 1.1 .

${ }^{15}$ Por. A. Kopańska, Partnerstwo publiczno-prywatne jako sposób realizacji zadań publicznych. Czynniki rozwoju w Polsce, [w:] Finansowanie gminnego samorzadu terytorialnego, red. D. A. Hałaburda, Wydawnictwo Wyższej Szkoły Ekonomicznej w Białymstoku, Białystok 2008, s. 28. Wykazy instytucji i ich zadań oraz roli we wspieraniu PPP w Polsce przytoczone zostały w opracowaniu D. Hajdys, Instytucjonalne wsparcie partnerstwa publiczno-prywatnego, materiał w druku.

${ }^{16}$ Closing the Infrastructure Gap: The Role of Public-Private Partnerships, Global and U.S. reports, Deloite 2006, s. 8.

${ }^{17} \mathrm{Na}$ podstawie danych zawartych w Market Update. Review of the European PPP Market in 2010 and 2011, European PPP Expertise Centre; International Handbook on public Private Partnerships, ed. by G. A. Hodge, C. Greve, A. E. Boardman, Edward Elgar: a Family Business in international Publishing 2012, s. 307-497. 
Większość przedsięwzięć przypada na kraje Europy, gdzie zrealizowano 900 umów na łączną wartość 207 mld euro (wartościowo 62,71\%, w tym Europa Środkowa i Wschodnia 3,48\%). Pozostała wartość PPP przypada na kraje Ameryki Północnej (10,45\%), Azji (9,76\%), Afryki (8,36\%) oraz na Australię $(6,62 \%)^{18}$. Strukturę rozmieszczenia terytorialnego przedsięwzięć PPP na świecie w latach 1994-2011 prezentuje wykres 1.1.

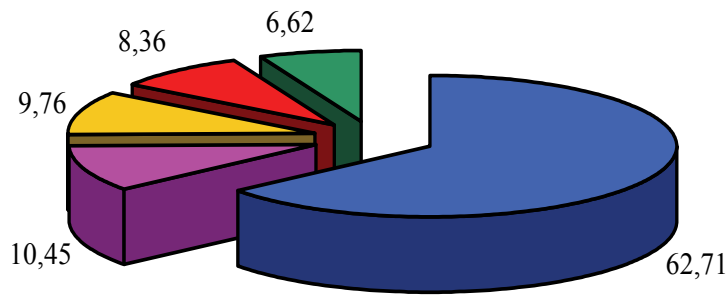

$\square$ Europa $\square$ Ameryka Północna $\square$ Azja $\square$ Afryka $\square$ Australia

Wykres 1.1. Struktura rozmieszczenia terytorialnego przedsięwzięć PPP na świecie w latach 1994-2011 (w \%)

Źródło: oprac. własne na podstawie European PPP Expertise Centre www.eib.org/epec/

$\mathrm{Na}$ przestrzeni ostatnich dwudziestu lat systematycznie rosła liczba i wartość przedsięwzięć PPP. Wzrostowy trend został zatrzymany w ostatnich latach w związku z kryzysem finansowym.

Rozwój partnerstwa publiczno-prywatnego w znacznej mierze zależy od zakresu zaangażowania państwa w promocję tej formuły. Istotną rolę odgrywa także władza lokalna. W zależności od tego jaką pozycję w państwie odgrywają samorządy, ich wkład w rozwój PPP jest zróżnicowany. W Wielkiej Brytanii pozycja samorządów nie należy do silnych, toteż wiele zadań o charakterze lokalnym i regionalnym jest realizowanych przez specjalne agencje rządowe, chętniej kierujące dotacje inwestycyjne na te działania, które miały być realizowane $\mathrm{w}$ formule PPP.

W Stanach Zjednoczonych samorządy cieszą się dużą swobodą, co jest sprzyjającym czynnikiem rozwoju PPP. Rządy federalne czy stanowe nie ingerują bezpośrednio w działalność samorządów i sposób realizacji inwestycji. Zaangażowanie rządu można uznać za symboliczne, ogranicza się ono do promowania przedsięwzięć partnerskich ${ }^{19}$.

${ }^{18} \mathrm{~K}$. Wąsowski, Rola zasad corporate governance $w$ partnerstwie publiczno-prywatnym, „Przegląd Corporate Governance” 2009, nr 2. www.spolkigieldowe.bdo.pl (22.03.2011)

${ }^{19}$ Por. A. Kopańska, Partnerstwo publiczno-prywatne jako sposób realizacji zadań..., s. 29. 
W Polsce rola władz samorządowych w dostarczaniu usług publicznych jest znaczna, co może stanowić istotny przyczynek rozwoju partnerstwa publiczno-prywatnego. Rola władz powinna polegać na zintensyfikowaniu działań promocyjnych oraz stworzeniu przyjaznego klimatu dla PPP.

\subsection{Pojęcie partnerstwa publiczno-prywatnego i jego cechy}

\subsubsection{Pojęcie partnerstwa publiczno-prywatnego $\mathrm{w}$ uregulowaniach organizacji międzynarodowych}

Pojęcie partnerstwa publiczno-prywatnego stało się terminem, który na stałe zagościł w słowniku pojęć ekonomicznych, politycznych i prawnych. Doczekało się ono wielu definicji, co oznacza, że nie jest pojęciem jednoznacznym. W praktyce partnerstwo publiczno-prywatne pojawiło się znacznie wcześniej niż jego definicja i teoretyczne konstrukcje. Przez wiele lat realizowano przedsięwzięcia PPP nie posługując się tym terminem. Przedsięwzięcia inwestycyjne realizowane we współpracy sektora publicznego z sektorem prywatnym przybierały konkretne formy, nie nadając im jeszcze waloru uniwersalności. Ich realizacja następowała na podstawie ogólnie obowiązujących przepisów prawnych, nie stwarzając potrzeby ścisłego zdefiniowania zjawiska. Skonkretyzowanie koncepcji i jednoczesne zdefiniowanie pojęcia nastąpiło dopiero w momencie legislacji postępowania opartego na współpracy sektorów publicznego i prywatnego ${ }^{20}$. Ze względu na różnorodność form występujących w państwach stosujących formułę PPP do realizacji inwestycji publicznych znajdujemy różne jego określenia. Większość z nich formułowana jest przez różnorodne instytucje doradcze, agencje rządowe czy instytucje finansowe uczestniczące w przedsięwzięciach partnerstwa. Geneza pojęcia partnerstwa publiczno-prywatnego wywodzi się z samej istoty partnerstwa.

Partnerstwo oznacza porozumienie między dwoma lub więcej stronami, które współpracują na rzecz osiągnięcia wspólnego celu. Jest najpełniejszą formą partycypacji społecznej, której podstawę stanowi wspólna analiza i hierarchizacja potrzeb społecznych oraz planowanie sposobu ich zaspokojenia. Podstawę współpracy stanowi kompromis, otwarcie na potrzeby drugiej strony oraz negocjacyjny charakter podejmowania decyzji ${ }^{21}$. Partnerstwo, to wzajemne relacje pomiędzy organizacjami, oparte na zaufaniu, mające doprowadzić do

${ }^{20}$ Por. J. Zysnarski, Partnerstwo publiczno-prywatne w sferze ustug komunalnych, Ośrodek Doradztwa i Doskonalenia Kadr Sp. z o.o., Gdańsk 2007, s. 7.

${ }^{21}$ Z. Woźniak, Między rywalizacja a partnerstwem. Bariery wspótpracy władz samorządowych z organizacjami pozarządowymi, [w:] Samoorganizacja spoleczeństwa polskiego. Trzeci sektor, red. P. Gliński, B. Lewenstein, A. Siciński, IFiS PAN, Warszawa 2002, s. 100. 
osiągnięcia wspólnie wyznaczonych celów ${ }^{22}$. Wymaga woli współpracy wszystkich zaangażowanych stron, opiera się na precyzyjnie skonstruowanych umowach określających prawa i obowiązki poszczególnych uczestników. Pojęcie „partnerstwo" ujmowane jest wielowymiarowo, w zależności od dziedziny społeczno-gospodarczej. Stąd można mówić o partnerstwie gospodarczym, przemysłowym bądź politycznym. Partnerami mogą być podmioty, organizacje, instytucje reprezentujące różne sektory. Partnerstwo tworzą ludzie i organizacje reprezentujące sektor publiczny, prywatny i społeczny, w sposób dobrowolny angażujący się $\mathrm{w}$ związek mający na celu uzyskanie wspólnych korzyści. Rozważając przesłanki tworzenia partnerstwa można wskazać na ich typy. W skali geograficznej mówi się o partnerstwach lokalnych, regionalnych czy międzynarodowych. Z punktu widzenia formy prawnej wyróżnia się partnerstwa formalne, nieformalne oraz publiczno-prywatne. Patrząc przez pryzmat podmiotu działania wyróżnia się partnerstwa projektowe, branżowe, partnerstwa dwui trójsektorowe. Związki partnerskie mogą reprezentować różny stopień sformalizowania - od luźnego aliansu po formalnie utworzone instytucje współzarządzające i współfinansujące, których działalność objęta jest ramami strategicznymi związanymi z osiągnięciem wyznaczonego celu ${ }^{23}$.

Partnerstwa, które tworzone są z inicjatywy organów publicznych, najczęściej stanowią partnerstwo określane jako publiczno-prywatne. Idea partnerskiej współpracy jest odpowiedzią na zmianę paradygmatu konkurencji i wyzwań, jakie niosą globalizacja, postęp techniczny i informatyzacja. Elementy te tworzą klimat sprzyjający funkcjonowaniu władz lokalnych w roli zarządców rozwoju lokalnego i regionalnego. Władze lokalne stają się aktywnym uczestnikiem procesów rozwojowych, a tworzenie partnerstwa staje się przejawem konkurencyjności, przedsiębiorczości i innowacyjności ${ }^{24}$.

Partnerstwo publiczno-prywatne najczęściej w początkowej fazie współpracy koncentruje się wokół spraw powiązanych z poprawą stanu infrastruktury i obiektów użyteczności publicznej. W dłuższej perspektywie współpraca powinna skupiać się na kwestiach związanych z rozwojem regionu ${ }^{25}$.

Różnorodność stosowanych pojęć partnerstwa publiczno-prywatnego utrudnia wskazanie jednej, powszechnie akceptowanej, wzorcowej definicji. W praktyce skutkuje to skłonnością do określenia mianem partnerstwa publicznoprywatnego zróżnicowanych form współpracy między sektorem publicznym

${ }^{22}$ T. Żabińska, Partnerstwo jako determinanta rozwoju turystyki w regionie, [w:] Turystyka w badaniach naukowych. Prace ekonomiczne, red. A. Nowakowska, M. Przydział, Wydawnictwo Wyższej Szkoły Informatyki i Zarządzania z siedzibą w Rzeszowie, Rzeszów 2006, s. 410.

${ }^{23}$ Szerzej: M. Słodowa-Hełpa, Partnerstwo: pojęcie, przedmiot, cele, [w:] Strategie zarzadzania wspótpraca, red. J. Hałdyński, Akademia Rolnicza im. A. Cieszkowskiego w Poznaniu, Centralna Baza Danych, Poznań 2006, s. 12-18.

${ }^{24}$ Por. T. Żabińska, Partnerstwo jako determinanta rozwoju turystyki..., s. 411.

${ }^{25}$ Szerzej: M. Słodowa-Hełpa, Partnerstwo: pojęcie, przedmiot, cele..., s. 12-18. 
i prywatnym. Powyższa tendencja została dostrzeżona przez Urząd Komitetu Integracji Europejskiej, który w swoich publikacjach partnerstwo publiczno-prywatne określa

jako każdego rodzaju współpracę sektora publicznego i sektora prywatnego, której celem jest realizacja szeroko pojętego dobra publicznego, lub też jako współpraca partnerska przy realizacji dużych przedsięwzięć z zakresu użyteczności publicznej ${ }^{26}$.

Współpraca może przyjmować różne konfiguracje w zależności od podejścia do PPP. Mogą to być umowy oparte na podziale zysku, kontraktowanie wykonania zadań publicznych, tworzenie podmiotów o ,specjalnym przeznaczeniu" (najczęściej w formie spółek) czy też realizowanie i zarządzanie całymi przedsięwzięciami inwestycyjnymi, a nawet prywatyzacja ${ }^{27}$.

Wzrost zainteresowania partnerstwem publiczno-prywatnym, jakie nastąpiło w latach osiemdziesiątych i dziewięćdziesiątych XX w. spowodował, iż wiele instytucji międzynarodowych w sposób bezpośredni zaangażowało się w rozwój i promocję idei współpracy między sektorami. Efektem tego zaangażowania był zbiór dokumentów regulujących PPP.

Komisja Europejska przygotowała kilka dokumentów, które nie stanowią jednak prawa bezwzględnie obowiązującego, a jedynie wskazówki, jak należy postępować w sytuacjach, gdy inwestycje będą realizowane przy współpracy sektora publicznego i partnera prywatnego. Opracowane dokumenty stanowią tzw. miękkie prawo w zakresie PPP. W opublikowanych w 2003 r. Wytycznych dotyczacych udanego partnerstwa publiczno-prywatnego Komisja Europejska za partnerstwo publiczno-prywatne uznała współpracę pomiędzy sektorem publicznym a sektorem prywatnym, w celu dostarczenia projektu lub wykonania zadania przypisanego historycznie sektorowi publicznemu. Strony obopólnie czerpią korzyści ze współpracy, odpowiednio do stopnia zaangażowania. Ideą współpracy jest takie kształtowanie stosunków pomiędzy stronami, aby każda z nich przejęła na siebie takie ryzyko, którym najlepiej potrafi zarządzać ${ }^{28}$.

Rok później Komisja Europejska w dokumencie Green paper on publicprivate partnerships and community law on public contracts and concessions (zwanym Zielona Ksiega PPP) jednoznacznie stwierdza brak definicji PPP na poziomie Wspólnoty. Niemniej jednak Księga podaje określenie, jakie przyjmuje dla partnerstwa publiczno-prywatnego i odnosi je do „form współpracy pomiędzy organami/władzami publicznymi a światem biznesu, którego celem

${ }^{26}$ Definicja umieszczona na stronie internetowej Urzędu Komitetu Integracji Europejskiej, www.polskawue.gov.pl (10.01.2011).

${ }^{27}$ Por. Ustawa o partnerstwie publiczno-prywatnym. Komentarz, red. M. Bejm, Wydawnictwo C. H. BECK, Warszawa 2010, s. 5.

${ }^{28}$ Wytyczne dotyczace udanego partnerstwa publiczno-prywatnego, Komisja Europejska, Bruksela 2003, s. 17. 
jest zapewnienie finansowania, konstrukcji, odnawiania, zarządzania i utrzymania infrastruktury bądź długotrwałe świadczenie usług"29. Komisja Europejska nie narzuca standardowego sposobu zawiązywania współpracy, zwraca wręcz uwagę na jego ewoluujący charakter, który dostosowuje się do wymogów związanych z konkretną inwestycją. Poza tym wypracowane praktyki można wielokrotnie stosować przy zbliżonych przedsięwzięciach.

Partnerstwo publiczno-prywatne w ujęciu Parlamentu Europejskiego to oparta na umowie współpraca pomiędzy sektorami publicznym i prywatnym, w której strona prywatna zobowiązuje się dostarczać usługi publiczne, stanowiące domenę sektora publicznego. Celem podjętej współpracy jest uzyskanie wyższego poziomu korzyści niż wynika to z tradycyjnego zamówienia publicznego (volume for money). Prawidłowo wdrożona koncepcja prowadzi do redukcji kosztów całego projektu, lepszej alokacji ryzyka, szybszego udostępnienia świadczonych usług oraz poprawy jakości, co w konsekwencji powinno przełożyć się na dodatkowy strumień wpływów pieniężnych ${ }^{30}$.

Bank Światowy partnerstwo publiczno-prywatne postrzega jako

formę długotrwałej współpracy sektora prywatnego i publicznego przy świadczeniu usług, których celem jest osiągnięcie obopólnych korzyści, a kluczową cechą jest jej ukierunkowanie na realizację celów społecznych i komercyjnych ${ }^{31}$.

Europejski Bank Inwestycyjny jest jedną z najważniejszych instytucji finansowych wspierających rozwój partnerstwa publiczno-prywatnego poprzez finansowe zaangażowanie $\mathrm{w}$ wiele przedsięwzięć. W publikacji Banku poświęconej partnerstwu publiczno-prywatnemu koncepcja PPP rozumiana jest jako związek pomiędzy podmiotem publicznym i podmiotem prywatnym, w którym to związek podmiot prywatny udostępnia swoje zasoby finansowe, materialne oraz wiedzę sektorowi publicznemu w celu dostarczania aktywów i usług w sferze publicznej ${ }^{32}$.

Europejski Bank Odbudowy i Rozwoju partnerstwo publiczno-prywatne rozumie jako długoterminowe porozumienie zawarte pomiędzy sektorem publicznym a prywatnym, w ramach którego sektor prywatny przyjmuje na siebie odpowiedzialność za planowanie, budowę, eksploatację i świadczenie

${ }^{29}$ Dokument roboczy na temat Zielonej Księgi Komisji w sprawie partnerstw publiczno-prywatnych oraz prawa wspólnotowego dotyczacego zamówień publicznych i koncesji, Komisja Rynku Wewnętrznego i Ochrony Konsumentów, Pe 374.146v01-00, s. 2.

${ }^{30}$ A. Renda, L. Schrefler, Public-Private Partnerships. Models and Trends in the Europen Union, European Parlament, IP/A/IMCO/SC/2005-161, February 2006.

${ }^{31}$ Definicja partnerstwa publiczno-prywatnego zamieszczona na stronie internetowej Banku Światowego www.worldbank.org

${ }^{32}$ Por. The EIB's role In Public-Private Partnerships (PPPS), Europan Investment Bank, 15 July 2004, s. 2. 
usług publicznych. Związane $\mathrm{z}$ odpowiedzialnością ryzyko stanowi element negocjacji i jest przypisywane stronie, która lepiej sobie $\mathrm{z}$ nim poradzi ${ }^{33}$.

Europejska Komisja Gospodarcza Organizacji Narodów Zjednoczonych odnosząc się do partnerstwa publiczno-prywatnego nie tworzy jednobrzmiącego tekstu, ale charakteryzuje koncepcję poprzez zbiór cech, do których należą ${ }^{34}$ :

- długoterminowość współpracy,

- transfer ryzyka do sektora prywatnego,

- różnorodne formy umowy pomiędzy sektorem publicznym a prywatnym,

- finansowe zaangażowanie sektora prywatnego,

- terminowość realizacji przedsięwzięcia,

- zachowanie odpowiedzialności za jakość i zakres usług publicznych przez sektor publiczny.

W publikacjach znajdujących się na stronach internetowych OECD partnerstwo publiczno-prywatne rozumiane jest jako długoterminowe kontrakty, w których sektor prywatny świadczy usługi w imieniu sektora publicznego w sektorze usług społecznych oraz realizuje inwestycje w infrastrukturę umożliwiającą realizację zadań publicznych ${ }^{35}$.

Wśród określeń stosowanych przez różne instytucje na uwagę zasługuje definicja jaką stosuje agencja ratingowa Standard \& Poor's, zgodnie z którą partnerstwo publiczno-prywatne to jakikolwiek średnio- lub długookresowy związek pomiędzy sektorem publicznym i prywatnym oparty na takim podziale ryzyk i korzyści, który odpowiada umiejętnościom, doświadczeniu i możliwościom finansowym każdego partnera oraz umożliwia uzyskanie zakładanych wyników ${ }^{36}$.

W Polsce termin partnerstwo publiczno-prywatne pojawił się w drugiej połowie lat dziewięćdziesiątych minionego stulecia i nie stanowił nazwy rodzajowej dla ściśle określonej współpracy pomiędzy jednostkami sektora publicznego a podmiotami prywatnymi. Skonkretyzowanie pojęcia nastąpiło w roku 2005 na gruncie ustawy o partnerstwie publiczno-prywatnym ${ }^{37}$. Zgodnie $\mathrm{z}$ art. 1 ust. 2

partnerstwo publiczno-prywatne, $w$ rozumieniu ustawy, to oparta na umowie o partnerstwie publiczno-prywatnym wspótpraca podmiotu publicznego i partnera prywatnego, stużaca realizacji zadania publicznego, jeśli odbywa się na zasadach określonych w ustawie.

${ }^{33}$ Public Finance Guidelines. PPP Toolkit, European Bank for Reconstruction and Development, 30 January 2004, s. 2.

${ }^{34}$ Guidebook on Promoting Good Govermance in Public-Private Partnerships, United Nations, New York-Genewa 2008, s. 1.

${ }^{35}$ Określenie partnerstwa publiczno-prywatnego pojawia się w licznych publikacjach oraz informacjach z sympozjów poświęconych problematyce, www.oecd.org

${ }^{36}$ Standard \& Poor's, A Global Survey Of PPPs: New Legislation Sets Context For Growth, London, October 2005, s. 1.

${ }^{37}$ Ustawa z dnia 28 lipca 2005 r. o partnerstwie publiczno-prywatnym, DzU, 2005, nr 169, poz. 1420 . 
W cytowanej ustawie nie pojawiła się klasyczna, jednolita definicja partnerstwa publiczno-prywatnego, a jedynie wskazano zasady, na których musi opierać się współpraca, aby została ona uznana za PPP. Należy jednak wyraźnie zaznaczyć, że ustawodawca w sposób pośredni określił PPP jako współpracę pomiędzy podmiotami publicznymi i prywatnymi $\mathrm{w}$ celu realizacji zadania publicznego opartej na przepisach ustawy. Jednoznacznie $\mathrm{z}$ takiego zapisu wynikało, iż partnerstwem publiczno-prywatnym nie może być żadne inne współdziałanie, nawet jeśli inne akty prawne przewidują podobne rozwiązania ${ }^{38}$.

W dniu 27 lutego 2009 r. weszła w życie nowa ustawa o partnerstwie publiczno-prywatnym, która uchyliła dotychczas obowiązujące przepisy. W ustawie z 19 grudnia 2008 r. o partnerstwie publiczno-prywatnym ustawodawca zaproponował nowe ujęcie, według którego partnerstwo publiczno-prywatne

jest wspólna realizacja przedsięwzięcia opartego na podziale zadań i ryzyk pomiędzy podmiotem publicznym i partnerem prywatnym ${ }^{39}$.

Obecnie w Polsce mianem PPP określa się długoterminową współpracę pomiędzy podmiotami sektora publicznego a podmiotami sektora prywatnego, której celem jest zapewnienie świadczenia usług użyteczności publicznej lub realizacja przedsięwzięć inwestycyjnych służących zaspokojeniu potrzeb publicznych.

W raporcie Amerykańskiej Izby Handlowej w Polsce poświęconym partnerstwu publiczno-prywatnemu koncepcja PPP traktowana jest jako

długoterminowa współpraca sektora prywatnego i publicznego przy świadczeniu usług. Celem współpracy jest osiągnięcie obopólnych korzyści, a kluczową cechą jest jej ukierunkowanie na realizację zarówno celów komercyjnych, jak i społecznych danego przedsię wzięcia $^{40}$.

Działające w Polsce organizacje - Centrum Partnerstwa PublicznoPrywatnego oraz Instytut Partnerstwa Publiczno-Prywatnego - zajmujące się promocją koncepcji, również zdefiniowały PPP. Centrum definiuje partnerstwo jako

współpracę pomiędzy jednostkami administracji rządowej i samorządowej (administracji publicznej) a podmiotami prywatnymi w sferach zazwyczaj kontrolowanych przez administrację, np. gospodarka komunalna. To przedsięwzięcia realizowane w oparciu o długotermi-

38 Szerzej: M. Kulesza, M. Bitner, A. Kozłowska, Ustawa o partnerstwie publicznoprywatnym, Dom Wydawniczy ABC, Warszawa 2006, s. 28-30.

${ }^{39}$ Ustawa z dnia 19 grudnia 2008 r. o partnerstwie publiczno-prywatnym, DzU., 2009, nr 19, poz. 100, art. 1 ust. 2.

${ }^{40}$ Partnerstwo publiczno-prywatne jako metoda rozwoju infrastruktury $w$ Polsce, Raport Amerykańskiej Izby Handlowej w Polsce, Warszawa 2002, s. 3. 
nową umowę zawartą pomiędzy sektorem publicznym i sektorem prywatnym, której celem jest stworzenie składników infrastruktury umożliwiającej świadczenie usług o charakterze publicznym $^{41}$.

Instytut Partnerstwa Publiczno-Prywatnego postrzega partnerstwo jako formę realizacji inwestycji infrastrukturalnych, w ramach której administracja publiczna dąży do sprawnego wywiązywania się z zadań publicznych, w tym świadczenia usług użyteczności publicznej we współpracy z sektorem prywatnym. Budowa i modernizacja infrastruktury jest konsekwencją lub warunkiem sprawnego wykonywania zadań. W konsekwencji PPP jest narzędziem w rękach władz publicznych, za pomocą którego mogą one sprawnie wywiązywać się ze spoczywających na nich obowiązków względem społeczeństwa ${ }^{42}$.

Przytoczone definicje powstały na gruncie stosowanej praktyki, czy to poprzez bezpośredni udział w finansowaniu przedsięwzięć inwestycyjnych realizowanych we współpracy międzysektorowej (określenia stosowane przez instytucje finansowe), czy też na gruncie unormowań prawnych przyjętych przez międzynarodowe organizacje $i$ agendy rządowe.

W Wielkiej Brytanii, która postrzegana jest jako prekursor koncepcji PPP, przez partnerstwo publiczno-prywatne rozumie się umowy, w ramach których dochodzi do wszelkiego rodzaju współpracy sektora publicznego z sektorem prywatnym, służącej opracowaniu i realizacji wspólnej taktyki w zakresie świadczenia usług lub budowy infrastruktury wykorzystywanej do zaspokajania potrzeb społecznych ${ }^{43}$. W roku $2000 \mathrm{w}$ dokumencie Public Private Partnerships - the Government's approach wyróżniono trzy różnorodne formy współpracy sektora publicznego z sektorem prywatnym, jako zasadnicze kategorie partnerstwa publiczno-prywatnego. W ramach poszczególnych kategorii ujęto ${ }^{44}$ :

1. Uwłaszczenie sektora prywatnego w odniesieniu do przedsięwzięć stanowiących własność publiczną w drodze sprzedaży udziałów większościowych lub mniejszościowych;

2. Private Finance Inititive (PFI) polegające na zawarciu długoterminowej umowy zakupu przez sektor publiczny od prywatnych podmiotów wysokiej jakości usług. Zawarcie umowy umożliwiło wykorzystanie doświadczenia i kapitału strony prywatnej, która przejęła na siebie, na okres trwania umowy,

41 Definicja zamieszczona na stronach internetowych Centrum Partnerstwa Publiczno-Prywatnego, www.centrum-ppp.pl

${ }^{42}$ Określenie partnerstwa publiczno-prywatnego zamieszczone przez Instytut PPP na stronie internetowej www.ippp.pl/instytut

${ }^{43}$ Określenie partnerstwa publiczno-prywatnego zamieszczone na stronie Ministerstwa Finansów Wielkiej Brytanii, www.hm-treasury.gov.uk/ppp (20.10. 2010).

${ }^{44}$ Szerzej: D. Hajdys, Partnerstwo publiczno-prywatne jako alternatywna forma finansowania działalności inwestycyjnej, [w:] Strukturalne reformy finansów publicznych $w$ Polsce $i$ Europie, red. J. Węcławski, „Studia i Prace Naukowe Polskiego Stowarzyszenia Finansów i Bankowości, Zeszyty Naukowe” 2007, nr 1, s. 63. 
odpowiedzialności za dostarczanie usług publicznych, jak również wybudowanie bądź utrzymanie infrastruktury w stanie, który umożliwia wywiązywanie się z postanowień umowy;

3. Sprzedaż usług świadczonych przez stronę publiczną, umożliwiających dostęp do doświadczenia sektora prywatnego oraz środków finansowych znajdujących się $\mathrm{w}$ jego dyspozycji w celu wykorzystania aktywów sektora publicznego na zasadach komercyjnych.

Termin PPP wykorzystywany jest do szerokiego zakresu uzgodnień roboczych - od luźnych, nieformalnych, po kontrakty usługowe typu np. DBFO ${ }^{45}$ i oficjalne spółki. W praktyce Wielkiej Brytanii w ramach partnerstwa publiczno-prywatnego najszerzej stosuje się PFI w odniesieniu do inwestycji, których istotą jest świadczenie usług publicznych o wysokim standardzie. To sprzyja systematycznemu inwestowaniu $\mathrm{w}$ infrastrukturę zgodnie $\mathrm{z}$ ujętym $\mathrm{w}$ umowie czasem i budżetem ${ }^{46}$.

W Irlandii kwestie związane $\mathrm{z}$ partnerstwem publiczno-prywatnym uregulowane zostały w ustawie, która nie zawiera jednoznacznej definicji. Określone zostały w niej warunki, na jakich strony publiczna i prywatna mogą zawierać porozumienia o wspólnej współpracy. Natomiast w dokumencie Framework for Public Private Partnerships, „,Working together for quality public service” partnerstwo określono jako porozumienie pomiędzy sektorem publicznym i partnerem prywatnym zawarte na podstawie umowy, z wyraźnie sformułowanym celem, obejmującym udostępnienie dobra i/lub usługi które mogłyby być dostarczane przez sektor publiczny w tradycyjny sposób ${ }^{47}$.

W Niemczech istotę PPP stanowi cel, rozumiany jako „Zwiększenie wydajności projektów infrastrukturalnych przez długoterminową współpracę sektora publicznego i sektora prywatnego". Kluczowe znaczenie ma całościowe podejście do przedsięwzięcia ${ }^{48}$.

Władze Czech stoją na stanowisku, że nie ma potrzeby wprowadzania do obiegu prawnego definicji partnerstwa publiczno-prywatnego, gdyż PPP, PFI (Private Finance Initiative), PSP (Private Sector Participation) oraz PPI (Private Participation in Infrastructure) stanowią jedynie pojęcia techniczne odpowiadające licznej grupie projektów, które mogą być realizowane we współpracy międzysektorowej $\mathrm{w}$ celu zaspokajania potrzeb społecznych stanowiących domenę sektora publicznego. Wymienione pojęcia stosowane są $\mathrm{w}$ praktyce $\mathrm{w}$ sposób mało uporządkowany w odniesieniu do wszystkich form współpracy ${ }^{49}$.

${ }^{45}$ DBFO (Desing-Build-Finance-Operate) rodzaj kontraktu obejmujący fazy: projektową, budowy i eksploatacji, inwestor jest finansującym całe przedsięwzięcie, szersze omówienie kontraktów w podpunkcie 1.4.2.

${ }^{46}$ Por. A. Cenkier, Partnerstwo publiczno-prywatne..., s. 46.

${ }^{47}$ Public Private Partnership, Framework for Public Private Partnerships, ,, Working together for quality public service”, November 2001, www.ppp.gov.ie.files/dokuments (20.10. 2010).

${ }^{48}$ Zob. D. Hajdys, Partnerstwo publiczno-prywatne jako alternatywna forma ..., s. 63.

${ }^{49}$ Por. A. Cenkier, Partnerstwo publiczno-prywatne..., s. 47. 
Rada Narodowa do spraw Partnerstwa Publiczno-Prywatnego Stanów Zjednoczonych Ameryki zdefiniowała partnerstwo publiczno-prywatne jako umowę pomiędzy agencją publiczną i podmiotem reprezentującym sektor prywatny. W ramach zawartego porozumienia umiejętności i zasoby każdej ze stron są wykorzystywane do dostarczania usług lub dóbr społeczeństwu. Strony dzielą się ryzykiem i korzyściami związanymi z dostarczaniem danych świadczeń objętych porozumieniem ${ }^{50}$.

\subsubsection{Pojęcie partnerstwa publiczno-prywatnego w literaturze}

W literaturze zarówno światowej, jak i polskiej istnieje wiele definicji partnerstwa publiczno-prywatnego. Wiele $\mathrm{z}$ nich bazuje na unormowaniach prawnych zaprezentowanych wcześniej, inne stanowią analizę pojęciową w kontekście warunków prawno-politycznych, wyznaczających ramy dla koncepcji.

W literaturze anglojęzycznej definicje PPP obarczone są z jednej strony konkretnym typem podejścia, $\mathrm{w}$ jakim koncepcja poddawana jest diagnozie i ocenie, a z drugiej strony uwarunkowane specyfiką terytorialną, która nadaje takiemu przedsięwzięciu unikatowy charakter. Specyfika danego terytorium wyznaczana jest przez system uwarunkowań prawno-politycznych i relacje pomiędzy poszczególnymi uczestnikami przedsięwzięcia. Inne wyzwania stoją przed PPP na obszarach o silnie rozwiniętym kapitale relacyjnym podmiotów publicznych i prywatnych, a inaczej przebiegać ono będzie na obszarach, gdzie trudno buduje się relacje partnerskie. Łatwiej koncepcje PPP rozwijają się w gminach przedsiębiorczych, a trudniej w silnie zhierarchizowanych i nieinnowacyjnych środowiskach skupionych wokół władz lokalnych ${ }^{51}$. R. W. McQuaid definiuje PPP jako

przedsięwzięcie partnerskie pomiędzy podmiotem publicznym i prywatnym w celu realizacji wspólnych, jednakże nie identycznych celów poprzez różne mechanizmy realizacji i zmieniającą się rolę kluczowych uczestników ${ }^{52}$.

Wzajemne korzyści wynikające ze współpracy stanowią wartość dodaną dla jej uczestników oraz odbiorców dóbr i/lub usług dostarczanych w tej formule.

${ }^{50}$ Pojęcia podane na stronach internetowych The National Council for Public-Private Partnerships, www.ncppp.org (20.10. 2010).

${ }^{51}$ Zob. M. Baron, A. Ochojski, Partnerstwo publiczno-prywatne - próba systematyzacji doświadczeń, [w:] Studia regionalne w Polsce. Teoria, polityka, projektowanie, red. F. Kużnik, Prace Naukowe Akademii Ekonomicznej im. K. Adameckiego w Katowicach, Katowice 2005, s. 347.

${ }^{52}$ R. W. McQuaid, The Role of Partnerships in Urban Economic Regeneration, ,International Journal of Public-Private Partnerships. Sheffield Hallam University Press" [Sheffield] 1999, vol. 2 (1), s. 3-5; cyt. za . M. Baron, A. Ochojski, Partnerstwo publiczno-prywatne - próba systematyzacji..., s. 348 . 
Wartość dodana stanowi istotę PPP, a nie, jak to jest najczęściej przyjmowane, pozyskanie określonych zasobów. Znacznie szerzej PPP postrzega N. Flynn ${ }^{53}$, dla którego współdziałanie sektorów publicznego i prywatnego jest próbą zmian w obszarze kontroli finansowej i zarządzania poprzez transfer określonych aspektów usług publicznych na rzecz sektora prywatnego, z uwzględnieniem racjonalnego podziału ryzyk. N. Flynn wskazuje również na odmienny charakter PPP i PFI. Różnica pomiędzy formami polega na długości trwania współpracy. O ile PFI mają, według autora, ściśle określony czas trwania, którym często jest moment zakończenia inwestycji, o tyle w przypadku PPP współpraca z reguły nawiązywana jest na kilkunastoletni okres z możliwością jej przedłużenia. Obecnie obie formy często traktowane są jako bliskoznaczne, a ich rozróżnienie wynika z przesłanek historycznych (określenie PFI pochodzi z Wielkiej Brytanii, gdzie w latach dziewięćdziesiątych zostało zastąpione pojęciem PPP).

S. H. Linder partnerstwo publiczno-prywatne postrzega przez pryzmat sześciu elementów charakteryzujących tę formułę. Według autora na partnerstwo publiczno-prywatne można spojrzeć jako na ${ }^{54}$ :

1. Element reformy zarządzania; postrzegane jest wówczas jako narzędzie zmiany sposobu zarządzania polegającej na przepływie wiedzy i doświadczenia ze sfery biznesu do sfery administracji;

2. Komercjalizację zadań związanych z świadczeniem usług publicznych;

3. Moralne odrodzenie władz zarządzających sprawami publicznymi;

4. Zmianę (przerzucenie) ryzyk, będącą odpowiedzią władz publicznych na ograniczenia fiskalne i zainteresowanie sektora prywatnego sprawami (zadaniami) publicznymi;

5. Restrukturyzację usług publicznych; dostosowanie procedur administracyjnych $\mathrm{w}$ zakresie realizacji zadań publicznych do procedur występujących w sektorze prywatnym;

6. Zmianę pozycji władzy; następuje ewolucja postrzegania przez władzę publiczną etosu współpracy z biznesem, korzystnego podziału odpowiedzialności, wiedzy i ryzyka oraz umiejętności negocjowania współpracy i osiągania kompromisu.

Według S. H. Lindera partnerstwo publiczno-prywatne to formuła polegająca na zmianie zachowania władz publicznych w kontekście realizacji zadań publicznych i czynnego zaangażowania partnera publicznego $\mathrm{w}$ realizację owych zadań. Istotne miejsce zajmuje problematyka negocjacji warunków współpracy oraz osiągnięcie kompromisu w kwestii podziału ryzyk pomiędzy strony.

${ }^{53}$ N. Flynn, Public Sector Management, Pearson Education Ltd., Essex 2002, s. 257.

${ }^{54}$ S. H. Linder, Coming to terms with the public-private partnership, „American Behavioral Scentist" 1999, 43 (1), s. 35-51. 
Kolejne podejście, często w literaturze przywoływane, prezentuje B. G. Peters. Zdaniem autora partnerstwo publiczno-prywatne ${ }^{55}$ :

1) obejmuje dwa lub więcej podmiotów, z których jeden zaliczany jest do sektora publicznego,

2) to równoprawne traktowanie partnerów realizujących zadanie publiczne,

3) to trwały związek pomiędzy partnerami i ich wzajemnymi interakcjami,

4) polega na konieczności finansowego lub materialnego partycypowania w związku,

5) to wspólna odpowiedzialność wobec odbiorców dóbr i usług publicznych za skutki podjętych wspólnie działań.

Spojrzenie B. G. Petersa na istotę partnerstwa publiczno-prywatnego jest wyprowadzone $\mathrm{z}$ formalno-prawnego punktu widzenia. Definicja PPP jest wypunktowaniem niezbędnych, formalnych elementów, jakie muszą zaistnieć, aby można było relacje pomiędzy co najmniej dwoma podmiotami z różnych sektorów nazwać partnerstwem publiczno-prywatnym. Zbieżne poglądy na definicję partnerstwa reprezentuje O. J. Andersen, dodatkowo zwracając uwagę na rozwiązania organizacyjne, które muszą $\mathrm{w}$ formule być dostosowane do celów, zakresu zadań oraz formy finansowania ${ }^{56}$.

Znaczenie podziału zadań i wynikających z nich zobowiązań oraz ryzyk zaakcentowane zostało w pozycji P. Nijkampa ${ }^{57}$, gdzie partnerstwo publicznoprywatne definiowane jest jako zinstytucjonalizowana forma współpracy podmiotów publicznych i prywatnych, które na podstawie zawartej umowy współpracują na rzecz wspólnie określonego celu, a obie strony przyjmują ryzyka inwestycyjne na podstawie z góry określonej dystrybucji przychodów i kosztów.

Klijn \& Reisman ${ }^{58}$, obok wymienianych cech, zwracają uwagę na wartość dodaną wynikającą z partnerstwa publiczno-prywatnego. Według nich partnerstwo to oznacza trwałą (długoterminową) współpracę podmiotów publicznych i prywatnych, w której ryzyko, koszty i korzyści są wspólne, a wynikiem jest

${ }^{55}$ B. G. Peters, Witch alittle help from our friends: public-private partnerships as institutions and instruments, [w:] J. Pierre (ed.), Partnerships in Urban Governance: European and American Experiences, Macmillan, London 1997, s. 11-33.

${ }^{56}$ Definicja partnerstwa publiczno-prywatnego w ujęciu Andersena złożona jest z czterech charakterystycznych dla formuły (powszechnie uznanych) elementów. Autor wymieniane elementy charakteryzuje w sposób odpowiadający podejściu wcześniej omówionej definicji Petersa. O. J. Andersen, Public-private partnerships: organizational hybrids as channel for local mobilisation and participation?, „Scandinavian Political Studies” 2004, 27 (1), s. 1-21.

${ }^{57}$ P. Nijkamp, M. Burch, G. Vindigni, A comparative institutional evaluation of publicprivate partnerships in Dutch urban land-use and revitalization projects, „Urban Studies” 2002, 39 (10), s. 1865.

${ }^{58}$ E. H. Klijan, G. R. Teisman, Institutional and strategic barriers to public-private partnership: an analysis of Dutch cases, „Public Money and Management” 2003, 23 (3), s. 137. 
wartość dodana, której przejawem powinno być ograniczenie kosztów i wzrost efektywności świadczonych usług publicznych.

Zaprezentowane określenia wyraźnie akcentują formalne wymogi, które składają się na elementy definicji partnerstwa publiczno-prywatnego. Przytoczone definicje zawierają tylko część określeń przyjętych przez podmioty stosujące koncepcję PPP. Pomimo zastosowania różnorodnych sformułowań są zgodne co do istoty partnerstwa, a zarazem oddają różnorodność i złożoność zjawiska, jakie występuje w praktyce.

W literaturze polskiej dominuje punkt widzenia władz (podmiotów) publicznych na koncepcję PPP. Przykładem jest ujęcie zaproponowane przez B. P. Korbusa i M. Strawińskiego, według których partnerstwo publiczno-prywatne to

forma (instrument) sprawnego wywiązywania się przez administrację (czy obsługiwaną przez nią władzę) z zadań publicznych, w tym świadczenia usług użyteczności publicznej we współpracy z partnerem prywatnym, a sama budowa lub modernizacja infrastruktury jest jedynie konsekwencją lub warunkiem sprawnego wykonywania określonych zadań stawianych władzom lokalnym ${ }^{59}$.

Tak sformułowaną definicję propaguje Instytut Partnerstwa PublicznoPrywatnego w Polsce. Główny nacisk położony zostaje na obowiązki władz lokalnych wobec społeczeństwa, a przyjęte formy realizacji zadań stanowią jedynie narządzie wywiązywania się z nałożonych obowiązków.

Zdaniem J. Stefanowicza wszelkie formy zaangażowania pozagospodarczego środków prywatnych, bez powiększania zadłużenia publicznego, dla realizacji zadań publicznych można określić mianem partnerstwa ${ }^{60}$.

M. Moszoro przez partnerstwo publiczno-prywatne rozumie

przedsięwzięcie o charakterze użyteczności publicznej prowadzone przez współpracujące podmioty prywatne i publiczne, przy wzajemnym zaangażowaniu instytucjonalnym, kapitałowym oraz solidarnym podziale korzyści i ryzyka z niego wynikających ${ }^{61}$.

\section{Dla K. Brzozowskiej partnerstwo publiczno-prywatne oznacza}

współpracę między sektorami: publicznym i prywatnym, polegającą na realizacji zadań tradycyjnie wykonywanych przez sektor publiczny ${ }^{62}$.

Jest to model przynoszący korzyści obu stronom, rozdzielający zadania i ryzyko w sposób uwzględniający specyfikę danego sektora. Każdy z sektorów

${ }^{59}$ B. P. Korbus, M. Strawiński, Partnerstwo publiczno-prywatne. Nowa forma realizacji zadań publicznych, Wydawnictwo Prawnicze LexisNexis, Warszawa 2006, s. 23.

${ }^{60}$ J. A. Stefanowicz, Kiedy partnerstwo publiczno-prywatne, www.freepress.org.pl (10.11. 2010).

${ }^{61}$ M. Moszoro, Partnerstwo publiczno-prywatne..., s. 49.

${ }^{62}$ K. Brzozowska, Partnerstwo publiczno-prywatne w Europie, cele, uwarunkowania, efekty, Wydawnictwo Fachowe CeDeWu, Warszawa 2010, s. 30. 
działa na tym obszarze, na którym jest specjalistą, co umożliwia wykonanie zadań w sposób bardziej efektywny niż w okresie poprzedzającym nawiązanie współpracy.

J. Zysnarski partnerstwo publiczno-prywatne rozumie jako współpracę podmiotów zaliczanych do sektora publicznego oraz podmiotów z sektora prywatnego, której przedmiotem jest sfera zadań publicznych ${ }^{63}$.

A. Cenkier definiuje formułę PPP jako

współpracę sektora publicznego z sektorem prywatnym w realizacji zadań publicznych, umożliwiającą każdej ze stron osiągniecie własnego celu: sektorowi publicznemu - zaspokojenie potrzeb zbiorowych, inwestorom prywatnym - uzyskanie satysfakcjonującej ich stopy zwrotu $^{64}$.

Mnogość definicji i podejść do PPP w literaturze powoduje, że trudno wyodrębnić jedną uniwersalną, standardową definicję, która unifikowałaby współpracę pomiędzy sektorem publicznym i sektorem prywatnym, eliminując różnorodność i wieloznaczność form. Funkcjonujące definicje można pogrupować na te zawarte w przepisach prawa regulujących partnerstwo publicznoprywatne oraz ukształtowane przez praktykę. Przytoczone definicje zawierają w swojej treści trzy aspekty: finansowy, prawny i administracyjno-organizacyjny (tab. 1.1).

Tabela 1.1

Aspekty definicji partnerstwa publiczno-prywatnego

\begin{tabular}{|l|l|}
\hline \multicolumn{1}{|c|}{ Aspekt } & \multicolumn{1}{c|}{ Zakres } \\
\hline Aspekt finansowy & $\begin{array}{l}\text { - plan finansowy współpracy } \\
\text { - podział ryzyk } \\
\end{array}$ \\
\hline \multirow{2}{*}{ Aspekt prawny } & $\begin{array}{l}\text { - } \text { umowy } \\
\text { - podmioty } \\
\text { - przepisy prawa }\end{array}$ \\
\hline Aspekt administracyjno-organizacyjny & $\begin{array}{l}\text { - zadania i zakres odpowiedzialności } \\
\text { - harmonogram prac } \\
\text { - zakres uprawnień do podejmowania decyzji }\end{array}$ \\
\hline
\end{tabular}

Źródło: oprac. własne na podstawie M. Bult-Spiering, G. Dewulf, Strategic Issues in PublicPrivate Partnerships. An international perspective, Blackwell Publishing, Oxford 2006, s. 19.

W każdym z przytoczonych ujęć pojawiają się charakterystyczne czynniki, którymi są:

${ }^{63}$ J. Zysnarski, Partnerstwo publiczno-prywatne w sferze ustug komunalnych, Ośrodek Doradztwa i Doskonalenia Kadr Sp. z o.o., Gdańsk 2007, s. 9.

${ }^{64}$ A. Cenkier, Partnerstwo publiczno-prywatne, INFOS, Zagadnienia społeczno-gospodarcze nr 13 (37), Biuro Analiz Sejmowych, Warszawa 2008, s. 1. 
- potrzeba publiczna,

- podmiot publiczny,

- partner prywatny,

- usługa,

- współpraca.

Jednoczesne wystąpienie wymienionych czynników jest przesłanką do podjęcia partnerstwa publiczno-prywatnego, które przełoży się na:

- partnerskie działanie,

- całościowe podejście do przedsięwzięcia,

- połączenie kompetencji,

- podział korzyści i ryzyk,

- zachowanie odpowiedzialności i kontroli przez podmiot publiczny.

Wzajemne zależności i powiązania jakie zachodzą w modelu partnerstwa publiczno-prywatnego przedstawia wykres 1.2.

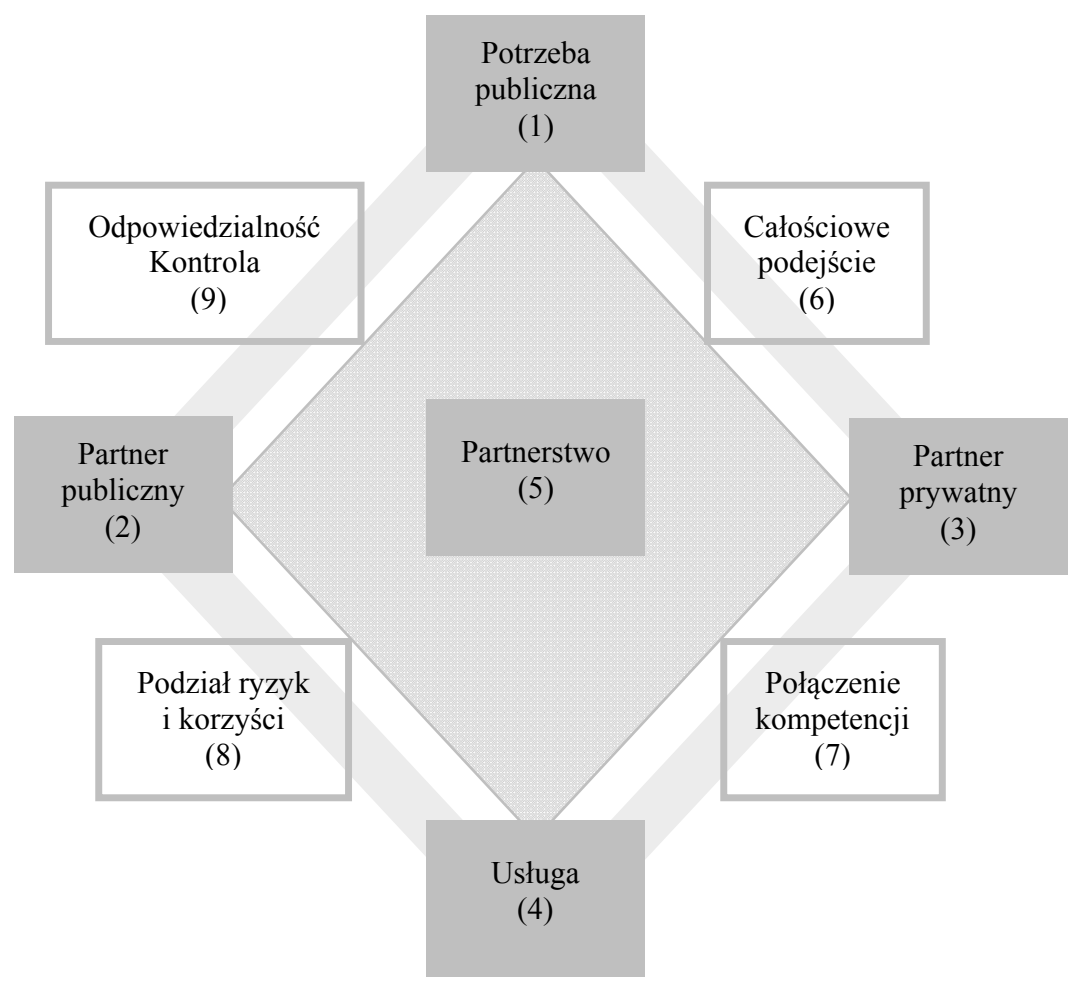

Wykres 1.2. Wzajemne powiązania w formule partnerstwa publiczno-prywatnego

Źródło: A. Gajewska-Jedwabny, Partnerstwo publiczno-prywatne, Wydawnictwo C. H.

Beck, Warszawa 2007, s. 4 
Na pojęcie partnerstwo publiczno-prywatne można spojrzeć w kontekście jego zakresu, wyróżniając ujęcie węższe i szersze. Rozszerzone ujęcie wskazuje, że partnerstwem publiczno-prywatnym są wszelkie formy współpracy sektora publicznego z sektorem prywatnym przy realizacji szeroko pojętego dobra publicznego. Węższe ujęcie zostało sprecyzowane dla przedsięwzięć o charakterze użyteczności publicznej prowadzonych przez podmioty publiczne i prywatne, przy wzajemnym zaangażowaniu, podziale ryzyk i korzyści wynikających ze wspólnego zaangażowania ${ }^{65}$.

Sektor publiczny i sektor prywatny od zawsze funkcjonowały obok siebie, a skala i zakres ich współpracy na przestrzeni wieków ulegały zmianie. Sektor publiczny był zawsze, choć w różnym stopniu, hermetyczny i wykazywał tendencję do samowystarczalności w zakresie swej działalności. W tych warunkach przekazanie zadań publicznych do realizacji sektorowi prywatnemu traktowane było jako przejaw rozdawania przywilejów, nagradzania. Wiek XX był okresem, w którym sektor publiczny był niemalże jedynym dostawcą dóbr i usług publicznych. W konsekwencji mieliśmy do czynienia z jednej strony z niską efektywnością usług, których rozmiary nie odpowiadały szybko rosnącym potrzebom zgłaszanym przez obywateli, a $\mathrm{z}$ drugiej strony $\mathrm{z}$ rosnacym zadłużeniem sektora publicznego. W latach siedemdziesiątych minionego stulecia rządzący systematycznie ograniczali zakres stosowania koncepcji „welfare state” i coraz częściej przekazywali zadania publiczne do sektora prywatnego.

Tak rozumiane partnerstwo publiczno-prywatne charakteryzują następujące $\operatorname{cechy}^{66}$ :

- długoterminowość umowy; partner prywatny staje się długoletnim dostawcą usługi publicznej, co skutkuje koniecznością zawarcia umowy na okres kilkunastu lat; umożliwi to planową, harmonijną politykę władz lokalnych w zakresie rozwoju infrastruktury i sfery usług publicznych; działanie strony prywatnej nie ogranicza się tylko do pojedynczego wykonania zadania, ale wymaga długoterminowego zaangażowania stron (strona prywatna wykonuje inwestycje i dostarcza zamówione usługi, a strona publiczna planuje i monitoruje wykonanie),

${ }^{65}$ K. Brzozowska, Partnerstwo publiczno-prywatne..., s. 21.

${ }^{66}$ Szerzej na temat cech w: A. Cenkier, Partnerstwo publiczno-prywatne..., s. 52; K. Brzozowska, Partnerstwo publiczno-prywatne..., s. 30; K. Kietlińska, Rozwój form powiazań instytucji sektora publicznego i prywatnego $w$ Polsce, [w:] Nauki finansowe wobec współczesnych problemów gospodarki polskiej. Finanse publiczne, t. I, red. S. Owsiak, Akademia Ekonomiczna w Krakowie, Kraków 2004, s. 45; Nowoczesne systemy realizacji zadań publicznych. Poradnik $P P P$, red. M. Chałas, Dom Wydawniczy ELIPSA, Warszawa 2006, s. 18. 
- konkurencyjność ofert; wybór partnera prywatnego dokonuje się w sposób obiektywny, oparty na postępowaniu przetargowym,

- efektywny podział zadań i ryzyk dokonany według zasady, że każda ze stron przyjmuje na siebie te zadania i ten rodzaj ryzyka, którym potrafi najlepiej zarządzać,

- wykorzystanie zdolności zarządczych podmiotu prywatnego, które daje szansę na prawidłowy, zgodny z przyjętym harmonogramem, przebieg realizacji przedsięwzięcia stanowiącego przedmiot umowy,

- realizacja wyznaczonego celu i osiągnięcie korzyści przez strony umowy; każdy z podmiotów realizuje określone zadanie, strona publiczna zaspokaja potrzeby społeczne, strona prywatna realizuje satysfakcjonującą ją stopę zwrotu. Osiąganie celów jednostkowych przekłada się na cel główny zawarty w umowie i będący najważniejszym powodem nawiązania współpracy,

- zwiększenie wartości (value for money); niezbędne jest przeprowadzenie analizy porównawczej pomiędzy sumą korzyści wynikających z zastosowania PPP w odniesieniu do kosztów. Istotna rolę we wskaźniku odgrywają koszty, które należy porównać w metodzie tradycyjnej (zamówienie publiczne) koncepcji PPP,

- oparcie współpracy na zasadach uwzględniających realia rynkowe, ściśle związane z osiąganiem wyznaczonego celu. Oparcie współpracy na zasadach rynkowych daje pierwszeństwo uwarunkowaniom ekonomicznym, a nie politycznym, w realizacji przedsięwzięć i zaspokajaniu potrzeb publicznych, dzięki czemu jest wielce prawdopodobne, że świadczenie dóbr i usług stanie się efektywniejsze i tańsze.

Współpraca podmiotów, aby uznana została za partnerstwo publiczno-prywatne powinna odpowiadać następującym zasadom ${ }^{67}$ :

1) musi opierać się na umowie o partnerstwie publiczno-prywatnym,

2) musi być zawiązana pomiędzy podmiotami, które w ustawie o PPP zostały określone jako podmiot publiczny i jako partner prywatny,

3) musi służyć realizacji zadania publicznego,

4) przedmiotem umowy o PPP musi być realizacja przez partnera prywatnego przedsięwzięcia za wynagrodzeniem na rzecz podmiotu publicznego,

5) parter prywatny co najmniej w części powinien ponosić nakłady na realizację przedsięwzięcia lub zapewnić ich poniesienie przez podmioty trzecie,

6) partnerstwo powinno przynosić korzyści dla interesu publicznego, przeważające w stosunku do korzyści wynikających z innych sposobów realizacji tego przedsięwzięcia,

${ }^{67}$ Por. M. Kulesza, M. Bitner, A. Kozłowska, Ustawa o partnerstwie publiczno-prywatnym..., s. 29. 
7) przystąpienie do współpracy z partnerem prywatnym powinno być poprzedzone zamieszczeniem informacji o planowanej realizacji zadania $\mathrm{W}$ „Biuletynie Zamówień Publicznych” (BZP) i „Biuletynie Informacji Publicznej” (BIP), „Europejskim Dzienniku Zamówień Publicznych” („Tenders Electronic Daily" - TED) ${ }^{68}$,

8) wybór partnera prywatnego musi zostać dokonany na zasadach i w trybie określonym w ustawie o PPP,

9) realizację przedsięwzięcia ma określać umowa zawarta pomiędzy stronami.

Partnerstwo publiczno-prywatne to złożony proces, obejmujący całokształt działań organizacyjnych, prawnych i finansowych zmierzających do osiągnięcia założonego celu, który wynika $\mathrm{z}$ roli i funkcji podmiotu publicznego.

Udział partnerów prywatnych $\mathrm{w}$ przedsięwzięciach realizowanych $\mathrm{w}$ formule partnerstwa publiczno-prywatnego umożliwia sektorowi publicznemu dostęp do:

1) środków finansowych sektora prywatnego, do których sektor publiczny nie ma dostępu przy tradycyjnych metodach finansowania zadań,

2) nowoczesnych, innowacyjnych rozwiązań, które podmioty prywatne udostępniają w ramach realizowanego przedsięwzięcia,

3) wiedzy i umiejętności prywatnego inwestora.

Na potrzeby niniejszej pracy autorka przyjęla, że partnerstwem publicznoprywatnym będzie formula finansowania zadań publicznych oparta na wspótpracy dwóch sektorów - publicznego i prywatnego - $w$ zakresie realizacji przedsięwzięć inwestycyjnych lub świadczenia ustug, która będzie efektem zgodnej woli w zakresie osiaganych korzyści (volue for money) z przedsięwzięcia $i$ racjonalnego podziatu ryzyk z nim związanych, będaca rezultatem wychodzenia naprzeciw oczekiwaniom i potrzebom zglaszanym przez użytkowników, oparta $n a$ regulacjach prawnych $w$ zakresie PPP. Jednocześnie formuła ta zwiększa możliwości inwestycyjne sektora publicznego, gdyż środki finansowe zaangażowane w przedsięwzięcia PPP pochodzą od prywatnego inwestora. Tym samym sektor publiczny własne środki pieniężne może przeznaczać na zadania, których realizacja byłaby niemożliwa przy tradycyjnej metodzie finansowania wszystkich zadań. Zmienia się rola podmiotu publicznego z głównego dostawcy zadań publicznych w zarządcę i kontrolera. Rośnie zarazem znaczenie i rola sektora prywatnego z wykonawcy w dostawcę i koordynatora, a także głównego inwestora.

68 „Biuletyn Zamówień Publicznych” i „Europejski Dziennik Zamówień Publicznych” zamiennie stosuje się $\mathrm{w}$ pracy określenie publikatory. 


\subsection{Aktualne regulacje prawne w zakresie partnerstwa publiczno- -prywatnego w Unii Europejskiej i w Polsce}

\subsubsection{Instytucja partnerstwa publiczno-prywatnego $w$ regulacjach Unii Europejskiej}

Przepisy dotyczące partnerstwa publiczno-prywatnego pojawiły się dopiero w ostatnich latach i były konsekwencją czynnego zaangażowania podmiotów prywatnych $\mathrm{w}$ realizacje zadań stanowiących domenę sektora publicznego. Ponadto pojawiające się regulacje prawne stanowiły próbę uregulowania specyficznych rozwiązań występujących $\mathrm{w}$ procesie inwestycyjnym realizowanym w modelu PPP.

$\mathrm{W}$ połowie lat dziewięćdziesiątych XX w. rosnąca liczba inwestycji publicznych realizowanych we współpracy z prywatnym inwestorem spowodowała żywe zainteresowanie Komisji Europejskiej, która aktywnie zaangażowała się w proces uregulowania mechanizmu. Podjęte działania wynikały z konieczności zapewnienia zgodności z prawem unijnym oraz przygotowania opracowań, które stanowiłyby wskazówki dla tworzenia standardów obejmujących najlepsze praktyki.

Do podstawowych dokumentów zajmujących się problematyką PPP na szczeblu unijnym należy zaliczyć:

1) Wytyczne dotyczace udanego partnerstwa publiczno-prywatnego (Guidelines for Successful Public-Private Partnerships) ze stycznia 2003 r.

2) Zielona Ksiege w sprawie partnerstwa publiczno-prywatnego oraz prawa wspólnotowego w zakresie zamówień publicznych i koncesji (Green Paper on Public-Private Partnerships and Community Law on Public Contracts and Concessions) z 30 kwietnia 2004 r.

3) decyzję Eurostatu dotyczącą wpływu przedsięwzięć typu PPP na dług i deficyt publiczny.

Wytyczne należą do najbardziej znanych dokumentów przygotowanych przez Komisję Europejską dotyczących PPP. Dokument jest swoistym stanowiskiem Komisji Europejskiej odnoszącym się do form i zasad współpracy sektora publicznego z sektorem prywatnym podejmowanej w celu realizacji inwestycji o charakterze publicznym. Wytyczne stanowią istotny fundament dla przedsięwzięć realizowanych w ramach PPP. Podstawowym celem Wytycznych było uporządkowanie najważniejszych zagadnień i terminologii związanej z formułą PPP oraz przedstawienie wskazówek, jak postępować w sytuacji, gdy strony decydują się na wykorzystanie partnerstwa publiczno-prywatnego przy realizacji zadań publicznych. 
Dokument składa się z pięciu tematycznych części, które dotyczą ${ }^{69}$ :

- struktur PPP, ich odpowiedniości i czynników gwarantujących powodzenie,

- struktur prawnych i regulacyjnych,

- finansowych i gospodarczych następstw PPP,

- integracji finansowania dotacyjnego z celami PPP,

- koncepcji, planowania i wdrożenia PPP.

$\mathrm{Z}$ treści wynikają kluczowe kwestie dla mechanizmu PPP, obejmujące ${ }^{70}$ :

- zapewnienie otwartego dostępu do rynku i konkurencji, czego celem jest przeciwdziałanie negatywnym skutkom pojawiającym się w przypadku naruszenia warunków uczciwej konkurencji; przedsięwzięcia PPP muszą być realizowane zgodnie $\mathrm{z}$ zasadami wolnego rynku oraz procedur związanych $\mathrm{z}$ wyborem partnera prywatnego,

- zabezpieczenie interesu publicznego i maksymalizację korzyści dla społeczeństwa,

- uzyskanie pełnej kompatybilności między rozwiązaniami partnerstwa publiczno-prywatnego a zasadami pomocy publicznej,

- zdefiniowanie poziomu grantów unijnych - przy zapewnieniu, że partner prywatny nie będzie osiągał nienależnych zysków,

- wybór najbardziej odpowiedniej formy PPP,

- czynniki sukcesu oraz ograniczenia.

Wytyczne nie stanowią metodologii nawiązania współpracy pomiędzy sektorami, ani wytycznych dla polityki w tym zakresie, lecz prezentują podstawowe kwestie związane z formalno-organizacyjnymi i finansowymi kwestiami, które winny być rozwiązane przed nawiązaniem współpracy pomiędzy sektorem publicznym a partnerem prywatnym. Nacisk kładzie się na kwestie finansowe i zakres ryzyka towarzyszący przedsięwzięciom. Alokacja ryzyka powinna wynikać z możliwości i doświadczenia stron. Finansowanie przedsięwzięć PPP powinno odpowiadać normom europejskim, łącznie z wymiernymi efektami społecznymi wynikającymi z ich realizacji.

Zwraca się uwagę na istotną rolę struktur instytucjonalnych, których zadaniem powinno być kreowanie przyjaznego klimatu dla rozwoju PPP oraz stworzenie ram prawnych dla ochrony interesów wszystkich stron uczestniczących w przedsięwzięciach PPP. Wskazuje się, że w początkowym okresie rozwoju PPP rola instytucji skoncentrowana będzie na stworzeniu odpowiednich ram prawnych, natomiast $\mathrm{w}$ miarę zdobywania doświadczenia rola takich instytucji ewoluować będzie w kierunku doradztwa, pomocy przy wyborze formy pozyskania kapitału prywatnego oraz wsparcia politycznego. Powodzenie PPP w znacznej mierze uzależnione jest od przyjętych rozwiązań prawnych.

${ }^{69}$ Wytyczne dotyczace udanego partnerstwa publiczno-prywatnego, Komisja Europejska, www.ippp.pl (20.07.2008), s. 5.

${ }^{70}$ Por. J. Zysnarski, Partnerstwo publiczno-prywatne..., s. 59. 
Kwestie proceduralne mogą być rozwiązane na szczeblu unijnym, krajowym (przykład Wielkiej Brytanii), regionalnym (Francja), lokalnym badź branżowym. Przepisy w państwach członkowskich muszą być zgodne z uregulowaniami prawnymi na szczeblu unijnym, co prowadzi do zachowania hierarchii reżimów prawnych. Hierarchię reżimów prawnych w ramach PPP przedstawia wykres 1.3 .

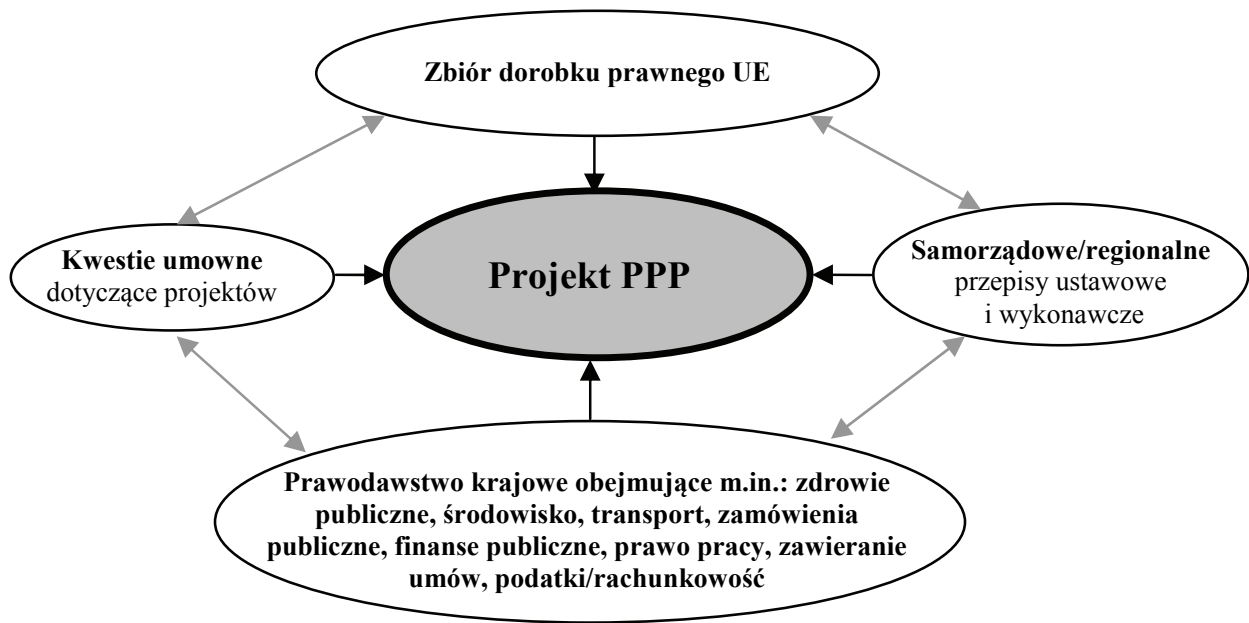

Wykres 1.3. Hierarchia reżimów prawnych w prawodawstwie regulującym przedsięwzięcia partnerstwa publiczno-prywatnego

Źródło: Wytyczne dotyczace udanego partnerstwa publiczno-prywatnego, Komisja Europejska, styczeń 2003, s. 45

W Wytycznych wielokrotnie przewija się stwierdzenie, że nie funkcjonuje jeden uniwersalny model wzajemnych stosunków pomiędzy sektorem publicznym a sektorem prywatnym. W praktyce mogą pojawić się różnorodne kombinacje, które powinny być dostosowane do specyfiki danego przedsięwzięcia oraz potrzeb stron nawiązujących współpracę, a których liczba i forma będą ulegać zwiększeniu w miarę wzrostu liczby zrealizowanych inwestycji. $\mathrm{Z}$ dokumentu wynika też, że Komisja Europejska jest zainteresowana wspieraniem i rozwojem PPP $\mathrm{w}$ ramach dotacji, których udziela. Wyraża gotowość do pomocy w zakresie rozwoju i wdrożenia PPP oraz wykorzystania finansowania dotacyjnego w celu umocnienia takich rozwiązań.

Zielona Księga $w$ sprawie partnerstwa publiczno-prywatnego i prawa wspólnotowego $w$ zakresie zamówień publicznych $i$ koncesji przyjęta przez Komisję Europejską 30 kwietnia 2004 r. była dokumentem otwierającym 
szeroko rozumianą debatę w kwestii partnerstwa publiczno-prywatnego w kontekście skutecznej konkurencji i przejrzystości prawnej, równego traktowania, proporcjonalności i obopólnego uznania, wynikających z Traktatu Europejskiego. W dokumencie Komisja Europejska odniosła się do przyjętych na szczeblu unijnym rozwiązań w zakresie wzmacniania konkurencji. Postawiono 22 pytania dotyczące partnerstwa publiczno-prywatnego oczekując konkretnego ustosunkowania się do nich. Zamierzeniem Komisji było sprawdzenie, czy i w jakim zakresie prawo odnoszące się do zamówień publicznych w poszczególnych państwach członkowskich ma zastosowanie do różnych form PPP oraz czy istnieje konieczność szczegółowego wyjaśnienia, uszczegółowienia lub poprawienia ram prawnych już istniejących na poziomie wspólnotowym.

Podstawowe obszary, które poddane zostały szczegółowym rozważaniom, dotyczyły $^{71}$ :

1) procedury wyboru partnerów do realizacji zadań publicznych; rozważania skoncentrowane zostały na dwóch zasadniczych sposobach wyboru partnera prywatnego: koncesji i dialogu konkurencyjnym;

2) problematyki inicjowania współpracy przez stronę prywatną i przywilejów z tym związanych; Komisja Europejska stoi na stanowisku, że przedsięwzięcia mające swój początek w inicjatywie prywatnej nie powinny zmieniać warunków kontraktów już uregulowanych prawnie na szczeblu Wspólnoty; podniesiona została kwestia równego dostępu do informacji o inwestycji wszystkich zainteresowanych podmiotów gospodarczych w całej Wspólnocie (konieczność publikowania ogłoszeń w „Europejskim Dzienniku Zamówień Publicznych");

3) zmian umowy w trakcie realizacji przedsięwzięcia;

4) zagadnień podkontraktowania.

Zielona Księga wskazuje na wiele kwestii spornych, jakie mogą pojawić się przy przedsięwzięciach PPP, toteż Komisja Europejska poddała pod rozwagę rozwiązania już przyjęte oraz zwróciła się do państw członkowskich o opinię w zakresie dyskutowanych zagadnień.

Pojawia się stwierdzenie o braku jednolitej definicji PPP dla całej Wspólnoty oraz odrębnego systemu prawnego w tej dziedzinie. Powszechnie partnerstwo publiczno-prywatne kojarzone jest z dużymi przedsięwzięciami inwestycyjnymi realizowanymi w skali makro, jednakże praktyka pokazała pewną prawidłowość - PPP coraz częściej realizowane są w skali lokalnej w takich obszarach, jak: gospodarka odpadami, dystrybucja wody, energii, gospodarka ściekami, świadczenie usług zdrowotnych i edukacyjnych.

Analizowane w Księdze rozwiązania wprowadzane są w odniesieniu do dwóch form PPP: pierwszej o naturze czysto kontraktowej, w której partnerstwo

${ }^{71}$ Dokument roboczy na temat Zielonej Księgi Komisji w sprawie partnerstw publicznoprywatnych... 
pomiędzy sektorem publicznym a partnerem prywatnym oparte jest jedynie na powiązaniach wynikających z kontraktu, i drugiej, o charakterze instytucjonalnym, sankcjonującym współpracę w formie nowego podmiotu (spółki specjalnego przeznaczenia SVP - special purpose vehicle). Debata zapoczątkowana w Zielonej Księdze spotkała się z dużym zainteresowaniem i ogólnym poparciem. Wpłynęło blisko 200 uwag od różnych respondentów, w tym z wielu państw członkowskich. W 2005 r. Komisja Europejska wydała Komunikat dla Parlamentu Europejskiego, Rady, Europejskiego Komitetu Ekonomiczno-Społecznego oraz Komitetu Regionów, będący wynikiem przeprowadzonych konsultacji. Wnioski były następujące ${ }^{72}$ :

1) brak jest ogólnej zgody na regulacje horyzontalne w prawie unijnym,

2) występuje potrzeba określenia jasnej definicji PPP na szczeblu unijnym,

3) zachodzi potrzeba uregulowania koncesji i dialogu konkurencyjnego, jako optymalnych form dla PPP.

Tabela 1.2

Wybrane akty prawne Komisji Europejskiej w sprawie partnerstwa publiczno-prywatnego

\begin{tabular}{|l|c|}
\hline \multicolumn{1}{|c|}{ Nazwa dokumentu } & Rok opublikowania \\
\hline Communication on Concession under Community Law & 2000 \\
\hline Guidelines for Successful Public-Private Partnerships & 2003 \\
\hline Resource Book on PPP. Case Studies & 2004 \\
\hline $\begin{array}{l}\text { Directive 2004/17/EC of the European Parliament and of the Council of } \\
31 \text { March 2004 coordinating the procurement procedures of entities } \\
\text { operating in the water, energy, transport and postal services sectors }\end{array}$ & 2004 \\
\hline $\begin{array}{l}\text { Directive 2004/18/EC of the European Parliament and of the Council of } \\
\text { 31 March 2004 on the coordination of procedures for the award of } \\
\text { public works contracts, public supply and public service contracts }\end{array}$ & 2004 \\
\hline $\begin{array}{l}\text { Communication from the Commission to the European parliament, the } \\
\text { Council, the European Economic and Social Committee and the } \\
\text { Committee of the Regions on Public-Private Partnerships and Commu- } \\
\text { nity Law on Public Procurement Concessions }\end{array}$ & 2005 \\
\hline $\begin{array}{l}\text { Commission Interpretative Communication on the application of } \\
\text { Community law on Public Procurement and Concessions to Institution- } \\
\text { alised Public-Private Partnerships (IPPP) }\end{array}$ & 2008 \\
\hline $\begin{array}{l}\text { Mobilising Private and Public Investment for Recovery and Long Term } \\
\text { Structural Change: Developing Public private partnerships }\end{array}$ & 2009 \\
\hline $\begin{array}{l}\text { The financial crisis and the PPP market. Potential Remedial Actions } \\
\text { European PPP Expertise Centre-EPEC }\end{array}$ & 2010 \\
\hline Anual on government deficit and debt, implementation of ESA 95 & 2010 \\
\hline
\end{tabular}

Źródło: oprac. własne na podstawie dokumentów znajdujących się na stronie internetowej Unii Europejskiej, www.europa.eu (15.11.2010).

${ }^{72}$ Tamże. 
Wraz z rozwojem PPP i wzrastającym zainteresowaniem formułą następowała modyfikacja przepisów na szczeblu unijnym (tab. 1.2) mająca na celu optymalizację warunków realizacji i upowszechnienie ich formuły. Także w okresie globalnego kryzysu finansowego Komisja przedstawiła wykaz działań w zakresie PPP dla całej Unii.

W dokumencie Kryzys finansowy a rynek PPP. Potencjalne dziatania naprawcze Europejskie Centrum Ekspertyzy PPP - EPEC zawarto listę problemów i uwarunkowań, które powinny być uwzględniane przez podmioty publiczne planujące nawiązanie współpracy w ramach PPP.

Jednoznacznie należy wskazać, iż na szczeblu unijnym nie istnieje akt kompleksowo regulujący problematykę funkcjonowania PPP. Wymienione dokumenty odnoszą się do wybranych kwestii i stanowią przewodnik właściwego procedurowania przedsięwzięć realizowanych jako PPP.

Unormowania, jakie znajdują się $\mathrm{w}$ dokumentach unijnych wynikają ze szczególnego zainteresowania Unii Europejskiej koncepcją PPP. Motywowanie przez Komisję Europejską władz publicznych poszczególnych państw do wykorzystania partnerstwa wynika $\mathrm{z}$ trzech czynników $^{73}$ :

1) wzrostu znaczenia inwestycji infrastrukturalnych; tempo oraz stopień wzrostu gospodarczego w znacznym stopniu uzależniony jest od rozwoju i rozbudowy infrastruktury, szczególnie w sektorze użyteczności publicznej (gospodarka wodno-ściekowa, odpadowa, energetyka, telekomunikacja, transport), ponadto istnieje duże zapotrzebowanie na infrastrukturę socjalną (szpitale, edukacja, więziennictwo, gospodarka mieszkaniowa); są to obszary największego zainteresowania wykorzystaniem sektora prywatnego jako partnera,

2) większej efektywności w wykorzystaniu zasobów; doświadczenia w zakresie prywatyzacji zadań publicznych pokazały, że wiele działań - nawet tych tradycyjnie zastrzeżonych dla sektora publicznego - można realizować w sposób kosztowo efektywniejszy przy zastosowaniu metod zarządczych i kompetencji sektora prywatnego,

3) generowanie wartości handlowej z aktywów sektora publicznego; znaczne kwoty ze środków publicznych inwestuje się w wypracowanie aktywów (np. technika obronna, wyspecjalizowane systemy informacyjne), które następnie wykorzystywane są $\mathrm{w}$ wąskim zakresie $\mathrm{w}$ innych dziedzinach sektora publicznego, wykorzystanie wiedzy specjalistycznej sektora prywatnego w celu wykorzystania tych aktywów w szerszym zakresie może prowadzić do istotnego przyrostu wartości w sektorze publicznym.

Do ważnych dokumentów w zakresie regulacji PPP należy decyzja Eurostatu z lutego 2004 r. o traktowaniu partnerstwa publiczno-prywatnego i jego

${ }^{73}$ Partnerstwo publiczno-prywatne $w$ Polsce i jego funkcjonowanie na przyktadzie wybranych projektów, red. J. Rutkowski, Wydawnictwo Uniwersytetu Łódzkiego, Łódź 2010, s. 65-66. 
wpływie na dług i deficyt publiczny ${ }^{74}$. Decyzja określa warunki, jakim musi podlegać umowa partnerstwa, aby powstałe zobowiązania sektora publicznego nie zostały zaliczone do długu publicznego. Zawarte w komunikacie Eurostatu stanowisko zostało kilka miesięcy później sprecyzowane w opublikowanym metodologicznym podręczniku o długu i deficycie finansów sektora publicznego - znanym jako ESA 95 - europejskiego systemu kont.

Powodem zainteresowania Eurostatu problematyką PPP była popularyzacja formuły partnerstwa w odniesieniu do budowy i eksploatacji obiektów infrastrukturalnych. Zadaniem urzędu statystycznego było zapewnienie jednolitego podejścia do statystyki sektora publicznego we wszystkich krajach członkowskich, określenie zakresu sektora oraz liczb i wskaźników dotyczących deficytu i zadłużenia, które będą w pełni porównywalne.

Większość umów, jakie zawierane są pomiędzy podmiotami sektora publicznego i prywatnego, nie budzi wątpliwości z punktu widzenia statystyki. Inaczej wygląda sytuacja w odniesieniu do współpracy w ramach PPP. Długoterminowa współpraca oraz powstające $\mathrm{w}$ jej wyniku aktywa majątkowe muszą być właściwie zaksięgowane, a tym samym zaklasyfikowane w poczet majątku publicznego lub prywatnego, stąd stanowisko Eurostatu. Zgodnie z przyjętym przez Eurostat rozwiązaniem aktywa będące składnikiem partnerstwa publiczno-prywatnego będą uważane za aktywa nienależące do bilansu finansów publicznych wówczas, kiedy spełnione zostaną następujące warunki:

○ partner prywatny ponosi ryzyko budowlane,

○ partner prywatny ponosi co najmniej jedno z dwóch ryzyk: ryzyko dostępności bądź ryzyko popytu.

W przeciwnym przypadku, jeśli wskazane warunki nie zostaną spełnione, aktywa znajdą się $\mathrm{w}$ bilansie instytucji publicznej, a tym samym powstałe zobowiązania będą skutkowały wzrostem deficytu i długu publicznego.

\subsubsection{Partnerstwo publiczno-prywatne $w$ ustawodawstwie polskim}

W Polsce przed podjęciem rządowej inicjatywy ustawodawczej toczyła się szeroko zakrojona dyskusja na temat konieczności wypracowania odrębnych przepisów prawa, regulujących model PPP. Przeciwnicy tego rozwiązania wskazywali Wielką Brytanię jako kraj, w którym PPP rozwija się dynamicznie bez specjalnej ustawy, natomiast $w$ przyjaznym klimacie i przy wsparciu ze strony rządu. Proponowali dokonanie zmian w istniejących przepisach, zwłaszcza w Prawie zamówień publicznych oraz w przepisach dotyczących finansów publicznych. Zwolennicy argumentowali za koniecznością wprowadzenia odrębnego aktu istotnością nadania mu rangi ustawowej i możliwie precyzyjne-

${ }^{74}$ Decyzja Eurostatu o traktowaniu partnerstwa publiczno-prywatnego i jego wplywie na dlug $i$ deficyt publiczny, Released 11 Feb. 2004, www.epp.eurostat. 
go określenia ram funkcjonowania. Stanowisko to wynikało z często pojawiających się zarzutów, że partnerstwo publiczno-prywatne będzie kolejną formą nadużyć. W efekcie działania legislacyjne zakończyły się przyjęciem odrębnej ustawy. Początkowo przy konstruowaniu prawa w zakresie PPP przyjęto metodę wprowadzenia zmian na dwóch poziomach: ogólnym, w ustawie o PPP i regulacyjnym, w odrębnej ustawie wprowadzającej ustawę o PPP, w której przewidywało się nowelizację kilkudziesięciu ustaw szczegółowych (jak uczyniono później z ustawą o finansach publicznych z 2009 r.). Ostatecznie zdecydowano się na wprowadzenie jednego aktu - Ustawy o partnerstwie publiczno-prywatnym $^{75}$ przyjętej przez Sejm 28 lipca 2005 r. Ustawa przewidywała wprowadzenie trzech rozporządzeń wykonawczych. Rozporządzenia miały stanowić doprecyzowanie przepisów ustawy. W rzeczywistości prace nad przepisami wykonawczymi trwały bardzo długo, gdyż wydane zostały blisko rok po przyjęciu ustawy, co skutecznie zniechęciło potencjalnych zainteresowanych nawiązaniem długofalowej współpracy w nowej formie prawnej.

W czerwcu 2006 r. przyjęto trzy rozporządzenia:

- Rozporządzenie Ministra Finansów w sprawie niezbędnych elementów analizy przedsięwzięcia $w$ ramach partnerstwa publiczno-prywatnego ${ }^{76}$,

- Rozporzadzenie Ministra Gospodarki w sprawie ryzyk zwiazanych z realizacja przedsięwzięć w ramach partnerstwa publiczno-prywatnego ${ }^{77}$,

- Rozporządzenie Ministra Finansów w sprawie szczególowego zakresu, form i zasad sporządzania informacji dotyczacych umów o partnerstwie publiczno-prywatnym ${ }^{78}$.

Celem ustawy o PPP było pobudzenie inwestycji sektora publicznego, zwłaszcza infrastrukturalnych, poprzez stworzenie optymalnych ram prawnych dla przedsięwzięć publicznych $\mathrm{z}$ udziałem partnerów prywatnych, a także zniesienie przeszkód prawnych powodujących, że przedsięwzięcia PPP obarczone są dużym ryzykiem dla obu stron. W szerszym kontekście ustawa miała za zadanie usunięcie barier psychologicznych dotyczących postrzegania roli i funkcji administracji publicznej $\mathrm{w}$ wykonywaniu zadań publicznych przy współpracy z prywatnymi podmiotami, miała także zapobiec sytuacjom, w których PPP stałoby się instrumentem politycznym lub podatnym na naciski polityczne $^{79}$.

${ }^{75}$ Ustawa z dnia 28 lipca 2005 r. o partnerstwie publiczno-prywatnym..., poz. 1420.

${ }^{76}$ Rozporzadzenie z dnia 30 czerwca 2006 r. w sprawie niezbędnych elementów analizy przedsięwzięć w ramach partnerstwa publiczno-prywatnego, DzU, 2006, nr 125, poz. 866.

${ }^{77}$ Rozporzadzenie z dnia 30 czerwca $2006 r$. w sprawie ryzyk zwiazanych z realizacja przedsięwzięć w ramach partnerstwa publiczno-prywatnego, DzU, 2006, nr 125, poz. 868.

${ }^{78}$ Rozporzadzenie z dnia 30 czerwca 2006 r. w sprawie szczegółowego zakresu, form i zasad sporzadzania informacji dotyczacych umów o partnerstwie publiczno-prywatnym, DzU, 2006, nr 125 , poz. 867.

${ }_{79}$ Uzasadnienie do projektu ustawy o partnerstwie publiczno-prywatnym, druk sejmowy 3174 . 
Przyjęta w 2005 r. ustawa nie stanowiła prawa przyjaznego dla rozwoju formuły, a wręcz przeciwnie, stworzyła szereg ograniczeń, do których należy zaliczyć:

- skomplikowane procedury prowadzące do zawarcia umowy,

- konieczność przeprowadzenia przez podmiot publiczny rozbudowanych, kosztownych analiz o charakterze prawno-finansowym,

- ograniczenia w zakresie wyboru dopuszczalnych prawem struktur partnerstwa,

- ograniczenia co do formy wkładu podmiotu publicznego i sposobu wynagrodzenia partnera prywatnego,

- brak wymaganych ustawą wzorów dokumentów,

- procedury skoncentrowane na dużych przedsięwzięciach, wymagających wysokich kapitałów.

Przyjęty wówczas akt prawny nie przyczynił się do upowszechnienia partnerstwa publiczno-prywatnego ani nie okazał się ,złotym środkiem” prowadzącym do szybkiego rozwoju infrastruktury, jak to zakładano na etapie prac nad ustawą. Wyraźnie akcentowano, że ustawa nie różnicuje przedsięwzięć. Takie same obowiązki spoczywały na stronach przygotowujących inwestycje o dużej i małej wartości, co automatycznie podnosiło koszty przygotowania małego przedsięwzięcia i uszczuplało oszczędności wynikające z PPP. W rezultacie akt ten nie spełnił pokładanych w nim oczekiwań podmiotów, które skłonne były podjąć trud przygotowania procesu inwestycyjnego zgodnie z przepisami ustawy o PPP. Skomplikowane analizy, długi okres przygotowań i wysoki stopień zbiurokratyzowania spowodowały, że ustawa szybko stała się „martwym prawem".

Urzędujący w tym czasie sekretarz stanu w Ministerstwie Gospodarki szybko dostrzegł konieczność rozpoczęcia prac nad nowelizacją prawa w zakresie PPP. Projekt nowych regulacji miał być „odpowiedzią na potrzebę stworzenia akceptowalnych rozwiązań prawnych, które mogłyby uwolnić realizację przedsięwzięć z wykorzystaniem partnerstwa publiczno-prywatnego w Polsce" ${ }^{\prime 80}$. Projekt miał szczególny walor praktyczny, gdyż powstawał w ścisłej współpracy pomiędzy adresatami ustawy: przedstawicielami zainteresowanych ministerstw oraz urzędami centralnymi, organizacjami pracodawców, przedstawicielami samorządu gospodarczego i terytorialnego. Pracom przyświecała idea stworzenia takiej regulacji prawnej, która gwarantowałaby ochronę interesów publicznych, interesów partnerów prywatnych, ochronę długu publicznego oraz zgodności $\mathrm{z}$ prawem unijnym, a przede wszystkim umożliwiła swobodne kształtowanie partnerstwa. Prace legislacyjne oparto na dwóch zasadach. Po

${ }^{80}$ Por. Wystapienie Sekretarza Stanu w Ministerstwie Gospodarki Adama Szejnfelda, 27. posiedzenie Sejmu RP z dnia 28.10.2008; Sejm Rzeczypospolitej Polskiej VI Kadencji, Uzasadnienie do projektu ustawy o partnerstwie publiczno-prywatnym, Druk Sejmowy $\mathrm{nr} 1180$, Warszawa 2008, www.orka,sejm.gov.pl (15.01.2011). 
pierwsze, tam, gdzie to możliwe starano się nie tworzyć nowego prawa, a oprzeć się na przepisach już obowiązujących i sprawdzonych (np. prawie handlowym, cywilnym). Po drugie, zostawić stronom jak największy margines działania, aby wzajemne relacje objęte umową zostały dostosowane do potrzeb projektu. Nie chciano tworzyć ,sztywnego pancerza”, a jedynie rozwiązania ramowe.

Rządowy projekt ustawy trafił do Sejmu 22 października 2008 r., a ostatecznie przyjęty został 19 grudnia 2008 r. W przeciwieństwie do poprzedniej ustawa ma charakter ramowy, na jego bazie możliwe będzie realizowanie zadań publicznych.

W nowej ustawie wyeliminowano szereg barier poprzez:

- usunięcie obligatoryjnego obowiązku sporządzenia analiz, nadając im cechę dobrowolności,

- wprowadzenie przejrzystej procedury wyboru partnera prywatnego (Prawo zamówień publicznych, Ustawa o koncesji na roboty budowlane lub ustugi),

- szczegółowe uregulowanie kwestii wkładu własnego,

- nadanie umowie PPP ramowego charakteru,

- umożliwienie stosowania elastycznych form PPP,

- rezygnację z określenia przedsięwzięć, co uelastyczni ich zakres i umożliwi realizację w ramach PPP,

- wprowadzenie zasad racjonalnej kontroli realizacji przedsięwzięć,

- umożliwienie wykorzystania środków z funduszy Unii Europejskiej do finansowania przedsięwzięć PPP.

Ważnym udogodnieniem zawartym w ustawie, jest brak wymogu zgody ministra finansów na sfinansowanie projektów inwestycyjnych $\mathrm{z}$ budżetu państwa w kwocie niższej niż 100 mln PLN. Ustawodawca wprowadził ogólne ramy, w których ujęta w sposób jawny została idea partnerstwa, a potencjalni partnerzy mają możliwość stworzenia takiej przestrzeni (opartej na umowie), która pozwoli realizować zadania o charakterze użyteczności publicznej. Porównanie ustawy o partnerstwie publiczno-prywatnym z 2005 r. i ustawy o partnerstwie publiczno-prywatnym z 2008 r. przedstawiono w tab. 1.3.

Tabela 1.3

Porównanie ustawy o PPP z 2005 r. i ustawy o PPP z 2008 r.

\begin{tabular}{|c|c|}
\hline $\begin{array}{c}\text { Ustawa o partnerstwie publiczno-prywatnym } \\
\mathrm{z} 28 \text { lipca } 2005 \mathrm{r} .\end{array}$ & $\begin{array}{c}\text { Ustawa o partnerstwie publiczno-prywatnym } \\
\mathrm{z} 19 \text { grudnia 2008 r. }\end{array}$ \\
\hline 1 & 2 \\
\hline $\begin{array}{c}\text { Akt normatywny o charakterze edukacyjno-ins- } \\
\text { trukcyjnym }\end{array}$ & Ustawa ramowa \\
\hline Konieczność sporządzania analiz & Brak obowiązku sporządzania analiz \\
\hline $\begin{array}{c}\text { Procedura wyboru partnera prywatnego oparta } \\
\text { na przepisach ustawy Prawo zamówień pub- } \\
\text { licznych }\end{array}$ & $\begin{array}{c}\text { Procedura wyboru partnera prywatnego oparta } \\
\text { na przepisach ustawy o koncesji na roboty } \\
\text { budowlane lub usługi bądź ustawy Prawo } \\
\text { zamówień publicznych }\end{array}$ \\
\hline
\end{tabular}


Tabela $1.3(\mathrm{~cd}$.

\begin{tabular}{|c|c|}
\hline \multicolumn{1}{|c|}{1} & \multicolumn{1}{|c|}{2} \\
\hline Obowiązek realizacji zadania publicznego & $\begin{array}{l}\text { Brak odwołania do realizacji zadania publicz- } \\
\text { nego }\end{array}$ \\
\hline Szerszy zakres zdefiniowanych pojęć & Węższy zakres zdefiniowanych pojęć \\
\hline $\begin{array}{c}\text { Enumeryczny katalog podmiotów publicznych } \\
\text { odpowiadający definicji przyjętej w ustawie } \\
\text { o finansach publicznych w 2004 r. }\end{array}$ & $\begin{array}{c}\text { Rozszerzony katalog podmiotów publicznych } \\
\text { wykraczający poza definicje ujęte w ustawie } \\
\text { o finansach publicznych z 2004 r. (spółka } \\
\text { celowa) }\end{array}$ \\
\hline Wykaz obligatoryjnych elementów umowy & Elastyczna zawartość umowy \\
\hline $\begin{array}{c}\text { Ścisłe zdefiniowanie form, wakich można } \\
\text { zawiązać partnerstwo (spółka celowa) }\end{array}$ & $\begin{array}{l}\text { Rozszerzony katalog typów spółek wakich } \\
\text { może być prowadzone partnerstwo (spółki } \\
\text { komandytowe i komandytowo-akcyjne) }\end{array}$ \\
\hline $\begin{array}{c}\text { Wymóg uzyskania zgody ministra finansów, } \\
\text { jeśli przedsięwzięcie w części wymaga } \\
\text { finansowania z budżetu panstwa, niezależnie } \\
\text { od jego wartości }\end{array}$ & $\begin{array}{l}\text { Wymóg uzyskania zgody ministra finansów, } \\
\text { jeśli wartość finansowanego przedsięwzię- } \\
\text { cia przekracza określony w ustawie próg } \\
\text { kwotowy }\end{array}$ \\
\hline $\begin{array}{c}\text { Sześćdziesięciodniowy termin na wydanie } \\
\text { decyzji i przyznanie ministrowi prawa do } \\
\text { oceny merytorycznej przedsięwzięcia i } \\
\text { wpływu na finanse publiczne }\end{array}$ & $\begin{array}{l}\text { Sześciotygodniowy termin wydania decyzji, } \\
\text { która nie ma charakteru decyzji administra- } \\
\text { cyjnej }\end{array}$ \\
\hline $\begin{array}{c}\text { Niewielka możliwość bieżącej kontroli partnera } \\
\text { prywatnego przez podmiot publiczny }\end{array}$ & $\begin{array}{l}\text { Prawo podmiotu publicznego do bieżącej kon- } \\
\text { troli realizacji przedsięwzięcia przez partne- } \\
\text { ra prywatnego }\end{array}$ \\
\hline $\begin{array}{c}\text { Brak jednoznacznego przyzwolenia współfinan- } \\
\text { sowania PPP ze środków unijnych }\end{array}$ & $\begin{array}{l}\text { Jednoznaczne przyzwolenie na współfinanso- } \\
\text { wanie PPP ze środków unijnych }\end{array}$ \\
\hline
\end{tabular}

Źródło: oprac. własne na podstawie Ustawy z dnia 28 lipca 2005 r. o partnerstwie publicznoprywatnym, DzU, 2005, nr 169, poz. 1240; Ustawy z dnia 19 grudnia 2008 r. o partnerstwie publiczno-prywatnym, DzU, 2009, nr 19, poz. 100 ze zm.

Ujęte w ustawie o PPP z 2008 r. regulacje prawne opierają się na pięciu podstawowych zasadach $^{81}$ :

1) zapewnieniu podmiotom uczestniczącym możliwie największej swobody w kształtowaniu partnerstwa,

2) ochronie najważniejszych interesów publicznych,

3) ochronie uzasadnionych interesów partnerów prywatnych,

4) przestrzeganiu zasad dotyczących długu publicznego,

5) zachowaniu zgodności z prawem unijnym.

Należy wyraźnie zaznaczyć, że nowe uregulowania wyraźnie odwołują się do istniejącego porządku prawnego, a w szczególności do rozwiązań określo-

${ }^{81}$ T. Korczyński, A. Kozłowska, K. Kozłowski, A. Mednis, A. Nowaczek, Koncesja na roboty budowlane lub ustugi a inne formy realizacji inwestycji publiczno-prywatnych, $\mathrm{ABC}$ a Wolters Kluwer business, Warszawa 2010, s. 46. 
nych w prawie cywilnym. Dzięki temu przyjęte przepisy stały się łatwe do zrozumienia i zastosowania. Potwierdzają to badania przeprowadzone przez Firmę Ernst \& Young w fokusowo wybranych 11 miastach $^{82}$.

Rozwiązania przyjęte w nowej ustawie o PPP odnoszą się do silniejszych związków pomiędzy stronami niż dzieje się to w ustawie Prawo zamówień publicznych czy ustawie o koncesjach na roboty budowlane lub ustugi, dotyczą bowiem „wspólnego wykonania zadania”, któremu towarzyszy zawarcie skomplikowanej, wcześniej wynegocjowanej umowy. Proste zlecenie usług, w których w zamian za wykonanie określonego świadczenia sektor publiczny wypłaca uzgodnione wynagrodzenie (zamówienie publiczne) lub upoważnia do pobierania pożytków (koncesja) wykonywane są na podstawie prostych umów, co wyraźnie różni powiązania sektora publicznego z prywatnym przy tradycyjnym zleceniu i przedsięwzięciu PPP.

Równolegle $\mathrm{z}$ pracami nad nową ustawą o partnerstwie publiczno-prywatnym trwały prace nad ustawą o koncesji na roboty budowlane lub usługi ${ }^{83}$. Ustawa koncesyjna w zamyśle ustawodawcy miała być komplementarnym aktem prawnym w stosunku do ustawy o PPP. Oba akty prawne miały tworzyć nowe ramy instytucjonalne dla partnerstwa publiczno-prywatnego w Polsce. Celem ustawy o koncesji było

stworzenie nowych możliwości wykonywania zadań publicznych poprzez zaangażowanie środków prywatnych i wykorzystanie potencjału prywatnych podmiotów, które mogą wpłynąć korzystnie na poprawę ich dostępności i jakości ${ }^{84}$.

Przyjęte regulacje miały $\mathrm{z}$ jednej strony chronić interes publiczny oraz uwzględniać obowiązujące prawo krajowe i wspólnotowe, a $z$ drugiej strony otwierać szerokie spektrum działalności, pozwalające łączyć wiedzę, doświadczenie i kapitał prywatny z publicznym.

Należy zauważyć, że koncesja jako forma funkcjonowała w systemie prawa polskiego zarówno w postaci klasycznego aktu administracyjnego, jak i pewnego rodzaju stosunku obligacyjnego. Przykładem są ustawy o autostradach płatnych i Krajowym Funduszu Drogowym, gdzie ta instytucja prawna została uregulowana i działa sprawnie. Koncesja na gruncie samorządu terytorialnego również miała swój początek w latach dziewięćdziesiątych ubiegłego stulecia, kiedy to pojawily się próby unormowania koncesji komunalnej jako umowy

${ }^{82}$ Raport T. Tasan-Kok, M. Załęczna, Partnerstwo publiczno-prywatne w rozwoju przestrzeni miejskiej. Polska praktyka na tle regulacji unijnych, Sprawne Państwo Program Ernst \& Young, Warszawa 2010.

${ }^{83}$ Ustawa z dnia 9 stycznia 2009 r. o koncesji na roboty budowlane lub ustugi, DzU, 2009, nr 19, poz. 101 ze zm.

${ }^{84}$ Uzasadnienie do projektu ustawy o koncesji na roboty budowlane lub ustugi, Druk Sejmowy nr 834 z 17 lipca 2008, s. 1. 
obligacyjnej. W praktyce nie doczekała się faktycznego wdrożenia. Koncesja jako nowy instrument prawny pojawiła się dopiero w $2004 \mathrm{r}$. w ustawie z dnia 29 stycznia 2004 r. Prawo zamówień publicznych. W rozdziale 4 tejże ustawy ${ }^{85}$ dopuszczono wykorzystanie koncesji na roboty budowlane jako jednej z możliwości realizacji zadań publicznych. Pomimo że takie regulacje istniały już od 2004 r. rynek koncesji na roboty budowlane nie był w pełni wykorzystany (do 2010 r. znalazła zastosowanie jedynie w dwunastu przypadkach). Koncesji samorządy gminne udzielały na budowę składowisk odpadów komunalnych bądź budowę parkingów podziemnych. Dodatkowo obowiązujący w Polsce porządek prawny nie uwzględniał koncesji na usługi. Stąd pojawiła się idea, aby stworzyć odrębną regulację prawną, jednocześnie uwzględniając regulacje Wspólnotowe ${ }^{86}$. Instytucja koncesji odrębnie została już wcześniej prawnie uregulowana w niektórych krajach europejskich, m.in. w Czechach, Bułgarii, we Włoszech czy w Hiszpanii. Z tego powodu Ministerstwo Infrastruktury przy udziale prezesa Urzędu Zamówień Publicznych podjęło się w 2008 r. zadania uregulowania procedury zawierania umowy koncesji na roboty budowlane łącznie z instytucją koncesji na usługi. W efekcie łącznie z przygotowaną nową ustawą o partnerstwie publiczno-prywatnym stworzono akceptowalne rozwiązania prawne, które będą mogły przyczynić się do uruchomienia przedsięwzięć partnerstwa publiczno-prywatnego, jednocześnie poszerzając prawne możliwości realizacji zadań publicznych.

Koncesja nie stanowi formy prywatyzacji zadań publicznych, gdyż podmiot publiczny nadal pozostaje odpowiedzialny za ich realizację. Ryzyko ekonomiczne powodzenia przedsięwzięcia przeniesione zostaje w zasadniczej części na podmiot prywatny. Jest to najistotniejszy element, który odróżnia koncesję od tradycyjnego zamówienia publicznego. W zamówieniu publicznym mamy do czynienia ze stosunkiem między zamawiającym a wykonawcą, który w zamian za określone wynagrodzenie zobowiązuje się do wykonania określonego świadczenia na rzecz zamawiającego. Ryzyko ekonomiczne związane z przedsięwzięciem w całości pozostaje po stronie zamawiającego. Przepisy o koncesji znajdą zastosowanie w przypadku, kiedy odbiorcą świadczeń mogą być osoby

${ }^{85}$ Ustawa z dnia 29 stycznia 2004 r. Prawo zamówień publicznych, DzU, 2004, nr 19, poz. 177 ze zm., art. 128-131.

${ }^{86}$ Prawo Wspólnotowe dopuszcza realizację zadań publicznych w formie koncesji. Podstawę prawną stanowią: Dyrektywa 2004/18/WE Parlamentu Europejskiego i Rady z dnia 31 marca 2004 r. w sprawie koordynacji procedur udzielania zamówień publicznych na roboty budowlane, dostawy i ustugi; Dyrektywa 2004/17/WE Parlamentu Europejskiego i Rady z dnia 31 marca 2004 r. koordynująca procedury udzielania zamówień przez podmioty działające w sektorach gospodarki wodnej, energetyki; Rozporządzenie Komisji (WE) nr 1564/2005 z dnia 7 września 2005 r. ustanawiające standardowe formularze do publikacji ogłoszeń w ramach procedur zamówień publicznych zgodnie z Dyrektywami 2004/17/WE i 2004/18/ Deparlamentu Europejskiego i Rady Europy. 
trzecie, tj. faktyczni użytkownicy przedmiotu koncesji (użytkownicy płatnej drogi, kibice sportowi kupujący bilety na stadion, kierowcy pozostawiający samochód na parkingu). W sytuacji, gdy odbiorcą świadczenia będzie bezpośrednio zamawiający, wówczas będziemy mieć do czynienia z zamówieniem publicznym. O tym, które przepisy należy zastosować decydować będzie forma płatności. Jeśli płatność wobec przedsiębiorcy będzie ustalona w pieniądzu i zamawiający będzie zobowiązany do zapłaty wynagrodzenia, to należy stosować przepisy dotyczące zamówień publicznych. W przypadku koncesji przynajmniej część zapłaty należnej wykonawcy powinna pochodzić z uzyskiwanych korzyści ze świadczonej usługi od bezpośrednich usługobiorców. Wynagrodzenie koncesjonariusza stanowi, w przypadku:

- koncesji na roboty budowlane - wyłączne prawo do korzystania z obiektu budowlanego albo takie prawo wraz z płatnością koncesjodawcy,

- koncesji na usługi - wyłączne prawo do korzystania z usługi albo takie prawo wraz z płatnością koncesjodawcy.

Taki zapis oznacza, że koncesjonariusz ma prawo do korzystania z przedmiotu koncesji oraz może mu przysługiwać dodatkowe wynagrodzenie od koncesjodawcy, który pokrywa w ten sposób część kosztów ponoszonych przez koncesjonariusza. Wysokość wynagrodzenia została jednak wyraźnie określona i nie może przekroczyć całości nakładów poniesionych przez koncesjonariusza na wykonanie zadania objętego koncesją. Koncesja jest więc formą współpracy pomiędzy podmiotem publicznym a prywatnym, w której zasoby (nakłady finansowe i realizowana inwestycja) są wykorzystywane do tworzenia infrastruktury na potrzeby społeczne. Koncesję można zatem stosować do większości przykładów realizacji partnerstwa publiczno-prywatnego zmierzających do powstawania, modernizacji lub ulepszania już istniejących obiektów. Porównanie rozwiązań prawnych w ustawie o partnerstwie publiczno-prywatnym z $2008 \mathrm{r}$. oraz ustawie o koncesji na roboty budowlane lub usługi z 2009 r. przedstawiono w tab. 1.4.

Przez dłuższy czas toczyła się dyskusja, w jakiej relacji znajdować się będą wobec siebie ustawa o PPP i ustawa koncesyjna. Wiele firm doradczych współpracujących z samorządami wypowiadało się na temat przygotowanych rozwiązań. Zdaniem Ch. Schnella ${ }^{87}$ ustawa o koncesjach ma charakter lex specialis w stosunku do ustawy o PPP i ustawy Prawo zamówień publicznych. Odmienny pogląd reprezentują M. Bejm, P. Bogdanowicz, P. Piotrowski ${ }^{88}$, którzy uważają przepisy obu aktów za konkurencyjne względem siebie. $\mathrm{W}$ praktyce podmioty publiczne nie mając dokładnie sprecyzowanego modelu finansowania przedsięwzięcia będą miały problem $\mathrm{z}$ wyborem jednej $\mathrm{z}$ dwóch ustaw, wyznaczających ścieżkę wyboru partnera prywatnego. Podobne wątpli-

${ }^{87}$ Ch. Schnell, Kiedy stosować ustawę o partnerstwie, a kiedy o koncesjach, „Rzeczpospolita” z 15.12.2008 r., www.new-arch.rp.pl (08.11.2010).

${ }^{88}$ Ustawa o partnerstwie publiczno-prywatnym. Komentarz..., s. 122. 
wości zgłaszała A. Kozłowska ${ }^{89}$, według której dopiero praktyka pokaże jak przyjęte rozwiązania legislacyjne wpływają na rozwój przedsięwzięć partnerskich, przypisując dużą rolę instytucjom doradczym w pierwszej fazie przygotowań partnerstwa.

Tabela 1.4

Porównanie rozwiązań prawnych Ustawy o partnerstwie publiczno-prywatnym z 2008 r. z Ustawa o koncesji na roboty budowlane lub ustugi z $2009 \mathrm{r}$.

\begin{tabular}{|c|c|}
\hline Ustawa o partnerstwie publiczno-prywatnym & $\begin{array}{l}\text { Ustawa o koncesji na roboty budowlane } \\
\text { lub ustugi }\end{array}$ \\
\hline Ramowy charakter & Charakter ramowo-proceduralny \\
\hline Brak obowiązku sporządzania analiz & $\begin{array}{l}\text { Decyzja podmiotu publicznego powinna być } \\
\text { przemyślana, poparta odpowiednimi anali- } \\
\text { zami }\end{array}$ \\
\hline $\begin{array}{l}\text { Możliwość całościowego lub częściowego wy- } \\
\text { nagrodzenia przez podmiot publiczny }\end{array}$ & $\begin{array}{l}\begin{array}{l}\text { Określone warunki i poziom wynagradzania } \\
\text { pochodzącego od koncesjodawcy }\end{array} \\
\end{array}$ \\
\hline $\begin{array}{l}\text { Założony podział ryzyka pomiędzy podmiot } \\
\text { publiczny a prywatny }\end{array}$ & Większościowe ryzyko koncesjonariusza \\
\hline $\begin{array}{l}\text { Współpraca uwzględniająca przesunięcia skład- } \\
\text { ników majątkowych pomiędzy stronami }\end{array}$ & $\begin{array}{l}\text { Brak powiązania pomiędzy współpracą a prze- } \\
\text { sunięciami składników majątkowych }\end{array}$ \\
\hline Możliwość zawiązania spółki celowej & Brak możliwości zawiązania spółki celowej \\
\hline $\begin{array}{l}\text { Bezterminowy okres umowy (uzależniony od } \\
\text { rodzaju przedsięwzięcia) }\end{array}$ & Określony czas trwania umowy (15-30 lat) \\
\hline Szeroki krąg podmiotów publicznych & Określony krąg koncesjodawców \\
\hline $\begin{array}{l}\text { Procedura wyboru partnera oparta na przepi- } \\
\text { sach ustawy Prawo zamówień publicznych } \\
\text { lub ustawy o koncesji na roboty budowlane } \\
\text { lub usługi }\end{array}$ & $\begin{array}{l}\text { Szczegółowo określony tryb i zasady wyboru } \\
\text { koncesjonariusza }\end{array}$ \\
\hline Ściśle określony cel partnerstwa & $\begin{array}{l}\text { Brak konieczności definiowania celu zawarcia } \\
\text { umowy koncesyjnej }\end{array}$ \\
\hline Uprawnienia kontrolne podmiotu publicznego & $\begin{array}{l}\text { Brak zdefiniowanych uprawnień kontrolnych } \\
\text { na rzecz koncesjodawcy }\end{array}$ \\
\hline $\begin{array}{l}\text { Konieczność uzyskania zgody ministra finan- } \\
\text { sów dla umowy partnerstwa }\end{array}$ & Brak konieczności zgody właściwego ministra \\
\hline
\end{tabular}

Źródło: oprac. własne na podstawie Ustawy z dnia 19 grudnia 2008 r. o partnerstwie publiczno-prywatnym, DzU, 2009, nr 19, poz. 100 ze zm.; Ustawy z dnia 9 stycznia 2009 r. o koncesji na roboty budowlane lub ustugi, DzU, 2009, $\mathrm{nr}$ 19, poz. $101 \mathrm{ze} \mathrm{zm}$.

Z krótkiej obserwacji polskiego rynku wynika, że nowe rozwiązania prawne już w latach 2009-2011 skutkowały pojawieniem się procedur związanych z wyborem partnerów prywatnych dla przedsięwzięć publiczno-prywatnych opartych na nowych rozwiązaniach legislacyjnych (tab. 1.5).

${ }^{89}$ T. Korczyński, A. Kozłowska, K. Kozłowski, A. Mednis, A. Nowaczek, Koncesja na roboty budowlane..., s. 67-68. 
Tabela 1.5

Liczba ogłoszeń dotycząca przedsięwzięć w formie PPP i koncesji w latach 2009-2011 w Polsce

\begin{tabular}{|l|c|c|c|}
\hline \multirow{2}{*}{ Formuła realizacji przedsięwzięcia } & \multicolumn{3}{|c|}{ Rok } \\
\cline { 2 - 4 } & 2009 & 2010 & 2011 \\
\hline Partnerstwo publiczno-prywatne & 8 & 22 & 18 \\
\hline Koncesja & 33 & 39 & 24 \\
\hline Ogółem & $\mathbf{4 1}$ & $\mathbf{6 1}$ & $\mathbf{4 2}$ \\
\hline
\end{tabular}

Źródło: oprac. własne na podstawie raportów Rynek PPP $w$ Polsce za poszczególne lata, Investment Suport.

W 2009 r. w „Biuletynie Zamówień Publicznych” ukazało się 41 ogłoszeń w sprawie realizacji zadań publicznych, które zaplanowano do realizacji we współpracy z prywatnym partnerem. W 2010 r. nastąpił blisko 50\% wzrost zainteresowania realizacją zadań z partnerem prywatnym. Taki trend wynikał z czasu, jaki jest niezbędny do przygotowania procedury wyboru partnera prywatnego oraz rozstrzygnięcia podstawowej kwestii, jaką jest wybór modelu realizacji zadania, tradycyjny czy partnerski, oparty na wstępnych analizach. W 2011 r. nastąpiło zmniejszenie liczby inwestycji zakwalifikowanych do realizacji w modelu PPP lub koncesji. Był to wynik przeprowadzonych jesienią 2010 r. wyborów i zmiana władz w samorządach, co spowodowało zahamowanie prac nad nowymi przedsięwzięciami. Nowa władza dokonuje przeglądu przedsięwzięć i podejmuje decyzje o ich realizacji bądź rezygnacji z nich. Najlepszy okres dla działań obserwuje się w drugim i trzecim roku kadencji. Ze społecznego punktu widzenia nie jest to korzystna sytuacja. Każde odroczenie w czasie działań pociąga za sobą zmniejszenie puli oferowanych usług lub obniżenie standardu ich jakości, a w konsekwencji niezadowolenie obywateli wspólnoty.

\subsection{Modele i formy realizacji przedsięwzięć partnerstwa publiczno-prywatnego}

\subsubsection{Modele partnerstwa publiczno-prywatnego}

Wybór struktury organizacyjnej PPP uzależniony jest od charakteru inwestycji i warunków, w jakich będzie ona realizowana. Złożoność koncepcji i brak jednomyślności co do interpretacji partnerstwa publiczno-prywatnego powodują, że w praktyce wygenerowano różne rozwiązania (modele, formy), które odpowiadają idei. PPP nie przypisuje się w związku z powyższym jednego, konkretnego schematu działania, ale umożliwia kombinacje zależne od specyfiki realizowanego przedsięwzięcia. Podstawą wyodrębnienia schematu współpracy są relacje pomiędzy stronami, charakter uczestnictwa w przedsięwzięciu oraz 
podział ryzyka. Za najważniejszy jednak element przyjmuje się prawo własności do infrastruktury. $Z$ tego punktu widzenia wyróżnia się dwa zasadnicze warianty:

- wariant I - łączenie funkcji właściciela i operatora majątku,

- wariant II - oddzielenie funkcji właściciela i operatora majątku ${ }^{90}$.

W wymienionych wariantach w praktyce ukształtowały się następujące modele, $\mathrm{w}$ ramach których mogą być realizowane przedsięwzięcia partnerstwa publiczno-prywatnego:

- model niemiecki,

- model brytyjski,

- model francuski,

- model przemysłowy ${ }^{91}$.

Zdaniem J. Zysnarskiego ${ }^{92}$ każdy z tych modeli może występować w formie czystej bądź mieszanej (typu BOT, Build-Operate-Transfer), łącząc w sobie elementy charakterystyczne dla co najmniej dwóch podstawowych modeli. Wyznacznikiem poszczególnych modeli jest prawo do własności infrastruktury.

W modelu niemieckim następuje połączenie funkcji właściciela i operatora. Podmioty, które sprawują obie te funkcje pozostają własnością jednostki samorządu terytorialnego, najczęściej gminy. Na uwagę zasługuje fakt, że podmiot świadczący usługi jest uzależniony od polityki władz lokalnych. Atrybut władzy najczęściej wykorzystywany jest przy ustalaniu cen za usługi (taryf), przy czym należy mieć na względzie interes najuboższych grup lokalnej społeczności. Polityka władz lokalnych w odniesieniu do cen i poziomu świadczonych usług w tym modelu zaostrza się w okresach wyborczych, niejednokrotnie stanowiąc ważną kartę przetargową. Doraźna polityka cenowa nie uwzględnia wydatków inwestycyjnych, co przekłada się na brak możliwości planowania cen w przyszłości, określenia przychodów, a nawet przygotowania dobrego biznesplanu, który stanowiłby podstawę określenia źródeł finansowania niezbędnych inwestycji. W sytuacji, gdy wpływy z opłat nie są w stanie pokryć wydatków inwestycyjnych oraz niemożliwe jest precyzyjne zaplanowanie przychodów niezbędne jest wsparcie finansowe ze strony władz lokalnych. W sposób naturalny ograniczane są przyszłe możliwości inwestycyjne, które uzależnione są od budżetu gminy.

Model niemiecki charakterystyczny jest dla większości funkcjonujących w Polsce przedsiębiorstw wodno-kanalizacyjnych oraz ciepłowniczych. Jego zaletą jest łatwość utrzymania kontroli nad daną sferą usług, niski poziom cen,

${ }^{90}$ J. Zysnarski, Partnerstwo publiczno-prywatne w sferze ustug..., s. 28.

${ }^{91}$ M. Bitner, Modele partnerstwa publiczno-prywatnego w krajach Unii Europejskiej, „Finanse Komunalne" 2003, nr 2 Ekstra, s. 23-34; J. Szreder, Współdziałanie sektora publicznego i prywatnego w rozwoju lokalnym, Wyższa Szkoła Zarządzania w Słupsku, Słupsk 2004, s. 113114; J. Zysnarski, Partnerstwo publiczno-prywatne w sferze ustug..., s. 28.

${ }^{92}$ J. Zysnarski, Partnerstwo publiczno-prywatne w sferze ustug..., s. 28. 
ochrona interesów najsłabszych grup społecznych. Za wadę należy uznać wpływ polityki lokalnej, ograniczoną rolę operatora oraz brak samodzielności w kształtowaniu polityki cenowej. Podmioty najczęściej zawierają kontrakty na usługi lub kontrakty na obsługę i zarządzanie.

Model brytyjski w ogólnych założeniach zbieżny jest z modelem niemieckim. Różnica polega na tym, że infrastruktura jest w nim własnością prywatną. Takie rozwiązanie stwarza możliwość działania kilku podmiotom świadczącym ten sam rodzaj usługi. Gmina zostaje pozbawiona praw kontrolno-nadzorczych nad zakresem świadczonych usług i poziomem cen za usługi. W odniesieniu do monopoli naturalnych wpływ na wybrane elementy może zostać zagwarantowany w umowie sporządzanej przez strony. Przyjmuje się, że istotna rola spoczywa wówczas na branżowych organach regulacyjnych, które kontrolują wzrost taryf oraz określają zasady przyłączenia do sieci nowych odbiorców. Rozwiązania przyjęte $\mathrm{w}$ tym modelu dopuszczają możliwość funkcjonowania kilku podmiotów świadczących daną usługę, co sprzyja konkurencji. Właściciel świadczenie usług opiera na rachunku ekonomicznym. Cena usługi powinna pokrywać koszty stałe utrzymania sieci, koszty zmienne wytworzenia usługi oraz marżę zysku dla właściciela. Stąd wszelkie zmiany w otoczeniu prawno-ekonomicznym skutkują prawie natychmiastową zmianą cen. Wysokość taryf jest więc podstawowym elementem, za pośrednictwem którego właściciel-operator osiąga swój cel. Postuluje się, aby dostawcami usług były podmioty silne finansowo, które w razie wystąpienia przejściowych kłopotów zapewnią ciągłość dostaw usług publicznych.

Swoboda działania podmiotu dostarczającego usługi publiczne, stabilne warunki działania, możliwość prognozowania dochodów, a tym samym kształtowanie polityki inwestycyjnej oraz brak bezpośredniego uzależnienia od władz lokalnych to zalety modelu brytyjskiego. Za wadę należy uznać brak ochrony interesów słabych finansowo grup społecznych. Charakterystyczne dla modelu typy umów to kontrakty na budowę, kontrakty na usługi, dzierżawa oraz sprzedaż.

Cechą charakterystyczną dla modelu francuskiego jest wyraźne oddzielenie funkcji właściciela infrastruktury od funkcji operatora. Właścicielem infrastruktury pozostaje gmina, a operatorem jest podmiot prywatny, którego wybór następuje $\mathrm{w}$ drodze przetargu ${ }^{93}$. W modelu występują dwie formy: concession de travaux et de sernice, polegające na tym, że koncesjonariusz buduje i finansuje inwestycje w zamian za prawo do eksploatacji i pobierania opłat od użytkowników oraz concession de services, w ramach którego koncesjonariusz eksploatuje

${ }^{93} \mathrm{~W}$ polskich warunkach wybór operatora następuje na podstawie przepisów Prawa zamówień publicznych. Wybór partnera prywatnego może nastąpić także na podstawie Ustawy o koncesji na roboty budowlane lub ustugi bądź Ustawy o partnerstwie publiczno-prywatnym. Forma pobierania korzyści przez partnera prywatnego jest wyznacznikiem wyboru odpowiednich regulacji prawnych. 
już istniejącą infrastrukturę (lub obiekt), utrzymuje, finansuje naprawy, uzyskując przychody ze świadczonych usług. Po terminie umowy przedmiot koncesji trafia do podmiotu publicznego. Podmiot prywatny ma wpływ na politykę cenową oraz czynnie współpracuje z władzami gminy nad opracowaniem planu inwestycyjnego. Władze gminy określają taryfy cen na usługi, decydują o kierunku rozwoju infrastruktury. Umowy zawierane są na okres od 15 do 30 lat. Zarządzanie infrastrukturą może odbywać się w formie kontraktu menedżerskiego, umowy dzierżawy czy koncesji. Wybór formy uzależniony jest od indywidualnych warunków w jakich mają być dostarczane usługi. Wybór konkretnej formy decyduje o zaletach i wadach poszczególnych rozwiązań. Zestawienie cech charakteryzujących powyższe modele prezentowane jest $\mathrm{w}$ tab. 1.6.

Tabela 1.6

Zestawienie charakterystycznych cech modeli partnerstwa publiczno-prywatnego

\begin{tabular}{|c|c|c|c|}
\hline Cecha & Model niemiecki & Model brytyjski & Model francuski \\
\hline 1 & 2 & 3 & 4 \\
\hline $\begin{array}{l}\text { Właściciel infrastruk- } \\
\text { tury }\end{array}$ & Sektor publiczny & Sektor prywatny & Sektor publiczny \\
\hline Operator & Sektor publiczny & Sektor prywatny & Sektor prywatny \\
\hline $\begin{array}{l}\text { Obszar aktywności } \\
\text { sektora publicznego }\end{array}$ & $\begin{array}{l}\text { kształtowanie polityki } \\
\text { cenowej, } \\
\text { podejmowanie decyzji } \\
\text { inwestycyjnych }\end{array}$ & $\begin{array}{l}\text { ograniczona kontrola } \\
\text { nad partnerem pry- } \\
\text { watnym przez sektor } \\
\text { publiczny, istotna rola } \\
\text { branżowych organów } \\
\text { regulacyjnych }\end{array}$ & $\begin{array}{l}\text { określanie taryf, } \\
\text { kształtowanie polityki } \\
\text { modernizacji i rozwo- } \\
\text { ju sieci, } \\
\text { finansowanie inwes- } \\
\text { tycji }\end{array}$ \\
\hline $\begin{array}{l}\text { Obszar aktywności } \\
\text { sektora prywatnego }\end{array}$ & $\begin{array}{l}\text { utrzymanie infrastruk- } \\
\text { tury, finansowanie } \\
\text { modernizacji, } \\
\text { zarządzanie mieniem, } \\
\text { pobieranie opłat }\end{array}$ & $\begin{array}{l}\text { dążenie do efektywno- } \\
\text { ści inwestycji, kształ- } \\
\text { towanie cen, } \\
\text { samodzielność } \\
\text { w kształtowaniu po- } \\
\text { lityki inwestycyjnej }\end{array}$ & $\begin{array}{l}\text { eksploatacja sieci, } \\
\text { doradztwo na rzecz } \\
\text { gminy w zakresie cen } \\
\text { za usługi, współpraca } \\
\text { przy ustalaniu kie- } \\
\text { runków rozwoju i in- } \\
\text { westycji }\end{array}$ \\
\hline $\begin{array}{l}\text { Poziom samodzielno- } \\
\text { ści partnera prywat- } \\
\text { nego (operatora) }\end{array}$ & mała & duża & ograniczona \\
\hline Zalety & $\begin{array}{l}\text { utrzymanie kontroli } \\
\text { przez sektor publicz- } \\
\text { ny, niski poziom cen } \\
\text { na usługi, ochrona } \\
\text { interesów najsłab- } \\
\text { szych grup społecz- } \\
\text { nych }\end{array}$ & $\begin{array}{l}\text { stabilne warunki dzia- } \\
\text { łania operatora, brak } \\
\text { uzależnienia od poli- } \\
\text { tyki władz lokalnych, } \\
\text { swoboda w kształto- } \\
\text { waniu polityki } \\
\text { inwestycyjnej, } \\
\text { swobodna polityka } \\
\text { cenowa }\end{array}$ & $\begin{array}{l}\text { stabilne warunki funk- } \\
\text { cjonowania operatora, } \\
\text { niewielkie uzależnie- } \\
\text { nie od decyzji polity- } \\
\text { cznych }\end{array}$ \\
\hline
\end{tabular}


Tabela $1.6(\mathrm{~cd}$.

\begin{tabular}{|l|l|l|l|}
\hline \multicolumn{1}{|c|}{1} & \multicolumn{1}{|c|}{2} & \multicolumn{1}{c|}{3} & \multicolumn{1}{c|}{4} \\
\hline Wady & $\begin{array}{l}\text { ograniczona samo- } \\
\text { dzielność operatora, } \\
\text { uzależnienie operatora } \\
\text { od polityki władz } \\
\text { lokalnych }\end{array}$ & $\begin{array}{l}\text { brak ochrony inte- } \\
\text { resów najuboższych } \\
\text { grup społecznych }\end{array}$ & $\begin{array}{l}\text { ograniczona umową } \\
\text { swoboda w kształto- } \\
\text { waniu polityki inwe- } \\
\text { stycyjnej }\end{array}$ \\
\hline Zastosowanie & $\begin{array}{l}\text { gospodarka wodno- } \\
\text { kanalizacyjna, głównie } \\
\text { w Niemczech, Belgii, } \\
\text { Holandii, USA }\end{array}$ & $\begin{array}{l}\text { komunikacja, } \\
\text { oczyszczanie miasta, } \\
\text { gospodarka cieplna }\end{array}$ & $\begin{array}{l}\text { ochrona zdrowia, } \\
\text { edukacja, gospodarka } \\
\text { wodno-kanalizacyjna }\end{array}$ \\
\hline Typ umowy & $\begin{array}{l}\text { kontrakty na usługi, } \\
\text { kontrakty na obsługę } \\
\text { i zarządzanie }\end{array}$ & $\begin{array}{l}\text { dzierżawa, kontrakty } \\
\text { na budowę, kontrakty } \\
\text { na usługi, sprzedaż }\end{array}$ & $\begin{array}{l}\text { kontrakty menedżer- } \\
\text { skie, koncesje na okres } \\
\text { 15-30 lat, dzierżawa }\end{array}$ \\
\hline
\end{tabular}

Źródło: oprac. własne na podstawie J. Zysnarski, Partnerstwo publiczno-prywatne. Teoria i praktyka, ODiDK Sp. z o.o., Gdańsk 2003, s. 24-33, Zarys ekonomii sektora publicznego, red. M. Brol, Wydawnictwo Uniwersytetu Ekonomicznego we Wrocławiu, Wrocław 2010, s. 180.

W literaturze pojawia się także model przemyslowy jako połączenie prywatnej własności infrastruktury z zewnętrznym operatorem. W obszarze świadczenia usług publicznych model ten nie występuje. Zastosowanie może znaleźć w sieciach przemysłowych, gdzie dąży się do poprawy ich funkcjonowania przez przekazanie zarządu wyspecjalizowanym podmiotom ${ }^{94}$.

Doświadczenia zagraniczne $\mathrm{w}$ realizacji zadań komunalnych sprowadzają się w zasadzie do zastosowania dwóch modeli: brytyjskiego, realizowanego $\mathrm{w}$ formie pełnej prywatyzacji i francuskiego, w którym publiczna sieć jest w zarządzie prywatnym prowadzonym na zasadzie koncesji lub w formie spółek joint venture.

\subsubsection{Formy organizacyjne występujące $w$ formule partnerstwa publiczno-prywatnego}

W praktyce wypracowano wiele form (typów) realizacji publicznych przedsięwzięć inwestycyjnych współfinansowanych kapitałem prywatnym. Należą do nich koncesje, kontrakty czy umowy dzierżawy. W rzeczywistości każda z tych form może być zastosowana do formuły PPP i zmodyfikowana na potrzeby

${ }^{94}$ Por. D. Hajdys, Formalnoprawne możliwości wspótpracy sektora publicznego i prywatnego w ramach modelu partnerstwa publiczno-prywatnego, „Finanse Komunalne” 2009, nr 9, s. 25 26; J. Zysnarski, Partnerstwo publiczno-prywatne w sferze..., s. 28-33; M. Bitner, Bariery rozwoju partnerstwa publiczno-prywatnego jako metody wykonywania zadań zwiazanych $z$ realizacja inwestycji lokalnych i regionalnych $w$ Polsce, [w:] Realizacja zadań publicznych przez jednostki samorzadu terytorialnego..., s. 31-32. 
konkretnego przedsięwzięcia i warunków, w jakich będzie realizowana inwestycja. W związku z powyższym formy współpracy można podzielić ze względu na specyfikę realizowanych zadań, stopień ich złożoności, zakres zaangażowania kapitału prywatnego oraz warunki rynkowe (występowanie monopolu naturalnego, wielkość obszaru działania) oraz stan majątku podmiotu publicznego. Pierwszą grupę stanowią te formy, w których dochodzi do czasowego (określonego umową) przekazania majątku publicznego w eksploatację podmiotowi prywatnemu (operatorowi). Drugą grupę stanowią formy, w których dochodzi do powiększenia publicznej masy majątkowej. Wśród tych form dominują systemy oparte na kontraktach typu BOT (Build-Operate-Transfer).

Różnorodność typów zależy od celu, jaki stawiają sobie strony umowy. Wynika to z odmiennych priorytetów, motywów i kryteriów działania. Podmiot prywatny z reguły zainteresowany jest jak największym zwrotem z zainwestowanego kapitału. Decyzjom partnera publicznego przyświecać powinno dobro publiczne, a nie bezpośrednie korzyści ekonomiczne. W formach mogą więc zachodzić następujące relacje ${ }^{95}$ :

- publiczna własność $\rightarrow$ prywatne zarządzanie (charakterystyczne dla umów typu: koncesje, kontrakty, dzierżawa, leasing),

- publiczno-prywatna własność $\rightarrow$ publiczno-prywatne zarządzanie (spółki specjalnego przeznaczenia SPV),

- publiczno-prywatna własność $\rightarrow$ prywatne zarządzanie (spółki specjalnego przeznaczenia zarządzane prywatnie).

Partnerstwo publiczno-prywatne to konkretne typy umów między stroną publiczną a stroną prywatną, związanych z realizacją konkretnego przedsięwzięcia inwestycyjnego. Do najczęściej stosowanych form umów, a zarazem najbardziej skomplikowanych zalicza się koncesje i kontrakty.

Słownik wyrazów obcych definiuje koncesję jako umowę administracyjną upoważniającą osobę fizyczną do wykonania określonej działalności zwłaszcza gospodarczej $^{96}$. Szerokiej analizy istoty koncescji można doszukać się w opracowaniu M. Wierzbowskiego, według którego koncesja to: po pierwsze, zgoda państwa (gminy) na prowadzenie działalności gospodarczej w obszarze zarezerwowanym dla podmiotów publicznych, a więc znajdującym się poza sferą działalności podmiotów prywatnych, po drugie, udzielenie koncesji wynika z woli państwa (gminy), określającej jednostronny zakres działalności, po trzecie, koncesja co do zasady udzielana jest podmiotom prywatnym, po czwarte, ma charakter $\mathrm{w}$ pełni konstytutywny, przyznając koncesjobiorcy

${ }_{95}$ J. Szreder, Współdziałanie sektora publicznego i prywatnego..., s.122.

${ }^{96}$ W. Kopaliński, Stownik wyrazów obcych i zwrotów obcojęzycznych, Wiedza Powszechna, Warszawa 1989, s. 273. 
określone prawa wobec koncesjodawcy i określając równocześnie warunki, w jakich ma być prowadzona działalność ${ }^{97}$.

Pojęcie koncesji, rozumiane jako sfera uprawnień przyznana podmiotowi do prowadzenia określonej działalności, po raz pierwszy pojawiło się w XV w. i dotyczyło pobierania opłat za towary przewożone po Renie ${ }^{98}$. Zasady współpracy pomiędzy stronami publiczną i prywatną, określone w zamówieniach publicznych, stanowią rozwiązania mało elastyczne. Wskazuje się, że instytucja koncesji w większym zakresie poszerza możliwości wykonywania zadań publicznych oraz wpływa na poprawę dostępności i jakości usług publicznych ${ }^{99}$. Istota koncesji polega na wyrażeniu zgody na podjęcie działalności gospodarczej w sferze objętej wyłącznością lub własnością publiczną. Najczęściej przyznawane są one w drodze przetargu publicznego, co ma zagwarantować konkurencyjność wśród podmiotów ubiegających się o koncesję oraz optymalność ceny i efektów dla społeczeństwa. Koncesje wydawane są na przedsięwzięcia inwestycyjne i eksploatację urządzeń lub całych sieci infrastrukturalnych przy zachowaniu przez sektor publiczny prawa do regulowania cen za świadczone usługi w określonym umową koncesyjną okresie, najczęściej od 10 do 30 lat. Zdarzają się także umowy o dłuższym terminie (np. umowa koncesyjna na parking na Groblach w Krakowie na okres 70 lat). W czasie trwania umowy koncesjonariusz prowadzi proces inwestycyjny i eksploatacyjny we własnym imieniu i na własne ryzyko.

Najważniejszymi cechami umów koncesji są ${ }^{100}$ :

- przeniesienie odpowiedzialności za prowadzenie procesu inwestycyjnego na sektor prywatny,

- powierzenie eksploatacji usług infrastrukturalnych podmiotom prywatnym $\mathrm{z}$ jednoczesnym przeniesieniem na nie ryzyka technicznego, operacyjnego i rynkowego,

- przyznanie podmiotowi prywatnemu wynagrodzenia w postaci opłat wnoszonych przez użytkowników usług.

Przez okres trwania umowy na podmiocie prywatnym ciąży obowiązek dostarczania zakontraktowanych usług konsumentom, zapewnienia odpowiedniego poziomu i jakości usług wynikających z obowiązujących standardów. Za ich określenie odpowiada koncesjodawca, który określa je w umowie.

${ }^{97}$ Por. Prawo gospodarcze. Zagadnienia administracyjnoprawne, red. C. Balasiński, M. Wierzbowski, M. Wyrzykowski, WP PWN, Warszawa 1998, s. 167-169.

${ }^{98}$ Por. D. R. Kijowski, Pozwolenia w administracji publicznej, Studium z teorii prawa administracyjnego, Temida 2, Białystok 2000, s. 35.

${ }^{99}$ Zob. A. Panasiuk, Koncesja na roboty budowlane lub ustugi. Partnerstwo publiczno-prywatne. Komentarz, Wydawnictwo C. H. Beck, Warszawa 2009, s. 25.

${ }^{100}$ Por. Partnerstwo publiczno-prywatne. Zagadnienia teorii i praktyki, red. M. Perkowski, Temida 2, Białystok 2007, s. 31. 
Jak już wspomniano wcześniej, w Polsce w rozwiązaniach prawnych mamy do czynienia z koncesją na roboty budowlane i koncesją na usługi. Koncesja na roboty budowlane pojawiła się wraz z wejściem w życie ustawy z 29 stycznia 2004 r. Prawo zamówień publicznych ${ }^{101}$. Rozwiązanie to wprowadziło kilkuetapową współpracę zamawiającego i wykonawcy (zaprojektowanie lub wybudowanie, eksploatację i rozliczenie inwestycji) i zdecydowanie odbiegało od tradycyjnego zamówienia publicznego (robota/budowlana/dostawa/usług - zapłata). Należy wyraźnie wskazać, że „zwykłe” zamówienie publiczne dotyczy wykonania konkretnego zamówienia i uregulowania płatności bez długotrwałych relacji i powiązań pomiędzy zamawiającym a wykonawcą oraz że cała odpowiedzialność za zlecenie spoczywa na stronie publicznej. W przypadku koncesji jest to długookresowa współpraca przy zachowaniu wcześniej wymienionych warunków.

Przyjęte w 2009 r. w Prawie zamówień publicznych rozwiązania doczekały się odrębnego uregulowania $\mathrm{w}$ postaci ustawy o koncesji na roboty budowlane i usługi ${ }^{102}$ i wraz z ustawą o partnerstwie publiczno-prywatnym z 2008 r. miały stanowić trzon proceduralny dla przedsięwzięć inwestycyjnych wykonywanych przez strony publiczną i prywatną. Należy zwrócić uwagę, że przedmiotem koncesji mogą być roboty budowlane i usługi określone w ustawie ${ }^{103}$.

Opłaty wynikające z koncesji definiowane są już na początku postępowania przetargowego. Mogą zostać określone jako opłata stała lub procent od obrotów. Najkorzystniejszym rozwiązaniem jest ustalenie opłaty w postaci procentu od obrotów, gdyż unika się wówczas wszelkich zmian w sytuacji społecznogospodarczej, która może rzutować na warunki wykonania umowy. Partnerowi

101 Ustawa z dnia 29 stycznia 2004 r. Prawo zamówień publicznych, DzU, 2004, nr 19, poz. $177 \mathrm{ze} \mathrm{zm}$.

${ }^{102}$ Ustawa z dnia 9 stycznia 2009 r. o koncesji na roboty budowlane i ustugi, DzU, 2009, nr 19, poz. 101 ze zm.

${ }^{103}$ Zagadnienia związane $\mathrm{z}$ budową lub remontem obiektu budowlanego uregulowane zostały w Ustawie z dnia 7 lipca 1994 r. Prawo budowlane (DzU, 2006, nr 156, poz. 1118 ze zm.). Według Prawa budowlanego przez „obiekt budowlany” należy rozumieć budynek wraz z instalacjami i urządzeniami technicznymi, budowlę stanowiącą całość techniczno-użytkową wraz $\mathrm{z}$ instalacjami i urządzeniami oraz obiekt małej architektury. Za „budowę” uznaje się wykonanie obiektu budowlanego w określonym miejscu, a także odbudowę, rozbudowę oraz nadbudowę. „Remont” oznacza wykonanie w istniejącym obiekcie budowlanym robót budowlanych polegających na odtworzeniu stanu pierwotnego, a nie stanowiących bieżącej konserwacji, przy czym dopuszcza się wykorzystanie wyrobów budowlanych innych niż użyte w stanie pierwotnym. „Usługi” to świadczenia, których przedmiotem nie są roboty budowlane lub dostawy. Jest to tzw. negatywna definicja, która wzorowana jest na przepisach dyrektywy klasycznej i na dyrektywie sektorowej 2004/18/WE Parlamentu Europejskiego i Rady z dnia 31 marca 2004 r. w sprawie koordynacji procedur udzielania zamówień publicznych na roboty budowlane, dostawy i usługi oraz dyrektywie 2004/17/WE Parlamentu Europejskiego i Rady z dnia 31 marca 2004 r. koordynującej procedury udzielania zamówień..., a także Ustawie z dnia 29 stycznia 2004 r. Prawo zamówień publicznych... 
prywatnemu w zamian za całościowe podejście do przedmiotu koncesji (budowa, eksploatacja) przysługuje wynagrodzenie $\mathrm{w}$ postaci opłaty wnoszonej przez użytkowników - odbiorców usług. Stawki powinny być tak skalkulowane, aby wystarczały na pokrycie kosztów operacyjnych działalności, w tym również koszty obsługi kredytów i amortyzacji inwestycji prowadzonej w ramach koncesji.

Udział kapitału i rozmieszczenie ryzyka w koncesji może przyjąć różne formy, co w praktyce spowodowało, że w ramach koncesji może dojść do niejednakowych rozwiązań. Najczęściej spotykane i omówione w literaturze ujęto w tab. 1.7.

Tabela 1.7

Rodzaje najczęściej realizowanych koncesji

\begin{tabular}{|c|c|c|}
\hline $\begin{array}{c}\text { Skrót } \\
\text { koncesji }\end{array}$ & Nazwa angielska & Nazwa polska \\
\hline 1 & 2 & 3 \\
\hline \multicolumn{3}{|c|}{ Koncesje rozpoczynające sie faza budowlana } \\
\hline BOT & Build - Operate - Transfer & Buduj - eksploatuj - przekaż \\
\hline BTO & Build - Transfer - Operate & Buduj - przekaż - eksploatuj \\
\hline $\mathrm{BOO}$ & Build - Own - Operate & Buduj - bądź właścicielem - eksploatuj \\
\hline BOOT & Build - Own - Operate - Transfer & $\begin{array}{l}\text { Buduj - bądź właścicielem - eksploatuj - } \\
\text { przekaż }\end{array}$ \\
\hline BRTO & Build - Rent - Transfer-Operate & Buduj - wydzierżaw - eksploatuj - przekaż \\
\hline BLOT & Build - Lease - Operate - Transfer & Buduj - leasinguj - eksploatuj - przekaż \\
\hline $\mathrm{BT}$ & Build - Transfer & Buduj - przekaż \\
\hline \multicolumn{3}{|c|}{ Koncesje rozpoczynajace sie faza modernizacji } \\
\hline MOT & Modernize - Operate - Transfer & Modernizuj-eksploatuj - przekaż \\
\hline MOO & Modernize - Own - Operate & Modernizuj - bądź właścicielem - przekaż \\
\hline MOOT & $\begin{array}{l}\text { Modernize - Own - Operate - } \\
\text { Transfer }\end{array}$ & $\begin{array}{l}\text { Modernizuj - bądź właścicielem - eksploatuj } \\
\text { - przekaż }\end{array}$ \\
\hline \multicolumn{3}{|c|}{ Koncesje rozpoczynające sie faza projektowa } \\
\hline DB & Design - Build & Projektuj - buduj \\
\hline DBM & Design - Build - Maintain & Projektuj - buduj - utrzymaj \\
\hline DBO & Design - Build - Operate & Projektuj - buduj - eksploatuj \\
\hline DBMO & $\begin{array}{l}\text { Design - Build - Maintain - } \\
\text { Operate }\end{array}$ & Projektuj - buduj - utrzymaj - eksploatuj \\
\hline DBOT & Design - Build - Operate - Transfer & Projektuj - buduj - eksploatuj - przekaż \\
\hline DBOO & Design - Build - Own - Operate & $\begin{array}{l}\text { Projektuj - buduj - bądź właścicielem - } \\
\text { eksploatuj }\end{array}$ \\
\hline DBFO & Design - Build - Finance - Operate & Projektuj - buduj - finansuj - eksploatuj \\
\hline DCMF & $\begin{array}{l}\text { Design - Construct - Manage - } \\
\text { Finance }\end{array}$ & Projektuj - buduj - zarządzaj - finansuj \\
\hline
\end{tabular}




\begin{tabular}{|c|c|c|}
\hline 1 & 2 & 3 \\
\hline \multicolumn{3}{|c|}{ Koncesje rozpoczynające się faza zakupu/dzierżawy } \\
\hline $\mathrm{BBO}$ & Buy-Build - Operate & Kupuj - buduj - eksploatuj \\
\hline BDO & Buy - Develop - Operate & Kupuj-rozwijaj-eksploatuj \\
\hline LDO & Lease-Develop-Operate & Dzierżaw - rozwijaj - eksploatuj \\
\hline \multicolumn{3}{|c|}{ Pozostate rodzaje koncesji } \\
\hline ROO & Renew - Own - Operate & Odnawiaj - bądź właścicielem - eksploatuj \\
\hline \multirow[t]{2}{*}{ ROT } & Renew - Operate - Transfer & Odnawiaj - eksploatuj - przekaż \\
\hline & Turnkey Operation & Inwestycja pod klucz \\
\hline
\end{tabular}

Źródło: oprac. własne na podstawie literatury przedmiotu ze szczególnym wykorzystaniem K. Brzozowska, Partnerstwo publiczno-prywatne w Europie. Cele, uwarunkowania, efekty, Wydawnictwa Fachowe CeDeWu, Warszawa 2010, s. 40; A. Cenker, Partnerstwo publiczno-prywatne jako metoda wykonywania zadań publicznych, Szkoła Główna Handlowa w Warszawie, Warszawa 2009, s. 137.

Najbardziej popularnym rodzajem koncesji jest BOT. Podmiot prywatny odpowiada za wybudowanie obiektu zgodnie z ustaleniami określonymi przez podmiot publiczny. Po zakończeniu budowy przysługuje mu prawo eksploatacji przez okres objęty umową koncesji. W tym czasie odpowiada za świadczenie usług na rzecz społeczności. W okresie trwania umowy partner prywatny oczekuje zwrotu poniesionych nakładów oraz zysku. Jeśli podmiot publiczny nie dotuje usług świadczonych przez koncesjobiorcę, to partner prywatny ma swobodę w ustalaniu opłat pobieranych od użytkowników i w całości je przejmuje. Rola strony publicznej ograniczona zostaje do nadzorowania przedsięwzięcia. Po zakończonym okresie umowy podmiot prywatny przekazuje obiekt na własność podmiotowi publicznemu. Sektor publiczny może przejąć zadanie i wykonywać je we własnym imieniu lub podpisać nową umowę z podmiotem prywatnym (może być to ten sam podmiot, jeśli taki wariant został zapisany w pierwszej umowie, lub nowy, wyłoniony w nowym postępowaniu przetargowym). W ramach BOT występuje szereg rozwiązań. Różnica między nimi polega na zakresie uprawnień partnera prywatnego w trakcie trwania umowy i po jej zakończeniu. Część rozwiązań sprowadza się do ostatecznego przekazania obiektu podmiotowi publicznemu (BT, BOOT), w pozostałych partner prywatny staje się właścicielem obiektu (ROO, BOO, BDO) bądź uzyskuje prawo jego dzierżawienia (BTO).

Rozwiązania przyjęte w koncesji typu DB (Desing-Build) sprowadzają się do sytuacji, w której sektor prywatny odpowiedzialny jest za przygotowanie projektu obiektu i jego wybudowanie. Z chwilą zakończenia budowy sektor publiczny staje się właścicielem obiektu i przejmuje pełny zakres obowiązków związanych $\mathrm{z}$ funkcjonowaniem obiektu i świadczeniem usług. Również $\mathrm{w}$ tym przypadku możliwe są różne rozwiązania związane z przyznaniem inwestorowi prawa do czasowej eksploatacji (DBOT) lub całkowitego przekazania przedmiotu umowy partnerowi prywatnemu (DBOO). 
Inwestycja pod klucz (Turnkey Operation) jest rozwiązaniem, w którym podmiot prywatny odpowiada za zaprojektowanie, wybudowanie i eksploatację obiektu oraz świadczenie usług w czasie ustalonym z publicznym partnerem. Środki na sfinansowanie przedsięwzięcia mogą pochodzić od podmiotu publicznego. Takie rozwiązanie gwarantuje skrócenie fazy projektowania i budowy do niezbędnego minimum, a także prowadzi do redukcji kosztów. Podmiot prywatny jest właścicielem obiektu, co znacznie ogranicza kontrolę podmiotu publicznego.

Występujące w ramach koncesji różnorodne rozwiązania $\mathrm{K}$. Brzozowska pogrupowała na trzy typy ${ }^{104}$. Typ I odnosi się do odmian projektuj - finansuj - eksploatuj, w których sektor prywatny odpowiada za zaprojektowanie, budowę, eksploatację i zarządzanie infrastrukturą, bez konieczności przeniesienia własności na rzecz sektora publicznego (BOO, BDO, DCMF). Typ II dotyczy rozwiązań, w ramach którego sektor prywatny nabywa lub leasinguje istniejącą infrastrukturę od władz publicznych, dokonuje stosowych modernizacji, a następnie ją eksploatuje. Nie jest zobligowany do przeniesienia własności na sektor publiczny (BBO, LDO). W ramach typu III sektor prywatny projektuje, buduje, eksploatuje, a następnie po okresie umowy przenosi aktywa na rzecz sektora publicznego. Partner prywatny po przekazaniu obiektu stronie publicznej może ubiegać się o dzierżawę lub leasing zdanego obiektu (BOT, BOOT, BROT, BLOT, BTO).

Kontrakty są drugą obok koncesji grupą rozwiązań PPP cieszącą się dużą popularnością. Kontrakt to układ, umowa między stronami zawarta na piśmie ${ }^{105}$. Kontrakty dotyczą umów zawieranych najczęściej na krótki, co najwyżej kilkuletni, okres. Kontraktacja usług odbywa się na podstawie przetargów, co sprzyja efektywności świadczonych usług. W rozwiązaniu tym sektor prywatny uczestniczy w bieżącej eksploatacji i zarządzaniu infrastrukturą bez konieczności zmian w zakresie własnościowym wykorzystywanej infrastruktury. Zmianie ulega rola podmiotu publicznego z bezpośredniego usługodawcy do roli zarządcy, kontrolera. W kontraktach istotne znaczenie ma standaryzacja umów, określenie katalogu bodźców finansowych oraz kar, a co najważniejsze, mierników efektywnego wykonania usługi. W zależności od obszaru działania objętego kontraktami wyróżniamy kontrakty na wykonawstwo, świadczenie usług oraz zarządzanie.

Kontrakty na wykonawstwo (podwykonawstwo, nadzór techniczny) zawierane są pomiędzy sektorem publicznym a prywatnym na wykonanie określonych prac projektowo-budowlanych, wykończeniowych, dostaw urządzeń oraz zadań wynikających z obowiązku projektowego i budowlanego. Podmiot prywatny nie angażuje swojego kapitału, realizuje jedynie zlecenie złożone przez stronę publiczną. Ryzyko, jakie występuje, dotyczy sektora prywatnego i odnosi się do ryzyka związanego z zapłatą za wykonanie zlecenia.

\footnotetext{
${ }^{104}$ K. Brzozowska, Partnerstwo publiczno-prywatne w Europie..., s. 41.

${ }^{105}$ W. Kopaliński, Słownik wyrazów obcych $i$ zwrotów..., s. 278.
} 
Kontrakty na świadczenie uslug to umowy zawierane między stronami publiczną i prywatną na świadczenie określonej usługi w imieniu władz publicznych. Podmiot prywatny realizuje usługi bez angażowania własnego kapitału. Za ich wykonanie otrzymuje zapłatę od sektora publicznego. W sytuacji, gdy świadczone usługi mają charakter odpłatny, korzystający rozliczają się bezpośrednio z sektorem publicznym.

Kontrakty na zarzadzanie, zwane menedżerskimi (Operation \& Maintanance Contract) to umowy o eksploatację i utrzymanie infrastruktury. Podmioty prywatne odpowiedzialne są za właściwe użytkowanie istniejących urządzeń i obiektów w sposób gwarantujący odpowiednią wydajność i odpowiedni stan techniczny. Partner prywatny wynagradzany jest w ramach stałego wynagrodzenia lub na podstawie ustalonych systemów premiujących zaangażowanie w osiąganiu wyznaczonych przez stronę publiczną parametrów. Strona publiczna odpowiada za rozwój infrastruktury i ponosi na nią nakłady. Kontrakty, jako forma umów, przyjmują postać umów zleceń lub umów o dzieło i nie wymagają od sektora prywatnego zaangażowania finansowego ${ }^{106}$.

Umowa dzierżawy polega na tym, że podmiot prywatny zawiera umowę dzierżawy na majątek stanowiący własność podmiotu publicznego. Dzierżawca, zwany operatorem, nie prowadzi inwestycji z wyjątkiem bieżących, zapewniających ciągłość dostaw lub usług. Działalność inwestycyjna pozostaje w gestii podmiotu publicznego. Podmiot prywatny uiszcza opłaty za wyłączne prawo do użytkowania obiektów i urządzeń objętych umową dzierżawy. Opłaty z reguły mają stały charakter, a ewentualne oszczędności, związane $\mathrm{z}$ działaniami proefektywnościowymi, stanowią źródło dodatkowych zysków dla dzierżawcy. Operator może uzyskiwać dodatkowe wynagrodzenie w przypadku osiągnięcia określonych rezultatów działania.

Umowy dzierżawy zawierane są na okres od 6 do 10 lat i powinny precyzyjnie określać ${ }^{107}$ :

- nakłady oraz standardy robót związane z utrzymaniem stanu technicznego dzierżawionych urządzeń i obiektów,

- parametry rezultatów działań, które będą stanowiły podstawę do oceny operatora,

- zasady kontroli wydatków ponoszonych przez operatora,

- procedury wprowadzania w życie umowy, zmiany umowy oraz wysokość i zakres kar za niewywiązywanie się z umowy.

${ }^{106}$ Por. Partnerstwo publiczno-prywatne. Zagadnienia teorii i praktyki..., s. 29-30; K. Brzozowska, Partnerstwo publiczno-prywatne w Europie..., s. 38.

${ }^{107}$ Por. J. Zysnarski, Partnerstwo publiczno-prywatne $w$ sferze ustug...s. 43-44; B. P. Korbus, M. Strawiński, Partnerstwo publiczno-prywatne..., s. 65-69. 
Umowy dzierżawy są chętnie zawierane w odniesieniu do gospodarki wodno-kanalizacyjnej. Gmina nie pozbywa się własności obiektów infrastrukturalnych, a jedynie korzysta $\mathrm{z}$ doświadczeń i umiejętności sektora prywatnego w celu zapewnienia sobie jak najlepszego poziomu usług.

Umowy leasingowe stanowią kolejną możliwość, w ramach których dochodzi do współpracy sektora publicznego z sektorem prywatnym. Umowa taka zawierana jest na czas określony, w którym podmiot prywatny leasinguje urządzenia i/lub obiekty za odpłatnością uwzględniającą część wartości użytkowanych urządzeń. Umowy leasingowe zawierane są z reguły z kontraktami na zarządzanie lub koncesjami. Jeśli umowa zawierana jest łącznie $\mathrm{z}$ kontraktem na zarządzanie, to umowa leasingowa dotyczy leasingu operacyjnego. W przypad$\mathrm{ku}$ koncesji umowa leasingowa przyjmuje formę leasingu finansowego. Tego typu umowy charakterystyczne są dla państw przechodzących transformację ustrojową. Jako przykład w literaturze podaje się 30-letnią umowę leasingową na sieć wodociągową, zawartą przez władze Pragi ze spółką, w której miasto miało $100 \%$ udziałów. Leasingobiorca zawarł $\mathrm{z}$ kolei umowę $\mathrm{z}$ operatorem, który po uzyskaniu kredytu zobowiązał się do przeprowadzenia modernizacji sieci wodociągowej ${ }^{108}$. Wykaz charakterystycznych cech modeli/form partnerstwa publiczno-prywatnego zawiera tab. 1.8.

Tabela 1.8

Cechy charakterystyczne modeli/form partnerstwa publiczno-prywatnego

\begin{tabular}{|c|c|c|c|c|c|c|}
\hline Model & $\begin{array}{c}\text { Okres trwania } \\
\text { umowy }\end{array}$ & $\begin{array}{l}\text { Własność } \\
\text { aktywów }\end{array}$ & $\begin{array}{c}\text { Finansowa- } \\
\text { nie } \\
\text { inwestycji }\end{array}$ & $\begin{array}{c}\text { Finansowanie } \\
\text { eksploatacji }\end{array}$ & $\begin{array}{c}\text { Pobieranie } \\
\text { opłat }\end{array}$ & $\begin{array}{l}\text { Wynagro- } \\
\text { dzenie } \\
\text { partnera } \\
\text { prywatnego }\end{array}$ \\
\hline 1 & 2 & 3 & 4 & 5 & 6 & 7 \\
\hline Koncesja & 10-30 lat & publiczna & \begin{tabular}{|l|} 
podmiot \\
prywatny
\end{tabular} & $\begin{array}{l}\text { podmiot } \\
\text { prywatny }\end{array}$ & $\begin{array}{l}\text { podmiot } \\
\text { prywatny }\end{array}$ & - \\
\hline $\begin{array}{l}\text { Rozwiąza- } \\
\text { nia typu } \\
\text { BOT }\end{array}$ & $\begin{array}{l}\text { w zależności } \\
\text { od typu od } \\
\text { kilku do } \\
\text { kilkunastu lat }\end{array}$ & $\begin{array}{l}\text { publiczna/ } \\
\text { prywatna }\end{array}$ & $\begin{array}{l}\text { podmiot } \\
\text { prywatny }\end{array}$ & $\begin{array}{l}\text { podmiot } \\
\text { prywatny }\end{array}$ & $\begin{array}{l}\text { podmiot } \\
\text { prywatny }\end{array}$ & $\begin{array}{l}\text { możliwość } \\
\text { dotowania } \\
\text { podmiotu } \\
\text { prywatne- } \\
\text { go }\end{array}$ \\
\hline $\begin{array}{l}\text { Kontrakt na } \\
\text { wyko- } \\
\text { nawstwo }\end{array}$ & $\begin{array}{l}\text { zgodny } \\
\text { z harmono- } \\
\text { gramem } \\
\text { i podpisanym } \\
\text { kontraktem }\end{array}$ & publiczna & $\begin{array}{l}\text { podmiot } \\
\text { publiczny }\end{array}$ & $\begin{array}{l}\text { podmiot } \\
\text { publiczny }\end{array}$ & & $\begin{array}{l}\text { zgodnie } \\
\text { z kontrak- } \\
\text { tem }\end{array}$ \\
\hline
\end{tabular}

${ }^{108}$ K. Brzozowska, Partnerstwo publiczno-prywatne w Europie..., s. 39; T. Kuczborski, M. Stańczuk, Jak zdobyć pieniądze na inwestycje?, „Rzeczpospolita” 1999, nr 142, s. B3. 


\begin{tabular}{|c|l|l|l|l|l|l|}
\hline 1 & \multicolumn{1}{|c|}{2} & \multicolumn{1}{c|}{3} & \multicolumn{1}{c|}{4} & \multicolumn{1}{c|}{5} & \multicolumn{1}{c|}{6} & \multicolumn{1}{c|}{7} \\
\hline $\begin{array}{c}\text { Kontrakt na } \\
\text { świad- } \\
\text { czenie } \\
\text { usług }\end{array}$ & $\begin{array}{l}\text { maksymal- } \\
\text { nie 5 lat }\end{array}$ & publiczna & $\begin{array}{l}\text { podmiot } \\
\text { publiczny }\end{array}$ & $\begin{array}{l}\text { podmiot } \\
\text { prywatny }\end{array}$ & $\begin{array}{l}\text { podmiot } \\
\text { publiczny }\end{array}$ & $\begin{array}{l}\text { zgodnie } \\
\text { z kontrak- } \\
\text { tem }\end{array}$ \\
\hline $\begin{array}{c}\text { Karzątrakt na } \\
\text { nie }\end{array}$ & $3-10$ lat & publiczna & $\begin{array}{l}\text { podmiot } \\
\text { publiczny }\end{array}$ & $\begin{array}{l}\text { podmiot } \\
\text { prywatny }\end{array}$ & $\begin{array}{l}\text { podmiot } \\
\text { publiczny }\end{array}$ & $\begin{array}{l}\text { zgodnie } \\
\text { z kontak- } \\
\text { tem }\end{array}$ \\
\hline $\begin{array}{c}\text { Umowa } \\
\text { dzierża- } \\
\text { wy }\end{array}$ & $6-10$ lat & publiczny & $\begin{array}{l}\text { podmiot } \\
\text { publiczny }\end{array}$ & $\begin{array}{l}\text { podmiot } \\
\text { prywatny }\end{array}$ & $\begin{array}{l}\text { podmiot } \\
\text { publiczny }\end{array}$ & $\begin{array}{l}\text { dodatkowe } \\
\text { z tytułu } \\
\text { osiagnięcia } \\
\text { dodatko- } \\
\text { wych } \\
\text { rezultatów }\end{array}$ \\
\hline $\begin{array}{c}\text { Umowa } \\
\text { leasingu }\end{array}$ & $\begin{array}{l}\text { okres odpo- } \\
\text { wiadający } \\
\text { umorzeniu } \\
\text { przedmiotu } \\
\text { leasingu }\end{array}$ & publiczna & $\begin{array}{l}\text { podmiot } \\
\text { publiczny }\end{array}$ & $\begin{array}{l}\text { podmiot } \\
\text { prywatny }\end{array}$ & podmiot \\
publiczny & & & \\
\hline
\end{tabular}

Źródło: oprac. własne.

Przedstawione modele i formy partnerstwa publiczno-prywatnego to nie wszystkie rodzaje partnerstwa, jakie mogą mieć zastosowanie w praktyce. Pozwalają one natomiast zauważyć, jak różny może być stopień skomplikowania struktur partnerstwa. Szeroka gama rozwiązań umożliwia podmiotom elastyczne kształtowanie struktury współpracy, dostosowane do konkretnych przedsięwzięć, jakie mają być wspólnie realizowane.

Strony podejmujące decyzje o współpracy nie są z góry skazane na konkretne rozwiązanie i ścisłe przestrzeganie reżimu procedury nakreślonej przez konkretny model/formę. Dotychczasowe doświadczenia pokazują, że strony cenią sobie swobodę $\mathrm{w}$ nakreślaniu ram współpracy wynikających $\mathrm{z}$ ich preferencji. Każdy z modeli ma swoje charakterystyczne elementy, można je traktować jako wzorce postępowania, które w razie potrzeby mogą zostać zmodyfikowane na potrzeby konkretnego przedsięwzięcia. Próby jakiegokolwiek usztywnienia mogą stanowić istotne ograniczenie $\mathrm{i}$ utrudnienie $\mathrm{w}$ przygotowaniu i przeprowadzeniu wspólnego przedsięwzięcia. Dostępne rozwiązania powinny stanowić bazę ułatwiającą współpracę. Każde nowe doświadczenie w modyfikacji przyjętych rozwiązań powinno tworzyć katalog „lepszych” struktur partnerstwa.

\subsubsection{Partnerstwo publiczno-prywatne a prywatyzacja}

Partnerstwo publiczno-prywatne jako jedna z metod realizowania zadań publicznych często (zwłaszcza $w$ potocznym znaczeniu) utożsamiana jest $\mathrm{z}$ prywatyzacją. Przyczyn takiego podejścia można dopatrywać się $\mathrm{w}$ braku 
jednomyślności i zgodności co do zdefiniowania pojęcia partnerstwa publicznoprywatnego. Zdaniem B. Korbusa i M. Strawińskiego ${ }^{109}$ PPP można zdefiniować negatywnie, co umożliwi wskazanie, że współpraca podmiotu publicznego $\mathrm{z}$ podmiotem prywatnym nie jest prywatyzacją w ogólnie przyjętym w Polsce znaczeniu.

Termin ,prywatyzacja” po raz pierwszy do literatury wprowadził P. Druc$\operatorname{ker}^{110} \mathrm{w}$ swojej pracy The Age of Discontinuity. Według autora prywatyzacja była formą przejścia od rozwiązań z silnym zaangażowaniem państwa w stronę rozwiązań o słabym zaangażowaniu państwa, którego wynikiem miało być zwiększenie efektywności sektora publicznego. Przyczyną niskiej efektywności tego sektora była niewielka wydajność pracy mierzona stosunkiem nakładów do ich wyników, co było spowodowane w znacznej mierze przerostem zatrudnienia i przeinwestowaniem ${ }^{111}$.

Prywatyzacja stała się zjawiskiem szeroko dyskutowanym na świecie w latach osiemdziesiątych XX w. na skutek zmian zapoczątkowanych w polityce gospodarczej Wielkiej Brytanii (thacheryzm) i Stanów Zjednoczonych (reganoekonomika). Związana była $\mathrm{z}$ procesem prowadzącym do zmiany kontroli państwa nad gospodarką $\mathrm{w}$ wyniku przekształcenia gospodarki państwowej w gospodarkę prywatną, przy równoczesnym ograniczeniu roli państwa w gospodarce. E. S. Savas twierdził, że prywatyzować oznacza „czynić prywatnym”, tzn. zmieniać własność ze społecznej na prywatną. Dopuszczał także w ramach prywatyzacji zmianę kontroli nad działalnością gospodarczą lub produkcyjną bez konieczności zmian własnościowych majątku. Z punktu widzenia partnerstwa to istotne spostrzeżenie, gdyż wskazuje na alternatywne mechanizmy zachowania „odpowiedzialności właścicielskiej”, niezakładającej przy tym własności prywatnej w klasycznym rozumieniu ${ }^{112}$.

W Polsce idea prywatyzacji pojawiła się w Programie Gospodarczym rządu w 1989 r. i odnosiła się do zmian własnościowych przedsiębiorstw państwo-

${ }^{109}$ B. P. Korbus, M. Strawiński, Partnerstwo publiczno-prywatne..., s. 111.

${ }^{110}$ P. F. Drucker, The Age of Discontinuity: Guidelines to our Changing Society, Harper \& Row, New York 1969, cyt. za: Zarys ekonomii sektora publicznego, red. M. Brol, Wydawnictwo Uniwersytetu Ekonomicznego we Wrocławiu, Wrocław 2010, s. 120.

${ }^{111}$ A. Karwińska, D. Wiktor, Przedsiębiorczość i korzyści społeczne: identyfikacja dobrych praktyk w ekonomii społecznej, „Ekonomia Społeczna Teksty” 2008, nr 6, s. 12.

${ }^{112}$ Szerzej E. S. Savas, Prywatyzacja. Klucz do lepszego rzadzenia, PWE, Warszawa 1992, s. 11. Autor omawia motywy prywatyzacji wskazując, że nie jest to proces jedynie ekonomiczny, ale przede wszystkim akt polityczny, który wymaga odpowiedniego klimatu i akceptacji. Savas uważał, że decydujące znaczenie dla teorii prywatyzacji ma rola państwa i sektora prywatnego w zapewnieniu dostępu do dóbr i usług, które podzielone zostały przez autora na dobra i usługi publiczne nieodpłatne, odpłatne, wspólne i zespołowe. Taki podział dóbr i usług stanowił przesłankę do wyboru różnych rozwiązań prywatyzacyjnych, które znajdują także zastosowanie w przypadku partnerstwa publiczno-prywatnego, np. kontrakty menedżerskie czy umowy dzierżawy. 
wych, które przeprowadzone zostały na mocy Ustawy z 13 lipca 1990 r. o prywatyzacji przedsiębiorstw państwowych ${ }^{113}$.

Ponieważ pierwsze doświadczenia prywatyzacyjne wykazały wady przyjętych rozwiązań prawnych zdecydowano się na zmianę koncepcji prywatyzacyjnej i połączenie jej z komercjalizacją przedsiębiorstw państwowych, co skutkowało przyjęciem w 1996 r. ustawy o komercjalizacji i prywatyzacji przedsiębiorstw państwowych ${ }^{114}$. Zgodnie z tą ustawą prywatyzacja polega na:

1) obejmowaniu akcji przez podmioty niepubliczne w podwyższonym kapitale zakładowym spółek Skarbu Państwa lub jednostek samorządu terytorialnego albo

2) zbywaniu należących do Skarbu Państwa lub JST akcji w spółkach, albo

3) rozporządzaniu wszystkimi składnikami materialnymi i niematerialnymi majątku przedsiębiorstwa państwowego lub spółki powstałej w wyniku komercjalizacji poprzez:

a) sprzedaż przedsiębiorstwa,

b) wniesienie przedsiębiorstwa do spółki,

c) oddanie przedsiębiorstwa do odpłatnego korzystania.

Zgodnie z wcześniej przedstawioną definicją partnerstwo publiczno-prywatne jest opartą na umowie o partnerstwie współpracą podmiotu publicznego i partnera prywatnego. Pojęcia prywatyzacja i partnerstwo publiczno-prywatne w ujęciu ustawowym nie są pojęciami tożsamymi, a także PPP samo $\mathrm{w}$ sobie nie jest prywatyzacją w rozumieniu ustawy o prywatyzacji i komercjalizacji $^{115}$.

Prywatyzacja oznacza działanie polegające na przeprowadzeniu zmian w zakresie własności, połączonych z rezygnacją władz publicznych z prowadzenia określonej działalności lub świadczenia usług. W ujęciu ogólnym jest

${ }^{113}$ Ustawa z dnia 13 lipca 1990 r. o prywatyzacji przedsiębiorstw państwowych, DzU, 1990, nr 5, poz. 298 ze zm. Proces prywatyzacji przedsiębiorstw działających w różnych sektorach, np. $\mathrm{w}$ rolnictwie czy też zaliczanych do grupy przedsiębiorstw o szczególnym znaczeniu dla gospodarki regulowały odrębne akty prawne. Ten fakt oraz krytyczna ocena procesu prywatyzacyjnego skłoniły do zmiany obowiązujących rozwiązań i wprowadzenia nowej Ustawy o komercjalizacji i prywatyzacji przedsiębiorstw państwowych. W przypadku prywatyzacji rolnictwa zachowano natomiast odrębność prawną, która regulowana jest Ustawa z dnia 19 października 1991 r. o gospodarowaniu nieruchomościami rolnymi Skarbu Państwa oraz o zmianie niektórych ustaw, DzU, 1991, nr 107, poz. 464 ze zm. Szerzej na temat procesów prywatyzacyjnych przedsiębiorstw m.in. C. Kosikowski, Polskie publiczne prawo gospodarcze, Wydawnictwa Prawnicze PWN, Warszawa 2000, s. 273-286; Prawo cywilne $i$ handlowe $w$ zarysie, red. W. J. Katner, Oficyna a Wolters Kluwer business, Warszawa 2009, s. 72-73

${ }^{114}$ Ustawa z dnia 30 sierpnia 1996 r. o komercjalizacji i prywatyzacji przedsiębiorstw państwowych, DzU, 1996, nr 118, poz. 561 ze zm.

${ }^{115} \mathrm{Z}$ prawnego punktu widzenia szerokiej analizy pojęciowej prywatyzacji i PPP dokonuje Z. Jerzmanowski, Prywatyzacja a partnerstwo, „Wspólnota” 2007, nr 13, s. 26-27, idem, Partnerstwo publiczno-prywatne a prywatyzacja, „Przegląd Komunalny” 2005, nr 10, s. 56. 
transferem własności bądź władzy zarządczej ze sfery publicznej do sfery prywatnej. W sferze użyteczności publicznej prywatyzacja wymaga przeniesienia kompetencji zarządczych czy wykonywania zadań publicznych $\mathrm{w}$ taki sposób, aby podmioty prywatne cieszyły się niezależną władzą i swobodą regulacyjną, ale by nie oznaczała własności większościowej ${ }^{116}$.

Według innej definicji prywatyzacja jest procesem mającym na celu przeniesienie własności bądź wykonywania zadań publicznych na podmioty prywatne. Jednak, ze względu na charakter użyteczności publicznej sprywatyzowanych zadań publicznych, należy zachować kontrolę nad wykonywanymi przez podmioty prywatne zadaniami $\mathrm{w}$ zakresie wykorzystania przyznanych im środków publicznych ${ }^{117}$.

W teorii i praktyce ciągle poszukuje się odpowiedzi na pytanie, czy określone zadania powinny być wykonywane przez państwo i jego administrację, czy też powinno się je przekazać przedsiębiorcom, organizacjom społecznym albo jednostkom? Zdaniem m.in. A. Grzesiok ${ }^{118}$ problem nadal jest sporny i każdorazowo powinien być rozpatrywany indywidualnie, z uwzględnieniem aspektów politycznych, społecznych i gospodarczych. Przekazanie zadań publicznych podmiotom gospodarczym często może być sposobem (a nawet jedyną drogą) zapewniającym społeczeństwu zachowanie świadczeń, ich konkurencyjność prowadzi do wzrostu efektywności. Podmiotom prywatnym realizującym zadania publiczne przypisuje się funkcje pionierskie w zakresie tworzenia nowych metod zarządzania sprawami publicznymi. Oferta świadczeń tych podmiotów jest często lepsza pod względem ilościowym, jakościowym i organizacyjnym oraz bardziej zróżnicowana niż publiczna, co umożliwia lepsze, obszarowo szersze zaspokojenie potrzeb społecznych. Przykładowo, w Stanach Zjednoczonych prywatyzacja objęła prowadzenie lotnisk, więzień, obsługę systemów wojskowych, kontrolę ruchu drogowego. Przesłanką takiego działania był profesjonalizm i niższe koszty realizacji tych zadan ${ }^{119}$.

${ }^{116}$ Zagadnienie prywatyzacji w kontekście PPP rozważa M. Moszoro w: Partnerstwo publiczno-prywatne $w$ monopolach..., s. 47-52; też B. P. Korbus, M. Strawiński, Partnerstwo publiczno-prywatne. Nowa forma..., s. 110-113. Kwestia odpowiedzialności za zadania publiczne w formie PPP i prywatyzacji rozstrzygnięta została także w Guidebook on Promating Good Governance in Public-Private..., s. 4.

${ }^{117}$ Opinia General Accounting Office za: M. Moszoro, Kapitat prywatny w finansowaniu inwestycji publicznych..., s. 232, www.mikro.uni.szczecin.pl (2.06.2011).

${ }^{118}$ A. Grzesiok, Zasady realizacji partnerstwa publiczno-prywatnego, [w:] Partnerstwo publiczno-prywatne jako instrument rozwoju zrównoważonego, red. M. Urbaniec, P. Stec, S. Dolata, Wydawnictwo Akademii Polonijnej w Częstochowie „Educator”, Częstochowa 2009, s. 110.

${ }^{119}$ Więcej: S. Biernat, Prywatyzacja zadań publicznych. Problematyka prawna, Wydawnictwo Naukowe PWN, Warszawa-Kraków 1994, s. 25-26; S. Najnigier, Administracja czy biznes, [w:] Administracja publiczna. Wyzwania $w$ dobie integracji europejskiej, red. J. Czaputowicz, Europejski Instytut Administracji Publicznej, Wydawnictwo Naukowe PWN, Warszawa 2008, s. $161-162$. 
Prywatyzacja usług publicznych wymaga od administracji publicznej, w tym przede wszystkim samorządowej, podjęcia decyzji o prywatyzowaniu jednego $\mathrm{z}$ trzech obszarów gospodarki komunalnej, tj. prywatyzacji zadań komunalnych, prywatyzacji majątku, prywatyzacji zarządzania zadaniami.

W literaturze dominuje stanowisko ${ }^{120}$, że nie można prywatyzować zadań publicznych, gdyż ustawowo są one przypisane samorządowi terytorialnemu, natomiast można prywatyzować ich wykonanie. Zdaniem M. Kuleszy

państwo wycofało się z wielu dziedzin praktycznej działalności gospodarczej, społecznej, a nawet publicznej. Jednak w znaczniejszych sektorach życia zbiorowego i gospodarczego, rezygnując $\mathrm{z}$ bezpośredniej działalności za pośrednictwem własnych instytucji i przedsiębiorstw, pozostawiło sobie, a nawet rozbudowało, odpowiedzialność publiczno-prawną za stan rzeczy w tej dziedzinie, poprzez ustalanie standardów i klasyczne uprawnienia do reglamentacji zachowań podmiotów prywatnych oraz instrumenty nadzorcze”. W ten sposób państwo otworzyło dostęp konkurentów zarówno krajowych, jak i zagranicznych do wykonywania zadań publicznych ${ }^{121}$.

Procesy prywatyzacji usług publicznych wynikają z trzech zasadniczych powodów $^{122}$ :

- zmniejszenia kosztów,

- uzyskania dostępu do nowych technologii w celu uzyskania lepszych efektów przy tych samych nakładach,

- zmniejszenia ryzyka związanego ze świadczeniem usług.

W warunkach polskich dodatkowo zwraca się uwagę na potrzebę dostępu do kapitału inwestycyjnego koniecznego do modernizacji infrastruktury, a co za tym idzie zwolnienie sektora publicznego z konieczności finansowania inwestycji infrastrukturalnych.

Prywatyzacja w sferze usług publicznych ma wielu przeciwników, co stanowi jedną z głównych barier rozwoju partnerstwa publiczno-prywatnego. Obserwowany brak zaufania do tego typu rozwiązań wydaje się wynikać z niezrozumienia znaczenia istoty partnerstwa oraz z powszechnie akcentowanych negatywnych skutków prywatyzacji majątku publicznego ${ }^{123}$. PPP w swej

${ }^{120}$ Rozważania w kwestii prywatyzacji zadań i zarządzania zadaniami publicznymi podejmują M. Wojarska, I. Zabielska, Partnerstwo publiczno-prywatne jako narzędzie budowy rynkowego modelu gospodarki komunalnej, [w:] Partnerstwo $w$ regionie, red. J. Karwowski, Uniwersytet Szczeciński, Szczecin 2004, s. 355-357.

${ }^{121}$ Porównanie kwestii prywatyzacji wykonania zadania publicznego i PPP omawia M. Kulesza: Partnerstwo publiczno-prywatne. Uwagi wstępne, „Finanse Komunalne” 2003, nr 2 Ekstra, s. $7-11$.

${ }^{122}$ M. Moszoro, Kapitat prywatny $w$ finansowaniu inwestycji publicznych..., s. 232, www.mikro.uni.szczecin.pl (2.06.2011).

${ }^{123} \mathrm{~K}$. Brzozowska opierając się na analizach przeprowadzonych przez ONZ w ramach United Nationals Development Programme na początku lat dziewięćdziesiątych wskazuje błędy i argumenty przeciwko prywatyzacji. Analiza uwypukliła krótkowzroczność, brak długofalowych 
istocie opiera się na mechanizmie rynkowym i w uzasadnionych przypadkach wymaga powołania spółek kapitałowych specjalnego przeznaczenia, nie prowadzi jednak do ostatecznego (docelowego) przekazania własności infrastruktury służącej świadczeniu usług stronie prywatnej. Tym samym nie przenosi odpowiedzialności za określoną dziedzinę życia z podmiotu publicznego na podmiot prywatny. W wielu formach (typu BOT), w jakich może być realizowane PPP, nie ma konieczności przejęcia przez stronę prywatną jakiegokolwiek majątku publicznego. W większości przypadków wystarczy, że podmiot prywatny ma wpływ na proces wykorzystania infrastruktury do świadczenia określonych zadań. Zawarte umowy zezwalają najczęściej na eksploatację urządzeń i obiektów oraz sprawne zarządzanie procesem dostarczania usług społeczności. Jeśli już dochodzi do przekazania praw własności na rzecz podmiotu prywatnego, to jest to przekazanie czasowe wynikające z zawartej umowy, a strona publiczna w całym okresie obowiązywania umowy sprawuje nadzór nad sposobem wykonywania przez podmiot prywatny powierzonych mu obowiązków. Po zakończonym okresie umowy prawa własności wracają do podmiotu publicznego, a stan techniczny obiektów musi zapewnić kontynuację świadczeń o nieobniżonym standardzie. W przypadku pełnej prywatyzacji majątek publiczny definitywnie przechodzi na własność podmiotu prywatnego. Tym samym strona publiczna pozbywa się majątku uzyskując jednorazowy dopływ znacznych środków finansowych. Pozbywa się jednak tym samym innych możliwości czerpania z niego korzyści, np. w postaci opłat z czynszu lub dzierżawy, gdyby sprzedaż zastąpiona została inną formą zlecenia zadania publicznego. Sprzedaż majątku pozbawia także sektor publiczny praw do kontroli nad wykonywaniem zadań, gdyż w praktyce nadzór sektora publicznego nad działalnością podmiotu prywatnego nie jest praktykowany.

Argumentem przemawiającym przeciwko utożsamianiu PPP z prywatyzacją jest fakt podziału ryzyka pomiędzy strony umowy. W ramach PPP nie ma możliwości całkowitego przeniesienia odpowiedzialności za realizację przedsięwzięcia na partnera prywatnego. Zgodnie $\mathrm{z}$ ideą PPP strony dzielą się ryzykiem stosownie do swoich możliwości i umiejętności. W przypadku prywatyzacji całe ryzyko związane z pomyślnością przedsięwzięcia przechodzi na prywatnego przedsiębiorcę.

Odrębny problem wiąże się z opłatami za świadczone usługi. W przypadku partnerstwa partner prywatny może pokrywać ponoszone nakłady opłatami pobranymi od korzystających. Dodatkowo podmiot publiczny może dokonywać na rzecz przedsiębiorcy transferów z budżetu. W przypadku prywatyzacji wysokość opłat powinna być tak skalkulowana przez przedsiębiorcę, aby

celów związanych z dobrobytem społecznym, brak akceptacji społecznej dla procesów prywatyzacyjnych oraz jednomyślności politycznej względem procesów prywatyzacyjnych. Por. Partnerstwo publiczno-prywatne w Europie..., s. 136-137. 
zapewnić mu zwrot poniesionych nakładów i zapewnić odpowiednią marżę zysku.

Partnerstwo jest współpracą, w której każda ze stron dostarcza pewnych umiejętności i predyspozycji w celu osiągnięcia obopólnych korzyści. Między partnerstwem publiczno-prywatnym a prywatyzacją zarysowują się istotne różnice ${ }^{124}$ :

1) odpowiedzialność polityczna za usługi świadczone w ramach PPP spoczywa bezpośrednio na jednostce zamawiającej, natomiast w przypadku prywatyzacji jest z niej zdjęta,

2) społeczeństwo nie jest świadome tego, że usługa oferowana w ramach PPP świadczona jest przez podmiot prywatny, a nie publiczny, co w przypadku prywatyzacji jest oczywiste,

3) w przypadku PPP sektor publiczny zachowuje (lub odzyskuje po upływie czasu określonego w umowie) prawo własności infrastruktury, podczas gdy prywatyzacja oznacza przejęcie tej własności na stałe przez sektor prywatny,

4) partnerstwo publiczno-prywatne jest zwykle związane z monopolistycznym świadczeniem usług, prywatyzacja oznacza wprowadzenie konkurencji na rynku danej usługi,

5) w PPP zakres i koszt usług określa się w umowie pomiędzy sektorem publicznym i prywatnym, po sprywatyzowaniu, jeśli koszty podlegają kontroli ze strony sektora publicznego, nadzór przyjmuje formę licencji, w przeciwnym wypadku podlega prawom rynkowym.

Różnice pomiędzy partnerstwem publiczno-prywatnym a prywatyzacją przedstawiono $\mathrm{w}$ tab. 1.9.

Tabela 1.9

Różnice pomiędzy partnerstwem publiczno-prywatnym a prywatyzacją

\begin{tabular}{|l|l|l|}
\hline \multicolumn{1}{|c|}{ Cecha } & Partnerstwo publiczno-prywatne & Prywatyzacja \\
\hline 1 & \multicolumn{1}{|c|}{2} & 3 \\
\hline Istota & $\begin{array}{c}\text { Partnerstwo publiczno-prywatne jest } \\
\text { określoną czasowo współpracą po- } \\
\text { między sektorem publicznym i pry- } \\
\text { watnym bez trwałej zmiany własno- } \\
\text { ściowej zaangażowanego we współ- } \\
\text { pracę majątku }\end{array}$ & $\begin{array}{c}\text { Prywatyzacja to trwała zmiana } \\
\text { własności publicznej na } \\
\text { prywatną }\end{array}$ \\
\hline Cel & $\begin{array}{l}\text { Przekazanie praw własnościowych } \\
\text { służy poprawie efektywności świad- } \\
\text { czonych usług }\end{array}$ & $\begin{array}{c}\text { Przekazanie praw własnościo- } \\
\text { wych zwalnia podmiot publi- } \\
\text { czny z odpowiedzialności za } \\
\text { świadczenie usług }\end{array}$ \\
\hline
\end{tabular}

${ }^{124}$ Por. E. R. Yescombe, Partnerstwo publiczno-prywatne. Zasady wdrażania i finansowania, Oficyna Wolters Kluwer business, Kraków 2008, s. 37. 
Tabela $1.9(\mathrm{~cd}$.

\begin{tabular}{|c|c|c|}
\hline 1 & 2 & 3 \\
\hline Czas & $\begin{array}{l}\text { Współpraca ma ściśle określony czas, } \\
\text { prawa własnościowe po zakończo- } \\
\text { nym okresie współpracy wracają do } \\
\text { sektora publicznego }\end{array}$ & $\begin{array}{l}\text { Prywatyzacja ma charakter } \\
\text { stały }\end{array}$ \\
\hline $\begin{array}{l}\text { Rola sektora publicz- } \\
\text { nego }\end{array}$ & $\begin{array}{l}\text { W okresie trwania współpracy sektor } \\
\text { publiczny nadzoruje działania part- } \\
\text { nera prywatnego }\end{array}$ & $\begin{array}{l}\text { Sektor publiczny w momencie } \\
\text { przekazania praw własno- } \\
\text { ściowych traci wszelkie } \\
\text { uprawnienia } \\
\end{array}$ \\
\hline Ryzyko & $\begin{array}{c}\text { Ryzyko ekonomiczne rozłożone jest } \\
\text { pomiędzy strony w zależności od } \\
\text { predyspozycji i możliwości }\end{array}$ & \begin{tabular}{|l|} 
Ryzyko ekonomiczne przed- \\
sięwzięcia przechodzi w ca- \\
łości na partnera prywatnego \\
\end{tabular} \\
\hline Opłaty & $\begin{array}{l}\text { Opłaty stanowią źródło pokrycia po- } \\
\text { niesionych nakładów, mogą być } \\
\text { uzupełnione transferami od pod- } \\
\text { miotu publicznego }\end{array}$ & $\begin{array}{l}\text { Opłaty stanowią źródło docho- } \\
\text { dów partnera prywatnego, } \\
\text { podlegają prawom rynko- } \\
\text { wym }\end{array}$ \\
\hline Opłacalność & $\begin{array}{l}\text { Strony zaangażowane osiągają obo- } \\
\text { pólne korzyści }\end{array}$ & $\begin{array}{l}\text { Prywatyzacja powinna przyno- } \\
\text { sić korzyść partnerowi pry- } \\
\text { watnemu }\end{array}$ \\
\hline
\end{tabular}

Źródło: oprac. własne.

Wskazane w tab. 1.9 różnice pomiędzy partnerstwem publiczno-prywatnym i prywatyzacją pozwalają na sformułowanie następujących wniosków:

1) partnerstwo publiczno-prywatne stanowi określoną czasowo współpracę sektora publicznego z sektorem prywatnym, nie powoduje ona trwałej zmiany własnościowej majątku, gdy tymczasem prywatyzacja jest stałym i ostatecznym przekazaniem praw własnościowych sektorowi prywatnemu,

2) w trakcie trwania partnerstwa warunki określające współpracę gwarantują sektorowi publicznemu nadzór nad działalnością partnera prywatnego, przy prywatyzacji sektor publiczny traci zaś uprawnienia kontrolne nad działalnością podmiotu prywatnego,

3) w partnerstwie publiczno-prywatnym następuje podział ryzyk i zadań pomiędzy strony umowy, w celu osiągnięcia obopólnych korzyści, w przypadku prywatyzacji sektor publiczny zwolniony zostaje z wszystkich ryzyk i zadań, a realizowana działalność ma przynosić korzyści wyłącznie stronie prywatnej,

4) opłaty pobierane przez podmiot prywatny w ramach partnerstwa stanowią źródło pokrycia nakładów i mogą być uzupełniane transferami z budżetu podmiotu publicznego, w przypadku prywatyzacji opłacalność przedsięwzięcia przenoszona jest na podmiot prywatny, a pobierane opłaty stanowią główne źródło pokrycia ponoszonych przezeń kosztów.

Partnerstwo publiczno-prywatne nie jest prywatyzacją, ale ze względu na występujący element zaangażowania kapitałowego i przejęcie części odpowie- 
dzialności za realizację zadań publicznych przez prywatnych inwestorów wpisuje się $\mathrm{w}$ nurt restrukturyzacji i reorganizacji wykonywania tych zadań. Zmienia dominujący pogląd, że zadania publicznie mogą być realizowane tylko i wyłącznie przy użyciu majątku publiczne zarządzanego. PPP może okazać się praktycznym sposobem nie tylko na finansowanie inwestycji komunalnych, ale także na ich zarządzanie. Jest pośrednim modelem pomiędzy gospodarką publiczną a prywatyzacją. Niezależnie od korzyści organizacyjno-ekonomicznych partnerstwo stanie się niewątpliwie sposobem na restrukturyzację gospodarki komunalnej w Polsce. 



\section{EKONOMICZNE, PRAWNE I ORGANIZACYJNE UWARUNKOWANIA WDRAŻANIA FORMULY PARTNERSTWA PUBLICZNO-PRYWATNEGO}

\subsection{Procedura przygotowania formuly partnerstwa publiczno-prywatnego}

Wykorzystanie partnerstwa publiczno-prywatnego wymaga nie tylko uporządkowanego systemu prawnego, ale także wypracowania procedury przygotowania formuły. Powszechna zarówno w środowisku prawników, ekonomistów, jak i praktyków samorządowych jest opinia, że Polska była krajem pionierów na etapie tworzenia prawa, a stała się outsiderem na etapie jego wykorzystania. Zastosowanie PPP w Polsce jest istotną determinantą poprawy poziomu i jakości świadczenia usług publicznych oraz przyspieszenia rozwoju infrastruktury w tym obszarze. Ograniczenia budżetowe, kryzys gospodarczy, a także konieczność rezerwacji środków publicznych dla projektów finansowanych z funduszy unijnych stanowią dodatkowy bodziec do aktywnego wykorzystania metody PPP. Sprzyja temu także korzystny klimat wokół PPP, jaki pojawił się w Polsce od 2009 r.

Partnerstwo publiczno-prywatne, jak zostało to już przedstawione, nie jest prostą i łatwą formą realizacji przedsięwzięć. Trudności stwarza samo zdefiniowanie formuły, przygotowanie przedsięwzięcia, skonstruowanie umowy, która w sposób jednoznaczny określi zobowiązania stron, korzyści i zakres ryzyk, stanowiąc charakterystyczny zapis dla formuły. Obok profesjonalnej wiedzy wymagana jest też umiejętność dokonania oceny stopnia korzyści ekonomicznej uzyskanej w wyniku zastosowania formuły PPP versus metody tradycyjnej ${ }^{1}$. Stąd ważną rolę odgrywa właściwe opracowanie formalnych czynności zmierzających do zawarcia umowy PPP. Z uwagi na stopień złożoności przedsięwzięć uzasadnione wydaje się skorzystanie z pomocy doradców. Im bardziej skompli-

\footnotetext{
${ }^{1}$ Metoda tradycyjna to samodzielne wykonanie zadania publicznego przez jednostkę samorządu terytorialnego. Realizowane jest ono ze środków znajdujących się w dyspozycji jednostki, takich jak środki budżetowe czy kapitał zwrotny. Zadanie wykonywane jest zgodnie z procedurą i regulacjami prawnymi Prawa zamówień publicznych.
} 
kowane przedsięwzięcie, a mniejsza wiedza i umiejętności stron umowy, tym większe znaczenie doradcy w jego przygotowaniu. Z uwagi na dotychczasowy brak doświadczeń w zakresie partnerstwa publiczno-prywatnego w Polsce Centrum PPP przygotowało dwa ważne dokumenty mające pomóc potencjalnym zainteresowanym $\mathrm{w}$ sprawnym, a przede wszystkim poprawnym pod względem formalno-prawnym przygotowaniu partnerstwa. Dokumenty te to Kodeks Dobrych Praktyk Doradcy PPP oraz „Ścieżka dojścia” podmiotu publicznego do opracowania i realizacji projektu $P P P$.

Procedura zmierzająca do uruchomienia przedsięwzięcia realizowanego $\mathrm{w}$ formule partnerstwa wymaga przygotowania i przeprowadzenia szeregu czynności, jakie muszą zostać wykonane przez podmiot publiczny w celu wyłonienia partnera prywatnego i zawarcia z nim umowy. Czynności te muszą być wykonane przez decydentów w gminie. Należy jednak pamiętać, że partnerstwo jest formułą złożoną, która wymaga zaangażowania wielu stron. Każdy $\mathrm{z}$ podmiotów biorących udział $\mathrm{w}$ partnerstwie będzie dążył do osiągnięcia swoich indywidualnych celów. Dlatego też ważne jest takie przygotowanie inwestycji i koordynacja zadań rzeczowo-finansowych, które doprowadzą do optymalnego rozmieszczenia zadań i ryzyk pomiędzy uczestników przedsięwzięcia.

W literaturze przygotowanie inwestycyji, w tym realizowanych $\mathrm{w}$ formule PPP, dzieli się na fazy. Europejski Bank Inwestycyjny ${ }^{2}$ realizację partnerstwa publiczno-prywatnego dzieli na cztery fazy: identyfikacji przedsięwzięcia, szczegółowego przygotowania, zamówienia oraz jego realizacji. Podział PPP na cztery fazy przyjęty został także przez Ministerstwo Gospodarki i Pracy ${ }^{3}$ i obejmuje fazę rozpoznania przedsięwzięcia, przeglądu i przygotowania, przetarg oraz realizację. Inaczej problem postrzega A. Gajewska-Jedwabny ${ }^{4}$ i K. Brzozowska. Pierwsza autorka wyróżnia pięć faz tworzenia partnerstwa publiczno-prywatnego: fazę identyfikacji potrzeb i metod realizacji, opracowania koncepcji, przetargu i wyboru partnera, realizacji i kontroli oraz fazę zakończenia związaną z zakończeniem umowy, przekazaniem aktywów i dokonaniem końcowej oceny realizacji umowy.

${ }^{2}$ Przewodnik po PPP, Europejski Bank Inwestycyjny, Europejskie Centrum Ekspertyz PPP, Luksemburg, www.eib.org/epec (20.06.2011).

${ }^{3}$ Partnerstwo publiczno-prywatne jako metoda realizacji zadań publicznych, Ministerstwo Gospodarki i Pracy, Departament Polityki Regionalnej, Warszawa 2005, s. 6; podział taki przyjmuje również M. Chałas, Nowoczesne systemy realizacji zadań publicznych, Dom Wydawniczy ELIPSA, Warszawa 2006, s. 63-70.

${ }^{4}$ Partnerstwo publiczno-prywatne, red. A. Gajewska-Jedwabny, Wydawnictwo C.H. Beck, Warszawa 2007, s. 70. 
FAZA 1

projektowo-przetargowa

Czynności w ramach fazy 1

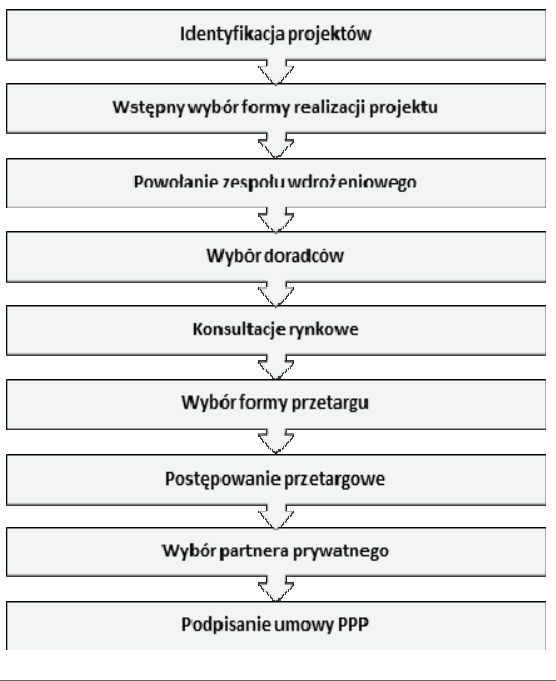

FAZA 2

inwestycyjno-eksploatacyjna

\section{Czynności w ramach fazy 2}

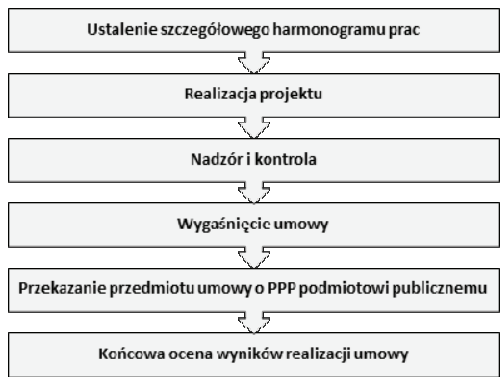

Schemat 2.1. Fazy realizacji przedsięwzięcia w formule PPP

Źródło: oprac. własne 
K. Brzozowska ${ }^{5}$ z kolei zakłada, że istnieją trzy fazy i są one tożsame z przyjętym $w$ teorii inwestycji podziałem na fazę przedinwestycyjną, inwestycyjną i eksploatacyjną. Liczba faz występująca w podanych przykładach wynika z mniejszej lub większej liczby czynności podejmowanych w fazie identyfikacji i opracowania studium wykonalności przedsięwzięcia. Im bardziej skomplikowane przedsięwzięcie (obejmujące budowę nowego obiektu lub urządzenia), tym bardziej poszerza się zakres prac koniecznych do wykonania, również przed przystąpieniem do zasadniczych czynności związanych z opracowaniem studium wykonalności. Zdaniem autorki, ogół czynności, jaki towarzyszy przygotowaniu, a następnie realizacji inwestycji w ramach PPP można przyporządkować do dwóch zasadniczych faz: fazy projektowo-przetargowej i fazy realizacji mającej charakter inwestycyjno-eksploatacyjny. Zaproponowany podział faz realizacji przedsięwzięcia i czynności przedstawiono na schemacie 2.1 .

$\mathrm{Na}$ schemacie 2.1. zaproponowano ujęcie czynności związanych z przygotowaniem i realizacją przedsięwzięcia $\mathrm{w}$ formule PPP $\mathrm{w}$ dwie zasadnicze fazy: fazę pierwszą, projektowo-przetargową oraz fazę drugą, inwestycyjno-eksploatacyjną. Faza pierwsza obejmuje czynności związane z identyfikacją przedsięwzięć planowanych do realizacji przez jednostkę samorządu terytorialnego, ze wskazaniem tych, których realizacja może nastąpić w formule PPP. Następstwem tego jest powołanie w jednostce zespołu wdrożeniowego składającego się z pracowników danej jednostki oraz zewnętrznych doradców. W dalszej kolejności przeprowadza się konsultacje rynkowe, których celem jest uzyskanie akceptacji dla proponowanych rozwiązań w zakresie planowanego przedsięwzięcia. Kolejnym krokiem jest przygotowanie procedury przetargowej na wybór partnera prywatnego. Faza pierwsza kończy się podpisaniem umowy o PPP $\mathrm{z}$ podmiotem prywatnym wyłonionym $\mathrm{w}$ wyniku rozstrzygnięcia postępowania przetargowego.

Po zakończeniu fazy pierwszej przedsięwzięcie wchodzi w fazę drugą, która obejmuje czynności związane z realizacją inwestycji, a następnie z eksploatacją składnika majątkowego powstałego w wyniku dokonanej inwestycji. W fazie drugiej mamy do czynienia $\mathrm{z}$ ustaleniem szczegółowego harmonogramu prac związanych z poszczególnymi etapami realizacji przedsięwzięcia. Po zakończonym procesie inwestycyjnym podmiot publiczny sprawuje nadzór i kontrolę nad realizacją zadań. Po wypełnieniu umowy następuje przekazanie aktywów przedsięwzięcia stronie publicznej oraz dokonuje się końcowej oceny wyników realizacji umowy. Szczegółowego omówienia poszczególnych faz realizacji przedsięwzięcia dokonano w podrozdziałach 2.2 .1 i 2.2 .2 pracy.

${ }^{5}$ K. Brzozowska, Partnerstwo publiczno-prywatne. Przesłanki, możliwości, bariery, Wydawnictwa Fachowe CeDeWu, Warszawa 2006, s. 51. 


\subsection{Fazy przedsięwzięcia partnerstwa publiczno-prywatnego}

\subsubsection{Faza projektowo-przetargowa}

Faza pierwsza procesu rozpoczyna się od identyfikacji zadań inwestycyjnych możliwych do realizacji $\mathrm{w}$ formule partnerstwa. Model PPP odróżnia od typowego zamówienia publicznego sposób podejścia do przedsięwzięcia. W PPP strona publiczna definiuje wymagania w kategorii rezultatów, jakie mają być osiągnięte, $\mathrm{w}$ tradycyjnym zamówieniu nacisk kładziony jest na parametry wyjściowe. W partnerstwie poszczególne aktywa i usługi są przedmiotem jednej, kompleksowej umowy zawartej pomiędzy stronami. W przypadku tradycyjnego zamówienia jest to odrębny, pojedynczy przetarg na każdą dostawę lub usługę na rzecz podmiotu publicznego. Zastosowanie PPP wymaga zasadniczej zmiany sposobu przygotowania inwestycji oraz zakresu informacji, jakie muszą być udzielone przez stronę publiczną inwestorom z sektora prywatnego. Zanim jednostka samorządu podejmie decyzje o zaangażowaniu się w PPP powinna starannie przeanalizować wszelkie okoliczności, które przemawiają za formułą partnerstwem lub metodą tradycyjną, gdyż PPP nie zawsze musi być najlepszą formą realizacji zadań publicznych czy dostarczania usług użyteczności publicznej.

Niewłaściwy wybór formy może przyczynić się do nieprawidłowych relacji pomiędzy partnerami, niezadowolenia społeczności z dostarczanych usług, co w konsekwencji przełoży się na niekorzystny klimat wokół partnerskiej współpracy. Ostrożność wymagana jest już na etapie wyboru przedsięwzięć, które mogą być zakwalifikowane do realizacji w formule PPP. Wskazane jest przyjęcie zasad stosowanych przez sektor publiczny do oceny wszystkich inwestycji (najczęściej wykonywanych $\mathrm{w}$ tradycyjnej formule zamówienia publicznego). Stąd proces przygotowawczy, a następnie jego wykonanie (współpraca partnera publicznego z prywatnym przez cały czas trwania inwestycji), nabiera szczególnego znaczenia. Przygotowanie przedsięwzięcia spoczywa na stronie publicznej. Wymaga się, aby władze publiczne odpowiednio wcześnie i z zachowaniem wszelkiej staranności przystąpiły do planowania poszczególnych etapów przedsięwzięcia. Wybór konkretnego zadania powinien zostać poprzedzony analizą wstępną warunków zewnętrznych i określeniem, w jakim stopniu budżet jest w stanie udźwignąć finansowo daną inwestycję. Na etapie identyfikacji decydenci powinni odpowiedzieć na następujące pytania:

1) Czy zidentyfikowane zadanie może być wykonane w ramach tradycyjnego zamówienia?

2) Czy partner prywatny jest $w$ stanie podnieść jakość i różnorodność świadczonych usług $\mathrm{w}$ sposób, $\mathrm{w}$ jaki nie byłby $\mathrm{w}$ stanie samodzielnie tego zrobić sektor publiczny? 
3) Czy istnieje możliwość stworzenia konkurencyjnego rynku (istotny jest problem, czy np. monopol naturalny nie zostanie zastąpiony monopolem prywatnym)?

4) Czy partner prywatny pobieranymi opłatami będzie w stanie pokryć ponoszone nakłady, czy też wymagane będzie wsparcie finansowe ze strony podmiotu publicznego?

5) Czy planowane PPP będzie sprzyjać rozwojowi innowacyjności i nowym technologii? ${ }^{6}$

6) Jakie są źródła ryzyka związane z przedsięwzięciem oraz jaka będzie strategia alokacji i zarządzania ryzykiem?

Odpowiedź na powyższe pytania pozwoli ocenić warunki, w jakich budowany ma być model partnerstwa i ocenić możliwości finansowe. Efektem tego etapu prac jest zgromadzenie maksymalnej puli informacji na temat przedsięwzięcia. Na tej podstawie możliwe będzie ustalenie celów szczegółowych, jakie mają być osiągnięte $\mathrm{w}$ ramach przedsięwzięcia. Wybór przedsięwzięcia do PPP powinien przyczyniać się do poprawy jakości życia mieszkańców, a władze samorządowe winny być w stanie go zrealizować 7 .

Po zidentyfikowaniu potrzeby oraz zdefiniowaniu celów, jakie podmiot publiczny chce osiągnąć, organizuje się spotkanie osób, które w sposób bezpośredni będą uczestniczyć w przygotowaniu inwestycji. Ponieważ często są to osoby $\mathrm{z}$ różnych komórek organizacyjnych, wskazane jest powołanie odrębnego „zespołu wdrożeniowego”, który będzie skupiać wiedzę ekspercką, odpowiedzialność i zajmie się obsługą inwestycji ${ }^{8}$. Członkowie zespołu rekrutowani są spośród pracowników jednostki, którzy wzmocnieni mogą zostać zewnętrznymi doradcami. Już na tym etapie prac warto skorzystać z pomocy profesjonalnych doradców. Z uwagi na złożoność przedsięwzięć typu PPP pożądane jest wykorzystanie doradców technicznych, ekonomicznych i prawnych lub od spraw ochrony środowiska (tab. 2.1). W sytuacjach, gdy istnieje już doświadczenie przy realizacji partnerstwa, doradcy mogą służyć pomocą na wybranych etapach

\footnotetext{
${ }^{6}$ Przewodnik po PPP, s. 15 (20.06.2011).

${ }^{7}$ Zob. A. Pilarska, Jak przygotować przedsięwzięcie w formule PPP, „Gazeta Samorządu i Administracji" 2009, nr 15, s. VII.

${ }^{8}$ Warunkiem optymalnego przygotowania przedsięwzięcia do realizacji $\mathrm{w}$ formule PPP jest skompletowanie zespołu osób, które przez okres życia przedsięwzięcia będą nim zarządzały. Ważne jest, aby były to osoby przeszkolone w zakresie PPP, którym problematyka jest już znana. $\mathrm{W}$ tym celu wskazane jest wcześniejsze przeszkolenie osób zajmujących się dotychczas np. inwestycjami, zamówieniami publicznymi w kontekście PPP. W Polsce wiele firm doradczokonsultingowych organizuje szkolenia zarówno dla podmiotów publicznych jak i prywatnych $\mathrm{z}$ tematyki PPP. Zakres szkoleń jest szeroki, od zagadnień prawnych np. wyboru partnera, konstrukcji umowy, po zagadnienia ekonomiczno-finansowe, w tym umiejętność szacowania korzyści i efektów w ramach poszczególnych metod. Zespół może przyjąć różne nazwy, np. przy tradycyjnym zamówieniu publicznym posługuje się terminologią komisji przetargowej, przy PPP może być to zespół projektowy, zespół zadaniowy, itp.
} 
procedury. Takie rozwiązanie stosowane jest np. w Wielkiej Brytanii, Irlandii czy Hiszpanii, gdzie wykorzystuje się już zebrane doświadczenia. W krajach, gdzie formuła jest dopiero wdrażana, współpraca $z$ doradcami będzie uzasadniona przez cały cykl życia przedsięwzięcia.

Podmiot publiczny już na wstępnym etapie prac będzie musiał uwzględnić w budżecie odpowiednie środki, które pozwolą na zaangażowanie zewnętrznych doradców ${ }^{9}$.

Tabela 2.1

Przykładowy zakres usług doradców w ramach PPP

\begin{tabular}{|c|c|c|c|}
\hline Doradca prawny & Doradca finansowy & Doradca techniczny & $\begin{array}{c}\text { Doradca ds. ochrony } \\
\text { środowiska }\end{array}$ \\
\hline 1 & 2 & 3 & 4 \\
\hline $\begin{array}{l}\text { Określa zakres pełno- } \\
\text { mocnictw dla przed- } \\
\text { stawicieli sektora } \\
\text { publicznego }\end{array}$ & $\begin{array}{l}\text { Pomaga w opracowa- } \\
\text { niu wszelkich aspe- } \\
\text { któw finansowych } \\
\text { projektu }\end{array}$ & $\begin{array}{l}\text { Sporządza wymagania } \\
\text { i specyfikacje dla } \\
\text { projektu }\end{array}$ & $\begin{array}{l}\text { Bada potencjalny } \\
\text { wpływ projektu na } \\
\text { środowisko naturalne }\end{array}$ \\
\hline $\begin{array}{l}\text { Ocenia wykonalność } \\
\text { projektu od strony } \\
\text { prawnej }\end{array}$ & $\begin{array}{l}\text { Analizuje dostępne } \\
\text { źródła finansowania } \\
\text { i dokonuje ich opty- } \\
\text { malizacji w ramach } \\
\text { poszczególnych } \\
\text { struktur finansowa- } \\
\text { nia } \\
\end{array}$ & $\begin{array}{l}\text { Opracowuje mecha- } \\
\text { nizm płatności uwz- } \\
\text { ględniony w umo- } \\
\text { wie (w porozumie- } \\
\text { niu z doradcą finan- } \\
\text { sowym) }\end{array}$ & $\begin{array}{l}\text { Pomaga w uzyskaniu } \\
\text { potrzebnych zezwo- } \\
\text { leń i zaświadczeń } \\
\text { w zakresie ochrony } \\
\text { środowiska }\end{array}$ \\
\hline $\begin{array}{l}\text { Doradza w sprawie } \\
\text { wyboru formy } \\
\text { zamówienia }\end{array}$ & $\begin{array}{l}\text { Dba o zgodność wszel- } \\
\text { kich aspektów finan- } \\
\text { sowych rozwiązań } \\
\text { proponowanych } \\
\text { przez oferentów }\end{array}$ & $\begin{array}{l}\text { Ocenia rozwiązania } \\
\text { techniczne } \mathrm{w} \text { fazie } \\
\text { zamówienia }\end{array}$ & $\begin{array}{l}\text { Wskazuje potencjalne } \\
\text { czynniki ryzyka } \\
\text { w ochronie środowi- } \\
\text { ska i weryfikuje, czy } \\
\text { zostały uwzględnio- } \\
\text { ne w składanych } \\
\text { ofertach }\end{array}$ \\
\hline $\begin{array}{l}\text { Przygotowuje doku- } \\
\text { menty przetargowe } \\
\text { (np. SIWZ) }\end{array}$ & $\begin{array}{l}\text { Optymalizuje i wnik- } \\
\text { liwie ocenia modele } \\
\text { finansowe zgłaszane } \\
\text { przez oferentów }\end{array}$ & $\begin{array}{c}\text { Przeprowadza analizę } \\
\text { techniczną rozwią- } \\
\text { zań proponowanych } \\
\text { przez oferentów }\end{array}$ & \begin{tabular}{|c|} 
Dokonuje analizy mo- \\
żliwości minimali- \\
zowania czynników \\
ryzyka oraz ich \\
wpływu na zakres \\
i strukturę projektu
\end{tabular} \\
\hline $\begin{array}{l}\text { Nadzoruje prawidło- } \\
\text { wy przebieg wery- } \\
\text { fikacji ofert }\end{array}$ & $\begin{array}{l}\text { Dokonuje stałej ana- } \\
\text { lizy oferty finanso- } \\
\text { wej na etapie nego- } \\
\text { cjacji }\end{array}$ & $\begin{array}{l}\text { Ocenia warunki w ja- } \\
\text { kich będzie realizo- } \\
\text { wany projekt (np. } \\
\text { miejsce inwestycji, } \\
\text { czas prowadzenia } \\
\text { prac budowlanych, } \\
\text { remontowych) }\end{array}$ & \\
\hline
\end{tabular}

${ }^{9}$ Szerzej: Przewodnik po PPP, s. 29 (20.06.2011); B. Korbus red., Partnerstwo publicznoprywatne. Poradnik, Urząd Zamówień Publicznych, Warszawa 2010, s. 75-79. 
Tabela 2.1. (cd.)

\begin{tabular}{|c|c|c|c|}
\hline \multicolumn{1}{|c|}{1} & 2 & 3 & 4 \\
\hline $\begin{array}{c}\text { Uczestniczy w negocja- } \\
\text { cjach }\end{array}$ & $\begin{array}{c}\text { Dokonuje wnikliwej } \\
\text { oceny finansowej } \\
\text { złożonych ofert }\end{array}$ & $\begin{array}{c}\text { Nadzoruje przebieg } \\
\text { realizacji projektu }\end{array}$ & \\
\hline Sporządza umowę & & & \\
\hline $\begin{array}{c}\text { Czuwa nad prawidło- } \\
\text { wym przebiegiem } \\
\text { całego procesu od } \\
\text { strony prawnej }\end{array}$ & & & \\
\hline
\end{tabular}

Źródło: oprac. własne na podstawie Przewodnik po PPP, Europejski Bank Inwestycyjny, Europejskie Centrum Ekspertyz PPP, Luksemburg, s. 33-34, www.partnerstwo publicznoprywatne.info/docs/Przewodnik_PPP.pdf.

Organizacja spotkań zespołu sprzyja wymianie poglądów tzw. metodą „,burzy mózgów". Zaletą takich spotkań jest konfrontacja opinii i uwzględnienie różnych aspektów i poglądów na dane przedsięwzięcie. Często pojawia się kilka wariantów jego wykonania, z których wybiera się od trzech do pięciu najlepszych. Selekcja opiera się na kryteriach technicznych (wybór np. pomiędzy budową nowego obiektu a remontem, przebudową lub modernizacją istniejących), prawnych i ekonomicznych. Na tym etapie prac przeprowadza się pierwsze, bardzo ogólne analizy opłacalności, np. test zasadności i test możliwości.

W teście zasadności uwzględnia się czynniki, które na bazie doświadczenia ze zrealizowanych lub zaniechanych przedsięwzięć mogą stanowić podstawę do oszacowania stopnia przydatności modelu PPP dla danego przedsięwzięcia. W teście uwzględnia się czynniki związane z naturą przedsięwzięcia, ryzykiem, zakresem zadań i zmian nim objętych oraz z możliwościami nałożenia płatności bezpośrednio na końcowych odbiorców usługi. Przeprowadzony test na odpowiedzieć na pytanie: czy zasadne jest zakontraktowanie danej usługi publicznej $\mathrm{w}$ formie partnerstwa? Przekonanie, że zastosowanie PPP do realizacji zadań partnera publicznego byłoby uzasadnione, nie oznacza automatycznie wykorzystania jej w danym przedsięwzięciu. Wiąże się z tym przeprowadzanie testu możliwości, który także pełni funkcję wstępnego weryfikatora formuły PPP.

W teście możliwości wymienia się kluczowe czynniki, które mają wpływ na PPP. Wśród nich znajdują się: ramy prawne, definicję usługi, wartość i zakres przedsięwzięcia, ryzyko oraz zainteresowanie rynku przedsięwzięciem i formą jego realizacji. Na tym etapie analiz istotne jest, czy pierwsza próba oszacowania opłacalności wypada pozytywnie, czy też nie. W sytuacji, gdy wynik testów nie jest jednoznaczny, często sprawdza się, czy istnieje możliwość innego 
rozmieszczenia zadań/ryzyk pomiędzy partnerów. W konsekwencji prowadzi to do modyfikacji przedsięwzięcia ${ }^{10}$.

Jeśli modyfikacje jednoznacznie wskażą na opłacalność PPP zespół wdrożeniowy przystępuje do uszczegółowienia koncepcji. Określa się zakres inwestycji i główne zadania potencjalnych wykonawców. Przygotowany dokument nadal traktowany jest jako wstępny, posłuży do późniejszego doprecyzowania warunków na dalszym etapie prac. Podmiot publiczny określa wynik, jaki zamierza osiągnąc poprzez realizację inwestycji, a nie koncentruje się na sposobie jego osiągnięcia. Duże znaczenie przypisuje się doświadczeniu i knowhow podmiotów prywatnych. W tym momencie znaczenia nabierają konsultacje $\mathrm{z}$ rynkiem (market sounding). Analiza interesariuszy, przygotowanie materiałów promocyjnych i biznesplanu, promocja przedsięwzięcia (roadshows), fora inwestycyjne - działania te mają na względzie, po pierwsze, uzyskanie akceptacji dla planowanego zadania inwestycyjnego (społeczności lokalnej, mediów), po drugie, zbadanie stopnia zainteresowania przedsięwzięciem potencjalnych inwestorów. Zespół wdrażający przygotowuje raport i rekomendacje z przeprowadzonych działań ${ }^{11}$. Z badań rynku jednoznacznie powinno wynikać, czy istnieje na tyle duże zainteresowanie ze strony podmiotów prywatnych inwestycją, że uzasadnione jest kontynuowanie prac. W przypadku znikomego zainteresowania może dojść do sytuacji, w której przygotowanie procedury przetargowej nie zapewni zadowalającej konkurencji pomiędzy ofertami. Wydłuży to czas przygotowania przedsięwzięcia oraz zwiększy jego koszty. W takiej sytuacji podmiot publiczny powinien ponownie zmodyfikować przedsięwzięcie i poddać je ocenie rynkowej. Jednoznaczne, pozytywne ustosunkowanie się do wykonania zadania w koncepcji PPP stanowi przesłankę do dalszych prac, przygotowania się do wyboru partnera prywatnego. Należy pamiętać, że poszczególne etapy prac powinny zostać ujęte w harmonogramie. Jest ważne, by działania znajdujące się na tzw. ścieżkach krytycznych rozpoczynały się $\mathrm{w}$ zaplanowanych terminach i były ściśle monitorowane, tak aby ich przebieg odbywał się zgodnie z planem. Dobrym rozwiązaniem jest skorzystanie z oprogramowania do planów inwestycyjnych i utworzenie harmonogramu w formie wykresu Gantta ${ }^{12}$.

${ }^{10}$ Zob. Partnerstwo publiczno-prywatne, red. A. Gajewska-Jedwabny, s. 75-77.

${ }^{11} \mathrm{Na}$ podstawie materiałów szkoleniowych firmy Investment Support.

${ }^{12} \mathrm{H}$. L. Gantt po raz pierwszy zastosował do przedstawienia planu produkcji formę graficzną w roku 1917. Na typowym wykresie Gantta wiersze zawierają stanowiska pracy, natomiast kolumny oznaczają jednostki czasu. Układ zdarzeń na wykresie przedstawiany jest najczęściej w wersji planowanej przed rozpoczęciem działania oraz rzeczywistej, nanoszonej na wykres wraz z upływem czasu. Za pomocą wykresu Gantta można nie tylko planować i kontrolować wykonanie planu, ale także, poprzez zastosowanie odpowiedniego systemu oznaczeń, uwzględniać zmienność przebiegu wykonania zadania. W przypadku wykresu wydajności pracy analizę przeprowadza się na podstawie zapisów rzeczywistych, uzupełnionych o oznaczenia zakłóceń (np. brak pracownika, brak materiałów, brak instrukcji, remont maszyny, brak energii, brak narzędzi, brak doświadczenia 
Pozytywny wynik wstępnej analizy prawno-finansowej i market sounding pozwalają przejść do kolejnego etapu procedury przygotowania PPP, która związana jest $\mathrm{z}$ przygotowaniem postępowania $\mathrm{w}$ sprawie wyboru partnera prywatnego. Wybór prywatnego inwestora stanowi newralgiczną część całego procesu. Decyzje podjęte na tym etapie będą rzutować na dalszą współpracę stron, stąd ważne jest, aby wcześniej przeprowadzić konsultacje rynkowe. Staranne przygotowanie procedury przetargowej jest kluczowym zadaniem podmiotu publicznego. Prawo Unii Europejskiej rygorystycznie podchodzi do problematyki zamówień publicznych, toteż podmiot publiczny musi dołożyć wszelkiej staranności, aby właściwie przygotować zamówienie, zgodnie z obowiązującym prawem unijnym i krajowym.

Wejście w życie nowych regulacji prawnych, tj. ustawy o partnerstwie publiczno-prywatnym ${ }^{13}$ oraz ustawy o koncesji na roboty budowlane lub usługi ${ }^{14}$ w sposób istotny wpłynęło na dotychczasowe przepisy określające współpracę sektora publicznego z sektorem prywatnym. Należy zaznaczyć, że przed 2009 r. (pomijając „,martwą" ustawę o PPP z 2005 r. oraz marginalnie wykorzystywaną instytucję koncesji z 2004 r., regulowaną przepisami Prawa zamówień publicznych) $\mathrm{w}$ Polsce funkcjonowały i funkcjonują przepisy regulujące kwestie współpracy sektora publicznego z podmiotami prywatnymi. Należą do nich ustawy: Prawo zamówień publicznych ${ }^{15}$, o drogach publicznych ${ }^{16}$, o autostradach platnych oraz o Krajowym Funduszu Drogowym ${ }^{17}$, o gospodarce nieruchomościami $^{18}$ oraz o gospodarce komunalnej ${ }^{19}$.

wykonawcy, święta, narady, strajki, braki w kwalifikacjach wykonawcy, brak zlecenia). Wykres Gantta jest graficznym sposobem planowania i kontroli. Planowanie i koordynowanie przebiegu różnych czynności w przekroju czasowym odgrywa istotną rolę w tworzeniu i funkcjonowaniu organizacji. Wykresy Gantta służą do planowania działań wielopodmiotowych zarówno zespołowych, jak i grupowych. Przedstawiają następstwo kolejnych zdarzeń, uwzględniając również zadania wykonywane równolegle. Dzięki tej technice można także kontrolować realizację zaplanowanego przedsięwzięcia. Encyklopedia Zarządzania, www.mfiles.pl.

${ }^{13}$ Ustawa z dnia 19 grudnia 2008 r. o partnerstwie publiczno-prywatnym, DzU, 2009, nr 19, poz. $100 \mathrm{ze} \mathrm{zm}$.

${ }^{14}$ Ustawa z dnia 9 stycznia 2009 r. o koncesji na roboty budowlane lub ustugi, DzU, 2009, nr 19, poz. 101ze zm.

${ }^{15}$ Ustawa z dnia 29 stycznia 2004 r. Prawo zamówień publicznych, DzU, 2011, nr 87, poz. 484 ze zm.

${ }^{16}$ Ustawa z dnia 21 marca 1985 r. o drogach publicznych, DzU, 2011, nr 159, poz. 945.

${ }^{17}$ Ustawa z dnia 27 października 1994 r. o autostradach płatnych oraz o Krajowym Funduszu Drogowym, DzU, 2009, nr 223, poz. 1776.

${ }^{18}$ Ustawa z dnia 21 sierpnia 1997 r. o gospodarce nieruchomościami, DzU, 2011, nr 163, poz. 981.

${ }^{19}$ Ustawa z dnia 20 grudnia 1996 r. o gospodarce komunalnej, DzU, 2011, nr 45, poz. 236. 
Obowiązujące wówczas rozwiązania uznawano za utrudniające realizację przedsięwzięć $\mathrm{w}$ formule PPP. Zdaniem prawników najważniejsze utrudnienia dotyczyły ${ }^{20}$ :

1) przepisów PZP, w ramach których zawarcie umowy dotyczącej świadczeń okresowych lub ciągłych, na okres dłuższy niż 3 lata, wymagało zgody prezesa Urzędu Zamówień Publicznych wyrażonej w drodze decyzji administracyjnej udzielonej przed wszczęciem postępowania o udzielenie zamówienia,

2) faktu, że PZP nie pozwalało na wybór partnera prywatnego w trybie negocjacji z ogłoszeniem,

3) braku możliwości następczej zmiany treści umowy w sprawie zamówienia publicznego,

4) ograniczeń wynikających z przepisów ustawy o gospodarce nieruchomościami dotyczących nieodpłatnego obrotu nieruchomościami przez podmioty publiczne oraz konieczności stosowania procedury przetargowej w przypadku przekazywania nieruchomości spółce celowej lub partnerowi prywatnemu,

5) określenia przez ustawę o gospodarce komunalnej form, w jakich samorząd mógł wykonywać zadania z zakresu tej gospodarki.

Ustawodawca, przyjmując kompleksowe rozwiązania w zakresie partnerstwa publiczno-prywatnego dążył do stworzenia wyraźnie określonych jego ram organizacyjnych usuwających sygnalizowane utrudnienia. Uchwalenie odrębnej ustawy miało spowodować zmianę filozofii w finansowaniu zadań publicznych i zachęcić podmioty prywatne do przyjmowania finansowania nakładów koniecznych do realizacji zadań publicznych ${ }^{21}$. Przyjęcie ustawy o partnerstwie publiczno-prywatnym wymusiło dokonanie zmian $\mathrm{w}$ przepisach wymienionych wcześniej ustaw, co doprowadziło do ${ }^{22}$ :

1) rozszerzenia katalogu trybów postępowania o wybór partnera prywatnego dla przedsięwzięcia PPP o dialog konkurencyjny i negocjacje z ogłoszeniem,

2) możliwości zastosowania partnerstwa do budowy i utrzymania autostrad i dróg ekspresowych, a także określenia katalogu opłat, które mogą być pobierane przez partnera prywatnego (Ustawa o drogach publicznych),

3) uzupełnienia o partnerstwo publiczno-prywatne listy sposobów, w zakresie umów, na podstawie których jednostki samorządu terytorialnego mogą

${ }^{20}$ Por. Ustawa o partnerstwie publiczno-prywatnym. Komentarz, red. M. Bejm, Wydawnictwo C.H. BECK, Warszawa 2010, s. 29-31; T. Korczyński, A. Kozłowska, K. Kozłowski, A. Mednis, A. Nowaczek, Koncesja na roboty budowlane lub ustugi a inne formy realizacji inwestycji publiczno-prywatnych, ABC a Wolters Kluwer business, Warszawa 2010, s. 33; R. Cieślik, Partnerstwo publiczno-prywatne $w$ samorzadzie terytorialnym, Infor Ekspert, Warszawa 2011, s. 49-52; R. Poznalski, Granice partnerstwa publiczno-prywatnego. Zmiany w obowiazujacych przepisach, www.partnerstwopublicznoprywatne.info (05.04.2013).

${ }^{21}$ Por. Ustawa o partnerstwie publiczno-prywatnym. Komentarz..., s. 32.

${ }^{22} \mathrm{Na}$ podstawie A. Panasiuk, Koncesja na roboty budowlane lub uslugi. Partnerstwo publiczno-prywatne. Komentarz, C.H. Beck, Warszawa 2009, s. 358-365. 
powierzyć wykonywanie zadań dotyczących gospodarki komunalnej, stwarzając tym samym możliwość powierzenia zadań z zakresu gospodarki komunalnej nie tylko na podstawie przepisów Prawa zamówień publicznych, o finansach publicznych czy działalności pożytku publicznego i o wolontariacie, ale alternatywnie także ustawy o partnerstwie publiczno-prywatnym. Zmiany przyczyniły się do zwiększenia elastyczności wyboru typu umowy w sytuacji powierzenia zadań z obszaru gospodarki komunalnej. Dopuszczono także możliwość tworzenia przez jednostki samorządu terytorialnego spółek komandytowych i spółek komandytowo-akcyjnych w ramach partnerstwa publiczno-prywatnego, co stanowi nowość nawet w stosunku do pierwotnej ustawy o PPP (Ustawa o gospodarce komunalnej),

4) umożliwienia w ramach Ustawy o gospodarce nieruchomościami nieodpłatnego przekazania partnerowi prywatnemu lub spółce nieruchomości na czas realizacji przedsięwzięcia $\mathrm{w}$ ramach partnerstwa publiczno-prywatnego oraz uproszczenia (złagodzenia) zasady gospodarowania nieruchomościami poprzez przekazanie nieruchomości partnerowi prywatnemu lub spółce celowej w trybie bezprzetargowym albo sprzedaży $\mathrm{z}$ bonifikatą. Złagodzenie zasad wynika z faktu, że interes publiczny jest zabezpieczony zasadą zwrotu nieruchomości po zakończeniu umowy partnerstwa publiczno-prywatnego. Sprzedaż z bonifikatą może nastąpić wyłącznie z zastrzeżeniem prawa odkupu, co ma zabezpieczyć stronę publiczną przed nielojalnym zachowaniem partnera prywatnego.

Zespół koordynacyjny jest zobowiązany dokładnie przeanalizować regulacje prawne w zakresie trybów postępowania o zamówienie i wybranie jednego z możliwych. Podstawowym narzędziem do zapewnienia efektywności przy wydatkowaniu środków publicznych jest konieczność zastosowania procedur przetargowych. Ponadto podmiot publiczny zobowiązany jest działać zgodnie z zasadami przejrzystości, konkurencyjności, równości i niedyskryminacyjnego traktowania podmiotów biorących udział $\mathrm{w}$ postępowaniu. Zasady te mają fundamentalne znaczenie dla prawidłowego wyboru prywatnego inwestora i zapewnienia wszystkim zainteresowanym równego dostępu do możliwości realizacji przedsięwzięcia. Należy je stosować na każdym etapie postępowania, tj. zarówno na etapie przygotowania (tworzenie projektów dokumentacji postępowania) oraz w samej fazie wyboru partnera. Obowiązek zachowania tych zasad wynika, po pierwsze, wprost $\mathrm{z}$ art. 6 Ustawy o koncesji na roboty budowlane lub uslugi oraz przepisów obowiązujących Polskę w związku z przystąpieniem do Unii Europejskiej. Podstawowym przepisem jest postanowienie Dyrektywy 2004/18/WE $E^{23}$. Ponadto w prawie unijnym odwołanie do zasad równego traktowania, uczciwej konkurencji, przejrzystości i niedyskryminacji

${ }^{23}$ Dyrektywa 2004/18/WE Parlamentu Europejskiego i Rady z 31.03.2004 r. w sprawie koordynacji procedur udzielenia zamówień publicznych na roboty budowlane, dostawy i ustugi, DzUrz. UE, L 134/114. 
wskazują art. 12, 43 i 49 Traktu ustanawiajacego Wspólnotę Europejską ${ }^{24}$ oraz orzeczenie Trybunału Sprawiedliwości ${ }^{25}$. Przywołane artykuły Traktatu odnoszą się do:

- zakazu wszelkiej dyskryminacji ze względu na przynależność państwową (art. 12), ograniczenia swobody przedsiębiorczości obywateli jednego państwa członkowskiego na terytorium innego państwa członkowskiego są zakazane (art. 43) oraz

- ograniczenia w swobodnym świadczeniu usług wewnątrz Wspólnoty są zakazane także w odniesieniu do obywateli państw członkowskich mających swe przedsiębiorstwo $\mathrm{w}$ państwie wspólnoty innym niż państwo odbiorcy świadczenia (art. 49).

Z prawnego punktu widzenia powyższe zasady traktowane są jako ogólne zasady postępowania, które wpływają na kształt postępowania i stosunków materialnoprawnych poprzez ingerencję $\mathrm{w}$ sferę określonych zachowań uczestników postępowania. Naruszenie ogólnych zasad postępowania traktowane jest jako naruszenie przepisów prawa, które obwarowane jest różnymi następstwami prawnymi, mogącymi powodować odwołanie lub unieważnienie postępowania, powtórzenie czynności czy nawet unieważnienie zawartej umowy ${ }^{26}$. Na komisji przetargowej/zespole wdrożeniowym ciąży zatem obowiązek staranności przygotowania i przeprowadzenia postępowania $\mathrm{z}$ zachowaniem powyższych zasad.

W obowiązującym polskim porządku prawnym istnieją cztery sposoby wyłonienia prywatnego inwestora dla współpracy partnerskiej. Są to:

1) wybór koncesjonariusza w trybie ustawy o koncesjach,

2) wybór partnera prywatnego w trybie ustawy o koncesjach,

3) wybór partnera prywatnego w trybie ustawy o PPP (czyli de facto PZP),

4) wybór partnera prywatnego w trybie art. 4 ust. 3 ustawy o PPP.

Bezpośrednie prace związane z wyłonieniem wykonawcy poprzedzone są pracami przygotowawczymi. Wszelkie błędy i niedociągnięcia, jakie zostaną popełnione na etapie prac przygotowawczych, będą rzutować na efekt końcowy. $\mathrm{Z}$ tego względu utworzony zespół powinien zarezerwować sobie wystarczająco dużo czasu na opracowanie odpowiednich dokumentów, w tym najważniejszych

${ }^{24}$ Traktat ustanawiający Wspólnotę Europejska, DzU, 2004, nr 90, poz. 864/2 ze zm.

${ }^{25}$ Por. wyr. ETS: Orzeczenie z dnia 20 marca 1990 r. w sprawie C-21/88 Du Pont de Nemours Italiana SPA przeciw Unita Sanitaria lokale no 2 di Carrara; Orzeczenie z 28 października 1999 r. w sprawie C-328/96 Komisja Wspólnot Europejskich przeciwko Austrii; Orzeczenie z 18 listopada 1999 r. w sprawie C-275/98 Unitron Scadinavia przeciwko Ministeriat for Frdevaret; Orzeczenie z 3 czerwca 1992 r. w sprawie C-360/89 Komisja Wspólnot Europejskich przeciw Republice Włoskiej; Orzeczenie z dnia 22 czerwca 1993 r. w sprawie C-243/89 Komisja Wspólnot Europejskich przeciw Królestwu Danii.

${ }^{26}$ A. Panasiuk, Koncesja na roboty budowlane lub uslugi..., s. 81. 
- ogłoszenia o koncesji lub specyfikacji istotnych warunków zamówienia (SIWZ) oraz opisu przedmiotu zamówienia.

Rolą zespołu koordynującego postępowanie na wybór partnera jest uświadomienie sobie, że procedura wyłonienia partnera dla PPP nie jest tym samym, co wybór wykonawcy $\mathrm{w}$ tradycyjnym zamówieniu. W tradycyjnej formie zamówienia publicznego główną rolę odgrywa przestrzeganie przepisów dotyczących zamówień publicznych. Zakres współpracy pomiędzy stronami ma charakter zlecenia działań (np. robót budowlanych, dostaw, usług) wykonawcy (sektor prywatny) przez zamawiającego (podmiot sektora publicznego). Ustawa Prawo zamówień publicznych ma charakter prawa proceduralnego, gdyż wyznacza granice, w ramach których mogą poruszać się podmioty publiczne udzielające zamówienia publicznego. $\mathrm{Na}$ podstawie przepisów zamówień publicznych doszło w Polsce do podpisania pierwszych umów, którym powszechnie przypisuje się znamiona umowy partnerstwa publiczno-prywatnego ${ }^{27}$.

Tryb wyboru partnera prywatnego dla PPP wyznaczony zostaje w polskim porządku prawnym poprzez sposób jego wynagrodzenia. Nowa ustawa o PPP nie określa własnego trybu wyboru partnera, jedynie umożliwia wybór jednego $\mathrm{z}$ dostępnych w prawie trybów. Zgodnie z art. 4.

jeśli wynagrodzeniem partnera prywatnego jest prawo do pobierania pożytków z przedmiotu partnerstwa publiczno-prywatnego, albo przede wszystkim to prawo wraz zapłata sumy pieniężnej, wyboru partnera dokonuje się stosując przepisy ustawy z dnia 9 stycznia 2009 r. o koncesjach na roboty budowlane lub ustugi.

W innych przypadkach wybór partnera prywatnego będzie dokonywany na podstawie przepisów Prawa zamówień publicznych, do czego nawiązuje art. 4 ust 2. i ust 3. ustawy o PPP.

$\mathrm{W}$ przypadku, gdy wynagrodzeniem prywatnego inwestora będą dochody związane z realizacją przedmiotu PPP (np. opłaty za korzystanie z usług wodnokanalizacyjnych, usług transportowych), to tryb wyboru będzie prowadzony zgodnie z ustawą o koncesji. W sytuacji, gdy wynagrodzenie w całości będzie pochodzić od podmiotu publicznego, wybór prywatnego inwestora dokonany zostać powinien z wykorzystaniem przepisów Prawa zamówień publicznych ${ }^{28}$.

${ }^{27}$ Do pierwszych umów powszechnie pretendujących do PPP zalicza się umowę koncesji na roboty budowlane dotyczące budowy garażu podziemnego w Krakowie, umowy składające się na kontrakty, stanowiące pakiet do realizacji określonych zadań publicznych (szpital w Ostródzie).

${ }^{28}$ Warianty wynagrodzenia partnera prywatnego omawia G. Ostrzołek, Finansowanie budowy drogi $w$ mieście na prawach powiatu na zasadach partnerstwa publiczno-prywatnego (ustawowego), „Finanse Komunalne” 2009, nr 12, s. 57-58 zwracając uwagę, iż wysokość wynagrodzenia uzależniona może być od jednego z dwóch czynników: 1) rzeczywistego wykorzystania przez partnera prywatnego przedmiotu umowy partnerstwa związanego np. $\mathrm{z}$ popytem na efekty przedsięwzięcia (liczby samochodów korzystających $\mathrm{z}$ ulicy, liczby odbiorców korzystających z sieci wodno-kanalizacyjnej), 2) faktycznej dostępności przedmiotu partnerstwa - związanego z utrzymaniem standardów jakościowych i ilościowych (jakości drogi, jakości wody). 
Charakter wynagrodzenia stanowi podstawową determinantę ścieżki wyboru partnera prywatnego (schemat 2.2).

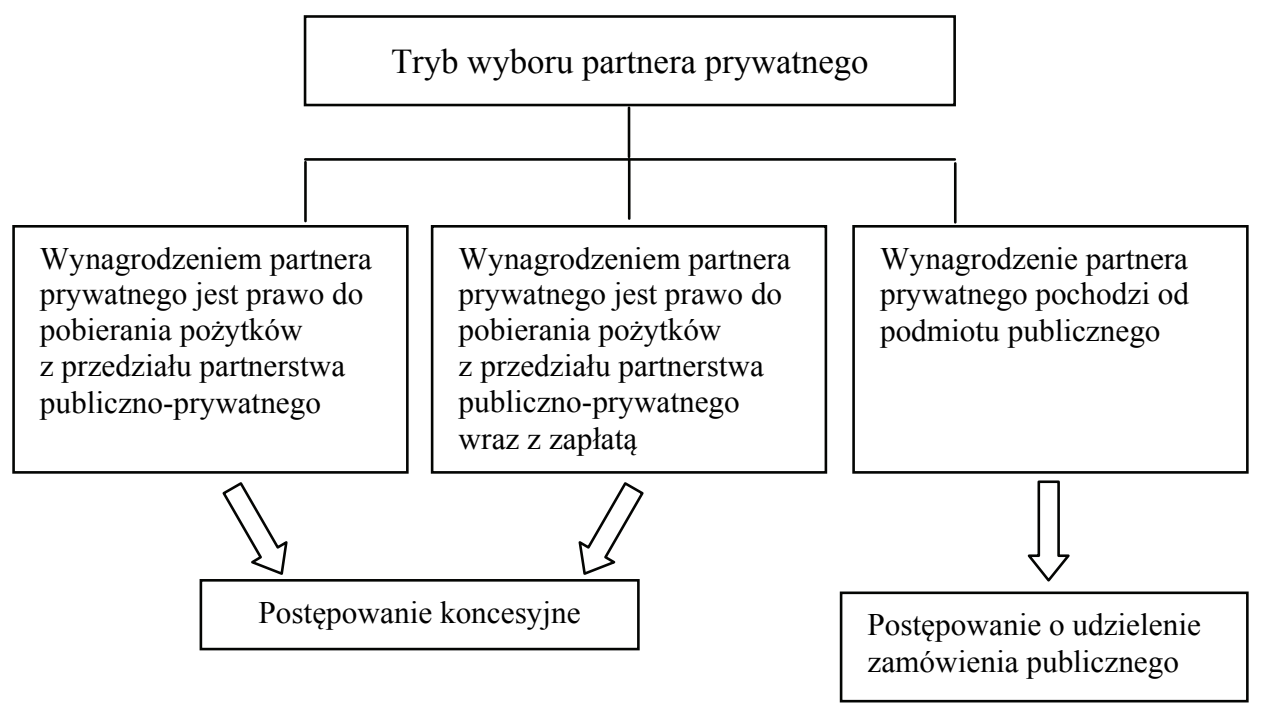

Schemat 2.2. Tryb wyboru partnera prywatnego dla PPP Źródło: oprac. własne

W przypadku, gdy wynagrodzenie podmiotu prywatnego nie będzie pochodzić wyłącznie od strony publicznej, a przynajmniej w części z pożytków pochodzących z przedmiotu partnerstwa, wybór dokonany zostanie według zapisów ustawy koncesyjnej (w przypadku modelowego PPP). Ustawa o koncesji jest dostosowana do przedsięwzięć typu partnerstwa i zastosowanie jej przepisów może następować wprost bez żadnych modyfikacji. Prawnicy przyznają, że w przypadku partnerstwa najkorzystniejszą formą będzie tryb negocjacji lub dialog konkurencyjny prowadzony na zasadach równości i niedyskryminacji uczestników postępowania, zapewniający przejrzystość i uczciwość konkurencji.

Podjęcie decyzji o sposobie wynagrodzenia prywatnego podmiotu jednoznacznie wytyczy ścieżkę postępowania o wybór podmiotu. Jeśli będzie to ustawa o koncesji, to postępowanie rozpoczyna się od sporządzenia przez koncesjodawcę opisu przedmiotu koncesji, który powinien być sporządzony tak, aby umożliwić zainteresowanym podmiotom jednakowy, nieograniczony dostęp do wykonania koncesji. Opis może zostać sporządzony na trzy sposoby ${ }^{29}$ :

${ }^{29}$ T. Korczyński, A. Kozłowska, K. Kozłowski, A. Mednis, A. Nowaczek, Koncesja na roboty budowlane..., s. 77. 
1) po pierwsze, poprzez odniesienie do specyfikacji technicznej,

2) po drugie, poprzez charakterystykę lub wymagania w zakresie funkcjonalności,

3) po trzecie, w sposób mieszany, tzn. poprzez częściowe odniesienie do specyfikacji technicznej oraz częściowe odniesienie się do charakterystyki lub wymagań w zakresie funkcjonalności.

Przedmiot koncesji opisuje się za pomocą dokładnych i zrozumiałych określeń, w sposób jednoznaczny i wyczerpujący, który pozwoli oferentom przedstawić oferty odpowiadające rzeczywistym oczekiwaniom zamawiającego. Dokonując opisu w formie specyfikacji technicznej koncesjodawca odnosi się do oznaczonych cech technicznych i jakościowych ${ }^{30}$. W specyfikacji podaje się odniesienia do norm technicznych, metod i technologii produkcji, parametrów produktu lub usługi, zasad projektowania i kosztorysowania. Jeśli opis przedmiotu koncesji został sporządzony w formie charakterystyki lub wymagań w zakresie funkcjonalności, to jego forma jednoznacznie powinna wyrażać intencje koncesjodawcy i nie budzić żadnych wątpliwości ze strony zainteresowanych koncesją podmiotów. Oznacza to, że koncesjodawca nie jest bezwzględnie zobowiązany do odnoszenia się do norm jakościowych i technicznych, jeśli tylko sam jest $\mathrm{w}$ stanie precyzyjnie określić cechy przedmiotu koncesji.

Przed ogłoszeniem postępowania podmiot publiczny oblicza szacunkową wartość przedsięwzięcia. Szacunkowa wartość partnerstwa publiczno-prywatnego to spodziewany (przybliżony) przez podmiot publiczny koszt realizacji przedsięwzięcia. Zaznaczyć należy, że postępując zgodnie z przepisami ustawy koncesyjnej, przy określeniu wartości szacunkowej zawsze będzie to koszt realizacji przedmiotu partnerstwa, a nie spodziewana wysokość wynagrodzenia, w przeciwieństwie do procedur prowadzonych na podstawie regulacji zamówień publicznych. Ustawodawca w ustawie koncesyjnej, w przeciwieństwie do ustawy Prawo zamówień publicznych, nie wskazuje konkretnej metody ani sposobu ustalenia szacunkowej wartości. Tym samym podmiot publiczny ma swobodę działania, pod warunkiem, że owo działanie będzie się mieścić $\mathrm{w}$ ramach należytej staranności ${ }^{31}$. W przypadku, gdy przedmiotem przedsię-

${ }^{30}$ Opisu przedmiotu zamówienia należy dokonać z zachowaniem Polskich Norm przenoszących normy europejskie lub norm innych państw członkowskich Europejskiego Obszaru Gospodarczego przenoszących te normy, europejskich aprobat technicznych, wspólnych specyfikacji technicznych, norm międzynarodowych, systemów referencji technicznych. Ustawa $z$ dnia 30 sierpnia 2002 r. o systemie oceny zgodności, DzU, 2004, nr 204, poz. 2087 ze zm., art. 5 pkt 14.

${ }^{31}$ Ustawa o koncesji na roboty budowlane lub usługi nie definiuje pojęcia „należyta staranność", ale z uwagi na fakt, że art. 5 tej ustawy odsyła do kodeksu cywilnego w każdej sytuacji nie oznaczonej w ustawie. Zgodnie z powyższym, w zakresie definicji „należytej staranności” należy posłużyć się art. 355 k.c., według którego przez należytą staranność powinno się rozumieć 
wzięcia będzie budowa lub remont obiektu budowlanego, zachowanie należytej staranności będzie wymagało zastosowania się do regulacji zawartych w rozporządzeniu ministra infrastruktury ${ }^{32}$ dotyczącym metod i podstaw sporządzania kosztorysu inwestorskiego, obliczenia planowanych kosztów prac projektowych oraz planowanych kosztów robót budowlanych, które zostało wydane do art. 33 ust. 3 PZP. Podmiot publiczny przy ocenie wartości szacunkowej może także skorzystać $\mathrm{z}^{33}$ :

- opinii odpowiedniego specjalisty,

- rozeznania cen rynkowych danego rodzaju robót budowlanych, dostaw lub usług (np. poprzez rozesłanie zapytania do podmiotów świadczących tego typu prace, korzystanie z fachowych wydawnictw (np. „Biuletyny Sekocenbud” w sprawie cen robót budowlanych, elektrycznych, cen pracy sprzętu budowlanego), cenników itp.

- bazowania na cenach tego rodzaju robót lub usług świadczonych na rzecz podmiotu publicznego we wcześniejszych okresach z uwzględnieniem inflacji.

Na potrzeby koncesji na usługi wartość szacunkową określa się dla wszystkich usług świadczonych w całym okresie trwania umowy. Liczbę tych usług ustala się na podstawie rzeczywistej ich wartości świadczonej przez lub na rzecz podmiotu publicznego $\mathrm{w}$ okresie ostatnich 12 miesięcy albo planowanych rzeczywistych potrzeb podmiotu publicznego.

Przy stosowaniu przepisów ustawy o koncesji (art. 9) w odniesieniu do robót budowlanych podstawą obliczenia wartości szacunkowej jest kwota niezawierająca podatku od towarów i usług, która uwzględnia szacunkowy koszt robót budowlanych oraz szacunkową wartość dostaw niezbędnych do wykonania zadania bez względu na planowany sposób zapłaty wynagrodzenia koncesjonariusza. W przypadku usług jest to, analogicznie, kwota niezawierająca podatku VAT, która uwzględnia szacunkowy koszt świadczonych usług. Stosując przepisy o zamówieniach publicznych wartość szacunkową podajemy w wartościach brutto.

Postępowanie o zawarcie umowy o partnerstwie publiczno-prywatnym rozpoczyna się $\mathrm{w}$ momencie publikacji ogłoszenia, przez które rozumie się jego upublicznienie, tj. uzewnętrznienie woli podmiotu publicznego, o wszczęcie postępowania i umożliwienie zapoznania się $\mathrm{z}$ nim przez zainteresowane

staranność ogólnie wymaganą w stosunkach danego rodzaju. Ustawa z dnia 23 kwietnia 1964 r. Kodeks cywilny, DzU, 1964, nr 16, poz. 93 ze zm.

${ }^{32}$ Rozporządzenie Ministra Infrastruktury z dnia 18 maja 2004 r. w sprawie określenia metod $i$ podstaw sporzadzania kosztorysu inwestorskiego, obliczenia planowanych kosztów prac projektowych oraz planowanych kosztów robót budowlanych określonych w programie funkcjonalno użytkowym, DzU, 2004, nr 130, poz. 1389 ze zm.

${ }^{33}$ T. Skoczyński, Ustawa o partnerstwie publiczno-prywatnym. Praktyczny komentarz, Lex Wolters Kluwer business, Warszawa 2011, s. 96. 
podmioty ${ }^{34}$. Ogłoszenie o koncesji zawiera w szczególności ${ }^{35}$ elementy wymienione w tab. 2.2.

Tabela 2.2

Elementy treści ogłoszenia o koncesji

\begin{tabular}{|l|}
\hline \multicolumn{1}{|c|}{ Elementy ogłoszenia o koncesji } \\
\hline Nazwa (firma) i adres koncesjodawcy \\
\hline Określenie przedmiotu koncesji \\
\hline Wskazanie miejsca i terminu składania wniosków o zawarcie umowy koncesji \\
\hline $\begin{array}{l}\text { Opis potrzeb i wymagan koncesjodawcy lub informacje o sposobie uzyskania tego } \\
\text { opisu }\end{array}$ \\
\hline $\begin{array}{l}\text { Termin wykonania przedmiotu koncesji, o ile jest to podyktowane specyfiką } \\
\text { zawieranej umowy koncesji }\end{array}$ \\
\hline $\begin{array}{l}\text { Warunki udziału oraz opis sposobu dokonywania oceny spełnienia warunków udziału } \\
\text { w postępowaniu }\end{array}$ \\
\hline $\begin{array}{l}\text { Informacja o dokumentach składanych przez oferenta, którego oferta zostanie uznana } \\
\text { za najkorzystniejszą albo oferenta, który złoży najkorzystniejszą ofertę spośród } \\
\text { pozostałych ofert w celu potwierdzenia spełnienia warunków udziału w postępowaniu }\end{array}$ \\
\hline Informacja na temat wadium, o ile jego wniesienie jest wymagane \\
\hline $\begin{array}{l}\text { Kryteria oceny ofert, jakimi koncesjodawca będzie się kierował przy wyborze oferty } \\
\text { najkorzystniejszej oraz, o ile to możliwe, ich znaczenie }\end{array}$ \\
\hline $\begin{array}{l}\text { Warunki uznania oferty za nieodpowiadającą wymaganiom koncesjodawcy, skutkują- } \\
\text { ce niedopuszczeniem oferty do oceny i porównania }\end{array}$ \\
\hline Okoliczności uzasadniające odwołanie postępowania \\
\hline
\end{tabular}

Źródło: oprac. własne na podstawie Ustawy z dnia 9 stycznia 2009 r. o koncesji na roboty budowlane lub ushugi, DzU, 2009, nr 19, poz. 101 ze zm., art. 11.

W celu zapewnienia pełnej przejrzystości i jawności procedury wyłonienia partnera przewiduje się potrójny system upublicznienia informacji dotyczących planowanych przedsięwzięć PPP. Publikacji ogłoszenia dotyczącego koncesji na usługi dokonuje się w „Biuletynie Zamówień Publicznych” (BZP) udostępnionym na stronach portalu internetowego Urzędu Zamówień Publicznych. Ogłoszenie o koncesji na roboty budowlane dodatkowo umieszcza się drogą elektroniczną w „Europejskim Dzienniku Zamówień Publicznych” (TED) ${ }^{36}$ na stronie Urzędu Oficjalnych Publikacji Wspólnot Europejskich. Jeśli postępowanie odbywa się na podstawie ustawy o PPP, dodatkowo informację należy umieścić

34 T. Skoczyński, Ustawa partnerstwie publiczno-prywatnym. Praktyczny komentarz..., s. 101.

${ }^{35}$ Ustawa z dnia 9 stycznia 2009 r. o koncesji na roboty budowlane lub ustugi..., poz. 101 ze zm., art. 11 .

${ }^{36}$ „Europejski Dziennik Zamówień Publicznych” - Tenders Electronic Daily (powszechnie stosowany skrót TED). 
w „Biuletynie Informacji Publicznej” (BIP). Stosowne ogłoszenie powinno także zostać umieszczone w siedzibie podmiotu oraz na jego stronie internetowej. Opublikowanie ogłoszenia jest możliwe wyłącznie w formie elektronicznej poprzez interaktywne formularze, których wzór określony został w Rozporzadzeniu Prezesa Rady Ministrów ${ }^{37}$, znajdujących się na stronach portalu.

Ogłoszenie w „Europejskim Dzienniku Zamówień Publicznych” zamieszcza się wówczas, gdy wartość zamówienia w przeliczeniu na PLN jest równa lub przekracza $^{38}$ :

1) 125000 euro dla dostaw lub usług,

2) 4845000 euro dla robót budowlanych.

Zamieszczenie ogłoszeń w BZP i TED ma zagwarantować równy dostęp zainteresowanych przedsiębiorców do uczestnictwa w procedurze przetargowej. Natomiast ogłoszenie w BIP pełni jedynie funkcję informacyjną.

Termin składania wniosków o zawarcie umowy uzależniony został od wartości koncesji. Gdy wartość koncesji jest równa lub przekracza kwotę 4845000 euro, termin składania wniosków nie może być krótszy niż 45 dni licząc od dnia zamieszczenia ogłoszenia w BZP lub, dla koncesji na roboty, w TED. W sytuacji, gdy wartość koncesji jest niższa od tej kwoty, termin składania wniosków nie może być krótszy niż $21 \mathrm{dni}$. W pilnych sytuacjach ustawodawca dopuścił skrócenie okresu do 14 dni. Wysokość powyższych kwot określona została w Rozporzadzeniu Prezesa Rady Ministrów z dnia 23 grudnia 2009 r. w sprawie kwot wartości zamówień oraz konkursów, od których uzależniony jest obowiązek przekazywania ogłoszeń Urzędowi Oficjalnych Publikacji Wspólnot Europejskich $^{39}$. Zainteresowane podmioty składają wnioski o zawarcie umowy koncesji. Prawidłowy wniosek musi zawierać:

- oświadczenie o zgłoszeniu udziału w postępowaniu,

- oświadczenie o spełnieniu opisanych w ogłoszeniu warunków udziału,

- inne oświadczenia związane z wykonaniem przedmiotu koncesji, jeśli taki wymóg zawarty został w koncesji.

Oświadczenia mogą dotyczyć: zdolności ekonomicznej i finansowej podmiotu składającego wniosek, kwalifikacji technicznych lub zawodowych (posiadanie wiedzy, umiejętności, doświadczenia, dysponowanie potencjałem technicznym i kadrowym), uprawnień do wykonywania określonej działalności lub czynności, niekaralności. Złożenie przez wnioskodawców niekompletnych wniosków powoduje niedopuszczenie ich do kolejnego etapu postępowania. Do

${ }^{37}$ Rozporzadzenie Prezesa Rady Ministrów z dnia 3 marca 2009 r. w sprawie wzorów ogłoszenia o koncesji na ustugi zamieszczonego w „Biuletynie Zamówień Publicznych”, DzU, 2009, nr 39, poz. 311.

${ }^{38}$ Rozporzadzenie Prezesa Rady Ministrów z dnia 23 grudnia 2009 r. w sprawie kwot wartości zamówień oraz konkursów, od których uzależniony jest obowiązek przekazywania ogłoszeń Urzędowi Oficjalnych Publikacji Wspólnot Europejskich, DzU, 2009, nr 224, poz. 1795, §1, ust. 1.

${ }^{39}$ Ibidem. 
wszystkich tych wnioskodawców, których wnioski były prawidłowo przygotowane, podmiot publiczny wysyła zaproszenie do udziału w negocjacjach.

Jest to najistotniejszy etap w całej procedurze, gdyż od jego prawidłowego przebiegu uzależnione jest powodzenie całej procedury. Ponieważ PPP cechuje duży stopień złożoności i trudno z góry ustalić dokładnie wszystkie szczegóły przedsięwzięcia, zwłaszcza w obszarze technicznym, ustawodawca przewidział możliwość prowadzenia negocjacji, które pozwolą stronom na zgłaszanie propozycji, a w konsekwencji doprecyzowanie opisu przedmiotu koncesji ${ }^{40}$. Negocjacje mogą dotyczyć wszystkich aspektów przedsięwzięcia tj. finansowych, prawnych, technicznych. Zakres negocjacji jest szeroki i może obejmować: szczegółowe określenie czynności realizowanych przez partnera prywatnego, zobowiązań poszczególnych stron w odniesieniu do współpracy, sposobu wynagrodzenia inwestora prywatnego, rozliczenia pożytków $\mathrm{z}$ inwestycji, wysokości dopłat do świadczonych usług, formy prawnej realizacji przedsięwzięcia, skutków niedochowania zobowiązań stron, przesłanek rozwiązania umowy itp. W wyniku przeprowadzonych negocjacji koncesjodawca zaprasza kandydatów, z którymi prowadził negocjacje, do składania ofert, przesyłając im jednocześnie opis warunków koncesji. Równocześnie informuje wszystkich kandydatów o zakończeniu negocjacji. Z przeprowadzonych negocjacji podmiot publiczny sporządza protokół, który ma charakter jawny.

Treść opisu warunków koncesji jest w swej istocie powtórzeniem informacji zawartych w ogłoszeniu o postępowaniu koncesyjnym i zgodnie z art. 15 ust. 2 powinna zawierać w szczególności następujące elementy ${ }^{41}$ :

1) nazwę (firma) i adres koncesjodawcy,

2) opis przedmiotu koncesji,

3) wskazanie miejsca i terminu składania ofert,

4) termin związania ofertą,

5) termin wykonania przedmiotu koncesji, o ile jest to podyktowane specyfiką koncesji,

6) określenie opłat za korzystanie z przedmiotu koncesji przez koncesjonariusza lub podmioty trzecie albo sposobu ich ustalania, o ile jest to podyktowane specyfiką koncesji,

7) warunki udziału oraz opis sposobu dokonywania oceny spełniania warunków udziału w postępowaniu,

8) informację o dokumentach składanych przez zainteresowany podmiot, którego oferta zostanie uznana za najkorzystniejszą, w celu potwierdzenia spełniania warunków udziału,

9) informację na temat wadium, o ile obowiązek jego wniesienia był przewidziany w ogłoszeniu o koncesji,

\footnotetext{
${ }^{40}$ T. Skoczyński, Ustawa partnerstwie publiczno-prywatnym. Praktyczny komentarz..., s. 119.

${ }^{41}$ Ustawa z dnia 9 stycznia 2009 r. o koncesji na roboty budowlane..., art. 15.
} 
10) kryteria oceny ofert $i$ ich znaczenie,

11) warunki uznania oferty za niespełniającą wymagań koncesjodawcy, skutkujące niedopuszczeniem oferty do oceny i porównania,

12) okoliczności uzasadniające odwołanie postępowania,

13) pouczenie o prawie do wniesienia skargi na czynności podejmowane przez koncesjodawcę $\mathrm{w}$ trakcie postępowania.

Koncesjodawca wyznacza miejsce i termin złożenia ofert, uwzględniając czas niezbędny do przygotowania i złożenia oferty. Informacje zawarte $\mathrm{w}$ ofercie pokrywają się $\mathrm{w}$ części $\mathrm{z}$ informacjami, jakie oferent składał we wniosku przystępując do negocjacji. W momencie, kiedy koncesjodawca dysponuje złożonymi ofertami, ma prawo żądać od oferentów złożenia wyjaśnień, sprecyzowania lub dopracowania złożonych ofert. Czynności te nie mogą jednak prowadzić do zmiany oferty lub warunków zawartych w opisie koncesji. Celem działań jest uniknięcie sytuacji, gdy z powodu pewnych, drobnych nieścisłości ofertę należałoby odrzucić. Postępowanie prowadzone jest także w sytuacji, gdy wpłynie tylko jedna oferta. Po zakończeniu oceny ofert i wyborze najkorzystniejszej koncesjodawca informuje o wyniku postępowania wszystkich oferentów. Oferent, którego oferta została uznana za najkorzystniejszą, składa wymagane dokumenty. Przepisy ustawy o koncesji dopuszczają możliwość odwołania postępowania przez koncesjodawcę w sytuacji gdy zaistniały okoliczności przewidziane w ogłoszeniu o koncesji. Jeśli postępowanie kończy się sukcesem i wyłoniony został koncesjonariusz, podmiot publiczny sporządza $\mathrm{w}$ formie pisemnej protokół $\mathrm{z}$ postępowania i podaje go do wiadomości zainteresowanym i osobom trzecim.

$\mathrm{Z}$ oferentem, którego oferta została wybrana, podmiot publiczny zawiera umowę koncesji, która pod rygorem nieważności przyjmuje formę pisemną. Umowę zawiera się w terminie 10 dni od powiadomienia pozostałych oferentów o wyniku negocjacji, jeśli informację przekazano drogą elektroniczną. Jeśli informacja przekazana była w inny sposób to umowę można zawrzeć dopiero po 15 dniach. W sytuacji, gdy oferta złożona została tylko przez jednego oferenta nie ma obowiązku przestrzegania powyższych terminów.

Postępowanie o zawarcie umowy wymaga od oferenta przedstawienia wszystkich wymaganych dokumentów, jakie wymienione były w warunkach udziału w postępowaniu koncesyjnym. W przypadku, gdy oferent uchyla się od wywiązania $\mathrm{z}$ obowiązku podmiot publiczny ma prawo zawrzeć umowę z oferentem, który złożył najkorzystniejszą ofertę. Jest to sytuacja niekomfortowa dla strony publicznej, gdyż wydłuża czas procedurowania postępowania o zawarcie umowy. Wobec oferenta uchylającego się od zawarcia umowy koncesjodawca zachowuje prawo do zatrzymania kwoty pieniężnej złożonej w postaci wadium lub dochodzi zaspokojenia kwoty z przedmiotu zabezpieczenia, jeśli wadium nie było wymagane. Podpisana umowa o koncesji nie może 
być zmieniana, $\mathrm{z}$ wyjątkiem sytuacji, gdy konieczna jest zmiana wynikająca z powstania zdarzeń, których nie można było przewidzieć w dniu jej zawierania.

Umowa na koncesję jest zawierana na czas określony. Strony umowy obowiązuje zasada, że czas obowiązywania umowy powinien gwarantować koncesjonariuszowi zwrot poniesionych nakładów związanych z wykonaniem przedmiotu koncesji. Stąd dla koncesji na roboty budowlane okres ten nie powinien być dłuższy niż 30 lat, a dla koncesji na usługi 15 lat. W sytuacjach spornych wszelkie skargi kierowane są do wojewódzkiego sądu administracyjnego właściwego dla siedziby koncesjodawcy.

Ustawa o partnerstwie publiczno-prywatnym dopuszcza także drugi tryb wyboru partnera prywatnego zgodnie z przepisami Prawa zamówień publicznych. $\mathrm{Z}$ wyborem partnera $\mathrm{w}$ trybie przepisów dotyczących zamówień publicznych mamy do czynienia wtedy, gdy:

1) dominującym elementem wynagrodzenia partnera prywatnego będzie wynagrodzenie inne niż prawo do pobierania pożytków z przedmiotu partnerstwa, w tym m.in. zapłata określonej sumy pieniężnej,

2) przewidziane będą inne formy wynagrodzenia partnera prywatnego, np. całkowita zapłata ze strony podmiotu publicznego.

W ramach procedury zamówieniowej zasadniczo wybór partnera prywatnego może nastąpić poprzez ${ }^{42}$ :

${ }^{42}$ Negocjacje z ogłoszeniem polegają na tym, że po ukazaniu się ogłoszenia w „Biuletynie Zamówień Publicznych" zainteresowani wykonawcy składają wnioski o dopuszczenie do udziału w postępowaniu. Zamawiający po dokonaniu oceny złożonych wniosków dokonuje ich kwalifikacji. Zakwalifikowani wykonawcy zaproszeni zostają do złożenia wstępnych ofert wraz ze SIWZ. W dalszej kolejności zamawiający prowadzi negocjacje z wykonawcami, którzy złożyli wstępne oferty w celu doprecyzowania ekonomiczno-technicznych warunków zamówienia. Po zakończeniu negocjacji zamawiający przesyła zainteresowanym wykonawcom ostateczną wersję SIWZ, na podstawie której sporządza się ostateczną wersję oferty. Ten tryb postępowania może być zastosowany do wyboru partnera $\mathrm{w}$ formule PPP $\mathrm{w}$ sytuacji, gdy nie można $\mathrm{z}$ góry określić szczegółowych cech przedmiotu zamówienia, a negocjacje mają pomóc w ostatecznym ukształtowaniu i doprecyzowaniu sposobu realizacji zamówienia.

Negocjacje bez ogłoszenia tym różnią się od negocjacji z ogłoszeniem, że zamawiający wszczyna postępowanie bez konieczności publikacji ogłoszenia, tylko bezpośrednio wybranym przez siebie wykonawcom składa zaproszenie do negocjacji. Pozostała procedura wyboru wykonawcy odbywa się w sposób analogiczny do trybu negocjacji z ogłoszeniem.

Zamówienie z wolnej ręki jest formą negocjacji tylko $\mathrm{z}$ jednym wykonawcą. Tryb ten może znaleźć zastosowanie jeśli zachodzą przesłanki określone w art. 67 ust. 1. PZP. Tryb ten ma charakter niekonkurencyjny, co powoduje, że nie powinien mieć zastosowania przy wyborze partnera prywatnego.

Zapytanie o cenę to tryb, w którym zamawiający kieruje zapytanie o cenę do wybranych przez siebie wykonawców i zaprasza ich do składania ofert. Jest to tryb, który może być zastosowany do zamówień dotyczących dostaw lub usług powszechnie dostępnych o ustalonych standardach jakościowych, a wartość zamówienia jest mniejsza od kwoty określonej przez Prezesa Rady Ministrów w rozporządzeniu od wysokości, przy której obowiązuje konieczność publikacji ogłoszenia. W związku z powyższym tryb ten nie jest możliwy do procedury wyboru partnera 
- przetarg nieograniczony,

- przetarg ograniczony,

- negocjacje z ogłoszeniem,

- dialog konkurencyjny,

- negocjacje bez ogłoszenia,

- zamówienie z wolnej ręki,

- zapytanie o cenę,

- licytację elektroniczną.

Wybór partnera w formie przetargu (nieograniczonego lub ograniczonego) jest postępowaniem o charakterze eliminacyjnym, które zmierza do wyboru najkorzystniejszej oferty spośród złożonych, najbardziej odpowiadającej wymogom organizatora przetargu. Rozstrzygniecie postępowania przetargowego prowadzi do personifikacji strony, która będzie realizowała przedmiot zamówienia. Zdaniem A. Panasiuka ${ }^{43}$ w przypadku zamówienia publicznego tryby nieograniczony i ograniczony są podstawowymi sposobami prowadzącymi do udzielenia zamówienia, jednak w przypadku partnerstwa publiczno-prywatnego nie będą one miały zasadniczego zastosowania ze względu na sztywne podejście do możliwości negocjacji stron. W przypadku partnerstwa główna rola przypadnie dialogowi konkurencyjnemu i negocjacjom z ogłoszeniem, umożliwiającym wypracowanie wspólnej formy realizacji przedmiotu przedsięwzięcia.

Szczególne znaczenie przypisuje się dialogowi konkurencyjnemu, gdyż tryb ten umożliwia przeprowadzenie rokowań w zakresie skonkretyzowania potrzeb i wymagań samorządu, a także stworzenie ostatecznej oferty najlepiej odpowiadającej oczekiwaniom. Tryb ten powinien być wybrany, gdy nie można przeprowadzić postępowania przetargowego nieograniczonego lub ograniczonego. Przeszkodą może być brak możliwości opisania przedmiotu przetargu lub obiektywnego określenia warunków prawnych bądź fizycznych wykonania zamówienia, a cena nie jest jedynym kryterium wyboru najkorzystniejszej oferty. Dialog konkurencyjny jest też akceptowanym trybem wyboru partnera prywatnego dla projektów PPP przez Komisję Europejską, która w Komunikacie nr CC/2005/04 44 odnosi się do trudności z określeniem przedmiotu partnerstwa, co uzasadnia wykorzystanie dialogu konkurencyjnego. W ślad za rekomendacją

prywatnego gdyż przedmiotem zamówienia nie są standardowe dostawy ani usługi, a cena nie może być jedynym kryterium wyboru wykonawcy.

Licytacja elektroniczna jest trybem udzielenia zamówienia, w którym za pomocą formularza umieszczonego na stronie internetowej wykonawcy w sposób bezpośredni mają możliwość składania ofert i podlegają automatycznej klasyfikacji. Zamówienie w trybie licytacji elektronicznej jest możliwe jeśli wartość zamówienia jest mniejsza niż kwota określona przez Prezesa Rady Ministrów w rozporządzeniu. Ustawa z dnia 29 stycznia 2004 r. Prawo zamówień publicznych, DzU, 2011, nr 240, poz. 1429.

${ }^{43}$ A. Panasiuk, Koncesja na roboty budowlane ..., s. 318-319.

${ }^{44}$ Komunikat CC/2005/04 z dnia 5 października 2005 r. 
unijną polski ustawodawca wskazał w uzasadnieniu do ustawy o partnerstwie dialog konkurencyjny jako akceptowalny tryb wyboru partnera prywatnego. Dialog $\mathrm{z}$ powodzeniem można zastosować podczas wdrażania istotnych, zintegrowanych projektów w zakresie infrastruktury transportowej, dużych sieci komputerowych, projektów obejmujących złożone procesy finansowania o skomplikowanej strukturze, dla których $\mathrm{w}$ fazie projektowej trudno $\mathrm{z}$ góry zdefiniować wszystkie rozwiązania finansowe lub prawne ${ }^{45}$. W momencie, kiedy zapada decyzja, że procedura prowadzona będzie według trybu zamówienia, powołuje się komisję przetargową ${ }^{46}$.

Wybór trybu wyłonienia partnera warunkuje niezbędne czynności związane ze sposobem ogłoszenia i sporządzenia dokumentacji przetargowej. Pierwszym krokiem jest przygotowanie przez komisję przetargową specyfikacji istotnych warunków zamówienia (SIWZ), która określa zasady udziału w postępowaniu o udzielenie zamówienia publicznego. Artykuł 36 ustawy Prawo zamówień publicznych wymienia elementy składowe specyfikacji, które przedstawiono w tab. 2.3.

Zakres szczegółowości specyfikacji zależy od przedmiotu zamówienia. W przypadku PPP często specyfikacja może być bardziej ogólna, szczegóły zaś będą dopracowywane na etapie sporządzania umowy ${ }^{47}$. Tak jak w przypadku koncesji, ważny jest opis przedmiotu zamówienia, który przygotowuje się analogicznie jak dla koncesji, stosując te same zasady i kryteria przygotowania. Zasadnicza różnica pomiędzy tradycyjnym zamówieniem a PPP polega na jakości zakontraktowanej usługi, a nie sposobie jej wykonania. $Z$ tego względu ważne jest sprecyzowanie przedmiotu partnerstwa, a nie metod i sposobów realizacji usługi. Metody, sposoby będą stanowić przedmiot negocjacji pomiędzy stronami.

${ }^{45}$ Por. A. Kozłowska, Jak wybrać partnera prywatnego, „Gazeta Samorządu i Administracji” 2009, nr 21, s. 42-43.

${ }^{46}$ Każdy z trybów posługuje się odmienną terminologia w zakresie komórek powołanych do przygotowania i przeprowadzenia wyboru prywatnego wykonawcy. Prawo zamówień publicznych posługuje się terminem „komisja przetargowa”. Natomiast w przypadku koncesji nie wprowadzono odrębnego określenia dla zespołu koordynującego prace. Stąd w pracy zamiennie stosuje się zespół wdrożeniowy lub koordynacyjny.

${ }^{47}$ Art. 11 Ustawy o koncesji na roboty budowlane lub ustugi wymienia informacje, jakie muszą się znaleźć w ogłoszeniu o koncesji. Ich zawartość jest zbieżna z elementami SIWZ, z taką różnicą, iż informacje zawarte w SIWZ można podzielić na dwie gruby: obligatoryjne i fakultatywne, co wynika ze specyfiki zamówienia publicznego, PPP dąży do uzyskania końcowego rezultatu, którego elementy składowe zostaną ustalone w procesie negocjacyjnym. Ważne jest także zastosowanie właściwej terminologii dla postępowania o zamówienie lub PPP, np. zamawiający - podmiot publiczny. 
Tabela 2.3

Elementy specyfikacji istotnych warunków zamówienia

\begin{tabular}{|l|}
\hline \multicolumn{1}{|c|}{ Elementy składowe SIWZ } \\
\hline Nazwa (firma) oraz adres zamawiającego \\
\hline Tryb udzielenia zamówienia \\
\hline Opis przedmiotu zamówienia \\
\hline Termin wykonania zamówienia \\
\hline $\begin{array}{l}\text { Opis warunków udziału w postępowaniu oraz opis sposobu dokonywania oceny } \\
\text { spełnienia tych warunków }\end{array}$ \\
\hline Wykaz oświadczeń i dokumentów, jakie mają dostarczyć wykonawcy \\
\hline Informacje o sposobie porozumiewania się zamawiającego z wykonawcami \\
\hline Wymagania dotyczące wadium \\
\hline Termin związania ofertą \\
\hline Opis sposobu przygotowania ofert \\
\hline Miejsce, termin składania i otwarcia ofert \\
\hline Opis sposobu obliczenia ceny \\
\hline Opis kryteriów wyboru oferty \\
\hline Informacje dotyczące zabezpieczenia \\
\hline Istotne postanowienia, które mogą być zawarte w treści umowy \\
\hline $\begin{array}{l}\text { Pouczenie o środkach ochrony prawnej przysługujących wykonawcy w toku } \\
\text { postępowania o udzielenie zamówienia }\end{array}$ \\
\hline Warunki uznania oferty za nieodpowiadającą wymaganiom zamawiającego \\
\hline Okoliczności uzasadniające odwołanie postępowania \\
\hline
\end{tabular}

Źródło: oprac. własne na podstawie Ustawy z dnia 29 stycznia 2004 r. Prawo zamówień publicznych, DzU, 2011, nr 87, poz. 484.

Opublikowanie ogłoszenia i SIWZ stanowi dla przedsiębiorców zaproszenie do złożenia oferty. Publikacja ogłoszenia i SIWZ podlega takim samym zasadom, jak w przypadku publikacji ogłoszenia na koncesję. Wzory formularza dotyczącego publikacji ogłoszeń z tytułu zamówienia podane są w Rozporządzeniu Prezesa Rady Ministrów w sprawie wzorów ogłoszeń zamieszczonych $w$ Biuletynie Zamówień Publicznych ${ }^{48}$. Podmiot publiczny zobowiązany jest do rzetelnego i obiektywnego ocenienia złożonych propozycji w celu wyłonienia wykonawcy zadania i utworzenia ostatecznej struktury PPP. W obecnej sytuacji z powodu braku doświadczeń w tym względzie, istotna rola będzie spoczywała na doradcach, którzy mogą korzystać $\mathrm{z}$ doświadczeń innych państw realizujących przedsięwzięcia PPP. Pierwsze czynności będą związane z fazą wstępnej kwalifikacji ofert, prowadzącej do utworzenia katalogu podmiotów, z którymi podmiot publiczny rozpocznie dialog lub negocjacje. Kryterium wyboru

${ }^{48}$ Rozporzadzenie Prezesa Rady Ministrów z dnia 28 stycznia 2010 r. w sprawie wzorów ogłoszeń zamieszczonych w Biuletynie Zamówień Publicznych, DzU, 2010, nr 12, poz. 69. 
oferentów stanowić będą kryteria oceny ofert, gdzie w przypadku PPP za najkorzystniejsze uważa się te, które przedstawiają ${ }^{49}$ :

- najkorzystniejszy bilans wynagrodzenia oraz, w dalszej kolejności,

- podział zadań i ryzyk związanych z przedsięwzięciem pomiędzy podmiotem publicznym i prywatnym,

- terminy i wysokość przewidywanych płatności lub innych świadczeń podmiotu publicznego w sytuacji, gdy takie są przewidziane,

- podział dochodów pochodzących z przedsięwzięcia pomiędzy podmioty partnerstwa,

- stosunek wkładu własnego podmiotu publicznego do wkładu partnera prywatnego,

- efektywność realizacji przedsięwzięcia, w tym efektywność wykorzystania składników majątkowych,

- kryteria odnoszące się w sposób bezpośredni do przedmiotu przedsięwzięcia: jakość, funkcjonalność, parametry techniczne, poziom oferowanych technologii, koszt utrzymania, serwis.

Tak jak już było powiedziane, w przypadku przedsięwzięć typu PPP najkorzystniejszym trybem wyłonienia partnera prywatnego będzie dialog konkurencyjny. Uregulowany został on $\mathrm{w}$ art. 60a-60e ustawy Prawo zamówień publicznych. Zdaniem E. Norka

dialog konkurencyjny jest trybem postępowania łączącym w sobie elementy przetargu ograniczonego i negocjacji $\mathrm{z}$ ogłoszeniem, w prawie europejskim szczegółowo opisanym w art. 29 dyrektywy 2004/18/WE ${ }^{50}$. $\mathrm{kach}^{51}$ :

Dialog konkurencyjny jest możliwy do zastosowania w dwóch przypad-

1) jeśli nie można wykorzystać przetargu nieograniczonego lub ograniczonego,

2) gdy cena nie jest jedynym kryterium wyboru najkorzystniejszej oferty.

Jest to tryb elastyczny, polegający na publicznym ogłoszeniu o zamówieniu, gdzie podmiot publiczny prowadzi z wybranymi przez siebie inwestorami dialog, a następnie zaprasza do składania ofert. Ze względu na specyfikę, ze strony podmiotu zamawiającego wymaga się przestrzegania zasad dyskrecji. Dialog konkurencyjny jest postępowaniem, które składa się z dwóch etapów. Pierwszy etap to negocjacje w sprawie doprecyzowania warunków zamówienia i określenia przedmiotu. Etap ten kończy się w momencie, gdy zamawiający jest

${ }^{49}$ Ustawa z dnia 19 grudnia 2008 r. o partnerstwie publiczno-prywatnym, DzU, 2009, nr 19, poz. 100 ze zm., art. 6.

${ }^{50}$ E. Norek, Prawo zamówień publicznych. Komentarz, LexisNexis, Warszawa 2009, s. 163.

${ }^{51}$ Por. M. Kania, P. Marquardt, Partnerstwo publiczno-prywatne. Komentarz do ustawy z 19 grudnia 2008 r., TNOiK, Toruń 2012, s. 66-67. 
w stanie określić swoje wymagania co do przedmiotu zamówienia i sposobu realizacji. W praktyce stosuje się dwie strategie negocjowania kontraktu liniową i równoległą.

Strategia liniowa polega na tym, iż oferentom wyłonionym we wstępnej kwalifikacji przedstawia się szczegółowe informacje dotyczące przedsięwzięcia. $\mathrm{Na}$ ich podstawie przygotowują oni swoje oferty. Następnie komisja przetargowa formułuje tzw. short list. Negocjacje podejmowane są z podmiotami zajmującymi pierwsze miejsce na liście. Jeśli rozmowy nie przyniosą oczekiwanych przez podmiot publiczny rezultatów, negocjacje prowadzone są $\mathrm{z}$ drugim na liście oferentem.

W strategii równoległej negocjacje prowadzone są z kilkoma oferentami, co sprzyja większej konkurencji. Jest to procedura kosztowna i czasochłonna dla każdej strony. Może prowadzić do wycofania się oferentów. Dlatego często w praktyce łączy się obie strategie, tzn. prowadzi się kilka rund negocjacji i na ich podstawie zaprasza się jeden podmiot do zasadniczych rozmów celem opracowania ostatecznej treści umowy partnerstwa, która kończy pierwszą fazę procedury partnerstwa publiczno-prywatnego. Końcowe czynności poprzedzające przygotowanie i podpisanie umowy wymagają rozwiązania szczegółowych kwestii i dopracowania ustaleń, gdyż często oprócz strony publicznej i partnera prywatnego występują instytucje finansowe, podwykonawcy, którzy będą finansowo i technicznie wspierać głównego partnera prywatnego. Po zakończeniu pierwszego etapu zamawiający zaprasza wykonawców do złożenia ofert.

Dalsze postępowanie jest analogiczne, jak w przypadku koncesji. Na etapie zawierania umów różnica proceduralna dotyczy kwestii spornych. Zasady korzystania ze środków ochrony prawnej zostały wyczerpująco uregulowane w rozdziale VI PZP. Ochrona przysługuje wykonawcom, którzy ponieśli szkodę w wyniku naruszenia przepisów o zamówieniach publicznych. Przysługuje im odwołanie do prezesa Krajowej Izby Odwoławczej (KIO) lub skarga do sądu powszechnego. W przypadku, gdy podmiot prywatny wniesie odwołanie do KIO, zamawiający nie może zawrzeć umowy aż do momentu ogłoszenia przez organ odwoławczy wyroku lub postanowienia kończącego postępowanie odwoławcze. Na orzeczenie wydane przez KIO strony sporu mogą wnieść skargę do sądu okręgowego właściwego dla siedziby podmiotu publicznego. Od wyroku sądu nie przysługuje skarga kasacyjna.

Przebieg fazy projektowo-przetargowej przesądza o powodzeniu procedur wdrażających przedsięwzięcia inwestycyjne do realizacji. Wybór partnera prywatnego dla przedsięwzięć inwestycyjnych może, zgodnie z prawem, nastąpić na dwa sposoby. Wybór procedury uwarunkowany jest nie tylko otoczeniem prawnym, ale także otoczeniem administracyjno-organizacyjnym. Brak odpowiednich umiejętności i doświadczeń w przeprowadzeniu procedur przetargowych prowadzi do zwiększenia kosztów przygotowania przedsię- 
wzięcia oraz odsuwa w czasie moment jego realizacji. Stąd w fazie przetargowej szczególnego znaczenia nabiera pomoc profesjonalnych doradców i konsultantów.

\subsubsection{Faza inwestycyjno-eksploatacyjna}

Druga faza związana jest $\mathrm{z}$ faktyczną realizacją umowy, a więc obejmuje czynności związane z przedmiotem umowy partnerstwa publiczno-prywatnego zarządzania umową. Równie istotne jak prawidłowo przygotowana faza projektowo-przetargowa znaczenie ma faza zarządzania umową. Będzie ona stanowiła klucz do powodzenia lub porażki całego przedsięwzięcia. W momencie podpisania umowy PPP podmiot publiczny nadal pozostaje odpowiedzialny za prawidłowe świadczenie zadań publicznych, a podmiot prywatny staje się faktycznym wykonawcą zadania. Właściwy przebieg umowy wymaga stałego monitorowania i kontroli realizacji przedsięwzięcia. W tym celu stała kontrola nad umową powinna pozostawać w gestii powołanego w pierwszej fazie zespołu wdrożeniowego, który dysponuje największą wiedzą w zakresie realizowanej inwestycji, zdobytą $\mathrm{w}$ trakcie jej przygotowywania. Członkowie zespołu mogą podlegać pewnym rotacjom (np. uzupełnienia o inżynierów nadzoru budowlanego, ochrony środowiska), tak aby możliwe było stałe, profesjonalne kontrolowanie działań partnera prywatnego.

Stały monitoring powinien dotyczyć:

- przestrzegania harmonogramu prac,

- osiągania kluczowych wskaźników jakości,

- weryfikacji procedur kontroli i zapewnienia jakości w celu potwierdzenia skuteczności działania systemów,

- terminowości płatności dla partnera prywatnego,

- utrzymania stałych kontaktów z partnerem prywatnym,

- regularnego opracowania sprawozdań z realizacji przedsięwzięcia.

W przedsięwzięciach PPP pojęcie „kontrola” partnera prywatnego nabiera szczególnego znaczenia. Staje się ona narzędziem, którego użycie rozłożone jest na kilku- lub kilkunastoletni okres. Jej zakres powinien wynikać bezpośrednio $\mathrm{z}$ treści umowy PPP i obejmować kwestie związane z wykonaniem poszczególnych etapów przedsięwzięcia. Podmiot publiczny nie ma prawa ingerować w know-how zastosowane przez partnera prywatnego czy sposób zarządzania powstałą infrastrukturą, ponieważ jest to jeden z głównych powodów zawiązania współpracy. Kontrola obejmuje ryzyka, jakie przyjął na siebie partner prywatny. Obszar kontroli dotyczy dwóch aspektów:

- norm jakościowych, standardu zaspokojenia potrzeb publicznych;

- norm wynikających z przepisów prawa, np. kryteriów bezpieczeństwa, norm technicznych, itp. 
Działania kontrolne nie powinny być zawężane do czynności ex post, polegających na ocenie osiągniętych przez stronę prywatną celów i porównania ich ze stanem wymaganym. Wskazane jest także podejmowanie działań ex ante, na etapie planowania działań oraz stanu ich wykonywania. W takim ujęciu kontrola staje się elementem zarządzania przedsięwzięciem (controlling governance). Różnica pomiędzy kontrolą inspekcyjną a zarządczą tkwi w stopniu i charakterze zaangażowania środków i metod ich wykonania. Kontrola ex post ma charakter lustracyjny, rewizyjny, reagujący na ewentualne błędy ${ }^{52}$. Ze względu na długoterminowy charakter umowy wszelkie problemy, jakie mogą pojawić się w trakcie jej trwania, powinny być jak najszybciej identyfikowane i rozwiązywane, co ułatwi prawidłowy przebieg procesu. W razie pojawiających się odstępstw od zdefiniowanych parametrów jakościowych lub technicznych należy z partnerem prywatnym wyjaśnić przyczynę i próbować znaleźć racjonalne rozwiązanie. Kontrola ex ante ma dążyć do osiągnięcia wytyczonego celu. Brak stałego monitorowania oraz dopuszczenie do powstania nieprawidłowości może narazić podmiot publiczny na niebezpieczeństwo niezrealizowania wyznaczonego zadania oraz społeczną krytykę.

Faza eksploatacyjna kończy się w momencie wygaśnięcia umowy. Zgodnie $\mathrm{z}$ ideą partnerstwa przedmiot partnerstwa przekazywany jest stronie publicznej. Jeśli $\mathrm{w}$ umowie zawarto inne postanowienia, to partnerowi prywatnemu będzie przysługiwało prawo pierwokupu nieruchomości, która była wkładem własnym i służyła realizacji partnerstwa. W ten sposób gwarantuje się mu szansę kontynuowania działalności z wykorzystaniem nieruchomości, która została wniesiona przez niego do partnerstwa. Jeśli zaś partner publiczny uzna, że dane zadanie nadal powinno być realizowane $\mathrm{w}$ formule PPP, to konieczne jest rozpisanie nowego postępowania przetargowego.

Partnerstwo publiczno-prywatne stanowi zintegrowane podejście do danego przedsięwzięcia. Ścieżka dojścia podmiotu publicznego do opracowania i realizacji PPP stanowi całościowy cykl, w którym poszczególne etapy stanowią elementy cząstkowe projektu, postrzegane jako zintegrowany zespół zadań związany z ,życiem" danego przedsięwzięcia. W związku z tym mamy do czynienia $\mathrm{z}$ jedną specyfikacją i pojedynczym wyborem prywatnego inwestora, który sam (lub przy współudziale podwykonawców) podejmie się „obsłużyć” cały cykl projektowy na poziomie i według standardów określonych w umowie $^{53}$. Opisany proces jest procesem standardowym, który może być wykorzystany do różnych przedsięwzięć zarówno o charakterze usługowym, jak i budowlano-usługowym, bez względu na to, czy podstawą będzie postępowanie

52 Zob. J. Płoskonka, Pojęcie kontroli w ujęciu zarządczym, „Kontrola Państwowa” 2006, nr 2, s. 7; A. Kozłowska, Kontrola partnera prywatnego, „Gazeta Samorządu i Administracji” 2006, nr 3, s. VI-VII, B. Korbus, Jak wdrożyć udany projekt PPP, Urząd Komitetu Integracji Europejskiej, luty 2005, s. 33-34.

${ }^{53}$ Partnerstwo publiczno-prywatne jako metoda realizacji zadań..., s. 8. 
o charakterze zamówienia publicznego, czy koncesji. Podejmując się realizacji PPP strona publiczna musi zadbać o dobry zespół fachowców, którzy będą czuwać nad prawidłowym przebiegiem poszczególnych faz procesu partnerstwa i korzystać z doświadczeń innych krajów w celu stworzenia modelu spełniającego warunki lokalne.

\subsection{Uczestnicy przedsięwzięcia partnerstwa publiczno-prywatnego}

Realizacja przedsięwzięcia partnerstwa publiczno-prywatnego wymaga zaangażowania dużej liczby uczestników. Każdy z podmiotów ma do odegrania istotną rolę i od jego umiejętności i doświadczenia uzależniony będzie sukces bądź porażka przedsięwzięcia.

Głównymi uczestnikami projektu PPP mogą być ${ }^{54}$ :

Podmioty sektora publicznego, przez które rozumie się jednostki sektora finansów publicznych ${ }^{55} \mathrm{w}$ rozumieniu Ustawy o finansach publicznych, osoby prawne utworzone $\mathrm{w}$ celu zaspokojenia potrzeb o charakterze powszechnym, niemających charakteru przemysłowego ani handlowego, jeśli podmioty te bezpośrednio lub pośrednio:

○ finansują ją w ponad $50 \%$ bądź

- posiadają ponad połowę udziałów lub akcji, albo

- sprawują nadzór nad organem zarządzającym, lub

- mają prawo do powoływania ponad połowy składu organu nadzorczego lub zarządzającego, a także związki tych podmiotów.

Zadaniem podmiotów publicznych jest zdefiniowanie potrzeb w zakresie infrastruktury, mających znaczny wpływ na określenie wielkości, sposobu finansowania, struktury własności, sposobu eksploatacji gotowych urządzeń. Decyzje sektora publicznego zależą od wielu czynników, m.in. indywidualnych cech samego przedsięwzięcia czy aktualnej sytuacji polityczno-gospodarczej. Dążeniem władz publicznych jest uzyskanie odpowiedniej infrastruktury przy jak najniższych kosztach społecznych, zaspokajających funkcje społeczne. Niedobór środków budżetowych zmusza je do poszukiwania nowych metod

${ }^{54}$ Zob. K. Brzozowska, Partnerstwo publiczno-prywatne. Przestanki..., s. 34-37; Zarys ekonomii sektora publicznego, red. M. Brol, Wydawnictwo Uniwersytetu Ekonomicznego we Wrocławiu, Wrocław 2010, s. 178; Partnerstwo publiczno-prywatne jako metoda rozwoju infrastruktury $w$ Polsce, Raport Amerykańskiej Izby Handlowej w Polsce, Warszawa 2002, s. $8-10$.

${ }^{55} \mathrm{~W}$ art. 2 Ustawy o partnerstwie publiczno-prywatnym z $2008 \mathrm{r}$. znajduje się słowniczek ustawowy, w którym określone zostały pojęcia na potrzeby powyższej ustawy. W ustępie 1 ustawodawca określił podmiot publiczny jako jednostkę sektora publicznego. Nie dokonał jednak numerycznego wymienienia podmiotów. Określając krąg podmiotów publicznych, którym przysługuje prawo nawiązania współpracy partnerskiej, należy odnieść się do art. 9 Ustawy z dnia 27 sierpnia 2009 r. o finansach publicznych (DzU, 2009, nr 157, poz. 1240 ze zm.). 
finansowa, partnerstwo publiczno-prywatne stwarza zaś możliwość wykorzystania kapitału prywatnego powszechnie niedostępnego dla sektora publicznego. Fakt ten nabrał szczególnego znaczenia w 2011 r., z chwilą umocowania prawnego zakazu finansowania bieżących wydatków $\mathrm{z}$ innych źródeł niż dochody bieżące ${ }^{56}$. Wzrosła presja na ograniczenie wydatków bieżących poprzez przekazanie części zadań w ręce sektora prywatnego, co przełoży się na odciążenie długu publicznego ${ }^{57}$.

> Partner prywatny, rzeczywisty wykonawca przedsięwzięcia. Partnerem prywatnym może być przedsiębiorca krajowy lub zagraniczny. Nowa ustawa o PPP zawęziła grono prywatnych inwestorów, wykluczając z niego organizacje pozarządowe, Kościół i związki wyznaniowe ${ }^{58}$. Podmiot prywatny odpowiada za zorganizowanie przedsięwzięcia, prowadzenie negocjacji ze stronami potencjalnie zainteresowanymi realizacją inwestycji, opracowanie struktury finansowania, promocję przedsięwzięcia. Fizycznie odpowiadają za realizację przedsięwzięcia, od etapu przygotowania, wykonania, eksploatacji i finansowania, po ostateczne przekazanie sektorowi publicznemu. Współpraca pomiędzy podmiotem publicznym i podmiotem prywatnym może zostać zawarta w formie spółki celowej. Jej zawarcie uznane jest za najbardziej złożoną i zaawansowaną formę współpracy partnerskiej określaną mianem partnerstwa zinstytucjonalizowanego ${ }^{59}$.

${ }^{56}$ M. Mekiński, Finanse publiczne 2010. Tekst nowej ustawy o finansach publicznych z praktycznym omówieniem, Wydawnictwo Wiedza i Praktyka Sp. z o.o., Warszawa 2010, s. 61.

${ }^{57} \mathrm{~W}$. Lubieniecki, Koncepcja partnerstwa publiczno-prywatnego na drogach wojewódzkich Dolnego Ślaska, „Inwestycje sektora publicznego” 2011, nr 5, s. 13.

${ }^{58}$ Ustawa o PPP z 2005 r. jednoznacznie wskazywała, że za partnera prywatnego będzie przyjmować się przedsiębiorcę, którego statut został określony w ustawie o swobodzie działalności gospodarczej. Zgodnie z art. 4 ust. 1 za przedsiębiorcę uznaje się osobę fizyczną, osobę prawną i jednostkę organizacyjną niebędącą osobą prawną, której odrębna ustawa przyznaje zdolność prawną - wykonująca we własnym imieniu działalność gospodarczą. Za przedsiębiorców zaś uznaje się wspólników spółki cywilnej w zakresie wykonywanej przez nich działalności gospodarczej. (zob. Ustawa o swobodzie działalności gospodarczej, DzU, 2011, nr 232, poz. 1378). W ustawie o PPP z $2008 \mathrm{r}$. ustawodawca nie sprecyzował pojęcia przedsiębiorcy. Z uwagi na brak w polskim prawodawstwie jednobrzmiącej definicji przedsiębiorstwa podmioty zawiązujące współpracę muszą bazować na zapisach ustawy o swobodzie działalności gospodarczej oraz kodeksu cywilnego, który w art. $43^{1}$ określa przedsiębiorcę jako osobę fizyczną, osobę prawną i jednostkę organizacyjną niebędącą osobą prawną, której ustawa przyznaje zdolność prawną, prowadzoną we własnym imieniu działalność gospodarczą lub zawodową. (Ustawa z dnia 23 kwietnia 1964 r. Kodeks cywilny, DzU, 2011, nr 230, poz. 1370). Identyczną definicję zawiera także Ustawa z dnia 28 lutego 2003 r. Prawo upadlościowe i naprawcze, DzU, 2012, nr 173, poz. 578 , art. 5 ust. 1 poprzez odwołanie do zapisów kodeksu cywilnego.

${ }^{59}$ Partnerstwo zinstytucjonalizowane może funkcjonować w formie spółki z ograniczoną odpowiedzialnością, spółki akcyjnej, komandytowej lub komandytowo-akcyjnej z zastrzeżeniem, że strona publiczna nie może być komplementariuszem. Zapis taki wynika z konieczności uniknięcia sytuacji, w której podmiot publiczny zobowiązany byłby do odpowiedzialności za zobowiązania spółki całym swoim majątkiem. Ustawa o partnerstwie publiczno-prywatnym 
Instytucje finansujące przedsięwzięcie, najczęściej banki, które uczestniczą w PPP poprzez jego finansowanie w formie kredytów. Pieniądz pożyczkowy najczęściej udzielany jest spółce SPV. Jego wielkość, struktura uzależnione są od ryzyka kredytowego związanego z przedsięwzięciem i od możliwości generowania przyszłych przychodów oraz poniesionych kosztów. W praktyce niewielu prywatnych inwestorów dysponuje tak dużym kapitałem, aby w całości pokryć koszty inwestycji. Konieczne jest więc wsparcie i udział banków jako dawców kapitału. W celu zabezpieczenia własnych interesów banki tworzą konsorcja bankowe dzieląc ryzyko proporcjonalnie do wniesionego wkładu ${ }^{60}$. Bank jako uczestnik przedsięwzięcia sprawuje stałą kontrolę nad przebiegiem inwestycji, służy doradztwem w celu minimalizowania ryzyka.

Podwykonawcy - obowiązki wynikające z umowy wobec sektora publicznego bezpośrednio realizowane są przez wyspecjalizowanych podwykonawców. Na nich ciąży techniczna realizacja przedmiotu umowy. Zadania obejmować mogą budowę obiektu, dostarczanie materiałów budowlanych, wyposażenia. Każde zadanie wykonywane przez podwykonawcę wymaga sporządzenia odrębnej umowy $\mathrm{z}$ głównym podmiotem partnerstwa, np. spółką celową (SPV). Banki kredytujące przedsięwzięcie mogą wymagać od podwykonawców zaangażowania kapitałowego, które będzie stanowić swoistą gwarancję terminowego i rzetelnego wykonania kontraktu.

$>$ Operatorzy - spółki operatorskie, które zajmują się eksploatacją i utrzymaniem stanu gotowości urządzeń infrastruktury. Funkcję operatora może pełnić jeden ze sponsorów lub podwykonawców. Możliwe jest także wyłonienie zewnętrznego operatora. Decyzji o zaangażowaniu operatora zewnętrznego przyświeca dążenie do zatrudnienia profesjonalnego i doświadczonego zespołu lub wyeliminowanie wszelkich możliwych ogniw konfliktu pomiędzy firmami które występują w roli sponsorów, podwykonawców i operatorów.

Instytucje ubezpieczające przedsięwzięcie - udział instytucji ubezpieczeniowych ma na celu zmniejszenie ryzyka komercyjnego i politycznego przedsięwzięcia. Instytucje ubezpieczeniowe najczęściej ściśle współpracują $\mathrm{z}$ instytucjami finansowymi $\mathrm{w}$ celu stworzenia pakietu ubezpieczeniowego redukującego negatywne skutki poszczególnych ryzyk w zamian za przystępną opłatę.

$>$ Inni uczestnicy, m.in. doradcy, agencje ratingowe, instytucje gwarantujące. Doradcy odgrywają istotną rolę świadcząc usługi doradcze zarówno sektorowi publicznemu, jak i prywatnemu przy PPP. Doradztwo prowadzone jest $\mathrm{w}$ obszarze finansowym, prawnym, a także technicznym. Z uwagi na

z 2008 r. w rozdziale 4 precyzuje zasady funkcjonowania partnerstwa w formie spółki oraz prawa stron wynikające ze zinstytucjonalizowanej formy prowadzenia przedsięwzięcia. $W$ art. 16 powyższej ustawy określono zasady zbycia akcji lub udziałów w spółce przy zachowaniu przez podmiot publiczny prawa pierwokupu.

${ }^{60}$ Ustawa z dnia 29 sierpnia 1997 r. Prawo bankowe, DzU, 2011, nr 232, poz. 1378, art. 73. 
złożony charakter przedsięwzięć PPP wsparcie doradców podnosi jakość i efektywność inwestycji, prowadzi do podpisania kontraktu. Zadaniem agencji ratingowych jest nadanie oceny wiarygodności kredytowej w sytuacji, gdy przedsięwzięcie finansowane jest poprzez publiczną emisję papierów dłużnych. Agencje zaangażowane są wówczas w początkowej fazie realizacji przedsięwzięcia, aby uzgodnić warunki finansowania i pozyskania na niego niezbędnych funduszy.

Optymalny układ uczestników przedsięwzięcia partnerstwa publiczno-prywatnego prezentuje schemat 2.3.

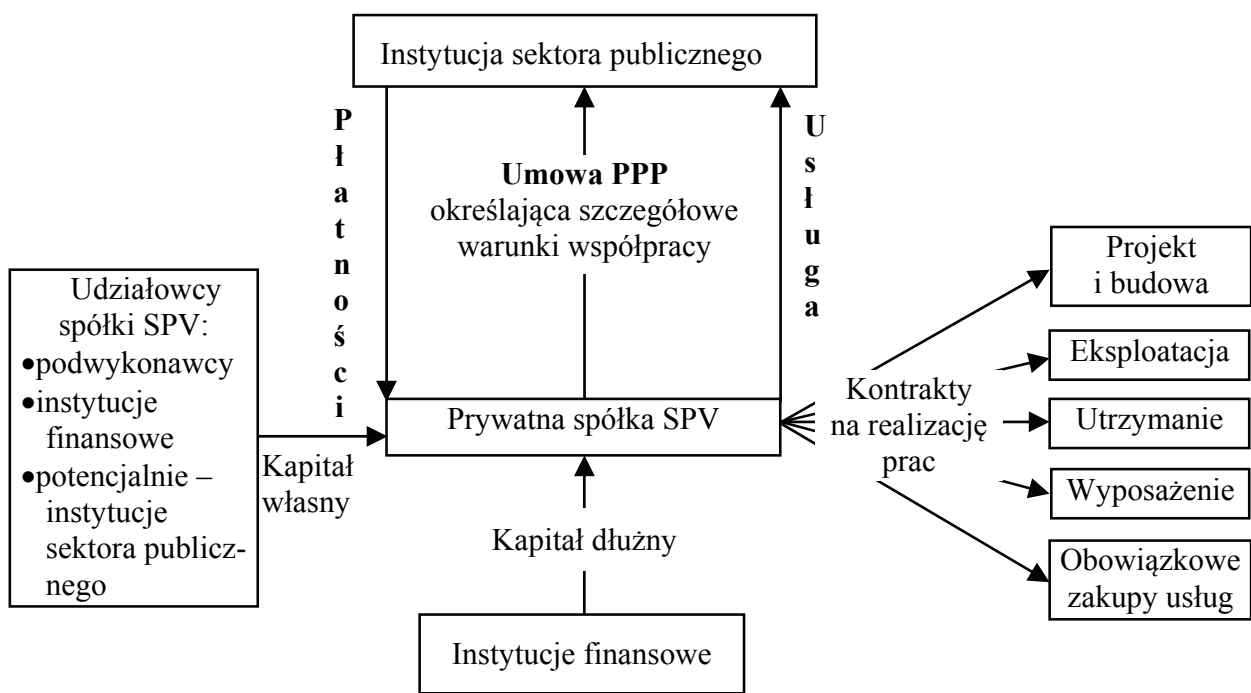

Schemat 2.3. Uczestnicy przedsięwzięcia partnerstwa publiczno-prywatnego Źródło: Partnerstwo publiczno-prywatne jako metoda rozwoju infrastruktury w Polsce, Raport Amerykańskiej Izby Handlowej w Polsce, Warszawa 2002, s. 7

Autorzy raportu przygotowanego przez Amerykańską Izbę Handlową ${ }^{61}$ zwracają uwagę, że w koncepcji PPP nie należy ograniczać się do współpracy pomiędzy jednostką występującą po stronie sektora publicznego i jednym podmiotem prywatnym. W praktyce może występować wiele pośrednich powiązań tych dwóch sektorów na różnych poziomach. Za przykład podaje się agencję rządową jako instytucję bezpośrednio realizującą przedsięwzięcie PPP, ale istotna może być także rola jednostek o profilu nadzorczym, np. rządu lub jednostki samorządu terytorialnego. Po stronie prywatnej wystąpić może nie tylko wybrany zgodnie z przyjętą procedurą podmiot, ale także kredytodawcy, podwykonawcy, dostawcy.

\footnotetext{
${ }^{61}$ Partnerstwo publiczno-prywatne jako metoda rozwoju..., s. 6-7.
} 
Wszyscy uczestnicy, z wyjątkiem władz publicznych, zaangażowani w partnerstwo publiczno-prywatnego zaliczani są do sektora prywatnego, a wniesione środki traktowane są jako kapitał prywatny. Szeroki krąg uczestników partnerstwa wymaga więc ścisłej współpracy i płynnego przeprowadzenia poszczególnych czynności składających się na poszczególne etapy procedury partnerstwa. Następujące po sobie czynności, wykonywane przez partnera publicznego lub prywatnego składają się na cykl życia przedsięwzięcia, obejmujący zagadnienia techniczne (przygotowanie, projektowanie, budowę, utrzymanie, eksploatację i zarządzanie), ekonomiczno-finansowe (wstępne analizy opłacalności i efektywności, źródła finansowania, opłaty za usługi, zwrot kapitału, wynagrodzenie partnera prywatnego) i prawne (prawa własności majątku, pozwolenia, tryb wyboru partnera prywatnego, konstrukcja umowy).

\subsection{Umowa jako podstawa prawna realizacji przedsięwzięcia partnerstwa publiczno-prywatnego}

Umowy są podstawowym i najważniejszym źródłem stosunków cywilnoprawnych. Zaliczane są do czynności prawnych dwustronnych, gdyż wymagane jest uczestnictwo przynajmniej dwóch podmiotów, którym przysługuje status strony uprawnionej lub zobowiązanej. Podstawą każdej umowy jest konsensus, czyli zgodne oświadczenie woli stron.

Umowa partnerstwa publiczno-prywatnego stanowi najważniejszy dokument regulujący prawa, obowiązki i zobowiązania partnerów przedsięwzięcia. W uzasadnieniu do ustawy o PPP z 2005 r. wskazywano na cywilnoprawny charakter umowy, którą od innych umów miał odróżniać szczególny cel zawarcia, zasady podziału ryzyk związanych z zawarciem i wykonaniem umowy. W literaturze przedmiotu nadal sporny pozostaje charakter umowy PPP. Niektórzy autorzy zaliczają tę umowę do umów nazwanych, inni do grupy umów nienazwanych ${ }^{62}$.

${ }^{62}$ Analiza poglądów wskazuje, że nie ma jednomyślności co do charakteru umowy PPP. Do grupy prawników, zdaniem których umowa PPP ma charakter umowy nienazwanej należy zaliczyć W. Goneta, A. Miruća, J. Jacyszyna i T. Kalinowskiego, A. Bieliński. Twierdzą oni, że „zamiarem ustawodawcy nie było stworzenie nowej umowy nazwanej [...] a elementy umowy wymienione $\mathrm{w}$ art. 18 nie należą do przedmiotowo istotnych, a zatem nie muszą być zawarte w umowie o PPP” [W. Gonet]. „W założeniach PPP nie przybiera cech nowej umowy nazwanej, lecz jest rozumiane jako nowy sposób - metoda realizacji zadań publicznych [...] jest odmianą umowy cywilnoprawnej, niezastępującą aktu administracyjnego, ściśle związaną z instytucją zamówień publicznych" [A. Miruć]; J. Jacyszyn i T. Kalinowski twierdzą, że ,ustawa o PPP nie aspiruje do tego, by ją traktować jako typową umowę nazwaną, gdyż ma być rozumiana jako nowy sposób przeprowadzania przedsięwzięcia publicznego, zawierając niezbędne elementy charakterystyczne dla umów cywilnoprawnych. Odmienny pogląd reprezentują M. Kulesza, M. Bitner oraz A. Kozłowska. Zdaniem prawników umowa PPP jest nowym, pozakodeksowym typem umowy 
Zgodnie z art. 18 ustawy o PPP z 2005 r. umowa o partnerstwie powinna zawierać następujące obowiązkowe elementy:

1) cel i przedmiot przedsięwzięcia oraz harmonogram jego realizacji,

2) łączną wartość środków przewidzianych na realizację całości przedsięwzięcia będącego przedmiotem umowy, niezależnie od źródła ich pochodzenia,

3) zobowiązania partnera prywatnego do poniesienia w całości albo w części nakładów na realizację przedsięwzięcia lub zapewnienia poniesienia tych nakładów przez osoby trzecie,

4) zobowiązania podmiotu publicznego, w tym wielkość, zasady i terminy wnoszenia wkładu własnego, jeżeli wkład taki jest przewidziany, a także zasady dysponowania tym wkładem,

5) normy jakościowe, wymagania i standardy stosowane przy realizacji przedsięwzięcia,

6) uprawnienia podmiotu publicznego w zakresie bieżącej kontroli realizacji przedsięwzięcia przez partnera prywatnego (lub spółkę kapitałową zawiązaną przez strony w celu realizacji przedsięwzięcia) oraz zasady okresowego przeprowadzania przez strony wspólnej oceny realizacji przedsięwzięcia wraz $\mathrm{z}$ ustaleniami realizacyjnymi,

7) czas, na jaki umowa została zawarta oraz warunki przedłużenia lub skrócenia okresu obowiązywania, warunki i sposób jej rozwiązania, zasady rozliczeń i odszkodowań,

8) warunki i procedurę zmiany umowy,

9) formy, wysokość i zasady ustalania i przekazywania wynagrodzenia partnera prywatnego,

10) podział ryzyk związanych z realizacją przedsięwzięcia,

11)zasady i zakres ubezpieczeń realizowanego przedsięwzięcia, dodatkowe gwarancje i umowy oraz zobowiązania stron w tym przedmiocie,

12) tryb i zasady rozstrzygania sporów,

13) postanowienia zawiązania spółki celowej, jeśli strony postanowią taką zawiązać.

Wymieniony w art. 18 katalog postanowień umowy nie miał charakteru zamkniętego. Dla prawidłowości przebiegu współpracy umowa mogła być uszczegółowiona lub zawężona w zależności od potrzeb.

nazwanej. Na potwierdzenie swojego stanowiska przywołują wyrok SN z 21.05.1982 r. mówiący, że „w sytuacji, gdy dla określonej usługi przepisy KC albo przepisy szczególne wyodrębniły oddzielny typ umowy, to do takiej usługi mają zastosowanie przede wszystkim przepisy normujące wyodrębniony typ umowy nazwanej”. Szerzej Ustawa o partnerstwie publiczno-prywatnym. Komentarz..., s. 303-312. Pogląd tożsamy z poglądami M. Kuleszy, M. Bitnera i A. Kozłowskiej reprezentuje W. Grzybowski w opracowaniu poświęconym umowom PPP Umowa o partnerstwie publiczno-prywatnym - ramy określające standardowa zawartość, Warszawa 2007, s. 19. 
W nowej ustawie o partnerstwie publiczno-prywatnym elementy definicji umowy „są rozrzucone po całym akcie prawnym”63, co upoważnia do krytycznej oceny takiego zapisu.

W rozumieniu art. 7 ust. 1 ustawy z 2009 r.

przez umowę o partnerstwie publiczno-prywatnym partner prywatny zobowiązuje się do realizacji przedsięwzięcia za wynagrodzeniem oraz poniesienia w całości albo w części wydatków na jego realizację lub poniesienia ich przez osobę trzecią, a podmiot publiczny zobowiązuje się do współdziałania w osiągnięciu celu przedsięwzięcia, w szczególności poprzez wniesienie wkładu własnego.

Umowa staje się więc dokumentem, który z jednej strony wiąże strony w celu osiągnięcia zamierzonego efektu, z drugiej zaś bezpośrednio akcentuje aspekt współpracy (współdziałania) partnerów publicznego z prywatnym. Stanowi najważniejszy dokument, na podstawie którego wdrażany będzie projekt partnerstwa publiczno-prywatnego. Zaleca się, aby już na wczesnym etapie postępowania o partnerstwie przygotować projekt umowy. Pierwsza propozycja umowy powinna być przedstawiona potencjalnym partnerom prywatnym wraz z zaproszeniem do negocjacji, nie później jednak niż po odbyciu pierwszej sesji negocjacyjnej. Umożliwi to podmiotowi publicznemu prowadzenie postępowania $\mathrm{w}$ sposób uporządkowany i zorganizowany. Jednocześnie będzie sprzyjać wyeliminowaniu kontrowersyjnych postanowień, które w przyszłości mogłyby zakłócić prawidłowy przebieg przedsięwzięcia. Od jakości zawartej umowy o PPP zależeć będzie, czy interes publiczny zostanie właściwie zabezpieczony oraz czy jakość realizowanych usług publicznych $\mathrm{w}$ ramach partnerstwa odpowiadać będzie oczekiwaniom jednostki publicznej i ostatecznych odbiorców usług.

Zdaniem A. J. Derkacza prawidłowo skonstruowana umowa o PPP powinna zawierać trzy charakterystyczne znamiona ${ }^{64}$ :

1) zobowiązanie partnera prywatnego,

2) określenie pozycji podmiotu publicznego,

3) podział ryzyk związanych z przedsięwzięciem.

Prywatny przedsiębiorca poprzez zobowiązanie wykonania określonego zadania publicznego i pokrycia w całości lub w części kosztów zadania staje się jednocześnie inwestorem i wykonawcą. Podmiot publiczny ma współpracować z przedsiębiorcą, aby wspólnie osiągnąć wyznaczony cel. Współpraca ze strony publicznej przejawia się wniesieniem wkładu własnego, ale także rodzi szereg ryzyk, których podział następuje w drodze negocjacji z zachowaniem zasady, że

${ }^{63}$ Uzasadnienie do projektu ustawy o PPP, Druk Sejmowy nr 1180, s. 19.

${ }^{64}$ A. J. Derkacz, Partnerstwo publiczno-prywatne w kontekście nowej ustawy. Funkcjonalna analiza ustawy z dnia 19 grudnia 2008 r. o partnerstwie publiczno-prywatnym, Szkoła Główna Handlowa w Warszawie, Warszawa 2009, s. 12. 
ryzykiem zarządza ta strona, która jest do tego lepiej przygotowana. Tak zdefiniowana umowa stwarza nieograniczone możliwości modelowania treści w zależności od liczby partnerów, modelu finansowania, udziału instytucji finansowych i rozmieszczenia ryzyka.

Istotnym elementem umowy jest kwestia wynagrodzenia, które uzależnione jest przede wszystkim od rzeczywistego wykorzystania lub faktycznej dostępności przedmiotu partnerstwa publiczno-prywatnego. Prawnicy zwracają uwagę, że nowe przepisy, w przeciwieństwie do poprzedniej ustawy, nie zawierają legalnej definicji wynagrodzenia partnera prywatnego, a jego wysokość i formę uzależnia się do faktycznego dostępu do przedmiotu PPP lub jego wykorzystania przez odbiorców (np. ciągłość w dostawie wody, gotowość wykorzystania łóżek w szpitalu). Wynagrodzenie będzie więc ściśle uzależnione od efektów pracy partnera prywatnego. Celem takiego zapisu jest ochrona nie tylko interesów podmiotu prywatnego, ale również interesu publicznego. Taki model wynagrodzenia wymusza po stronie partnera prywatnego zapewnienie ciągłości dostaw usług, odpowiednie skalkulowanie opłat, które powinny uwzględniać koszty, spłatę zobowiązań oraz odpowiedni zysk. Wszelkie „przestoje” i niedotrzymanie postanowień umowy będą oznaczać dla podmiotu prywatnego straty finansowe.

Ochrona interesu publicznego znalazła także odzwierciedlenie w zapisie art. 7, ust. 3 ustawy o PPP, dotyczącego rezultatów nienależytego wykonania i niewykonania zobowiązania skutkującego karami umownymi lub obniżeniem wynagrodzenia partnera prywatnego. Był to efekt postulatów zgłoszonych m.in. przez M. Rudnickiego, który dostrzegał konieczność ustawowego uzupełnienia kwestii odpowiedzialności za niewłaściwe wykonanie umowy i zwolnienia partnera prywatnego $\mathrm{z}$ odpowiedzialności za nieprzestrzeganie standardów świadczenia usług i zasad użytkowania obiektów lub urządzeń powstałych $\mathrm{w}$ wyniku przedsięwzięcia PPP $^{65}$. Postulaty te zostały uwzględnione tylko w sposób ramowy w nowych regulacjach, ponieważ nie wskazano żadnego konkretnego rozwiązania, nie odwołano się do innych przepisów prawnych oraz nie wskazano wysokości i formy kar. Uregulowanie kwestii kar pozostawiono bezpośrednio stronom umowy.

W efekcie nowych zapisów wyposażono podmiot publiczny w prawo bieżącej kontroli realizacji przedsięwzięcia przez podmiot prywatny. Zakres, zasady i forma kontroli powinny zostać określone expressis verbis w umowie. Taki zapis jednoznaczne czyni podmiot publiczny odpowiedzialnym za zachowanie odpowiedniego standardu usług bez względu na jej wykonawcę.

Treść umowy powinna stanowić także rozwiązanie zagadnień dotyczących wniesienia wkładu własnego (składnika majątkowego), które może nastąpić poprzez sprzedaż, użyczenie, użytkowanie, najem lub dzierżawę. Kontrakt

${ }^{65}$ M. Rudnicki, Partnerstwo publiczno-prywatne. Wybrane zagadnienia prawno-ustrojowe i prawno-finansowe, ,Samorząd Terytorialny” 2006, nr 7-8, s. 74. 
powinien precyzować postępowanie w przypadku niewłaściwego wykorzystania składnika majątkowego przez partnera prywatnego lub przez podmiot publiczny w zależności od tego, kto ów składnik wniósł do przedsięwzięcia.

Po zakończeniu umowy partner prywatny przekazuje podmiotowi publicznemu składnik majątkowy, który był wykorzystywany do realizacji przedsięwzięcia. Sposób przekazania powinien określić zapis umowy.

Pomimo że obecnie przepisy nie narzucają konkretnej formuły oraz zawartości umowy, to można wyodrębnić pewne grupy elementów, które pojawiają się we wszystkich kontraktach oraz ogólne regulacje, polegające na tym, że każda umowa poza postanowieniami ogólnymi odnosi się do chronologicznie następujących po sobie zdarzeń związanych z cyklem życia każdego przedsięwzięcia ${ }^{66}$.

Po przyjęciu pierwszej ustawy o PPP Ministerstwo Gospodarki w roku 2007 opracowało ramy określające standardową umowę w zakresie partnerstwa. Treść poszczególnych elementów umowy opracowana została przy uwzględnieniu zapisów ustawy i przyjętych do niej rozporządzeń. W. Grzybowski zwraca uwagę, że istnieje możliwość zawierania umów na podstawie innych przepisów, wówczas wymagania co do układu i treści umowy będą wynikać $\mathrm{z}$ aktów prawnych, które będą stanowić bazę prawną partnerstwa. Przygotowana treść poszczególnych klauzul odpowiada zachodnioeuropejskiej praktyce prawnej w zakresie partnerstwa, z uwzględnieniem polskich rozwiązań. Umowa wzorcowa dotyczy przedsięwzięcia. W jej ramach odbędzie się wybudowanie odpowiedniej infrastruktury, eksploatacja oraz przekazanie składnika majątkowego stronie publicznej. Zawartość umowy podzielona została na 11 rozdziałów (tab. 2.4).

Tabela 2.4

Ramowa struktura umowy partnerstwa publiczno-prywatnego

\begin{tabular}{|c|l|}
\hline \multicolumn{1}{|c|}{ Rozdział } & \multicolumn{1}{|c|}{ Zawartość rozdziału } \\
\hline \multicolumn{1}{|c|}{1} & \multicolumn{1}{|c|}{2} \\
\hline Część A. Postanowienia ogólne & Strony umowy \\
& Preambuła \\
& Definicje i interpretacje \\
& Przedmiot umowy \\
& Wejście w życie i czas trwania umowy \\
& Warunki zawieszające \\
& Pomoc ze strony podmiotu publicznego \\
& Zapewnienia i oświadczenia \\
& Dodatkowe gwarancje \\
& Dokumenty projektu oraz kolizja postanowień \\
& Podział odpowiedzialności \\
\hline
\end{tabular}

${ }^{66}$ Umowa o partnerstwie publiczno-prywatnym - ramy..., s. 30. 


\begin{tabular}{|c|c|}
\hline 1 & 2 \\
\hline Część B. Składniki majątkowe & $\begin{array}{l}\text { Opis składników majątkowych } \\
\text { Tytuł prawny } \\
\text { Nabycie/przekazanie składników } \\
\text { Rekompensata za nieadekwatność } \\
\text { Miejsce inwestycji } \\
\text { Uporządkowanie terenu }\end{array}$ \\
\hline $\begin{array}{l}\text { Część C. Faza inwestycyjna - projekt, budowa } \\
\text { i odbiór }\end{array}$ & $\begin{array}{l}\text { Harmonogram budowy } \\
\text { Przygotowanie projektu } \\
\text { Kryteria techniczne inwestycji } \\
\text { Dokumentacja inwestycji } \\
\text { Wybór przedstawicieli stron } \\
\text { Kryteria oceny projektu } \\
\text { Zapewnienie bezpieczeństwa } \\
\text { Emisje w trakcie inwestycji } \\
\text { Roboty budowlane } \\
\text { Regulacje branżowe i normy } \\
\text { Pozwolenia } \\
\text { Tryb wyboru i zatwierdzenia wykonawców } \\
\quad \text { i podwykonawców } \\
\text { Warunki weryfikacji i zatwierdzenia projektu } \\
\text { Dostawy urządzeń i materiałów } \\
\text { Normy jakości } \\
\text { Kontrola } \\
\text { Dokumenty podlegające kontroli } \\
\text { Zmiany w harmonogramie } \\
\text { Znaleziska } \\
\text { Drogi dostępu, transportu, regulacja ruchu } \\
\text { Zarządzanie kryzysowe } \\
\text { Media } \\
\text { Zakończenie robót } \\
\text { Przekazanie do użytkowania } \\
\text { Opóźnienia w zakończeniu inwestycji } \\
\text { Wady }\end{array}$ \\
\hline Część D. Eksploatacja i utrzymanie & $\begin{array}{l}\text { Warunki świadczenia usług } \\
\text { Eksploatacja obiektu } \\
\text { Konserwacje i remonty } \\
\text { Monitoring i kontrola świadczonych usług } \\
\text { Audyt procedur eksploatacji i konserwacji } \\
\text { Wymuszone zmiany eksploatacyjne } \\
\text { Harmonogram usług } \\
\text { Odstępstwa od standardu } \\
\text { Relacje z użytkownikami } \\
\text { Inne postanowienia dotyczące eksploatacji }\end{array}$ \\
\hline
\end{tabular}


Tabela 2.4 (cd.)

\begin{tabular}{|c|c|}
\hline 1 & 2 \\
\hline Część E. Zobowiązania stron & $\begin{array}{l}\text { Przestrzeganie standardów } \\
\text { Zabezpieczenie wykonania zobowiązań } \\
\text { Przejęcie pracowników } \\
\text { Amortyzacja } \\
\text { Informacja i reklama } \\
\text { Zmiany w przedsięwzięciu } \\
\text { Kluczowe decyzje } \\
\text { Optymalizacja wydatków publicznych } \\
\text { Odpowiedzialność wobec osób trzecich } \\
\text { Umowy z osobami trzecimi oraz zmiany } \\
\text { wykonawców } \\
\text { Wstąpienie w prawa i obowiązki partnera } \\
\text { prywatnego } \\
\text { Ubezpieczenie } \\
\text { Ryzyko nieubezpieczalne i nieubezpieczone }\end{array}$ \\
\hline Część F. Finanse & $\begin{array}{l}\text { Finansowanie przedsięwzięcia } \\
\text { Wydatki partnerów } \\
\text { Wynagrodzenie partnera prywatnego } \\
\text { Regulacja opłat końcowych } \\
\text { Sposób pobierania opłat i rachunki bankowe } \\
\text { Zysk partnera prywatnego } \\
\text { Dywidenda } \\
\text { Struktura wynagrodzenia } \\
\text { Sprawozdania finansowe }\end{array}$ \\
\hline Część G. Kary finansowe & $\begin{array}{l}\text { Naliczanie kar i ich potrącenia } \\
\text { Zapobieganie powtarzającym się naruszeniom } \\
\text { oraz powstawaniu szkody } \\
\text { Przerwy w dostawie usług }\end{array}$ \\
\hline Część H. Zmiany & $\begin{array}{l}\text { Zmiany zakresu przedsięwzięcia } \\
\text { Zmiany w prawie } \\
\text { Zmiany w treści umowy } \\
\text { Refinansowanie } \\
\text { Zmiany podmiotowe }\end{array}$ \\
\hline Część I. Wygaśnięcie i rozwiązanie umowy & $\begin{array}{l}\text { Wygaśnięcie umowy } \\
\text { Rozwiązanie umowy } \\
\text { Szczególne przypadki rozwiązania umowy } \\
\text { Współpraca z następcą } \\
\text { Przedłużenie okresu wykonywania niektórych } \\
\text { postanowień umowy }\end{array}$ \\
\hline
\end{tabular}




\begin{tabular}{|c|c|}
\hline 1 & 2 \\
\hline $\begin{array}{l}\text { Część J. Przekazanie składnika majątkowego } \\
\text { podmiotowi publicznemu }\end{array}$ & $\begin{array}{l}\text { Tryb przekazania } \\
\text { Zakres przekazania } \\
\text { Zwolnienie zabezpieczeń } \\
\text { Przejęcie pracowników }\end{array}$ \\
\hline Część K. Pozostałe postanowienia & $\begin{array}{l}\text { Dostosowanie modelu finansowego } \\
\text { Podwykonawstwo } \\
\text { Własność intelektualna } \\
\text { Informacje poufne } \\
\text { Zakaz nieuzgodnionych wypowiedzi publicz- } \\
\quad \text { nych } \\
\text { Odsetki } \\
\text { Dane osobowe } \\
\text { Ograniczenie odpowiedzialności } \\
\text { Zbieg roszczeń } \\
\text { Całość umowy } \\
\text { Język i egzemplarze } \\
\text { Zawiadomienia } \\
\text { Częściowa nieważność } \\
\text { Rozwiązywanie sporów, prawo właściwe i } \\
\quad \text { jurysdykcja }\end{array}$ \\
\hline
\end{tabular}

Źródło: oprac. własne na podstawie Umowa o partnerstwie publiczno-prywatnym - ramy określające standardowa zawartość, Ministerstwo Gospodarki, Warszawa 2007, s. 34-37.

Umowa o partnerstwie publiczno-prywatnym jest sporządzana przez podmiot publiczny. Zakres jej będzie każdorazowo dostosowany do zakresu inwestycji. Przy przedsięwzięciach budowlano-eksploatacyjnych zakres ten będzie szerszy niż w przypadku przedsięwzięć o charakterze eksploatacyjnym. Projekt umowy powinien stanowić integralną część dokumentacji przetargowej, która może być negocjowana w trakcie postępowania przetargowego. Ustawodawca pozostawił stronom swobodę w wyborze formy, co umożliwia zawarcie jej $\mathrm{w}$ dowolnej formie. Zdaniem K. Płonki-Bielenin sformułowanie praw i obowiązków stron przemawia za formą pisemną umowy. Dodatkowym argumentem za takim rozwiązaniem jest fakt, że zachowanie formy pisemnej stanowi podstawę do dochodzenia ewentualnych roszczeń, np. $\mathrm{z}$ tytułu nierzetelnego wykonania umowy. Ponadto w przypadku powołania spółki celowej umowa o PPP powinna być zawarta w formie aktu notarialnego ${ }^{67}$.

W obliczu nowej regulacji prawnej w zakresie PPP umowa stanie się dokumentem nadającym swoistą i niepowtarzalną strukturę polskiemu partnerstwu.

${ }^{67}$ Szerzej na temat aspektów prawnych umowy o PPP pisze m.in. K. Płonka-Bielenin, Charakter prawny umowy o partnerstwo publiczno-prywatne, „Samorząd Terytorialny” 2010, nr 9, s. 7-12; A. Tyszkiewicz-Mazur, Umowa o partnerstwie publiczno-prywatnym - wybrane zagadnienia, „Samorząd Terytorialny” 2008, nr 11, s. 19-28. 
Rola umowy powinna sprowadzać się, z jednej strony, do zapewnienia sprawnej realizacji przedsięwzięcia, a $\mathrm{z}$ drugiej chronić interes publiczny. Powinna ona gwarantować zachowanie odpowiedzialności i kontroli podmiotu publicznego za przedmiot przedsięwzięcia. Zakres treści umowy to pochodna wyniku negocjacji prowadzonych na etapie wyłaniania partnera prywatnego. Od zakresu i czasu rokowań z potencjalnymi podmiotami uzależniona będzie także jakość przyjętej umowy. Wymaga się, aby zapisy umowy (możliwie precyzyjnie sformułowanej, a więc takiej, która nie będzie wymagała w przyszłości korekt) dawały jasny obraz wzajemnych płatności, podziału ryzyk, określały prace, jakie mają być wykonane, ze szczegółowym opisem ich jakości, standardu usługi oraz ilości i jakości ewentualnych produktów, jakie mogą powstać w trakcie współpracy. Kontrakt powinien zawierać także harmonogram działań, system kar i zachęt gwarantujących realizację zobowiązań. Ważne jest także określenie zasad zmian partnera prywatnego $\mathrm{w}$ przypadku zaistnienia nieprzewidzianych okoliczności i zdarzeń, procedury rozwiązania umowy i rozliczenia wkładów własnych ${ }^{68}$.

W dotychczasowej praktyce pojawiają się tzw. pakiety kontraktowe PPP przygotowane przez kancelarie prawnicze świadczące usługi w zakresie partnerstwa. W strukturze pakietów znajdują się: umowa główna oraz wiele umów wykonawczych obejmujących zagadnienia związane z projektowaniem, robotami budowlanymi, eksploatacją obiektu. Przygotowane pakiety stanowią wzorce skonstruowane przez daną kancelarię dla konkretnego podmiotu publicznego, który jest $\mathrm{w}$ trakcie prac nad przygotowaniem partnerstwa.

Powszechnie dominuje pogląd, że w Polsce większość umów w początkowej fazie rozwoju formuły będzie miała charakter umów negocjowanych. $\mathrm{Z}$ czasem powinno dojść do wypracowania pewnego standardu, wzorca, który będzie można pogrupować według przedmiotu przedsięwzięcia bądź branży. Standaryzacja umów przyczyniłaby się do skrócenia procedur przygotowania przedsięwzięcia i obniżenia kosztów. Wzory umów powinny znaleźć się na stronie np. Ministerstwa Gospodarki bądź instytucji promujących partnerstwo publiczno-prywatne (Centrum PPP, Instytut PPP czy powołanych w ostatnich czasach - bazy PPP, platformy PPP działającej przy Ministerstwie Gospodarki i Ministerstwie Rozwoju Regionalnego).

${ }^{68}$ B. Korbus (red.), Partnerstwo publiczno-prywatne. Poradnik..., s. 118. 


\section{FINANSOWE UWARUNKOWANIA INWESTYCJI JEDNOSTEK SAMORZĄDU TERYTORIALNEGO}

\subsection{Specyfika inwestycji jednostek samorządu terytorialnego}

Inwestycje samorządowe stanowią specyficzny rodzaj przedsięwzięć realizowanych $\mathrm{z}$ reguły przez jednostki samorządu terytorialnego. Złożoność problematyki związanej z przygotowaniem inwestycji, finansowaniem, wykonaniem oraz eksploatacją urządzeń i obiektów narzuca odrębne zindywidualizowane podejście do tej kategorii inwestycji. Zagadnienie to wymaga opracowania adekwatnej metodyki działania, stanowiącej element systemu ukierunkowanego na rozwiązanie problemów społecznych i gospodarczych o charakterze bieżącym oraz rozwojowym w ramach wspólnoty samorządowej. Inwestycje samorządowe w przeważającej mierze realizowane są na szczeblu gminnym. Wynika to $\mathrm{z}$ charakteru potrzeb lokalnych społeczności oraz zakresu zadań własnych przypisanych gminom ${ }^{1}$.

Literatura przedmiotu zawiera bogaty zasób pojęciowy ujmujący zagadnienia związane $\mathrm{z}$ inwestowaniem oraz szerzej $\mathrm{z}$ problematyką finansowania inwestycji. W rzeczywistości niezmiernie trudno jest podać jedną definicję, która w sposób uniwersalny oddawałaby istotę podejmowanych przedsięwzięć inwestycyjnych w różnych uwarunkowaniach makroekonomicznych, lokalnych, w odniesieniu do strategii działania oraz celów, a także w kontekście subiektywnych decyzji inwestorów ${ }^{2}$.

$\mathrm{Na}$ współczesne znaczenie pojęcia „inwestycje” wpływ wywarło łacińskie słowo investiura, które w średniowiecznym ustroju feudalnym oznaczało ${ }^{3}$ :

- uroczyste wprowadzenie wasala przez seniora w posiadanie lenna (ziemi lub urzędu) po złożeniu hołdu przez wasala, przy jednoczesnym przekazaniu mu przedmiotu symbolizującego to lenno (np. chorągiew, pastorał lub włócznia),

\footnotetext{
${ }^{1}$ K. Jarosiński, Finansowanie inwestycji komunalnych $w$ Polsce $w$ warunkach samorzadności lokalnej, Monografie i Opracowania nr 523, Oficyna Wydawnicza SGH, Warszawa 2003, s. 114.

${ }^{2}$ Ibidem.

${ }^{3}$ M. Noga, Państwo a inwestycje w gospodarce rynkowej z uwzględnieniem procesu transformacji, Dolnośląska Oficyna Wydawnicza, Wrocław 1994, s. 5.
} 
- nadanie lenna biskupom albo opatom przez monarchę (inwestytura świecka duchowieństwa).

Słowo ,inwestycje” pochodzi od łacińskiego investire i oznacza ,przykrywać, otaczać, odziewać”4 . Słownik języka polskiego odróżnia pojęcia „inwestować" i ,inwestycja”. Inwestowanie rozumiane jest jako

czynienie nakładów gospodarczych w taki sposób, aby przynosiły dochód. Inwestycja to przeznaczenie środków finansowych na stworzenie nowych lub powiększenie istniejących obiektów majątku trwałego ${ }^{5}$.

Encyklopedia Popularna PWN przez inwestycje rozumie „nakłady gospodarcze na stworzenie lub powiększenie majątku trwałego"6. Leksykon PWN rozszerza zaś pojęcie inwestycji określając je jako

nakłady dokonywane w celu stworzenia lub zwiększenia środków trwałych, które przyczyniają się do wytworzenia dla przyszłego spożycia dopływu dóbr i usług ${ }^{7}$.

Ustawa o rachunkowości inwestycje określa jako aktywa nabyte w celu osiągnięcia korzyści ekonomicznych wynikających z przyrostu wartości tych aktywów, uzyskania z nich przychodów w formie odsetek, dywidend (udziałów w zyskach) lub innych pożytków, w tym również transakcji handlowej, a w szczególności aktywa finansowe oraz te nieruchomości i wartości niematerialne i prawne, które nie są użytkowane przez jednostkę lecz zostały nabyte w celu osiągnięcia tych korzyści. Inwestycje w ujęciu ustawy odnoszą się do aktywów znajdujących się w dyspozycji danej jednostki, o charakterze inwestycji rzeczowych, finansowych i niematerialnych.

Inwestycja jest kategorią ekonomiczną, stąd w opracowaniach makroekonomicznych inwestycje definiuje się jako ,powiększenie lub utrzymanie na dotychczasowym poziomie zasobu kapitału w postaci maszyn, urządzeń, budynków i infrastruktury technicznej”, , ,przyrost lub odnowienie zużytego majątku produkcyjnego" "10 bądź jako ,zakupy nowych dóbr kapitałowych przez przedsiębiorstwa" ${ }^{\text {11 }}$. Ponieważ inwestycje obejmują szeroki zakres form

${ }^{4}$ W. Kopaliński, Stownik wyrazów obcych i zwrotów obcojęzycznych, Wiedza Powszechna, Warszawa 1989, s. 236.

${ }^{5}$ Nowy słownik języka polskiego, Wydawnictwo Naukowe PWN, Warszawa 2002, s. 280.

${ }^{6}$ Encyklopedia Popularna, Wydawnictwo Naukowe PWN, Warszawa 1993, s. 323.

${ }^{7}$ Leksykon PWN, Wydawnictwo Naukowe PWN, Warszawa 2004, s. 466.

${ }^{8}$ Ustawa z dnia 29 września 1994 r. o rachunkowości, DzU, 2002, nr 76, poz. 694 ze zm.

${ }^{9}$ R. Milewski, Elementarne zagadnienia ekonomii, Wydawnictwo Naukowe PWN, Warszawa 2002, s. 263.

${ }^{10}$ Ekonomia, red. W. Caban, Wydawnictwo Wyższej Szkoły Finansów i Informatyki, Łódź 2006, s. 225.

${ }^{11}$ D. Begg, S. Fischer, R. Dornbusch, Makroekonomia, PWE, Warszawa 2007, s. 29. 
działalności gospodarczej, w literaturze ${ }^{12}$ spotykamy wiele definicji inwestycji i sposobów ich klasyfikacji. Pozwala to na wyróżnienie dwóch podstawowych nurtów definiowania pojęcia inwestycji:

- nurt monetarny (finansowy) - postrzegający inwestycje z pozycji ruchu pieniądza (w podejściu tym nie jest akcentowany materialny wymiar inwestycji),

- nurt rzeczowy - inwestycja widziana jest jako ruch dóbr (w podejściu tym szczególną uwagę zwraca się na wymierny, materialny efekt inwestycji).

Coraz częściej w celu zdefiniowania pojęcia „inwestycja” wykorzystuje się cechy, które ją charakteryzują. Są to: kapitał - jako źródło finansowania, korzyść - postrzegana jako efekt zaangażowania kapitału, czas - związany z realizacją, wykorzystaniem, a następnie likwidacją inwestycji oraz ryzyko - związane z możliwością pojawienia się odchyleń od wartości oczekiwanych.

Różnorodność podejść do inwestycji pozwala na wyodrębnienie trzech głównych ich grup:

1) inwestycje rzeczowe - które definiowane są jako procesy gospodarcze, polegające na przyroście, odtworzeniu, modernizacji majątku a służą tworzeniu trwałych obiektów i zdolności technicznych dla produkcji dóbr i usług,

2) inwestycje kapitałowe - rozumiane jako zakup papierów wartościowych oraz udziałów w przedsiębiorstwach w celu osiągnięcia zysku w postaci dochodów, dywidend, odsetek itp.,

3) inwestycje w kapitał ludzki (niematerialne) - polegające na podnoszeniu wykształcenia i kwalifikacji człowieka lub całego społeczeństwa.

Dwie pierwsze kategorie dotyczą inwestycji w aktywa materialne firmy (rzeczowe lub kapitałowe). Obecnie coraz większego znaczenia nabierają inwestycje w aktywa niematerialne. Do lat 90. minionego stulecia proces inwestycyjny łączono głównie z działaniami zmierzającymi do powiększenia

${ }^{12}$ P. Epingrad, Proces inwestowania wobec wyzwań technologicznych i informatycznych, przekł. K. Malaga, Wydawnictwo EFP - Francusko-Polskiej Wyższej Szkoły Nowych Technik Informatyczno-Komunikacyjnych, Poznań 1995, s.7; Finanse przedsiębiorstwa z elementami zarzązania i analizy, red. M. Wypych, Wydawnictwo Absolwent, Łódź 1998. s. 357; J. Śliwa, Zarzadzanie finansami przedsiębiorstwa, od diagnozy do projekcji, Fundacja Rozwoju Rachunkowości w Polsce, Warszawa 1998, s. 273; W. Bień, Zarządzanie finansami przedsiębiorstwa, Difin, Warszawa 1999, s. 233; W. Rogowski, Rachunek efektywności inwestycji, Oficyna Wolters Kluwer business, Kraków 2008, s. 20-23; J. Różański, Inwestycje rzeczowe $w$ procesach rozwojowych przedsiębiorstw, Wydawnictwo Uniwersytetu Łódzkiego, Łódź, 1998, s. 40; J. Różański, M. Czerwiński, Inwestycje rzeczowe i kapitałowe, Przedsiębiorstwo Specjalistyczne Absolwent, Łódź 1999, s. 91; K. Dziworska, Pojęcie i rodzaje inwestycji, [w:] Projekty inwestycyjne. Finansowanie, metody i procedury oceny, red. T. Gostkowska-Drzewicka, Ośrodek Doradztwa i Doskonalenia Kadr, Gdańsk 1996, s. 11; eadem, Inwestycje przedsiębiorstw, Wydawnictwo Uniwersytetu Gdańskiego, Gdańsk 1993, s. 12; K. Marcinek, H. Walica, Zarys ekonomiki i organizacji procesu inwestycyjnego i polityki inwestycyjnej, Akademia Ekonomiczna w Katowicach, Katowice 1998, s. 19-35. 
aktywów bilansowych o charakterze rzeczowym lub finansowym. Przełom nastąpił $\mathrm{w}$ wyniku zmian $\mathrm{w}$ rozumieniu procesów inwestycyjnych, rozszerzeniu ich o aktywa niematerialne, tzw. kapitał intelektualny ${ }^{13}$.

Inwestycje są oznaką rozwoju. Wymagają znacznych nakładów finansowych ponoszonych w dhugim okresie w wyniku czego powstają nowe substancje lub następuje poprawa stanu dotychczasowych. W praktyce inwestycje mogą być różnorodne, co umożliwia ich klasyfikowanie. Kryterium podziału może być: cel inwestycji, czas, charakter, źródło finansowania, podmiot podejmujący decyzję inwestycyjną ${ }^{14}$ (wykres 3.1 ).

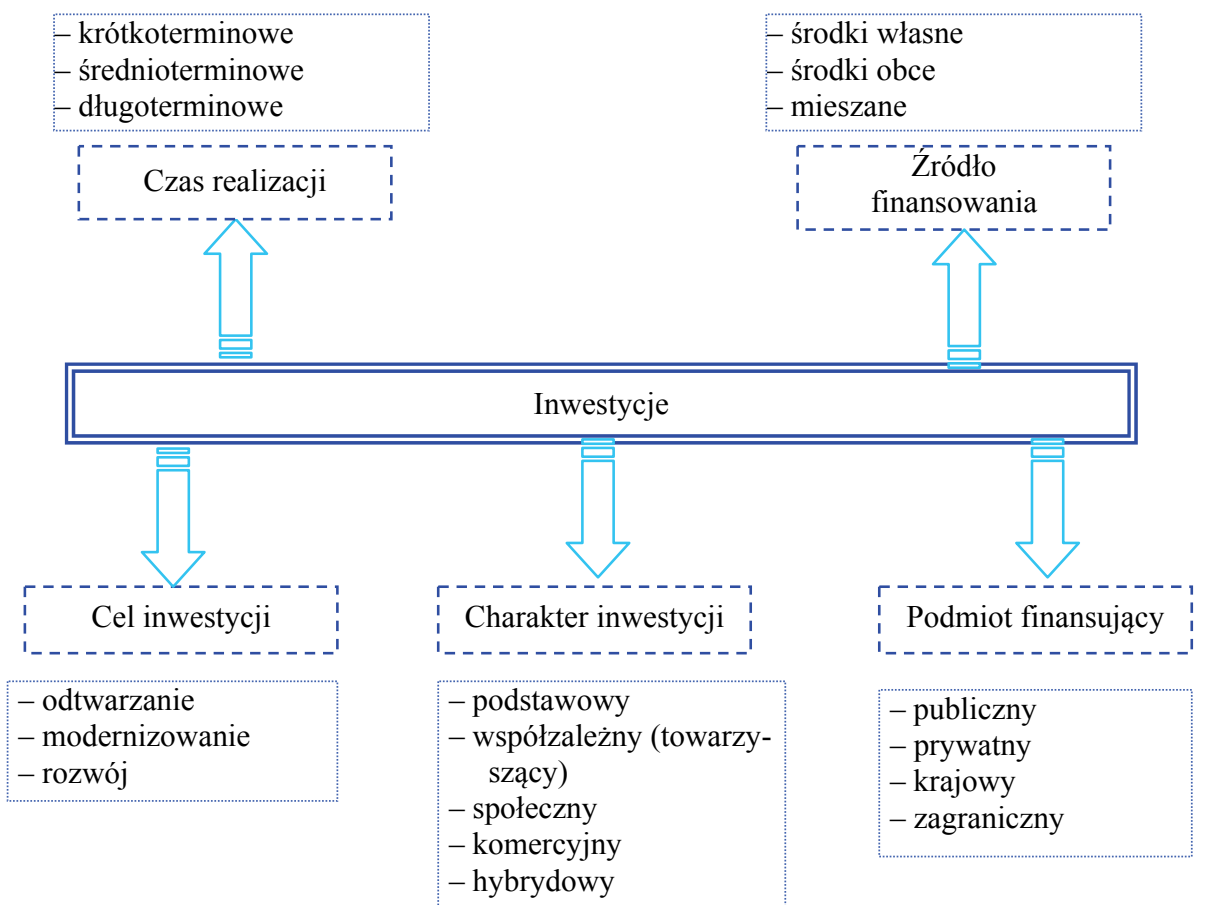

Wykres 3.1. Kryteria klasyfikacji inwestycji

Źródło: oprac. własne

${ }^{13}$ Analizę znaczenia inwestycji w aktywa niematerialne i ich rola w tworzeniu wartości współczesnego przedsiębiorstwa zawiera m.in. publikacja S. Jasiewicz, W. Rogowski, M. Kicińska, Kapitat intelektualny - spojrzenie z perspektywy interesariuszy, Oficyna Ekonomiczna, Kraków 2006.

${ }^{14} \mathrm{~W}$ literaturze poszczególne rodzaje inwestycji zostały dokładnie omówione przez m.in. takich autorów, jak: S. Dyżewska, P. Kawa, S. Wydymus, M. Poszwa, M. Sierpińska, T. Jachna, K. Marcinek, E. F. Brigham, H. Gawron, V. Jog, C. Suszyński, T. Jajuga, Z. Wilimowska, W. Pluta, W. Rogowski, W. Dębski. 
Słownik pojęć komunalnych inwestycje definiuje jako działania ukierunkowane na zwiększenie wartości zasobów materialnych jednostki, związane $\mathrm{z}$ nakładami finansowymi przeznaczonymi na tworzenie, zwiększenie i modernizowanie majątku trwałego $\mathrm{w}$ danej jednostce samorządu terytorialnego ${ }^{15}$. Generalnie inwestycja jest finansowym zaangażowaniem w przedsięwzięcie w celu uzyskania przyszłych korzyści ${ }^{16}$. W odniesieniu do działalności jednostek samorządu terytorialnego nabiera ona szczególnego charakteru.

Jak już wspomniano wcześniej, w literaturze związanej z inwestycjami pojawiają się takie pojęcia jak ,przedsięwzięcie” oraz „projekt”. Pojęcia te, mimo że powszechnie używane, nie mają jednolitej i powszechnie obowiązującej definicji. H. Henzel uważa, że

przedsięwzięcie można zdefiniować jako działanie złożone, wielopodmiotowe, przeprowadzone zgodnie z planem, który jest sporządzony za pomocą specjalnych metod, natomiast projekt najczęściej jest definiowany jako zespół dodatkowych cech, które powinno spełniać przedsięwzięcie, aby można je było określić mianem projektu. Do tych cech często zalicza się unikatowość, odrębność organizacyjną, celowość, ograniczoność środków i czasu oraz terminowość ${ }^{17}$.

\section{Z kolei H. Walica przyjmuje, że}

przedsięwzięcie jest zespołem zaplanowanych, wzajemnie ze sobą powiązanych czynności, których celem jest powstanie lub unowocześnienie określonego pod względem rzeczowym, finansowym i czasowym zasobu majątku trwałego ${ }^{18}$.

M. Dobija zauważa, że przedsięwzięcie należy do podstawowych form działalności gospodarczej charakteryzując się efektem odłożonym w czasie, nieciągłością przydziałów środków kapitałowych oraz ryzykiem ${ }^{19}$. Zbliżone stanowisko znajdujemy u A. Manikowskiego oraz Z. Tarapaty, zdaniem których przedsięwzięcie jest zamierzeniem rozwojowym o jasno określonym celu, skonkretyzowanym co do zakresu rzeczowego, miejsca i czasu realizacji, ujętym w sposób kompleksowy ${ }^{20}$.

${ }^{15}$ W. Wróblewski, Słownik pojęć komunalnych, Włocławskie Towarzystwo Naukowe, Włocławek 2007, s. 26.

${ }^{16}$ Por. M. Dylewski, B. Filipiak, M. Gorzałczyńska-Koczkodaj, Analiza finansowa $w$ jednostkach samorzadu terytorialnego, Municypium, Warszawa 2004, s. 163.

${ }^{17} \mathrm{H}$. Henzel, Decyzje $w$ działalności inwestycyjnej - uwarunkowania, metody, efekty, Wydawnictwo Akademii Ekonomicznej w Katowicach, Katowice 2007, s. 175.

${ }^{18} \mathrm{H}$. Walica, Integracja wykonawców przedsięwzięć inwestycyjnych, Wydawnictwo Akademii Ekonomicznej w Katowicach, Katowice 1992, s. 7.

${ }^{19}$ M. Dobija, Rachunkowość zarządcza, Wydawnictwo Naukowe PWN, Warszawa 1994, s. 50.

${ }^{20}$ Por. A. Manikowski, Z. Tarapata, Ocena projektów gospodarczych. Modele i metody, cz. 1, Difin, Warszawa 2001, s. 14. 


\section{Projekt to}

tymczasowe przedsięwzięcie, mające na celu stworzenie unikatowego produktu lub usługi, gdzie tymczasowość oznacza, że przedsięwzięcie ma ściśle oznaczony początek i koniec, a unikalność, że produkt lub usługa wyraźny sposób jest inna niż wszystkie podobne produkty lub usługi ${ }^{21}$.

Mianem projektu określa się ,przedsięwzięcie realizowane w ramach określonej organizacji, które jest przedsięwzięciem nowym, nietypowym, odmiennym od działań rutynowych takim, $\mathrm{z}$ jakim dana organizacja nie miała nigdy wcześniej do czynienia ${ }^{22}$.

Projekt jest pojęciem węższym niż przedsięwzięcie. Aby dane przedsięwzięcie mogło być nazwane projektem, spełnione muszą zostać następujące założenia ${ }^{23}$ :

- jednokrotność, czyli realizacja przedsięwzięcia po raz pierwszy,

- celowość, czyli wynik określonej strategii,

- odrębność, czyli brak powiązań z normalną, rutynową działalnością firmy,

- ograniczoność, czyli istnienie ograniczenia czasowego realizacji przedsięwzięcia,

- odrębność strukturalna, czyli wydzielenie realizacji przedsięwzięcia jako osobnej struktury w firmie.

Porównanie istoty przedsięwzięcia i projektu przedstawiono w tab. 3.1.

Tabela 3.1

Porównanie istoty przedsięwzięcia i projektu

\begin{tabular}{|l|l|}
\hline \multicolumn{1}{|c|}{ Przedsięwzięcia } & \multicolumn{1}{c|}{ Projekty } \\
\hline - Istniejące systemy & - Jednorazowa konfiguracja zasobów \\
- Powtarzalność & - Wyjątkowość i indywidualność \\
- Wydajność i stabilizacja & - Efektywność i elastyczność \\
- Oparcie w standardowych procedurach & - Spójność i ukierunkowanie \\
- Zarządzanie liniowe & - Dążenie do ukończenia projektu \\
- Skoncentrowanie na „zachowawczości” & - Skoncentrowanie na „,zmianie” \\
\hline
\end{tabular}

Źródło: M. T. Wilczek, Podstawy zarządzania projektami inwestycyjnymi, Wydawnictwo Akademii Ekonomicznej w Katowicach, Katowice 2002, s. 12.

Z punktu widzenia praktyki samorządowej przedsięwzięcia inwestycyjne można rozpatrywać jako przedsięwzięcia wielozadaniowe, jednozadaniowe złożone i jednozadaniowe proste ${ }^{24}$.

${ }^{21}$ P. Pietras, Zarządzanie projektami. Wybrane metody i techniki, Oficyna Księgarsko-Wydawnicza „Horyzont”, Łódź 2003, s. 9.

${ }^{22}$ M. Pawlak, Zarzadzanie projektami, Wydawnictwo PWN, Warszawa 2011, s. 15.

${ }^{23}$ M. T. Wilczek, Podstawy zarządzania projektami inwestycyjnymi, Wydawnictwo Akademii Ekonomicznej w Katowicach, Katowice 2002, s. 11. 
Przedsięwzięcia wielozadaniowe stanowią duże inwestycje rzeczowe, które angażują znaczne zasoby kapitału, okres ich realizacji jest znaczący i wymagają prac budowlanomontażowych. W skład przedsięwzięcia wchodzi zazwyczaj więcej niż jedno zadanie, jeden lub więcej projekt i więcej niż jeden proces. Przedsięwzięcia te stanowią podstawę rozwoju społeczno-gospodarczego zapisanego w strategii danej jednostki samorządowej. Bardzo często efektem ich realizacji jest zwiększenie skali dotychczasowej działalności usługowej, umożliwienie zmiany jakościowej dostarczanych usług publicznych, czy też rozwój nowych usług, na które zgłasza zapotrzebowanie społeczeństwo.

Przedsięwzięcia jednozadaniowe złożone dotyczą znacznie mniejszej skali aktywności inwestycyjnej. Obejmują zwykle jedno zadanie. Nie wymagają zaangażowania wielu podmiotów, często wykonywane są we własnym zakresie. Charakteryzują się nieznacznym zwiększeniem skali dotychczasowej działalności poprzez tworzenie nowych obiektów. Nie są tak kosztowne jak przedsięwzięcia wielozadaniowe, ale mogą zwiększać jakość i podnosić poziom satysfakcji odczuwanej przez społeczeństwo z dostarczanych usług publicznych.

Przedsięwzięcia inwestycyjne jednozadaniowe proste mają charakter krótkoterminowy, zakupowy i opierają się zazwyczaj na decyzjach prostych odtworzeniowych. Ich celem jest utrzymanie dotychczasowego świadczenia usług społeczeństwu na poziomie przez nie akceptowanym ${ }^{25}$.

Inwestycje realizowane przez jednostki samorządu terytorialnego $\mathrm{w}$ formule partnerstwa publiczno-prywatnego mają charakter złożony, wymagają długookresowego zaangażowania znacznych kapitałów, efektem czego jest powstanie nowych składników majątkowych, zwiększenie skali dostarczanych usług oraz wzrost ich jakości, przez co następuje wzrost zadowolenia lokalnych społeczności. Z tego powodu na potrzeby pracy przyjmuje, że w ramach partnerstwa publiczno-prywatnego jednostki samorządu terytorialnego realizują przedsięwzięcia inwestycyjne.

Realizacja zadań własnych i zleconych przez jednostki samorządu terytorialnego wymaga zaangażowania majątku trwałego, który stanowi własność danej jednostki, tzw. mienie komunalne. Cechą charakterystyczną tego majątku jest to, że zużywa się on w długim okresie, ale zanim nastąpi jego techniczne zużycie musi być utrzymany w stałej sprawności technicznej, co gwarantuje nieprzerwalność świadczenia usług. Wymaga to ponoszenia wydatków na naprawy, remonty i konserwacje. Mieści się to w ramach wydatków bieżących. Ponadto wykonywanie zadań związanych z zaspokajaniem potrzeb zbiorowych mieszkańców wiąże się z koniecznością prowadzenia działalności inwestycyjnej i ponoszenia wydatków inwestycyjnych. Działalność inwestycyjna jednostek samorządu terytorialnego stanowi jedną $\mathrm{z}$ ich podstawowych funkcji publicz-

${ }^{24}$ A. Michalak, Finansowanie inwestycji w teorii i praktyce, Wydawnictwo Naukowe PWN, Warszawa 2007, s. 23 i n.

${ }^{25}$ M. Dylewski, B. Filipiak, M. Gorzałczyńska-Koczkodaj, Metody analityczne $w$ działalności jednostek podsektora samorzadowego, Difin, Warszawa 2010, s. 122 i n. 
nych. Działalność ta polega na powiększaniu stanu i wartości mienia komunalnego poprzez inwestycje.

W warunkach gospodarki budżetowej samorządów inwestycje realizowane są w przeważającej mierze w sferze rzeczowych składników. Jednostki samorządu terytorialnego prowadzą przede wszystkim działalność w sferze użyteczności publiczneje ${ }^{26}$, tj. mającej na celu bieżące i nieprzerwane zaspokojenie zbiorowych potrzeb obywateli, co wynika z art. 9 ust. 4 ustawy o samorządzie gminnym $^{27}$. Działalność gospodarcza samorządów w sferze usług publicznych wiąże się przede wszystkim z ciągłością i powszechnością świadczenia produkcji i usług, ich dostępnością, zaspokojeniem potrzeb o charakterze publicznym, brakiem motywacji do maksymalizowania zysku oraz możliwością występowania nie ekwiwalentności $\mathrm{W}$ świadczeniu usług. W przypadku działalności w zakresie infrastruktury technicznej (często przyjmującej pozycję monopolisty) specyfika wynika z niepodzielności technicznej urządzeń infrastrukturalnych, wysokiej kapitałochłonności cyklu inwestycyjnego, jednoczesności produkcji, dostawy i konsumpcji oraz znacznego zróżnicowania w czasie zapotrzebowania na usługi (dotyczy to zwłaszcza zapotrzebowania na wodę, ciepło, odprowadzenie ścieków, transport lokalny), a także wysokiego stopnia nieelastyczności popytu względem ceny ${ }^{28}$.

Działalność zakwalifikowana do sfery użyteczności publicznej z jednej strony przyjmuje cechy monopolu naturalnego (wodociągi, ciepłownictwo), a z drugiej cechuje się dobroczynnością (szpital, biblioteka publiczna) ${ }^{29}$. Na pierwszy plan w działalności inwestycyjnej samorządów wysuwają się inne niż

${ }^{26} \mathrm{~W}$ literaturze spotyka się wiele pojęć definiujących usługi użyteczności publicznej. Definiowanie odbywa się poprzez wskazanie charakterystycznych cech oraz porównanie z pojęciem usług publicznych. Powszechnie usługi użyteczności publicznej definiuje się jako bieżące i nieprzerwalne zaspokojenie potrzeb ludności w drodze świadczenia usług powszechnie dostępnych. To działalność jednostki samorządu terytorialnego nienastawiona na osiąganie zysku, podejmowana $\mathrm{w}$ celu zaspokojenia potrzeb zgłaszanych przez lokalną wspólnotę. To usługi charakteryzujące się ,nałożoną przez władzę ustawodawczą odpowiedzialnością administracji publicznej (rządowej lub samorządowej) za zaspokajanie potrzeb zbiorowych". Zob. Ustawa z dnia 20 grudnia 1996 r. o gospodarce komunalnej, DzU, 2011, nr 45, poz. 236; A. Miszczuk, M. Miszczuk, K. Żuk, Gospodarka samorzadu terytorialnego, Wydawnictwo Naukowe PWN, Warszawa 2007; M. Dylewski, B. Filipiak, Ustugi publiczne, [w:] Wspótczesna ekonomika ustug, red. S. Flejterski, A. Panasiuk, J. Perenc, G. Rosa, PWN, Warszawa 2005; K. Bobińska, Zdefiniowanie pojęcia „ustugi użyteczności publicznej”, [w:] Użyteczność publiczna w sektorach infrastruktury gospodarczej, red. K. Bobińska, Bellona, Warszawa 2003; J. Stiglitz, Ekonomia sektora publicznego, Wydawnictwo Naukowe PWN, Warszawa 2004; K. Bajoch, S. Redeł, Prawo gospodarki komunalnej, Wydawnictwo Naukowe PWN, Warszawa 2000.

${ }^{27}$ Ustawa z dnia 8 marca 1990 r. o samorzadzie gminnym, DzU, 2001, nr 142, poz. 1591 ze zm.

${ }^{28}$ Rynek ustug komunalnych w Polsce, red. T. Aziewicz, Instytut Badań nad Gospodarką Rynkową, Gdańsk-Lublin 1994, s. 7.

${ }^{29}$ M. Pyziak-Szafnicka, P. Płaszczyk, Działalność gospodarcza gmin a granice sfery użyteczności publicznej, „Finanse Komunalne” 1997, nr 2, s. 12. 
zysk cele, tj. tworzenie infrastruktury, spadek bezrobocia, aktywizacja gospodarki, poprawa jakości usług. Nie zwalnia to jednostek z dążenia do efektywnego i sprawiedliwego gospodarowania środkami. Jednak wyliczenie ekonomicznych rezultatów działań jest bardzo trudne, a często ze względu na cel bezzasadne. Inwestowanie $\mathrm{w}$ sferę usług użyteczności komunalnej należy uznać za elementarne działanie samorządów, a więc takie, które powinno być zaspokojone w każdym przypadku wobec każdego członka społeczności. Wiąże się to bezpośrednio z obowiązkiem zapewnienia pełnej dostępności ${ }^{30}$.

Działalność w sferze usług publicznych przyjmuje określone, charakterystyczne cechy:

- zaspokojenie codziennych, powszechnych potrzeb zarówno ludności jak i innych podmiotów gospodarczych, społecznych i administracyjnych działających na danym terenie,

- niemożność magazynowania produkcji na większą skalę i wynikająca stąd konieczność działania w ciągłym ruchu,

- monopolistyczny charakter większości działań, prowadzący do ograniczonej suwerenności odbiorców,

- konieczność dysponowania znacznymi rezerwami zdolności produkcyjnych, prowadząca do dużego udziału kosztów stałych w ogólnych kosztach produkcji,

- potrzeba znaczącej ingerencji administracji/władzy samorządowej w zarządzanie działalnością w sferze użyteczności publicznej ze względu na wysoką kapitałochłonność, monopolistyczny charakter działalności oraz społeczny charakter zaspokajania potrzeb ${ }^{31}$.

Działalność inwestycyjna jednostek samorządu terytorialnego znacznie odbiega od inwestycji podmiotów gospodarczych zarówno w kontekście celu, źródeł finansowania, jak i sposobu liczenia efektywności. A. B. Atkinson i J. E. Stigliz trafnie zauważają, że podmioty prywatne i publiczne to dwubiegunowe rozwiązania mające do spełnienia w przyszłości inne cele ${ }^{32}$. Podmioty z sektora prywatnego nastawione są na maksymalizację zysku. Poziom zysku, jaki będzie można osiągnąć w przyszłości w wyniku działań inwestycyjnych, będzie decydował o tym, czy podmioty te podejmą się realizacji danego przedsięwzięcia, czy też nie. Podmioty publiczne, w tym samorządowe, realizują zadania bardziej skomplikowane oraz mniej bezpośrednie, odnoszące się do ogółu społeczeństwa i służące $\mathrm{w}$ większości przypadków interesom publicznym. Takie

${ }^{30}$ Zob. L. Garbarski, I. Rutkowski, W. Wrzosek, Marketing. Punkt zwrotny nowoczesnej firmy, PWE, Warszawa 2000, s. 144.

${ }^{31}$ M. Sadowy, Ekonomika przedsiębiorstw komunalnych. Zarys problematyki, [w:] Samorzad terytorialny a rozwój lokalny, red. M. Majchrzak, A. Zalewski, Monografie i Opracowania nr 483, Oficyna Wydawnicza SGH, Warszawa 2000, s. 138.

${ }^{32}$ A. B. Atkinson, J. E. Stiglitz, Lectures on Public, Ekonomics, Mc Graw-Hill Book Co. LTD, New York 1980, s. 311. 
stanowisko reprezentuje M. Kulesza. Jego zdaniem jednostki samorządu terytorialnego, podobnie jak prywatne firmy, prowadzą działalność gospodarczą, $\mathrm{w}$ tym inwestycyjną, $\mathrm{z}$ tą różnicą, że pozytywnym rezultatem działań dla firm jest zysk, a dla samorządów „korzyść dla interesu publicznego" ${ }^{33}$. Korzyści te są wymierne i podlegają ocenie zarówno przez radnych, jak i mieszkańców, czego rezultatem są wyniki wyborów samorządowych ${ }^{34}$. W związku z powyższym władze odpowiedzialne za przebieg procesów inwestycyjnych na danym terenie powinny wykorzystywać zarówno mechanizmy funkcjonowania poszczególnych komórek organizacyjnych danego urzędu, jak i lokalną wspólnotę. Ma to na celu nawiązanie wielopłaszczyznowej współpracy pomiędzy władzą lokalną a różnymi grupami oraz instytucjami społecznymi i gospodarczymi.

Inwestycje realizowane przez jednostki samorządu terytorialnego często określane są jako inwestycje komunalne, szczególnie gdy dotyczą infrastruktury komunalnej. Za inwestycje komunalne uznaje się celowe wydatkowanie środków finansowych przez jednostkę samorządu terytorialnego, nakierowane na powiększenie korzyści materialnych i niematerialnych wspólnoty samorządowej $^{35}$. Stopień konkurencyjności gminy i szanse dla jej rozwoju gospodarczego w znacznej mierze warunkuje zakres i rodzaj prowadzonych inwestycji, a zwłaszcza inwestycji komunalnych, służących zaspokojeniu podstawowych potrzeb mieszkańców. O ich wielkości decyduje poziom kapitału postawionego do dyspozycji władz samorządowych oraz przyjęta polityka rozwoju wspólnoty. Realizacja inwestycji komunalnych przyjąć może konkretny wymiar w postaci korzyści materialnych i niematerialnych. Do korzyści materialnych zalicza się wzrost dochodów gminy, wzrost wartości majątku gminnego (mienia komunalnego). Korzyści niematerialne mogą dotyczyć m.in. poprawy stanu zdrowia mieszkańców, warunków mieszkaniowych, lepszego dostępu do miejsc pracy, wyższego zakresu i jakości usług oświatowych, opieki społecznej, zaopatrzenia w wodę, czystości, poprawy stanu środowiska naturalnego na terenie gminy ${ }^{36}$. Sektor samorządowy odpowiedzialny jest za dostarczenie lokalnym społecznościom podstawowych usług, takich jak edukacja, ochrona zdrowia, opieka społeczna czy dostęp do podstawowej infrastruktury.

Zasadniczym instrumentem realizacji tych zadań są publiczne przedsięwzięcia inwestycyjne, dzięki którym możliwy jest szeroko pojmowany rozwój społeczno-gospodarczy. Inwestycje te najczęściej realizowane są w sferze ${ }^{37}$ :

${ }^{33}$ M. Kulesza, Burmistrz musi mieć prawo do ryzyka, „Gazeta Prawna” 2008, nr 82, s. 20.

${ }^{34}$ Ibidem.

${ }^{35}$ J. Czempas, Inwestycje gminne - zakres i pomiar, [w:] Polska samorzadność w integrujacej się Europie, I Forum Samorządowe, Fundacja na rzecz Uniwersytetu Szczecińskiego, Szczecin 2004, s. 85.

${ }^{36}$ Ibidem.

${ }^{37}$ Por. A. Drobniak, Ocena projektów publicznych, Wydawnictwo Akademii Ekonomicznej w Katowicach, Katowice 2005, s. 39-40. 
- społecznej - poprzez dążenie do poprawy standardów w zakresie usług edukacyjnych, ochronę najsłabszych grup społecznych, poprawę warunków funkcjonowania opieki zdrowotnej, przeciwdziałanie bezrobociu czy wzrost poczucia bezpieczeństwa;

- gospodarczej - sprzyjają wzrostowi gospodarczemu samorządów, wspieraniu prywatnego biznesu, restrukturyzację nieefektywnych branż;

- infrastrukturalnej - zmierzają do wzrostu sieci i liczby urządzeń infrastrukturalnych warunkujących rozwój lokalny i regionalny;

- środowiskowej - warunkują poprawę stanu środowiska.

Jak już wspomniano, najistotniejszą różnicą pomiędzy inwestycjami publicznymi a prywatnymi jest cel realizacji przedsięwzięcia. W przypadku gmin, powiatów, województw chodzi przede wszystkim o poprawę bytu lokalnej społeczności, dlatego podstawowym kryterium wyboru przedsięwzięć jest reżim ustawowy i wynikający z niego katalog obowiązkowych zadań publicznych. Analiza celowości przy wyborze przedsięwzięcia ma charakter wtórny. Wynika to z kontekstu społecznego (stopnia zaspokojenia potrzeb społecznych) oraz rozwojowego, widzianego przez pryzmat stopnia aktywizacji gospodarczej regionu $^{38}$. Mniejsze znaczenie przypisuje się okresowi zwrotu inwestycji czy możliwości jej samofinansowania z przyszłych wpływów, o czym świadczy postulat porównywania efektywności na etapie realizacji inwestycji, a nie na etapie jej wyboru ${ }^{39}$.

Zgodnie $\mathrm{z}$ art. 2 ustawy o samorządzie gminnym, gmina wykonuje zadania publiczne we własnym imieniu i na własną odpowiedzialność. Ponosi zatem pełną odpowiedzialność nie tylko za bieżące utrzymanie infrastruktury komunalnej w stanie sprawności technicznej, ale także za jej modernizację i rozbudowę oraz tworzenie nowej poprzez działania inwestycyjne.

Zdecydowana większość inwestycji realizowanych przez samorządy, to inwestycje infrastrukturalne. Infrastruktura jest kategorią ekonomiczną stanowiącą podstawowy element mienia komunalnego, służącą zarówno potrzebom produkcji jak i konsumpcji ${ }^{40}$.

W literaturze przedmiotu nie spotyka się jednolitej, ogólnie przyjętej definicji infrastruktury. Jak zauważa K. Brzozowska ${ }^{41}$ rozbieżności pojawiają się już w samej etymologii wyrazu ,infrastruktura”. Jej przydatność można uznać za ograniczoną z uwagi na zbyt ogólny charakter terminu, dlatego przytoczone

${ }^{38}$ Por. W. Misterek, Zewnętrzne źródła finansowania działalności inwestycyjnej jednostek samorzadu terytorialnego, Difin, Warszawa 2008, s. 35.

${ }^{39}$ Por. K. Brzozowska, Finansowanie inwestycji infrastrukturalnych przez kapitat prywatny na zasadach Project finance, Wydawnictwa Fachowe CeDeWu, Warszawa 2005, s. 67-70.

${ }^{40}$ A. Ginsberg-Gebert, Cz. Rudzka-Lorentz, M. Woźniak, A. Zielińska-Kołtyś, Infrastruktura komunalna a funkcjonowanie systemu osadniczego kraju, Ossolineum, Warszawa 1984, s. 242-243.

${ }^{41}$ Szerzej na temat genezy pojęcia infrastruktura i znaczenia pojęciowego pisze K. Brzozowska, Finansowanie inwestycji infrastrukturalnych przez kapitat prywatny..., s. 9-15. 
zostaną tylko wybrane definicje w celu podkreślenia znaczenia infrastruktury. Ponadto konstrukcja pojęcia uzależniana jest od akcentowanych cech i funkcji, jakie ma spełniać $\mathrm{w}$ życiu publicznym ${ }^{42}$.

W ujęciu encyklopedycznym infrastruktura to urządzenia, budynki i instytucje usługowe, których istnienie jest niezbędne do prawidłowego funkcjonowania gospodarki i społeczeństwa ${ }^{43}$. Infrastruktura w polskich badaniach ekonomicznych najwcześniej zdefiniowana została przez W. Grzywacza i Z. Dziembowskiego. Autorzy dokonali podziału infrastruktury na gospodarczą, stanowiącą impuls do rozwoju gospodarki, zaspokajającą materialne potrzeby społeczeństwa oraz infrastrukturę społeczną, która w sposób pośredni kreuje wzrost gospodarczy, zaspokajając potrzeby niematerialne ludności ${ }^{44}$.

T. Kamińska pisze, że

infrastruktura jest dobrem ekonomicznym, które warunkuje funkcjonowanie gospodarki w krótkim okresie i jako jedna $\mathrm{z}$ determinant decyduje o rozwoju w długim okresie ${ }^{45}$.

\section{A. Piskozub za infrastrukturę uważa zaś}

stworzone przez człowieka, trwale zlokalizowane, liniowe i punktowe obiekty użytku publicznego, stanowiące podbudowę życia społeczno-gospodarczego, z uwagi na ich funkcje przemieszczenia osób i ładunków, wiadomości, energii elektrycznej i wody ${ }^{46}$.

Definicja ta akcentuje publiczne znaczenie dóbr tworzących infrastrukturę oraz jej społeczno-gospodarczy wymiar.

Z. Karst rozumie infrastrukturę jako

zbiór urządzeń i instytucji użytku publicznego, wynikający z działalności człowieka trwale zlokalizowany i zorganizowany w systemy, których świadczenia mają istotne znaczenie dla funkcjonowania gospodarki i organizacji życia ludności w mieście i na wsi oraz które służą za pomocą różnych urządzeń technicznych funkcjom wytwarzania, przesyłania, rozdzielania i rozprowadzania, a więc przemieszczania $\mathrm{z}$ jednego na drugie miejsce: wody, ścieków, energii, wiadomości, obrazu, osób i ładunków ${ }^{47}$.

${ }^{42}$ D. Hajdys, Źródła finansowania inwestycji infrastrukturalnych realizowanych przez jednostki samorzadu terytorialnego, „Finanse Komunalne” 2007, nr 10, s. 5.

${ }^{43}$ Encyklopedia Popularna PWN..., s. 318.

44 Z. Dziembowski, Pojęcie infrastruktury i jej charakterystyka, „Miasto” 1966, nr 2; W. Grzywacz, Infrastruktura transportu a gospodarka narodowa, „Przegląd Komunikacyjny” 1983, nr 5 [za:] T. Kamińska, Makroekonomiczna ocena efektywności inwestycji infrastrukturalnych na przykładzie transportu, Wydawnictwo Uniwersytetu Gdańskiego, Gdańsk 1999, s. 46.

${ }^{45}$ T. Kamińska, Makroekonomiczna ocena efektywności inwestycji..., s. 11.

${ }^{46}$ A. Piskozub, Funkcja przemieszczenia jako cecha wspólna infrastruktury, „Problemy Ekonomiki Transportu. Biuletyn Informacyjny OBET" 1977, nr 2.

${ }^{47}$ Z. Karst, Techniczno-ekonomiczna infrastruktura gospodarki narodowej, Wydawnictwo Naukowe PWN, Warszawa 1986, s. 9-11. 
Przytoczona definicja w sposób bardzo szeroki traktuje zakres przedmiotowy infrastruktury oddając jej znaczenie w życiu każdego obywatela. Zwraca uwagę, iż obiekty tworzące infrastrukturę służą do przemieszczania i rozprowadzania, a więc rzeczywistego pokonywania przestrzeni. E. Gramlich infrastrukturę uważa

za naturalne monopole kapitałochłonne, takie jak autostrady, inne urządzenia transportowe, linie wodne i kanalizacyjne oraz systemy telekomunikacyjne ${ }^{48}$.

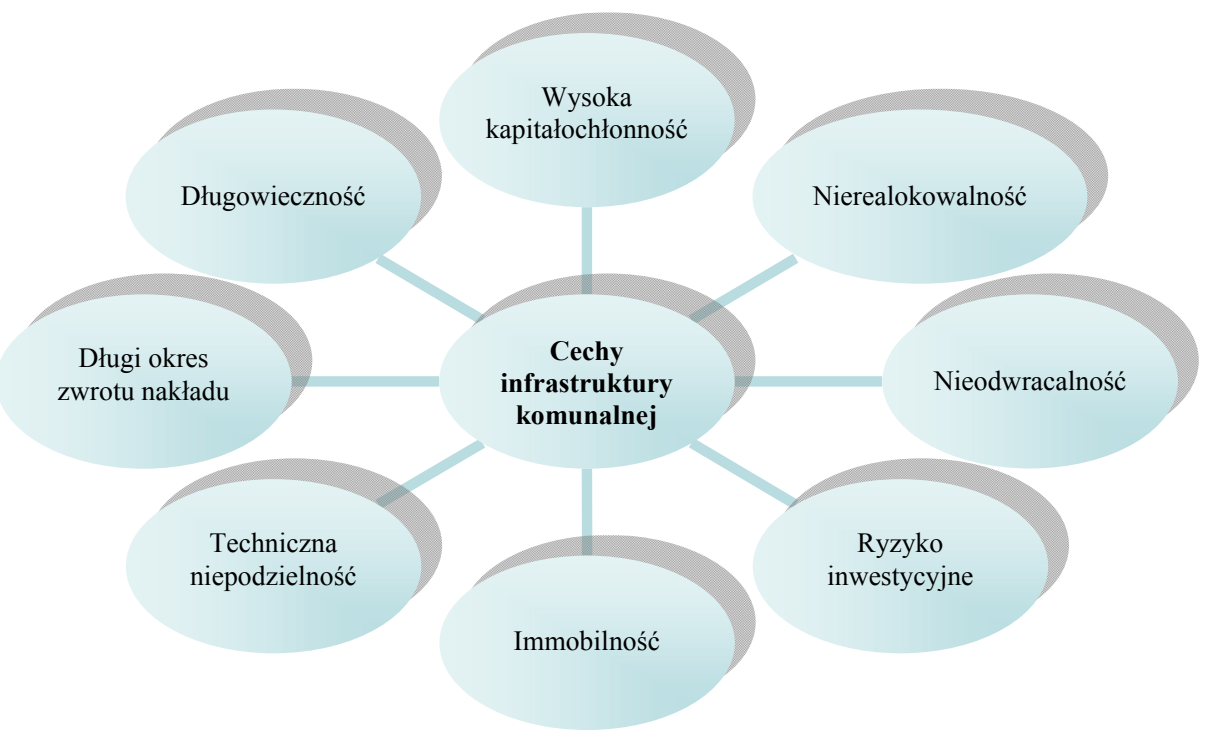

Schemat 3.1. Cechy infrastruktury komunalnej

Źródło: oprac. własne

Podsumowując, przez infrastrukturę należy rozumieć obiekty i urządzenia, w przeważającej części o charakterze przesyłowym, których celem jest umożliwienie funkcjonowania gospodarki i społeczeństwa. Można je podzielić uwzględniając kryterium funkcji na infrastrukturę gospodarczą (ekonomiczną) oraz infrastrukturę społeczną, według kryterium własności zaś - na publiczną i prywatną.

Infrastruktura pozostająca $\mathrm{w}$ zarządzaniu podmiotów samorządowych określana jest mianem infrastruktury komunalnej. Obejmuje podstawowe urządzenia $\mathrm{i}$ instytucje usługowe niezbędne do funkcjonowania gospodarki i społeczeństwa ${ }^{49}$. Cechuje ją wysoka kapitatochłonność, dlugowieczność, techniczna niepodzielność

${ }^{48}$ E. Gramlich, Infrastructure investment, „A Review Essay, Journal of Economic Literature” 1994, No 32 (3), s. 1177 [za:] K. Brzozowska, Finansowanie inwestycji infrastrukturalnych przez kapitat prywatny..., s. 13.

${ }^{49}$ Infrastruktura komunalna w 2010 r., Główny Urząd Statystyczny, Warszawa 2011, s. 7. 
obiektów oraz immobilność ${ }^{50}$, a także wysokie ryzyko inwestycyjne, długi okres zwrotu nakładów inwestycyjnych, nieodwracalność i nierealokowalność nakładów na nią ponoszonych, ograniczona możliwość podziału procesu inwestycyjnego na etapy $^{51}$ (schemat 3.1).

Znamienną cechą inwestycji samorządowych jest fakt, że mają one charakter ciągły, co powoduje systematyczne obciążenie budżetu jednostki. Zakres ilościowy i wartościowy potrzeb inwestycyjnych w zakresie infrastruktury stanowi jeden z poważnych problemów rozwoju wielu samorządów gminnych. Poszczególne obszary gospodarki komunalnej wymagają znacznych nakładów inwestycyjnych w celu sprostania potrzebom społecznym oraz wymogom wynikającym m.in. z Traktatu Akcesyjnego. Do szczególnie kapitałochłonnych oraz technologicznie i technicznie skomplikowanych branż komunalnych należą sektory wodnokanalizacyjny, energetyczny, ciepłowniczy, gospodarka odpadami. Specyfika finansowania inwestycji samorządowych polega na tym, że inwestycje infrastrukturalne stanowią element wydatków budżetowych. W długim okresie i przy nasilających się potrzebach w tym obszarze środki własne stają się niewystarczające. Wprawdzie samorządy mają możliwość pozyskiwania przychodów zwrotnych w postaci pożyczek, kredytów, emisji papierów wartościowych, jednak w dłuższym okresie tylko dochody, a ściślej nadwyżki dochodów ponad poziom wydatków bieżących, pozostają ostatecznym źródłem finansowania. Ograniczenia w pozyskiwaniu zwrotnych źródeł wynikają z konieczności wygospodarowania w przyszłości wolnych środków na spłatę zadłużenia. Jest to szczególnie widoczne w przypadku jednostek wiejskich i słabo rozwiniętych, gdzie większość dochodów pochłaniana jest przez wydatki bieżące ${ }^{52}$.

Specyfiką inwestycji samorządowych jest to, że część z nich pociąga za sobą konieczność ponoszenia określonych nakładów finansowych przez mieszkańców danej jednostki. To powoduje, że część usług jest świadczona odpłatnie (usługi wodno-kanalizacyjne), a część nieodpłatnie (edukacja, opieka społeczna). W przypadku inwestycji płatnych może się okazać, że struktura demograficzna i gospodarcza, preferencje odbiorców uniemożliwią osiągnięcie wcześniej zakładanych rezultatów i konieczne będzie poszukiwanie nowych rozwiązań organizacyjnych. W sytuacji, gdy własne zasoby rzeczowo-finansowe okazują się niewystarczające, potrzeba efektywnego wywiązywania się z rosnącej liczby

${ }^{50}$ Cz. Rudzka-Lorentz, J. Sierak, Zarządzanie finansami gmin, [w:] Zarządzanie gospodarka i finansami gmin, red. H. Sochacka-Krysiak, Oficyna Wydawnicza SGH, Warszawa 2006, s. 232.

${ }^{51}$ Por. M. Zioło, Zewnętrzne źródla finansowania infrastruktury komunalnej na przykładzie Gminy Miasto Szczecin, [w:] Gospodarka finansowa jednostki samorzadu terytorialnego. Zagadnienia wybrane, red. L. Patrzałek, Wydawnictwo Wyższej Szkoły Bankowej w Poznaniu, Poznań 2010, s. 354; H. Janowska, Strategie finansowania gminnych inwestycji infrastrukturalnych w Polsce, Wydawnictwo Uniwersytetu Szczecińskiego, Szczecin 2002, s. 6.

52 Działalność inwestycyjna jednostek samorządu terytorialnego w latach 1999-2004, www.rio.gov.pl (10.05.2012). 
zadań oraz towarzyszące temu ograniczenia budżetowe skłaniają władze lokalne do sięgnięcia po kapitał prywatny ${ }^{53}$. Inicjowanie partnerskiej współpracy wynika także ze zmiany w dotychczasowej koncepcji finansowania inwestycji komunalnych. Do głównych czynników, które wpłynęły na zmianę podejścia należy zaliczyć:

- proces deregulacji i decentralizacji zadań publicznych, polegający na przeniesieniu miejsca realizacji zadania jak najbliżej obywatela, oraz rezygnacja podmiotów publicznych z roli bezpośredniego operatora i zarządcy infrastruktury na rzecz organizatora i kontrolera realizowanych przez sektor prywatny zadań publicznych;

- wzrost potrzeb społecznych w zakresie rozwoju i modernizacji infrastruktury, podyktowany procesami globalizacji, mobilnością społeczeństwa, wzrostem wymagań co do poziomu świadczeń w zakresie edukacji, ochrony zdrowia, opieki społecznej;

- rosnące zadłużenie, powodujące niedobór środków finansowych niezbędnych do rozwoju sektora publicznego, co wpływa na rosnąca lukę finansową w relacji: obecne i przyszłe potrzeby tego sektora a faktyczne możliwości ich realizacji;

- rozwój rynków finansowych oraz wzrost płynności i mobilności kapitału prywatnego, co powoduje rosnące zainteresowanie sektora prywatnego publicznymi inwestycjami; zaangażowanie kapitału prywatnego znacznie wpływa na wartość dodaną, co skutkuje odpowiednim poziomem zwrotu z jego zainwestowania.

Stale poszerzający się zakres zadań publicznych realizowanych przez jednostki samorządu terytorialnego oraz brak adekwatności $\mathrm{w}$ środkach na ich realizację powiększają rozbieżności pomiędzy potrzebami inwestycyjnymi a możliwościami finansowymi. Dodatkowo postęp techniczny, technologiczny, procesy globalizacji uwidaczniają nowe oczekiwania, w przypadku których ciężar realizacji spada na samorządy, zwiększając tym samym ich wydatki inwestycyjne. Przykładem są popularne ostatnio ścieżki rowerowe czy dostęp do internetu szerokopasmowego. Pilącym problemem w ostatnim czasie staje się kwestia dostosowania gospodarki odpadami do nowych przepisów krajowych i unijnych. W tym kontekście decyzja dotycząca realizacji inwestycji powinna zostać poprzedzona prawidłowym procesem planowania długookresowego i oceną efektywności poszczególnych działań.

Inwestycje komunalne realizowane przez poszczególne samorządy powinny: oddziaływać na poziom życia mieszkańców, umożliwiać prowadzenie działalności inwestycyjnej przez inwestorów, tworzyć bazę techniczną pod

${ }^{53}$ P. Galiński, Zarzadzanie ryzykiem $w$ inwestycjach jednostek samorzadu terytorialnego, [w:] Finanse publiczne, red. J. Sokołowski, M. Sosnowski, A. Żabiński, Prace Naukowe Uniwersytetu Ekonomicznego we Wrocławiu nr 112, Wydawnictwo Uniwersytetu Ekonomicznego we Wrocławiu, Wrocław 2010, s. 157; S. Jasiewicz, W. Rogowski, Inwestycje hybrydowe - nowe ujęcie oceny efektywności, Oficyna Wydawnicza SGH, Warszawa 2009, s. 20. 
tereny inwestycyjne ${ }^{54}$. Decyzja o charakterze inwestycji winna być w samorządzie decyzją przemyślaną i perspektywiczną. W tym obszarze działalność samorządu nabiera szczególnego znaczenia i sprzyja tworzeniu tzw. klimatu inwestycyjnego. Pojęcie to często utożsamiane jest $\mathrm{z}$ atrakcyjnością inwestycyjną rozumianą jako tworzenie warunków do przyciągania inwestorów zainteresowanych nowymi inwestycjami lub wnoszeniem kapitału w już istniejące na danym terenie przedsięwzięcia ${ }^{55}$. Nieodzownym warunkiem jest tu jednak istniejąca już infrastruktura i jej stan techniczny, które ułatwiają lub utrudniają prowadzenie bieżącej działalności i przyszłych inwestycji.

\subsection{Pomiar efektywności inwestycji jednostek samorządu terytorialnego}

\subsubsection{Efektywność inwestycji jednostek samorządu terytorialnego}

Efektywność w najprostszym rozumieniu kojarzy się z tzw. dobrym gospodarowaniem. W teorii ekonomii gospodarowanie definiowane jest jako świadome działanie podmiotów (publicznych/prywatnych) polegające na rozdzieleniu ograniczonych zasobów pomiędzy konkurencyjne przedsięwzięcia na podstawie racjonalnych przesłanek i przy użyciu tych zasobów osiągnięcie możliwie najlepszego (optymalnego) wyniku, tj. wytworzenia i podziału wartości (dóbr i usług) w sposób zapewniający zaspokojenie potrzeb społecznych, a jednocześnie oszczędne ich spożytkowanie bez szkody dla środowiska naturalnego i warunków życia społeczeństwa. W praktyce oznacza to konieczność poszukiwania w określonych warunkach (prawnych, politycznych, ekonomicznych) optymalnego punktu, w którym poniesione nakłady skalkulują się z wynikami ekonomicznymi i społecznymi. Dobre gospodarowanie to przede wszystkim racjonalne gospodarowanie, które w odniesieniu do procesów gospodarczych wiąże się z podejmowaniem ekonomicznie uzasadnionych decyzji i ze skutecznym działaniem. W szerszym kontekście odnoszone jest do efektywności oznaczającej uzyskanie jak najlepszych rezultatów w zakresie produkcji oraz dostarczanie dóbr i usług po najniższych kosztach ${ }^{56}$. Pojęcie efektywności zazwyczaj kojarzone jest z działalnością przedsiębiorstwa. Słownik ekonomiczny

${ }^{54}$ J. Rosińska, Źródła finansowania inwestycji komunalnych na przykładzie miast na prawach powiatu w województwie zachodniopomorskim, [w:] Samorzad terytorialny $w$ zintegrowanej Europie, t. 2, red. B. Filipiak, A. Szewczuk, Uniwersytet Szczeciński, Zeszyty Naukowe nr 426, Ekonomiczne Problemy Usług nr 1, Szczecin 2006, s. 159 i n.

${ }^{55}$ Zob. R. Waśkiewicz, Budżet zadaniowy jako narzędzie racjonalizacji wydatków inwestycyjnych $w$ gminie, [w:] Budżet zadaniowy metoda racjonalizacji wydatków, red. B. Woźniak, M. Postuła, Oficyna Wydawnicza SGH, CeDeWu Sp. z o.o., Warszawa 2012, s. 287.

56 Por. J. Penc, Leksykon biznesu, Wydawnictwo Placet, Warszawa 1997, www.placet.pl (14.05.2012). 
przedsiębiorcy określa efektywność ekonomiczną jako stosunek między wartością poniesionych nakładów a wartością efektów uzyskanych dzięki tym nakładom. Przedsiębiorstwa dążą do pełnego wykorzystania posiadanych zasobów $^{57}$. Efektywność opiera się na zasadach racjonalnego działania, które polega na uzyskaniu maksymalnego efektu przy danych nakładach lub minimalizacji nakładów przy danym efekcie. Nieefektywne gospodarowanie może prowadzić do stopniowego wyczerpania się zasobów podmiotu, a w konsekwencji nawet do jego upadku ${ }^{58}$.

W teorii ekonomii wyróżnia się dwa rodzaje efektywności - produkcyjną oraz alokacyjną. Pierwsza wyraża przeciętny koszt wytworzenia produktu lub usługi. Wskaźnikiem efektywności produkcji jest jednostkowy koszt produkcji. Wyrazić ją można także za pomocą wskaźnika rentowności w relacji do kosztów lub przychodów. Efektywność alokacyjna dotyczy zgodności struktury produkcji wytworzonej przez system ekonomiczny ze strukturą preferencji konsumpcyjnych ludności ${ }^{59}$. Jest praktycznie niemierzalna. Często określa się ją jako efektywność lub optimum Pareta (teorii leżącej u podstaw nowoczesnej teorii dobrobytu). Według Pareta optymalna sytuacja występuje wówczas, gdy nie ma sposobu poprawienia sytuacji niektórych grup ludzi bez pogorszenia sytuacji innych. Wielkość podaży na rynku dóbr i usług to taka wielkość, przy której krzywe podaży i popytu przecinają się, gdyż jest to jedyny punkt, gdzie cena jaką nabywcy są skłonni zapłacić za dodatkową jednostkę dobra równa się cenie, za jaką dostawcy są skłonni tę dodatkową jednostkę dostarczyćc ${ }^{60}$. Gospodarka osiąga optymalną alokację w warunkach konkurencji doskonałej. W rzeczywistości rynki odbiegają od tego modelu. Przedsiębiorstwa dążą do maksymalizacji zysku poprzez konkurencję pomiędzy podmiotami nie tylko wewnątrz gałęzi, ale także między gałęziami. Międzygałęziowa konkurencja powoduje przepływ kapitału z gałęzi o niższej do gałęzi o wyższej stopie zysku. W wyniku przepływu kształtuje się przeciętna stopa zysku w gospodarce. W efekcie następuje poprawa efek-

${ }^{57}$ Stownik ekonomiczny przedsiębiorcy, red. Z. Dowgiałło, Wydawnictwo Znicz, Warszawa 2004, s. 94 i n.

${ }^{58}$ Por. G. Gołębiowski, A. Tłaczała, Analiza ekonomiczno-finansowa w ujęciu praktycznym, Difin, Warszawa 2005, s. 95; B. Granosik, Metody oceny efektywności inwestycji rzeczowych w zarządzaniu przedsiębiorstwem, Wydawnictwo Politechniki Koszalińskiej, Koszalin 2007, s. 34; szerzej problem efektywności inwestycji w podmiotach prywatnych i publicznych przedstawia Z. Grzymała, Inwestycje komunalne $w$ miastach, [w:] Inwestycje w mieście. Uwarunkowania ekonomiczne, organizacyjne i przestrzenne, red. M. J. Nowak, T. Skotarczak, CeDeWu Sp. z o.o., Warszawa 2012; W. Bachor, Efektywność majątku trwałego w spótkach komunalnych. Wybrane zagadnienia i wyniki badań, Oficyna Wydawnicza SGH, Warszawa 2009.

${ }^{59}$ A. Zalewski, Reformy sektora publicznego $w$ duchu nowego zarzadzania publicznego, [w:] Nowe zarządzanie publiczne $w$ polskim samorzadzie terytorialnym, red. A. Zalewski, Oficyna Wydawnicza SGH, Warszawa 2005, s. 46.

${ }^{60}$ H. Varian, Mikroekonomia, Kurs średni - ujęcie nowoczesne, Wydawnictwo Naukowe PWN, Warszawa 2006, s. 328. 
tywności alokacyjnej całej gospodarki, ponieważ przesunięcie zasobów do produkcji dóbr o wyższej zyskowności prowadzi do zwiększenia ich produkcji i lepszego dostosowania struktury produkcji do preferencji konsumentów ${ }^{61}$.

Efektywność inwestycji może być szacowana ex ante i ex post. Efektywność ex ante polega na zidentyfikowaniu i szacowaniu przewidywanych (przyszłych) efektów, nakładów, czasu, obarczona jest zawsze ryzykiem niedokładności. Efektywność ex post dotyczy skutków określonych działań, a więc faktycznych rezultatów. Stopień dokładności efektów jest wyższy, obarczony niższym ryzykiem $^{62}$. Ocena efektywności przedsięwzięć powinna opierać się na zasadach, które w większości mają charakter uniwersalny (tzn. mają zastosowanie zarówno w analizie ekonomicznej, jak i finansowej) i dzielą się na dwie zasadnicze grupy:

- dotyczące procesu oceny efektywności, oraz

- dotyczące metod oceny efektywności.

Tabela 3.2

Zasady oceny efektywności przedsięwzięć inwestycyjnych

\begin{tabular}{|c|c|}
\hline Zasada efektywności & Interpretacja \\
\hline 1 & 2 \\
\hline \multicolumn{2}{|c|}{ Zasady dotyczace procesu oceny efektywności przedsięwzięć inwestycyjnych } \\
\hline $\begin{array}{l}\text { Zasada dodatkowości (addytyw- } \\
\text { ności) }\end{array}$ & $\begin{array}{l}\text { Postuluje, aby podstawą oceny efektywności projektu były } \\
\text { jedynie te strumienie pieniężne, które bezpośrednio wpływa- } \\
\text { ją na przedsięwzięcie }\end{array}$ \\
\hline Zasada porównywalności & $\begin{array}{l}\text { Postuluje, aby ocena dokonana została przy uwzględnieniu } \\
\text { zależności przyczynowo-skutkowej pomiędzy nakładami } \\
\text { a efektami przedsięwzięcia inwestycyjnego }\end{array}$ \\
\hline $\begin{array}{l}\text { Zasada ignorowania kosztów } \\
\text { utopionych }\end{array}$ & $\begin{array}{l}\text { Postuluje wyeliminowanie kosztów poniesionych przed } \\
\text { podjęciem decyzji inwestycyjnej, w sytuacji gdy nie istnieje } \\
\text { szansa ich odzyskania w momencie zaniechania realizacji } \\
\text { przedsięwzięcia }\end{array}$ \\
\hline $\begin{array}{l}\text { Zasada określenia okresu życia } \\
\text { przedsięwzięcia }\end{array}$ & $\begin{array}{l}\text { Postuluje określenie realnego okresu życia przedsięwzięcia } \\
\text { uwzględniającego czynniki techniczne, rynkowe, społeczne }\end{array}$ \\
\hline $\begin{array}{l}\text { Zasada wartości końcowej } \\
\text { (rezydualnej) }\end{array}$ & $\begin{array}{l}\text { Postuluje uwzględnienie wartości rezydualnej jeśli technicz- } \\
\text { na/społeczna/rynkowa wartość przedsięwzięcia przekracza } \\
\text { przewidywany okres eksploatacji bądź gdy po zakończeniu } \\
\text { inwestycji pozostaną składniki o dodanej wartości }\end{array}$ \\
\hline Zasada spójności & $\begin{array}{l}\text { Postuluje przyjęcie do oceny efektywności jednolitych para- } \\
\text { metrów np. stopa dyskontowa, inflacja, waluta, dla wszyst- } \\
\text { kich ocenianych projektów }\end{array}$ \\
\hline $\begin{array}{l}\text { Zasada nieuwzględnienia } \\
\text { kosztów niepieniężnych } \\
\text { (księgowych) }\end{array}$ & $\begin{array}{l}\text { Postuluje oparcie analizy na wielkościach mających charakter } \\
\text { realny przepływów wartości }\end{array}$ \\
\hline
\end{tabular}

${ }^{61}$ T. P. Tkaczyk, Wybrane problemy konkurencji, WESI, Warszawa 2000, s. 15.

${ }^{62}$ Por. J. Penc, Leksykon biznesu... 


\begin{tabular}{|l|l|}
\hline \multicolumn{1}{|c|}{ Zasady dotyczace metod oceny efektywności projektów inwestycyjnych } \\
\hline Zasada jednoznaczności & $\begin{array}{l}\text { Postuluje opracowanie procedury oceny efektywności } \\
\text { inwestycji, która pozwoli na porównywalność rezultatów } \\
\text { bez względu na osobę dokonującą oceny }\end{array}$ \\
\hline Zasada uniwersalności & $\begin{array}{l}\text { Postuluje zastosowanie takich metod (algorytmów) oceny } \\
\text { efektywności przedsięwzięć, które zagwarantują porówny- } \\
\text { walność wyników }\end{array}$ \\
\hline Zasada spójności & $\begin{array}{l}\text { Interpretacja zasady jednoznaczna jak przy zasadach dotyczą- } \\
\text { cych procesu oceny efektywności przedsięwzięć inwesty- } \\
\text { cyjnych }\end{array}$ \\
\hline
\end{tabular}

Źródło: oprac. własne na podstawie M. Molo, Zasady oceny efektywności ekonomicznej realizowanych przedsięwzięć, s. 14, www.malopolskie.pl/pliki/2008/ekspertyza_efektywnosc _ekonomiczna.pdf (14.05.2012).

Odnosząc efektywność ekonomiczną do problematyki inwestycji samorządowych analogicznie można zauważyć, że jest to stosunek między środkami wydatkowanymi na realizację inwestycji a uzyskanymi dzięki nim efektami. Dążenie do efektywności inwestycji jest naturalnym działaniem samorządów i wynika z dwóch przesłanek, po pierwsze z ograniczonych zasobów, po drugie z nieograniczonych potrzeb. Problem ten dotyczy zwłaszcza gmin, które z uwagi na ograniczone możliwości finansowe i ogromne potrzeby inwestycyjne, w tym także w obszarze infrastruktury, powinny poszukiwać wszelkich dostępnych sposobów na podniesienie efektywności wydatków na cele inwestycyjne. Punktem wyjścia tych poszukiwań winna być zmiana w sposobie zarządzania wpisująca się obecnie w nurt nowego zarządzania publicznego powszechnie zwanego jako New Public Management (NPM). Samorządy gminne poświęcają około $80-90 \%$ swoich zasobów finansowych na dostarczanie dóbr i usług publicznych, co pozwala spojrzeć na nie jak na przedsiębiorstwa ${ }^{63}$. Jednocześnie należy wyraźnie wskazać, że w swojej działalności są monopolistami na danym terenie, a więc znajdują się $\mathrm{w}$ uprzywilejowanej pozycji. Nie determinuje to możliwości wprowadzania procedur i narzędzi wykorzystywanych w zarządzaniu komercyjnym, pamiętać musimy bowiem o tym, że nie wszystkie rozwiązania stosowane $\mathrm{w}$ sektorze prywatnym nadają się do adaptacji w sektorze samorządowym. Samorządy w celu podniesienia efektywności inwestycji muszą w pełni wykorzystać także możliwości, jakie daje prawo i rozwiązania ekonomiczne dla sektora samorządowego. Chodzi przede wszystkim o zamówienia publiczne oraz zarządzanie strategiczne i budżetowanie.

Podstawą racjonalizacji wydatków samorządowych jest badanie ich efektywności, które w ujęciu sformalizowanym wymaga porównania uzyskanych

${ }^{63}$ Por. A. Zimny, Uwarunkowania efektywności inwestycji gminnych w sferze infrastruktury technicznej, Państwowa Wyższa Szkoła Zawodowa w Koninie, Konin 2008, s. 24 i n. 
efektów z poniesionymi nakładami. W ujęciu bardziej ogólnym władza samorządowa powinna kierować się zasadą maksymalizacji efektu przy minimalizacji nakładów lub minimalizacji nakładów przy danych efektach ${ }^{64}$. Porównanie nakładów z efektami może dać wynik dodatni (nadwyżkę finansową) lub ujemny (deficyt).

Analizując efektywność inwestycji samorządowych należy mieć na uwadze przede wszystkim efekt, jaki zostaje osiągnięty dzięki wydatkowaniu środków publicznych. Zostaje on poddany ocenie, której celem jest

weryfikacja racjonalności społeczno-ekonomicznej wydatkowanych środków. Kwestia bezpośrednich korzyści finansowych dla inwestora (który nie działa w celu osiągnięcia zysku) jest drugorzędna, a zatem ocena efektywności finansowej przedsięwzięcia powinna służyć przede wszystkim ocenie płynności finansowej (która wpływa na trwałość) i finansowej wykonalności przedsięwzięcia ${ }^{65}$.

W odniesieniu do jednostek samorządu terytorialnego ocena efektywności inwestycji komunalnych powinna być dokonywana z punktu widzenia korzystających z usług (mieszkańca) i samej jednostki samorządowej. Usługi świadczone przez samorząd zaspokajają podstawowe potrzeby społeczne i należą do tych kategorii, w których rynek jako mechanizm alokacji zasobów zawodzi. W związku z tym decyzje o zakresie i charakterze usług podejmują władze i nie podlegają one weryfikacji rynkowej tylko społecznej poprzez określenie sprawiedliwości $\mathrm{w}$ dostępie do świadczeń oraz stopnia ich dostosowania do potrzeb i preferencji ludności ${ }^{66}$. W celu dokonania oceny efektywności wydatków dokonywanych przez władze samorządowe niezbędne jest zastosowanie procedur zmierzających do ${ }^{67}$ :

- zidentyfikowania alternatywnych rozwiązań, do których należy także utrzymanie status quo,

- zidentyfikowania konsekwencji każdego postępowania w kategoriach rzeczowych (wielkości nakładów, efektów jakie pociąga za sobą każdy projekt) w całym okresie trwania przedsięwzięcia,

- oszacowania, na podstawie liczby i cen rynkowych czynników wytwórczych, kosztów i przychodów w całym okresie trwania przedsięwzięcia,

${ }^{64}$ Budżet władz lokalnych. Narzędzie zarządzania, red. S. Owsiak, PWE, Warszawa 2002, s. 50. Problem efektywności i jej pomiaru w sektorze publicznym szczegółowo analizie poddany został przez T. Strąka, Modele dokonań jednostek sektora finansów publicznych, Difin, Warszawa 2012.

${ }^{65}$ M. Molo, Zasady oceny efektywności ekonomicznej realizowanych przedsięwzięć, s. 14, www.malopolskie.pl/pliki/2008/ekspertyza_efektywnosc_ekonomiczna.pdf (14.05.2012).

${ }^{66}$ A. Zalewski, Reformy sektora publicznego $w$ duchu nowego zarzadzania ..., s. 48.

${ }^{67}$ Por. K. Gałuszka, Ocena efektywności finansowania rozwoju lokalnego, [w:] Finanse samorzadu terytorialnego. Zagadnienia wybrane, red. L. Patrzałek, Wydawnictwo Wyższej Szkoły Bankowej w Poznaniu, Poznań-Wrocław 2005, s. 142. 
- zdyskontowania kosztów i przychodów,

- zsumowania zdyskontowanych kosztów i przychodów oraz skalkulowania oczekiwanej stopy zwrotu dla każdego wariantu przedsięwzięcia, tak aby wybrać najbardziej optymalne (zyskowne) rozwiązanie.

Pomiar efektywności w sektorze publicznym nie jest zjawiskiem łatwym. O ile w przypadku inwestycji realizowanych przez sektor prywatny określenie ich efektywności nie stwarza problemów, ponieważ zarówno nakłady, jak i efekty mają na ogół charakter wymierny wyrażony w pieniądzu, a decydującą rolę odgrywają kryteria ekonomiczno-finansowe, to w przypadku inwestycji sektora samorządowego jest to zadaniem bardzo złożonym i możliwym do realizacji jedynie w ograniczonym zakresie. Określenie wysokości nakładów nie stwarza większych problemów, natomiast określenie efektów bywa kłopotliwe, mają one bowiem wymiar nie tylko ekonomiczno-finansowy, ale także społeczny, a nawet ekologiczny i ujawnić się mogą ze znacznym opóźnieniem ${ }^{68}$. Ustalenie korzyści społecznych następuje w sposób arbitralny, według oceny każdego zainteresowanego. Ocena ma charakter jakościowy, a nie ilościowy. Dodatkową komplikacją przy takiej ocenie może być fakt, że część obywateli nie odniesie żadnych korzyści, może zaś ponieść koszty (podwyższonych opłat) ${ }^{69}$.

Kolejnym podstawowym pytaniem, jakie się tu pojawia, jest problem wyceny efektów. Jakie ceny przyjąć? Nie zawsze możliwe jest przyjęcie cen rynkowych za dostarczane dobra i świadczone usługi, a zastosowanie innych cen (niższych) uniemożliwia pomiar, ponieważ nie będą one w pełni odzwierciedlać rzeczywistych kosztów poniesionych na wytworzenie dobra lub świadczenie usługi $i^{70}$.

\subsubsection{Metody oceny efektywności inwestycji jednostek samorządu terytorialnego}

Dokonując analizy przygotowanego przedsięwzięcia oraz dokonując oceny jego efektywności (opłacalności) jednostka samorządu terytorialnego musi dysponować odpowiednimi narzędziami, które pozwolą na dokonanie takiej oceny. Służyć temu będą różne koncepcje, metody, wskaźniki mające bardzo

${ }^{68}$ Efekty działań jednostek samorządu terytorialnego przedstawia M. Poniatowicz, J. M. Salachna, D. Perło, Efektywne zarzadzanie dtugiem w jednostkach samorzadu terytorialnego, Wolters Kluwer, Warszawa 2010, s. 48.

${ }^{69}$ K. Gałuszka, Efektywność sektora publicznego a alokacja dóbr publicznych, [w:] Finanse samorządu terytorialnego, red. L. Patrzałek, „Zeszyty Naukowe Wyższej Szkoły Bankowej we Wrocławiu" 2011, nr 21 [Wydawnictwo Wyższej Szkoły Bankowej, Poznań 2011], s. 123; idem, Efektywność wydatków inwestycyjnych jednostek samorzadu terytorialnego, [w:] Polska samorządność w integrującej się Europie, I Forum Samorządowe, Wydział Zarządzania i Ekonomiki Usług Uniwersytetu Szczecińskiego, Szczecin 2004, s. 124.

${ }^{70}$ B. Filipiak, Finanse samorządowe. Nowe wyzwania bieżace i perspektywiczne, Difin, Warszawa 2011, s. 144. 
prostą konstrukcję lub wymagające dokładniejszej analizy i bardziej szczegółowego rozpatrywania poszczególnych faz realizacji inwestycji. Przedsięwzięcia inwestycyjne samorządów bada się w kontekście trwałości finansowej oraz efektywności ekonomicznej. Trwałość finansowa jest istotna, ponieważ pokazuje aktualne i przyszłe możliwości budżetowe jednostki ${ }^{71}$.

Analiza i ocena samorządowych przedsięwzięć inwestycyjnych jest zagadnieniem istotnym i ważkim z punktu widzenia całokształtu działalności samorządu terytorialnego. Od wyników analizy zależy, czy dana inwestycja będzie realizowana, czy też zostanie odrzucona. Kluczowe znaczenie przy ocenie efektywności realizacji zadań inwestycyjnych w samorządzie ma wybór metody pomiaru nakładów i efektów. Przedsięwzięcie inwestycyjne bez względu na rozmiary nakładów inwestycyjnych, oczekiwane korzyści, źródła finansowania, czas realizacji i eksploatacji wymaga indywidualnego traktowania ${ }^{72}$. Wynika to ze specyfiki usług komunalnych świadczonych za pośrednictwem zespołu urządzeń technicznych i obiektów powstających w efekcie realizacji inwestycji. Trudność metodyczna przy wyborze mierników oceny samorządowych przedsięwzięć inwestycyjnych jest pochodną dużego zróżnicowania działalności. Publiczny charakter usług powoduje, że należy dokonać takiego doboru mierników, które pozwolą przeprowadzić rachunek inwestycji. Należy jednak zaznaczyć, że ograniczenie analiz oceny inwestycji tylko do kryteriów ekonomicznych może nie dać odpowiedzi dotyczących rzeczywistych relacji kosztów i korzyści z planowanej inwestycji. Jak proponuje A. Sulejewicz ${ }^{73}$ analizę finansową należy poszerzyć o aspekty ogólnospołeczne i gospodarcze.

Analiza przedsięwzięcia jest procesem iteracyjnym, z którym mamy do czynienia $^{74}$ :

- w momencie uruchomienia przedsięwzięcia (faza przedinwestycyjna), aby progresywnie pogłębiać jego analizę i znaleźć rozwiązanie, które może być realizowane,

- okresowo, w trakcie realizacji przedsięwzięcia, kiedy zmiany w otoczeniu, poziomie wiedzy lub stwierdzone rozbieżności w stosunku do informacji wyjściowych prowadzą do zrewidowania wcześniejszej analizy.

Metody oceny efektów przedsięwzięć inwestycyjnych mają wskazać korzyści, jakie osiąga dana jednostka samorządu terytorialnego z przeprowadzonego procesu inwestycyjnego. Metody oceny efektywności stosowane są tylko do tych inwestycji, z którymi wiąże się w przyszłości odpłatność. Korzyść

${ }^{71}$ J. Sierak, R. Górniak, Ocena efektywności i finansowanie projektów inwestycyjnych jednostek samorząu terytorialnego wspólfinansowanych funduszami Unii Europejskiej, Oficyna Wydawnicza SGH, Warszawa 2011, s. 84.

72 Z. Grzymała, Inwestycje komunalne w miastach..., s. 161.

${ }^{73}$ A. Sulejewicz, Analiza społecznych kosztów i korzyści. Między ekonomia dobrobytu a planowaniem rozwoju, Wydawnictwo Naukowe PWN, Warszawa 1991, s. 5.

${ }^{74}$ H. Brandenburg, Zarządzanie projektami, Wydawnictwo Politechniki Śląskiej, Gliwice 1999, s. 84. 
z przedsięwzięcia inwestycyjnego, która stanowi podstawę oceny efektywności (opłacalności), ma charakter korzyści netto, tzn. stanowi różnicę między efektami uzyskanymi z inwestycji a nakładami i kosztami poniesionymi na jej realizację i funkcjonowanie. Korzyść netto z inwestycji (zwaną także korzyścią różnicową) można wyrazić dwoma wielkościami ekonomicznymi: zyskiem oraz przepływem pieniężnym netto. Korzyść inwestycyjna wyrażona zyskiem (ujęcie memoriałowe) obejmuje przychody, koszty i nakłady inwestycyjne. Przychody powstają w wyniku sprzedaży usług, koszty ponoszone są w związku ze świadczeniem usług lub dostarczaniem dóbr, natomiast nakłady inwestycyjne obejmują trzy podstawowe grupy: nakłady na rzeczowe składniki majątku trwałego, nakłady przedinwestycyjne (koszty pozyskania kapitału, opracowanie dokumentacji technicznej, koszty analiz przedinwestycyjnych) oraz nakłady na kapitał obrotowy ${ }^{75}$.

Przedstawienie korzyści $\mathrm{z}$ inwestycji $\mathrm{w}$ postaci przepływów pieniężnych netto, zdaniem R. Aggarwala ${ }^{76}$, z metodycznego punktu widzenia jest bardziej złożone i powinno być wykonane jako pierwsza i podstawowa czynność przy ocenie jej opłacalności. Należy w niej określić kierunki przepływu środków pieniężnych oraz rodzaj strumienia pieniężnego, czyli wydatki (wartość środków pieniężnych wydatkowanych $\mathrm{w}$ związku z realizacją i eksploatacją inwestycji) oraz wpływy (wartość środków pieniężnych uzyskiwanych w związku z realizacją i eksploatacją inwestycji) ${ }^{77}$. Prawidłowe określenie przepływów pieniężnych inwestycji wymaga rzetelnej analizy rozłożenia w czasie poszczególnych elementów strumieni pieniężnych generowanych przez inwestycję. W trakcie szacowania przepływów mogą wystąpić problemy wynikające $\mathrm{z}$ indywidualnego charakteru przedsięwzięcia, dostępności i wiarygodności posiadanych informacji. Stwarza to trudności w wypracowaniu uniwersalnych zasad szacowania przepływów pieniężnych. W literaturze zwraca się uwagę na cztery ogólne zasady, których przestrzeganie zapewnia bezbłędny i efektywny proces szacowania. Należą do nich zasady przyrostowości, ignorowania nakładów i kosztów już poniesionych, kosztów utraconych korzyści oraz nieujmowania bezpośredniego amortyzacji jako elementu przepływów pieniężnych ${ }^{78}$. W praktyce przepływy pieniężne netto mogą w jednym okresie przyjmować zarówno wartość ujemną, jak i wartość dodatnią. Ujemna występuje wtedy, gdy $\mathrm{w}$ danym okresie mamy do czynienia $\mathrm{z}$ samymi wydatkami lub wydatki są

${ }^{75}$ W. Rogowski, Rachunek efektywności inwestycji..., s. 69.

${ }^{76}$ R. Aggarwal, Capital Budgeting Under Uncetainty, Prentice-Hall, Englewood Cliffs 1993, s. 11.

${ }^{77}$ W. Rogowski, Rachunek efektywności przedsięwzięć inwestycyjnych, C.H. Beck, Warszawa 2006, s. 45 .

${ }^{78}$ Odwołanie i omówienie zasad: W. Dębski, Zarządzanie finansami, t. 1, Centrum Informacji Menedżera, Warszawa 1996, s. 112 i n.; W. Rogowski, Rachunek efektywności inwestycji..., s. $75 \mathrm{in}$. 
wyższe od wpływów. Wynik dodatni otrzymujemy, gdy wpływy są wyższe od wydatków. W uproszczeniu można to przedstawić w następujący sposób ${ }^{79}$ :

$$
\sum_{t=1}^{n} N C F_{P} \geq \sum_{t=1}^{n} N C F_{W}
$$

gdzie:

$N C F_{P}$ - wpływy uzyskiwane w związku z realizacją i eksploatacją inwestycji, $N C F_{W}$ - wydatki ponoszone w związku z realizacją i eksploatacją inwestycji.

Do oceny efektywności przedsięwzięć inwestycyjnych wykorzystuje się trzy główne grupy metod (por. schemat 3.2) ${ }^{80}$ :

- metody statystyczne (proste) - porównania kosztów, porównania zysków, okresu zwrotu nakładów, metodę prostej stopy zwrotu (ROI),

- metody dynamiczne (dyskontowe) - bieżąca zaktualizowana wartość netto (NPV), wewnętrzna stopa zwrotu (IRR), metoda wskaźnika rentowności;

- metody ekonomiczne: analiza kosztów i korzyści (CBA), analiza efektywności kosztowej (CEA), analiza wielokryterialna.

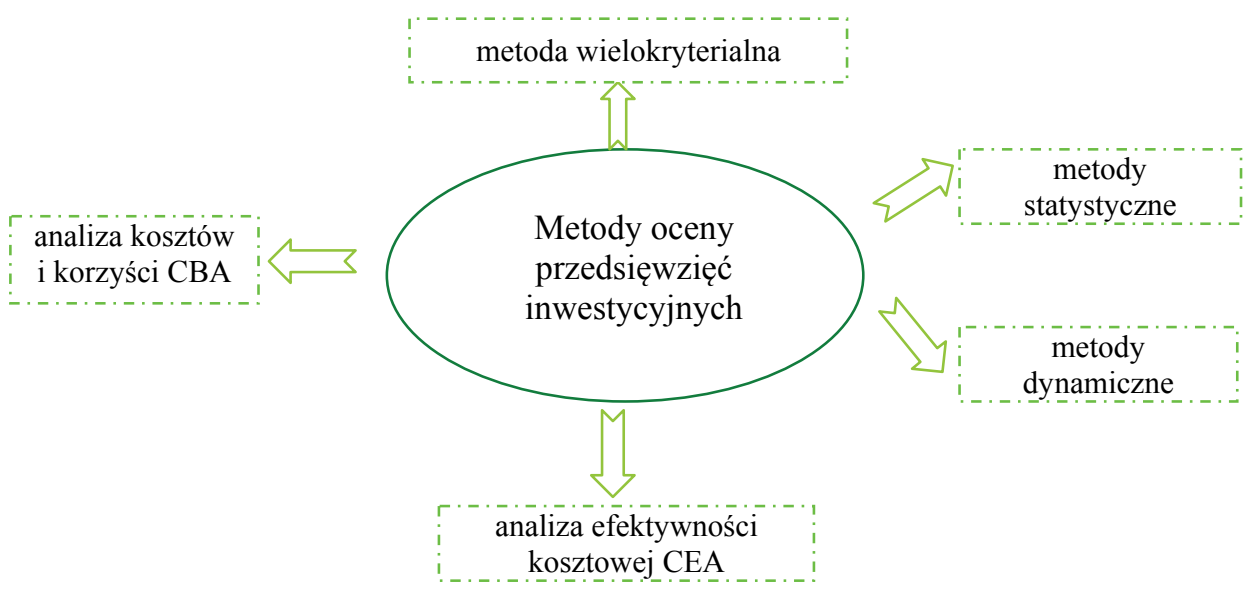

Schemat 3.2. Metody oceny efektywności przedsięwzięć inwestycyjnych

Źródło: oprac. własne

${ }^{79}$ B. Filipiak, Finanse samorzadowe. Nowe wyzwania..., s. 172.

${ }^{80}$ M. Dylewski, B. Filipiak, M. Gorzałczyńska-Koczkodaj, Metody analityczne w dziatalności jednostek..., s. $126 \mathrm{i} \mathrm{n}$. 
Metody i mierniki oceny przedsięwzięć inwestycyjnych zostały rozpoznane i przedstawione dość szczegółowo zarówno w literaturze krajowej, jak i zagranicznej. W pracy zaprezentowano jedynie te, które mogą znaleźć zastosowanie przy ocenie przedsięwzięć realizowanych $\mathrm{w}$ formule partnerstwa publicznoprywatnego.

Metoda oparta na porównaniu kosztów zaliczana jest do podstawowych metod oceny efektywności inwestycji. Porównuje się grupy kosztów (związane $\mathrm{z}$ realizacją przedsięwzięcia oraz generowane w przyszłości) we wszystkich alternatywnych projektach w ramach przedsięwzięcia. Metodę tę stosuje się do inwestycji związanych z modernizacją, wymianą urządzeń infrastrukturalnych. Za najbardziej efektywny przyjmuje się ten wariant, który zakłada najmniejsze koszty jednostkowe ${ }^{81}$.

Metoda porównania zysków ma dwie odmiany. Pierwszą stosuje się w sytuacji, gdy istnieje możliwość oszacowania przychodów i kosztów. Zysk jest różnicą pomiędzy osiągniętymi przychodami a poniesionymi kosztami. Sposób oceny możemy zastosować wówczas, gdy koszty stałe i zmienne nie wykazują znacznej różnorodności i istnieje możliwość oceny wielkości dostarczanych dóbr lub świadczonych usług w efekcie zakończenia inwestycji ${ }^{82}$. Zastosowanie drugiej odmiany możliwe jest w sytuacji, gdy wystąpi konieczność obliczenia efektu dla społeczeństwa. Zysk, w tym przypadku, rozumiany jest jako efekt dla społeczeństwa i wylicza się go za pomocą wzoru ${ }^{83}$ :

$$
Z_{j}=(c * p)-\left(K_{z} * p\right)-K_{s}
$$

gdzie:

$Z_{j}-$ zysk jednostkowy (efekt dla społeczeństwa),

$c$-jednostkowa cena sprzedaży,

$p$ - wielkość dostarczanych dóbr lub świadczonych usług,

$K_{z}-$ jednostkowe koszty zmienne,

$K_{s}-$ jednostkowe koszty stałe.

Okres zwrotu nakładów (playback period metod, $P P M$ ) jest prostą metodą przedstawiającą czas, $\mathrm{w}$ jakim nastąpi zwrot poniesionych nakładów z osiągniętych efektów i korzyści. Metoda ta ma zastosowanie do przedsięwzięć, które będą dostarczane społeczeństwu odpłatnie, zgodnie z przyjętą polityką cenową ${ }^{84}$. Korzyści obliczane są dla kolejnych lat funkcjonowania przedsięwzięcia. Wyższą efektywność przedsięwzięcia, którego okres zwrotu jest krótszy,

${ }^{81}$ A. Manikowski, Z. Tarapata, Ocena projektów gospodarczych ..., s. 147.

${ }^{82}$ M. Dylewski, B. Filipiak, A. Guranowski, J. Hołub-Iwan, Zarządzanie finansami projektu europejskiego, C.H. Beck, Warszawa 2009, s. 111.

${ }^{83}$ B. Filipiak, Finanse samorządowe. Nowe wyzwania..., s. 173.

${ }^{84}$ Finanse przedsiębiorstwa z elementami zarzadzania..., s. 364. 
uzasadnia się tym, że odzyskane nakłady można wcześniej zainwestować. Uproszczone podejście do metody prezentuje poniższy wzór ${ }^{85}$ :

$$
T N=\frac{N}{K}
$$

gdzie:

$T N$ - okres zwrotu nakładów,

$N$ - suma nakładów poniesionych na przedsięwzięcie,

$K$ - korzyści z realizowanego przedsięwzięcia (rozumiane jako zysk netto oraz odpisy amortyzacyjne w okresie eksploatacji).

Przytoczona formuła ma charakter uproszczony i może być zastosowana do oceny mniejszych przedsięwzięć o jasno zarysowanej skali działalności, gdzie nadwyżki nad poniesionymi kosztami są w kolejnych okresach takie same. W przypadku zróżnicowanych wpływów oraz kosztów, metoda nie znajduje zastosowania i powinna zostać zastąpiona metodą skumulowanych przepływów gotówkowych netto (skumulowana nadwyżka netto - accumulated cash flow). Formuła przybierze wówczas postać ${ }^{86}$ :

$$
T N=\frac{N}{\sum_{t=0}^{n} C F_{t}}
$$

gdzie:

$T N$ - okres zwrotu nakładów,

$N$ - suma nakładów poniesionych na przedsięwzięcie,

$C F$ - przepływy pieniężne netto w okresie $t$,

$n$ - liczba lat eksploatacji przedsięwzięcia.

Metoda prostej stopy zwrotu (ROI) obrazuje stosunek średniorocznych efektów generowanych przez przedsięwzięcie, powiększonych o odsetki od kapitału (zysk operacyjny), do nakładów zaangażowanych w realizację przedsięwzięcia. Metodę tę stosuje się do oceny efektywności przedsięwzięć, które będą świadczone odpłatnie. Efektywniejsze jest to przedsięwzięcie, dla którego

${ }^{85}$ B. Filipiak, Finanse samorzadowe. Nowe wyzwania..., s. 173.

${ }^{86}$ K. Jarosiński, Finansowanie inwestycji komunalnych $w$ Polsce..., s. 160. 
wskaźnik ROI przyjmuje wyższe wartości. Matematyczne odwzorowanie zależności zaprezentowano poniżej ${ }^{87}$ :

$$
R O I=\frac{Z O}{N}
$$

gdzie:

$R O I$ - prosta stopa zwrotu,

Zo - zysk operacyjny,

$N$ - suma nakładów poniesionych na przedsięwzięcie.

Metody statystyczne wykorzystywane są do oceny efektywności inwestycji na wstępnym etapie ${ }^{88}$. Pozwalają zorientować się o ich opłacalności i uzasadniają decyzję o wyborze danej inwestycji do realizacji. Zaletami prostych metod oceny efektywności przedsięwzięć inwestycyjnych jest ich przejrzystość, łatwość porównań. Wadą z kolei jest brak uwzględnienia wartości pieniądza w czasie oraz przepływów pieniężnych, jakie wystąpią po okresie zwrotu. Dlatego za bardziej precyzyjne narzędzie oceny opłacalności i weryfikacji korzyści uznaje się metody dyskontowe, które umożliwiają sprawdzenie wszystkich przyszłych nakładów, kosztów, przychodów z różnych okresów na jeden konkretny moment. Pozwala to na dokonanie realnego porównania wszelkich przepływów pieniężnych występujących w różnym czasie ${ }^{89}$.

Bieżąca zaktualizowana wartość netto (NPV - net prezent value) jest metodą pozwalająca na porównanie nakładów z planowanymi korzyściami w różnych okresach. Dzięki temu wskaźnikowi możliwa do ustalenia jest wartość przyszła środków, które decydujemy się zainwestować i odwrotnie, ocenić, jaka jest wartość przyszła środków (korzyści) jaką mamy nadzieję uzyskać z danego przedsięwzięcia. Dokonując porównania wartości przyszłej i wartości bieżącej inwestor ma świadomość, jakim zmianom ulegnie wartość w czasie i jaki to będzie miało wpływ na oczekiwane efekty oraz korzyści z zainwestowanego kapitału. Połączeniem metody wartości bieżącej i przyszłej jest metoda zaktualizowanej wartości netto, w której porównuje się wielkość nakładów na przedsięwzięcie ze zdyskontowanymi efektami, jakie szacuje się osiągnąć w czasie planowanego okresu eksploatacji. NPV jest sumą zdyskon-

${ }^{87}$ Metodyka kompleksowej oceny gospodarki finansowej jednostki samorzadu terytorialnego, red. B. Filipiak, Difin, Warszawa 2009, s. 200.

${ }^{88}$ A. Manikowski, Z. Tarapata, Metody oceny projektów gospodarczych ..., s. 73.

${ }^{89}$ J. Sierak, R. Górniak, Ocena efektywności i finansowanie projektów inwestycyjnych..., s. $86-88$. 
towanych, oddzielnie dla każdego okresu, przepływów pieniężnych netto, planowanych do realizacji $\mathrm{w}$ całym okresie objętym rozrachunkiem przy stałym poziomie stopy procentowej. Wartość ta wyraża zdyskontowane na moment dokonywania oceny wielkości korzyści, jakie są możliwe do osiągnięcia z danego (rozpatrywanego) przedsięwzięcia ${ }^{90}$. Wielkość $N P V$ można obliczyć za pomocą poniższej formuły:

$$
N P V=\sum_{t=0}^{n} \frac{N C F_{t}}{(1+i)^{t}}
$$

gdzie:

$N P V$ - zaktualizowana wartość bieżąca netto inwestycji,

$N C F$ - przepływy pieniężne w kolejnych okresach inwestycji,

$i$ - stopa procentowa (lub stopa dyskontowa),

$n$ - liczba okresów przedsięwzięcia.

Metoda wewnętrznej stopy zwrotu (IRR - internal rate of return) pozwala na określenie stopy procentowej $I R R$, przy której bieżąca wartość strumieni wydatków środków pieniężnych ponoszonych na inwestycje jest równa bieżącej wartości strumieni wpływów pieniężnych (korzyści) realizowanych już w fazie eksploatacji. Jest to taka stopa procentowa, przy której zaktualizowana wartość bieżąca netto $(N P V)$ jest równa zero ${ }^{91}$. IRR pokazuje rzeczywistą stopę zysku całego nakładu inwestycyjnego, może więc być wykorzystana do ustalenia warunków kredytowych, ponieważ pozwala określić maksymalną stopę oprocentowania kredytów ${ }^{92}$. Jest to niezwykle ważne w sytuacji gdy podmiot publiczny będzie ubiegać się o finansowanie zwrotne. Do realizacji akceptuje się tylko te przedsięwzięcia, dla których $I R R$ jest wyższe od stopy dyskontowej. IRR oblicza się za pomocą:

${ }^{90}$ M. Dylewski, B. Filipiak, M. Gorzałczyńska-Koczkodaj, Finanse samorzadowe. Narzędzia, decyzje, procesy, PWN, Warszawa 2006, s. 128; J. J. Glynn, J. Perrin, M. P. Murphy, Rachunkowość dla menedżerów, Wydawnictwo Naukowe PWN, Warszawa 2003, s. 357 i n.; H. Wirth, K. Wanielista, J. Butra, J. Kicki, Strategiczna i ekonomiczna ocena przemystowych projektów inwestycyjnych. Poradnik praktyczny, Instytut Gospodarki Surowcami Mineralnymi i Energią PAN, Kraków 2000, s. 76 i n.

${ }^{91}$ M. Dylewski, B. Filipiak, M. Gorzałczyńska-Koczkodaj, Metody analityczne $w$ działalności jednostek podsektora samorzadowego, Difin, Warszawa 2010, s. 130.

${ }^{92}$ H. Brandenburg, Zarządzanie projektami, Wydawnictwo Politechniki Śląskiej, Gliwice 1999, s. 106-108. 


$$
N P V=\sum_{t=0}^{n} \frac{N C F_{t}}{(1+I R R)^{t}}=0
$$

gdzie:

$N P V$ - zaktualizowana wartość bieżąca netto,

$N C F$ - szacowane korzyści w ujęciu wartościowym dla planowanego okresu eksploatacji w $t$ okresie,

$I R R$ - stopa procentowa (lub stopa dyskontowa),

$n$ - liczba okresów w planowanym przedsięwzięciu.

W sytuacji, gdy na podstawie IRR i $N P V$ wystąpią niezgodności decyzyjne, powinno się przyjąć to przedsięwzięcie, które ma wyższy poziom $N P V$ niż IRR $R^{93}$.

Metoda wskaźnika rentowności pozwala na porównanie uzyskanych efektów w stosunku do poniesionych nakładów. Zależność ta wyrażona jest poprzez wzór:

$$
P I=\frac{\sum_{t=m+1}^{n} \frac{N C F_{t}{ }^{\prime+"}}{(1+i)^{t}}}{\left|\sum_{t=0}^{m} \frac{N C F_{t}{ }^{\prime-}}{(1+i)^{t}}\right|}=\frac{\sum_{t=m+1}^{n} \frac{N C F_{t}{ }^{\prime++"}}{(1+i)^{t}}}{N I} \geq 1
$$

gdzie:

$P I$ - wskaźnik rentowności,

$N C F$ - szacowane korzyści w ujęciu wartościowym dla planowanego okresu eksploatacji w $t$ okresie (dodatnie z ,+", ujemne z ,-"),

$i$ - stopa procentowa (lub stopa dyskontowa),

$n$ - liczba okresów w planowanym przedsięwzięciu,

$m$ - liczba okresów występowania ujemnych przepływów,

$N I$ - nakłady inwestycyjne.

Wartość wskaźnika $P I$ równa lub większa od jedności przesądza o jego efektywności. Jeśli inwestor ma do wyboru kilka przedsięwzięć, w których

${ }^{93}$ M. Dylewski, B. Filipiak, M. Gorzałczyńska-Koczkodaj, Metody analityczne $w$ działalności jednostek..., s. 131; zob. też A. Zalewski, Metody oceny projektów rozwojowych ..., s. 216. 
powyższy wskaźnik spełnia kryteria efektywności, powinien wybrać ten, dla którego wartość $P I$ jest najwyższa ${ }^{94}$.

Zaprezentowane metody dynamiczne w sposób całościowy ujmują czynnik czasu, a więc rozkład wpływów i wydatków związanych z danym przedsięwzięciem. Zastosowanie tych metod wymaga od analityków gruntownej wiedzy nie tylko z ekonomii, ale także innych dziedzin (matematyki finansowej, znajomości rynków kapitałowych, badań operacyjnych) ${ }^{95}$.

Analiza ekonomiczna jest kolejnym etapem oceny przedsięwzięcia. Uzasadnieniem konieczności jej zastosowania jest możliwość oszacowania kosztów i korzyści nie tylko z ekonomicznego (finansowego), ale także społecznego punktu widzenia. Jest to analiza, która dostarcza informacji, jaką cenę społeczeństwo byłoby gotowe zapłacić za określone dobro lub usługę. Przygotowanie analizy ekonomicznej ma na celu ocenę oczekiwanego wpływu przedsięwzięcia inwestycyjnego na sytuację społeczno-gospodarczą danego obszaru w okresie realizacji i po jego zakończeniu. Za pomocą analizy sprawdza się, czy inwestycja jest uzasadniona ze społecznego punktu widzenia, jeśli $\mathrm{z}$ finansowego pociąga za sobą koszty netto. W ramach analizy ekonomicznej sporządza się analizę kosztów i korzyści, analizę efektywności kosztowej oraz analizę wielokryterialną ${ }^{96}$.

Analiza kosztów i korzyści (cost-benefit analysis $-C B A)^{97}$ sporządzana jest w celu ustalenia, czy i w jakim zakresie dane przedsięwzięcie zasługuje na realizację z publicznego lub społecznego punktu widzenia ${ }^{98}$. Ma ona określić efekty zewnętrzne, które towarzyszą realizacji inwestycji publicznej, w tym także samorządowej, jak również kwantyfikuje korzyści dla wszystkich bezpośrednich i pośrednich użytkowników przedsięwzięcia.

Metoda ta oparta jest na założeniu, że społeczeństwo dysponując ograniczonymi zasobami, dąży do takiego ich rozdysponowania, aby osiągnąć maksymalne cele społeczne. W metodzie tej przyjęto, że na decyzje o realizacji inwestycji wpływają ograniczenia ekonomiczne ${ }^{99}$. Wyznaczają one dopuszczalną wysokość kosztów i nakładów, które warto ponieść w celu uzyskania korzyści społecznych. Określenie tych granic należy do podstawowych zadań analizy CBA, gdyż

${ }^{94}$ B. Filipiak, Finanse samorzadowe. Nowe wyzwania ..., s. 177.

${ }^{95}$ A. Manikowski, Z. Tarapata, Ocena projektów gospodarczych. Modele..., s. 146.

${ }^{96}$ W. Bachor, B. Ekstowicz, Z. Grzymała, P. Jeżowski, G. Maśloch, M. Sadowy, A. Zalewski, Podstawy ekonomiki i zarządzania w gospodarce komunalnej, Oficyna Wydawnicza SGH, Warszawa 2011, s. 309.

${ }^{97}$ Geneza metod CBA i CEA, ich istota, zastosowanie zostały omówione przez N. Maską, Efektywność gospodarowania środkami publicznymi, [w:] Źródła finansowania i miary oceny finansowej podmiotów publicznych $i$ prywatnych, red. J. Iwin-Garzyńska, Wydawnictwo Uniwersytetu Szczecińskiego, Rozprawy i Studia nr 738, Szczecin 2009, s. 58-62.

${ }^{98}$ W. Bachor, B. Ekstowicz, Z. Grzymała, P. Jeżowski, G. Maśloch, M. Sadowy, A. Zalewski, Podstawy ekonomiki i zarzadzania w gospodarce..., s. 310.

${ }^{99}$ J. E. Stiglitz, Ekonomika sektora publicznego..., s. 331. 
bez nich każde działanie zmierzające do poprawy życia społeczności należy uznać za zbędne ${ }^{100}$.

W związku z powyższym zastosowanie metody analizy kosztów i korzyści wymaga podjęcia działań zmierzających do ${ }^{101}$ :

1. Estymacji wszystkich kosztów i korzyści w całym cyklu przedsięwzięcia,

2. Wyrażenia wszystkich kosztów i korzyści w postaci pieniężnej,

3. Przyjęcia odpowiedniej stopy dyskontowej, umożliwiającej wyznaczenie wartości bieżącej przyszłych kosztów i korzyści związanych z inwestycją w celu porównania ich z możliwościami finansowymi inwestora.

Określenie wszystkich kosztów i korzyści związanych z przedsięwzięciem inwestycyjnym ma na celu zidentyfikowanie czynników, które mogą wpływać na wielkość tych kosztów i korzyści. Mogą one być bezpośrednie i pośrednie. Koszty bezpośrednie, to te bezpośrednio łączące się z realizacją inwestycji (nakłady związane $\mathrm{z}$ budową, modernizacją, eksploatacją). Bezpośrednią korzyścią jest produkt bądź usługa publiczna. Koszty i korzyści pośrednie to takie, które uwidaczniają się poprzez pozytywne lub negatywne oddziaływanie na społeczeństwo i otoczenie ${ }^{102}$.

Ujęcie kosztów i korzyści w postaci pieniężnej w sektorze publicznym nie jest zadaniem łatwym. Podstawowy problem polega na określeniu cen, jakie będą przyjęte do analizy. W sytuacji, gdy możliwe jest odniesienie się do mechanizmu rynkowego, najlepiej jest przyjmować ceny rynkowe. Największy problem w ustaleniu poziomu kosztów i korzyści niosą za sobą usługi i dobra, które nie podlegają sprzedaży na rzecz społeczności, co utrudnia ocenę w ujęciu wartościowym korzyści wynikających $\mathrm{z}$ inwestycji. Dlatego też $\mathrm{w}$ praktyce często wykorzystuje się ceny rynkowe do poszukiwania cen alternatywnych, które pozwolą na oszacowanie rzeczywistych nakładów i korzyści.

Ostatnim etapem analizy jest przeprowadzenie zdyskontowanego rachunku przyszłych korzyści i kosztów (NPV) związanych z planowanym zadaniem, w celu porównania go z możliwościami finansowymi lub limitem środków, jakie zostały zabezpieczone na ten cel $^{103}$.

${ }^{100}$ S. Franek, Teoretyczne aspekty zarzadzania finansami w podmiotach sfery publicznej, [w:] Teoretycznoprawne aspekty zarzadzania finansami $w$ podmiotach publicznych i prywatnych, red. J. Iwin-Garzyńska, Wydawnictwo Uniwersytetu Szczecińskiego, Rozprawy i Studia nr 690, Szczecin 2008, s. 66.

${ }^{101}$ P. Jeżowski, Metody szacowania korzyści $i$ strat $w$ dziedzinie ochrony środowiska i zdrowia, Oficyna Wydawnicza SGH, Warszawa 2009, s. 36.

${ }^{102}$ M. Dylewski, Ocena kosztów i korzyści realizacji zadań w jednostkach samorzadu terytorialnego na podstawie metody CBA, [w:] Finanse samorzadu terytorialnego. Zagadnienia wybrane, Wydawnictwo Wyższej Szkoły Bankowej w Poznaniu, Poznań-Wrocław 2005, s. 172; J. Kawala, M. Modras, E. Kalinowska, Studium wykonalności dla inwestycji komunalnych, to wcale nie trudne, LEMTECH Konsulting, Kraków 2003, s. 174-183.

${ }^{103}$ Dokładniej M. Dylewski, Planowanie budżetowe w podsektorze samorzadowym. Uwarunkowania, procedury, modele, Difin, Warszawa 2007, s. 178 i n. 
Metoda kosztów i korzyści ma zastosowanie w różnych dziedzinach. Szersze jej wykorzystanie zauważa się $\mathrm{w}$ przedsięwzięciach sektora publicznego. Wynika to $\mathrm{z}$ faktu, że przedsięwzięcia publiczne realizowane są na dużą skalę, a jednocześnie pozytywnie bądź negatywnie oddziałują na dużą liczbę podmiotów gospodarczych i jednostek (osób). Istotną wagę przywiązuje się więc do efektów mnożnikowych i faktu, że koszty i korzyści bezpośrednie mają tu mniejsze znaczenie niż koszty i korzyści pośrednie ${ }^{104}$.

Metoda efektywności kosztowej (cost-effectiveness analysis - CEA) znajduje zastosowanie $\mathrm{w}$ sytuacji, gdy nie można $\mathrm{z}$ różnych powodów skorzystać z tradycyjnej metody kosztów i korzyści. Podstawowym problemem jest brak możliwości uzyskania równoległych danych o kosztach i korzyściach w jednostkach pieniężnych. Niekiedy pieniężna wycena korzyści jest nie tylko niemożliwa, ale wręcz nieetyczna, niewskazana lub zbędna. W metodzie tej dokonuje się porównania kosztów do korzyści wyrażonych w jednostkach naturalnych ${ }^{105}$.

Powszechnie uznaje się, że metoda efektywności kosztowej jest pochodną metody CBA. Nie należy uważać ich jednak za tożsame. Po pierwsze wartość kosztów i korzyści nie jest mierzona tymi samymi jednostkami. Po drugie metoda CEA odnosi się do ewaluacji ex post, CBA zaś do ewaluacji ex ante. Po trzecie w metodzie CEA rachunek koszów ogranicza się zazwyczaj do kosztów bezpośrednich lub finansowych, a przy metodzie CBA uwzględnia się koszty bezpośrednie i pośrednie. Po czwarte metoda CAE jest metodą węższą i mniej kompleksową $\mathrm{w}$ porównaniu $\mathrm{z}$ CBA przez fakt okrojenia korzyści ${ }^{106}$. Jako najkorzystniejszą wybiera się tę inwestycję publiczną, która pozwala osiągnąć identyczny efekt jednostkowy przy najniższych kosztach ${ }^{107}$.

Metoda wielokryterialna ma na celu ocenę ilościową i jakościową ekonomicznych oraz społecznych skutków, jakie generuje przedsięwzięcie dla otoczenia. Władze samorządowe powinny wymienić i opisać wszystkie ekonomiczne, społeczne i środowiskowe skutki zadania i jeśli to jest możliwe ująć je ilościowo (np. liczba nowo zatrudnionych, zmniejszona liczba wypadków, mniejsza emisja zanieczyszczeń). W metodzie tej podstawowym kryterium odniesienia są cele przedsięwzięcia.

${ }^{104}$ P. Jeżowski, Metody szacowania korzyści i strat..., s. 38.

105 Jednostki naturalne, w jakich dokonuje się analizy korzyści mogą wystąpić jako jednostki fizyczne, umowne, wskaźniki techniczno-eksploatacyjne, demograficzne lub społeczne. Przykładami takich jednostek w projektach z zakresu ochrony zdrowia, ochrony środowiska, infrastruktury mogą być m.in. wskaźnik wydłużenia życia, wskaźnik zmniejszenia umieralności, redukcja zanieczyszczeń, ilość zneutralizowanych odpadów, długość dróg.

${ }^{106}$ P. Jeżowski, Metody szacowania korzyści i strat..., s. 40 i n.; A. Drobniak, Podstawy oceny efektywności projektów publicznych, Wydawnictwo Akademii Ekonomicznej w Katowicach, Katowice 2008, s. 188 i n.

${ }^{107}$ S. Jasiewicz, W. Rogowski, Inwestycje hybrydowe - nowe ujęcie..., s. 61. 
Analizę wielokryterialną można przeprowadzić na dwa sposoby:

- zero-jedynkowy, oceniane rezultaty przedsięwzięcia podlegają akceptacji bądź odrzuceniu w odniesieniu do przyjętego kryterium,

- wagowy, w którym nadaje się wagi poszczególnym zdefiniowanym kryteriom.

Dla skomplikowanych inwestycji komunalnych sposób zero-jedynkowy jest zazwyczaj niewystarczający i w sytuacji, gdy kilka przedsięwzięć inwestycyjnych kwalifikuje się do realizacji poddaje się je dalszej ocenie z wykorzystaniem systemu wagowego. Metoda wagowa sprawdza się w złożonych przedsięwzięciach, w których ocena dokonywana jest na podstawie przyznanych wag dla poszczególnych określonych kryteriów (celów) ${ }^{108}$.

\subsection{Potencjał inwestycyjny jednostek samorządu terytorialnego}

Warunkiem realizacji zadań zarówno o charakterze bieżącym, jak i inwestycyjnym jest zapewnienie jednostkom samorządu terytorialnego odpowiednich dochodów, adekwatnych do zakresu zadań. Rzeczywista wielkość środków postawiona do dyspozycji gminy ma wpływ na kreowanie skłonności do inwestowania. Skłonność do inwestowania jednostek samorządu terytorialnego zależy od wielkości nadwyżki operacyjnej lub wolnych środków. Wzrost tych kategorii zwiększa możliwości inwestycyjne. Skłonność inwestycyjną kreują także bieżące wydatki związane $\mathrm{z}$ realizacją bieżących zadań. Im więcej środków pochłaniają bieżące cele i utrzymanie infrastruktury, tym mniejsze są możliwości finansowe $\mathrm{w}$ zakresie nowych przedsięwzięć inwestycyjnych. Kolejnym czynnikiem, który wpływa na stopień skłonności do inwestowania, jest poziom zadłużenia. Stopień dostępności zewnętrznych źródeł finansowania wytycza w znacznej mierze granice możliwości inwestycyjnych w przyszłości. Nadwyżka operacyjna ${ }^{109}$ jest różnicą pomiędzy dochodami bieżącymi a wydat-

${ }^{108}$ W. Bachor, B. Ekstowicz, Z. Grzymała, P. Jeżowski, G. Maśloch, M. Sadowy, A. Zalewski, Podstawy ekonomiki i zarządzania w gospodarce..., s. 314; U. Brochocka, R. Gajęcki, Metody oceny projektów inwestycyjnych, Oficyna Wydawnicza SGH, Warszawa 1997.

${ }^{109}$ Nadwyżkę operacyjną przyjmuje się za jedną z najważniejszych miar obrazującą sytuację finansową jednostki samorządu terytorialnego. Pojęcie to, zdaniem P. Swianiewicza, w ostatnich latach znacznie zyskało na znaczeniu. Poszerzył się krąg osób rozumiejących jego znaczenie, do grona ekspertów, którzy posługiwali się kategorią nadwyżki operacyjnej, dołączyli politycy i urzędnicy samorządowi. Nadwyżka operacyjna precyzyjnie określa, ile środków pozostaje w kasie samorządu po dokonaniu niezbędnych wydatków. Nie bierze się pod uwagę środków pochodzących z jednorazowej sprzedaży gruntu komunalnego, a jedynie regularne wpływy, co do których jest pewność ich wystąpienia. Tak określoną nadwyżkę operacyjną można przeznaczyć na zadania znajdujące się $\mathrm{w}$ zasięgu starego rozwoju jednostki, ale przede wszystkim na nowe inwestycje lub spłatę zadłużenia. Nadwyżka operacyjna wytycza finansowe możliwości rozwoju w przyszłości. Sytuacja przeciwna - deficyt operacyjny - występuje wówczas, gdy wydatki bieżące przewyższają dochody bieżące. Oznacza to, że samorząd funkcjonuje „na kredyt” lub 
kami bieżącymi. Pojęcie dochodów i wydatków JST w podziale na bieżące i majątkowe zostało zawarte $\mathrm{w}$ art. 165a ustawy z dnia 30 czerwca 2005 r. i art. 235 ustawy z dnia 27 sierpnia 2009 r. o finansach publicznych.

Do dochodów majątkowych zalicza się:

- dotacje i środki otrzymane na inwestycje,

- dochody ze sprzedaży majątku,

- dochody z tytułu przekształcenia prawa użytkowania wieczystego w prawo własności.

Wydatki majątkowe obejmują:

- inwestycje i zakupy inwestycyjne,

- zakup i objęcie akcji oraz wniesienie wkładów do spółek prawa handlowego.

Zdaniem P. Swianiewicza, o ile nie ma wątpliwości co do zakresu interpretacyjnego wydatków bieżących, to takie wątpliwości pojawiają się przy oznaczeniu dochodów bieżących. Kreatywna rachunkowość w tym zakresie może prowadzić do zwiększenia lub zaniżenia wielkości nadwyżki, co w konsekwencji rzutuje na zakres zadań przeznaczonych do realizacji. Do dochodów bieżących nie zalicza się wielkości otrzymanych dotacji inwestycyjnych, dochodów pochodzących $\mathrm{z}$ przekształcenia prawa użytkowania wieczystego $\mathrm{w}$ prawo własności, środków ze sprzedaży składników majątkowych, dywidend i kwot uzyskanych ze zbycia praw majątkowych. Kreatywność może występować w przypadku zaliczenia wpływów z dzierżawy czy wynajmu majątku komunalnego do dochodów bieżących. Gdyby zaliczyć te wpływy do dochodów kapitałowych, nadwyżka operacyjna byłaby oczywiście odpowiednio mniejsza. Tymczasem sposób takiego zaliczenia nie jest oczywisty. Jako dochód kapitałowy powinniśmy bowiem potraktować przynajmniej odpis związany z amortyzacją dzierżawionego majątku, ale praktyka, zdaniem wspomnianego autora, pokazuje, że sprawozdania budżetowe nie pokazują tak szczegółowego rozróżnienia.

W literaturze dla zobrazowania możliwości inwestycyjnych samorządu terytorialnego stosuje się określenie potencjału inwestycyjnego ${ }^{110}$. Potencjał to zasób możliwości, mocy bądź zdolności wytwórczych tkwiących w jakiejś dziedzinie, np. gospodarczej ${ }^{111}$, potencjał inwestycyjny będzie zaś wyznaczony poprzez środki budżetowe, które wykorzystuje się do finansowania przedsię-

„przejada majątek”. W dłuższej perspektywie taka sytuacja rodzi poważne kłopoty finansowe i znacznie ogranicza rozwój w przyszłości. Wielkość nadwyżki operacyjnej stanowi jeden z najważniejszych parametrów wykorzystywanych przy opracowywaniu wieloletnich programów inwestycyjnych. P. Swianiewicz, Kondycja finansowa samorzadów? Nadwyżka operacyjna w 2007, www.wspólnota.org.pl (dostęp z 30.11.2010).

${ }^{110}$ T. Kaczor, M. Tomalak, Potencjat inwestycyjny jednostek samorzadu terytorialnego, Instytut Badań nad Gospodarką Rynkową, Warszawa 2000, s. 9.

${ }^{111}$ Nowy stownik języka polskiego..., s. 728. 
wzięć inwestycyjnych. Potencjał inwestycyjny uzależniony jest od czynników składowych mających na niego wpływ.

Poziom dochodów budżetowych, jakim w danym momencie dysponuje jednostka samorządu terytorialnego wyznacza jej własny potencjal. T. Lubińska stosuje określenie własny potencjał dochodowy, który wyznaczony jest przez sumę wpływu z udziałów w podatkach dochodowych od osób fizycznych i od osób prawnych, podatku od nieruchomości, środków transportowych, czynności cywilnoprawnych, a w gminach wiejskich także w podatku rolnym i podatku leśnym. Własny potencjał dochodowy jest jednym $\mathrm{z}$ elementów dochodów bieżących stabilnych, które obejmują także subwencję ogólną, dotacje celowe, dochody bieżące stabilne z majątku oraz pozostałe dochody bieżące stabilne ${ }^{112}$.

Można więc przyjąć, że potencjałem własnym są dochody ogółem (własny potencjał dochodowy) pomniejszone o wydatki bieżące oraz o wydatki związane $\mathrm{z}$ obsługą długu (raty kapitałowe i odsetki), które wyznaczają poziom wolnych środków brutto.

Jak już wspomniano, różnica pomiędzy dochodami bieżącymi a wydatkami bieżącymi stanowi wynik bieżący, który w przypadku wielkości dodatniej określany jest mianem nadwyżki operacyjnej, a w przypadku wielkości ujemnej deficytem operacyjnym. Wynik budżetu operacyjnego określa, czy jednostka samorządu terytorialnego jest w stanie pokryć własne wydatki bieżące uzyskanymi dochodami bieżącymi. Im wyższa jest wartość nadwyżki operacyjnej, tym większe możliwości samorządu $\mathrm{w}$ odniesieniu do realizacji nowych przedsięwzięć inwestycyjnych w sposób bezpośredni po przeznaczeniu odpowiednich kwot na zadania inwestycyjne lub w sposób pośredni poprzez redukowanie wcześniej zaciągniętych zobowiązań na cele inwestycyjne ${ }^{113}$. Poziom zobowiązań zdeterminowany jest ustawowymi limitami, zdolnością kredytową oraz skłonnością jednostki do zaciągania zobowiązań.

Potencjał własny powiększony o nadwyżkę budżetową z lat poprzednich, przychody z prywatyzacji oraz możliwości pozyskania środków obcych w tym

${ }^{112}$ Dochody bieżące stabilne, to taka kategoria dochodów, których charakterystyczną cechą jest regularność wpływów do budżetu i które nie wygasają wraz z upływem określonego czasu. Do stabilnych dochodów bieżących $\mathrm{z}$ majątku zalicza się dochody z czynszu, najmu, dzierżawy, opłaty za wieczyste użytkowanie. Pozostałe dochody bieżące stabilne obejmują wpływy z opłat, z pozostałych podatków nie ujętych we własnym potencjale dochodowym oraz inne wpływy, które wynikają z organizacji usług publicznych (np. wpływy ze sprzedaży biletów komunikacji miejskiej), szerzej: T. Lubińska, M. Będzieszak, Własny potencjat inwestycyjny jako miara pozycji wydatkowej gmin w latach 2004 i 2005, [w:] Budżet państwa i samorzadów, decentralizacja - oświata. Studium porównawcze, red. T. Lubińska, Difin, Warszawa 2005, s. 67-70.

${ }^{113}$ Nadwyzka operacyjna w jednostkach samorzadu terytorialnego w latach 2004-2006, Ministerstwo Finansów, sierpień 2007, s. 3-4; szerzej na temat nadwyżki operacyjnej E. MarkowskaBzducha, Potencjat inwestycyjny jednostek samorzadu terytorialnego w Polsce, [w:] Wspótczesne problemy finansów i gospodarki jednostek samorzadu terytorialnego, Wydawnictwo Akademii Ekonomicznej w Poznaniu, Poznań 2008, s. 257-260. 
samym czasie stanowią potencjał inwestycyjny. T. Lubińska wraz z zespołem określa własny potencjał inwestycyjny, przyjmując, że

jest pojęciem pochodnym od nadwyżki bieżącej, gdyż oznacza środki dostępne do dyspozycji władz po sfinansowaniu wszystkich wydatków bieżących oraz po spłacie rat kredytów, pożyczek i wykupie papierów wartościowych. Własny potencjał inwestycyjny oznacza środki, które powinny zostać przeznaczone na finansowanie inwestycji $1^{114}$.

Autorzy wyróżniają trzy stopnie potencjału inwestycyjnego, którego interpretacja jest następująca ${ }^{115}$ :

1) potencjał inwestycyjny pierwszego stopnia - oznacza część dochodów bieżących jaka pozostaje po uregulowaniu bieżących wydatków i po spłacie zadłużenia,

2) potencjał inwestycyjny drugiego stopnia - określony jest przez część dochodów budżetowych pozostających do dyspozycji po dokonaniu bieżących wydatków i spłacie zadłużenia,

3) potencjał inwestycyjny trzeciego stopnia - uwzględnia także dochody pozabudżetowe pochodzące na przykład ze środków Unii Europejskiej, finansujące daną inwestycję.

Wyznaczenie wielkości potencjału inwestycyjnego przedstawia schemat 3.3.

Autorka przez potencjał inwestycyjny rozumie zasoby finansowe znajdujące się w dyspozycji jednostki samorządu terytorialnego do realizacji przedsięwzięć inwestycyjnych po zrealizowaniu wydatków bieżących oraz uregulowaniu zobowiązań wynikających z obsługi zadłużenia powiększone o środki uzyskane ze sprzedaży majątku. W literaturze zdolność jednostek samorządu terytorialnego do finansowania działalności inwestycyjnej można przedstawić poprzez określenie poziomu nadwyżki operacyjnej. Jak już wcześniej wspomniano, nadwyżka operacyjna to różnica pomiędzy dochodami bieżącymi a wydatkami bieżącymi. Powstaje w wyniku pokrycia wydatków bieżących dochodami bieżącymi w danym roku budżetowym i obliczana jest jako strumień przepływów finansowych. Poziom nadwyżki operacyjnej można ustalić za pomocą jednej z dwóch metod.

Pierwsza metoda bazuje na klasycznym ujęciu budżetowym przepływów finansowych i ujęciu ich w postaci cash flow. W tym celu wymagana jest identyfikacja następujących zmiennych ${ }^{116}$ :

${ }^{114}$ T. Lubińska, M. Będzieszak, Własny potencjat inwestycyjny jako miara pozycji..., s. 71.

${ }^{115}$ Ibidem.

${ }^{116}$ M. Dylewski, B. Filipiak, M. Gorzałczyńska-Koczkodaj, Metody analityczne $w$ działalności jednostek..., s. 137. 


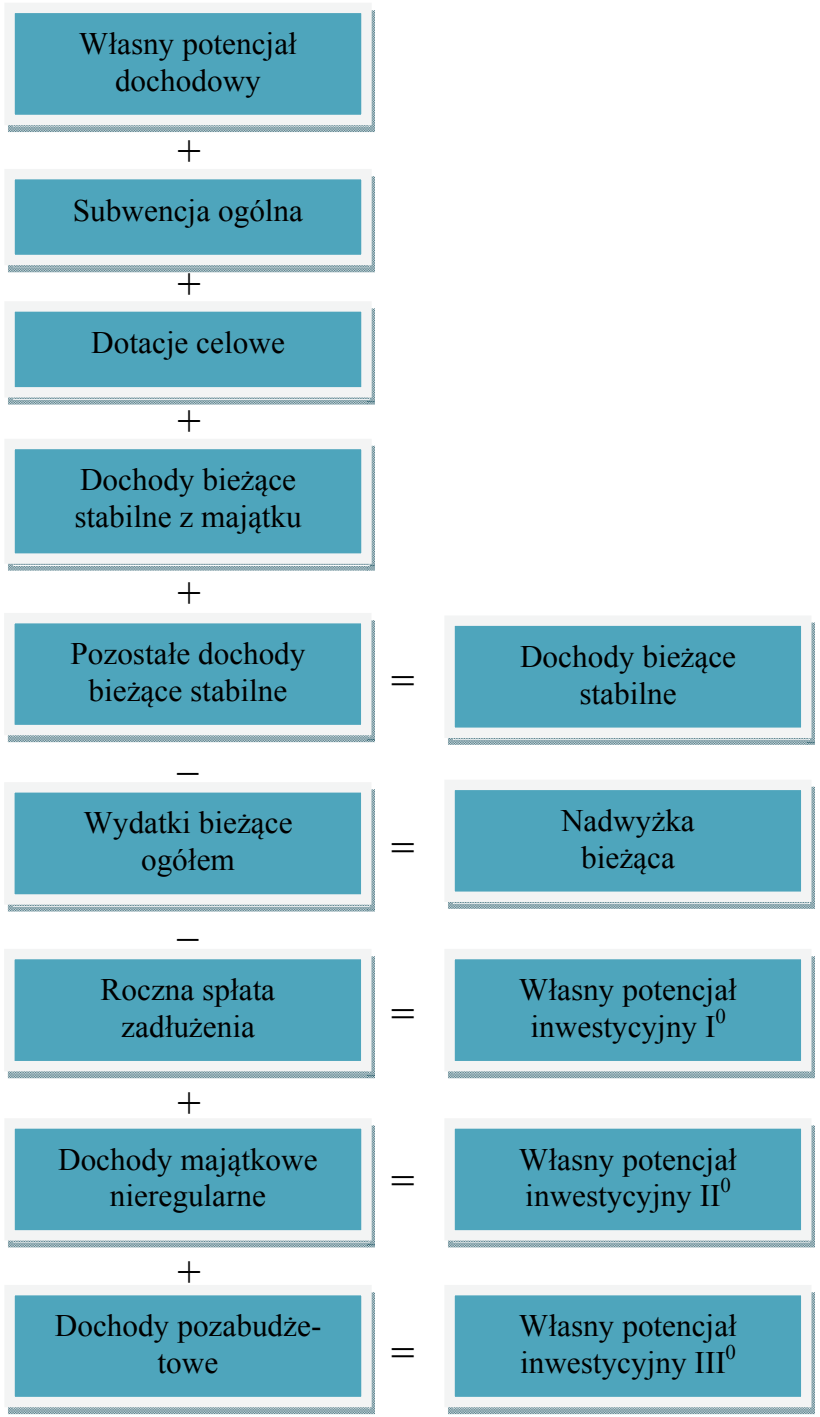

Schemat 3.3. Potencjał inwestycyjny jednostki samorządu terytorialnego

Źródło: T. Lubińska, M. Będziaszek, Własny potencjat inwestycyjny jako miara pozycji wydatkowej gmin w latach 2004 i 2005, [w:] Budżet państwa i samorzadów, decentralizacja oświata. Studium porównawcze, red. T. Lubińska, Difin, Warszawa 2005, s. 68

- określenie trendów w zakresie kształtowania się wpływów (dochodów i przychodów) budżetowych, jest to niezwykle istotne, zwłaszcza w warunkach kryzysu finansowego, gdzie następują wahania w poziomie dochodów oraz mogą wystąpić trudności w pozyskaniu przychodów (finansowanie długiem, związane z pokryciem bieżących niedoborów),

- kosztów realizacji zadań bieżących oraz rozchodów (środków budżetowych związanych $\mathrm{z}$ obsługą długu). 
Dochody osiągane przez jednostki samorządu terytorialnego powinny kształtować się na poziomie gwarantującym realizację bieżących zadań. Dochody bieżące winny odzwierciedlać relację:

$$
D_{b}=\sum_{t=1}^{n}\left(D_{p c}+D_{p o}+D_{i}+D_{c}+S+D_{m}\right)
$$

gdzie:

$D_{b}-$ dochody bieżące,

$D_{p c}$ - dochody z udziałów w podatkach centralnych (PIT, CIT),

$D_{p o}-$ dochody z podatków i opłat lokalnych,

$D_{i}$ - dochody z darowizn i spadków,

$D_{c}$ - dotacje celowe na zadania bieżące,

$S$ - subwencja ogólna,

$D_{m}$ - dochody z mienia, które mogą mieć charakter cykliczny

Wydatki bieżące związane są z realizacją zadań bieżących i obejmują koszty wynagrodzeń i pochodnych, zakupu materiałów i usług, dotacje na realizację zadań bieżących wykonywanych przez jednostki organizacyjne oraz koszty związane z realizacją zadań bieżących wynikające z zawartych umów i porozumień. Koszty te nie obejmują zadań związanych z inwestycjami. Sposób liczenia cash flow bieżącego opartego na nadwyżce operacyjnej przedstawiono w tab. 3.3.

Tabela 3.3

Nadwyżka operacyjna w ujęciu cash flow bieżącego - metoda pierwsza

\begin{tabular}{|l|l|}
\hline \multicolumn{1}{|c|}{ Lp. } & \multicolumn{1}{c|}{ CASH FLOW } \\
\hline A & Dochody bieżące \\
\hline B & Wydatki bieżące \\
\hline C & Nadwyżka operacyjna/deficyt brutto (A-B) \\
\hline D & Finansowanie bieżące (D1-D2) \\
\hline D.1 & Przychody \\
\hline D.2 & Rozchody ogółem \\
\hline E & Cash flow danego roku (C+D) \\
\hline F & Wydatki inwestycyjne \\
\hline G & Nadwyżka operacyjna netto/deficyt (E-F) - cash flow \\
\hline H & Finansowanie inwestycyjne (H1-H2) \\
\hline H.1 & Przychody \\
\hline H.2 & Rozchody ogółem \\
\hline I & Cash flow danego roku z inwestycji (G+H) \\
\hline J & Środki na początek roku \\
\hline K & Cash flow na koniec roku (I+J) \\
\hline
\end{tabular}

Źródło: M. Dylewski, B. Filipiak, M. Gorzałczyńska-Koczkodaj, Metody analityczne $w$ działalności jednostek podsektora samorzadowego, Difin, Warszawa 2010, s. 138. 
Metoda druga, służąca do pomiaru potencjału inwestycyjnego, oparta jest na ustaleniu nadwyżki operacyjnej będącej różnicą pomiędzy dochodami bieżącymi a wydatkami bieżącymi. Dochody bieżące to dochody budżetowe niebędące dochodami majątkowymi (dotacjami i środkami otrzymanymi na inwestycje, dochodami ze sprzedaży majątku, przekształcenia prawa użytkowania wieczystego w prawo własności). Wydatkami bieżącymi są wydatki, które nie stanowią wydatków majątkowych (wydatki na zakupy inwestycyjne i inwestycje, zakup i objęcie akcji oraz wniesienie wkładów do spółek prawa handlowego).

Tabela 3.4

Nadwyżka operacyjna w ujęciu cash flow bieżącego - metoda druga

\begin{tabular}{|l|l|}
\hline \multicolumn{1}{|c|}{ Lp. } & \multicolumn{1}{c|}{ CASH FLOW } \\
\hline A & Dochody bieżące \\
\hline B & Wydatki bieżące \\
\hline C & Nadwyżka operacyjna/deficyt brutto (A-B) \\
\hline D & Finansowanie bieżące (D1-D2) \\
\hline D.1 & Przychody \\
\hline D.2 & Rozchody ogółem \\
\hline E & Cash flow danego roku (C+D) - nadwyżka operacyjna netto \\
\hline F & Środki na początek roku \\
\hline G & Cash flow na koniec roku (E+F) \\
\hline
\end{tabular}

Źródło: M. Dylewski, B. Filipiak, M. Gorzałczyńska-Koczkodaj, Metody analityczne w działalności jednostek podsektora samorządowego, Difin, Warszawa 2010, s. 139.

Metody różnią się ujęciem dochodów bieżących. W pierwszej metodzie włączono dochody cyklicznie otrzymywane z mienia do dochodów bieżących i wyeliminowano wydatki, które mają charakter inwestycyjny. Sposób liczenia cash flow bieżącego na podstawie nadwyżki operacyjnej drugą metodą, opracowaną przez Ministerstwo Finansów, przedstawiony został w tab. 3.4.

Wybór jednego ze sposobów obliczenia potencjału inwestycyjnego pozwala określić jakimi możliwościami inwestycyjnymi dysponuje jednostka $\mathrm{w}$ danym okresie. Jednostki prowadzące ostrożną politykę kredytową będą dysponowały niższym poziomem potencjału inwestycyjnego, ale też w każdej chwili mogą zwiększyć swe zadłużenie i w ten sposób finansować swoje inwestycje. Prowadzi to do wzrostu potencjału inwestycyjnego. Na przeciwnym biegunie znajdują się samorządy, w których wysoki poziom zadłużenia ogranicza możliwości inwestycyjne poprzez kapitał pożyczkowy. Wówczas jedynym rozwiązaniem jest dążenie do wzrostu potencjału własnego. Praktyka wykazuje, że samorządy zadłużają się poniżej ustawowych limitów, co świadczy o utrzymywaniu bezpiecznego poziomu zadłużenia. 
Po zrealizowaniu wydatków bieżących niezbędnych do zapewnienia prawidłowego funkcjonowania samorządu pozostała kwota może być przeznaczona na trzy kategorie wydatków ${ }^{117}$ :

- zakupy inwestycyjne - obejmują nakłady finansowe przeznaczone na funkcjonowanie już istniejących instytucji, które mają na celu zapewnienie sprawnego działania samorządu i podległych mu jednostek. Nakłady te nie są zaliczane do potencjału inwestycyjnego, gdyż wstrzymanie ponoszenia ich w bieżącym okresie wpływa oczywiście na wzrost wielkości potencjału inwestycyjnego, ale w przyszłości znacznie go ogranicza;

- finansowanie inwestycji kontynuowanych - obejmują wydatki ponoszone na rozpoczęte $w$ latach poprzednich przedsięwzięcia inwestycyjne objęte wieloletnim planem inwestycyjnym. Podobnie jak w przypadku zakupów inwestycyjnych można ograniczyć wydatki kontynuowane zwiększając potencjał inwestycyjny, ale w dłuższej perspektywie następuje odroczenie inwestycji, co przekłada się najczęściej na spadek efektywności wydatkowania pieniędzy;

- nowe inwestycje - obejmują nakłady uruchomione na realizację nowego przedsięwzięcia inwestycyjnego, które znalazło akceptację władz lokalnych, wpisane zostało do planu inwestycyjnego wraz ze wskazaniem źródeł finansowania. Podstawą rozpoczęcia nowej inwestycji jest posiadanie odpowiedniego poziomu potencjału inwestycyjnego, który w przypadku pojawienia się nieprzewidzianych trudności będzie gwarantował realizację dalszych etapów inwestycji.

Tabela 3.5

Potencjał inwestycyjny jednostek samorządu terytorialnego ogółem w latach 2005-2011 (w mln zł)

\begin{tabular}{|c|c|c|c|c|c|c|c|c|}
\hline \multirow{2}{*}{ Lp. } & \multirow{2}{*}{ Wyszczególnienie } & \multicolumn{7}{|c|}{ Wykonanie za rok } \\
\hline & & 2005 & 2006 & 2007 & 2008 & 2009 & 2010 & 2011 \\
\hline 1 & Dochody ogółem & 102911 & 117040 & 131380 & 142569 & 154842 & 162815 & 171309 \\
\hline 2 & Wydatki bieżące & 85376 & 95081 & 102047 & 113260 & 124702 & 133517 & 139160 \\
\hline 3 & $\begin{array}{l}\text { Wolne środki brutto } \\
(1-2)\end{array}$ & 17535 & 21959 & 29333 & 29309 & 30140 & 29298 & 32149 \\
\hline 4 & Obsługa zadłużenia & 997 & 839 & 994 & 1315 & 1400 & 1852 & 2711 \\
\hline 5 & \begin{tabular}{|l|} 
Potencjal wlasny (3- \\
4)
\end{tabular} & 16538 & 21120 & 28339 & 27994 & 28740 & 27446 & 29338 \\
\hline 6 & $\begin{array}{c}\text { Nadwyżka budżetowa } \\
\text { z lat poprzednich }\end{array}$ & 2302 & 2516 & 2326 & 3655 & 3865 & 2686 & 1697 \\
\hline 7 & $\begin{array}{l}\text { Przychody z pry- } \\
\text { watyzacji majątku }\end{array}$ & 83 & 17 & 19 & 123 & 80 & 197 & 1463 \\
\hline 8 & $\begin{array}{c}\text { Potencjal inwesty- } \\
\text { cyjny }(5+6+7)\end{array}$ & 18923 & 23653 & 30684 & 31772 & 32685 & 30329 & 32598 \\
\hline
\end{tabular}

Źródło: oprac. własne na podstawie Informacji z wykonania budżetów jednostek samorządu terytorialnego za lata 2005-2011, Warszawa 2006-2011, strony internetowe Ministerstwa Finansów.

${ }^{117}$ T. Kaczor, M. Tomalak, Potencjat inwestycyjny jednostek samorządu..., s. 10. 
Zdaniem M. Dylewskiego potencjał inwestycyjny stanowi miarę ilościową, jaką można przedstawić w ujęciu statystycznym oraz dynamicznym ${ }^{118}$, które w sposób syntetyczny i ogólnikowy określają potencjał i atrakcyjność jednostki samorządu terytorialnego. Wielkość potencjału inwestycyjnego jednostek samorządu terytorialnego w latach 2006-2010 ujęto w tab. 3.5.

$\mathrm{Z}$ danych przedstawionych $\mathrm{w}$ tab. 3.5 wynika, iż ujęcie nominalne pokazuje systematycznie rosnący potencjał inwestycyjny jednostek samorządu terytorialnego. Rok 2005 jest pierwszym pełnym rokiem przynależności Polski do struktur UE. Od tego czasu obserwujemy systematyczny wzrost potencjału inwestycyjnego jednostek samorządu terytorialnego (związany z zaangażowaniem dotacji unijnych na zadania inwestycyjne). Jest on wynikiem wzrastającej wielkości wolnych środków brutto oraz nadwyżek osiągniętych w latach poprzednich, za wyjątkiem roku 2011, gdy odnotowano spadek wielkości nominalnej nadwyżki z roku poprzedniego. Na poziom potencjału inwestycyjnego wpływa także wielkość środków pozyskiwanych z prywatyzacji majątku. Należy wskazać na dwa okresy, w których jednostki samorządu aktywnie prywatyzowały majątek. To rok 2005 , w którym sprywatyzowano majątek za łączną kwotę $83 \mathrm{mln}$ zl, oraz lata 2007-2011, w których systematycznie rosła wartość nominalna przychodów z prywatyzacji. W roku 2009 nastąpił spadek przychodów podyktowany zastojem na rynku nieruchomości wywołanym globalnym kryzysem finansowym. W roku 2010 zauważalny stał się spadek wolnych środków finansowych samorządów, potencjału własnego i inwestycyjnego, co świadczy, że kryzys gospodarczy dopiero wywiera piętno na sytuacji finansowej samorządów. Odbija się to na spadku dochodów ogółem o 5,1\%, wydatków bieżących o 7,0\%, co w konsekwencji przekłada się na spadek w dwóch ostatnich latach potencjału własnego i inwestycyjnego odpowiednio o 4,5 i 7,2\%. Ogólna tendencja w latach 2005-2011 jest wzrostowa. I tak średniorocznie dochody ogółem wzrosły o 39,1\%, wydatki bieżące zaś o 40,4\%. Taka sytuacja odbiła się na poziomie potencjału własnego oraz inwestycyjnego, którego średnioroczny wzrost w tym okresie wyniósł odpowiednio 30,0 i 28,2\%.

Największym potencjałem inwestycyjnym dysponują gminy i miasta na prawach powiatu, co pokazuje, że jednostki te w obecnych uwarunkowaniach funkcjonowania samorządu stają się podstawowymi inwestorami. W tab. 3.6 zaprezentowano syntetyczne dane $\mathrm{w}$ ujęciu nominalnym dotyczące poziomu potencjału inwestycyjnego przypadające na poszczególne jednostki JST. Wyraźnie zaznacza się znaczący udział gmin, które koncentrują 44,2\% potencja-

${ }^{118}$ Potencjał inwestycyjny można oceniać w ujęciu rocznym lub wieloletnim, uwzględniając okresy przyszłe lub prognozy wieloletnie w zakresie inwestycji i planowanych źródeł finansowania tych inwestycji. Długookresowe podejście wydaje się praktyczniejsze gdyż uwzględnia strategiczne podejście do problematyki rozwoju jednostki samorządu terytorialnego. Więcej na ten temat M. Dylewski, Wpływ spowolnienia gospodarczego na zdolność inwestycyjna JST, [w:] Finanse publiczne, red. J. Sokołowski, M. Sosnowski, A. Żabiński..., s. 115-116. 
łu inwestycyjnego całego sektora. Niepokojącym zjawiskiem jest małe znaczenie powiatów jako szczebla samorządu o zasięgu ponadlokalnym w roli inwestorów. Poziom potencjału inwestycyjnego powiatów wynosi ok. $12,5 \%$, co stawia je na ostatnim miejscu pośród wszystkich jednostek.

Zbiorcze zestawienie (tab. 3.6) potencjału inwestycyjnego w latach 20052011 pokazuje poziom potencjału podsektora samorządowego.

Tabela 3.6

Potencjał inwestycyjny poszczególnych szczebli jednostek samorządu terytorialnego ogółem w latach 2005-2011 (w mln zł)

\begin{tabular}{|l|r|r|r|r|r|r|r|}
\hline \multicolumn{1}{|c|}{ Jednostka JST } & \multicolumn{1}{c|}{2005} & \multicolumn{1}{c|}{2006} & \multicolumn{1}{c|}{2007} & \multicolumn{1}{c|}{2008} & \multicolumn{1}{c|}{2009} & \multicolumn{1}{c|}{2010} & \multicolumn{1}{c|}{2011} \\
\hline Ogólem & $\mathbf{1 8 9 2 3}$ & $\mathbf{2 3 6 5 0}$ & $\mathbf{3 0 6 8 4}$ & $\mathbf{3 1 ~ 7 7 2}$ & $\mathbf{3 2} \mathbf{6 8 5}$ & $\mathbf{3 0 ~ 3 2 9}$ & $\mathbf{3 2} \mathbf{5 9 9}$ \\
\hline Gminy & 9182 & 10450 & 12383 & 13777 & 12612 & 13423 & 14412 \\
\hline Powiaty & 1378 & 1650 & 2181 & 2671 & 3090 & 3829 & 3798 \\
\hline MPP* & 5482 & 7870 & 11297 & 10059 & 7178 & 7828 & 8973 \\
\hline Województwa & 2881 & 3680 & 4823 & 5265 & 9805 & 5249 & 5416 \\
\hline
\end{tabular}

* MPP - miasta na prawach powiatu

Źródło: oprac. własne na podstawie Informacji z wykonania budżetów jednostek samorząu terytorialnego za lata 2005-2011, Warszawa 2006-2011, strony internetowe Ministerstwa Finansów.

W kontekście analizy potencjału inwestycyjnego samorządu warto zwrócić uwagę na poziom wydatków inwestycyjnych realizowanych przez poszczególne szczeble (tab. 3.7) podkreślając, że ich dynamika wyraźnie nabrała tempa (w części jest to zasługa środków UE).

W ujęciu nominalnym łączny potencjał inwestycyjny jednostek samorządu terytorialnego w latach 2005-2011 wyniósł $200644 \mathrm{mln} \mathrm{zł}$. W tym czasie łączne wydatki inwestycyjne wyniosły $225275 \mathrm{mln}$ zł. Jeśli weźmie się pod uwagę zakres realizowanych inwestycji, to ujawniają się duże różnice pomiędzy poszczególnymi szczeblami samorządu. Gminy i miasta na prawach powiatu wydają blisko 74,0\% ogółu środków przeznaczonych na inwestycje samorządowe w Polsce (gminy 41,9\%, MPP 31,8\%), na województwa i powiaty przypada łącznie 26,3\% wydatków inwestycyjnych (powiaty 10,0\%, województwa 16,3\%). W latach 2005-2009 wyraźnie obserwuje się wzrost udziału wydatków inwestycyjnych w wydatkach ogółem JST. Natomiast od 2010 r. następuje spadek udziału wydatków inwestycyjnych w wydatkach ogółem. W poszczególnych typach jednostek zjawisko to przebiega nierównomiernie. W okresie do 2010 r. obserwuje się okres wzrostu wydatków inwestycyjnych w strukturze wydatków ogółem, z wyjątkiem roku 2007, kiedy to w gminach i powiatach nastąpił ich spadek. W roku 2011 we wszystkich typach JST nastąpił spadek, z wyjątkiem samorządów wojewódzkich, które jako jedyne odnotowały niewiel- 
ki wzrost udziału wydatków inwestycyjnych w ogólnej kwocie wydatków (wzrost o $1,9 \%$ z poziomu 37,5 do poziomu $39,4 \%$ ).

Tabela 3.7

Wielkość wydatków ogółem i wydatków inwestycyjnych oraz udział wydatków inwestycyjnych poszczególnych szczebli jednostek samorządu terytorialnego w latach 2005-2011

\begin{tabular}{|c|c|c|c|c|c|c|c|}
\hline Jednostka JST & 2005 & 2006 & 2007 & 2008 & 2009 & 2010 & 2011 \\
\hline \multicolumn{8}{|c|}{ Wydatki ogółem (w mln zl) } \\
\hline JST ogótem & 103807 & 120038 & 129113 & 145182 & 167828 & 177766 & 181595 \\
\hline Gminy & 45837 & 53179 & 56074 & 62893 & 70003 & 79741 & 79687 \\
\hline Powiaty & 13891 & 15593 & 16069 & 18114 & 21155 & 23826 & 24059 \\
\hline MPP* & 36491 & 41238 & 45877 & 51173 & 56202 & 58954 & 61510 \\
\hline Województwa & 7588 & 10028 & 11093 & 13002 & 20468 & 15245 & 16339 \\
\hline \multicolumn{8}{|c|}{ Wydatki inwestycyjne (w mln zl) } \\
\hline JST ogótem & 17750 & 24380 & 26257 & 30819 & 41600 & 43281 & 41188 \\
\hline Gminy & 8218 & 10692 & 10363 & 12553 & 15777 & 19690 & 17922 \\
\hline Powiaty & 1609 & 2271 & 2097 & 2605 & 4054 & 5181 & 4469 \\
\hline MPP* & 5538 & 7854 & 9865 & 11135 & 12081 & 12698 & 12365 \\
\hline Województwa & 2384 & 3563 & 3931 & 4525 & 9688 & 5712 & 6432 \\
\hline \multicolumn{8}{|c|}{ Udzial wydatków inwestycyjnych w wydatkach ogółem (w \%) } \\
\hline JST ogótem & 17,1 & 20,3 & 20,3 & 21,2 & 24,8 & 24,3 & 22,7 \\
\hline Gminy & 17,9 & 20,1 & 18,5 & 20,0 & 22,5 & 24,7 & 22,5 \\
\hline Powiaty & 11,6 & 14,6 & 13,0 & 14,4 & 19,2 & 21,7 & 18,6 \\
\hline MPP* & 15,2 & 19,0 & 21,5 & 21,8 & 21,5 & 21,5 & 20,1 \\
\hline Województwa & 31,4 & 35,5 & 35,4 & 34,8 & 47,3 & 37,5 & 39,4 \\
\hline
\end{tabular}

* MPP - miasta na prawach powiatu

Źródło: oprac. własne na podstawie Informacji z wykonania budżetów jednostek samorządu terytorialnego za lata 2005-2011, Warszawa 2006-2011, strony internetowe Ministerstwa Finansów.

Analizując strukturę i rozłożenie wydatków inwestycyjnych jednoznacznie nasuwa się wniosek, że polityka inwestycyjna gmin i miast na prawach powiatu ma decydujące znaczenie na kształtowanie tempa i kierunków rozwoju infrastruktury w Polsce.

Uwzględniając dynamikę zmian należy stwierdzić, że:

1. Wydatki ogółem JST w latach 2007-2009 wzrastały, w dwóch kolejnych latach nastąpił zaś spadek o 9,6\% w 2010 r. i o 3,9\% w 2011 r. (licząc rok do roku) w tym: wydatki ogółem gmin charakteryzowały się zmienną tendencją, wzrostowo spadkową w stosunku rok do roku, wydatki ogółem powiatów wzrastały do 2009 r., a w kolejnych latach nastąpił spadek, wydatki miast na prawach powiatu wzrastały w latach 2007-2008, a następnie wykazywały tendencję spadkową, wydatki województw największy wzrost odnotowały w 2009 r., w 2010 uległy obniżeniu o 83\% , w 2011 r. zaś wzrosły o 32,6\% r./r.; 
2. Wydatki inwestycyjne ogółem JST największy przyrost odnotowały w 2006 i 2009 r., na co złożył się systematyczny wzrost wydatków inwestycyjnych wszystkich szczebli, z czego największy szczebla wojewódzkiego (przyrost o 114,1\%), a następnie spadek w 2010 r. (największy także na szczeblu wojewódzkim - o 155,14\%), rok 2011 przyniósł spadek wydatków inwestycyjnych na wszystkich szczeblach z wyjątkiem województw, gdzie odnotowano 53,6\% przyrostu;

3. Potencjał inwestycyjny $w$ dynamice $r . / r$. wykazywał tendencje malejące z wyjątkiem znaczącego wzrostu potencjału inwestycyjnego województwa w 2009 r., w 2011 r. tylko powiaty odnotowały spadek potencjału inwestycyjnego, pozostałe szczeble samorządu wykazały jego wzrost.

Tempo i poziom zmian prezentowanych wielkości w poszczególnych jednostkach samorządu terytorialnego zależą $\mathrm{w}$ dużym stopniu od aktywności władz lokalnych i umiejętności pozyskiwania zewnętrznych źródeł finansowania inwestycji. Racjonalnie prowadzona polityka finansowa pozwala, nawet przy zaangażowaniu niewielkich własnych środków budżetowych, na realizację szerszego zakresu inwestycji, o czym świadczy stosunek wydatków inwestycyjnych do potencjału inwestycyjnego.

Tabela 3.8

Dynamika wydatków ogółem, wydatków inwestycyjnych i potencjału inwestycyjnego JST w latach 2005-2011

\begin{tabular}{|c|c|c|c|c|c|c|}
\hline Jednostka JST & 2006 & 2007 & 2008 & 2009 & 2010 & 2011 \\
\hline \multicolumn{7}{|c|}{ Wydatki ogólem } \\
\hline JST ogótem & 115,6 & 107,5 & 112,4 & 115,6 & 106,0 & 102,1 \\
\hline Gminy & 116,0 & 105,4 & 112,2 & 111,3 & 114,0 & 99,9 \\
\hline Powiaty & 112,2 & 103 & 112,7 & 116,7 & 112,6 & 100,9 \\
\hline MPP* & 113,0 & 111,2 & 111,5 & 109,8 & 104,9 & 104,3 \\
\hline Województwa & 132,2 & 110,6 & 117,2 & 157,4 & 74,5 & 107,1 \\
\hline \multicolumn{7}{|c|}{ Wydatki inwestycyjne } \\
\hline JST ogótem & 137,3 & 107,6 & 117,3 & 135,0 & 104,0 & 95,2 \\
\hline Gminy & 130,1 & 96,9 & 121,1 & 125,7 & 124,8 & 91,0 \\
\hline Powiaty & 141,1 & 92,3 & 124,2 & 155,6 & 127,8 & 86,2 \\
\hline MPP* & 141,8 & 125,6 & 112,9 & 108,5 & 105,1 & 97,3 \\
\hline Województwa & 149,4 & 110,3 & 115,1 & 214,1 & 58,9 & 112,6 \\
\hline \multicolumn{7}{|c|}{ Potencjal inwestycyjny } \\
\hline JST ogótem & 125,0 & 129,7 & 103,6 & 102,9 & 92,8 & 107,5 \\
\hline Gminy & 113,8 & 118,5 & 111,3 & 91,5 & 106,5 & 107,4 \\
\hline Powiaty & 119,7 & 132,2 & 122,5 & 115,7 & 124,0 & 99,1 \\
\hline MPP* & 143,5 & 143,5 & 89,0 & 71,4 & 109,0 & 114,6 \\
\hline Województwa & 127,7 & 131,1 & 109,2 & 186,2 & 53,5 & 103,2 \\
\hline
\end{tabular}

*MPP - miasta na prawach powiatu

Źródło: oprac. własne. 
Z zaprezentowanych danych wynika, że zapał do inwestowania w jednostkach samorządu terytorialnego nie słabnie. Jest to zjawisko pozytywne zważywszy na konieczność ciągłych inwestycji szczególnie w infrastrukturę i możliwości pozyskiwania środków europejskich. Mają one jednak charakter uzupełniający i nie powinno się ich odbierać $w$ kategoriach stałych źródeł finansowania inwestycji. Główna rola wśród czynników kształtujących poziom potencjału inwestycyjnego przypadnie nadwyżce środków z lat ubiegłych oraz poziomowi zadłużenia $^{119}$. Ta pierwsza będzie stanowiła jeden $\mathrm{z}$ głównych czynników napędzających inwestycje. Wzrost zadłużenia, a tym samym kosztów obsługi zadłużenia, będzie ograniczał potencjał inwestycyjny. W tym miejscu pojawia się luka, która może z powodzeniem być wypełniona przez kapitał prywatny pozyskiwany dla inwestycji realizowanych $\mathrm{w}$ formule partnerstwa publicznoprywatnego. Nie będzie on kreował zadłużenia, a możliwości inwestycyjne jednostek z pewnością wzrosną.

\section{4. Źródła finansowania inwestycji jednostek samorządu terytorialnego}

\subsubsection{Systematyka źródel finansowania inwestycji jednostek samorządu terytorialnego}

Inwestycje samorządowe, $\mathrm{w}$ tym inwestycje $\mathrm{w}$ infrastrukturę, warunkują kierunki i możliwości rozwoju jednostek terytorialnych. Inwestycje te, z uwagi na ich długotrwały i kapitałochłonny charakter wymagają długofalowej strategii finansowej, zapewniającej sprawną realizację samego przedsięwzięcia, a następnie zapewnienia trwałości finansowej w okresie eksploatacji. Złożoność procesu inwestycyjnego i długi okres realizacji inwestycji komunalnych wymagają ustalenia źródeł finansowania. Na ogólne koszty inwestycji składają się koszty bezpośrednie, ponoszone $\mathrm{w}$ trakcie procesu inwestycyjnego jak również pojawiające się po jej zakończeniu koszty eksploatacyjne. Aby sprostać wszystkim wydatkom władze samorządowe stają przed koniecznością przygotowania montażu finansowego dla inwestycji, warunkującego jej wykonanie. W finansowanie mogą być zaangażowane różne podmioty, poza tradycyjnymi, tj. jednostka samorządu terytorialnego, czy zależne od niej spółki komunalne, zewnętrzne podmioty, m.in. instytucje finansowe, przedsiębiorstwa, osoby fizyczne. Wobec tak zróżnicowanych możliwości finansowych, w tym możliwości łączenia kapitału pochodzącego z różnych źródeł, szczególnego znaczenia

${ }^{119}$ Instytut Badań nad Gospodarką Rynkową przeprowadził badania dotyczące poziomu potencjału inwestycyjnego JST w latach 2001-2006. Z badań wynika, że samorządy o niskim potencjale miały także mniejsze możliwości pozyskiwania środków zwrotnych. A to oznacza ograniczenie możliwości inwestycyjnych lub poszukiwanie innych metod ich finansowania. Por. T. Kaczor, M. Tomalak, Potencjat inwestycyjny jednostek samorzadu... 
nabiera umiejętność planowania finansowego oraz określenie zasad finansowania ze strony każdego z dawców kapitału. $\mathrm{Z}$ uwagi na fakt, że budżety samorządowe cechuje ograniczony poziom środków budżetowych na inwestycje, władze lokalne stają przed koniecznością ustalenia listy priorytetowych inwestycji, które mogą być finansowane ze środków budżetowych ${ }^{120}$. Realizacja inwestycji komunalnych wymaga:

1. Precyzyjnego określenia źródeł ich finansowania;

2. Ustalenia wielkości środków finansowych niezbędnych dla każdego etapu realizacji inwestycji;

3. Zagwarantowania w budżecie odpowiednich kwot wynikających $\mathrm{z}$ harmonogramu inwestycji;

4. Terminowego regulowania zobowiązań wynikających z realizacji inwestycji.

Wysokie ilościowe i jakościowe zapotrzebowanie na inwestycje w samorządach wymusza umiejętne, bazujące na rachunku ekonomiczno-społecznym, stworzenie montażu finansowego, będącego głównym czynnikiem decydującym o podjęciu bądź zaniechaniu działań inwestycyjnych. Obecnie w Polsce oraz w Unii Europejskiej istnieje wiele możliwości finansowania inwestycji, z których część jest typowa dla sektora publicznego, a część została zapożyczona z sektora prywatnego. Pozwala to samorządom na stworzenie szerszego zestawu instrumentów finansujących inwestycje. W literaturze przedmiotu funkcjonuje wiele klasyfikacji dotyczących źródeł zasilających budżety jednostek samorządu terytorialnego. Mnogość klasyfikacji wynika z trudności ustalenia przejrzystego podziału dochodów oraz różnorodności kryteriów, które się na siebie nakładają. Różnorodność klasyfikacji wywodzi się ze zróżnicowanego podejścia do dochodów i celów, jakie przyświecają przy próbach ich klasyfikowania. Jeden z podziałów klasyfikuje dochody jednostek samorządu terytorialnego na ${ }^{121}$ :

- dochody publiczno-prawne,

- dochody prywatno-prawne, oraz

- dochody zwrotne.

Dochody publiczno-prywatne przypadają jednostkom samorządu terytorialnego na podstawie stosunku prawnego o charakterze publicznym. Wykorzystanie tych dochodów przysługuje im z mocy obowiązującego prawa, tj. ustaw, które oddają im we władanie określone podatki, udziały w podatkach, subwencje i dotacje.

Dochody prywatno-prawne osiągają jednostki samorządu terytorialnego poprzez realizację praw własnościowych $\mathrm{w}$ stosunku do posiadanego mienia komunalnego. Samorząd jako właściciel ma prawo składniki swojego majątku

${ }^{120}$ J. Sierak, R. Górniak, Ocena efektywności i finansowanie projektów inwestycyjnych ..., s. 33.

121 A. Borodo, Samorzad terytorialny. System prawno-finansowy, Wydawnictwa Prawne PWN, Warszawa 1997, s. 47-48. 
wynająć, wydzierżawić, oddać w użytkowanie wieczyste, wnieść jako wkład lub udział do spółki bądź sprzedać. Dochody prawno-prywatne samorządy uzyskują na podstawie zawieranych umów cywilnoprawnych lub czynności cywilnoprawnych wynikających z przepisów kodeksu cywilnego albo handlowego.

Konstytucja RP w art. 167 dochody jednostek samorządu terytorialnego grupuje w trzy kategorie: dochody własne, subwencję ogólną oraz dotacje ${ }^{122}$. Kontynuując prawne podejście do klasyfikacji źródeł dochodów JST, enumerycznie identyfikuje je ustawa o dochodach jednostek samorządu terytorialnego ${ }^{123}$, wskazując na:

- wpływy z podatków i opłat,

- dochody uzyskiwane przez gminne jednostki budżetowe oraz wpływy od gminnych zakładów budżetowych,

- dochody z majątku gminy,

- spadki, zapisy i darowizny na rzecz jednostek samorządu terytorialnego,

- dochody z kar pieniężnych i grzywien określonych w odrębnych przepisach,

- 5\% dochodów uzyskiwanych na rzecz budżetu państwa w związku z realizacją zadań z zakresu administracji rządowej oraz innych zadań zleconych ustawami, o ile odrębne przepisy nie stanowią inaczej,

- odsetki od pożyczek udzielanych przez jednostki samorządu terytorialnego, o ile odrębne przepisy nie stanowią inaczej,

- odsetki od nieterminowo przekazywanych należności stanowiących dochody jednostki samorządu terytorialnego,

- odsetki od środków finansowych gromadzonych na rachunkach bankowych jednostki samorządu terytorialnego, o ile odrębne przepisy nie stanowią inaczej,

- dotacje z budżetów innych jednostek samorządu terytorialnego,

- inne dochody należne jednostce samorządu terytorialnego na podstawie odrębnych przepisów,

- wysokość udziału we wpływach z podatku dochodowego od osób fizycznych, od podatników tego podatku zamieszkałych na obszarze jednostki samorządu terytorialnego, oraz

- wysokość udziału we wpływach z podatku dochodowego od osób prawnych, od podatników posiadających siedzibę na terenie jednostki samorządu terytorialnego.

Źródła finansowania jednostek samorządu terytorialnego wskazane w aktach prawnych nie wskazują, które kategorie dochodów służą finansowaniu zadań bieżących, a które zadań inwestycyjnych. Tym samym poszczególne dochody mogą być przeznaczone na dowolną kategorię wydatków. Pozwala to na wyodrębnienie wewnętrznych oraz zewnętrznych źródeł finansowania

${ }^{122}$ Konstytucja Rzeczypospolitej Polskiej z 2 kwietnia 1997 r., DzU, 1997, nr 78, poz. 483.

${ }^{123}$ Ustawa z dnia 13 listopada 2003 r. o dochodach jednostek samorzadu terytorialnego, DzU, 2003, nr 203, poz. 1966 ze zm., art. 4. 
jednostek samorządu terytorialnego ${ }^{124}$. Źródła finansowania inwestycji jednostek samorządu terytorialnego przedstawia schemat 3.4.

Podział źródeł finansowania inwestycji na wewnętrzne i zewnętrzne, nie podważając i nie umniejszając innych podziałów, wydaje się zasadny z uwagi na usytuowanie źródła finansowania inwestycji, co zgadza się z opinią B. Guziejewskiej, że

wspólnotę samorządową tworzy ludność zamieszkującą określone terytorium. Istotne jest więc wyróżnienie dochodów, które mają swoje źródło na tym terytorium oraz tych, które pochodzą z zewnątrz ${ }^{125}$.

Do wewnętrznych źródeł finansowania inwestycji zalicza się dochody podatkowe oraz dochody niepodatkowe pobierane w formie opłat, a także dochody $\mathrm{z}$ tytułu posiadanego majątku.

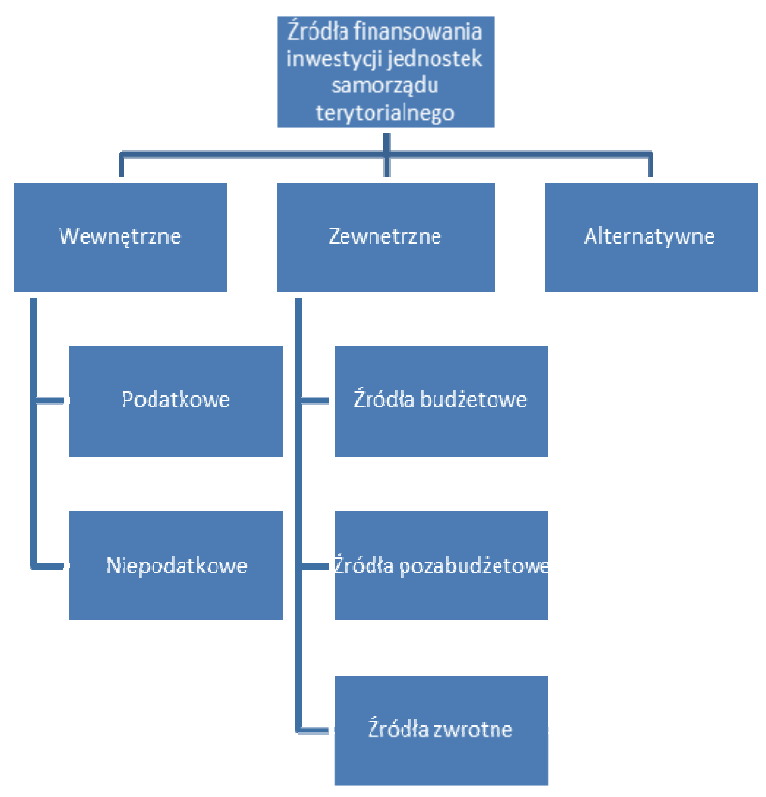

Schemat 3.4. Źródła finansowania inwestycji jednostek samorządu terytorialnego Źródło: oprac. własne

Zewnętrzne finansowanie inwestycji może przyjąć charakter źródeł budżetowych, pozabudżetowych oraz zwrotnych. Do źródeł budżetowych zalicza się

${ }^{124}$ Cz. Rudzka-Lorentz, J. Sierak, Zarzadzanie finansami jednostek samorzadu terytorialnego, [w:] Nowe zarzadzanie publiczne..., s. 175.

125 B. Guziejewska, Zewnętrzne źródła finansowania samorządu terytorialnego. Teoria i praktyka, Wydawnictwo Uniwersytetu Łódzkiego, Łódź 2008, s. 44. 
udziały w podatkach państwowych (podatek dochodowy od osób fizycznych i podatek dochodowy od osób prawnych), subwencję ogólną oraz dotacje celowe. Pozabudżetowe źródła finansowania obejmują środki pomocowe Unii Europejskiej i środki z funduszy celowych. Pożyczki, kredyty, emisja papierów wartościowych to podstawowe źródła o charakterze zwrotnym. Do dyspozycji jednostki samorządu terytorialnego mają jeszcze alternatywne źródła finansowania, które obejmują leasing, faktoring, forfaiting, partnerstwo publiczno-prywatne, czy project finance. Wykorzystanie powyższych źródeł zostało omówione w dalszej części rozdziału.

Każde ze źródeł ma swoje odrębne cechy i powinno być stosowane w zależności od występujących w danym momencie uwarunkowań społecznoekonomicznych. Decydenci powinni być świadomi korzyści i kosztów, jakie wiążą się z wykorzystaniem poszczególnych form finansowania inwestycji.

\subsubsection{Wewnętrzne źródła finansowania inwestycji jednostek samorządu terytorialnego}

Wewnętrzne źródła finansowania inwestycji obejmują własne środki budżetowe, w głównej mierze pochodzące $\mathrm{z}$ podatków i opłat lokalnych, a także dochodów z mienia komunalnego. Środki te pozostają do dyspozycji jednostki samorządu, są trwale związane $\mathrm{z}$ jej budżetem i nie podlegają ograniczeniom ze strony państwa ${ }^{126}$. Do dochodów własnych o charakterze podatkowym w gminach zalicza się: podatek od nieruchomości, rolny, leśny, od środków transportowych, czynności cywilnoprawnych, spadków i darowizn oraz podatek dochodowy płacony w formie karty podatkowej, a także opłaty lokalne m.in.: skarbową, targową, miejscową. Zgodnie z Ustawa o dochodach jednostek samorzadu terytorialnego ${ }^{127}$ do kategorii dochodów własnych gmin, powiatów i województw zalicza się także udziały w podatkach dochodowych stanowiących dochód budżetu państwa ${ }^{128}$. Źródłem generującym wpływy do budżetów

${ }^{126}$ H. Sochacka-Krysiak, Finanse lokalne, Poltext, Warszawa 1995, s. 24.

${ }^{127}$ Ustawa z dnia 13 listopada 2003 r. o dochodach jednostek samorzadu terytorialnego...

${ }^{128}$ Problematyka klasyfikacji dochodów jednostek samorządu terytorialnego budzi wiele kontrowersji. W literaturze trwa dyskusja, czy udziały w podatkach dochodowych stanowiących dochód budżetu państwa można/ powinno zaliczać się do dochodów własnych JST. Do wejścia w życie w 2004 r. ustawy o dochodach jednostek samorządu terytorialnego udziały były różnie przez autorów klasyfikowane. Dopiero ustawa wprowadziła jednoznaczny podział uznając udziały za dochody własne budżetów JST. Argumenty za i przeciw takiemu rozwiązaniu zob. m.in. w: S. Owsiak, Finanse publiczne, Wydawnictwo Naukowe PWN, Warszawa 2001; E. KornbergerSokołowska, Decentralizacja finansów publicznych a samodzielność finansowa jednostek samorząu terytorialnego, Liber, Warszawa 2001; B. Guziejewska, Problemy klasyfikacji źródet finansowania samorządu terytorialnego, „Samorząd Terytorialny” 2003, nr 6; Z. Gilowska, System ekonomiczny samorzadu terytorialnego w Polsce, Municipium, Warszawa 1998; K. Piotrowska-Marczak, Finanse lokalne $w$ Polsce, Wydawnictwo Naukowe PWN, Warszawa 
jednostek samorządu terytorialnego są także dochody z ich majątku. W stosunku do tej grupy wpływów jednostki samorządu mają największe możliwości kształtowania własnej polityki dochodowej. Poziom wpływów zależy od zasobów posiadanego mienia i prowadzonej przez władze polityki w tym zakresie. Wpływami z mienia najczęściej są: dochody ze sprzedaży majątku, z prywatyzacji przedsiębiorstw stanowiących własność jednostki samorządu, z najmu, dzierżawy, eksploatacji lokali komunalnych, z opłat za korzystanie z infrastruktury komunalnej, akcji i udziałów w spółkach akcyjnych oraz spółkach z o.o., z odsetek od środków finansowych zgromadzonych na rachunku bankowym, a także od udzielonych pożyczek, poręczeń i gwarancji ${ }^{129}$.

Finansowanie inwestycji ze źródeł budżetowych wiąże się z koniecznością ustalenia wysokości środków, które mogą zostać przeznaczone na działania inwestycyjne. Decyzje te muszą znaleźć odzwierciedlenie w uchwale budżetowej. W praktyce sprowadza się to do sporządzenia planu wydatków bieżących i inwestycyjnych (majątkowych). Opracowanie części inwestycyjnej budżetu zawiera informacje, jaka część planowanych wydatków może zostać przeznaczona na inwestycje, co jest wyrazem skali inwestycji w jednostce samorządu. Planowanie inwestycji powinno odbywać się zgodnie z wcześniej przyjętą polityką inwestycyjną, której formalnym wyrazem jest wieloletni plan inwestycyjny (WPI). Jego sporządzenie ma na celu zagwarantowanie ciągłości działań inwestycyjnych jednostki przy jednoczesnym ustaleniu hierarchii ważności przedsięwzięć.

Z finansowaniem inwestycji ściśle wiąże się także zagadnienie samodzielności finansowej samorządów. Do zapewnienia samodzielności finansowej konieczna jest decentralizacja finansów publicznych realizowana poprzez skuteczne regulacje prawne oraz finansowe zabezpieczenie. Zakres samodzielności zależy od dochodów, jakimi dysponuje jednostka oraz od swobody $\mathrm{w}$ dysponowaniu nimi ${ }^{130}$. Silna baza ekonomiczna pozwala uzyskiwać wyższe dochody budżetowe warunkujące realizację zadań inwestycyjnych. Należy zauważyć, że nie tylko poziom dochodów ogółem jednostki decyduje o rozmiarach inwestycji. Rozmiary działalności inwestycyjnej pozostają w ścisłej

1997; W. Miemiec, Prawne gwarancje samodzielności finansowej gminy w zakresie dochodów publicznych, Kolonia Limited, Wrocław 2005. J. Marczak proponuje wprowadzenie nowego, niebudzącego kontrowersji podziału na dochody czynne i bierne uwzględniający samodzielność jednostek w ich kształtowaniu: J. Marczak, W sprawie klasyfikacji dochodów jednostek samorzadu terytorialnego, [w:] Stan i kierunki rozwoju jednostek samorzadu terytorialnego, red. L. Patrzałek, Wydawnictwo Wyższej Szkoły Bankowej w Poznaniu, Poznań-Wrocław 2007, s. 175 i n.

${ }^{129}$ J. Sierak, R. Górniak, Ocena efektywności i finansowanie projektów..., s. 37. Charakterystykę poszczególnych kategorii źródeł dochodów JST prezentują M. Kosek-Wojnar, K. Surówka, Finanse samorzadu terytorialnego, Wydawnictwo Akademii Ekonomicznej w Krakowie, Kraków 2002, s. 60-69.

${ }^{130}$ E. Markowska-Bzducha, Samodzielność finansowa polskich gmin, Wydawnictwo Politechniki Gdańskiej, Radom 2005, s. 17. 
zależności od polityki i strategii władz lokalnych oraz polityki państwa w stosunku do inicjatyw lokalnych ${ }^{131}$. Omawiając własne źródła finansowania inwestycji w samorządzie nie wolno zapominać o możliwości samoopodatkowania. Kwestia samoopodatkowania się mieszkańców na cele publiczne rozstrzygana jest $\mathrm{w}$ drodze referendum gminnego ${ }^{132}$. Mieszkańcy gminy mogą opodatkować się tylko w zakresie zadań własnych. Danina nie może być źródłem finansowania zadań bieżących oraz wykraczających poza sferę użyteczności publicznej ${ }^{133}$. W tej formie najczęściej mogą być finansowane inwestycje, które z punktu widzenia wspólnoty mają ograniczony zasięg i służą zaspokojeniu potrzeb wąskiej grupy obywateli (np. utwardzenie drogi dojazdowej). W tej sytuacji mieszkańcy mogą wyrazić wolę partycypowania w kosztach inwestycji lub sfinansować ją w całości ze środków pochodzących z samoopodatkowania. Samoopodatkowanie jest daniną o charakterze celowym. W uchwale rady gminy w sprawie samoopodatkowania określa się podmiot, przedmiot opodatkowania, wysokość stawek, sposób powstania zobowiązania, sposób i czas realizacji, przeznaczenie i okres obowiązywania zobowiązania ${ }^{134}$. Koszty referendum w całości obciążają budżet gminy. Ważne jest, aby zostały pokryte dochodami uzyskanymi z samoopodatkowania. W praktyce jest to trudne, gdyż zwiększenie samodzielności finansowej $\mathrm{w}$ tej formie budzi wiele wątpliwości $\mathrm{i}$ jest trudne $\mathrm{z}$ uwagi na duży zakres obciążeń fiskalnych społeczeństwa ${ }^{135}$.

Wśród praktyków dominuje pogląd, że środki własne samorządu stanowią najprostszy sposób na finansowanie inwestycji. W praktyce okazuje się, że z trudem finansują one działalność bieżącą. W tej sytuacji montaż finansowy jest możliwy pod warunkiem pozyskania źródeł zewnętrznych.

\subsubsection{Zewnętrzne źródła finansowania inwestycji jednostek samorządu terytorialnego}

Subwencje, dotacje oraz fundusze z Unii Europejskiej zaliczane są do bezzwrotnych, zewnętrznych źródeł finansowania zadań jednostek samorządu terytorialnego. Są ważnym źródłem pozyskiwania dodatkowych środków

131 J. Sierak, Potrzeby $i$ wydatki inwestycyjne w samorządzie terytorialnym a możliwości $i$ źródta ich finansowania, [w:] Gospodarka finansowa jednostek samorzadu terytorialnego $w$ warunkach decentralizacji zarządzania sektorem publicznym, red. H. Sochacka-Krysiak, Oficyna Wydawnicza SGH, Warszawa 2008, s. 193.

${ }^{132}$ Ustawa z dnia 15 września 2000 r. o referendum lokalnym, DzU, 2011, nr 147, poz. 881.

133 Zarys finansów publicznych i prawa finansowego, wyd. 5, red. A. Gorgol, A. Kuś, A. Niezgoda, P. Smoleń, W. Wojtowicz, Wolter Kluwer, Warszawa 2008, s. 101.

${ }^{134}$ R. Stasikowski, Gwarancje samodzielności gminnej w systemie prawnym Republiki Federalnej Niemiec i Rzeczpospolitej Polskiej, Oficyna Wydawnicza Branta, Bydgoszcz-Katowice 2005, s. 225.

${ }^{135}$ A. J. Kozłowski, I. Z. Czaplicka-Kozłowska, Samorząd terytorialny w systemie zarządzania państwem. Zagadnienia wybrane, Pracownia Wydawnicza Elset, Olsztyn 2010, s. 102. 
pieniężnych, które mogą być przeznaczane na finansowanie inwestycji infrastrukturalnych. Subwencje i dotacje są transferowane z budżetu państwa do budżetów jednostek samorządu terytorialnego i stanowią wyraz realizacji funkcji alokacyjnej i redystrybucyjnej finansów publicznych. Wyraźnie jednak należy zaznaczyć, że oba instrumenty mają odmienny charakter oraz przeznaczenie. Środki z subwencji ogólnej mają charakter ogólny i służą równoważeniu budżetu, natomiast dotacje cechuje celowość związana z koniecznością realizacji określonych zadań - istotnych z punktu widzenia interesów państwa ${ }^{136}$. Dodatkowo rozdział środków ma częściowo charakter uznaniowy (dotyczy to dotacji), co nie sprzyja traktowaniu ich jako stabilnego źródła finansowania działań rozwojowych ${ }^{137}$. Subwencja ogólna jest jednym $\mathrm{z}$ podstawowych narzędzi redystrybucji dochodów $\mathrm{z}$ budżetu władz centralnych do budżetów władz samorządowych ${ }^{138}$. Jej zadaniem jest niwelowanie dysproporcji w rozkładzie źródeł dochodów własnych, nierówności w rozmieszczeniu terytorialnym zadań i wydatków związanych $\mathrm{z}$ zaspokajaniem potrzeb społeczeństwa zarówno w zakresie infrastruktury społecznej (socjalnej), jak i komunalnej ${ }^{139}$. Konieczność likwidacji nadmiernych odrębności w stanie infrastruktury technicznej wymaga od samorządów decyzji o kierunku wydatkowania środków. Ograniczenie wydatków na inwestycje infrastrukturalne będzie prowadziło do pogłębiających się dysproporcji w rozwoju poszczególnych jednostek samorządu terytorialnego, a tym samym do dysproporcji w poszczególnych regionach. Zasady przyznawania władzom lokalnym subwencji powinny gwarantować możliwość oszacowania jej wysokości w co najmniej kilkuletniej perspektywie, co pozwoli ustalić właściwą politykę wydatkową. Subwencję od innych zewnętrznych źródeł zasilania różni brak jej powiązania z celem, na jaki może zostać przeznaczona, co zapewnia jednostce swobodę $\mathrm{w}$ rozdysponowaniu, obligatoryjny charakter, zapewniający jednostkom stałe źródło dochodu, bezzwrotny charakter ${ }^{140}$. Wyjątek stanowi część oświatowa subwencji ogólnej, której środki służą finansowaniu zadań oświatowych. Ta część środków ma charakter celowy.

Dotacje celowe stanowią specyficzny sposób finansowania zadań jednostek samorządu terytorialnego. W myśl przepisów ustawy o dochodach jednostek

${ }^{136}$ Z. Ofiarski, Subwencje i dotacje jednostek samorzadu terytorialnego, Difin, Warszawa 2002, s. 24.

${ }^{137}$ Cz. Rudzka-Lorentz, J. Sierak, Zarzadzanie finansami w gminach..., s. 219.

${ }^{138}$ S. Owsiak, Finanse publiczne, teoria i praktyka, Wydawnictwo Naukowe PWN, Warszawa 2005 , s. 452.

${ }^{139}$ Konieczność subwencjonowania jednostek samorządu terytorialnego została dokładnie omówiona przez B. Guziejewską w pracy: Zewnętrzne źródła finansowania samorządu terytorialnego....

${ }^{140}$ Zob. L. Patrzałek, Finanse samorzadu terytorialnego, Wydawnictwo Akademii Ekonomicznej im. O. Langego we Wrocławiu, Wrocław 2004, s. 116. 
samorządu terytorialnego środki z dotacji można przeznaczyć na z góry określony cel z zakresu administracji rządowej i inne zadania zlecone ustawami, zadań realizowanych przez samorządy na mocy porozumień zawartych $\mathrm{z}$ administracją rządową, finansowania lub dofinansowania zadań własnych, zadań wynikających $\mathrm{z}$ umów międzynarodowych ${ }^{141}$. Pomoc ta jest ważnym źródłem dodatkowych środków pieniężnych, które można przeznaczyć na rozwój. Finansowanie zadań zleconych jest spełnieniem zasady, w myśl której za wzrostem zadań musi następować wzrost środków na ich realizację. W przypadku dotowania zadań własnych zwiększeniu ulega ta część dochodów, która bezpośrednio wiąże się $\mathrm{z}$ dotowaniem inwestycji ${ }^{142}$. Zakres dotowania zadań własnych obejmuje przede wszystkim obszar pomocy społecznej, wypłatę dodatków mieszkaniowych oraz inwestycje $\mathrm{w}$ sferze infrastruktury technicznej oraz ochrony środowiska. Uzyskanie dotacji powoduje, że samorząd może podjąć działania inwestycyjne wcześniej. Bez wsparcia przedsięwzięcie doczekałoby się realizacji w późniejszym terminie, a w drastycznym przypadku zostałoby odrzucone. Istotną barierą ograniczającą zasób dotowanych środków jest zapis, że inwestycja w kolejnych latach może być sfinansowana $\mathrm{z}$ dotacji $\mathrm{w}$ wysokości $50 \%$ wartości kosztorysowej ${ }^{143}$.

Ważnym źródłem pozabudżetowym w ramach dotacji kierowanych do samorządów są środki z funduszy celowych. Istotna rola przypada Narodowemu Funduszowi Ochrony Środowiska i Gospodarki Wodnej oraz jego oddziałom wojewódzkim. Środki z funduszu kierowane są na inwestycje i działania związane $\mathrm{z}$ edukacją ekologiczną, przygotowaniem i wdrażaniem inwestycji w zakresie ochrony środowiska i ochrony lasów. Zakres pomocy świadczonej przez Fundusz jest zróżnicowany. W praktyce środki najczęściej kierowane są na realizację inwestycji o szerszym, ogólnokrajowym zasięgu. Zazwyczaj finansową akceptację uzyskiwały projekty dotyczące budowy sieci wodociągowej i kanalizacyjnej, oczyszczalni ścieków, urządzeń przeciwpowodziowych oraz innych związanych z ochroną środowiska.

Wraz z przystąpieniem Polski do Unii Europejskiej jednostki samorządu terytorialnego stały się beneficjentami pomocy przyznawanej $\mathrm{w}$ ramach wspólnotowej polityki regionalnej. Jest ona niewątpliwie jednym z najlepszych źródeł pozyskiwania środków na finansowanie infrastruktury przez biedniejsze regiony w celu niwelowania dysonansu ekonomicznego. Członkostwo w Unii Europejskiej otworzyło Polsce drogę do finansowania inwestycji zarówno z funduszy strukturalnych, jak i Funduszu Spójności, doprowadzając tym samym do wielu pozytywnych przemian $\mathrm{w}$ gospodarce przejawiających się we wzroście gospo-

${ }^{141}$ S. Owsiak, Finanse publiczne, teoria..., s. 459.

${ }^{142}$ K. Jarosiński, Finansowanie inwestycji komunalnych $w$ Polsce..., s. 175.

${ }^{143}$ Ustawa z dnia 27 sierpnia 2009 r. o finansach publicznych, DzU, 2009, nr 157, poz. 1240 ze zm., art. 133. 
darczym, poprawie jakości życia społeczeństwa, rozwoju urządzeń i obiektów infrastrukturalnych. Dla samorządów stanowią niepowtarzalną szansę na rozwój społeczno-gospodarczy poprzez wsparcie bieżącej i inwestycyjnej działalności. Podobnie jak większość dotacji, mają one jednak charakter okresowy i uzupełniający, powinny być więc traktowane jako nadzwyczajne. Nie należy oczywiście lekceważyć ich znaczenia w sytuacji, gdy dochody własne pozostają $\mathrm{w}$ niedoborze $\mathrm{w}$ stosunku do potrzeb ${ }^{144}$. W okresie poprzedzającym przystąpienie do struktur unijnych Polska miała do dyspozycji fundusze przedakcesyjne ${ }^{145}$. Po uzyskaniu członkostwa uzyskała prawo do aplikowania po środki strukturalne. Uwzględniając wartość uzyskanej pomocy samorządy terytorialne tworzą największą grupę beneficjentów środków unijnych ${ }^{146}$. Tak jak już zaznaczono, ma ona charakter uzupełniający i nie powinna zastępować mechanizmów ekonomicznych, które mają funkcjonować w ramach własnych możliwości finansowych państwa i samorządów. W chwili obecnej należy budować i wdrażać mechanizmy, które na trwałe wpiszą się w obraz gospodarki samorządowej i zapewnią systematyczny rozwój poprzez ciągłe działania inwestycyjne (trzeba pamiętać, że infrastruktura komunalna wymaga stałego dofinansowania, aby być w ciągłej gotowości do świadczenia usług publicznych). Specyfika świadczenia zróżnicowanych usług publicznych prowadzi do konieczności wypracowania określonego pakietu instrumentów umożliwiających sprawne zarządzanie procesami bieżącego świadczenia usług oraz efektywnego zarządzania środkami pieniężnymi przeznaczonymi na inwestycje. Inwestycje samorządowe są związane $\mathrm{z}$ odtwarzaniem istniejącej masy infrastrukturalnej oraz budową nowych obiektów i urządzeń, podporządkowanych działaniom o charakterze rozwojowym.

W finansowaniu inwestycji samorządowych ważne miejsce odgrywają źródła zewnętrzne o charakterze zwrotnym. Zdaniem P. Swianiewicza

${ }^{144}$ Prawo samorządu terytorialnego, red. Z. Ofiarski, M. Mokrzyc, WSAP w Szczecinie, Szczecin 1999, s. 296.

${ }^{145}$ Polska miała do dyspozycji środki z trzech funduszy PHARE - funduszu udzielającego pomocy państwom kandydującym, wspierającym przemiany społeczno-gospodarcze, SAPARD - środki przeznaczane na modernizację obszarów wiejskich, ISPA - fundusz, z którego finansowano duże, o zasięgu ogólnokrajowym, inwestycje infrastrukturalne.

${ }^{146}$ W 2010 r. jednostki samorządu terytorialnego wydały łącznie 43,2 mld zł środków unijnych. Projekty samorządowe wypełniły lukę inwestycyjną wywołaną kryzysem globalnym w latach 2009-2010 w sektorze prywatnym. W 2009 r. wydatki samorządów stanowiły 60\% nakładów w sektorze publicznym i 14,6\% inwestycji w całej gospodarce. W porównaniu z $2008 \mathrm{r}$. wzrosły o $35 \%$ i były jednym z głównych czynników napędzających wzrost gospodarczy. W $2010 \mathrm{r}$. inwestycje samorządowe wyniosły $16 \%$, choć ich dynamika nie była już tak znaczna jak w poprzednim okresie. Ranking samorządów 2011, „Rzeczpospolita” z 19.07.2011; W. Szymański, Wykorzystanie środków z funduszy strukturalnych przez jednostki samorządu terytorialnego - szanse i zagrożenia, [w:] Samorząd terytorialny..., s. 279. 
koncepcja fiskal federalism dostarcza argumentów za stosowaniem kredytów, sugerując wręcz, że jest to metoda lepsza niż finansowanie inwestycji z dochodów bieżących ${ }^{147}$.

Autor wskazuje na szereg argumentów za wykorzystaniem instrumentów dłużnych, wymieniając $\mathrm{c}^{148}$ :

- równość międzypokoleniową i geograficzną;

- bliskość między tymi, którzy płacą i tymi, którzy korzystają z inwestycji, co sprzyja efektywnej alokacji środków;

- korzyści z przyspieszonego rozwoju gospodarki przewyższające koszt obsługi kredytu;

- obniżenie bieżących kosztów funkcjonowania;

- fakt, że długo prowadzona inwestycja kosztuje drożej;

- stabilizację wielkości potrzebnych środków budżetowych;

- dostęp do środków Unii Europejskiej i innych programów pomocowych.

Kredyty bankowe i pożyczki są tradycyjnymi i najbardziej powszechnymi formami finansowania inwestycji przez samorządy. Umożliwiają pokrycie występujących $\mathrm{w}$ trakcie roku budżetowego niedoborów budżetowych oraz finansowanie inwestycji w sytuacji, gdy brakuje własnych dochodów budżetowych i środków transferowanych z budżetu państwa. Pozyskanie źródeł zwrotnych oznacza czasowy napływ środków pieniężnych z jednej strony, a z drugiej skutkują one zaciągnięciem zobowiązania - nie stanowią czystego dochodu jednostek, obciążają budżet danego roku i przyszłych okresów, powiększając zadłużenie jednostki. Zapewniają zarazem wzrost płynności finansowej w danym okresie i pozwalają sfinansować więcej zadań, w tym inwestycyjnych, przekraczających możliwości rocznych dochodów budżetowych ${ }^{149}$.

Kredyty i pożyczki różnią się elementami konstrukcji i funkcjonowania. Umowę pożyczki regulują przepisy kodeksu cywilnego, a umowę kredytu przepisy ustawy Prawo bankowe ${ }^{150}$ i regulacje wewnątrzbankowe dotyczące np. wysokości oprocentowania, kwoty kredytu, wymaganych zabezpieczeń. Za wykorzystaniem tych form przemawia krótki okres pozyskania środków lub brak ekonomicznych przesłanek do skorzystania $\mathrm{z}$ innych źródeł finansowania ${ }^{151}$. Kredyt może być udzielony tylko przez bank z przeznaczeniem na ściśle określony cel. Pożyczki udzielają zarówno banki, jak i inne podmioty, np. państwowe fundusze celowe, fundacje. Ich charakter jest bardziej uniwersalny, przez co nie ma konieczności wskazywania w umowie celu przeznaczenia środków czy warunków wykorzystania pożyczonego kapitału. Korzystanie

\footnotetext{
${ }^{147}$ P. Swianiewicz, Finanse lokalne, teoria i praktyka, Municypium S.A., Warszawa 2004, s. 131.

${ }^{148}$ Ibidem, s. 131-133.

${ }^{149}$ Zob. L. Patrzałek, Finanse samorzadu terytorialnego..., s. 134-137.

${ }^{150}$ Ustawa z dnia 29 sierpnia 1997 r. Prawo bankowe, DzU, 2011, nr 232, poz. 1378.

${ }^{151}$ D. Hajdys, Źródta finansowania inwestycji infrastrukturalnych ..., s. 10 i n.
} 
z instrumentów dłużnych pozwala na przyspieszoną realizację inwestycji, co znajduje odbicie w strukturze zobowiązań jednostek. W 2010 r. kredyty i pożyczki stanowiły przeszło $90 \%$ zobowiązań jednostek wszystkich szczebli, z czego największy udział miały one w strukturze zobowiązań gmin $-96,6 \%$, a najmniejszy w województwach $-92 \%$. W ostatnich latach na znaczeniu zyskały kredyty i pożyczki preferencyjne, których popularność wynika z dostępności i niskich kosztów. Korzyści dla pożyczkobiorcy związane są z preferencyjnym oprocentowaniem lub zabezpieczeniem. Odsetki ustalane są na bardzo niskim poziomie, często nawet zerowym. W sytuacji terminowo i prawidłowo zrealizowanej inwestycji pożyczkodawca umarza część pożyczki, co dodatkowo motywuje samorządy do aplikowania o środki w tej formie.

Szczególnym źródłem finansowania inwestycji są obligacje komunalne. Prawo do emisji na mocy ustawy o obligacjach ${ }^{152}$ przyznane zostało wszystkim szczeblom samorządu terytorialnego. Obligacje ${ }^{153}$ są jednym z najstarszych papierów wartościowych, a jednocześnie stanowią istotny instrument finansowy we współczesnym świecie. W polskiej praktyce nie istnieje odrębny akt prawny regulujący obrót samorządowymi papierami wartościowymi. Tak jak wspomniano, zasadnicza regulacja określona została w ustawie o obligacjach. Środki pozyskane $\mathrm{w}$ efekcie emisji zostają przeznaczone na cel ujęty w uchwale emisyjnej. Przewaga obligacji nad kredytem czy pożyczką polega na tym, że emitent ma swobodę w kształtowaniu sposobu spłaty zobowiązania. Zgodnie z zasadami obowiązującymi w większości umów kredytowych i pożyczkowych mogą one pokryć tylko część wydatków związanych z przedmiotem umowy, resztę pożyczkobiorca musi sfinansować ze środków własnych ${ }^{154}$. W przypadku emisji obligacji nie ma takiego obowiązku. Wysokość emisji może zostać ustalona na takim poziomie, który pokryje wszystkie nakłady związane z inwestycją oraz procedurą przygotowania samej emisji. Specyfika obligacji pozwala emitentowi dowolnie kształtować warunki spłaty zobowiązania. Termin wykupu emisji oraz terminy płatności odsetek kształtuje się odpowiednio do możliwości

${ }^{152}$ Ustawa z dnia 29 czerwca 1995 r. o obligacjach, DzU, 2005, nr 157, poz. 1316 ze zm.

${ }^{153}$ Zgodnie z art. 4 Ustawy o obligacjach obligacja jest papierem wartościowym emitowanym w serii, w którym emitent stwierdza, że jest dłużnikiem właściciela obligacji i zobowiązuje się wobec niego do spełnienia określonego świadczenia. W uwagi na okres wykorzystania instrumentu rozróżnia się obligację komunalną, której okres wykupu jest dłuższy niż jeden rok (stanowią one źródło finansowania inwestycji) oraz bon komunalny, którego celem emisji jest sfinansowanie bieżących potrzeb budżetowych. Okres wykupu nie przekracza roku. Istota bonu komunalnego przedstawiona została przez M. Rybarczyka, Bon komunalny, „Gazeta Prawnicza” 1999, nr 16-17; E. Wojciechowski, A. Bogus, Bon komunalny w gospodarce finansowej gminy, [w:] Finanse, banki $i$ ubezpieczenia w Polsce u progu XXI wieku, Wydawnictwo Akademii Ekonomicznej w Poznaniu, Poznań, 2000, s. 214-216; J. Niechcielski, D. Wieloch, Szybki i tani pieniadz, „Rzeczpospolita” 1999, nr 125.

${ }^{154}$ A. Kopańska, Zewnętrzne źródła finansowania inwestycji jednostek samorządu terytorialnego, Difin, Warszawa 2003, s. 121. 
finansowych samorządu. Często w celu uelastycznienia emisji obligacje emitowane są w kilku seriach. Należy mieć jednak na uwadze fakt, że przy wyborze emisji mogą pojawić się koszty, które nie występują przy kredycie (związane z wyborem agenta, doradców prawno-ekonomicznych, koszt przygotowania prospektu/memorandum informacyjnego). Jest to uzależnione od wielkości i charakteru inwestycji, sytuacji ekonomicznej samorządu oraz aktualnej specyfiki rynku. Dokonując analizy efektywności instrumentów należy uwzględnić obok czynników finansowych również czynniki pozaekonomiczne. Chodzi tu o element promocji, marketingu samorządu. Jednostka emitująca obligacje postrzegana jest jako innowacyjna, dynamicznie się rozwijająca. Pojawienie się samorządu na rynku kapitałowym także wzmacnia jego wiarygodnośćc $155^{\circ}$. Kształtowanie takiego wizerunku często sprzyja pozyskaniu nowych inwestorów, tym samym pozwala na długookresowy rozwój gospodarczy regionu i pozytywnie wpływa na poziom życia lokalnej społeczności ${ }^{156}$. Obligacje stanowią dla samorządów interesujący sposób pozyskania środków na finansowanie działalności inwestycyjnej, obejmując wieloletnie i kosztowne przedsięwzięcia ${ }^{157}$. Najczęściej są źródłem finansowania obiektów infrastrukturalnych ${ }^{158}$, związanych z gospodarką wodno-kanalizacyjną, transportową, mieszkalnictwem komunalnym oraz urządzeniami z zakresu ochrony środowiska.

Od 2000 r. polskie samorządy uzyskały prawo do emisji nowego instrumentu, jakim jest obligacja przychodowa. Cechą charakterystyczną tego instrumentu jest ograniczenie odpowiedzialności emitenta za zobowiązania z niego płynące, do kwoty przychodów lub wartości majątku, jaką generuje przedsięwzięcie finansowane tym papierem. Automatycznie zmniejszeniu ulega ryzyko, gdyż jednostka nie odpowiada całym swoim majątkiem za zobowiązania wynikające $\mathrm{z}$ emisji ${ }^{159}$ (w przypadku emisji obligacji klasycznej odpowiedzialność jest całkowita). Dodatkowym atutem obligacji przychodowych jest to, że zobowiązania z nich wynikające nie obciążają budżetów samorządowych, tym samym nie zalicza się ich do zadłużenia jednostki, a więc ostatecznie nie wpływają na limity zadłużenia.

${ }^{155}$ Zob. R. Grynis, Obligacje komunalne - efektywny instrument finansowy czy promocja miasta, „Bank i Kredyt” 2002, nr 1, s. 63.

${ }^{156}$ Por. P. Śliwiński, Kryteria wyboru zewnętrznych źródel finansowania deficytu budżetowego jednostki samorzadu terytorialnego, „Finanse Komunalne” 2002, nr 5, s. 24 i n.

${ }^{157}$ A. Michalak, Finansowanie inwestycji w teorii i praktyce, Wydawnictwo Naukowe PWN, Warszawa 2007, s. 129.

${ }^{158}$ Szczegółowa analiza rynku obligacji komunalnych i przedsięwzięć finansowanych emisją przedstawiona została m.in. przez D. Hajdys, Rozwój rynku obligacji komunalnych $w$ Polsce w latach 1996-2000, Wydawnictwo Uniwersytetu Łódzkiego, Łódź 2003.

${ }^{159}$ P. M. Woroniecki, Obligacje przychodowe, „Inwestycje komunalne - Przegląd Zamówień Publicznych" 2004, nr 12, s. 22. 
Znaczny potencjał inwestycyjny pokazały pierwsze emisje obligacji. Pierwsza przeprowadzona została przez Miejskie Wodociągi i Kanalizację Spółkę z o.o. w Bydgoszczy, dwie kolejne przez Miejskie Przedsiębiorstwo Komunikacyjne Spółkę z o.o. w Łodzi i Zakład Komunikacji Miejskiej w Gdańsku. Obligacje postrzegane są wciąż jednak jako nowa, nieznana i niepewna metoda finansowania zadań. Wiele samorządów interesuje się tym instrumentem, lecz nie podejmuje działań służących faktycznemu jego wykorzystaniu ${ }^{160}$. Obawiają się kosztów i prac związanych z procedurą emisyjną. Można przypuszczać, że w momencie zbliżania się do granicy limitu zadłużenia, malejących możliwości uzyskania dofinansowania unijnego do przedsięwzięć inwestycyjnych instrument ten zacznie zyskiwać na popularności.

\subsubsection{Alternatywne źródla finansowania inwestycji jednostek samorządu terytorialnego}

Jednostki samorządu terytorialnego, podobnie jak inne podmioty, mogą finansować niektóre inwestycje leasingiem ${ }^{161}$. Leasing umożliwia samorządom sfinansowanie nowych inwestycji, jak również odmrożenie kapitału z już dokonanych (leasing zwrotny nieruchomości). Forma ta może być wykorzystana w sposób bezpośredni przez jednostkę samorządu terytorialnego lub wskazany przez nią inny podmiot ${ }^{162}$ (spółka komunalna, zakład budżetowy). Wykorzystanie leasingu do finansowania zadań inwestycyjnych przez samorządy stanowi alternatywę do kredytów i pożyczek, zwłaszcza w sytuacji braku środków budżetowych lub liberalizacji w podejściu do zarządzania sektorem samorządowym. Powszechnie formuła uznawana jest za efektywne źródło finansowania tych inwestycji infrastrukturalnych, w których podmiot prywatny występuje jako strona eksploatująca. Miarą atrakcyjności leasingu komunalnego jest ocena zdolności kontraktowej, a nie zdolności kredytowej, możliwość otrzymania obiektu infrastruktury bez konieczności wnoszenia wkładu własnego, korzystne

${ }^{160}$ L. Jędrzejewski, Gospodarka finansowa samorzadu terytorialnego w Polsce. Wybrane zagadnienia, Oficyna Wydawnicza Branta, Bydgoszcz-Gdańsk 2007, s. 189.

${ }^{161}$ Według kodeksu cywilnego przez umowę leasingu finansujący zobowiązuje się, nabyć rzecz od oznaczonego zbywcy w warunkach określonych w umowie i oddać tę rzecz korzystającemu do używania albo używania i pobierania pożytków przez oznaczony czas, a korzystający zobowiązuje się zapłacić finansującemu w uzgodnionych ratach wynagrodzenie pieniężne równe cenie lub wynagrodzeniu z tytułu nabycia rzeczy przez finansującego. Ustawa z dnia 23 kwietnia 1964 r. Kodeks cywilny, DzU z 2011 r., nr 230, poz. 1370; w zależności od charakteru leasingu wyróżnia się leasing bezpośredni, pośredni, finansowy, operacyjny, czysty, pełny, lombardowy, zwrotny. Poszczególne formy zostały dokładnie rozpoznane i opisane w literaturze.

162 J. Zawora, Samodzielność finansowa samorzadu gminnego, Wydawnictwo Uniwersytetu Rzeszowskiego, Rzeszów 2008, s. 132. 
warunki zabezpieczenia spłaty rat wynagrodzenia finansującego, prawo zawarcia w umowie opcji własności z możliwością podjęcia decyzji przez korzystającego przed terminem wygaśnięcia umowy ${ }^{163}$. Samorządy najczęściej leasingują ruchomości, które natychmiast można wykorzystać do realizacji zadań. Rzadziej przedmiotem leasingu są nieruchomości. Samorząd nie jest wówczas właścicielem, a jedynie ich użytkownikiem. Po zakończeniu umowy przysługuje mu prawo pierwokupu nieruchomości za symboliczną cenę. $Z$ punktu widzenia samorządu jest to korzystna forma finansowania. Przedmiot leasingu jest natychmiast po zawarciu umowy udostępniony do użytkowania bez konieczności finansowego zaangażowania. Środki finansowe, będące w dyspozycji, można w tym czasie przeznaczyć na inne działania i potrzeby. Tak jak wspomniano, najczęściej przedmiotem umów leasingowych jest mienie ruchome. $\mathrm{Z}$ uwagi na korzyści podatkowe umów najkorzystniej jest, gdy stroną nie jest bezpośrednio sama jednostka, a przedsiębiorstwo. Transakcja pozwala na transfer korzyści podatkowych od podmiotu, który potrzebuje określonego wyposażenia, lecz nie może pozwolić sobie na spożytkowanie korzyści, do podmiotu, który go nie potrzebuje, ale jest zainteresowany owymi korzyściami podatkowymi ${ }^{164}$.

Faktoring umożliwia samorządom realizację inwestycji nawet wówczas, gdy w danym roku budżetowym nie posiadają one całej sumy potrzebnej na sfinansowanie wydatków inwestycyjnych. Środki finansowe wobec przedsiębiorców zapewnia bank lub firma faktoringowa poprzez wydłużenie terminów płatności faktur wystawionych przez dostawców i kontrahentów JST. Usługa faktoringu przyczynia się do zwiększenia płynności finansowej jednostki poprzez likwidację opóźnień płatniczych, co pozwala skutecznie zaplanować przyszłe przepływy gotówki. Dzięki faktoringowi samorządy nie muszą obawiać się skutków luki finansowej pojawiającej się w sytuacji konieczności wydłużenia terminu płatności swoim kontrahentom i tym samym odraczać spłaty swoich faktur. W praktyce banki i firmy faktoringowe najczęściej oferują samorządom usługę faktoringu niepełnego, polegającego na tym, że bank lub firma faktoringowa nie ponosi ryzyka związanego z niewypłacalnością dłużnika. Oferowany jest też tzw. faktoring samorządowy przeznaczony dla przedsiębiorców dostarczających towary lub świadczących usługi, w tym wykonujących roboty budowlane dla JST. Polega on na nabyciu wystawionych na jednostkę samorzą-

${ }^{163}$ Zob. H. Janowska, Leasing jako źródło finansowania inwestycji w zakresie gminnej infrastruktury technicznej, [w:] Finanse przedsiębiorstw. Finanse publiczne i podatki, t. 2, red. K. Znaniecka, Wydawnictwo Akademii Ekonomicznej w Katowicach, Katowice 2002, s. 496; W praktyce poza wybranymi przypadkami leasing nie stanowi istotnego źródła finansowania. Natomiast jest szeroko wykorzystywany na rynku brytyjskim przy inwestycjach realizowanych metodą Private Finance Initiative, Wspótczesne problemy zarządzania finansami lokalnymi, red. A. Kożuch, K. Brzozowska, Fundacja Współczesne Zarządzanie, Kraków 2006, s. 105.

${ }^{164}$ Zob. Cz. Rudzka-Lorentz, J. Sierak, Zarzadzanie finansami jednostek samorzadu..., s. 181. 
du terytorialnego przez przedsiębiorców faktur z przejęciem pełnego ryzyka niewypłacalności JST, co oznacza że bank może dochodzić swojej należności wyłącznie od JST. Z kolei faktoring samorządowy odwrotny to usługa kierowana bezpośrednio do samorządów przez banki, w jej ramach samorząd za zgodą wykonawcy decyduje się na finansowanie inwestycji za pomocą faktoringu ${ }^{165}$.

Kolejnym alternatywnym źródłem finansowania jest forfaiting, który polega na

jednoczesnym zawarciu przez samorząd umowy realizacyjnej z wykonawcą inwestycji oraz zawarciu przez wykonawcę umowy forfaitingu z instytucja forfaitingową (bankiem), w której ceduje on na nią wierzytelność z tytułu wynagrodzenia od samorządu z wyłączeniem regresu (możliwości dochodzenia zapłaty wierzytelności od przedsiębiorcy w przypadku niewypłacalności JST). Umowa realizacyjna przewiduje wypłatę wynagrodzenia całości wynagrodzenia wykonawcy przez JST w ratach, a równoległa umowa forfaitingu gwarantuje wypłatę całości wynagrodzenia przez forfaitera przed terminem wymagalności rat, bezpośrednio po odbiorze prac przez JST. W efekcie bank płaci wykonawcom pełne wynagrodzenie (ewentualnie pomniejszone o prowizję) niezwłocznie po wykonaniu i odbiorze zakontraktowanych prac. Następnie JST spłaca na rzecz instytucji forfaitingowej wierzytelności tytułem wynagrodzenia powiększonego o należne oprocentowanie, w terminach pokrywających się $\mathrm{z}$ wieloletnimi terminami określonymi umową realizacyjną ${ }^{166}$.

Obok wymienionych, powszechnie znanych sposobów finansowania inwestycji, w literaturze wskazuje się także na partnerstwo publiczno-prywatne oraz project finance.

Partnerstwo publiczno-prywatne to formuła finansowania zadań publicznych oparta na współpracy dwóch sektorów, publicznego i prywatnego w zakresie realizacji przedsięwzięć inwestycyjnych lub świadczenia usług, która będzie efektem zgodnej woli w zakresie osiąganych korzyści (volue for money) z przedsięwzięcia i racjonalnego podziału ryzyk z nią związanych, będąca rezultatem wychodzenia naprzeciw oczekiwaniom i potrzebom zgłaszanym przez użytkowników, opartą na regulacjach prawnych w zakresie PPP. Aby mówić o PPP muszą być spełnione warunki obejmujące długookresową umowę, finansowanie, podział zadań i ryzyk oraz realizację i eksploatację przedsięwzięcia. Realizacja przedsięwzięcia $\mathrm{w}$ formule partnerstwa publicznoprywatnego musi przynosić korzyści zarówno stronie publicznej, jak i prywatnej. Należy pamiętać przy tym, że z punktu widzenia strony publicznej korzyści powinny być większe niż wynikające $\mathrm{z}$ innych sposobów realizacji tego przedsięwzięcia.

165 M. Jastrzębska, Finanse jednostek samorządu terytorialnego, LEX a Wolters Kluwer business, Warszawa 2012, s. 237.

${ }^{166}$ Ibidem. 
Project finance jest sposobem finansowania dużych, kapitałochłonnych inwestycji, zwłaszcza infrastrukturalnych. Do realizacji inwestycji tworzy się specjalną spółkę celową (SPV), której podstawowym przedmiotem działania jest zarządzanie inwestycją. Finansowanie w formule project finance polega

na dostarczeniu przez instytucję finansową lub grupę instytucji finansowych oraz inwestorów kapitałowych funduszy na pokrycie nakładów związanych z projektem inwestycyjnym, pod warunkiem, że zaangażowane środki zostaną zwrócone z nadwyżek pieniężnych wygenerowanych w trakcie eksploatacji gotowego obiektu. Nadwyżki finansowe stanowią jedyne źródło spłaty długu zaciągniętego na finansowanie inwestycji ${ }^{167}$.

Project finance jest kompozycją funduszy (kapitału) składającą się na tzw. montaż finansowy, w skład którego najczęściej wchodzą długoterminowe kredyty, papiery wartościowe, gwarancje oraz ubezpieczenia od ryzyka.

$\mathrm{O}$ ile leasing jest już rozpowszechnioną formą finansowania inwestycji, o tyle pozostałe omówione sposoby nie znalazły dotychczas w Polsce powszechnego zastosowania. Wynika to przede wszystkim z braku doprecyzowanych rozwiązań legislacyjnych, co powoduje, że samorządy unikają tych rozwiązań $\mathrm{w}$ obawie przed potencjalnymi zarzutami (chociażby ze strony opozycji) o korupcję, naruszenie dyscypliny finansów publicznych czy też uprawnień przez władze lokalne ${ }^{168}$.

Dobór źródeł finansowania przedsięwzięcia inwestycyjnego powinien być rezultatem przeprowadzonych analiz i przygotowanego zbioru alternatywnych scenariuszy jego finansowania. Nie ma jednego, uniwersalnego wzorca postępowania, który znalazłby zastosowanie do przygotowania scenariuszy finansowych inwestycji samorządowych. Każde przedsięwzięcie jest indywidualne, zależy od specyficznych czynników społeczno-ekonomicznych samorządu podejmującego działania inwestycyjne. Już na etapie planowania konieczne jest należyte zebranie informacji zarówno o inwestycji jak i możliwościach finansowych inwestora. Główny akcent powinien zostać położony na wytyczeniu dostępnych ścieżek finansowania. Rozwiązanie problemu winno zmierzać do rozstrzygnięcia, czy $\mathrm{w}$ realizację inwestycji mają być zaangażowane bieżące środki budżetowe i jak będzie wyglądać to zaangażowanie w przyszłych okresach. W sytuacji, kiedy bieżące warunki budżetu nie pozwolą na finansowanie inwestycji z bieżących środków budżetowych, należy określić warunki, na jakich możliwe będzie skorzystanie $\mathrm{z}$ finansowania zwrotnego.

Finansowanie inwestycji z bieżących środków budżetowych i finansowanie inwestycji ze źródeł zwrotnych oznacza w rzeczywistości konieczność opraco-

${ }^{167}$ M. Dylewski, B. Filipiak, M. Gorzałczyńska-Koczkodaj, Finanse samorzadowe. Narzędzia ..., s. 95.

${ }^{168}$ Szerzej B. Filipiak, Finansowanie rozwoju infrastruktury na przykładzie Miasta Szczecin, [w:] Wspótczesne problemy finansów i gospodarki jednostek samorządu terytorialnego, red. S. Kańduła, Wydawnictwo Akademii Ekonomicznej w Poznaniu, Poznań 2008, s. 308. 
wania przez samorządowych decydentów dwóch odmiennych scenariuszy tego finansowania.

Pierwsze rozwiązanie występuje, gdy całkowity ciężar finansowania inwestycji spada na budżet. Konieczne będzie wówczas przestrzeganie dyscypliny budżetowej i skuteczna polityka w zakresie pozyskiwania należnych dochodów podatkowych. Oznacza to, że cały ciężar finansowania inwestycji spocznie na podatnikach. Może to w skrajnej sytuacji prowadzić do obniżenia wydatków bieżących, a tym samym pogorszenia warunków zaspokajania dotychczasowych potrzeb. Pojawia się klasyczna sytuacja, w której następuje zmniejszenie poziomu konsumpcji przez „wymuszenie oszczędności” w celu zwiększenia stopy inwestycji ${ }^{169}$. Jest ona uzasadniona $w$ sytuacji, kiedy inwestycja rozwiąże problem całej wspólnoty. W sytuacji, kiedy inwestycja będzie miała charakter mikroskali i zaspokoi potrzeby wąskiej grupy odbiorców nastąpi efekt ,skurczenia" inwestycji.

Z finansowaniem inwestycji komunalnych związany jest także problem przesunięcia obciążeń finansowych łączących z inwestycją na przyszłe pokolenia, które $\mathrm{w}$ przyszłości staną się użytkownikami i konsumentami usług. Podjęcie decyzji o włączeniu przyszłych pokoleń w finansowanie inwestycji wymusi określenie stopy inwestycji, poprzez podział środków budżetowych na wydatki bieżące i majątkowe.

Drugie rozwiązanie polega na realizacji inwestycji przy wykorzystaniu kredytów, pożyczek bądź papierów wartościowych. Ciężar zobowiązań zostanie przeniesiony na przyszłych użytkowników. Przesunięcie w czasie zobowiązań wynikających z zaciągniętego długu odbierane jest przez podatników jako społecznie sprawiedliwe. Zaangażowanie kapitału obcego wymaga jednak znajomości specyfiki poszczególnych instrumentów, aby zaciągnięte zobowiązania nie pozbawiły samorządu bieżącej płynności i naruszenia ustawowych zasad w kwestii długu.

Inwestycja wymaga od władz samorządowych dogłębnej analizy wszystkich możliwych źródeł finansowania, przy czym każdorazowo rozważane powinny być kwestie związane z:

- wyznaczeniem możliwego do sfinansowania poziomu realizacji zadań inwestycyjnych,

- oszacowaniem kosztów wszystkich rozpatrywanych do realizacji projektów,

- zabezpieczeniem koniecznego własnego wkładu kapitałowego,

- racjonalizacją wydatków bieżących jako potencjalnego, uzupełniającego źródła finansowania realizowanej inwestycji,

${ }^{169}$ Zob. K. Jarosiński, Możliwości i zakres finansowania inwestycji sektora publicznego ze źródet pozabudżetowych, [w:] Gospodarka, społeczeństwo, przestrzeń w tradycji i badaniach Katedry Samorządu Terytorialnego i Gospodarki Lokalnej SGH, red. Z. Strzelecki, Kolegium Ekonomiczno-Społeczne, Oficyna Wydawnicza SGH, Warszawa 2008, s. 122. 
- możliwością pozyskania zewnętrznych źródeł finansowania,

- opracowaniem alternatywnych scenariuszy finansowania inwestycji, w tym różnego poziomu dofinansowania z pomocy strukturalnej Unii Europejskiej,

- uwzględnieniem w przepływach finansowych kosztów spłaty zaciągniętego długu,

- oceną bieżącej zdolności kredytowej,

- sporządzeniem długookresowych planów inwestycyjnych i finansowych gwarantujących realizację rozpoczętej inwestycj ${ }^{170}$.

Procesy decyzyjne związane $\mathrm{z}$ wyborem źródeł finansowana inwestycji, zwłaszcza infrastrukturalnych, powinny być każdorazowo poprzedzone indywidualną analizą przedsięwzięcia i możliwości jego finansowania. Decyzje nie powinny mieć charakteru „krótkowzrocznego” i nie należy podejmować ich pod presją bieżącej sytuacji finansowej w samorządzie ${ }^{171}$. Od decydentów wymaga się opracowania harmonogramu realizacji przedsięwzięcia inwestycyjnego uwzględniającego poziom zapotrzebowania na środki i źródło ich pochodzenia. Tak przygotowany harmonogram pozwoli na pełny monitoring finansowania inwestycji i sytuacji finansowej jednostki.

${ }^{170}$ Por. J. Sierak, R. Górniak, Ocena efektywności i finansowania projektów..., s. 62; zob. też M. Zioło, Zewnętrzne źródta finansowania infrastruktury komunalnej..., s. 355.

${ }^{171}$ L. Patrzałek, Kryteria wyboru i uwarunkowania wykorzystania zwrotnych źródel finansowania jednostki samorzadu terytorialnego, [w:] Gospodarka finansowa..., s. 213. 



\section{PARTNERSTWO PUBLICZNO-PRYWATNE JAKO ŹRÓDLO FINANSOWANIA INWESTYCJI JEDNOSTEK SAMORZĄDU TERYTORIALNEGO}

\subsection{Działalność inwestycyjna a deficyt budżetowy i dług publiczny jednostek samorządu terytorialnego}

W literaturze ekonomicznej powszechnie panuje pogląd, że deficyt budżetowy i dług publiczny są kategoriami wzajemnie ze sobą powiązanymi. Występowanie jednej kategorii jest najczęściej skutkiem lub przyczyną drugiej ${ }^{1}$. Pojęcia deficytu budżetowego i długu publicznego nie są pojęciami jednoznacznymi, wobec czego są różnie interpretowane zwłaszcza przez instytucje międzynarodowe ${ }^{2}$. Na potrzeby pracy, nie wdając się w spory definicyjne, przyjęto, że deficyt budżetowy to stan naruszenia równowagi budżetowej polegający na tym, że planowane wydatki budżetowe przewyższają planowane dochody ujęte w budżecie danego roku bez względu na ich treść ekonomiczną czy przeznaczenie ${ }^{3}$. Podstawową kategorią, za pomocą której dokonuje się oceny stanu gospodarki budżetowej samorządu nie są rozmiary deficytu, ale poziom długu. Dług publiczny, podobnie jak deficyt, jest rozmaicie definiowany. S. Owsiak określa go jako finansowe zobowiązanie władz publicznych (państwowych samorządowych) z tytułu zaciągnięcia pożyczek ${ }^{4}$. A. Wernik przez dług publiczny rozumie zaś skumulowaną sumę deficytów sektora finansów publicznych z poprzednich okresów $^{5}$. W. Misiąg i E. Malinowska uważają, że dług publiczny można

\footnotetext{
${ }^{1}$ Zob. K. Marchewka-Bartkowiak, Zarządzanie dlugiem publicznym w krajach Unii Europejskiej, Oficyna Wydawnicza Zarządzanie i Finanse, Warszawa 2003, s. 9-17.

${ }^{2}$ Interpretacji pojęcia deficytu i długu publicznego przez instytucje międzynarodowe dokonuje K. Marchewka-Bartkowiak, Zarzadzanie dtugiem publicznym ..., s. 9-17.

${ }^{3}$ Por. Stownik finansów samorzadowych, red. A. Borodo, Dom Organizatora TNOiK, Toruń 2007, s. 30; K. Piotrowska-Marczak, T. Uryszek, Zarzadzanie finansami publicznymi, Difin, Warszawa 2009, s. 54.

${ }^{4}$ S. Owsiak, Finanse publiczne. Teoria i praktyka, Wydawnictwo Naukowe PWN, Warszawa 2005, s. 330; za tak sformułowanym określeniem długu publicznego opowiada się także W. Ziółkowska, Finanse publiczne. Teoria $i$ zastosowanie, Wydawnictwo Wyższej Szkoły Bankowej, Poznań 2005, s. 258.

${ }^{5}$ A. Wernik, Finanse publiczne, PWE, Warszawa 2007, s. 106.
} 
definiować na dwa sposoby. Jako łączną kwotę zobowiązań podmiotów (osób prawnych) zaliczanych do sektora publicznego wobec podmiotów spoza tego sektora, oraz jako łączną kwotę zobowiązań podlegających spłacie ze środków publicznych $^{6}$. Najszersze podejście do pojęcia długu publicznego prezentuje E. Chojna-Duch. Wspomniana autorka przez dług publiczny rozumie łączne finansowe zobowiązania jednostek sektora publicznego $\mathrm{z}$ tytułu zróżnicowanych z ekonomicznego i prawnego punktu widzenia zdarzeń prawnofinansowych, wynikających $\mathrm{z}$ niedoborów powstających $\mathrm{w}$ efekcie finansowania nadwyżki wydatków publicznych ponad dochody publiczne skumulowane w poprzednich okresach. Zobowiązania powinny uwzględniać ich konsolidację, czyli eliminację przepływów finansowych między jednostkami sektora publicznego ${ }^{7}$. Definicja prezentowana przez autorkę jest prawnym nawiązaniem do definicji zawartej w ustawie o finansach publicznych ${ }^{8}$. Ustawa nie wprowadza odrębnej kategorii długu dla sektora samorządowego. Także w przepisach Konstytucji odnoszących się do państwowego długu publicznego (art. 216 ust. 5) nie zostało określone pojęcie „dług samorządowy”. A. Młynarczyk ${ }^{9}$ wskazuje na wątpliwości, jakie pojawiły się $\mathrm{w}$ doktrynie prawa, związane z zaliczaniem do państwowego długu publicznego zobowiązań jednostek samorządu terytorialnego oraz innych samorządowych osób prawnych. Stanowisko Autorki jest jednak zbieżne z poglądami Z. Gilowskiej ${ }^{10}$ twierdzącej, że zaliczanie zobowiązań JST do państwowego długu publicznego jest słuszne $\mathrm{z}$ powodu przynależności tych jednostek do sektora finansów publicznych i uzasadnione ekonomicznie. Potwierdzeniem takiego stanowiska jest art. 3 Konstytucji wskazujący, że Rzeczpospolita Polska jest państwem jednolitym, a zatem jednostki samorządu terytorialnego stanowią istotny element i część składową organizacji i funkcjonowania państwa, a nie są autonomiczną organizacją publiczno-prywatną działającą obok państwa. W konsekwencji państwowy dług publiczny jest także kategorią zbiorczą i ogólną złożoną z części rządowej (określanej mianem państwowej) oraz części samorządowej. Bez zmiany zapisu konstytucyjnego w tej materii nie jest więc możliwe odrębne traktowanie państwowego i samo-

${ }^{6}$ E. Malinowska, W. Misiąg, Finanse publiczne w Polsce. Przewodnik 2002, Ośrodek Doradztwa i Doskonalenia Kadr, Gdańsk 2002, s. 492.

${ }^{7}$ E. Chojna-Duch, Podstawy finansów publicznych i prawa finansowego, Lewis Nexis, Warszawa 2012, s. 273 i n.

${ }^{8}$ Zgodnie $\mathrm{z}$ art. 73 państwowy dług publiczny oblicza się jako wartość nominalną zobowiązań jednostek sektora publicznego po wyeliminowaniu wzajemnych zobowiązań między jednostkami tego sektora. Ustawa z dnia 27 sierpnia 2009 r. o finansach publicznych, DzU, 2009, nr 157, poz.1240 ze zm.

${ }^{9}$ A. Młynarczyk, Zadtużenie jednostek samorzadu terytorialnego a państwowy dtug publiczny, „Finanse Komunalne” 2012, nr 1-2, s. 45.

${ }^{10} \mathrm{Z}$. Gilowska, Formułowanie i finansowanie strategii rozwoju jednostki samorzadu terytorialnego, [w:] Księga pamiatkowa dla uczczenia pracy naukowej Profesora Antoniego Agopszowi$c z a$, red. R. Mikosz, „Prace Naukowe Uniwersytetu Śląskiego” 2000, nr 1871, s. 53 i n. 
rządowego długu publicznego ${ }^{11}$. Na gruncie prawa samorządowy dług publiczny jest elementem długu publicznego.

Natomiast w literaturze poświęconej problematyce samorządowej pojawia się termin „samorządowy dług publiczny”. Stownik finansów samorządowych ${ }^{12}$ podaje, że dług publiczny samorządu to suma zobowiązań powstałych w efekcie operacji polegających na zaciągnięciu kredytów, pożyczek, emisji obligacji. A. Borodo zwraca uwagę, że termin „dług publiczny samorządu” jest terminem umownym i powinno się go wiązać z innym - „kredyt publiczny samorządu”. Związek ten, zdaniem autora, wynika $\mathrm{z}$ działalności samorządu związanej z kredytami, pożyczkami, obligacjami i innymi zobowiązaniami na gruncie regulacji prawnych i określany jest mianem długu publicznego lub kredytu publicznego ${ }^{13}$.

Jednostki samorządu terytorialnego powołane zostały do realizacji zadań własnych i zleconych mających na celu zaspokojenie potrzeb społeczności lokalnych. Obowiązek ten wiąże się z koniecznością dokonywania wydatków bieżących, które pokrywane są $\mathrm{z}$ dochodów uzyskiwanych $\mathrm{w}$ trakcie roku budżetowego. Rozwój jednostki wymaga jednak ponoszenia dodatkowych wydatków na działania inwestycyjne, które są realizowane poprzez wydatki majątkowe. Działania rozwojowe najczęściej przyjmują postać inwestycji infrastrukturalnych, których głównym celem jest poprawa warunków życia obywateli oraz wzrost atrakcyjności obszaru, regionu dla inwestorów. Takie działania wymagają jednorazowych, rozłożonych w czasie znacznych nakładów finansowych, które zwykle nie znajdują zabezpieczenia finansowego w budżecie. Gdyby inwestycje miały być finansowane tylko z dochodów budżetowych, wymagałoby to od jednostek ograniczenia wydatków bieżących lub podniesienia obciążeń podatkowych, na które trudno uzyskać społeczne poparcie biorąc pod uwagę obecne obciążenia podatkowe. Konieczne jest więc wykorzystanie innych źródeł finansowania. Możliwości sfinansowania działań inwestycyjnych jest wiele (zostały przedstawione $\mathrm{w}$ podpunkcie 3.4 ). W praktyce ostatnich lat finansowanie inwestycji infrastrukturalnych odbywa się najczęściej ze środków zwrotnych lub bezzwrotnego wsparcia z funduszy strukturalnych Unii Europejskiej. W przypadku projektów współfinansowanych ze środków unijnych beneficjent musi zapewnić wkład własny. W sytuacji braku własnych środków budżetowych niezbędne jest wsparcie ze strony rynku finansowego. Pozyskanie środków w postaci kredytów, pożyczek czy też obligacji generuje dla samorządu przychód, który w późniejszym czasie staje się rozchodem. W ten sposób tworzy się dług, którego istotnym elementem są koszty jego obsługi w postaci odsetek oraz innych obciążeń związanych z pozyskaniem, a potem spłatą.

${ }^{11}$ A. Młynarczyk, Zadtużenie jednostek samorzadu..., s. 46.

${ }^{12}$ Stownik finansów samorządowych, red. A. Borodo, s. 31.

13 A. Borodo, System finansowy samorzadu terytorialnego $w$ Polsce, Dom Organizatora TNOiK, Toruń 2011, s. 161. 
Teoria finansów publicznych dostarcza argumentów przede wszystkim za wykorzystaniem kredytów w celu finansowania inwestycji samorządowych. Rozważania rozpoczyna się od „złotej reguły” budżetowej. Reguła ta, oparta na argumentach normatywnych, mówi, że budżet danego szczebla władz publicznych powinien być zrównoważony, co oznacza, iż w każdym roku budżetowym bieżące wpływy podatkowe, opłaty i uzyskane subwencje powinny pokryć wydatki publiczne zarówno na cele bieżące, jak i konsumpcyjne. W sytuacji takiej pojawia się jednak problem, ponieważ wydatki na projekty inwestycyjne powinny być finansowane na zasadzie „pay-as-you-use”, ponieważ korzyści z inwestycji czerpane będą przez wiele kolejnych lat. Wspomniana zasada oznacza „płacisz jeśli korzystasz” i postuluje przeniesienie części kosztów inwestycji na przyszłych beneficjentów ${ }^{14}$.

Respektując zasady równości i sprawiedliwości społecznej władze publiczne powinny dążyć do oddzielenia budżetu bieżącego od majątkowego (kapitałowego). Takie stanowisko znajdujemy w klasycznej pracy z zakresu finansów publicznych R. Musgrave'a ${ }^{15}$. „Złota reguła budżetu” powinna być w pełni respektowana w stosunku do budżetu bieżącego, natomiast budżet inwestycyjny może być finansowany środkami zwrotnymi. Taki sam pogląd prezentuje P. Rose, który stwierdza, że „preferowaną metodą finansowania długoterminowych projektów kapitałowych powinny być pożyczki długoterminowe a nie wzrost obciążeń podatkowych lokalnych społeczności"16. A więc instrumenty dłużne powinny stanowić najważniejsze źródło finansowania inwestycji. W takiej sytuacji uzasadnione społecznie wydaje się obciążenie przyszłych pokoleń kosztami inwestycyjnymi, zwłaszcza jeśli dotyczą one infrastruktury. Jednostki samorządu terytorialnego $\mathrm{z}$ reguły nie mają problemów z dostępem do zwrotnych źródeł finansowania, charakteryzują się bowiem dużym stopniem wiarygodności i dużą płynnością finansową, która jest rezultatem stałego dopływu środków pieniężnych. $Z$ przeprowadzonych badań wynika, że w krajach Unii Europejskiej w latach dziewięćdziesiątych przeciętnie połowa wydatków inwestycyjnych finansowana była $\mathrm{z}$ dochodów zwrotnych ${ }^{17}$. Dla niektórych jednostek (np. gmin wiejskich) spłata i bieżąca obsługa zadłużenia mogą stanowić poważny problem. W Polsce, podobnie jak w większości państw ${ }^{18}$

${ }^{14}$ B. Guziejewska, Ograniczenia w zaciaganiu dlugu przez samorząd terytorialny - aspekty teoretyczne a rozwiazania $w$ praktyce, [w:] Podsektor samorzadowy w sektorze finansów publicznych $w$ warunkach akcesji Polski do Unii Europejskiej, red. L. Patrzałek, Wydawnictwo Wyższej Szkoły Bankowej w Poznaniu, Poznań-Wrocław 2006, s. 228.

${ }^{15}$ R. Musgrave, The theory of public finance, MacGraw-Hill, New York 1959.

${ }^{16}$ P. S. Rose, Money and Capital Markets, The Financial system Ekonomy, Bussiness publ. plano, Teras 1986, s. 720.

${ }^{17}$ A. Kopańska, Zewnętrzne źródta finansowania inwestycji jednostek samorządu terytorialnego, Difin, Warszawa 2003, s. 74.

${ }^{18}$ Wyjątek stanowią rozwiązania przyjęte w Stanach Zjednoczonych i na Węgrzech, zob. M. Kosek-Wojnar, Dylematy wyznaczania granic zadlużania się jednostek samorzadu terytorialnego, [w:] Nauki finansowe wobec wspótczesnych problemów gospodarki polskiej, t. 1, red. S. Owsiak, Akademia Ekonomiczna w Krakowie, Kraków 2004, s. 336. 
samorządy nie podlegają procedurze upadłościowej ${ }^{19}$. W sytuacji utraty bieżącej płynności dochodzi do zawieszenia prac organów władzy, a w ich miejsce powoływany zostaje zarząd komisaryczny. Aby nie dopuścić do takiej sytuacji wprowadza się różne ustawowe ograniczenia mające na celu kontrolowanie zaciągania zobowiązań o charakterze pożyczkowo-kredytowym. Ograniczenia prawne mają gwarantować respektowanie fundamentalnych zasad zadłużania się przez wszystkie podmioty niezależnie od ich bieżącej sytuacji. Ograniczenia mogą przyjąć formę ograniczeń wysokości długu publicznego, ograniczeń w wysokości spłaty rocznych rat i odsetek bądź limitu wydatków inwestycyjnych $^{20}$. Do końca 2013 r. ustawowe regulacje dotyczące ograniczeń wysokości zadłużenia mają podwójny charakter. Po pierwsze, łączna kwota przypadających do spłaty $\mathrm{w}$ danym roku budżetowym rat kredytów i pożyczek oraz potencjalnych spłat kwot wynikających $\mathrm{z}$ udzielonych przez samorządy poręczeń wraz $\mathrm{z}$ należnymi $\mathrm{w}$ danym roku odsetkami od kredytów i pożyczek, a także wykupów papierów wartościowych wraz $\mathrm{z}$ należnymi odsetkami i dyskontem oraz potencjalnych spłat kwot wynikających z udzielonych poręczeń i gwarancji, nie może przekroczyć $15 \%$ planowanych na dany rok budżetowy dochodów ${ }^{21}$. Po drugie, łączna kwota długu jednostki samorządu terytorialnego na koniec roku budżetowego nie może przekroczyć $60 \%$ wykonanych dochodów ogółem ${ }^{22}$. Powyższe zapisy dotyczące limitów zadłużenia od dawna stanowiły przedmiot krytyki, m.in. z powodu braku indywidualnego określenia poziomu zadłużenia, który wyznaczany byłby przez zdolności ekonomiczne danej jednostki. Sytuacja ta ulegnie zmianie od 1 stycznia $2014 \mathrm{r}$. Na mocy nowej ustawy o finansach publicznych i przepisach ją wprowadzających ${ }^{23}$ poziom dla poszczególnych

${ }^{19}$ Rozporządzenie Prezydenta RP z dnia 24 października 1934 r. Prawo upadłościowe, DzU, 1991, nr 18, poz. 512 ze zm., art. 3 par. 1.

${ }^{20}$ Por. B. Guziejewska, Ograniczenia w zaciaganiu dtugu przez samorzad..., s. 232; problematyka zadłużenia JST i jego ograniczeń $\mathrm{w}$ m.in.: Zasilanie finansowe jednostek samorząu terytorialnego $w$ warunkach integracji europejskiej, red. T. Famulska, Prace Naukowe Uniwersytetu Ekonomicznego w Katowicach, Katowice 2010, s. 205-207; Samorzad terytorialny w procesach rozwoju regionalnego i lokalnego, red. W. Kosiedowski, Dom Organizatora TNOiK, Torun 2005, s. 278-279.

${ }^{21} \mathrm{~W}$ sytuacji gdy relacja państwowego długu publicznego do PKB przekroczy 55\%, wyżej określona kwota zadłużenia nie może przekroczyć $12 \%$ planowanych dochodów JST, chyba że obciążenia te powstały przed datą ogłoszenia powyższej relacji przez ministra finansów - art. 169, ust. 2 Ustawy z dnia 30 czerwca 2005 r. o finansach publicznych, DzU, 2005, nr 249, poz. 2103 ze zm.

${ }^{22}$ Ustawa z dnia 30 czerwca 2005 r. o finansach publicznych..., art. 169 i 170; ograniczenie to nie obejmuje zaciągniętych kredytów i pożyczek, wyemitowanych papierów wartościowych w związku z realizacją zadań finansowanych przy udziale środków z budżetu UE, środków uzyskiwanych od państw członkowskich EFTA i innych środków zagranicznych.

${ }^{23}$ Ustawa z dnia 29 sierpnia 2009 r. przepisy wprowadzajace ustawę o finansach publicznych, DzU, 2009, nr 157, poz. 1241 ze zm. 
jednostek będzie ustalany indywidualnie, według algorytmu określonego w art. 243 ust. 1 pkt 3, w postaci:

$$
\left(\frac{R+O}{D}\right)_{n} \leq \frac{1}{3} \times\left(\begin{array}{l}
\frac{D b_{n-1}+S m_{n-1}-W b_{n-1}}{D_{n-1}}+\frac{D b_{n-2}+S m_{n-2}-W b_{n-2}}{D_{n-2}}+ \\
+\frac{D b_{n-3}+S m_{n-3}-W b_{n-3}}{D_{n-3}}
\end{array}\right)
$$

gdzie:

$R$ - planowana na rok budżetowy łączna kwota $\mathrm{z}$ tytułu spłaty rat kredytów i pożyczek oraz wykupów papierów wartościowych emitowanych na pokrycie występującego w ciągu roku przejściowego deficytu budżetu JST, planowanego deficytu, spłatę wcześniej zaciągniętych zobowiązań z tytułu emisji papierów wartościowych oraz zaciągniętych kredytów i pożyczek, finansowanie działań finansowanych ze środków UE, finansowanie wydatków na inwestycje i zakupy inwestycyjne;

$O$ - planowane na dany rok budżetowy odsetki od kredytów i pożyczek, odsetki i dyskonto od papierów wartościowych emitowanych na cele określone w symbolu $R$ oraz spłaty kwot wynikających z udzielonych poręczeń i gwarancji;

$D$ - dochody ogółem budżetu w danym roku budżetowym;

$D_{b}$ - dochody bieżące;

$S_{m}$ - dochody ze sprzedaży majątku;

$W_{b}$ - wydatki bieżące;

$n$ - rok budżetowy na który ustalana jest relacja;

$n-1$ - rok poprzedzający rok budżetowy, na który ustalana jest relacja;

$n-2$ - rok poprzedzający rok budżetowy o dwa lata;

$n-3$ - rok poprzedzający rok budżetowy o trzy lata.

Analiza stanu zadłużenia jednostek samorządu terytorialnego stanowi ważny element $\mathrm{w}$ procesie analitycznym ukierunkowanym na ocenę możliwości finansowania inwestycji, w tym infrastrukturalnych. W aspekcie możliwości finansowania inwestycji samorządowych ważne jest ustalenie wielkości zadłużenia wynikającego z liczby, struktury oraz warunków spłat kredytów, pożyczek, wyemitowanych obligacji i innych instrumentów o charakterze zwrotnym. Z punktu widzenia inwestycji najważniejszą rolę odgrywa zadłużenie długookresowe. Krótkookresowe musi być spłacone w ciągu roku budżetowego, a jego rola sprowadza się do finansowania powstającego w trakcie roku tymczasowego niedoboru środków finansowych, utraty bieżącej płynności. Inaczej wygląda sytuacja, gdy zmianie ulegnie perspektywa czasowa, a dług będzie rozpatrywany w wymiarze długookresowym. Wówczas obawy, że w samorządach pojawią się problemy z jego obsługą stają się realne. 
Wykorzystanie długu do finansowania działań rozwojowych w samorządach wiąże się $\mathrm{z}$ obowiązkiem zarezerwowania środków pieniężnych na jego spłatę w przyszłości. Istotne jest właściwe rozpoznanie maksymalnego poziomu zadłużenia $\mathrm{w}$ aspekcie rzeczywistych możliwości sprostania przyszłym zobowiązaniom. Powstaje zatem problem faktycznej zdolności do obsługi długu oraz możliwości jego absorpcji. $Z$ ekonomicznego punktu widzenia nie ma jednej, identycznej granicy zadłużenia dla wszystkich jednostek samorządu. Jest to sytuacja indywidualna i zależy od ogólnych warunków społeczno-gospodarczych, w jakich w danym momencie działa jednostka. Zachowanie płynności jest zjawiskiem zmiennym. Samorząd, który jest w dobrej, stabilnej sytuacji finansowej, w perspektywie kilku lat ma możliwość pozyskiwania nowych przychodów bez obawy o utratę płynności. Sytuacja ta nie jest constans. Jakakolwiek zmiana w sytuacji gospodarczej państwa (zmiana cyklu koniunkturalnego, nowe zadania transferowane do samorządów) najczęściej odbija się na stabilności finansowej samorządów obniżając ich możliwości absorpcji długu ${ }^{24}$.

Potrzeba wykorzystania długu do finansowania zadań inwestycyjnych w samorządach wynika z dwóch przyczyn. Po pierwsze, z istoty potrzeb społecznych, które zawsze mają charakter nieograniczony. Po drugie, z ograniczonych środków budżetowych, których niedobór wymusza konieczność posiłkowania się źródłami zwrotnymi w celu wykonania nałożonych zadań, w tym inwestycji.

Wykorzystanie długu na sfinansowanie przedsięwzięć inwestycyjnych pozwala na realizację zwiększonej liczby i jakości usług. Należy jednak pamiętać, że oprócz „kreowania bazy finansowej i nowych możliwości rozwojowych nadmierne zadłużenie JST może stworzyć pułapkę zadłużenia" ${ }^{25}$, np. gdy dług będzie niewłaściwie zaciągnięty, błędnie zostanie oszacowana możliwość jego spłaty, zmienią się warunki gospodarcze, społeczne, polityczne, prawne w otoczeniu JST. Inwestycje samorządowe mogą być finansowane ze środków bezzwrotnych, tyle tylko, że kwoty wówczas wydatkowane będą ograniczone poziomem dochodów budżetowych oraz poziomem wydatków na zadania obligatoryjne, a także inne wynikające $\mathrm{z}$ bieżących potrzeb zgłaszanych przez mieszkańców jednostki. To w sposób oczywisty wydłuży cykl inwestycyjny i w efekcie zwiększy poziom kosztów stałych, tym samym wpływając na poziom środków wydatkowanych na inwestycje.

Realizacja przedsięwzięć inwestycyjnych z wykorzystaniem instrumentów zwrotnego finansowania przyczynia się do poprawy warunków życia lokalnych społeczności oraz do wzrostu majątku jednostki. Ponadto inwestycje samorzą-

${ }^{24}$ Zob. A. Borodo, Samorzą terytorialny, system prawnofinansowy, LexisNexis, Warszawa 2004, s. 240.

${ }^{25}$ M. Jastrzębska, Finanse jednostek samorzadu terytorialnego, LEX a Wolters Kluwer business, Warszawa 2012, s. 198. 
dowe w sposób pośredni zwiększają potencjał gospodarczy i atrakcyjność danej jednostki ${ }^{26}$.

Poziom i strukturę zadłużenia jednostek samorządu terytorialnego w latach 2005-2011 przedstawiono $\mathrm{w}$ tab. 4.1. i 4.3.

Tabela 4.1

Poziom zadłużenia JST w latach 2005-2011 oraz relacja zadłużenia do poziomu zrealizowanych dochodów budżetowych

\begin{tabular}{|c|c|c|c|c|c|c|c|}
\hline \multirow{2}{*}{ Wyszczególnienie } & \multicolumn{7}{|c|}{ Rok } \\
\hline & 2005 & 2006 & 2007 & 2008 & 2009 & 2010 & 2011 \\
\hline 1 & 2 & 3 & 4 & 5 & 6 & 7 & 9 \\
\hline $\begin{array}{l}\text { Zadłużenie JST ogółem } \\
\text { (w mln zł), } \\
\text { w tym: }\end{array}$ & 21181 & 24949 & 25876 & 28774 & 40294 & 55093 & 65756 \\
\hline - gminy & 8068 & 9586 & 9959 & 10821 & 14611 & 21930 & 25990 \\
\hline - powiaty & 1816 & 2493 & 2640 & 2889 & 3907 & 5436 & 6137 \\
\hline - MPP* & 10415 & 11296 & 11259 & 12775 & 18730 & 23438 & 28075 \\
\hline - województwa & 882 & 1574 & 2019 & 2289 & 3046 & 4291 & 5555 \\
\hline $\begin{array}{l}\text { Struktura zadłużenia } \\
\text { poszczególnych typów } \\
\text { JST (w \%), w tym: }\end{array}$ & 100 & 100 & 100 & 100 & 100 & 100 & 100 \\
\hline - gminy & 38,0 & 38,4 & 38,4 & 37,6 & 36,3 & 39,9 & 39,5 \\
\hline - powiaty & 8,7 & 10,0 & 10,2 & 10,0 & 9,7 & 9,9 & 9,3 \\
\hline$-\mathrm{MPP} *$ & 49,1 & 45,3 & 43,6 & 44,4 & 46,5 & 42,5 & 42,7 \\
\hline - województwa & 4,2 & 6,3 & 7,8 & 8,0 & 7,5 & 7,7 & 8,5 \\
\hline $\begin{array}{l}\text { Dochody JST ogółem } \\
\text { (w mln zł) }\end{array}$ & 102911 & 117040 & 131380 & 142568 & 154842 & 162796 & 171309 \\
\hline $\begin{array}{l}\text { Wskaźnik zadłużenia } \\
\text { (w \%), w tym: }\end{array}$ & 20,6 & 21,3 & 19,7 & 20,2 & 26,0 & 33,8 & 38,4 \\
\hline - gminy & 17,6 & 18,5 & 17,5 & 17,4 & 22,5 & 30,3 & 34,3 \\
\hline - powiaty & 13,1 & 16,8 & 16,3 & 15,9 & 19,5 & 24,2 & 26,1 \\
\hline - MPP* & 28,7 & 27,6 & 24,0 & 25,8 & 37,2 & 43,5 & 49,4 \\
\hline - województwa & 12,4 & 16,6 & 17,8 & 18,1 & 15,6 & 30,4 & 36,9 \\
\hline $\begin{array}{l}\text { Wskaźnik zadłużenia JST } \\
\text { bez środków związanych } \\
\text { z realizacją projektów }\end{array}$ & & & & & & & \\
\hline $\begin{array}{l}\text { finansowanych } \mathrm{z} \text { funduszy } \\
\text { UE (w \%) w tym: }\end{array}$ & $\mathrm{x}$ & 19,2 & 17,9 & 18,7 & 24,5 & 30,8 & 34,3 \\
\hline - gminy & $\mathrm{x}$ & 17,0 & 16,4 & 16,4 & 21,1 & 26,9 & 30,1 \\
\hline - powiaty & $\mathrm{x}$ & 15,5 & 15,6 & 15,6 & 18,7 & 23,1 & 24,7 \\
\hline - МРP* & $\mathrm{x}$ & 25,7 & 22,1 & 23,4 & 34,7 & 39,7 & 43,9 \\
\hline - województwa & $\mathrm{x}$ & 8,1 & 11,2 & 16,7 & 15,4 & 29,0 & 34,5 \\
\hline PKB (w mln zl) & 983302 & 1060194 & 175266 & 275432 & 343366 & 1415385 & 1522700 \\
\hline
\end{tabular}

${ }^{26}$ Ibidem, s. 198. 


\begin{tabular}{|l|c|c|c|c|c|c|c|}
\hline \multicolumn{1}{|c|}{1} & 2 & 3 & 4 & 5 & 6 & 7 & 8 \\
\hline Zadłużenie JST ogółem & & & & & & & \\
w relacji do PKB (w \%), & $\mathbf{2 , 1}$ & $\mathbf{2 , 4}$ & $\mathbf{2 , 2}$ & $\mathbf{2 , 3}$ & $\mathbf{3 , 0}$ & $\mathbf{3 , 8}$ & $\mathbf{4 , 3}$ \\
w tym: & & & & & & & \\
$\quad$ - gminy & 0,8 & 0,9 & 0,8 & 0,8 & 1,1 & 1,5 & 1,7 \\
$\quad$ - powiaty & 0,2 & 0,2 & 0,2 & 0,2 & 0,3 & 0,4 & 0,4 \\
$\quad$ - MPP* & 1,0 & 1,1 & 1,0 & 1,0 & 1,4 & 1,7 & 1,8 \\
- województwa & 0,1 & 0,1 & 0,2 & 0,2 & 0,2 & 0,3 & 0,4 \\
\hline
\end{tabular}

*MPP - miasta na prawach powiatu,

$\mathrm{x}$ - brak danych.

Źródło: oprac. własne na podstawie informacji o wykonaniu budżetów JST za lata 20052012, www.mf.gov.pl

Poziom zadłużenia jednostek samorządu terytorialnego w badanym okresie wzrósł z ponad $21 \mathrm{mld}$ zł w 2005 r. do przeszło 65 mld zł w 2011 r., co daje $310 \%$ wzrost długu. W głównej mierze wielkość zadłużenia generują miasta na prawach powiatu, a następnie gminy. Zadłużenie miast na prawach powiatu wzrosło z $10415 \mathrm{mln}$ zł w 2005 r. do $28075 \mathrm{mln}$ zł, co stanowi blisko 270\% wzrost zadłużenia, $w$ gminach poziom długu w tym samym czasie wzrósł zaś o 320\%. Wzrost poziomu zadłużenia przełożył się na wskaźnik zadłużenia ogółem, którego ogólny poziom wzrósł z 20,6\% w 2005 r. do 38,4\% w 2011 r. Wskaźnik ten zwiększył się we wszystkich typach JST w tym samym okresie odpowiednio: $\mathrm{w}$ gminach o $16,7 \%$, w powiatach o $13,0 \%$, miastach na prawach powiatu o $20,7 \%$ oraz w województwach o $24,5 \%$.

Największe zadłużenie generują miasta na prawach powiatu, co wynika z dualnego charakteru ich zadań. Z usług i urządzeń infrastrukturalnych korzysta także, oprócz mieszkańców, ludność spoza obszaru wspólnoty. Analogicznie wygląda wskaźnik zadłużenia bez zobowiązań wynikających $\mathrm{z}$ realizacji programów finansowanych ze środków unijnych.

Wskaźnik zadłużenia dla wszystkich JST bez środków związanych z realizacją projektów finansowanych z funduszy UE wzrósł z 19,2\% w 2006 r. do $34,3 \% \mathrm{w}$ 2011r (wzrost na przestrzeni analizowanego okresu o 15,1\%). W badanym okresie wskaźnik ten zwiększył się w poszczególnych JST odpowiednio: $\mathrm{w}$ gminach o $13,1 \%$, w powiatach o $9,2 \%$, w miastach na prawach powiatu o $18,2 \%$ oraz w województwach o $26,4 \%$.

Najwyższy poziom wskaźnika odnotowano $\mathrm{w}$ miastach na prawach powiatu, natomiast najniższy występuje w powiatach. Taki poziom zadłużenia miast na prawach powiatu i gmin wynika z tego, że na szczeble te nałożono najwięcej zadań nie zapewniając im jednocześnie adekwatnych źródeł dochodów.

Systematyczny wzrost zadłużenia całego podsektora samorządowego przełożył się na jego wzrost w relacji do produktu krajowego brutto z 2,1\% w $2005 \mathrm{r}$. do 4,3\% w 2011 r. Analogicznie poziom zadłużenia w relacji do PKB w gminach wzrósł o $0,9 \%$, w powiatach o $0,2 \%$, w miastach na prawach powiatu 
o $0,8 \%$, w województwach o $0,3 \%$. Najwyższy udział zadłużenia w PKB odnotowały miasta na prawach powiatu, w dalszej kolejności gminy, najmniejszy zaś województwa i powiaty.

Rosnąca dynamika długu samorządowego jest efektem rosnących potrzeb inwestycyjnych, co wiąże się z koniecznością dysponowania wkładem własnym do projektów współfinansowanych ze środków unijnych.

Tabela 4.2

Wskaźnik pokrycia wydatków inwestycyjnych długiem i przyrostem długu w JST w latach 2005-2011

\begin{tabular}{|c|c|c|c|c|c|c|c|}
\hline \multirow{2}{*}{ Wyszczególnienie } & \multicolumn{7}{|c|}{ Rok } \\
\hline & 2005 & 2006 & 2007 & 2008 & 2009 & 2010 & 2011 \\
\hline 1 & 2 & 3 & 4 & 5 & 6 & 7 & 8 \\
\hline \multicolumn{8}{|c|}{ JST - ogólem } \\
\hline $\begin{array}{l}\text { Wydatki ogółem } \\
\text { (mln zł) }\end{array}$ & 103807 & 120038 & 129113 & 145182 & 167828 & 177766 & 181595 \\
\hline $\begin{array}{l}\text { Wydatki inwestycyjne } \\
\text { (mln zł) }\end{array}$ & 17750 & 24380 & 26257 & 30819 & 41600 & 43281 & 41188 \\
\hline $\begin{array}{l}\text { Zadłużenie ogółem } \\
(\mathrm{mln} \mathrm{zl})\end{array}$ & 21181 & 24949 & 25876 & 28774 & 40294 & 55093 & 65756 \\
\hline Zmiana zadłużenia & $\mathrm{x}$ & 3768 & 927 & 2898 & 11520 & 14799 & 10663 \\
\hline $\begin{array}{l}\text { Wskaźnik pokrycia } \\
\text { wydatków inwesty- } \\
\text { cyjnych zadłuże- } \\
\text { niem ogółem (w \%) }\end{array}$ & 83,80 & 97,72 & 101,47 & 107,11 & 103,24 & 78,56 & 62,64 \\
\hline $\begin{array}{c}\text { Wskaźnik pokrycia wy- } \\
\text { datków inwestycyj- } \\
\text { nych zmianą zadłu- } \\
\text { żenia (w \%) }\end{array}$ & $\mathrm{x}$ & 647,03 & 2832,47 & 1063,46 & 361,11 & 292,46 & 386,27 \\
\hline \multicolumn{8}{|c|}{ gminy } \\
\hline $\begin{array}{l}\text { Wydatki ogółem } \\
\text { (mln zł) }\end{array}$ & 45837 & 53179 & 56074 & 62893 & 70003 & 79741 & 79687 \\
\hline $\begin{array}{l}\text { Wydatki inwestycyjne } \\
\text { (mln zł) }\end{array}$ & 8218 & 10692 & 10363 & 12553 & 15777 & 19690 & 17922 \\
\hline $\begin{array}{l}\text { Zadłużenie ogółem } \\
\quad(\mathrm{mln} \text { zł) }\end{array}$ & 8068 & 9586 & 9959 & 10821 & 14611 & 21930 & 25990 \\
\hline Zmiana zadłużenia & $\mathrm{x}$ & 1518 & 373 & 862 & 3790 & 7319 & 4060 \\
\hline $\begin{array}{l}\text { Wskaźnik pokrycia } \\
\text { wydatków inwesty- } \\
\text { cyjnych zadłuże- } \\
\text { niem ogółem (w \%) }\end{array}$ & 101,86 & 111,54 & 104,06 & 116,01 & 107,98 & 89,79 & 68,96 \\
\hline $\begin{array}{l}\text { Wskaźnik pokrycia } \\
\text { wydatków inwesty- } \\
\text { cyjnych zmianą } \\
\text { zadłużenia (w \%) }\end{array}$ & $\mathrm{x}$ & 704,35 & 2778,28 & 1456,26 & 416,28 & 269,03 & 441,43 \\
\hline
\end{tabular}




\begin{tabular}{|c|c|c|c|c|c|c|c|}
\hline 1 & 2 & 3 & 4 & 5 & 6 & 7 & 8 \\
\hline \multicolumn{8}{|c|}{ powiaty } \\
\hline \begin{tabular}{|l} 
Wydatki ogółem \\
(mln zł $)$
\end{tabular} & 13891 & 15593 & 16069 & 18114 & 21155 & 23826 & 24059 \\
\hline \begin{tabular}{|l}
$\begin{array}{l}\text { Wydatki inwestycyjne } \\
\text { (mln zf) }\end{array}$ \\
\end{tabular} & 1609 & 2271 & 2097 & 2605 & 4054 & 5181 & 4469 \\
\hline Zadłużenie (mln zł) & 1816 & 2493 & 2640 & 2889 & 3907 & 5436 & 6137 \\
\hline Zmiana zadłużenia & $\mathrm{x}$ & 677 & 147 & 249 & 1018 & 1529 & 701 \\
\hline $\begin{array}{l}\text { Wskaźnik pokrycia wy- } \\
\text { datków inwestycyj- } \\
\text { nych zadłużeniem } \\
\text { ogółem (w \%) }\end{array}$ & 88,60 & 91,10 & 79,43 & 90,17 & 103,76 & 95,31 & 72,82 \\
\hline $\begin{array}{c}\text { Wskaźnik pokrycia wy- } \\
\text { datków inwestycyj- } \\
\text { nych zmianą zadłu- } \\
\text { żenia (w \%) }\end{array}$ & $\mathrm{x}$ & 335,45 & 1426,53 & 1046,18 & 398,23 & 338,85 & 637,52 \\
\hline \multicolumn{8}{|c|}{ miasta na prawach powiatu } \\
\hline \begin{tabular}{|c|}
$\begin{array}{l}\text { Wydatki ogółem } \\
\text { (mln zł) }\end{array}$ \\
\end{tabular} & 36491 & 41238 & 45877 & 51173 & 56202 & 58954 & 61510 \\
\hline \begin{tabular}{|l}
$\begin{array}{l}\text { Wydatki inwestycyjne } \\
\text { (mln zl) }\end{array}$ \\
\end{tabular} & 5538 & 7854 & 9865 & 11135 & 12081 & 12698 & 12365 \\
\hline Zadłużenie (mln zł) & 10415 & 11296 & 11259 & 12775 & 18730 & 23438 & 28075 \\
\hline Zmiana zadłużenia & $\mathrm{x}$ & 881 & -37 & 1516 & 5955 & 4708 & 4637 \\
\hline $\begin{array}{l}\text { Wskaźnik pokrycia } \\
\text { wydatków inwesty- } \\
\text { cyjnych zadłuże- } \\
\text { niem ogółem (w \%) }\end{array}$ & 53,17 & 69,53 & 87,62 & 87,16 & 64,50 & 54,18 & 44,04 \\
\hline $\begin{array}{l}\text { Wskaźnik pokrycia wy- } \\
\text { datków inwestycyj- } \\
\text { nych zmianą zadłu- } \\
\text { żenia (w \%) }\end{array}$ & $\mathrm{x}$ & 891,49 & $\mathrm{x}$ & 734,50 & 202,87 & 269,71 & 266,66 \\
\hline \multicolumn{8}{|c|}{ województwa } \\
\hline Wydatki ogółem (mln zl) & 7588 & 10028 & 11093 & 13002 & 20468 & 15245 & 16339 \\
\hline $\begin{array}{l}\text { Wydatki inwestycyjne } \\
(\mathrm{mln} \mathrm{z})\end{array}$ & 2384 & 3563 & 3931 & 4525 & 9688 & 5712 & 6432 \\
\hline Zadłużenie (mln zl) & 882 & 1574 & 2019 & 2289 & 3046 & 4291 & 5555 \\
\hline Zmiana zadłużenia & $\mathrm{x}$ & 692 & 445 & 270 & 757 & 1245 & 1264 \\
\hline $\begin{array}{l}\text { Wskaźnik pokrycia } \\
\text { wydatków inwesty- } \\
\text { cyjnych zadłuże- } \\
\text { niem ogółem (w \%) }\end{array}$ & 270,29 & 226,37 & 194,70 & 197,68 & 318,06 & 133,12 & 115,79 \\
\hline $\begin{array}{l}\text { Wskaźnik pokrycia wy- } \\
\text { datków inwestycyj- } \\
\text { nych zmianą zadłu- } \\
\text { żenia (w \%) }\end{array}$ & $\mathrm{x}$ & 514,88 & 883,37 & 1675,93 & 1279,79 & 458,80 & 508,86 \\
\hline
\end{tabular}

Źródło: oprac. własne. 
Przy analizie problemu zadłużenia na uwagę zasługuje kwestia dotycząca związku poziomu zadłużenia ogółem i jego zmiany oraz poziomu ponoszonych wydatków inwestycyjnych. W tym celu obliczono wskaźnik pokrycia wydatków inwestycyjnych zadłużeniem ogółem oraz wskaźnik pokrycia wydatków inwestycyjnych zmianą (por. tab. 4.2).

Analiza wskaźnika pokrycia wydatków inwestycyjnych zadłużeniem pozwala zauważyć, że w latach 2005-2006 oraz 2010-2011 wydatki inwestycyjne jednostek samorządu terytorialnego wszystkich typów finansowane są długiem na poziomie $62-97 \%$. Natomiast w 2007 i 2008 r. poziom zadłużenia jest niższy niż poziom wydatków inwestycyjnych (poziom wskaźnika wynosi odpowiednio: 101,47, 107,11\%), co świadczy o korzystniejszej sytuacji finansowej samorządów. Wydatki finansowane są dochodami osiąganymi przez samorządy, co nie prowadzi do wzrostu poziomu zadłużenia. W 2009 r. nadal zauważa się kontynuację wcześniejszego trendu, ale ze słabszą siłą, gdyż wskaźnik pokrycia spada do poziomu 103,24\%. Odwołując się do wskaźnika zadłużenia JST ogółem widać wyraźnie, że w latach 2007-2008 poziom zadłużenia maleje, a następnie wykazuje tendencję rosnącą (roczny przyrost wskaźnika w latach 2009-2011 w odniesieniu do roku 2008 wyniósł odpowiednio: 6,2, 13,6, 18,2\%). W 2007 r. wskaźnik zadłużenia osiągnął najniższy poziom, co przełożyło się na najniższy przyrost zadłużenia w badanym okresie. Oznacza to, że nie było potrzeby zwiększania zadłużenia na wydatki inwestycyjne. Jak wynika ze sprawozdania $\mathrm{RIO}^{27}$, taki stan wynika z wygospodarowania przez JST poszczególnych typów nadwyżki dochodów nad wydatkami bieżącymi. Pozwoliło to samorządom na zwiększenie możliwości inwestycyjnych i spłatę zaciągniętych na realizację inwestycji zobowiązań. W sprawozdaniu wskazuje się jednak, że korzystna sytuacja finansowa, jaka się wówczas pojawiła, tylko częściowo została przez samorządy wykorzystana. Gminy i powiaty ograniczyły wydatki inwestycyjne, co w rezultacie przełożyło się na spadek dynamiki. Skuteczniej wykorzystano nadwyżkę, która przeznaczona została na spłatę zobowiązań. W rezultacie nastąpił spadek wskaźnika zadłużenia z 21,3\% w 2006 r. do 19,7\% w 2007 r. Korzystny poziom wskaźnika pokrycia wydatków inwestycyjnych zadłużeniem notuje się w gminach i województwach, gdzie wydatki inwestycyjne w badanym okresie w zasadzie nie wymagały finansowania zwrotnego, z wyjątkiem gmin w latach 2010-2012. Powiaty i miasta na prawach powiatów w całym okresie posiłkowały się pieniądzem pożyczkowym w celu realizacji przedsięwzięć inwestycyjnych.

W strukturze zobowiązań ogółem jednostek samorządu terytorialnego największy udział stanowią kredyty i pożyczki (83,3\% w 2005 r., 92\% w 2011 r.).

${ }^{27}$ Sprawozdanie z działalności Regionalnych Izb Obrachunkowych $i$ wykonania budżetu przez jednostki samorządu terytorialnego w 2007 r., Krajowa Rada Regionalnych Izb Obrachunkowych, Warszawa 2008, s. 147. 
Instrument ten stanowi najważniejsze źródło finansowania zadań, w tym inwestycji przez samorządy, o czym świadczy znaczny udziału kredytów i pożyczek o charakterze długoterminowym (wzrost z 79,5\% w 2005 r. do 91,0\% w 2011 r.). Równocześnie nastąpił spadek znaczenia papierów wartościowych w generowaniu długu samorządu z 15,4 do 7,6\% (tab. 4.3).

Tabela 4.3

Zobowiązania jednostek samorządu terytorialnego w latach 2005-2011 według tytułów dłużnych

\begin{tabular}{|c|c|c|c|c|c|c|c|}
\hline \multirow{2}{*}{ Wyszczególnienie } & \multicolumn{7}{|c|}{ Rok } \\
\hline & 2005 & 2006 & 2007 & 2008 & 2009 & 2010 & 2011 \\
\hline Zobowiązania JST & 21181 & 24949 & 25876 & 28774 & 40294 & 55093 & 65756 \\
\hline ogółem (mln zł), w tym: & & 3777 & 4067 & 2828 & & & 4005 \\
\hline $\begin{array}{c}\text { - papiery wartościowe, } \\
\text { w tym długotermi- }\end{array}$ & 3283 & 3777 & 4062 & 2828 & 5181 & 4406 & 4995 \\
\hline nowe & 3210 & 3733 & 4018 & 2810 & 5175 & 4399 & 4895 \\
\hline - kredyty i pożyczki, & 17634 & 20934 & 21633 & 25777 & 34920 & 50406 & 60469 \\
\hline $\begin{array}{l}\text { W tym atugoterm1- } \\
\text { nowe }\end{array}$ & 16841 & 19846 & 20730 & 25155 & 34654 & 49886 & 59880 \\
\hline - przyjęte depozyty & 0 & 3 & $\mathrm{x}$ & $\mathrm{x}$ & $\mathrm{x}$ & $\mathrm{x}$ & $\mathrm{x}$ \\
\hline $\begin{array}{l}\text { - wymagalne zobowią- } \\
\text { zania }\end{array}$ & 264 & 234 & 179 & 168 & 192 & 280 & 291 \\
\hline $\begin{array}{l}\text { Struktura zobowiązań } \\
\text { JST }(\%) \text {, w tym }\end{array}$ & 100 & 100 & 100 & 100 & 100 & 100 & 100 \\
\hline $\begin{array}{c}\text { - papiery wartościowe, } \\
\text { w tym długotermi- }\end{array}$ & 15,4 & 15,2 & 15,7 & 9,8 & 12,9 & 8,0 & 7,6 \\
\hline nowe & 15,1 & 14,9 & 15,2 & 9,7 & 12,8 & 7,9 & 7,4 \\
\hline $\begin{array}{l}\text { - kredyty i pożyczki, } \\
\text { w tym długotermi- }\end{array}$ & 83,3 & 83,9 & 83,6 & 89,6 & 86,7 & 91,5 & 92,0 \\
\hline nowe & 79,5 & 79,5 & 80,0 & 87,4 & 86,0 & 90,5 & 91,0 \\
\hline - przyjęte depozyty & 0,0 & 0,0 & 0,0 & $\mathrm{x}$ & $\mathrm{x}$ & $\mathrm{x}$ & $\mathrm{x}$ \\
\hline $\begin{array}{l}\text { - wymagalne zobowią- } \\
\text { zania }\end{array}$ & 1,3 & 0,9 & 0,7 & 0,6 & 0,4 & 0,5 & 0,4 \\
\hline
\end{tabular}

$\mathrm{x}$ - brak danych lub bardzo niski poziom, który nie wpływa na poziom struktury.

Źródło: oprac. własne na podstawie informacji o wykonaniu budżetów JST za lata 20052012, www.mf.gov.pl

Reasumując, zadłużenie kreowane w celu finansowania krótkookresowego niedoboru środków budżetowych oraz bieżącej działalności samorządu, z ekonomicznego punktu widzenia i bezpieczeństwa finansowego jest niebezpieczne, ale zarazem nieuniknione. Wynika to ze specyfiki przepływów pieniężnych w budżecie. Strumień wydatków nie zawsze pokrywa się ze strumieniem dochodów, co powoduje konieczność posiłkowania się pieniądzem pożyczkowym. Terminowość $\mathrm{w}$ regulowaniu tego długu nie zagraża bezpieczeństwu finansowemu, zagrożenie pojawia się dopiero w momencie, gdy bieżące wydatki 
finansowane są kredytem długoterminowym generującym dług. Generowanie długu samorządowego uzasadnione jest w sytuacji, gdy dochody o charakterze zwrotnym zostaną wykorzystane do tworzenia nowego majątku w jednostce samorządu. Wytworzenie nowych obiektów i urządzeń infrastrukturalnych sprzyja rozwojowi gospodarczemu danej jednostki, poprawie jakości życia lokalnych społeczności oraz stopnia zaspokojenia ich potrzeb, a w dłuższej perspektywie czasowej prowadzi do wzrostu konkurencyjności. Dlatego też główny nacisk położony powinien zostać nie tylko na poziom ogólnego zadłużenia, ale także na możliwości obsługi tego zadłużenia i przestrzeganie jego limitów, tak aby w przyszłości nie utracić zdolności kredytowej.

Zderzenie potrzeb inwestycyjnych z ograniczeniami politycznymi, prawnymi, a przede wszystkim fiskalnymi, sugeruje, że w dobie rosnącego zadłużenia władze samorządowe nie będą mogły realizować inwestycji bez skorzystania z finansowania prywatnego. Zastosowanie formuły PPP do finansowania inwestycji wydaje się tym bardziej uzasadnione i pożądane, że zobowiązania wynikające z umów o PPP przy odpowiedniej alokacji ryzyk pozostają neutralne na poziom długu publicznego. W dobie wzrastającego poziomu zadłużenia w interesie jednostek samorządu terytorialnego jest dywersyfikowanie źródeł finansowania inwestycji w taki sposób, aby nie kreować dodatkowego długu. Dobrze przemyślane i skonstruowane partnerstwo publiczno-prywatne umożliwia realizację inwestycji bez obciążenia budżetu. Neutralność formuły PPP w stosunku do długu publicznego została rygorystycznie określona, a sprostanie jej wymogom wymusza znajomość rozwiązań prawnych dotyczących tej problematyki. Wytyczne w tym zakresie zostały poddane analizie w dalszej części pracy.

\subsection{Partnerstwo publiczno-prywatne a deficyt i dług publiczny}

Problem alokacji ryzyka i sposób ujmowania zobowiązań wynikających z umów partnerstwa publiczno-prywatnego ma szczególne znaczenie z punktu widzenia deficytu i długu sektora publicznego. W obliczu rosnącego zadłużenia jednostek samorządu terytorialnego jednym ze sposobów realizowania zadań inwestycyjnych jest partnerstwo publiczno-prywatne. Zastosowanie partnerstwa publiczno-prywatnego stwarza możliwość ujęcia zobowiązań wynikających z umowy o PPP poza deficytem i dhugiem publicznym. Podstawowym kryterium, które pozwala na ulokowanie zobowiązań wynikających z PPP poza długiem, jest odpowiednia alokacja ryzyk. Zagadnienie wpływu umów o PPP na deficyt i dług publiczny zostało uregulowane prawem wspólnotowym. W Polsce brak jest odrębnych aktów prawnych regulujących w sposób szczegółowy zasady klasyfikowania zobowiązań z tytułu partnerstwa, nie ma też procedur weryfikujących poprawność kwalifikacji zobowiązań. Natomiast pojedyncze zapisy znaleźć można $\mathrm{w}$ obowiązującej ustawie o finansach publicznych i w rozporządzeniach ministra finansów. Wykaz kluczowych regulacji przedstawiono w tab. 4.4. 
Tabela 4.4

Akty prawne regulujące kwestię długu i deficytu publicznego w przedsięwzięciach PPP

\begin{tabular}{|c|c|}
\hline Nazwa aktu prawnego & Zakres regulacji \\
\hline 1 & 2 \\
\hline \multicolumn{2}{|c|}{ Prawo wspólnotowe } \\
\hline Decyzja Eurostat (ESA 95) & $\begin{array}{l}\text { Podstawowy dokument UE z } 2004 \text { r. określają- } \\
\text { cy sposób ujmowania umów partnerstwa } \\
\text { publiczno-prywatnego z perspektywy deficy- } \\
\text { tu i długu sektora instytucji rządowych i sa- } \\
\text { morządowych }\end{array}$ \\
\hline $\begin{array}{l}\text { Podręcznik deficytu i dlugu sektora instytucji } \\
\text { rzadowych i samorzadowych MGDD- } \\
\text { Implementacja ESA } 95 \text { (ang. Manual on } \\
\text { Gocernment Drficit and Debt) }\end{array}$ & $\begin{array}{l}\text { Podręcznik Eurostatu regulujący sposób sta- } \\
\text { tystycznego ujęcia zobowiązań wynikają- } \\
\text { cych z umów o PPP oraz zalecanych metod } \\
\text { analizy długu i deficytu publicznego }\end{array}$ \\
\hline \multicolumn{2}{|c|}{ Uregulowania polskie } \\
\hline $\begin{array}{l}\text { Ustawa o partnerstwie publiczno-prywatnym } \mathrm{z} \\
18 \text { grudnia } 2008 \mathrm{r} \text {. }\end{array}$ & $\begin{array}{l}\text { W sposób ramowy reguluje zasady współpracy } \\
\text { sektora publicznego z sektorem prywatnym, } \\
\text { zawiera wymóg uzyskania zgody ministra } \\
\text { finansów na finansowanie przedsięwzięć } \\
\text { PPP z budżetu państwa (z wykluczeniem } \\
\text { JST) w wysokości powyżej } 100 \text { mln zł }\end{array}$ \\
\hline $\begin{array}{l}\text { Ustawa o finansach publicznych z } 27 \text { sierpnia } \\
2009 \text { r., art. } 41 \text { ust. } 2 \text { pkt } 3\end{array}$ & $\begin{array}{l}\text { Nakłada na ministra finansów obowiązek } \\
\text { wydania przepisów wykonawczych określa- } \\
\text { jących rodzaje i zasady sporządzania spra- } \\
\text { wozdań dotyczących zobowiązań wynikają- } \\
\text { cych z umów PPP }\end{array}$ \\
\hline $\begin{array}{l}\text { Rozporządzenie Ministra Finansów z dnia } 3 \\
\text { lutego } 2010 \text { r. w sprawie sprawozdawczości } \\
\text { budżetowej }\end{array}$ & $\begin{array}{l}\text { Określa szczegółowe instrukcje sporządzania } \\
\text { kwartalnego sprawozdania } R B-Z-P P P \text { o } \\
\text { stanie zobowiązań wynikających z umów PPP }\end{array}$ \\
\hline $\begin{array}{l}\text { Rozporzadzenie Ministra Finansów z } 4 \text { marca } \\
2010 \text { r. w sprawie sprawozdań jednostek } \\
\text { sektora publicznego w zakresie operacji } \\
\text { finansowych }\end{array}$ & $\begin{array}{l}\text { Zawiera wytyczne, że zobowiązania z tytułu } \\
\text { umów o PPP winny być zaliczane do poży- } \\
\text { czek, gdy umowa ma wpływ na poziom } \\
\text { długu publicznego }\end{array}$ \\
\hline $\begin{array}{l}\text { Rozporządzenie Ministra Finansów z } 28 \text { grud- } \\
\text { nia } 2011 \text { r. w sprawie szczegółowego sposo- } \\
\text { bu klasyfikacji tytułów dtużyych zaliczanych } \\
\text { do państwowego dlugu publicznego }\end{array}$ & $\begin{array}{l}\text { Zawiera szczegółowe zasady w sprawie spo- } \\
\text { sobu klasyfikowania tytułów dłużnych do } \\
\text { państwowego długu publicznego }\end{array}$ \\
\hline
\end{tabular}

Źródło: oprac. własne na podstawie Decyzja Eurstat o traktowaniu partnerstwa publiczno-prywatnego i jego wplywie na dlug i deficyt publiczny, „Released” 2004, 18, 11 Feb. 2004; Rozporzadzenie Ministra Finansów z 3 lutego 2010 r. w sprawie sprawozdawczości budżetowej, DzU, 2010, nr 20, poz. 103; Rozporządzenie Ministra Finansów z dnia 4 marca 2010 r. w sprawie sprawozdań jednostek sektora publicznego $w$ zakresie operacji finansowych, DzU, 2010, nr 43, poz. 247; Rozporządzenie Ministra Finansów z 28 grudnia 2011 r. w sprawie szczegótowego sposobu klasyfikacji tytułów dlużnych zaliczanych do państwowego dlugu publicznego, DzU, 2011, nr 298, poz. 1767. 
Przedstawione regulacje mają na celu wyraźne wskazanie, że o sposobie zaliczenia PPP do długu publicznego będą decydowały szczegółowe postanowienia dotyczące kształtu umowy, w tym szczególnie informacje dotyczące podziału zidentyfikowanych dla projektu ryzyk. W Unii Europejskiej od 1994 r. obowiązuje tzw. procedura nadmiernego deficytu określona w Traktacie z Maastricht. Zgodnie z nią państwa członkowskie są zobowiązane do unikania nadmiernego deficytu poprzez spełnienie dwóch kryteriów: deficyt budżetowy nie może przekroczyć 3\% PKB, a dług publiczny 60\% PKB. Komisja Europejska przywiązuje szczególną wagę do przestrzegania powyższego zapisu. Jednocześnie, wspierając instytucję partnerstwa publiczno-prywatnego, położyła nacisk na uregulowanie kwestii umów o PPP i ich wpływ na poziom długu sektora publicznego. Taka postawa znalazła odzwierciedlanie w Decyzji Eurostatu 04/18 z 11 lutego 2004 r. Zgodnie z nią aktywa związane z długoterminowymi umowami zawieranymi pomiędzy instytucjami sektora publicznego a jednostkami spoza tego sektora będą uznawane za aktywa pozostające poza sektorem publicznym w sytuacji istnienia mocnych dowodów na to, że to partner prywatny ponosi większość ryzyk przez cały okres trwania umowy. Eurostat w celu ujednolicenia i uproszczenia analiz wskazał trzy główne ryzyka, których odpowiednia alokacja skutkuje powiększeniem długu publicznego bądź pozostaje w odniesieniu do niego neutralna. Są to ryzyko budowy, ryzyko dostępności i ryzyko popytu. Wytyczne jednoznacznie określają, że

podstawowym kryterium lokującym PPP poza lub w bilansie JST jest odpowiednia alokacja ryzyk, która może być określona jedynie na podstawie sformalizowanej analizy oraz stosowania się do wytycznych Eurostatu.

Zgodnie z Decyzja Eurostatu, aby umowa o PPP nie miała wpływu na dług publiczny, muszą być spełnione wszystkie następujące warunki:

1) partner prywatny ponosi ryzyko budowy,

2) partner prywatny ponosi ryzyko dostępności lub ryzyko popytu,

3) nie zostały zastosowane inne mechanizmy, na skutek zastosowania których nastąpi przejęcie przez sektor publiczny większości ryzyk dotyczących projektu (np. zakończenie umowy, finansowanie większościowe lub gwarancje).

Niespełnienie któregokolwiek z warunków skutkuje koniecznością ujęcia zobowiązań z tytutu umowy o PPP w bilansie strony publicznej ${ }^{28}$.

Na podstawie wytycznych Eurostatu ujętych w Decyzji Europejskie Centrum Ekspertyz PPP (European PPP Expertise Center) opracowało praktyczne wskazówki oraz listy kontrolne dotyczące statystycznego traktowania projektów PPP. Lista kontrolna zawiera 95 pytań ujętych w 11 rozdziałach. Pytania zostały skonstruowane tak, aby podmiot udzielił odpowiedzi „tak” lub „nie”, w celu

${ }^{28}$ Metodologia tworzenia analiz ryzyk $w$ projektach PPP $i$ ich podzialu pomiędzy stronę publiczna i prywatna w kontekście ich wplywu na klasyfikacje projektu pod katem dlugu i deficytu sektora publicznego, red. Ernest \& Young, Hogan Lovells, Ministerstwo Rozwoju Regionalnego, Warszawa 2012, s. 9. 
jednoznacznego stwierdzenia sposobu raportowania projektu z punktu widzenia statystyki, a tym samym wskazania czy projekt ujęty zostanie w bilansie podmiotu publicznego, czy podmiotu prywatnego. W sytuacji, gdy podmiot publiczny nie ma pewności co do sposobu ujęcia projektu w bilansie sektora publicznego zaleca się zasięgnięcie opinii Eurostatu ${ }^{29}$.

Ministerstwo Finansów jest organem odpowiedzialnym za opracowanie, wykonanie i kontrolowanie wykonania budżetu państwa, a więc także za zarządzanie długiem publicznym.

Dług publiczny obejmuje, zgodnie z art. 72 ust. 1 Ustawy o finansach publicznych z 2009 r. zobowiązania z następujących tytułów dłużnych:

1) wyemitowanych papierów wartościowych;

2) zaciągniętych kredytów i pożyczek;

3) przyjętych depozytów;

4) wymagalnych zobowiązań:

a) wynikających z odrębnych ustaw oraz prawomocnych orzeczeń sądów lub ostatecznych decyzji administracyjnych,

b) uznanych za bezsporne przez właściwą jednostkę sektora finansów publicznych będącą dłużnikiem.

W zaprezentowanej, ustawowej definicji długu nie ma odniesienia do zobowiązań wynikających z umów o partnerstwo publiczno-prywatne, ponieważ stanowią one jedną z podkategorii w klasyfikacji tytułów dłużnych. Jest to efekt zapisu art. 41 ust. 2 pkt 3 tejże ustawy, który nałożył na ministra finansów, po zasięgnięciu opinii Prezesa Głównego Urzędu Statystycznego, obowiązek określenia $\mathrm{w}$ formie rozporządzenia rodzaju i zasad sporządzania sprawozdań w zakresie zobowiązań wynikających z umów o PPP. Realizując ten zapis minister finansów wydał trzy rozporządzenia:

1) Rozporządzenie Ministra Finansów z dnia 3 lutego 2010 r. w sprawie sprawozdawczości budżetowej ${ }^{30}$,

2) Rozporzadzenie Ministra Finansów z dnia 4 marca 2010 r. w sprawie sprawozdań jednostek sektora finansów publicznych $w$ zakresie operacji finansowych ${ }^{31}$,

3) Rozporządzenie Ministra Finansów z dnia 28 grudnia 2011 r. w sprawie szczególowego sposobu klasyfikacji tytułów dlużnych zaliczanych do państwowego dlugu publicznego ${ }^{32}$.

${ }^{29}$ Podręcznik deficytu i dtugu sektora instytucji rządowych i samorządowych. Implementacja ESA 95, Edycja 2010, www.bazappp.gov.pl (20.02.1012).

${ }^{30}$ Rozporzadzenie Ministra Finansów z 3 lutego 2010 r. w sprawie sprawozdawczości budżetowej, DzU, 2010, nr 20, poz. 103.

${ }^{31}$ Rozporzadzenie Ministra Finansów z dnia 4 marca 2010 r.w sprawie sprawozdań jednostek sektora publicznego w zakresie operacji finansowych, DzU, 2010, $\mathrm{nr}$ 43, poz. 247.

${ }^{32}$ Rozporządzenie Ministra Finansów z 28 grudnia 2011 r. w sprawie szczegółowego sposobu klasyfikacji tytułów dlużnych zaliczanych do państwowego długu publicznego, DzU, 2011, nr 298, poz. 1767. 
Rozporzadzenie Ministra Finansów z dnia 28 grudnia 2011 w sprawie szczegótowego sposobu klasyfikowania tytułów dlużnych zaliczanych do państwowego dtugu publicznego zastąpiło wcześniej obowiązujące Rozporzadzenie Ministra Finansów z 23 grudnia 2010 r. w sprawie szczegótowego sposobu klasyfikowania tytułów dlużnych zaliczanych do państwowego dtugu publicznego, w tym do dlugu Skarbu Państwa ${ }^{33}$. W §3 pkt 2 rozporządzenia z 2010 r. zobowiązania z tytułu umów o PPP zaliczane zostały do długu publicznego w kategorii „kredyty i pożyczki” w sytuacji, gdy rzeczywiście wpływają na jego poziom. Nowe rozporządzenie w sprawie zaliczania tytułów dłużnych do państwowego długu publicznego podtrzymało niekorzystną dla jednostek samorządu terytorialnego definicję kredytów i pożyczek zaliczanych do długu, obejmującą ${ }^{34}$ :

1) mowy o partnerstwie publiczno-prywatnym, które mają wpływ na poziom długu publicznego,

2) papiery wartościowe, których zbywalność jest ograniczona,

3) umowy sprzedaży, w których cena jest płatna w ratach,

4) umowy leasingu zawarte $z$ producentem lub finansującym, w których ryzyko i korzyści z tytułu własności są przeniesione na korzystającego z rzeczy,

5) umowy nienazwane o terminie zapłaty dłuższym niż rok, związane z finansowaniem usług, dostaw, robót budowlanych, które wywołują skutki ekonomiczne podobne do umowy pożyczki lub kredytu z podziałem na:

a) krótkoterminowe - o pierwotnym terminie zapłaty nie dłuższym niż rok lub podlegające spłacie na żądanie,

b) długoterminowe - o pierwotnym terminie zapłaty dłuższym niż rok.

Samorządowcy wyraźnie akcentowali brak w rozporządzeniu z 2011 r., jak i uchylonym z roku 2010, jednoznacznego sposobu określającego warunki, czynniki, które przesądzałyby o wpływie tytułów dłużnych na poziom długu publicznego. Niepokojące sygnały płynące od samorządowców spowodowały, że na początku 2011 r. Ministerstwo Gospodarki wystąpiło do Ministerstwa Finansów o ich doprecyzowanie i zajęcie jednoznacznego stanowiska w kwestii klasyfikowania tytułów dłużnych. W odpowiedzi Ministerstwo Finansów w piśmie DP14/657/40/MKT/2011/1088 z dnia 10 marca 2011 r. jednoznacznie nakazało stosowanie przepisów ujętych w Decyzji Eurostatu 2004, nr 18. Powyższe pismo rozstrzygało kwestię zaliczania tytułów dłużnych wynikających $\mathrm{z}$ umów o PPP do długu publicznego. Zdaniem ekspertów zapisy Decyzji zostały inkorporowane do prawa polskiego w Rozporządzeniu Ministra Finansów z dnia 3 lutego 2010 r. w sprawie sprawozdawczości budżetowej. Inkorporacja przeja-

${ }^{33}$ Rozporzadzenie Ministra Finansów z dnia 23 grudnia 2010 r. w sprawie szczegótowego sposobu klasyfikacji tytułów dlużnych zaliczanych do państwowego dtugu publicznego, $w$ tym do dlugu Skarbu Państwa, DzU, 2010, nr 252, poz. 1692.

${ }^{34}$ Ibidem, poz. 1692, §3, ust. 2. 
wia się w obowiązku sporządzania przez jednostki sektora finansów publicznych, a więc także przez JST, kwartalnych sprawozdań Rb-Z-PPP i objęcie nim:

- wartości zobowiązań z tytułu umów o PPP, wynikających z obowiązku wniesienia tzw. wkładu własnego do przedsięwzięcia oraz

- wypłaty wynagrodzenia dla partnera prywatnego, których termin realizacji jeszcze nie upłynął.

Poziom zobowiązań wynikających z partnerstwa wykazywany jest także w części A sprawozdania Rb-Z zgodnie z Rozporządzeniem Ministra Finansów $z$ dnia 4 marca 2010 r. w sprawie sprawozdań jednostek sektora finansów publicznych $w$ zakresie operacji finansowych, gdzie wymienia się kredyty i pożyczki jako tytuły dłużne. Upoważnia to stronę publiczną umowy do zaliczenia powstałych zobowiązań do tej kategorii tytułów dłużnych. W sytuacji, gdy jednostki mają wątpliwości, czy aktywa PPP zaliczyć do bilansu własnego, czy bilansu podmiotu prywatnego, mogą zasięgnąć opinii GUS-u lub bezpośrednio Eurostatu.

Analiza wymienionych regulacji w zakresie wpływu umów o partnerstwo publiczno-prywatne na deficyt i dług publiczny nie jest zagadnieniem do końca określonym, co powoduje brak wypracowania jednoznacznej metodologii oceny powstających zobowiązań podmiotów publicznych zaangażowanych $\mathrm{w}$ przedsięwzięcia oraz zobowiązań Regionalnych Izb Obrachunkowych.

\subsection{Ekonomiczno-techniczna analiza przedsięwzięć partnerstwa publiczno-prywatnego}

\subsubsection{Zakres i obowiązek sporządzania analiz przedsięwzięcia partnerstwa publiczno-prywatnego}

Ustawa o partnerstwie publiczno-prywatnym z 2005 r. nakładała na stronę publiczną obowiązek sporządzenia analiz przedinwestycyjnych, których celem było wskazanie najlepszej metody wykonania danego przedsięwzięcia inwestycyjnego. Zakres analiz określały akty wykonawcze ${ }^{35}$. Bez względu na wartość inwestycji samorządy stanęły przed koniecznością poniesienia kosztów związanych z przygotowaniem, często kosztownych, analiz ekonomiczno-prawnych i środowiskowych. $Z$ powodu ostrej krytyki takiego zapisu nowe regulacje określone w ustawie o PPP z 2008 r. zniosły obowiązek przeprowadzenia analiz. W literaturze często podkreśla się, że partnerstwo publiczno-prywatne nie

${ }^{35}$ Por. nieobowiązujące rozporządzenia: Ministra Finansów z dnia 30 czerwca 2006 r. $w$ sprawie niezbędnych elementów analizy przedsięwzięcia $w$ ramach partnerstwa publiczno-prywatnego, DzU, 2006, nr 125, poz. 866 oraz Ministra Gospodarki z dnia 21 czerwca 2006 r. $w$ sprawie ryzyk zwiazanych $z$ realizacja przedsięwzięć $w$ ramach partnerstwa publiczno-prywatnego, DzU, 2006, nr 125, poz. 868. 
zawsze jest optymalnym sposobem realizacji zadań publicznych. Wykonanie zadania publicznego samodzielnie przez jednostkę samorządu terytorialnego może okazać się korzystniejsze. Z praktycznego punktu widzenia zniesienie obowiązku przeprowadzania analiz nie powinno zwalniać całkowicie podmiotów publicznych z ich przygotowania. Konieczność przygotowania takich analiz powinna zostać podyktowana chęcią wykazania efektywności rozwiązań partnerskich w stosunku do innych, alternatywnych sposobów finansowania. Przeprowadzenie analiz, chociażby w podstawowym zakresie, powinno wynikać $\mathrm{z}$ zasad racjonalnego gospodarowania mieniem publicznym, przejrzystości decyzji zarządczych względem majątku oraz konieczności uzasadnienia decyzji partnerskiego finansowania inwestycji przed władzami stanowiącymi samorządu oraz członkami lokalnej wspólnoty. Przygotowanie wstępnych analiz pozwoli także na określenie ścieżki wyboru partnera prywatnego. Artykuł 44 ust. 3 ustawy o finansach publicznych zawiera uwagę, że wydatki publiczne powinny być dokonywane w sposób celowy i oszczędny, z zachowaniem zasad uzyskiwania najlepszych efektów danych nakładów, optymalnego doboru metod i środków służących osiąganiu założonych celów i w sposób umożliwiający terminową realizację zadań. Uwzględniając powyższe przesłanki, wybór partnerstwa publiczno-prywatnego jako formy realizacji zadania publicznego powinien zostać poprzedzony analizami przedinwestycyjnymi. Zakres analizy uzależniony będzie od formy wkładu własnego podmiotu publicznego i konstrukcji wynagrodzenia partnera prywatnego. Złożoność analizy podyktowana jest skalą przedsięwzięcia oraz uwarunkowaniami prawnymi, ekonomicznymi, a także technicznymi planowanego przedsięwzięcia. Uzasadnieniem przeprowadzenia analiz zasadności wykorzystania PPP w sytuacji wystąpienia płatności z budżetu samorządu będzie konieczność zbadania, jak ryzyko polityczne i jego rozkład wpłynie na wieloletnie plany finansowe podmiotu publicznego.

Odpowiednie podejście do każdego przedsięwzięcia i przeprowadzenie wstępnych analiz pozwoli w przyszłości na unikniecie szeregu problemów natury ekonomiczno-społecznej oraz wpłynie na racjonalne, uzasadnione ekonomicznie wydatkowanie środków publicznych. Przeprowadzone analizy powinny więc służyć zaprezentowaniu najistotniejszych informacji niezbędnych do podjęcia decyzji o zasadności wyboru PPP jako sposobu finansowania przedsięwzięcia. Partnerstwo publiczno-prywatne nie w każdych warunkach musi stanowić najlepszą formę realizacji zadań publicznych czy dostarczania usług użyteczności publicznej. Niewłaściwie zaprojektowana współpraca międzysektorowa może być równie nieefektywna, co powszechnie stosowane zamówienie publiczne jako sposób wykonania zadania inwestycyjnego, a skutki błędnych decyzji daleko groźniejsze niż nietrafne rozstrzygnięcia podejmowane samodzielnie przez władze i administrację samorządową. Decyzja o realizacji przedsięwzięcia w formie kontraktu PPP powinna być efektem starannej 
i wszechstronnej analizy i jednoznacznie wskazywać, że jest on optymalnym rozwiązaniem ${ }^{36}$.

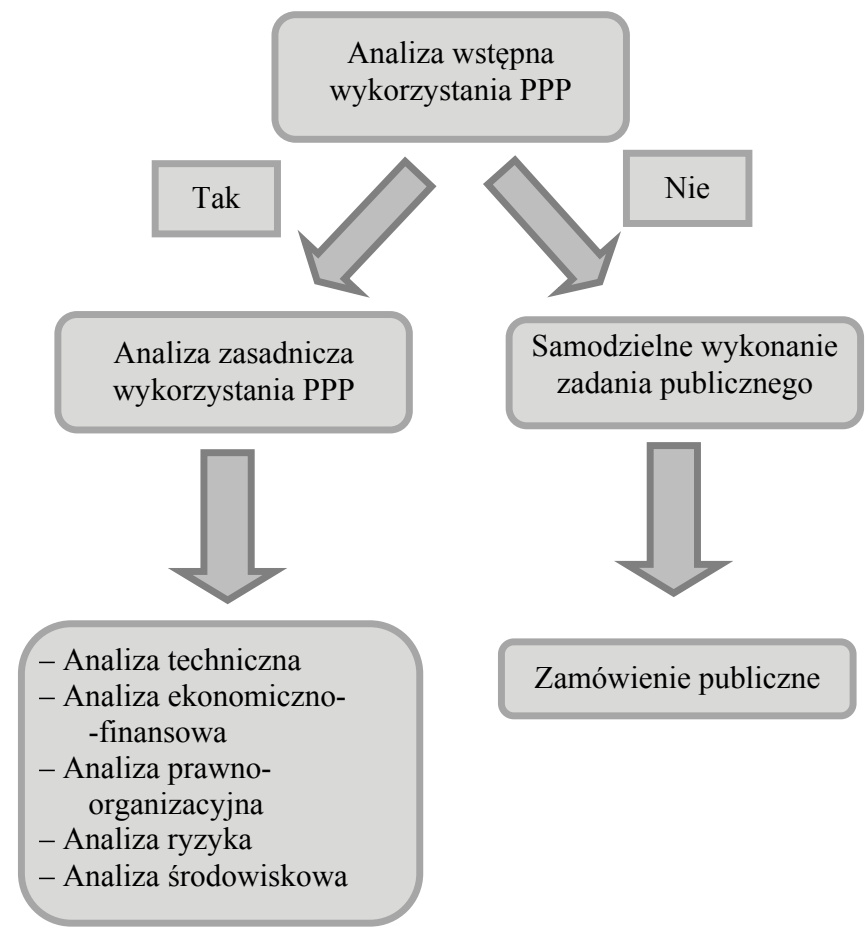

Schemat 4.1. Zakres analiz w przedsięwzięciach partnerstwa publiczno-prywatnego

Źródło: oprac. własne na podstawie A. Kozłowska, PPP krok po kroku. Podręcznik o partnerstwie publiczno-prywatnym, Dobre Praktyki Samorządowe, Warszawa 2011

W celu wykazania ekonomiczno-prawnej zasadności zastosowania formuły PPP przy realizacji inwestycji należy, bez względu na fakt braku obligatoryjności, sporządzić analizy przedrealizacyjne (schemat 4.1).

Analizy przedinwestycyjne dzielimy na: wstępne, które powinny dać odpowiedź, czy możliwa jest realizacja przedsięwzięcia w formule PPP, oraz zasadnicze, które jednoznacznie wskażą optymalną formułę realizacji inwestycji. W sytuacji, gdy analiza wstępna nie potwierdza zasadności zastosowania formuły PPP, jednostka samorządu terytorialnego może wykonać planowane przedsięwzięcie samodzielnie postępując zgodnie z procedurami i przepisami określonymi w Prawie zamówień publicznych. W sytuacji odwrotnej, gdy

${ }^{36}$ Por. M. Wawrzyniak, Analiza przedrealizacyjna przedsięwzięcia PPP - zagadnienia podstawowe, „Biuletyn Partnerstwa Publiczno-Prywatnego” 2012, nr 3, s. 7. 
analiza wstępna wskazuje na zasadność wyboru PPP do realizacji przedsięwzięcia, władze samorządowe mogą przejść do analiz zasadniczych. Przygotowując przedsięwzięcie wskazuje się na pięć obszarów, które powinny zostać poddane analizie. Są to zagadnienia: techniczne, finansowo-ekonomiczne, prawno-organizacyjne, związane z ryzykiem oraz środowiskowe (w pełnym zakresie sporządzane w zasadniczej fazie analiz przedinwestycyjnych).

\subsubsection{Analiza wstępna przedsięwzięć partnerstwa publiczno-prywatnego}

Analizy przedinwestycyjne polegają na określeniu potrzeb podmiotu publicznego i możliwości oraz metod/sposobów ich realizacji. W tym celu podmiot publiczny ${ }^{37}$ :

- określa cel przedsięwzięcia,

- dokonuje porównania efektywności realizacji przedsięwzięcia samodzielnie oraz we współpracy z partnerem prywatnym,

- określa parametry (wskaźniki) i standardy świadczonych usług oraz ich zakresu przez cały okres trwania przedsięwzięcia,

- przygotowuje optymalny wariant realizacji przedsięwzięcia, który stanowi podstawę do podjęcia negocjacji z prywatnym inwestorem.

Analiza wstępna obejmuje ${ }^{38}$ :

- analizę potrzeb i rynku,

- wstępne konsultacje społeczne,

- analizę interesariuszy,

- wstępne analizy wielowariantowe, w tym wstępne określenie podziału ryzyka,

- określenie możliwości finansowych podmiotu publicznego w kontekście uczestnictwa w planowanym przedsięwzięciu.

Analiza potrzeb i rynku polega na identyfikacji konkretnej potrzeby i ustaleniu pożądanego sposobu jej realizacji. W tym celu przeprowadza się ocenę możliwości wykonania danego zadania przy dostarczanym już poziomie usług publicznych i istniejącej strukturze. Na przykład w sytuacji, gdy samorząd planuje współpracę $\mathrm{z}$ partnerem prywatnym $\mathrm{w}$ zakresie gospodarki wodnokanalizacyjnej, musi udokumentować aktualny stan infrastruktury wodno-kanalizacyjnej, liczbę odbiorców i ich charakter (odbiorcy wykorzystujący usługę do celów socjalno-bytowych i odbiorcy wykorzystujący usługi do celów produkcyjnych, przemysłowych), zapotrzebowanie na daną usługę, potencjalny wzrost zapotrzebowania na usługi w postaci liczby nowych odbiorców. Władze

${ }^{37}$ Zob. A. Kozłowska, PPP krok po kroku. Podręcznik o partnerstwie publiczno-prywatnym, Dobre Praktyki Samorządowe, Warszawa 2011, s. 37; M. Majkowska, Jak przygotować się do partnerstwa, „Gazeta Prawna” 2011, nr 178, s. A9.

${ }^{38}$ Zob. A. Kozłowska, PPP krok po kroku..., s. 38; Partnerstwo publiczno-prywatne. Porad$n i k$, red. B. Korbus, Urząd Zamówień Publicznych, Warszawa 2010, s. 78-79. 
samorządowe powinny także ocenić realne możliwości sfinansowania zadania ze źródeł budżetowych. Taki wykaz informacji pozwala na prawidłowe sformułowanie celu przedsięwzięcia. Na tym etapie należy powołać się na obowiązujące regulacje prawa krajowego i miejscowego (wskazać akty prawne na podstawie których będzie realizowane przedsięwzięcie). Szacunkowy czas przeprowadzenia tych analiz waha się od dwu do czterech miesięcy.

W celu uniknięcia niebezpieczeństwa złego skonstruowania PPP pożądane jest przeprowadzenie wstępnych konsultacji społecznych, które mogą być realizowane poprzez badanie opinii społecznej lub działania informacyjne. Celem konsultacji jest poddanie społecznej debacie założeń realizacji przedsięwzięcia i uzyskanie akceptacji dla postulowanego sposobu realizacji zadania (w tym przypadku dla PPP). Konsultacje społeczne mogą przybrać formę ankiet bądź wywiadów. Pozytywnie ocenia się zastosowanie metod typu: sonda internetowa, wywiad telefoniczny czy bezpośrednie rozmowy. Konsultacje i działania informacyjne mogą być prowadzone za pomocą strony internetowej jednostki samorządu terytorialnego albo odrębnej strony stworzonej do danego przedsięwzięcia, przez zorganizowanie seminariów, spotkań poświęconych danemu przedsięwzięciu czy też bezpośrednio organizacji forum dla potencjalnych inwestorów.

Działania informacyjne mają na celu dostarczenie maksimum wiedzy o planowanym przedsięwzięciu. Powinny zostać skierowane do ${ }^{39}$ :

- lokalnej społeczności, która będzie stanowiła podstawową grupę odbiorców usługi po zrealizowaniu przedsięwzięcia;

- lokalnych polityków, którzy będą decydowali, poprzez przyjęcie stosownych uchwał, o formie realizacji danego przedsięwzięcia;

- lokalnych przedsiębiorców, którzy mogą odegrać rolę podwykonawców w ramach partnerstwa publiczno-prywatnego;

- organizacji społecznych, związanych z branżą lub dziedziną, w której planowana jest inwestycja, i organizacji ekologicznych. Ich zaangażowanie na etapie konsultacji może w sposób wymierny wpłynąć na przebieg inwestycji (wsparcie techniczne, zaniechanie manifestacji itp.);

- mediów, które kształtują opinię publiczną i mogą przyczynić się do promocji lub też blokowania PPP oraz ułatwić pozyskanie prywatnych partnerów dla przedsięwzięcia;

- potencjalnych prywatnych inwestorów, którzy stanowią podstawowy element przedsięwzięcia PPP.

Ideą przyświecającą konsultacjom społecznym jest poznanie opinii interesariuszy w danej sprawie (tzn. o przedsięwzięciu realizowanym w formie PPP),

${ }^{39}$ Por. R. Cieślak, Partnerstwo publiczno-prywatne w samorządzie terytorialnym, Infor Ekspert, Warszawa 2011, s. 96-100. 
którzy w sposób bezpośredni lub pośredni dotknięci zostaną jej rezultatami ${ }^{40}$. Poznanie opinii obywateli pozwala na podjęcie decyzji, która będzie uwzględniała różne interesy i potrzeby oraz złagodzi ewentualne napięcia. Warto zwrócić uwagę, że opór niekontrolowany jest trudniej złagodzić niż opór poprzedzony konsultacjami. Łatwiej uzyskać akceptację kontrowersyjnych decyzji w sytuacji, gdy obywatele uczestniczyli w ich podejmowaniu niż w sytuacji, gdy decyzja zostaje im zewnętrznie narzucona. Partnerstwo publiczno-prywatne samo $\mathrm{w}$ sobie postrzegane jest jako radykalna zmiana formy świadczenia usług i w sposób naturalny budzi sceptycyzm oraz niechęć. Konsultacje stanowią formę przybliżenia problematyki oraz ukazania kosztów i korzyści płynących ze zmiany sposobu wykonywania zadań publicznych ${ }^{41}$.

Wstępne analizy wielowariantowe powinny dotyczyć określenia stanu prawnego nieruchomości lub składników majątkowych, które mogą stanowić wkład własny podmiotu publicznego, określenia zasad wnoszenia wkładu własnego, określenia optymalnego modelu realizacji przedsięwzięcia (metoda tradycyjna, koncesja, umowa o PPP czy partnerstwo w formie spółki) oraz analizy możliwych montaży finansowych i możliwości pozyskania środków zwrotnych na realizację przedsięwzięcia. Ważna jest identyfikacja wszystkich dostępnych źródeł finansowania przy uwzględnieniu ich wpływu na budżet jednostki samorządu terytorialnego. Kluczowym elementem każdej wielowariantowej analizy jest wstępna identyfikacja ryzyk i ich podział pomiędzy podmiot publicznego i partnera prywatnego.

Przeprowadzenie na etapie wstępnym analizy możliwości finansowych jednostki samorządu terytorialnego ma na celu efektywniejsze przygotowanie się do analiz zasadniczych lub wycofanie się przez podmiot publiczny z dalszych prac przygotowawczych bez konieczności ponoszenia dodatkowych kosztów. Już na etapie wstępnym widać, czy uzasadnione są dalsze prace zmierzające do

${ }^{40}$ Raport końcowy z badania efektywności mechanizmów konsultacji spolecznych, Pracownia Badań i Innowacji Społecznych STOCZNIA, Warszawa 2011, s. 9.

${ }^{41}$ Zgodnie z prawem konsultacje społeczne mają charakter obowiązkowy, jeśli chodzi o istotne sprawy, np. tworzenie, łączenie, podział, znoszenie, ustalanie granic. W „ważnych sprawach społeczno-gospodarczych" organy władzy mają prawo do przeprowadzenia konsultacji, ale wymóg ten nie ma charakteru obligatoryjnego. $Z$ uwagi na znacząca rolę PPP w finansowaniu zadań, konsultacje społeczne organizowane przez władze samorządowe lub przez doradców wyłonionych na potrzeby projektu mogą być realizowane na podstawie modelu Czterech kroków Renna (omawiającym sposób, zasady i etapy procesu konsultacji społecznych, opisanym w publikacji L. Carson, K. Gerber, Ideas for community consultation: a discussion on principles and procedures for making consultation work, New South Wales. Dept. of Urban Affairs and Planning, 2001). Prawidłowo przeprowadzone konsultacje powinny odbywać się przy poszanowaniu następujących zasad: reprezentatywności, partnerstwa, efektywności, jawności, uczciwej konkurencji, suwerenności stron, zgodności z prawem. Omówienie zasad dobrych konsultacji zostało przedstawione w Raporcie końcowym z badania efektywności mechanizmów..., s. 15 i n. 
realizacji przedsięwzięcia $\mathrm{w}$ formie partnerstwa publiczno-prywatnego, czy też konieczne jest przyjęcie innego sposobu wykonania przedsięwzięcia ${ }^{42}$.

$\mathrm{Na}$ etapie prac związanych z przeprowadzeniem analizy wstępnej podejmuje się także decyzję w kwestii zaangażowania profesjonalnych doradców. Decyzja ta powinna być rezultatem prawidłowo sformułowanego celu i zakresu przedsięwzięcia. Władze samorządu mają do wyboru trzy rozwiązania ${ }^{43}$ :

- po pierwsze, przygotowanie przedsięwzięcia powierzają własnym wykwalifikowanym pracownikom,

- po drugie, przedsięwzięcie przygotowują pracownicy ze wsparciem zewnętrznych specjalistów,

- po trzecie, przedsięwzięcie przygotowują zewnętrzni doradcy specjalizujący się w PPP.

Władze samorządowe muszą zdecydować, z jakiej pomocy fachowców chcieliby skorzystać i jakie koszty będzie trzeba ponieść. Przygotowanie przedsięwzięcia w trybie PPP średnio kosztuje od 4 do $6 \%$ jego wartości. Doradcy wskazują, że dla małych zadań inwestycyjnych, do wartości $10 \mathrm{mln}$ zł, koszty te będą zwykle wyższe niż $6 \%$, przy dużych zaś, przekraczających wartość $100 \mathrm{mln}$ zł, koszt doradztwa nie przekroczy 4\% wartości przedsięwzię$\mathrm{cia}^{44}$. Środki na wynagrodzenie doradców muszą zostać zabezpieczone w budżecie samorządu.

Dysponując zestawem informacji o przedsięwzięciu i możliwościach jego realizacji analizę wstępną kończymy przygotowaniem studium wykonalności, $\mathrm{w}$ tym harmonogramu prac nad przygotowaniem przedsięwzięcia. Ważne jest, aby wyraźnie zakwalifikować przedsięwzięcie do jednej z czterech grup: rokujących wdrożenie w ramach PPP, nie rokujących wdrożenia w ramach PPP, nie rokujących wdrożenia $\mathrm{w}$ ramach PPP $\mathrm{w}$ najbliższym, dającym się przewidzieć terminie, takich, które powinny być wdrożone samodzielnie przez władze samorządowe. $\mathrm{W}$ początkowym okresie prac nad przygotowaniem przedsięwzięcia należy przeprowadzić analizę wykonalności alternatywnych rozwiązań lub tzw. analizę wariantów, która, poprzez wprowadzenie różnych wariantów rozwiązań, ma dostarczyć odpowiedzi, dotyczących oczekiwanych (ustalonych) celów. Dorobek metodologiczny, który powinny wykorzystać służby samorządowe to przede

${ }^{42}$ Zob. A. Kozłowska, PPP krok po kroku..., s. 42.

${ }^{43} \mathrm{Z}$ praktyki państw realizujących PPP wynika, że najmniejsze przedsięwzięcia realizowane są na podstawie doświadczenia i umiejętności własnych służb samorządowych, dla średnich pracownicy posiłkują się fachowym doradztwem, natomiast przy dużych, zwłaszcza przy infrastrukturze publicznej, przedsięwzięcia prowadzone są przez zespół zewnętrznych fachowych doradców. Zob. W. Grzybowski, Komu powierzyć realizacje projektu w ramach partnerstwa, „Gazeta Prawna” 2011, nr 178, s. A9.

${ }^{44} \mathrm{Na}$ podstawie wypowiedzi W. Grzybowskiego, doradcy PPP z Collect Consulting S.A., podczas VII Ogólnopolskiej Konferencji „Realizacja inwestycji sportowych i rekreacyjnych w formule partnerstwa publiczno-prywatnego, Łódź, 28 marca 2012. 
wszystkim przewodnik Analiza kosztów i korzyści projektów inwestycyjnych ${ }^{45}$. Analizy wstępne winny zostać wykonane w okresie 3-4 miesięcy.

Jeśli przedsięwzięcie ma znamiona pozwalające na realizację $\mathrm{w}$ formule PPP władze samorządowe przechodzą do etapu analiz zasadniczych. Pozytywny wynik analiz wstępnych nie przesądza jednak, że inwestycja będzie w tej formie realizowana. Decyzja dotycząca metody realizacji może ulec jeszcze zmianie zarówno na etapie analitycznym, jak i wyboru partnera prywatnego.

\subsubsection{Analiza techniczna przedsięwzięć partnerstwa publiczno-prywatnego}

Analiza techniczna sporządzana jest w celu zdefiniowania przedsięwzięcia. Służy opracowaniu struktury techniczno-technologicznej. $Z$ jednej strony określa zakres rzeczowy, a z drugiej funkcjonalność przedsięwzięcia. Analiza techniczna obejmuje zagadnienia związane m.in. z warunkami technicznymi i technologicznymi przedsięwzięcia, analizą lokalizacyjną, w tym terenu, na którym ma powstać inwestycja, określeniem powierzchni i kubatury obiektów, analizą materiałów i surowców możliwych do wykorzystania, norm prawnych z zakresu budownictwa. Analiza poszczególnych elementów pozwala na stworzenie koncepcji architektonicznej, w której określone zostaną warunki naturalne przyszłej inwestycji, wymagania funkcjonalno-użytkowe (liczba pomieszczeń, wielkość powierzchni użytkowej, instalacje sieci wodnej, kanalizacyjnej, cieplnej, energetycznej), wymagania konstrukcyjne, prawno-normatywne, wynikające z uzgodnień i norm branżowych, warunki estetyczno-kompozycyjne. Analizę techniczną sporządza się dla tych przedsięwzięć, których realizacja polegać będzie na budowie lub modernizacji. Wyraźnie należy zaznaczyć, że analiza techniczna powinna dotyczyć całego przedsięwzięcia, a nie tylko fragmentu, za który odpowiedzialny jest podmiot publiczny, ale także za część komercyjną służącą stronie prywatnej do generowania wynagrodzenia z przedsięwzięcia. Analiza techniczna kończy się przygotowaniem programu funkcjonalno-użytkowego dla przedsięwzięcia. Nie jest uzasadnione, aby podmiot publiczny ostatecznie sprecyzował rozwiązanie techniczne i uzyskał wymagane pozwolenia, gdyż może to prowadzić do spadku atrakcyjności przedsięwzięcia i poważnie ograniczyć zainteresowanie prywatnych przedsiębiorców. Szczegółowe rozwiązania powinny zostać doprecyzowane na etapie negocjacji z partnerem prywatnym, które będą sprzyjać optymalizacji ekonomicznej przedsięwzięcia oraz wpłyną korzystnie na ostateczny bilans inwestycji ${ }^{46}$.

${ }^{45}$ Analiza kosztów i korzyści projektów inwestycyjnych. Przewodnik (Fundusz Strukturalny EFRR, Fundusz Spójności i ISPA), Jednostka ds. Ewaluacji Dyrekcja Generalna - Polityka Regionalna, Komisja Europejska, Bruksela 1997.

${ }^{46}$ Por. M. Wawrzyniak, Analiza przedrealizacyjna przedsięwzięcia PPP..., s. 11. 


\subsubsection{Analiza ekonomiczno-finansowa przedsięwzięcia partnerstwa publiczno-prywatnego}

Analizy ekonomiczno-finansowe stanowią podstawowe narzędzie porównawcze (tzw. benchmarking) kosztów i korzyści przedsięwzięcia dla metody tradycyjnej oraz PPP.

Analiza ekonomiczna ma za zadanie określić wpływ podejmowanych decyzji na całokształt działalności jednostki samorządu terytorialnego „uwzględniając czynniki finansowe, wyniki analizy finansowej oraz pozafinansowe (jakościowe) dotyczące procesów związanych z dostarczaniem produktów i usług",47. $\mathrm{Z}$ uwagi na fakt, że realizacja przedsięwzięć PPP powinna przynieść efekty społeczne i gospodarcze, zakres przeprowadzonej analizy ekonomicznej nie może skupiać się tylko na ocenie działalności podmiotów zaangażowanych w PPP, ale i na efektach wynikających z realizacji przedsięwzięcia w wymiarze regionalnym, krajowym. Dlatego przeprowadzając analizę ekonomiczną nie należy zapominać o skutkach inwestycji dla podmiotów ją realizujących oraz o rzeczywistych pośrednich i bezpośrednich skutkach oddziaływania na otoczenie.

Kompleksowa analiza ekonomiczna przedsięwzięcia obejmuje ${ }^{48}$ :

- cele przedsięwzięcia, w tym jego wymiar społeczno-ekonomiczny dla danego obszaru, regionu,

- analizę wykonalności przedsięwzięcia z punktu widzenia technicznego, technologicznego oraz marketingu, zarzadzania, wdrażania i eksploatacji,

- analizę finansową,

- analizę wielokryteryjną,

- ocenę ryzyka.

Prawidłowo przeprowadzona analiza finansowa powinna uwzględniać następujące działania $^{49}$ :

- określenie założeń analizy - stosuje się tu metodę zdyskontowanych przepływów pieniężnych (DCF - Discounted Cash Flow),

- określenie wartości rezydualnej,

- określenie cen przyjętych do szacowania strumieni pieniężnych. W przypadku przyjęcia cen stałych, nieuwzględniających inflacji, stopa dyskonta, użyta w ramach kalkulacji wskaźników efektywności, powinna być wyrażona w wartościach realnych,

- określenie aspektu podatkowego PPP, w tym przede wszystkim możliwości odzyskania podatku od towarów i usług (podatku VAT) przez partnera

${ }^{47}$ M. Dylewski, Analiza ekonomiczna i finansowa projektu europejskiego, [w:] Zarzadzanie finansami projektu europejskiego, red. M. Dylewski, B. Filipiak, A. Guranowski, J. Hałub-Iwan, Wydawnictwo C.H. Beck, Warszawa 2009, s. 192.

${ }^{48}$ Ibidem, s. 194.

${ }^{49}$ Por. M. Wawrzyniak, Analiza przedrealizacyjna przedsięwzięcia PPP..., s. 29. 
prywatnego. Jeśli istnieje możliwość odzyskania podatku VAT przez jednostkę realizującą przedsięwzięcie, ceny użyte do analizy powinny być podane w wartościach netto. W przypadku, gdy nie ma możliwości odliczenia podatku VAT w analizie powinno się uwzględniać ceny brutto.

Ekonomicznej oceny przedsięwzięcia dokonuje się na podstawie poniżej wymienionych wskaźników ${ }^{50}$ :

- ekonomicznej wartości bieżącej netto strumieni kosztów i korzyści (ENPV - economical net present value),

- ekonomicznej stopy zwrotu (ERR - economical rate of return),

- relacji korzyści do kosztów (B/C - benefits/costs).

Ekonomiczna wartość bieżąca netto przedsięwzięcia jest różnicą ogółu zdyskontowanych korzyści i kosztów. Uznaje się, że przedsięwzięcie jest uzasadnione, jeśli wskaźnik jest dodatni. Im później osiągane są korzyści w stosunku do ponoszonych kosztów, tym niższa jest wartość bieżąca netto zdyskontowanych strumieni kosztów i korzyści.

Ekonomiczna stopa zwrotu z inwestycji to wartość, przy której ekonomiczna wartość bieżąca netto strumieni kosztów i korzyści wynosi zero. Oznacza to, że bieżąca wartość przyszłych korzyści ekonomicznych jest równa bieżącej wartości kosztów ekonomicznych przedsięwzięcia, ERR zaś jest równe przyjętej stopie dyskontowej. W sytuacji, gdy ERR jest niższe od przyjętej stopy dyskontowej, ENPV przyjmuje wartość ujemną, co oznacza, że bieżąca wartość przyszłych korzyści ekonomicznych jest niższa niż bieżąca wartość kosztów ekonomicznych. Jeżeli ekonomiczna stopa zwrotu jest mniejsza od zastosowanej stopy dyskontowej, wówczas projekt uważa się za nieefektywny.

Wskaźnik korzyści do kosztów B/C ustala się jako stosunek zdyskontowanych korzyści do sumy zdyskontowanych kosztów generowanych w przyjętym okresie odniesienia. Inwestycję uznaje się za efektywną, jeśli wskaźnik B/C jest większy lub równy jedności, co oznacza, że wartość korzyści przekracza wartość kosztów inwestycji ${ }^{51}$.

W celu zbadania efektywności zaangażowanego kapitału, w ramach przedsięwzięcia konieczne jest przeprowadzenie analizy finansowej. Powinna ona uwzględniać odpowiednie założenia makroekonomiczne, mające swoje uzasadnienie $\mathrm{w}$ kontekście specyfiki przedsięwzięcia $\mathrm{z}$ punktu widzenia podmiotu publicznego i partnera prywatnego, możliwości finansowe tych podmiotów oraz weryfikować trwałość finansową przedsięwzięcia. Analizą finansowa powinny zostać objęte następujące zagadnienia ${ }^{52}$ :

${ }^{50}$ M. Dylewski, Analiza ekonomiczna i finansowa projektu europejskiego..., s. 19.

${ }^{51}$ Wytyczne w zakresie wybranych zagadnień zwiąanych z przygotowaniem projektów inwestycyjnych, w tym projektów generujacych dochód, Ministerstwo Rozwoju Regionalnego, Warszawa 2009, s. 37.

${ }^{52}$ Por. M. Wawrzyniak, Analiza przedrealizacyjna przedsięwzięcia PPP..., s. 16. 
- określenie założeń analizy,

- oszacowanie nakładów inwestycyjnych,

- wskazanie źródeł finansowania przedsięwzięcia,

- kalkulacja przychodów i kosztów przedsięwzięcia,

- kalkulacja wskaźników efektywności przedsięwzięcia oraz zaangażowanego kapitału przez podmiot publiczny i partnera prywatnego.

Preferowanym sposobem przeprowadzenia analizy finansowej jest metoda zdyskontowanych przepływów pieniężnych. Umożliwia ona szacowanie przyszłych przepływów pieniężnych przy wykorzystaniu odpowiedniej stopy procentowej, służącej do zdyskontowania tych przepływów. Dyskontowanie umożliwia porównanie $\mathrm{w}$ czasie sald przepływów środków pieniężnych oraz uwzględnienie ryzyka zmienności pieniądza $\mathrm{w}$ czasie $^{53}$.

Nakładami inwestycyjnymi są wszystkie wydatki poniesione w ramach przedsięwzięcia do momentu wejścia przedsięwzięcia w fazę eksploatacji. Do nakładów na rzeczowe składniki aktywów trwałych zalicza się wszystkie wydatki niezbędne do wytworzenia infrastruktury określone w umowie pomiędzy podmiotem publicznym a partnerem prywatnym. Dotyczą one wydatków poniesionych na prace przygotowawcze (sporządzenie analiz, dokumentację techniczną, usługi doradcze), wartości niematerialnych i prawnych (oprogramowanie, licencje), nowo powstałych rzeczowych środków trwałych. Do nakładów inwestycyjnych zalicza się także nakłady związane z nadzorowaniem inwestycji w trakcie budowy oraz rozruchu ${ }^{54}$.

Po oszacowaniu nakładów inwestycyjnych trzeba wskazać źródła finansowania przedsięwzięcia PPP. Główne z nich to:

- środki partnera prywatnego,

- środki podmiotu publicznego,

- komercyjne źródła finansowania (pożyczki, kredyty),

- emisja dłużnych papierów wartościowych,

- dotacje bezzwrotne (pomoc unijna w ramach hybrydowego PPP).

Wybór źródła finansowania przedsięwzięcia uzależniony jest od szeregu czynników, m.in. dostępności, kosztu pozyskania, elastyczności, efektu dźwigni finansowej czy ryzyka obsługi. Dostępność poszczególnych źródeł finansowania uzależniona jest od pozycji partnera prywatnego. Bierze się pod uwagę jego kondycję finansową i zdolność kredytową. Część źródeł może być dla niego niedostępna. W przypadku bezzwrotnych dotacji należy sprawdzić, czy istnieje możliwość ubiegania się o nie $\mathrm{w}$ trakcie trwania realizacji przedsięwzięcia. Kryteria kosztu pozyskania i elastyczności kapitału są ze sobą ściśle powiązane. Większa elastyczność kapitału pociąga za sobą wyższy koszt jego wykorzysta-

53 Ibidem.

54 Por. K. Sobiech-Grabska, Analiza finansowo-ekonomiczna w PPP, „Biuletyn Partnerstwa Publiczno-Prywatnego" 2012, nr 4, s. 8. 
nia. Wykorzystanie kredytu $\mathrm{w}$ finansowaniu przedsięwzięcia pozwala zastosować dźwignię finansową, która - poprzez zaangażowanie kapitałów obcych powoduje wzrost rentowności kapitału własnego partnera prywatnego zaangażowanego w przedsięwzięcie PPP. Koszt wykorzystania kapitału obcego uzależniony jest także od wysokości i rodzaju wkładu własnego partnera prywatnego, który musi spełniać wymagania stawiane przez banki oraz od ryzyka związanego z przedsięwzięciem. Ocena ryzyka w dużej mierze oparta jest na przewidywaniu potencjalnych, przyszłych źródeł spłaty pożyczonego kapitału. W sytuacji, gdy źródłem przychodów będą dopłaty podmiotu publicznego z budżetu, ryzyko będzie niższe niż w sytuacji, gdy przychody partnera prywatnego pochodzić będą tylko z działalności komercyjnej.

Atrakcyjność przedsięwzięcia PPP dla partnera prywatnego uzależniona jest od możliwości osiągania korzyści powiązanych z przychodami i poziomem koniecznych do poniesienia kosztów. Szacując przychody należy określić źródła ich pozyskania, a następnie oszacować, jakie przychody każde z tych źródeł jest w stanie wygenerować. Przychody szacuje się w trzech podstawowych kategoriach (wnikających z rachunku zysków i strat): przychody ze sprzedaży, pozostałe przychody operacyjne i przychody finansowe. Przychody ze sprzedaży obejmują sprzedaż wyrobów, towarów, materiałów lub usług. PPP realizowane przez jednostki samorządu terytorialnego nie będą generowały przychodów ze sprzedaży, dlatego podstawowym źródłem przychodów będzie opłata za dostępność (dopłata podmiotu publicznego z budżetu na rzecz partnera prywatnego). Pozostałe przychody operacyjne mogą być pozyskiwane ze sprzedaży środków trwałych, wartości niematerialnych i prawnych, z likwidacji środka trwałego, rozwiązania rezerw, otrzymanych kar, grzywien i odszkodowania, darowizny. Źródłem przychodów finansowych mogą być posiadane papiery wartościowe, depozyty, udzielone pożyczki.

Podobnie jak przychody, oszacowanie kosztów powinno obejmować koszty operacyjne, pozostałe koszty operacyjne i koszty finansowe. Podstawowe kategorie kosztów operacyjnych obejmują pozycje kosztów według rodzajów: amortyzację, zużycie materiałów i energii, usługi obce, wynagrodzenia, ubezpieczenia i inne świadczenia, podatki i opłaty, pozostałe koszty rodzajowe oraz wartość sprzedanych towarów i materiałów według cen ich nabycia.

Pozostałe koszty operacyjne związane są ze sprzedażą środków trwałych, środków trwałych w budowie, wartości niematerialnych i prawnych, $\mathrm{z}$ utrzymaniem i sprzedażą nieruchomości, wartości niematerialnych i prawnych zaliczanych do inwestycji, $\mathrm{z}$ odpisem należności przedawnionych, umorzonych, nieściągalnych, utworzeniem i rozwiązaniem rezerw $-\mathrm{z}$ wyjątkiem rezerw związanych $\mathrm{z}$ operacjami finansowymi i odpisami aktualizującymi wartość aktywów. Koszty finansowe związane są bezpośrednio z przeprowadzonymi operacjami finansowymi, są to np. odsetki, prowizje od pożyczek, straty ze 
zbycia inwestycji, ujemne różnice kursowe ${ }^{55}$. Poza wymienionymi przychodami i kosztami uwzględnia się jeszcze zyski i straty nadzwyczajne, których wystąpienie uzależnione jest od zdarzeń losowych trudnych do przewidzenia.

Kalkulacja wskaźników efektywności przedsięwzięcia oraz kapitału zaangażowanego przez podmiot publiczny i partnera prywatnego dokonywana jest z wykorzystaniem metody bieżącej wartości netto (NPV) oraz wewnętrznej stopy zwrotu (IRR). W przypadku NPV niższego od zera oraz IRR niższego od kosztu kapitału, przedsięwzięcie PPP należy uznać za nieopłacalne.

Przeprowadzone analizy ekonomiczno-finansowe mają na celu wskazanie, że realizacja przedsięwzięcia doprowadzi do szeroko pojętego „wzrostu dobro-

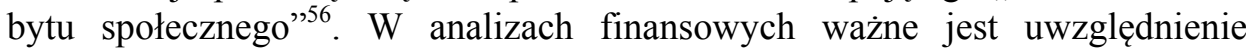
akceptowalnej przez podmiot prywatny wewnętrznej stopy zwrotu z przedsięwzięcia, której poziom uzależniony jest od specyfiki przedsięwzięcia, ryzyka branży, ryzyka kraju i w większości przypadków ma charakter subiektywny. Celem analizy ekonomiczno-finansowej jest przeprowadzenie oceny opłacalności (efektywności) przedsięwzięcia zarówno z punktu widzenia strony publicznej, jak i prywatnego partnera.

Analiza finansowa powinna także uwzględniać wskaźnik zadłużenia jednostki samorządu terytorialnego. Właściwy rozkład ryzyka oraz brak możliwości samodzielnego wykonania zadania może być przesłanką do zastosowania PPP pomimo gorszych wskaźników efektywności finansowej samorządu. Realizacja przedsięwzięcia w formule PPP może okazać się bardziej realna i korzystniejsza ze względów fiskalnych ${ }^{57}$.

\subsubsection{Analiza prawno-organizacyjna przedsięwzięcia partnerstwa publiczno-prywatnego}

Z uwagi na skomplikowany status przedsięwzięć PPP konieczne jest sporządzenie analiz prawnych. Analizy prawne przygotowywane są już na etapie wstępnym, ich rozwinięcie następuje $\mathrm{w}$ fazie zasadniczej przygotowań. Ich ranga uwydatnia się $\mathrm{w}$ chwili uruchomienia postępowania o wybór partnera prywatnego. Wówczas znane muszą być kwestie dotyczące odpowiedzialności poszczególnych stron za przedsięwzięcie, określenie struktury i formy prawnej dla poszczególnych etapów tego przedsięwzięcia, wskazanie optymalnego modelu jego wykonania, określenie wymaganych zezwoleń administracyjnych, uzgodnień oraz opinii wynikających z ustaw: o gospodarce nieruchomościami, o planowaniu i zagospodarowaniu przestrzennym oraz prawa budowlanego,

\footnotetext{
${ }^{55}$ Por. M. Wawrzyniak, Analiza przedrealizacyjna przedsięwzięcia PPP..., s. 16.

${ }^{56}$ W. Grzybowski, Przedpartnerska analiza kosztów i korzyści, „Gazeta Samorządu i Administracji” 2005, nr 22, s. 17.

${ }^{57}$ Por. M. Wawrzyniak, Analiza przedrealizacyjna przedsięwzięcia PPP..., s. 29.
} 
wskazanie procedury wyłonienia prywatnego partnera z przywołaniem stosownych regulacji, harmonogram postępowania przy wyborze tego partnera, ocena prawna składników majątkowych, które stanowić będą wkład własny podmiotu publicznego, ocena prawna zasad finansowania przedsięwzięcia, zagadnienia związane $\mathrm{z}$ ubezpieczeniem obiektu, zasady przygotowania inwestycji, sam proces jej realizacji i eksploatacji, zasady kontroli, kary za niedotrzymanie warunków umowy, sposób rozwiązania konfliktów, sposób i forma rozwiązania umowy i przekazania składników majątkowych. Doprecyzowanie zagadnień prawnych, obok ekonomiczno-finansowych, przesądza o sprawności przygotowania przedsięwzięcia, a następnie jego wdrożenia.

Obok rozwiązań prawnych konieczne jest wskazanie formy organizacyjnej, w jakiej projekt będzie wdrażany. Poza podstawowymi stronami umowy, tj. stroną publiczną i partnerem prywatnym, w przedsięwzięcie będą zaangażowane inne podmioty tj. podwykonawcy, instytucje finansujące, ubezpieczyciele, doradcy. Strony muszą podjąć decyzję, w jakiej formule będzie prowadzone przedsięwzięcie. Ustawa o partnerstwie publiczno-prywatnym dopuszcza dwa rozwiązania biznesowe: kontraktowe oraz spółkę SPV. Partnerstwo publicznoprywatne kontraktowe przedstawia schemat 4.2 , natomiast partnerstwo publiczno-prywatne w formie spółki SPV schemat 4.3.

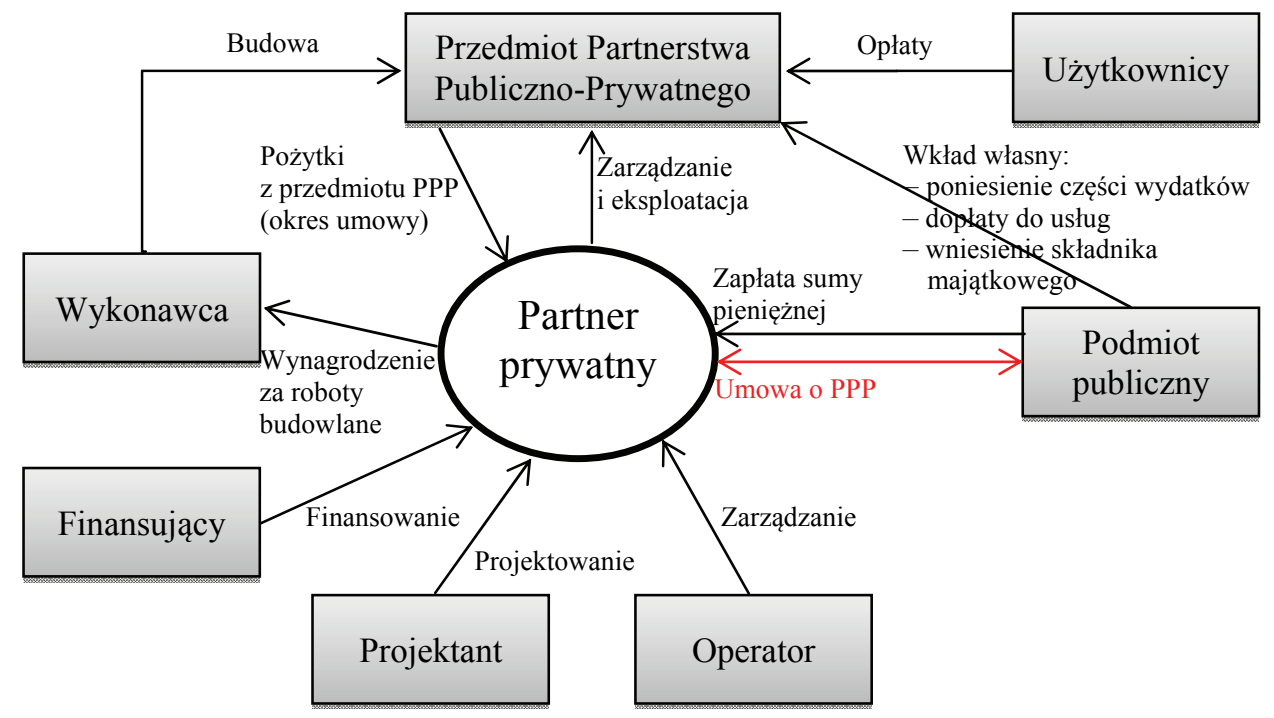

Schemat 4.2. Partnerstwo publiczno-prywatne kontraktowe

Źródło: A. Kozłowska, PPP krok po kroku. Podręcznik o partnerstwie publiczno-prywatnym, Dobre Praktyki Samorządowe, Warszawa 2011, s. 74 
$\mathrm{Na}$ schemacie 4.2 zaprezentowano partnerstwo publiczno-prywatne oparte na umowie zawartej pomiędzy podmiotem publicznym a partnerem prywatnym. Partner prywatny na podstawie umowy o PPP zobowiązany jest do wykonania przedmiotu umowy związanego z zaprojektowaniem (projektant), finansowaniem (finansujący), wykonaniem (wykonawca) oraz zarządzaniem i eksploatacją (operator). Podmiot publiczny wnosi wkład własny, który może przyjąć formę poniesienia części wydatków, dopłaty do usług, wniesienie składnika majątkowego. Zobowiązany jest także do zapłaty sumy pieniężnej stanowiącej wynagrodzenie partnera prywatnego. Partner ten, zgodnie z umową, ma prawo do pobierania opłat od użytkowników z tytułu świadczonych usług oraz pożytków z przedsięwzięcia ${ }^{58}$.

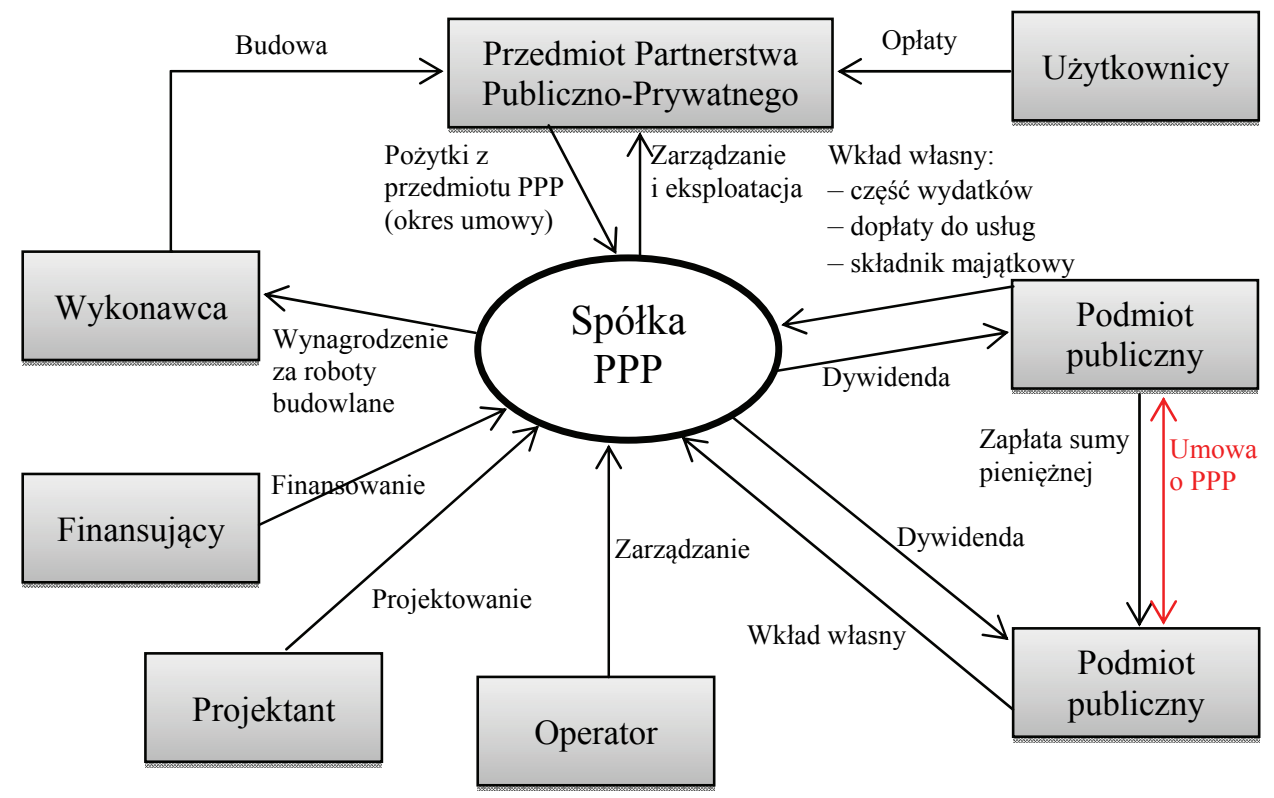

Schemat 4.3. Partnerstwo publiczno-prywatne w formie spółki SPV

Źródło: A. Kozłowska, PPP krok po kroku. Podręcznik o partnerstwie publiczno-prywatnym, Dobre Praktyki Samorządowe, Warszawa 2011, s. 75

Na schemacie 4.3 przedstawiono umowę o partnerstwo publiczno-prywatne, w której strony uzgodniły, że dla celów realizacji przedsięwzięcia powołają spółkę PPP. Obie strony do spółki wnoszą wkład własny oraz upoważnione są do pobierania dywidendy. Wkładem własnym strony publicznej, podobnie jak przy PPP kontraktowym, mogą być: część poniesionych wydatków, dopłaty do

\footnotetext{
${ }^{58}$ Por. A. Kozłowska, PPP krok po kroku..., s. 74.
} 
usług oraz składnik majątkowy. Podmiot publiczny ma obowiązek zapłaty sumy pieniężnej jako wynagrodzenia partnera prywatnego. Z kolei partner prywatny zobowiązany jest do zaprojektowania (projektant), finansowania (finansujący), wykonania (wykonawca) oraz zarządzania i eksploatacji przedmiotu umowy PPP. Z tytułu świadczonych usług partner ma prawo do pobierania opłat od użytkowników oraz pożytków z przedsięwzięcia ${ }^{59}$.

Jak wynika z przedstawionych schematów prawo dopuszcza możliwość realizacji przedsięwzięcia PPP poprzez wspólne działanie dwóch odrębnych podmiotów lub poprzez utworzenie przez strony spółki, której forma zostanie określona $\mathrm{w}$ umowie ${ }^{60}$. Powołanie spółki nie jest obligatoryjną formą dla zadań przeznaczonych do wykonania $\mathrm{w}$ formule PPP i powinno zawsze zostać poprzedzone wnikliwą analizą prawno-organizacyjną.

\subsubsection{Analiza ryzyka przedsięwzięcia partnerstwa publiczno-prywatnego}

Problematyka ryzyka $\mathrm{w}$ formule partnerstwa publiczno-prywatnego należy do kluczowych zagadnień, ponieważ od jego przewidywalności i odpowiedniego skalkulowania zależy decyzja o nawiązaniu partnerskiej współpracy pomiędzy podmiotem publicznym a prywatnym inwestorem. Pogląd, że świadczenie usług publicznych cechuje się stabilnością ze względu na niezbędność tych usług dla społeczeństwa nie eliminuje elementu ryzyka. Staje się ono istotnym czynnikiem $\mathrm{w}$ momencie przekazania zadania podmiotowi prywatnemu, który w swej działalności będzie kierował się zasadami rynkowymi. Poziom ryzyka wzrasta, gdy uwzględnione zostaną działania inwestycyjne, w które zaangażowany zostaje kapitał często pochodzący z rynku finansowego.

W PPP ryzyko ${ }^{61}$ stanowi jeden z podstawowych elementów odróżniających formułę od tradycyjnego zamówienia publicznego. Decyzje inwestycyjne

\section{${ }^{59}$ Ibidem, s. 75.}

${ }^{60} \mathrm{~W}$ rozdziale 4 ustawy o partnerstwie publiczno-prywatnym z $2008 \mathrm{r}$. zamieszczone zostały przepisy regulujące procedurę utworzenia spółki specjalnego przeznaczenia do wykonania przedsięwzięcia w ramach PPP. Strony mogą zawiązać spółkę kapitałową (akcyjną i z ograniczoną odpowiedzialnością) oraz spółkę osobową (komandytowa lub komandytowo-akcyjną). Ustawa z dnia 19 grudnia 2008 r. o partnerstwie publiczno-prywatnym, DzU, 2009, nr 19, poz. 100, ze zm. art. 14 ust. 1.

${ }^{61}$ Ryzyko stanowi nieodłączny element procesów inwestycyjnych. Często utożsamiane jest ze stanem niepewności. Problem definiowania i kategoryzacji ryzyka jest $\mathrm{w}$ literaturze szeroko dyskutowany. Za prekursora wyodrębnienia i zdefiniowania ryzyka i niepewności uznaje się F. H. Knighta, Risk, Uncertainty and Profit, Houghton Mifflin, Boston-New York 1921, s. 19-20; rozważania na temat ryzyka można podejmują też m.in. A. H. Willet, The Economic Theory of Risk Insurance, University of Pensylvania Press, Philadelphia 1951, s. 6; G. L. S. Shackle, Expectation Entprise and Profit, George Allen und Unwin, London 1970, s. 97-100; O. Lange, Optymalne decyzje, PWN, Warszawa 1964. 
podejmowane są $\mathrm{w}$ określonym momencie i $\mathrm{w}$ określonych warunkach działania podmiotów, natomiast realizacja inwestycji i jej efekty uzyskiwane się w dłuższej perspektywie, nawet kilkunastoletniej. Taka sytuacja powoduje, że decyzje inwestycyjne podejmowane są na podstawie pewnych przyjętych prognoz zachowania różnych czynników, które będą występować w trakcie realizacji i eksploatacji (schemat 4.4). Przewidywaniom, poprzedzonym różnymi analizami, zawsze będzie towarzyszyło ryzyko.

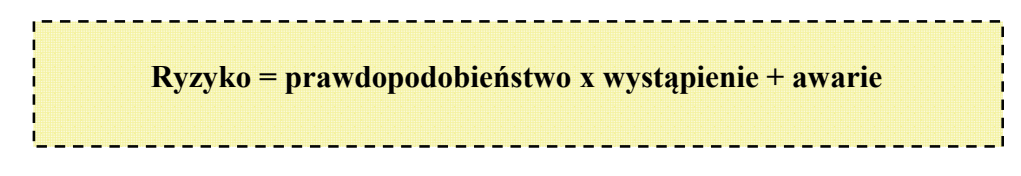

Schemat 4.4. Ryzyko w przedsięwzięciach partnerstwa publiczno-prywatnego Źródło: Public Sector Comparator. Technical Note, Department of Treasury and Finance, Melbourne Victoria 3002, Australia, czerwiec 2001, s. 51

R. S. Lintz wyodrębnił cztery kategorie ryzyka, które mogą wystąpić w ramach PPP $^{62}$ :

- ryzyko handlowe - dotyczące obszarów finansowych, np. spowodowane przekroczeniem nakładów, będące wynikiem opóźnień, przekroczenia planowanego poziomu kosztów operacyjnych, karami wynikającymi z niedotrzymania uzgodnionych parametrów lub standardów, wypłatą odszkodowań,

- ryzyko rynkowe i eksploatacyjne - pojawia się w momencie wzrostu cen, np. nośników energii, paliw, zmniejszenia popytu na usługi lub postępu technicznego,

- ryzyko polityczne - pozostające poza możliwością realnego oddziaływania przez strony partnerstwa, a w sposób istotny rzutujące na stopień jego realizacji; wynika ze zmian w przepisach prawa, działań dyskryminacyjnych, wywłaszczeniowych,

- ryzyko finansowe - związane ze zmianą stóp procentowych, ryzyko kursowe.

Komisja Europejska, szczególnie promująca formułę PPP, wskazuje, że realizacja przedsięwzięć PPP, podobnie jak każdego innego obarczona jest ryzykiem, czyli możliwością wystąpienia różnych czynników wpływających na

${ }^{62}$ R. S. Linzt, An overview of Alternative institutional Arrangements for the Delivery of Urban Service: Public/Private Partnerships. Opracowanie dla: Local Government Partnership Program, program USAID/Chemonics International, 1999, s. 26-29, cyt. za J. Zysnarski, Partnerstwo publiczno-prywatne. Teoria i praktyka, Ośrodek Doradztwa i Doskonalenia Kadr Sp. z o.o., Gdańsk 2003, s. 13. 
przebieg procesu realizacji. W odniesieniu do PPP Komisja wskazała dziesięć zasadniczych grup ryzyk, które najczęściej towarzyszą tego typu współpracy (tab. 4.5).

Tabela 4.5

Rodzaje ryzyk w partnerstwie publiczno-prywatnym według Komisji Europejskiej

\begin{tabular}{|c|c|}
\hline Rodzaj ryzyka & Obszar objęty ryzykiem \\
\hline 1 & 2 \\
\hline Związane $\mathrm{z}$ dochodem & $\begin{array}{l}\text { Podstawowe ryzyko w projektach ppp, którego } \\
\text { poziom uzależniony jest od poziomu dostępności } \\
\text { świadczonych usług i ich cen }\end{array}$ \\
\hline Wyboru partnera prywatnego & $\begin{array}{l}\text { Poziom ryzyka zależy od kompetencji partnera } \\
\text { prywatnego oraz prawidłowo przeprowadzonego } \\
\text { postępowania jego wyboru }\end{array}$ \\
\hline Związane z pracami budowlanymi & $\begin{array}{l}\text { Obszarem zarządzania ryzykiem są koszty kapitałowe } \\
\text { prac budowlanych, które należy utrzymać w gra- } \\
\text { nicach objętych budżetem projektu }\end{array}$ \\
\hline Walutowe & $\begin{array}{l}\text { Obejmuje projekty finansowane pożyczonym za } \\
\text { granicą kapitałem i niebezpieczeństwem wystąpie- } \\
\text { nia wahań kursowych }\end{array}$ \\
\hline Regulowane/umowne & $\begin{array}{l}\text { Obszarem zarządzania ryzykiem jest niebezpieczeń- } \\
\text { stwo niewywiązywania się przez administrację } \\
\text { publiczną z ustaleń objętych umową z prywatnym } \\
\text { partnerem }\end{array}$ \\
\hline Polityczne & $\begin{array}{l}\text { Poziom ryzyka uzależniony jest od poziomu } \\
\text { stabilności politycznej w państwie, częste zmiany } \\
\text { ekip rządzących, brak akceptacji decyzji poprzed- } \\
\text { ników nasilają ryzyko nieukończenia projektu }\end{array}$ \\
\hline Środowiskowe/archeologiczne & $\begin{array}{l}\text { Ryzyko dotyczy prawdopodobieństwa wystąpienia } \\
\text { społecznych protestów organizowanych przez } \\
\text { obrońców środowiska, co prowadzi do wzrostu } \\
\text { kosztów i opóźnień }\end{array}$ \\
\hline Ukrytych wad & $\begin{array}{l}\text { Ryzyko powstaje w projektach związanych z przeję- } \\
\text { ciem w eksploatację istniejącej infrastruktury, brak } \\
\text { właściwego udokumentowania inspekcji przyjmo- } \\
\text { wanych w zarząd obiektów zwiększa prawdopodo- } \\
\text { bieństwo wystąienia ryzyka }\end{array}$ \\
\hline Społecznej/ publicznej akceptacji & $\begin{array}{l}\text { Powstaje w efekcie braku akceptacji społecznej } \\
\text { wynikającej ze wzrostu opłat za usługę i przekłada } \\
\text { się na wzrost wydatków publicznych związanych } \\
\text { z wypłatą subsydiów koncesjonariuszowi }\end{array}$ \\
\hline
\end{tabular}




\begin{tabular}{|l|l|}
\hline \multicolumn{1}{|c|}{$\mathbf{1}$} & $\mathbf{2}$ \\
\hline Ukryty protekcjonizm & Zakresem ryzyka objęta jest niechęć społeczeństwa \\
& do przekazania zadań publicznych (domeny sektora \\
& publicznego) w prywatny zarząd, zjawisko nasila \\
& się, gdy podmioty prywatne pochodzą z zewnątrz, \\
& z krajów bogatych i mają możliwość osiągania \\
& zysków z inwestycji, podłoże ryzyka mieści się \\
& w świadomości społecznej związanej z ochroną \\
& rodzimego rynku i podmiotów na nim działających \\
\hline Utraty trwałości & Obszarem zarządzania jest efektywność generowana \\
& przez projekt, jej utrata zagraża ochronie interesu \\
& publicznego \\
\hline
\end{tabular}

Źródło: oprac. własne na podstawie Wytyczne dotyczace udanego partnerstwa publicznoprywatnego, Komisja Europejska, Dyrektoriat Generalny Polityka Regionalna, Bruksela 2003, s. $62-67$.

Ryzyko społecznej akceptacji, ukryty protekcjonizm i ryzyko utraty trwałości mają wpływ na interes społeczny i akceptację decyzji i działań, jakie wynikają z realizacji projektu PPP. Społeczne poparcie dla PPP w znacznej mierze może przyczynić się do zminimalizowania ryzyk z tej grupy, gdyż społeczność lokalna nie będzie nawoływać do wystąpień, protestów, itp. opóźniających prace związane z realizacją inwestycji.

$\mathrm{Na}$ gruncie uregulowań polskich obowiązująca ustawa o PPP nie definiuje pojęcia „ryzyka” oraz nie kategoryzuje ryzyk, pozostawiając tę kwestię w gestii uczestników przedsięwzięcia. Niemniej jednak należy zaznaczyć, że do ustawy z 2005 r. o PPP minister gospodarki wydał rozporządzenie, w którym wyraźnie sprecyzowano grupy ryzyk, które mogą pojawić się przy współpracy partnerskiej.

Rozporządzenie wymieniało 17 grup ryzyk, które w większości były zbieżne z ujętymi w Wytycznych Komisji Europejskiej. Obecnie mają one drugorzędne znaczenie i mogą stanowić jedynie punkt odniesienia przy pracach nad planami zarządzania ryzykiem dla przedsięwzięć PPP. Uchylone rozporządzenie obejmowało ryzyka ${ }^{63}$ :

1) związane $z$ budową,

2) związane $z$ dostępnością,

3) związane $z$ popytem,

4) związane z przygotowaniem przedsięwzięcia,

5) rynkowe,

6) o charakterze politycznym,

7) o charakterze legislacyjnym,

8) makroekonomiczne,

${ }^{63}$ Rozporządzenie z dnia 21 czerwca 2006 r. w sprawie ryzyk..., poz. 868. 
9) regulacyjne,

10) związane z przychodami z przedsięwzięcia,

11) wystąpienia siły wyższej,

12) związane $z$ rozstrzyganiem sporów,

13) związane ze stanem środowiska naturalnego,

14) związane $z$ lokalizacją przedsięwzięcia,

15) związane z przekazaniem składników majątkowych,

16) związane $z$ końcową wartością składników majątkowych,

17) związane $z$ brakiem społecznej akceptacji.

Rozmieszczenie ryzyka powinno odzwierciedlać określone właściwości przedsięwzięcia i pozycję stron umowy. Ważnym elementem przy podziale ryzyka są jego koszty, ponieważ przy każdym PPP osiągnięcie korzyści w stosunku do zaangażowanych nakładów często zależy od poziomu i kosztów ryzyka przeniesionego na prywatnego partnera. Do dobrej praktyki należy badanie i porównanie zakresu przenoszonego ryzyka w innych umowach. Jest to oczywiście możliwe w sytuacji istnienia bazy zrealizowanych przedsięwzięć. Taką bazą mogą pochwalić się kraje Europy Zachodniej, gdzie inwestycje $\mathrm{w}$ formule PPP realizowane są $\mathrm{w}$ różnych dziedzinach życia gospodarczego. Bogatą bazą dysponują m.in. Wielka Brytania, Irlandia czy Hiszpania. W Polsce, gdzie przedsięwzięcia znajdują się dopiero w fazie ogłoszeń wyboru partnera lub dochodzi do podpisania pierwszych umów, trudno mówić o bazie danych. Zaznaczyć trzeba, że ryzyka związane z realizacją PPP nie różnią się zasadniczo od ryzyk związanych z przedsięwzięciami o podobnym znaczeniu wykonywanych samodzielnie przez sektor publiczny bądź prywatny. Można więc dokonać pewnego wyodrębnienia ryzyk występujących w praktyce i wykorzystać zdobyte w tym zakresie doświadczenie.

Przeglądu ryzyka $\mathrm{w}$ inwestycjach dokonuje K. Brzozowska ${ }^{64}$ prezentując spojrzenie na kwestię ryzyka w literaturze anglojęzycznej i polskiej. Przeprowadzona analiza pozwala Autorce na wyodrębnienie trzech zasadniczych grup ryzyka:

1) ryzyko polityczne, związane $z$ brakiem stabilności $w$ państwie, np. wojna, zamieszki, wywłaszczenie, zmiana wysokości podatków, częste zmiany regulacyjno-prawne. Czynniki te $\mathrm{w}$ sposób znaczący mogą przyczynić się do naruszenia terminów realizacji inwestycji, wzrostu kosztów, a w skrajnych przypadkach nawet nieukończenia przedsięwzięcia;

2) ryzyko techniczne może wystąpić na każdym etapie realizacji przedsięwzięcia. Objęte są nim zarówno elementy związane z procedurą projektowobudowlaną jak i faktyczną eksploatacją przedmiotu partnerstwa. Ryzyko powstaje z przyczyn niewłaściwego doboru kadry zarządzającej inwestycją,

${ }^{64}$ K. Brzozowska, Finansowanie inwestycji infrastrukturalnych przez kapital prywatny na zasadach Project finance, Wydawnictwa Fachowe CeDeWu, Warszawa 2005, s. 88-99. 
nadzorującej realizację oraz ekip wykonujących poszczególne prace. Czynnikami zwiększającymi ryzyko techniczne są zastosowanie niewłaściwych technologii i rozwiązań technicznych. Nie należy pomijać także czynników przyrodniczych. Każdy z tych elementów może być przyczyną niedotrzymania harmonogramu prac, co w konsekwencji przekłada się na koszty realizacji przedsięwzięcia;

3) ryzyko ekonomiczne związane jest z osiągnięciem niższych dochodów $\mathrm{w}$ związku $\mathrm{z}$ niskim popytem na usługi, wzrostem kosztów operacyjnych i finansowych wynikających $\mathrm{z}$ dodatkowego zadłużenia, zmian stóp procentowych i kursów walutowych.

Identyfikacja ryzyka ma istotne znaczenie $\mathrm{z}$ uwagi na fazę realizacji inwestycji i formę zabezpieczenia. K. Brzozowska możliwość wystąpienia ryzyka rozpatruje $\mathrm{z}$ perspektywy fazy realizacji przedsięwzięcia (rozwoju, budowy i eksploatacji) oraz formy zabezpieczenia poszczególnych rodzajów ryzyka. Szczególna rola przypada towarzystwom ubezpieczeniowym oraz władzy publicznej jako instytucjom wyposażonym w odpowiednie instrumenty służące minimalizacji ryzyka (polisy ubezpieczeniowe, gwarancje, poręczenia rządowe).

Klasyfikacja M. Moszoro ${ }^{65}$ oparta jest na podziale ryzyka przeprowadzonego przez Esty'ego i J. Zysnarskiego. Autor wyodrębnił osiem głównych grup ryzyka wraz z czynnikami, które wpływają na dany rodzaj ryzyka. Ryzyko techniczne wyodrębnione przez K. Brzozowską zostało tu ujęte w dwóch odrębnych grupach jako ryzyko budowy i ryzyko operacyjne.

Europejski Bank Inwestycyjny ${ }^{66}$ czynniki ryzyka związane z PPP dzieli na dwie grupy: handlowe oraz prawno-polityczne. Ryzyko handlowe uwzględnia ryzyko związane z podażą i ryzyko łączące się z popytem. To pierwsze dotyczy głównie zdolności spółki PPP do realizacji powierzonych jej zadań, przy czym $\mathrm{w}$ tej grupie wyróżnia się dodatkowo ryzyko związane $\mathrm{z}$ budową, eksploatacją oraz ryzyko rynków finansowych. $Z$ kolei ryzyko związane $\mathrm{z}$ popytem dotyczy niedostatecznego natężenia ruchu lub niezgodności struktury ruchu z pierwotnymi założeniami. Ryzyko prawno-polityczne dotyczy norm prawnych obowiązujących $\mathrm{w}$ danym państwie i stopnia ich stabilności, sposobu rozstrzygania sporów, polityki władz, opodatkowania, groźby wywłaszczenia bądź nacjonalizacji.

W sprawie ryzyka PPP wypowiedział się także Urząd Statystyczny Unii Europejskiej, Eurostat. W 2004 r. w celu uporządkowania materii i nazewnictwa

${ }^{65}$ M. Moszoro, Partnerstwo publiczno-prywatne $w$ monopolach naturalnych $w$ sferze użteczności publicznej, Wydawnictwo Szkoły Głównej Handlowej w Warszawie, Warszawa 2005, s. 57-58. Autor dokonuje identyfikacji różnego rodzaju ryzyk jakie mogą wystąpić w przedsięwzięciach oraz ocenia prawdopodobieństwo wystąpienia ryzyka, potencjalnych szkód, a także dokonuje alokacji poszczególnych ryzyk między uczestników przedsięwzięcia. Przyjęta została trójstopniowa miara występowania zjawiska na poziomie małym, średnim bądź dużym.

${ }^{66}$ Przewodnik po PPP, Europejski Bank Inwestycyjny, Europejskie Centrum Ekspertyz PPP, Luksemburg, www.eib.org/epec, s. 17. 
oraz odnosząc się do kwestii rachunkowych związanych z PPP zaproponowano trzy podstawowe grupy ryzyka:

1) ryzyko budowy obejmujące zdarzenia związane $z$ opóźnieniami w dostawach, defekty techniczne, niezachowanie standardów, negatywne skutki zewnętrzne; podmiot publiczny ponosi większą część ryzyka w sytuacji, gdy zobowiąże się do regularnych płatności na rzecz partnera prywatnego;

2) ryzyko dostępności występuje wówczas, gdy partner prywatny nie jest w stanie dostarczyć zakontraktowanych usług o określonej jakości, przy braku zgodności $\mathrm{z}$ normami bezpieczeństwa czy normami branżowymi; ryzyko przypisuje się stronie prywatnej nawet $\mathrm{w}$ sytuacji, gdy podmiot publiczny w wyniku zaistnienia dodatkowych zdarzeń jest uprawniony do obniżenia wysokości okresowych płatności na rzecz podmiotu prywatnego;

3) ryzyko popytu dotyczy wahań popytu na świadczone przez partnera prywatnego usługi z powodów od niego niezależnych, których przyczyną może być pojawienie się konkurencji, nowych trendów, rozwiązań technologicznych; obciążenie ryzykiem strony publicznej następuje w sytuacji, jeśli jej zobowiązanie do płatności okresowych jest niezależne od poziomu zapotrzebowania na usługę, co zapewnia partnerowi prywatnemu stały poziom dochodów.

W sytuacji, gdy analizowane w podstawowym zakresie wyniki badania ryzyka nie doprowadzą do jednolitej konkluzji przyporządkowania ryzyka odpowiedniej stronie, zaleca się zastosowanie dodatkowych kryteriów, tj. statusu partnera prywatnego, zakresu gwarancji publicznych, statusu własnościowego wytworzonych aktywów PPP.

Stanowisko Eurostatu ma szczególną wagę dla podmiotów publicznych, gdyż przedstawiony podział i alokacja ryzyka $\mathrm{z}$ punktu widzenia systemu rachunkowości danego państwa ma istotne znaczenie w kwestii wpływu przedsięwzięć PPP na poziom deficytu i długu publicznego. Aktywa zaangażowane i wytworzone $w$ ramach partnerstwa publiczno-prywatnego zalicza się do bilansu partnera prywatnego, o ile ten przyjmie w zarząd ryzyko budowy i co najmniej jedno z ryzyk - ryzyko dostępności lub ryzyko popytu, co jednoznacznie zwalnia podmiot publiczny z ujmowania go w swoim bilansie i nie powoduje zmian $\mathrm{w}$ deficycie $\mathrm{i}$ długu publicznym ${ }^{67}$. Wytyczne wynikające $\mathrm{z}$ decyzji Eurostatu nie znajdują bezpośrednio odzwierciedlenia w polskich przepisach. Oceniając wpływ danego przedsięwzięcia PPP na dług publiczny należy bezpośrednio oprzeć się na zapisach decyzji Eurostatu. Takie stanowisko wynika z decyzji przekazanej przez ministra finansów ministrowi gospodarki. W chwili obecnej pojedyncze odniesienie do problematyki wpływu ryzyka na deficyt i dług publiczny można znaleźć w następujących aktach prawnych:

${ }^{67}$ Decyzja Eurostat o traktowaniu partnerstwa publiczno-prywatnego i jego wplywie na dhug i deficyt publiczny, „Released” 2004, 18, 11 Feb. 2004, www.europa.eu. 
- art. 41 ust. 2 pkt. 3 Ustawy o finansach publicznych, zgodnie z którym podmioty publiczne, jakie zawarły umowę o PPP zobowiązane są do sporządzania kwartalnych sprawozdań budżetowych, badających m.in. stan realizacji zasady podziału ryzyka, których instrukcję sporządzenia określa załącznik 41 do Rozporządzenia Ministra Finansów z 3 lutego 2010 r. w sprawie sprawozdawczości budżetowej ${ }^{68}$,

- w Rozporzadzeniu Ministra Finansów z 4 marca 2010 r. w sprawie sprawozdań jednostek sektora publicznego $w$ zakresie operacji finansowych ${ }^{69}$, w którym określono, że do pożyczek należy zaliczyć zobowiązania z tytułu umów PPP w przypadku, gdy umowa ta ma wpływ na poziom długu publicznego odwołując się do $\S 2$ ust. 1 rozdziału 1 załącznika 9 Instrukcji sporządzania sprawozdań oraz

- w Rozporzadzeniu Ministra Finansów z dnia 28 grudnia 2011r. w sprawie szczegółowego sposobu klasyfikacji tytułów dłużnych zaliczanych do państwowego dlugu publicznego ${ }^{70}$.

Ponieważ regulacje w zakresie przedsięwzięć PPP i ich wpływu na dług i deficyt budziły wiele kontrowersji i niejasności, Ministerstwo Gospodarki wystąpiło do Ministerstwa Finansów o ich doprecyzowanie i zajęcie stanowiska. W odpowiedzi Ministerstwo Finansów jednoznacznie nakazało stosowanie zapisów Eurostatu.

W PPP oszacowanie ryzyka i przypisanie odpowiedniej stronie umowy ma na celu ${ }^{71}$ :

- zmniejszenie kosztów projektu w dłuższym okresie poprzez przeniesienie ryzyka na tę stronę, która ma lepsze predyspozycje do zarządzania nim,

- dostarczenie zachęt dla wykonawcy, aby zrealizował inwestycję w czasie, zgodnie z wymaganymi normami i w ramach uzgodnionego budżetu,

- poprawę jakości usług oraz zwiększenie dochodu poprzez bardziej efektywne działanie,

- zapewnienie spójnego i przewidywalnego profilu wydatków.

Ryzyko stanowi element przedsięwzięcia i powinno podlegać procesowi zarządzania, tak jak każdy inny element procesu inwestycyjnego.

${ }^{68}$ Rozporzadzenie Ministra Finansów z 3 lutego 2010 r. w sprawie sprawozdawczości budżetowej..., poz. 103.

${ }^{69}$ Rozporzadzenie Ministra Finansów z dnia 4 marca 2010 r.w sprawie sprawozdań jednostek..., poz. 247

${ }^{70}$ Rozporzadzenie Ministra Finansów z 28 grudnia 2011 r. w sprawie szczegótowego sposobu klasyfikacji tytułów dlużnych..., poz. 1767.

${ }^{71}$ Por. M. Wawrzyniak, A. Jędrzejewski, Raport IPPP, Instytut Partnerstwa PublicznoPrywatnego, www.ippp.pl (10.12.2011). 


\section{Zarządzanie ryzykiem w przedsięwzięciach partnerstwa publiczno-pry- watnego}

Zarządzanie ryzykiem to podejmowanie decyzji i realizacja działań prowadzących do osiągnięcia akceptowalnego poziomu ryzyka ${ }^{72}$.

W naukach o zarządzaniu termin ,zarządzanie ryzykiem” jest definiowane jako systematyczne obchodzenie się ze zidentyfikowanymi możliwościami wystąpienia ryzyka straty ${ }^{73}$.

Zarządzanie ryzykiem jest naukowym podejściem do obchodzenia się z rodzajami ryzyka poprzez odgadywanie i uprzedzanie możliwych, przypadkowych strat i poprzez projektowanie i wprowadzanie działań (procedur) minimalizujących ryzyko lub rekompensujących straty finansowe w przypadku ich pojawienia $\operatorname{się}^{74}$.

Zarządzanie jest więc procesem polegającym na „pracowaniu” z różnymi rodzajami ryzyka, które pojawiają się $\mathrm{w}$ trakcie realizacji inwestycji i mogą przyczyniać się do powstania strat, najczęściej o charakterze finansowym. Zarządzanie ryzykiem nie jest jednorazowym zjawiskiem, ale ciągłym procesem podlegającym zarządzaniu przez cały okres życia przedsięwzięcia.

$\mathrm{Na}$ zarządzanie ryzykiem składają się z określone czynności (etapy) następujące po sobie w określonym czasie i determinujące się wzajemnie. Ostatecznie zamykają się tworząc tzw. pętlę ryzyka (schemat 4.5 ). W ramach tego procesu wyodrębnia się cztery etapy ${ }^{75}$ :

1) identyfikację ryzyka,

2) analizę i pomiar ryzyka,

3) alokację ryzyka,

4) monitoring i kontrolę ryzyka.

Pierwszym etapem zarządzania ryzykiem jest identyfikacja ryzyka, która polega na wskazaniu i nazwaniu zjawisk, mogących mieć niepożądany wpływ na przebieg inwestycji oraz na określenie prawdopodobieństwa wystąpienia danego czynnika. Proces zdefiniowania i podziału ryzyk jest zagadnieniem szczególnie trudnym i przypisuje się mu kluczowe znaczenie na etapie uruchomienia procedury negocjacji i zawarcia umowy PPP. Należy dążyć do wyróż-

${ }_{72}^{72}$ Zarzadzanie ryzykiem, red. K. Jajuga, Wydawnictwo Naukowe PWN, Warszawa 2009, s. 15.

${ }^{73}$ G. Rejda, Principles of Risk Management and Insurance, New York 1995; cyt. za W. Ronka-Chmielowiec, Wykorzystanie ubezpieczeń do zarządzania ryzykiem $w$ przedsiębiorstwie, [w:] Zarządzanie ryzykiem działalności organizacji, red. J. Monkiewicz, L. Gąsiorkiewicz, Wydawnictwo C.H. Beck, Warszawa 2010, s. 52.

${ }^{74}$ E. J. Vaughan, Risk Manegament, New York 1997.

${ }^{75}$ Wyodrębnienie etapów zarządzania ryzykiem dokonano na podstawie K. Brzozowska, Partnerstwo publiczno-prywatne. Przestanki, możliwości, bariery, Wydawnictwa Fachowe CeDeWu, Warszawa 2006, s. 67-71; Przewodnik po PPP..., s. 17; Zarzadzanie ryzykiem $w$ sektorze publicznym. Podręcznik wdrażania systemu zarządzania ryzykiem $w$ administracji publicznej w Polsce, Ministerstwo Finansów, Warszawa 2004. 
nienia wszystkich możliwych do zaistnienia $\mathrm{w}$ trakcie realizacji inwestycji niebezpiecznych zdarzeń. Wiele przedsięwzięć przygotowywanych do realizacji w formule partnerstwa może okazać się nowymi, nieznanymi, wręcz unikatowymi, co powoduje utrudnienia $\mathrm{w}$ ich zidentyfikowaniu. W takim przypadku należy wykorzystać wiedzę i doświadczenie ekspertów (doradców) oraz podmiotów prywatnych, które realizowały podobne przedsięwzięcia. Umożliwia to lepszą identyfikację i zarządzanie ryzykiem.

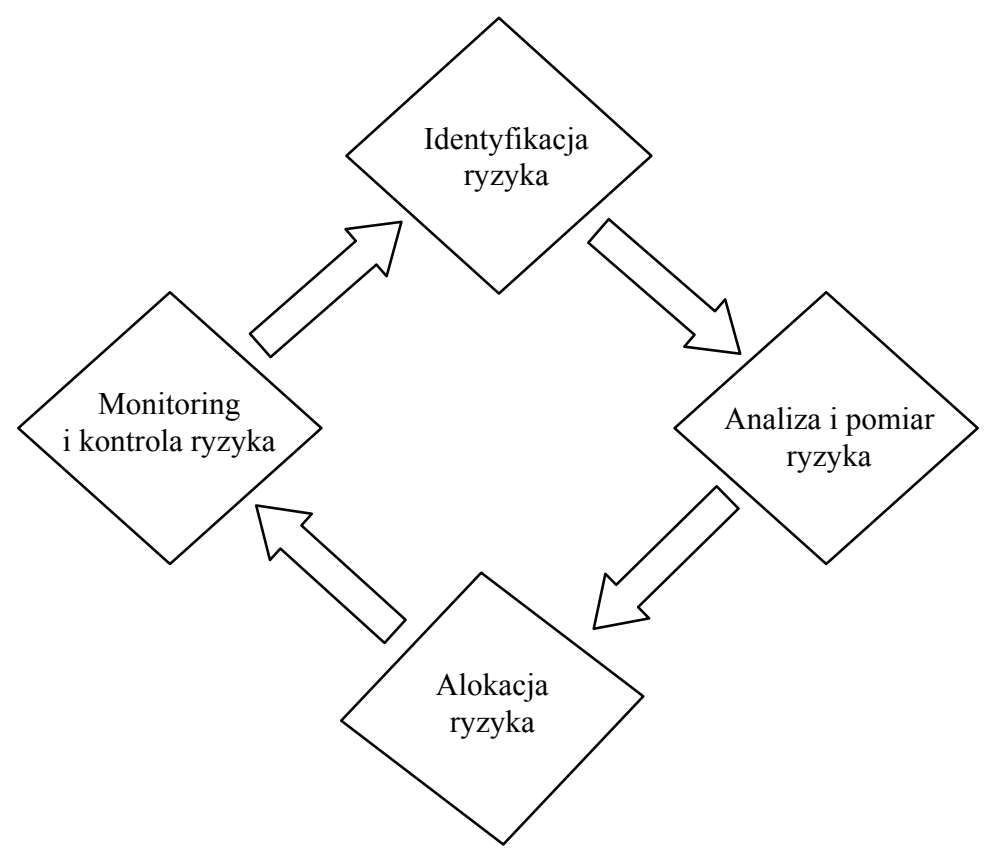

Schemat 4.5. Pętla ryzyka

Źródło: oprac. własne na podstawie Przewodnika po PPP, Europejski Bank Inwestycyjny, Europejskie Centrum Ekspertyz PPP, Luksemburg, www.eib.org/epec, s. 17 (20.09.2011)

Dominuje opinia, że w większości przypadków mogą wystąpić wszystkie rozpoznane ryzyka, przy czym $\mathrm{w}$ konkretnym przedsięwzięciu jedna $\mathrm{z}$ grup może mieć przewagę nad pozostałymi ${ }^{76}$. Konieczne staje się znalezienie wspólnego przelicznika dla wszystkich skutków, jakie mogą się pojawić w efekcie powstania ryzyka. Najlepszym, a zarazem uniwersalnym przelicznikiem wydaje się przyjęcie określonej wartości pieniężnej jako sposobu porównania efektów zdarzeń. Ryzyko po zidentyfikowaniu jego źródeł przestaje być nieznanym zagrożeniem, a staje się problemem, który powinien zostać rozwią-

${ }^{76}$ K. Brzozowska, Partnerstwo publiczno-prywatne..., s. 62. 
zany. Identyfikacja ryzyk jest procesem iteracyjnym, przeprowadzanym na każdym etapie realizacji przedsięwzięcia. Identyfikację ryzyk należy rozpocząć od sporządzenia planu zarządzania ryzykiem, bazującego na zbiorze danych historycznych dotyczących napotykanych trudności i sposobów ich rozwiązywania przy podobnych przedsięwzięciach oraz procesach kategoryzacji ryzyk.

W wyniku procesu identyfikacji ryzyk powinna powstać lista zidentyfikowanych ryzyk związanych z przedsięwzięciem oraz dane wyjściowe dla pozostałych procesów (etapów) przedsięwzięcia. Prawidłowo zbudowana lista ryzyk ma tworzyć kompleksowy rejestr ryzyk, który będzie miał szczególne znaczenie przy $^{77}$ :

- alokacji poszczególnych rodzajów ryzyk pomiędzy partnera publicznego i prywatnego,

- procesie optymalizacji PPP poprzez optymalizację poszczególnych kategorii i poziomu ryzyk przedsięwzięcia,

- negocjacjach z uczestnikami przedsięwzięcia (instytucjami finansowymi, podwykonawcami, dostawcami itp.).

Kolejnym etapem zarządzania ryzykiem jest ocena (pomiar) zidentyfikowanych ryzyk. Pomiar ten polega na nadaniu poszczególnym rodzajom ryzyka cech mierzalnych i ustaleniu siły oddziaływania na przedsięwzięcie inwestycyjne. Ryzyka poddaje się filtracji w procesie analizy, w celu ustalenia, które $\mathrm{z}$ nich mogą zostać zaakceptowane ze względu na niskie prawdopodobieństwo ich wystąpienia i potencjalne niskie zagrożenie dla wykonania przedsięwzięcia. Dokładne oszacowanie prawdopodobieństwa stanowi główne, a zarazem stałe źródło problemów. Analiza ryzyka jako procesu musi zawierać cechy, które umożliwią należytą percepcję ryzyka do konkretnego zadania. W tym celu można wykorzystać:

- własne doświadczenie, które gwarantuje uzyskanie realistycznej oceny,

- grupę delficką ${ }^{78}$, która powoła zespół do oceny ryzyka,

- dokumentację z zapisami na temat podobnych przedsięwzięć realizowanych w przeszłości,

${ }^{77}$ Metodologia tworzenia analiz ryzyka w projektach PPP..., s. 17.

${ }^{78}$ Mianem „grupa delficka” określa się to grupę ekspertów zewnętrznych, których celem jest wydanie opinii na temat specjalistycznego rodzaju ryzyka, np. związanego z ubezpieczeniem morskim. Inwestor oczekuje subiektywnej oceny ryzyka, którego rodzaje wyliczone są w określonym porządku. Zakłada się, że osobiste uprzedzenia jednych ekspertów zostaną zniwelowane przez opinie innych z tej samej grupy. Odpowiedzi mogą być zebrane w formie tabelarycznej, ujmującej np. rozkład potencjalnych kosztów lub harmonogram. Działania grupy winny pokazać, czy rozkład prawdopodobieństwa przechyla się w stronę prawą czy lewą, tzn. czy szacunkowe prognozy wskazują większe ryzyko niepowodzenia (w najgorszej sytuacji koszty inwestycji wzrosną lub nie zostaną dotrzymane terminy ujęte w harmonogramie). Por. Y. Y. Chong, E. M. Brown, Zarządzanie ryzykiem projektu, Dom Wydawniczy ABC, Kraków 2001, s. 62-63; The Delhi Metod: Techniques and Applications, eds H. A. Linstrone, M. Juroff, Addison-Wesley 2002. 
- heurystykę: zestaw zasad, które mogłyby być zastosowane przy danym przedsięwzięciu,

- symulację - ocenę rezultatów występujących w warunkach rzeczywistych lub zbliżonych do rzeczywistych,

- zestaw narzędzi do analizy ryzyka, który może zawierać wszystkie wymienione wyżej techniki (odpowiednio skonstruowany program komputerowy) ${ }^{79}$.

Komisja Europejska dodatkowo zwraca uwagę na konieczność posługiwania się wstępną, jakościową oceną ryzyka, która powinna być przeprowadzona w dwóch etapach:

- oszacowania potencjalnego wpływu ryzyka - to subiektywna miara wrażliwości (podatności) danego przedsięwzięcia na określone ryzyko, sklasyfikowane pod kątem skali wpływu na całe przedsięwzięcie jako wysokie, średnie lub niskie,

- oszacowanie prawdopodobieństwa wystąpienia ryzyka - polega na subiektywnym wskazaniu stopnia (wysokie, średnie, niskie) prawdopodobieństwa wystąpienia określonego ryzyka.

\begin{tabular}{ll|l|l|}
\cline { 2 - 3 } $\begin{array}{l}\text { ekonomiczna } \\
\text { Szkoda, jeżeli } \\
\text { zachodzi zdarzenie }\end{array}$ & suźa & duże \\
\cline { 3 - 4 } & mata & średnie & duze \\
& prawdopodobieństwo zachodzenia zdarzenia
\end{tabular}

Schemat 4.6. Oszacowanie ryzyka w partnerstwie publiczno-prywatnym na podstawie podejścia jakościowego

Źródło: M. Moszoro, Partnerstwo publiczno-prywatne w monopolach naturalnych $w$ sferze użyteczności publicznej, Wydawnictwo Szkoły Głównej Handlowej w Warszawie, Warszawa 2005, s. 59

W analizie uwzględnia się dwie zmienne - prawdopodobieństwo wystąpienia ryzyka i jego skutek. Prawdopodobieństwo i wpływ każdego z ryzyk można połączyć w jedną matrycę przedstawiającą miarę wartości jakościowej każdego ryzyka $^{80}$. Jeśli oba czynniki są duże to poziom ryzyka uważa się za wysoki.

${ }^{79}$ Por. Y. Y. Chong, E. M. Brown, Zarzadzanie ryzykiem projektu..., s. 61.

${ }^{80}$ B. Korbus, M. Strawiński, Partnerstwo publiczno-prywatne. Nowa forma realizacji zadań publicznych, Wydawnictwo Prawnicze LexisNexis, Warszawa 2006, s. 173. M. Kozera w odniesie- 
Analogicznie w sytuacji, gdy oba czynniki są małe, ryzyko uznaje się za małe. Wobec tak przyjętego schematu ryzyko występujące w pozostałych polach traktuje się jako średnie (schemat 4.6).

Te dwa wymiary wspólnie wskazują wagę ryzyka i umożliwiają stworzenie rankingu ryzyk, gdzie za mniej istotne uważa się te, których prawdopodobieństwo wystąpienia, jak i skutki z nimi związane są małe, najważniejsze są zaś te, gdzie prawdopodobieństwo i skutki są wysokie. Na czele rankingu znajdą się te drugie $\mathrm{i}$ to na nich koncentruje się zarządzanie ${ }^{81}$. Takie rozumowanie wydaje się proste. W praktyce uporządkowanie ryzyka nie jest jednak zadaniem prostym i obiektywnym, ponieważ każda ze stron w inny sposób może klasyfikować dane ryzyko. Jednocześnie podmiot publiczny pewne grupy ryzyka może pomijać w swoich założeniach, dla podmiotu prywatnego ta sama grupa ryzyk będzie zaś miała istotną wagę i znaczenie z punktu widzenia np. wysokości kosztów przedsięwzięcia, a tym samym będzie wyznaczała całkowity poziom kosztu ryzyka.

Prawidłowa analiza ryzyk w PPP powinna obejmować swoim zakresem ${ }^{82}$ :

- wstępną identyfikację rodzajów ryzyk związanych z inwestycją w podziale na istotne i nieistotne;

- wstępną ocenę i prognozę prawdopodobieństwa wystąpienia ryzyk w rekomendowanych wariantach realizacji przedsięwzięcia;

- wstępną projekcję rozkładu ryzyk pomiędzy strony w zależności od przyjętego modelu realizacji przedsięwzięcia;

- analizę kosztów i sposobów minimalizacji poszczególnych kategorii ryzyk;

- analizę wpływu zidentyfikowanych ryzyk na poziom długu publicznego.

Partner prywatny jest tą stroną, która zwykle ma wyższe kompetencje do zarządzania ryzykiem w przedsięwzięciach inwestycyjnych. Ryzyko wystąpienia w czasie trwania inwestycji różnych problemów podraża koszty przedsięwzięcia. Jeśli każda ze stron dołoży wszelkiej staranności, aby te koszty zminimalizować, a będzie zainteresowana tym ze względu na poziom przyszłych zysków, to wówczas koszty całego przedsięwzięcia zmaleją. Poziom wynagrodzenia poszczególnych partnerów powinien być uzależniony od zakresu ryzyk, jakie poszczególni partnerzy przyjęli w zarząd. Podstawą działania prywatnego inwestora będzie zawsze dążenie do zrównoważenia ryzyka perspektywą potencjalnego zysku oraz zminimalizowanie zagrożeń podjętego przedsięwzię-

niu do poziomu ryzyka stosuje określenia: normalny, dopuszczalny i niedopuszczalny, zob. M. Kozera, Organizowanie i funkcjonowanie partnerstw, [w:] Strategie zarzadzania wspótpraca, red. J. Hadyński, Akademia Rolnicza im. A. Cieszkowskiego w Poznaniu, Poznań 2006, s. 108.

${ }^{81}$ Por. A. Kopańska, A. Bartczak, J. Siwińska-Gorzelak, Partnerstwo publiczno-prywatne. Podmioty prywatne $w$ realizacji zadań publicznych sektora wodno-kanalizacyjnego, Wydawnictwo Fachowe CeDeWu, Warszawa 2008, s. 54-56.

${ }^{82}$ Por. M. Wawrzyniak, A. Jędrzejewski, Raport IPPP... 
cia w warunkach gospodarczych panujących w okresie objętym umową ${ }^{83}$. Ostrożność przy szacowaniu ryzyka jest więc szczególnie wskazana. Stąd ważna rola przypada metodom służącym do oszacowania poziomu i prawdopodobieństwa wystąpienia danego ryzyka. Dobór technik uzależniony jest od rodzaju i wielkości inwestycji, dostępności danych, możliwości czasowych oraz doświadczenia i wiedzy analityków (doradców).

Do oceny ryzyka wykorzystuje się metody jakościowe (opisowe) i/lub metody ilościowe. Przy badaniu zjawisk, którym nie można przypisać wielkości mierzalnych, zastosowanie mają oceny opisowe, wszędzie zaś tam, gdzie możliwe jest nadanie konkretnych wielkości wykorzystuje się metody ilościowe $^{84}$. K. Jajuga wyróżnia ${ }^{85}$ dwie ogólne koncepcje ilościowego (statystycznego) ujęcia ryzyka. W pierwszej koncepcji ryzyko utożsamiane jest ze zmiennością dochodu/ceny, w drugiej z wrażliwością dochodu/ceny. Wzrost wartości zmiennych prowadzi do wzrostu ryzyka. Zdaniem wspomnianego autora koncepcja ryzyka-wrażliwości jest bardziej przydatna, gdy podstawowym celem analizy jest zapobieganie ryzyku.

W opinii G. Witoszka „oceniając inwestycję jako ryzykowną koryguje się stopę procentową o tzw. premię ryzyka lub wykorzystuje rachunek prawdopodobieństwa przy szacowaniu przewidywanych przepływów pieniężnych"86.

Wśród najczęściej stosowanych metod oceny ryzyka znajdują się:

- metody korygowania efektywności przedsięwzięć inwestycyjnych,

- metody symulacyjne i analiza wrażliwości,

- metody badań operacyjnych,

- metody probalistyczno-statystyczne,

- metody osądu ekspertów.

Metody korygowania efektywności przedsięwzięć inwestycyjnych wykorzystywane są wówczas, gdy można jednoznacznie wskazać, które parametry rachunku są stałe (pewne), a które są obciążone ryzykiem (niepewnością). Korekcie podlegają te parametry, które są niepewne, np. stopa procentowa, stopa zysku, okres zwrotu nakładów kapitałowych. Korekta polega na zmianie wcześniej przyjętych parametrów poprzez ich zwiększenie lub zmniejszenie. Do tej grupy metod zalicza się: korektę stopy dyskontowej, równoważnik pewności,

${ }^{83}$ Por. H. Sochacka-Krysiak, Partnerstwo publiczno-prywatne - szansa czy konieczność?, [w:] Realizacja zadań publicznych przez jednostki samorzadu terytorialnego we wspótpracy $z$ sektorem prywatnym, red. E. Kornberger-Sokołowska, Uniwersytet Warszawski, Centrum Studiów Samorządu Terytorialnego i Rozwoju Lokalnego, Warszawa 2008, s. 16.

${ }^{84}$ Por. K. Marcinek, Ryzyko projektów inwestycyjnych, Wydawnictwo Akademii Ekonomicznej w Katowicach, Katowice 2001, s. 126-127.

${ }^{85} \mathrm{~K}$. Jajuga, Ryzyko w finansach. Ujęcie statystyczne, Instytut Cybernetyki Ekonomicznej, Akademia Ekonomiczna im. O. Langego we Wrocławiu, Wrocław 1996, s. 6.

${ }^{86}$ G. Witoszek, Techniki oceny ryzyka $w$ podejmowaniu przedsięwzięć inwestycyjnych, „Przegląd Organizacji” 2001, nr 3, s. 23. 
model wyceny aktywów kapitałowych CAMP (Capital Asset Pricing Model). Każda z tych metod ma słabości, które ograniczają ich wykorzystanie w praktyce, gdyż można je zastosować tylko we wstępnej fazie oceny (korekta stopy dyskontowej) lub do przygotowania dokładnej oceny liczbowej ryzyka (model CAMP) ${ }^{87}$.

Metody symulacyjne polegają na konstruowaniu modeli ekonometrycznych, które w sposób matematyczny opisują strukturę i funkcjonowanie badanego zjawiska, a następnie za pomocą modeli odtwarza się kolejne stany analizowanego obszaru w celu określenia np. jego efektywności czy prawidłowego przebiegu. Metody te stosuje się z powodzeniem w analizie finansowej przedsięwzięć inwestycyjnych obciążonych dużą niepewnością. Niezbędne jest wówczas szacowanie prawdopodobieństwa osiągnięcia określonego poziomu efektywności finansowej przedsięwzięcia. Modele symulacyjne umożliwiają analizę kilku zmiennych niepewnych jednocześnie wskazując na związki zachodzące między nimi. Pozwala to spojrzeć na problem ryzyka jako całości ${ }^{88}$.

E. Ostrowska ${ }^{89}$ i K. Jajuga ${ }^{90}$ metody symulacyjne określają zamiennie metodą Monte Carlo lub symulacją komputerową. K. Marcinek ${ }^{91}$, S. Nahotko ${ }^{92}$ metodę Monte Carlo traktują jako odrębną wśród metod symulacyjnych. W procesie symulacji stosuje się metody teorii gier, która przedstawia odmienne postawy uczestników gry w symulowanym środowisku lub proces powtarzalnego eksperymentowania. Proces ten może opierać się na deterministycznych lub probabilistycznych modelach symulacyjnych ${ }^{93}$.

Metody te mają szereg zalet związanych $\mathrm{z}$ łatwym dostępem do informacji niezbędnych do obliczeń, nie wymagają stosowania skomplikowanych wzorów,

${ }^{87}$ Szerzej: E. Ostrowska, Ryzyko projektów inwestycyjnych, PWE, Warszawa 2002, s. 103107; E. Dobrzelecka, Analiza ryzyka inwestycyjnego, „Wiadomości Statystyczne” 1995, nr 9, s. 10-12; R. Gumińska, Analiza współczynnika beta z uwzględnieniem ryzyka projektów inwestycyjnych, [w:] Finanse, ryzyko i ekologia w procesach inwestycyjnych, red. H. Henzel, Wyd. Śląsk, Katowice 1999, s. 211-220.

${ }^{88}$ Zob. K. Marcinek, Finansowa ocena przedsięwzięć inwestycyjnych przedsiębiorstw, Akademii Ekonomiczna im. K. Adamieckiego, Katowice 1998, s. 130-132.

${ }^{89}$ E. Ostrowska, Ryzyko projektów inwestycyjnych ..., s. 194.

${ }^{90} \mathrm{~K}$. Jajuga, Podejmowanie decyzji inwestycyjnych $w$ warunkach ryzyka, [w:] Budżetowanie kapitatów, red. W. Pluta, PWE, Warszawa 2000, s. 167.

${ }^{91} \mathrm{~K}$. Marcinek, Ryzyko projektów inwestycyjnych..., s. 145.

92 S. Nahotko, Ryzyko ekonomiczne $w$ działalności gospodarczej, Oficyna Wydawnicza Ośrodka Postępu Organizacyjnego Sp. z o.o., Bydgoszcz 2001, s. 126.

${ }^{93} \mathrm{~W}$ deterministycznym modelu symulacyjnym zmiennym przypisuje się określone wartości w celu uzyskania odpowiedzi na pytanie „co będzie jeśli”. Zmienne w modelach probabilistycznych wyrażone są za pomocą konkretnych liczb, traktowanych jako stałe, pewne. W przypadku braku możliwości zastosowania stałych wielkości, to zmienne wyraża się za pomocą rozkładów prawdopodobieństwa. Zmienne przyjmują wówczas charakter zmiennych losowych, pozostających poza kontrolą inwestora. Zob. więcej K. Marcinek, Ryzyko projektów inwestycyjnych ..., s. 145. 
umożliwiają określenie obszaru dopuszczalnych wartości wskaźnika efektywności i prawdopodobieństwo jego wystąpienia, wyniki są porównywalne z wynikami innych metod i mogą być stosowane w sytuacji braku możliwości zastosowania innych $\operatorname{metod}^{94}$.

Analiza wrażliwości ma na celu określenie krytycznego momentu, do którego można dokonywać zmian w założeniach projektu bez ryzyka ich wpływu na efektywność mierzoną np. NPV. W badaniu można uwzględnić zmianę jednego czynnika przy pozostałych będących stałymi lub równoczesną zmianę kilku czynników. Eliminacja czynników zagrażających przedsięwzięciu pozwala na stworzenie optymalnych warunków, w jakich powinno być ono realizowane. Metoda pozwala na ustalenie poziomu granicznego czynników ryzyka i marginesu bezpieczeństwa inwestycji ${ }^{95}$.

Metody badań operacyjnych polegają na analizie wybranego

wycinka rzeczywistości oraz ilościowej ocenie rezultatów podjętych decyzji. Metody stosowane są w sytuacji, gdy osiągnięcie celu wymaga skoordynowania wielu czynników przy optymalnym ich układzie, prowadzących do podjęcia optymalnej decyzji ${ }^{96}$.

W ramach tych metod najczęściej stosuje się strategię gier, metodę PERT (Program Evoluation and Review Technigue) oraz metodę GERT (Graphical Evaluation and Review Technigue).

Strategię gier wykorzystuje się w warunkach krańcowo niekorzystnych dla inwestycji. Zidentyfikowanie czynników ryzyka zagrażających inwestycji umożliwia opracowanie pesymistycznych scenariuszy. To z kolei pozwala na wybranie wariantu inwestycji najkorzystniejszego spośród najbardziej niekorzystnych (oparty na pesymistycznej zasadzie A. Walda) lub wariantu, w ramach którego maksymalne możliwe rozczarowanie jest najmniejsze (zasada rozczarowania L. Savage'a) $)^{97}$.

Metoda PERT polega na graficznym wytyczeniu najkrótszej ścieżki pozwalającej na przejście od momentu rozpoczęcia inwestycji do jej zakończenia. Zaliczana jest do metod sieci o strukturze logicznej zdeterminowanej.

${ }^{94}$ Por. A. Korombel, Ryzyko w finansowaniu działalności inwestycyjnej metoda Project finance, Difin, Warszawa 2007, s. 97-98.

${ }^{95}$ Szerzej: S. Nahotko, Ryzyko ekonomiczne w działalności gospodarczej..., s. 119; M. Sierpińska, T. Jachna, Ocena przedsiębiorstwa wedlug standardów światowych, Wydawnictwo Naukowe PWN, Warszawa 1994, s. 206-207. E. Ostrowska analizę wrażliwości określa mianem rachunku wrażliwości (E. Ostrowska, Ryzyko projektów inwestycyjnych..., s. 95), Metodologia tworzenia analiz ryzyk $w$ projektach PPP $i$ ich podzialu pomiędzy strona publiczna i prywatna $w$ kontekście ich wpływu na klasyfikacje projektu pod katem dlugu i deficytu sektora publicznego, Platforma Partnerstwa Publiczno-Prywatnego, www.ppp.gov.pl (20.09.2012).

${ }^{96}$ E. Ostrowska, Pomiar ryzyka w rzeczowych inwestycjach przedsiębiorstw, „Przegląd Organizacji” 1997, nr 4, s. 36-37.

${ }^{97}$ E. Ostrowska, Pomiar ryzyka w rzeczowych inwestycjach ..., s. 211. 
W metodzie GERT istotne znaczenie ma wykorzystanie rozbudowanych programów komputerowych pozwalających na określenie prawdopodobieństwa i czasu wystąpienia określonych zdarzeń na podstawie sieci odwzorowujących badaną rzeczywistość.

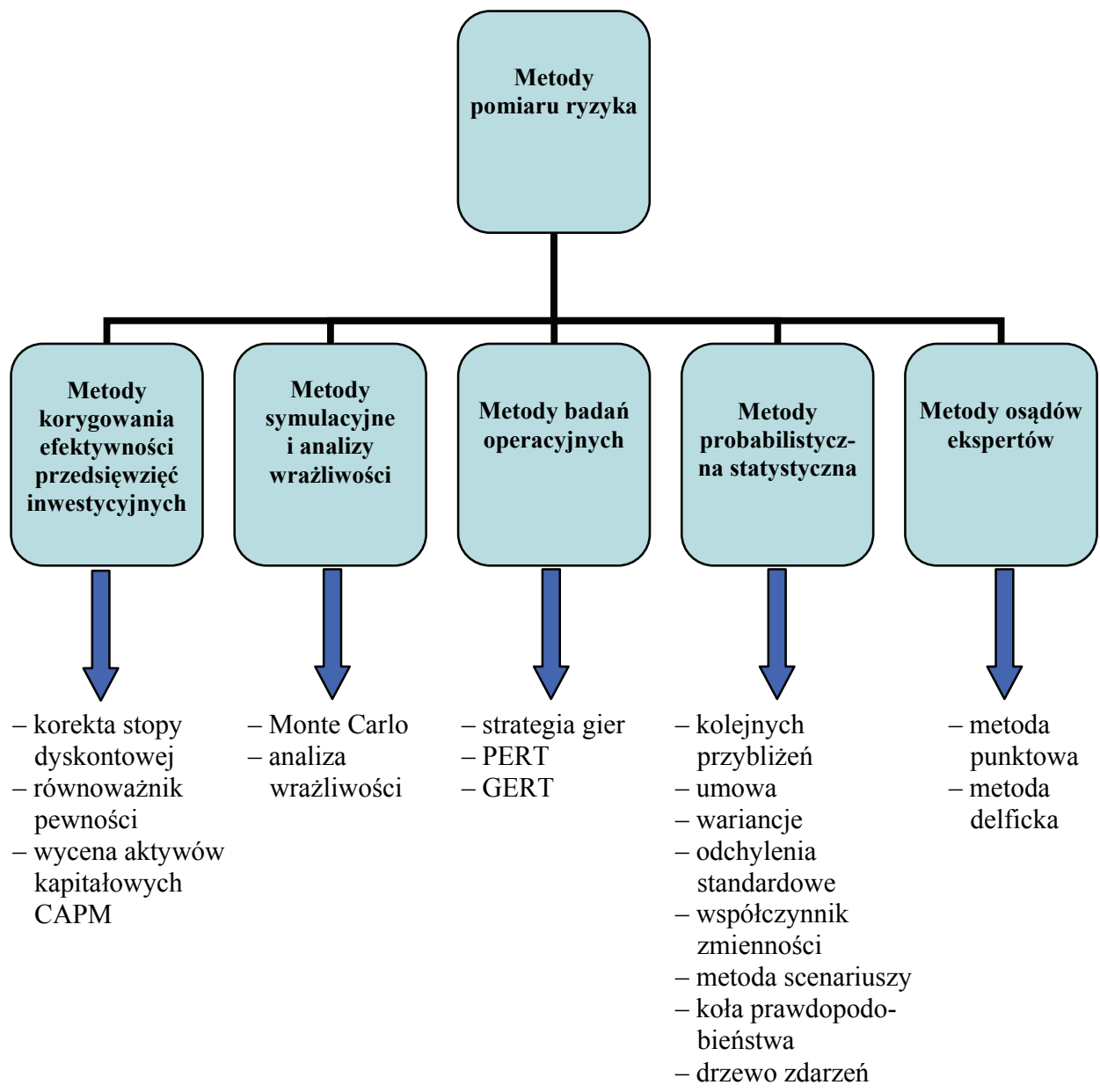

Schemat 4.7. Metody pomiaru ryzyka

Źródło: oprac. własne

Metody probabilistyczno-statystyczne mają na celu ustalenie rozmiarów ryzyka i prawdopodobieństwa jego wystąpienia. W metodach tych wykorzystuje się informacje historyczne oraz bazy danych. W przypadku ich braku lub ograniczonej liczby podstawę do analizy stanowią opinie ekspertów, a także własne oceny. W ramach tej grupy metod ryzyko przedsięwzięcia można ocenić 
za pomocą szeregu metod. Do najczęściej wymienianych zalicza się metody: kolejnych przybliżeń, koła prawdopodobieństwa, urnową, drzewa zdarzeń, drzewa decyzyjnego, wariancje, odchylenie standardowe i współczynnik zmienności oraz metodę scenariuszy. Metody te mają na celu określenie prawdopodobieństwa niewystąpienia określonych zdarzeń lub rzadkiego ich wystąpienia. Są metodami prostymi, niewymagającymi wykonywania skomplikowanych obliczeń $^{98}$.

Metody osądów ekspertów mają charakter uzupełniający w stosunku do innych metod i stosuje się je zarówno na etapie identyfikacji ryzyk, jak i również w trakcie oceny ryzyka. W tej grupie najczęściej stosuje się dwie metody punktową i delficką. Pierwsza polega na przydzieleniu wartości punktowych dla przedziałów wartościowych wskaźników finansowych. Metoda ta charakteryzuje się prostotą, co powoduje że osiągnięte wyniki obarczone są dużym przybliżeniem. Metoda delficka bazuje zaś na opiniach grupy ekspertów, którzy analizując przedsięwzięcie wskazują na grupy źródeł ryzyka i prawdopodobieństwo ich wystąpienia. Podstawowym narzędziem jest tu matryca ryzyk ${ }^{99}$.

Przy przedsięwzięciach PPP analizy jakościowej dokonuje się zazwyczaj za pomocą matrycy ryzyka lub kalkulatora ryzyka.

Matryca ryzyk polega na dokonaniu badania due diligence ${ }^{100}$ (należytej staranności) w zakresie charakteru ryzyka i jego skutków, właściwej alokacji w ramach kontraktu, określeniu form zabezpieczenia ryzyka przed finansowo-technicznymi konsekwencjami. W matrycy wymienia się zdefiniowane w poszczególnych fazach przedsięwzięcia ryzyka, a następnie dokonuje się opisu czynników, które mogą powodować powstanie danego ryzyka. Później ustala się, kto będzie odpowiadał za dane ryzyko. Jeśli ryzyko zostanie przeniesione na partnera prywatnego (spółkę lub podwykonawców), to należy dopilnować, aby poszczególne ryzyka zostały prawidłowo zdefiniowane i zapisane w umowie partnerstwa i wumowach $\mathrm{z}$ poszczególnymi podwykonawcami. Ważne jest zachowanie zgodności treści i przyjętych rozstrzygnięć w kwestii ryzyka. Oznacza to, że w negocjacjach dotyczących rozpoznania ryzyk i ich podziału uczestniczyć mogą nie tylko podmioty bezpośrednio uczestniczące w procedurze

${ }^{98}$ Szerzej o metodach i ich zaletach w: A. Korombel, Ryzyko w finansowaniu działalności inwestycyjnej...; S. Heilpern, Podejmowanie decyzji w warunkach ryzyka i niepewności, Wydawnictwo Akademii Ekonomicznej im. O. Langego we Wrocławiu, Wrocław 2001; J. Kulty, Ryzyko, niepewność i konflikt $w$ działalności gospodarczej, Wydawnictwo Akademii Ekonomicznej w Krakowie, Kraków 1995; A. Malina, B. Pawełek, S. Wanat, A. Zeliaś, Statystyczne metody oceny ryzyka $w$ działalności gospodarczej, red. A. Zeliaś, Wydawnictwo Akademii Ekonomicznej w Krakowie, Kraków 1998.

${ }^{99}$ S. Nahotko, Ryzyko ekonomiczne w działalności gospodarczej..., s. 63-65.

${ }^{100}$ Badanie due diligence, czyli szczegółowa analiza kontraktów, polega na działaniach mających na celu rzetelne zgromadzenie maksymalnie wielu informacji o projekcie i dokonanie ich analizy. Szerzej: E. R. Yescombe, Partnerstwo publiczno-prywatne. Zasady wdrażania i finansowania, Oficyna a Wolters Kluwer business, Kraków 2008, s. 129. 
wyboru partnera, ale także inne podmioty, których udział w przedsięwzięciu jest planowany (instytucje finansujące, podwykonawcy).

Firmy doradczo-konsultingowe często do analizy ryzyka wykorzystują kalkulator ryzyka. Jest to narzędzie umożliwiające przeprowadzenie wstępnej analizy ryzyka, która nie zastępuje jednak analiz szczegółowych. Ryzyko szacowane $\mathrm{w}$ kalkulatorze zostało podzielone na cztery kategorie: ryzyko gospodarcze, ryzyko związane z budową, dostępnością i z popytem.

Proces szacowania ryzyka jest trudny co wynika z faktu, że analizie podlegają zdarzenia przyszłe, mogące mieć charakter jednostkowy, a nawet unikalny.

Stopień wykorzystania różnych metod oceny ryzyka zależy od kilku podstawowych kryteriów ich wyboru:

- dostępności informacji oraz ich przewidywanej zmienności w czasie,

- warunków inwestowania, w tym horyzontu czasowego inwestycji,

- znajomości metod oceny ryzyka przez inwestorów,

- wiedzy i doświadczenia w zakresie szacowania skali i prawdopodobieństwa zdarzeń mających wpływ na ryzyko inwestycyjne,

- skłonności inwestorów do zaakceptowania określonego ryzyka ${ }^{101}$,

- znaczenia ryzyka $\mathrm{i}$ jego skutków z punktu widzenia powodzenia przedsięwzięcia.

Zaprezentowane metody i techniki zarządzania ryzykiem można z powodzeniem stosować $\mathrm{w}$ praktyce przy większości przedsięwzięć inwestycyjnych. Należy jednak pamiętać, że część z nich można $\mathrm{z}$ większym powodzeniem stosować we wstępnych fazach procesu, a inne w późniejszych. Wynika to z zawartości informacyjnej poszczególnych metod. Kluczem wyboru metody powinna być przydatność metody i pożąany typ informacji.

Problematyka kategoryzacji i alokacji ryzyk stanowi trzon współpracy w formule partnerstwa publiczno-prywatnego. Rozkład ryzyka pomiędzy partnerów zależy od ostatecznego kształtu umowy, która zostanie zawarta pomiędzy stronami. W niej zostaną określone ryzyka, jakie mogą pojawić się w trakcie wykonywania zadania oraz odpowiedzialność za nie przypadająca na poszczególne strony.

Kluczowym elementem definiującym partnerstwo publiczno-prywatne jest identyfikacja i alokacja ryzyka oraz analiza prawdopodobieństwa jego wystąpienia. Źródło atrakcyjności i efektywności partnerstwa oraz jego przewaga nad rozwiązaniami tradycyjnymi tkwi właśnie w podziale ryzyk pomiędzy strony umowy.

Alokacja oznacza przydział praw do zarządzania różnymi kategoriami ryzyka i podział obowiązków, obciążeń związanych z odpowiedzialnością za przydzielone prawa. Przewidywalność i możliwość prawidłowego skalkulowa-

${ }^{101}$ M. T. Wilczek, Wybrane zagadnienia podejmowania decyzji w przedsiębiorstwie, Wyższa Szkoła Zarządzania Marketingowego i Języków Obcych w Katowicach, Katowice 2000, s. 60-61. 
nia ryzyka jest dla partnera prywatnego podstawowym czynnikiem wpływającym na podjęcie decyzji o zaangażowaniu się $\mathrm{w}$ partnerstwo publicznoprywatne. Powodzenie każdego przedsięwzięcia będzie uzależnione od alokacji i zarządzania poszczególnymi kategoriami ryzyka. Kryterium alokacji czynników ryzyka powinno uwzględniać kompetencje i umiejętności stron partnerstwa. Optymalny podział ryzyka nie jest tożsamy z jego całkowitym przeniesieniem na sektor prywatny bądź całkowitym ubezpieczeniem, gdyż może się tak zdarzyć, że podział pomiędzy strony lub zachowanie pewnych rodzajów ryzyka po jednej z nich może okazać się rozwiązaniem korzystniejszym. Wymuszenie na którejkolwiek stronie przyjęcia ryzyka, którego nie jest ona w stanie należycie kontrolować może doprowadzić do zachwiania równowagi niezbędnej do osiągnięcia oczekiwanych korzyści. Podział ryzyk powinien być dokonany według zasady - kto jest w stanie lepiej zarządzać danym ryzykiem ten je przejmuje w zarząd, co oznacza, że będzie w stanie go kontrolować przy jak najniższym koszcie. Można przyjąć, że jest to tożsame $\mathrm{z}$ sytuacją, w której strona ponosząca ryzyko ma wolną rękę w wyborze najlepszego dla siebie sposobu zarządzania ryzykiem ${ }^{102}$. Umiejętny podział ryzyk pomiędzy strony warunkuje sukces przedsięwzięcia realizowanego w formule PPP, jego efektywność, zdolność do generowania przychodów i zaspokojenia potrzeb społecznych. Zdaniem M. Moszoro ${ }^{103}$ celem podziału ryzyka jest jego optymalizacja, a nie maksymalizacja.

Podział ryzyka, jak wskazuje E. R. Yescombe, nie następuje poprzez procentowe rozłożenie czynnika na poszczególne strony umowy, tylko poprzez całkowite obciążenie jednej ze stron. To powoduje ograniczenie w liczbie sposobów jego przyporządkowania. W związku z tym ${ }^{104}$ :

- ryzyko może ponosić tylko sektor publiczny,

- ryzyko może być przeniesione na spółkę celową,

- ryzyko może być przeniesione na spółkę celową, a następnie przerzucone na strony trzecie poprzez:

- przeniesienie w całości na podwykonawców,

- ubezpieczenie,

- gwarantowanie przez sponsorów,

- w przypadku koncesji ryzyko może być przeniesione na użytkowników końcowych poprzez zezwolenie spółce celowej na swobodne regulowanie opłat za usługi.

Podstawowym celem transferu ryzyka jest zapewnienie, że podmiot prywatny zostanie odpowiednio zmotywowany do świadczenia usług objętych umową partnerstwa publiczno-prywatnego.

${ }^{102}$ Por. E. R. Yescombe, Partnerstwo publiczno-prywatne. Zasady..., s. 339.

${ }^{103}$ M. Moszoro, Partnerstwo publiczno-prywatne w monopolach ..., s. 98.

${ }^{104}$ Por. E. R Yescombe, Partnerstwo publiczno-prywatne. Zasady wdrażania i finansowania, Oficyna a Wolters Kluwer business, Kraków 2008, s. 339. 
Carl L. Pritchard uważa, że każde ryzyko ma swoje przyczyny, które powinny być przez zespół koordynujący zidentyfikowane w celu wyznaczenia metod reagowania na poszczególne czynniki ryzyka. Autor wyodrębnił cztery metody reagowania na ryzyko: unikanie ryzyka, transfer ryzyka, łagodzenie ryzyka oraz akceptację ryzyka. Unikanie i łagodzenie ryzyka polega na podejmowaniu takich działań i rozwiązań, np. projektowych, które pozwolą uniknąć ryzyka. Transfer ryzyka dotyczy działań zmierzających do przeniesienia kosztów oraz zarządzania przedsięwzięciem na podmioty trzecie. W przypadku akceptacji podmiot uznaje, że dane zdarzenie może zaistnieć i należy przyjąć konsekwencje tego zdarzenia. Taka postawa wymaga przygotowania planów reakcji na owo zdarzenie. C. L. Pritched wskazuje dodatkowo, że akceptacja ryzyka może mieć charakter aktywny lub pasywny, co wiąże się z przygotowaniem bądź świadomym odstąpieniem od przygotowania planu awaryjnego.

Podmiot prywatny zawsze będzie oczekiwał rekompensaty proporcjonalne do ponoszonego ryzyka. Im większa będzie jego odpowiedzialność i zaangażowanie w przedsięwzięcie, tym większe powinny być korzyści. Alokację podstawowych rodzajów ryzyk występujących w PPP zaprezentowano w tab. 4.6.

Tabela 4.6

Alokacja podstawowych rodzajów ryzyk w przedsięwzięciach PPP

\begin{tabular}{|l|c|c|c|}
\hline \multicolumn{1}{|c|}{ Rodzaj ryzyka } & Sektor publiczny & $\begin{array}{c}\text { Sektor } \\
\text { prywatny }\end{array}$ & Wspólnie \\
\hline Uzyskanie niezbędnych zezwoleń & $\checkmark$ & & \\
\hline Pozyskanie gruntów & $\checkmark$ & & \\
\hline $\begin{array}{c}\text { Ryzyko utrudnień w realizacji prac spowodo- } \\
\text { wanych koniecznością szczegółowego } \\
\text { spełnienia wymagań projektu technicznego }\end{array}$ & & $\checkmark$ & \\
\hline Ryzyko wzrostu kosztów budowy & & $\checkmark$ & \\
\hline Ryzyko związane z opóźnieniem prac & & $\checkmark$ & \\
\hline $\begin{array}{l}\text { Ryzyko utrudnień spowodowanych odkryciami } \\
\text { archeologicznymi }\end{array}$ & $\checkmark$ & $\checkmark$ & \\
\hline Ryzyko kosztów utrzymania & & $\checkmark$ & \\
\hline $\begin{array}{l}\text { Ryzyko utrudnień spowodowanych wadami } \\
\text { ukrytymi obiektu/ wyposażenia związanego } \\
\text { z przedsięwzięciem }\end{array}$ & & $\checkmark$ & \\
\hline $\begin{array}{l}\text { Ryzyko utrudnień spowodowanych siłami } \\
\text { wyższymi }\end{array}$ & & $\checkmark$ & \\
\hline Ryzyko wzrostu stóp procentowych & & & $\checkmark$ \\
\hline Ryzyko zmiany poziomu inflacji & & & \\
\hline $\begin{array}{l}\text { Ryzyko wystąpienia utrudnień z powodu } \\
\text { protestów społecznych }\end{array}$ & & & \\
\hline
\end{tabular}

Źródło: Partnerstwo publiczno-prywatne jako metoda rozwoju infrastruktury $w$ Polsce, Raport Amerykańskiej Izby Handlowej w Polsce, Warszawa, październik 2002, s. 17. 
Szacowanie ryzyka (prawdopodobieństwo jego wystąpienia, potencjalny wpływ na przedsięwzięcie, kwalifikacja, rozmieszczenie) stanowi element zarządzania PPP. Dylemat związany z ryzykiem polega na tym, że z jednej strony władze publiczne powinny starać się jak najwięcej odpowiedzialności za przedsięwzięcie przekazać sektorowi prywatnemu, z drugiej zaś strony powinny być świadome, że nie uwolnią się od niego całkowicie.

Świadoma alokacja ryzyka powinna prowadzić do ${ }^{105}$ :

1) zmniejszenia kosztów przedsięwzięcia $w$ długim okresie poprzez przeniesienie ryzyka na stronę, która najlepiej będzie nim zarządzać,

2) dostarczenia zachęt dla partnera prywatnego, aby realizował poszczególne etapy przedsięwzięcia zgodnie $\mathrm{z}$ harmonogramem, wymaganymi normami i w ramach ustalonego budżetu,

3) poprawy jakości usług i zwiększenia dochodu w wyniku efektywnego działania,

4) zapewnienia spójnego i przewidywalnego profilu wydatków.

Całkowite ryzyko związane z PPP podlega ewaluacji w trakcie jego życia. Najwyższy poziom ryzyk występuje w pierwszych fazach realizacji inwestycji (okres budowy), kiedy to nie są jeszcze generowane żadne przychody związane z realizacją zakontraktowanych świadczeń oraz kiedy ponoszone są jedynie nakłady. Poziom ryzyka rośnie do momentu wejścia inwestycji w fazę eksploatacji. Świadczenie usług zgodne z warunkami umowy będzie sprzyjać systematycznemu zmniejszaniu ryzyka.

Należy pamiętać, że każde przedsięwzięcie ma swoją specyfikę, która wymusza konieczność odrębnego traktowania i zarządzania, w tym także w obszarze ryzyka. Zarządzanie ryzykiem w PPP tym różni się od inwestycji realizowanych tradycyjnie przez JST, że w tym drugim przypadku całe ryzyko realizacji inwestycji zawsze spoczywa na stronie publicznej, przy partnerstwie niezbędny jest zaś kompromis i współpraca stron.

Sprawne zarządzanie ryzykiem odbywa się poprzez monitoring i kontrolę ryzyka. Proces monitoringu polega na stałym obserwowaniu przebiegu procesu inwestycyjnego i zachowaniu poszczególnych grup czynników ryzyka. Informacje dotyczące poszczególnych ryzyk powinny być na bieżąco przekazywane do komórki zarządzającej inwestycją (swoistego banku danych). W procesie informacyjnym uczestniczyć powinni poszczególni uczestnicy przedsięwzięcia, wykonawcy, instytucje i organizacje. Zaangażowanie wszystkich grup pozwala na szybkie uchwycenie nieprawidłowości i na ich eliminację. Szczególną uwagę zwraca się na monitoring aktywów i pasywów inwestora, czyli proces gromadzenia i wydatkowania środków pieniężnych w fazie przygotowania, realizacji i eksploatacji inwestycji. Monitoringowi podlegają zarówno wartości nominalne,

${ }^{105}$ Por. Wytyczne dotyczace udanego partnerstwa publiczno-prywatnego, Komisja Europejska, Dyrektoriat Generalny Polityka Regionalna, Bruksela 2003, s. 62. 
jak i realne środków pieniężnych. Monitoring ryzyka dotyczy także czynności związanych z obsługą kredytów, pożyczek oraz terminów i wysokości płatności wszelkich zobowiązań wynikających z realizacji inwestycji. Stanowi pierwotną formę analizy ryzyka i jego weryfikacji. Pozwala inwestorowi na szybką reakcję w momencie pojawienia się nieprawidłowości i odchyleń od przyjętych założeń.

Monitoring ryzyka ma na celu ustalenie, czy $^{106}$ :

- wdrożono, zgodnie z planem, strategie reakcji na ryzyka,

- działania podejmowane $\mathrm{w}$ ramach realizacji planów reakcji na ryzyko skutkują oczekiwanymi rezultatami,

- założenia przedsięwzięcia są aktualne,

- podczas realizacji przedsięwzięcia nie doszło do zmian w szczegółowym i ogólnym poziomie ryzyka,

- wystąpiły czynniki wyzwalające zidentyfikowane ryzyka,

- wystąpiły nowe ryzyka uprzednio nierozpoznane.

Materiałami wyjściowymi do procesu monitorowania ryzyka i kontroli są plan zarządzania ryzykiem, plan reakcji na ryzyko, raporty i analizy ryzyka. Do narzędzi i technik stosowanych do monitorowania i kontroli ryzyka zalicza się audyty, okresowe przeglądy ryzyka, analizy wypracowanych wartości. Obok monitoringu, który powinien mieć charakter stały, przeprowadza się okresowe kontrole.

Kontrola jest pojęciem, które nie zostało jednoznacznie zdefiniowane, stąd w literaturze i doktrynie spotyka się wiele jej definicji. Słownik języka polskiego kontrolę definiuje jako porównanie stanu faktycznego ze stanem wymaganym ${ }^{107}$. J. Jagielski przez kontrolę rozumie proces sprawdzania i oceniania określonej działalności. W zakres kontroli wchodzi obserwowanie i rozpoznanie stanu w danym momencie, ocena stanu poprzez konfrontację rzeczywistego obrazu z założeniami wyjściowymi, prowadząca do stwierdzenia, czy są one prawidłowe oraz sformułowaniu wniosków zmierzających do zniwelowania i przeciwdziałania nieprawidłowościom w przyszłości ${ }^{108}$. Rozbudowaną definicję kontroli przedstawił J. Starościak ${ }^{109}$, wskazując, że polega ona na obserwowaniu, ustaleniu lub wykrywaniu stanu faktycznego, porównaniu rzeczywistości z zamierzeniami, występowaniu przeciwko zjawiskom niekorzystnym i sygnalizowaniu jednostkom kompetentnym dokonanych spostrzeżeń bez decydowania jednak o zmianie kierunku działania jednostki skontrolowanej.

${ }^{106}$ J. Winiarski, Analiza procesu zarządzania ryzykiem wedtug standardów PMBOK, [w:] Ryzyko. Zarządzanie ryzykiem w przedsiębiorstwie, red. J. Bizon-Górecka, TNOiK, Bydgoszcz 2007, s. 367.

${ }^{107}$ Stownik języka polskiego, PWN, Warszawa 2002, s. 353.

108 Zob. J. Jagielski, Kontrola administracji publicznej, Wydawnictwo Prawnicze PWN, Warszawa 1999, s. 7-9.

109 J. Starościak, Zarys nauki administracji, Wydawnictwo Prawnicze PWN, Warszawa 1971, s. 356. 
Regulacje prawne dotyczące kontroli zostały rozmieszczone w różnych aktach prawnych (np. prawie budowlanym, ustawie o finansach publicznych, prawie administracyjnym), mających za przedmiot organizację i funkcjonowanie organów powołanych do jej sprawowania. J. Boć ${ }^{110}$ uważa, że kontroli można nadać pewne cechy charakterystyczne dla zjawiska, polegające na:

- badaniu zgodności stanu istniejącego ze stanem postulowanym,

- ustaleniu zakresu i przyczyn odchyleń od postulowanego stanu,

- przekazaniu wyników podmiotowi odpowiedzialnemu za kontrolę.

K. Marcinek kontrolę postrzega jako plan zarządzania ryzykiem, który powinien dostarczać informacji obejmujących ${ }^{111}$ :

- cel, założenia w zakresie identyfikacji ryzyk i ich kwalifikacji,

- sposób aktualizowania osiąganych wyników,

- wykaz osób odpowiedzialnych za zarządzanie poszczególnymi grupami ryzyk,

- sposoby reagowania na nieprawidłowości i procedury ich wdrażania.

Przygotowanie i stosowanie planu ma na celu ciągły proces identyfikowania zagrożeń i dokumentowania (rejestrowania) spostrzeżeń, które mają na celu minimalizowanie ryzyka. Na zagadnienie rejestrowania i archiwizowania danych odnośnie do ryzyka zwraca uwagę także C. L. Pritchard ${ }^{112}$, który zaleca uzyskane informacje katalogować w zaproponowany sposób przy użyciu dostępnych systemów informatycznych. Plan ryzyka powinien być wdrażany równocześnie z planem przedsięwzięcia. Jeśli wdrażanie planów zostanie zintegrowane, przyczyni się to do automatycznego koordynowania ryzyk. Za najważniejszy element kontroli uważa się moment reakcji na czynnik ryzyka w momencie, kiedy ten faktycznie zaistnieje. Wówczas następuje rzeczywista weryfikacja przyjętych rozwiązań i strategii działania. Niektóre z nich okazują się skuteczne, inne znacznie mniej. Powoduje to konieczność powrotu do etapu określenia metod oceny ryzyka, a niekiedy nawet do etapu ponownego identyfikowania ryzyka. Najczęściej opóźnia to proces inwestycji oraz podnosi jego koszty.

Proces monitorowania i kontroli ryzyka powinien przynieść wymierne efekty w postaci zaktualizowanej listy ryzyk, propozycji zmian w procesie zarządzania ryzykiem, listy zaleceń korygujących i zapobiegawczych mających na celu doprowadzenie przedsięwzięcia do jego pozytywnego zakończenia.

${ }^{110}$ Zob. J. Boć, J. Blicharz, Prawo administracyjne, Kolonia Limited, Wrocław 2000, s. 357.

${ }^{111}$ K. Marcinek, Ryzyko projektów inwestycyjnych..., s. 206.

${ }^{112}$ Autor przedstawił propozycję sposobów katalogowania informacji dotyczących identyfikacji i sposobów reagowania na ryzyko. Zauważa, że w przypadku kluczowych inwestycji niezbędny jest częsty audyt, natomiast w odniesieniu do inwestycji o charakterze pomocniczym częstotliwość audytu może być mniejsza. Więcej C. L. Pritchard, Zarządzanie ryzykiem w projektach. Teoria i praktyka, WIG-PRESS, Warszawa 2002, s. 44-45. 


\subsubsection{Ubezpieczenie ryzyka w partnerstwie publiczno-prywatnym}

Ubezpieczenie jest niezbędnym elementem każdej umowy zawieranej na płaszczyźnie przepisów dotyczących koncesji czy partnerstwa publiczno-prywatnego. Ryzyko przedsięwzięć inwestycyjnych może wystąpić na każdym etapie i należy się przed nim chronić w ramach ubezpieczenia. Ubezpieczenie stanowi integralną część programów zarządzania ryzykiem. Stanowi zarazem transfer, jak i źródło finansowania ryzyka, ponieważ poprzez porozumienie zawarte pomiędzy ubezpieczycielem a inwestorem dochodzi do przeniesienia całości lub części ryzyka na zakład ubezpieczeniowy w zamian za uiszczenie składki ubezpieczeniowej.

Artykuł 22 pkt 12 Ustawy o koncesji na roboty budowlane lub ustugi wyraźnie wskazuje, na konieczność zawarcia w umowie o koncesji informacji dotyczących warunków i zakresu ubezpieczeń wykonania przedmiotu koncesji. Taki zapis nakłada na koncesjonariusza obowiązek odpowiedniego ubezpieczenia składników majątkowych przedmiotu koncesji oraz wszystkich rzeczy ruchomych $\mathrm{z}$ nim związanych. W sytuacji, gdy $\mathrm{w}$ finansowanie przedmiotu koncesji włączone zostają strony trzecie (banki, instytucje finansowe) ubezpieczyciele zabezpieczają także spłatę zadhużenia. Posiadanie odpowiedniego ubezpieczenia pozwala obniżyć koszty finansowania inwestycji. W przypadku przedsięwzięć koncesyjnych odpowiednia polisa ubezpieczeniowa jest istotna, z uwagi na możliwość wystąpienia szerokiej gamy ryzyk, w tym ryzyka ekonomicznego $^{113}$.

Ustawa o partnerstwie publiczno-prywatnym nie wskazuje bezpośrednio na obowiązek posiadania odpowiedniego ubezpieczenia. $Z$ uwagi jednak na to, że często wybór prywatnego inwestora dokonywany jest $\mathrm{w}$ drodze przepisów Prawa zamówien publicznych ${ }^{114}$, w specyfikacji istotnych warunków zamówienia podmiot publiczny ma prawo żądać oświadczeń i dokumentów potwierdzających spełnienie warunków udziału w postępowaniu przetargowym (art. 25). Jednym $\mathrm{z}$ dokumentów potwierdzających, że wykonawca znajduje się w sytuacji ekonomicznej i finansowej umożliwiającej realizację zamówienia jest polisa ubezpieczenia odpowiedzialności cywilnej ${ }^{115}$. Przepis ten jest wzorowany na art. 47 ust. 1 lit. a) Dyrektywy 2004/18/WE Parlamentu Europejskiego i Rady Europy z dnia 31 marca 2004 r. w sprawie koordynacji procedur udzielenia zamówienia publicznego na roboty budowlane, dostawy $i$ ustugi. Zgodnie z treścią Dyrektywy dowodem sytuacji finansowej i ekonomicznej wykonawcy

113 Zob. A. Panasiuk, Koncesja na roboty budowlane lub ustugi. Partnerstwo publicznoprywatne. Komentarz, C.H. Beck, Warszawa 2009, s. 226-227.

${ }^{114}$ Ustawa z dnia 29 stycznia 2004 r. Prawo zamówień publicznych, DzU, 2004, nr 19, poz. 177 ze zm.

${ }^{115}$ Rozporzadzenie Prezesa Rady Ministrów z dnia 30 grudnia 2009 r. w sprawie rodzajów dokumentów, jakich może żądać zamawiajacy od wykonawcy oraz form, w jakich te dokumenty moga być sktadane, DzU, 2009, nr 226, poz. 1817, §1 ust. 1 pkt 10. 
może być m.in. stosowny dokument posiadania odpowiedniego ubezpieczenia z tytułu ryzyka zawodowego ${ }^{116}$.

Stosując się do wytycznych, podmiot publiczny jest zobowiązany domagać się od podmiotu prywatnego stosownego dokumentu w zakresie ubezpieczenia. $\mathrm{W}$ opinii $\mathrm{K}$. Brzozowskiej ${ }^{117}$ włączenie firm ubezpieczeniowych do działań inwestycyjnych już na wczesnych etapach rozwoju przedsięwzięcia usprawni procesy identyfikacji, szacowania ryzyka i przypisania go odpowiedniej stronie. Rola brokera ubezpieczeniowego sprowadza się do zaproponowania odpowiedniego produktu ubezpieczeniowego oraz określenia prawdopodobieństwa wystąpienia ryzyka, co pociąga za sobą odpowiednie skalkulowanie składki ubezpieczenia.

W kontraktach budowlanych prywatny inwestor zwykle zawiera podstawowe ubezpieczenia w fazie budowy projektu i uwzględnia ich koszt w cenie kontraktu. Dopuszcza się zawieranie odrębnych polis ubezpieczeniowych dla okresu eksploatacji.

Transakcja ubezpieczeniowa składa się z czterech elementów ${ }^{118}$ :

- zawarcia umowy ubezpieczeniowej,

- płatności składki,

- wypłaty odszkodowania w przypadku wystąpienia zdarzeń ujętych w umowie ubezpieczeniowej,

- posiadania przez ubezpieczyciela zasobów kapitałowych niezbędnych na pokrycie kosztów roszczeń.

Zawarcie umowy ubezpieczeniowej ma na celu zapewnienie ubezpieczającemu się ${ }^{119}$ :

${ }^{116}$ Przez umowę ubezpieczenia odpowiedzialności cywilnej zakład ubezpieczeń zobowiązuje się do zapłacenia określonego w umowie odszkodowania za szkody wyrządzone osobom trzecim, względem których odpowiedzialność za szkodę ponosi ubezpieczający albo osoba, na rzecz której została zawarta umowa ubezpieczenia. Ustawa z dnia 23 kwietnia 1964 r. Kodeks cywilny, DzU, 2003, nr 124, poz. 1151, art. $882 \S 1$ ze zm. Zasadność przedstawiania polisy ubezpieczeniowej w celu oceny zdolności ekonomicznej i finansowej wykonawcy budzi kontrowersje. Zdaniem ekspertów nieuzasadnione jest domaganie się powyższego dokumentu na etapie postępowania przetargowego, gdyż nie wiadomo jeszcze, czy dany wykonawca uzyska zamówienie i czy w związku z tym wchodzić będzie w rachubę jego odpowiedzialność wobec zamawiającego. Ponadto posiadanie ochrony ubezpieczeniowej nie musi mieć bezpośredniego związku z kondycją ekonomiczną i finansową ubezpieczającego lub ubezpieczonego. Podmioty o niskim potencjale ekonomicznym mogą zawrzeć stosowne ubezpieczenia. Szerzej: J. Pokrzywiak, M. Bagłaj, Wymóg polisy, „Miesięcznik Ubezpieczeniowy” 2011, nr 4, s. 34-35.

${ }^{117}$ K. Brzozowska, Partnerstwo publiczno-prywatne w Europie. Cele, uwarunkowania, efekty, Wydawnictwa Fachowe CeDeWu, Warszawa 2010, s. 156-157.

118 Por. W. Ronka-Chmielowiec, Wykorzystanie ubezpieczeń do zarządzania ryzykiem..., s. 52.

${ }^{119}$ Por. Partnerstwo publiczno-prywatne, red. A. Gajewska-Jedwabny, Wydawnictwo C.H. Beck, Warszawa 2007, s. 55. 
- przychodów na pokrycie kosztów naprawy szkód wywołanych różnorodnymi ryzykami, w tym ryzykami, które pozostają poza bezpośrednią kontrolą np. pożarem, powodzią, huraganem oraz innymi kataklizmami,

- przychodów w okresie, kiedy nie będą spełnione warunki umożliwiające świadczenie zakontraktowanych usług na rzecz podmiotu publicznego z przyczyn niezależnych od ubezpieczającego się.

Tabela 4.7

Przykładowe ubezpieczenia zawierane w ramach formuły PPP

\begin{tabular}{|c|c|}
\hline Nazwa ubezpieczenia & Zakres ubezpieczenia \\
\hline \multicolumn{2}{|r|}{ Ubezpieczenia w fazie budowy } \\
\hline $\begin{array}{l}\text { Ubezpieczenie wszy- } \\
\text { stkich ryzyk budowy }\end{array}$ & $\begin{array}{l}\text { Obejmuje fizyczną utratę lub uszkodzenie obiektów, materiałów pro- } \\
\text { dukcyjnych i wyposażenia terenu budowy. Ubezpieczenie obejmuje } \\
\text { większość wypadków działania siły wyższej (działania wojenne, po- } \\
\text { żary, klęski żywiołowe) oraz szkody wywołane wadliwą konstrukcją. }\end{array}$ \\
\hline $\begin{array}{l}\text { Ubezpieczenie od od- } \\
\text { powiedzialności } \\
\text { cywilnej }\end{array}$ & $\begin{array}{l}\text { Ubezpieczenie powiązane z ubezpieczeniem wszystkich ryzyk budowy, } \\
\text { obejmuje roszczenia osób trzecich wobec wszystkich zaangażowa- } \\
\text { nych w realizację przedsięwzięcia. Zakres ubezpieczenia zazwyczaj } \\
\text { jest bardzo szeroki, a wysokość składki stosunkowo niska. }\end{array}$ \\
\hline $\begin{array}{l}\text { Ubezpieczenie od } \\
\text { opóźnień w uru- } \\
\text { chomieniu projektu }\end{array}$ & $\begin{array}{l}\text { Ubezpieczenie od utraty zysków lub wzrostu kosztów, powstałe w wy- } \\
\text { niku opóźnień w rozpoczęciu eksploatacji projektu, spowodowane } \\
\text { przez straty objęte polisą ubezpieczeniowa wszystkich ryzyk budo- } \\
\text { wy. Zakres i czas ubezpieczenia powinien odpowiadać najdłuższemu } \\
\text { z możliwych opóźnień spowodowanych przez utratę lub uszkodzenie } \\
\text { kluczowego elementu projektu. }\end{array}$ \\
\hline $\begin{array}{l}\text { Ubezpieczenie od dzia- } \\
\text { łania siły wyższej }\end{array}$ & $\begin{array}{l}\text { Ubezpieczenie nie dotyczy działań sił wyższych ujętych w kontrakcie } \\
\text { PPP, a jedynie umożliwia uregulowanie zobowiązań wynikających } \\
\text { z obsługi długu w przypadku opóźnień powstałych wskutek działania } \\
\text { siły wyższej. }\end{array}$ \\
\hline \multicolumn{2}{|r|}{ Ubezpieczenia w fazie eksploatacji } \\
\hline $\begin{array}{l}\text { Ubezpieczenie od } \\
\text { wszystkich ryzyk }\end{array}$ & $\begin{array}{l}\text { Obejmuje fizyczne uszkodzenie obiektu oraz uszkodzenie wyposażenia } \\
\text { obiektu. }\end{array}$ \\
\hline $\begin{array}{l}\text { Ubezpieczenie od od- } \\
\text { powiedziałności } \\
\text { cywilnej }\end{array}$ & $\begin{array}{l}\text { Ubezpieczenie, którego zakres przedmiotowy jest podobny jak w fazie } \\
\text { budowy. }\end{array}$ \\
\hline $\begin{array}{l}\text { Ubezpieczenie od } \\
\text { wstrzymania dzia- } \\
\text { łalności }\end{array}$ & $\begin{array}{l}\text { Ubezpieczenie zbliżone do ubezpieczenia opóźnień w uruchomieniu } \\
\text { projektu po rozpoczęciu jego eksploatacji. Zakres ubezpieczenia } \\
\text { powinien być na tyle szeroki aby pokryć wysokość strat w postaci } \\
\text { odsetek, kar umownych, stałych kosztów operacyjnych. }\end{array}$ \\
\hline $\begin{array}{l}\text { Warunkowe ubezpie- } \\
\text { czenie od wstrzyma- } \\
\text { nia działalności }\end{array}$ & $\begin{array}{l}\text { Ubezpieczenie zabezpieczające przed działaniami siły wyższej doty- } \\
\text { kającymi strony trzecie, co może mieć bezpośredni wpływ na sytua- } \\
\text { cję inwestora. }\end{array}$ \\
\hline
\end{tabular}

Źródło: oprac. własne na podstawie E. R Yescombe, Partnerstwo publiczno-prywatne. Zasady wdrażania i finansowania, Oficyna a Wolters Kluwer business, Kraków 2008, s. 298-301. 
Standardowa ochrona ubezpieczeniowa obejmuje poza ubezpieczeniem ryzyka także ubezpieczenie od odpowiedzialności cywilnej. Zakres ubezpieczeń występujących w kontraktach partnerstwa publiczno-prywatnego przedstawiono w tab. 4.7.

W niektórych typach przedsięwzięć wymagane są specjalne klauzule środowiskowe. Zawierając takie ubezpieczenie ubezpiecza się ryzyko opóźnień w wyniku podjęcia czynności mających na celu wyeliminowanie ewentualnych zagrożeń środowiskowych powstałych w wyniku uruchomienia przedsięwzięcia $^{120}$.

Ubezpieczenia $\mathrm{w}$ fazie eksploatacji nie można zawrzeć $\mathrm{z}$ wyprzedzeniem ani ustalić składek ubezpieczeniowych na stałym poziomie. Wynika to z dwóch powodów ${ }^{121}$ :

1) po pierwsze, z kosztów ubezpieczenia, które mogą być tak wysokie, że dalsze wnoszenie składek staje się nieopłacalne bądź wprowadza się nowe ograniczenia dotyczące warunków i zakresu ubezpieczenia, powodujące, że ubezpieczenie nie spełnia oczekiwań, np. w więziennictwie,

2) po drugie, z braku zwartych programów ubezpieczeniowych, które obejmowałyby ogół problemów mogących wystąpić w fazie budowy i eksploatacji.

Instytucja finansowa kredytująca przedsięwzięcie może nałożyć na partnera prywatnego dodatkowe wymagania. Klauzule dotyczące ubezpieczenia powinny precyzować ryzyka, których ubezpieczenie może zostać rozłożone na strony umowy partnerstwa. Standardowo postanowienia mogą określać zasady przedłużenia polisy ubezpieczeniowej czy nawet wymagania odnoszące się do wyboru firmy ubezpieczeniowej, w której może zostać zawarta polisa.

W klauzuli powinno znaleźć się także rozstrzygnięcie na temat podziału między stronami kwot wypłacanych przez ubezpieczyciela w związku z wystąpieniem zdarzenia ubezpieczeniowego ${ }^{122}$. Kwestia przedmiotowego zakresu ubezpieczenia powinna zostać uregulowana w umowie. Niezależnie od tego,

${ }^{120}$ Zob. Standardisation of PFI Contracts, wersja 4, Ministerstwo Skarbu Wielkiej Brytanii, marzec 2007, s. 54 i dalsze, www.hm-treasury.gov.uk (24.01.2012).

${ }^{121}$ Stworzenia całego pakietu ubezpieczeń obejmującego nie tylko ryzyko budowy, ale także ryzyko związane $\mathrm{z}$ finansowaniem, eksploatacją i utrzymaniem obiektów, wymagają główni kredytodawcy przedsięwzięcia. Ujęcie w jednym pakiecie tak różnorodnych ryzyk jest wyjątkowo trudne, zwłaszcza gdy same towarzystwa ubezpieczeniowe nie dysponują odpowiednim doświadczeniem $\mathrm{w}$ zakresie zarządzania tak szerokim ryzykiem. Przy tego typu przedsięwzięciach potrzeba jest stworzenia mechanizmu, który umożliwiałby pokrycie kosztów zadłużenia, kosztów operacyjnych, zapewniał zwrot dla inwestorów oraz uwzględniał ryzyko polityczne. W ten sposób firmy ubezpieczeniowe wraz z bankami i organizatorami przedsięwzięcia współuczestniczyłyby w podziale ryzyka. Szerzej: K. Brzozowska, Partnerstwo publiczno-prywatne. Przestanki..., s. $122-124$.

${ }^{122}$ Por. Ustawa o partnerstwie publiczno-prywatnym. Komentarz, red. M. Bejm, Wydawnictwo C.H. Beck, Warszawa 2010, s. 372. 
która ze stron zostanie zobligowana do zawarcia poszczególnych polis, bezwzględnie należy przewidzieć także sytuacje pojawienia się ryzyk, których nie można ubezpieczyć z powodu braku na rynku odpowiednich produktów ubezpieczeniowych (np. ubezpieczenie od skutków aktu terroru) lub z powodu wysokiej ceny ubezpieczenia. Partner prywatny często będzie wymagał także od swoich podwykonawców odpowiedniego zakresu ubezpieczenia, zwłaszcza na etapie budowy ${ }^{123}$. Ekonomicznym rozwiązaniem byłoby skorzystanie z kompleksowego ubezpieczenia w postaci pakietu ubezpieczeniowego.

$\mathrm{Na}$ rynku polskim firmy ubezpieczeniowe proponują prywatnym inwestorom ubiegającym się o zawarcie kontraktu z podmiotem publicznym dwa podstawowe produkty ubezpieczeniowe: gwarancje ubezpieczeniowe oraz produkty skierowane bezpośrednio do firm $\mathrm{w}$ ramach ubezpieczenia od odpowiedzialności cywilnej.

Gwarancje ubezpieczeniowe często stanowią niezbędny warunek zawarcia kontraktu z podmiotem publicznym. Dla przedsiębiorców, którzy składają oferty w przetargach i planują zawarcie kontraktu na dostawę towarów lub realizację usługi czy inwestycji firmy ubezpieczeniowe w ramach gwarancji ubezpieczeniowych proponują tzw. gwarancje kontraktowe, wśród których wyróżnia się cztery podstawowe rodzaje (por. tab. 4.8)

Tabela 4.8

Rodzaje gwarancji kontraktowych

\begin{tabular}{|c|c|}
\hline $\begin{array}{c}\text { Rodzaj } \\
\text { gwarancji }\end{array}$ & Zakres przedmiotowy gwarancji \\
\hline 1 & 2 \\
\hline $\begin{array}{c}\text { Gwarancja } \\
\text { wadium } \\
\text { zapłaty }\end{array}$ & $\begin{array}{l}\text { Gwarancja udzielana na wniosek przedsiębiorcy, który zamierza złożyć oferte } \\
\text { w przetargu. Zastępuje wadium gotówkowe, dzięki czemu umożliwia przed- } \\
\text { siębiorcy uczestnictwo w wielu przetargach bez angażowania własnych } \\
\text { środków. Gwarancje zapłaty wadium stosuje się zarówno w odniesieniu do } \\
\text { przetargów organizowanych na podstawie ustawy Prawo zamówień publicz- } \\
\text { nych, jak i w przypadku przetargów pozaustawowych, których regulamin } \\
\text { dopuszcza zastąpienie wadium gotówkowego gwarancją. Wydając beneficjen- } \\
\text { towi gwarancję Ubezpieczyciel zobowiązuje się do wypłaty kwoty wskazanej } \\
\text { w gwarancji w przypadku, gdyby przedsiębiorca, który wygrał przetarg, } \\
\text { odmówił podpisania kontraktu na warunkach oferty lub w inny sposób nie } \\
\text { wykonał zobowiązań wynikających z przetargu. }\end{array}$ \\
\hline $\begin{array}{c}\text { Gwarancja } \\
\text { należytego } \\
\text { wykonania } \\
\text { kontraktu }\end{array}$ & $\begin{array}{l}\text { Gwarancja należytego wykonania kontraktu jest udzielana na wniosek } \\
\text { przedsiębiorcy, który wygrał przetarg zabezpieczony gwarancją i zobowiąza- } \\
\text { ny jest do przedstawienia zabezpieczenia prawidłowego wykonania umowy. } \\
\text { Gwarancja jest zobowiązaniem Ubezpieczyciela do wypłaty wskazanej w niej } \\
\text { kwoty beneficjentowi, w przypadku, gdyby przedsiębiorca nie wykonał lub } \\
\text { nieprawidłowo wykonał kontrakt i odmówił naprawienia szkody. }\end{array}$ \\
\hline
\end{tabular}

${ }^{123}$ Por. Partnerstwo publiczno-prywatne, red. A. Gajewska-Jedwabny, s. 130. 


\begin{tabular}{|c|c|}
\hline \multicolumn{1}{|c|}{$\mathbf{2}$} & \multicolumn{1}{|c|}{$\mathbf{2}$} \\
\hline $\begin{array}{c}\text { Gwarancja } \\
\text { usunięcia } \\
\text { wad i uste- } \\
\text { rek }\end{array}$ & $\begin{array}{l}\text { Gwarancja usunięcia wad i usterek jest udzielana na wniosek przedsiębiorcy, } \\
\text { jeśli umowa zawarta z beneficjentem została wcześniej zabezpieczona } \\
\text { gwarancją należytego wykonania kontraktu. Gwarancja jest zobowiązaniem }\end{array}$ \\
& $\begin{array}{l}\text { Ubezpieczyciela do wypłaty wskazanej w niej kwoty beneficjentowi, } \\
\text { w przypadku, gdyby przedsiębiorca nie wykonał lub nienależycie wykonał } \\
\text { wynikające z umowy obowiązki z tytułu usunięcia wad i usterek ujawnionych } \\
\text { po zakończeniu jej realizacji. }\end{array}$ \\
\hline $\begin{array}{l}\text { Gwarancja } \\
\text { zwrotu } \\
\text { zaliczki }\end{array}$ & $\begin{array}{l}\text { Gwarancja zwrotu zaliczki udzielona jest na wniosek przedsiębiorcy, który } \\
\text { Ubezpieczyciel zobowiązuje się do wypłaty wskazanej w gwarancji kwoty } \\
\text { beneficjentowi w przypadku, gdyby przedsiębiorca nie wykonał umowy i nie } \\
\text { zwrócił w wyznaczonym terminie zaliczki. }\end{array}$ \\
\hline
\end{tabular}

Źródło: oprac. własne na podstawie Ustawy z dnia 22 maja 2003 r. o działalności ubezpieczeniowej, DzU, 2003, nr 124, poz. 1151, art. 3 ust. 3 pkt 1, ze zm.

W ramach gwarancji ubezpieczeniowej udziela się także gwarancji eksportowych, gwarancji celnych i akcyzowych. Te pierwsze często wymagane są przy zawieraniu kontraktów zagranicznych i obejmują gwarancje z tytułu przetargu, zwrotu zaliczki, wykonania lub dobrego wykonania kontraktu. W przypadku gwarancji celnych i akcyzowych stanowią one instrument umożliwiający wprowadzenie towaru na obszar celny UE bez potrzeby uprzedniego dokonywania stosownych opłat oraz objęcie go procedurą celną. Dwa ostatnie rodzaje gwarancji nie mają zastosowania w projektach partnerstwa publiczno-prywatnego z uwagi na charakter przedmiotowy gwarancji.

Wyraźnie należy zaznaczyć, że na potrzeby realizacji przedsięwzięć partnerstwa publiczno-prywatnego praktyka nie wypracowała szczególnych procedur zawierania ubezpieczenia oraz specjalnych produktów ubezpieczeniowych. W okresie obowiązywania umowy o PPP podmiot prywatny zobowiązany jest do posiadania umowy ubezpieczenia od odpowiedzialności cywilnej w zakresie prowadzonej działalności gospodarczej za szkody na osobie lub mieniu oraz za szkody $\mathrm{w}$ środowisku naturalnym powstałe $\mathrm{W}$ związku $\mathrm{z}$ wykonywaniem umowy. Kwota ubezpieczenia każdorazowo określana jest przez podmiot publiczny na etapie specyfikacji istotnych warunków zamówienia i na jej poziom ma wpływ szacunkowa wartość przedsięwzięcia. W celu zabezpieczenia interesu publicznego warunkiem podpisania umowy o PPP jest wniesienie przez podmiot prywatny gwarancji należytego wykonania umowy.

Umowa ubezpieczeniowa zawierana przez ubezpieczyciela $\mathrm{z}$ ubezpieczającym może zostać rozszerzona o klauzule dodatkowe, na podstawie których możliwe jest dostosowanie oferty do indywidualnych potrzeb ubezpieczającego. $\mathrm{W}$ przedsięwzięciach partnerstwa publiczno-prywatnego zakres ubezpieczenia będzie indywidualne dobierany do specyfiki inwestycji. Ważne jest, aby firmy ubezpieczeniowe wykazały się elastycznością w podejściu do poszczególnych przedsięwzięć. 
Po zakończeniu umowy o partnerstwo publiczno-prywatne przedmiot umowy przechodzi na stronę publiczną. Powstaje obowiązek ubezpieczenia przedmiotu partnerstwa przez jednostkę samorządu terytorialnego. Firmy ubezpieczeniowe oferują wiele produktów jednostkom samorządu terytorialnego, które związane są z ubezpieczeniem mienia oraz ubezpieczeniem od odpowiedzialności cywilnej JST wraz z jednostkami organizacyjnymi ${ }^{124}$. Zawarcie ubezpieczenia przez samorząd poprzedza procedura przetargowa. Jednostka samorządu terytorialnego określa w specyfikacji istotnych warunków zamówienia przedmiot i zakres ubezpieczenia, czas trwania umowy, katalog dokumentów, jakie musi przedstawić firma ubezpieczeniowa oraz klauzule rozszerzające zakres ubezpieczenia ${ }^{125}$. Zastosowanie systemu klauzul pozwala na dostosowanie oferty do indywidualnych potrzeb samorządu, a jednocześnie na wybór najdogodniejszej z punktu widzenia jej potrzeb polisy ${ }^{126}$. Umowy ubezpieczeniowe mogą być zawieranie maksymalnie na okres czterech lat, przy corocznym odnawianiu polisy ubezpieczeniowej, co wynika z art. 142 Prawa zamówień publicznych.

Ubezpieczenie odgrywa zatem rolę swoistego „wentyla bezpieczeństwa"127 powodzenia przedsięwzięcia, w szczególności poprzez możliwość zrekompensowania kosztów (szkód) powstałych w wyniku wystąpienia różnorodnych ryzyk lub pokrycie przychodów w przypadku braku możliwości czerpania ich z przedmiotu umowy partnerstwa.

\subsubsection{Analiza środowiskowa $w$ przedsięwzięciach partnerstwa publiczno-prywatnego}

Ostatnią grupę analiz sporządzanych dla przedsięwzięć partnerstwa publiczno-prywatnego stanowią analizy środowiskowe. Sporządza się je w celu określenia warunków środowiskowych, jakie muszą być spełnione, aby ograniczyć negatywny wpływ przedsięwzięcia na środowisko naturalne. Konieczność opracowania oceny oddziaływania na środowisko planowanych przedsięwzięć wynika z Ustawy o udostepnieniu informacji o środowisku i jego ochronie,

${ }^{124}$ M. Poniatowicz, J.M. Salachna, D. Perło, Efektywne zarządzanie dlugiem w jednostce samorzadu terytorialnego, Wolters Kluwer business, Warszawa 2010, s. 144.

${ }^{125} \mathrm{H}$. Wesołowska, Ubezpieczenie działalności jednostek samorzadu terytorialnego, „Gazeta Prawna" z 29 grudnia 2010, www.gazetaprawna.pl/artykuly/474901,ubezpieczenia_dzialalnosci jednostek_samorzadu_terytorialnego.html (15.04.2013).

${ }^{126}$ B. Filipiak, M. Niewęgłowska, Kompleksowy program ubezpieczenia odpowiedzialności gminy szansa na łagodzenie skutków ryzyk $w$ działalności samorzadu, [w:] Samorząd terytorialny $w$ zintegrowanej Europie, red. B. Filipiak, A. Szewczuk, Z. Zychowicz, Wydawnictwo Naukowe Uniwersytetu Szczecińskiego, Szczecin 2005, s. 197.

${ }^{127}$ Zob. A. Panasiuk, Koncesja na roboty budowlane lub ustugi. Partnerstwo..., s. 227. 
udziale społeczeństwa $w$ ochronie środowiska oraz o ocenach oddziaływania na środowisko ${ }^{128}$. Analiza prowadzi do wskazania przewidywanych oddziaływań na środowisko rozumianych jako zbiór powiązanych ze sobą różnych komponentów, w których zmiana jednego powoduje zmiany w innych komponentach. Analizy środowiskowe mają wymusić na inwestorze działania, które zminimalizują ingerencję w środowisko bądź doprowadzą do zrównoważenia powstałych strat. Ocena wpływu działań inwestycyjnych na środowisko stanowi podstawowe narzędzie zarządzania ochroną środowiska.

Przygotowanie analiz ma za zadanie wykazać zasadność realizacji przedsięwzięcia $\mathrm{w}$ formule PPP. Szacuje się, że całkowity okres przygotowania inwestycji od momentu podjęcia decyzji o realizacji zadania w formule PPP do podpisania umowy z partnerem prywatnym może wahać się od 2 do 3 lat. Stopień rzetelności i rozpiętości powinien udowodnić zasadność realizacji przedsięwzięcia $\mathrm{w}$ postulowanym modelu, wpłynąć na pozyskanie partnera prywatnego i doprowadzić do finansowego zamknięcia przedsięwzięcia. Rzetelnie przeprowadzone i udokumentowane analizy staną się podstawą do ubiegania się o środki finansowe przez partnera prywatnego $\mathrm{w}$ instytucjach finansowych. Ponadto istotna jest także kwestia aprobaty społecznej i politycznej dla planowanej inwestycji. Jednoznaczne wskazanie na PPP jako optymalny model realizacji inwestycji znajduje poparcie władz stanowiących jednostki samorządu i obywateli, co w przyszłości powinno przełożyć się na wymierne efekty społeczno-ekonomiczne.

${ }^{128}$ Zasady przeprowadzania analiz środowiskowych regulowane są na szczeblu krajowym i unijnym. Do podstawowych aktów prawnych regulujących problematykę zaliczyć należy: Ustawe z dnia 3 października 2008 r. o udostępnieniu informacji o środowisku i jego ochronie, udziale społeczeństwa w ochronie środowiska oraz o ocenach oddziaływania na środowisko, DzU, 2012, nr 178, poz. 472; na szczeblu unijnym Dyrektywa Rady 85/337/EWG z dnia 27 czerwca 1985 r. w sprawie oceny skutków wywieranych przez niektóre przedsięwzięcia publiczne i prywatne na środowisko naturalne; Dyrektywa Rady 92/43/EWG z dnia 21 maja 1992 r. w sprawie ochrony siedlisk przyrodniczych oraz dzikiej fauny i flory; Dyrektywa 2001/42/WE parlamentu Europejskiego i Rady z dnia 27 czerwca 2001 r. w sprawie oceny wplywu niektórych planów i programów na środowisko; Dyrektywa 2003/4/WE Parlamentu Europejskiego i Rady dnia 28 stycznia 2003 r.w sprawie publicznego dostepu do informacji dotyczacych środowiska i uchylajaca dyrektywę Rady 90/313/EWG; Dyrektywa 2003/35/WE Parlamentu Europejskiego $i$ Rady z dnia 26 maja 2003 r. przewidująca udziat spoleczeństwa w odniesieniu do sporządzania niektórych planów i programów w zakresie środowiska oraz zmieniająca $w$ odniesieniu do udziału społeczeństwa i dostępu do wymiaru sprawiedliwości dyrektywy Rady 85/337/EWG i 96/61/WE; Dyrektywa Parlamentu Europejskiego i Rady 2008/1/WE z dnia 15 stycznia 2008 r. dotyczaca zintegrowanego zapobiegania zanieczyszczeniom i ich kontroli. 


\subsection{Value for Money jako kryterium efektywności inwestycji partnerstwa publiczno-prywatnego}

Realizacja projektu w formule partnerstwa publiczno-prywatnego powinna prowadzić do osiągnięcia zarówno przez podmiot publiczny, jak i prywatny korzyści ekonomicznych i społecznych. Identyfikacja celów projektu, analiza ryzyk z nim związanych oraz właściwa ocena umiejętności, zasobów i kompetencji uczestników partnerstwa powinna pozwalać na przyjęcie takiego podziału zadań i ryzyk, aby projekt zrealizowano w sposób najbardziej efektywny. $Z$ tego powodu ważne dla efektywności jest łączenie w ramach partnerstwa publicznoprywatnego fazy budowy z fazą eksploatacyjną (operacyjną). Podejście takie można określić jako zintegrowane przedsięwzięcie inwestycyjne (kompleksowe przedsięwzięcie inwestycyjne). Osobne traktowanie fazy budowy i fazy eksploatacji podnosi koszty np. przygotowania dokumentów, pozwoleń, wyboru wykonawcy. Połączenie faz może przynieść korzyści stronie publicznej pod warunkiem jednakprawidłowo sformułowanej umowy.

Najważniejszym celem związanym z wdrażaniem partnerstwa jest umiejętność generowania wyższej ekonomicznej wartości dodanej, tzw. Volue for Money. Jest ona definiowana jako „optymalna kombinacja całościowego cyklu życia przedsięwzięcia z odpowiednim poziomem jakości, w efekcie której realizowane są oczekiwania użytkownika"129. Value for Money jest wskaźnikiem korzyści, będącym relacją sumy korzyści z zastosowania koncepcji PPP odniesionych przez sektor publiczny i społeczeństwo w stosunku do kosztów ${ }^{130}$. Udowodnienie Value for Money powinno być żelazną zasadą przy realizacji każdego przedsięwzięcia $\mathrm{w}$ ramach partnerstwa, wskazującą na optymalne korzyści PPP w konfrontacji z tradycyjnym zamówieniem publicznym. Punktem wyjścia przy ocenie przedsięwzięcia powinna być rzeczywista jego wartość, uwzględniająca elementy finansowe, społeczno-ekonomiczne, operacyjne i jakościowe.

Ekonomiczną opłacalność przedsięwzięcia wyznacza się poprzez ${ }^{131}$ :

- równowagę pomiędzy jakością a ceną,

- wymierną korzyść przy porównaniu PPP z inną metodą wykonania zadania; PPP powinno zapewnić wyższy poziom efektywności i jakości, ograniczenie kosztów całkowitych, innowacyjność, większą niezawodność, bardziej wydajny sposób zarządzania.

${ }^{129}$ PFI: meeting the investment challenge, HM Treasry, lipiec 2003, s. 7-8.

${ }^{130}$ Partnerstwo publiczno-prywatne jako metoda rozwoju infrastruktury w Polsce, Raport Amerykańskiej Izby Handlowej w Polsce, Warszawa 2002, s. 18.

${ }^{131}$ Partnerstwo publiczno-prywatne jako metoda realizacji zadań publicznych, Ministerstwo Gospodarki i Pracy, Departament Polityki Regionalnej, Warszawa 2005, s. 5. 
Opłacalność społeczna może dotyczyć ${ }^{132}$ :

- wzrostu poziomu edukacji lokalnej siły roboczej,

- wybudowania obiektów użyteczności publicznej ze środków prywatnego inwestora,

- stworzenia przesłanek do rozwoju lokalnego/regionalnego oraz zwiększenie atrakcyjności danego regionu,

- generowania dodatkowych dochodów,

- korzyści fiskalnych,

- rozwoju lokalnych rynków kapitałowych.

Korzyści wynikające ze współpracy nie ograniczają się wyłącznie do oszczędności kosztowych, ale obejmują również elementy jakościowe. Stwierdzenie, że dane przedsięwzięcie osiągnęło oczekiwany wskaźnik korzyści Value for Money wymaga analizy czynników mierzalnych, takich jak łączna wartość nakładów poniesionych na daną inwestycję, cena jednostkowa usługi, oraz czynników niemierzalnych w postaci jakości wykonywanej usługi, częstotliwości, niezawodności, dostosowania rozwiązań do potrzeb zgłaszanych przez beneficjentów.

Value for Money ma szczególne znaczenie w odniesieniu do przedsięwzięć PPP, ze względu na charakter usług publicznych, które powinny być świadczone zgodnie $\mathrm{z}$ oczekiwaniami odbiorców $\mathrm{w}$ warunkach ograniczonych możliwości budżetowych. Dążenie do maksymalizacji wskaźnika jest więc wyrazem gospodarności w zakresie wydatkowania środków publicznych ${ }^{133}$. Konieczność ustalenia Value for Money tworzy potrzebę jego pomiaru i określenia narzędzi tego pomiaru. Państwa wykorzystujące tę metodę wypracowały stosowne narzędzia ocen ${ }^{134}$ :

- W Holandii PPP uważane jest za opłacalne w sytuacji, gdy usługa tej samej jakości jest świadczona za niższą cenę lub usługa wyższej jakości za tę samą lub niższą cenę niż w przypadku zastosowania metody tradycyjnej;

- W Danii wskaźnik korzyści określany jest jako stosunek wyższa jakość/cena dla podatnika z perspektywy finansowej;

- W Belgii korzyść definiowana jest jako większa wartość stosunku jakość/cena z perspektywy wszystkich podmiotów administracji publicznej występujących $\mathrm{w}$ roli sponsorów w znaczeniu finansowym, ekonomicznym i operacyjnym;

- W Wielkiej Brytanii wskaźnik określany jest jako wyższa jakość/cena z finansowej perspektywy państwa.

${ }^{132}$ Por. K. Sobiech, Partnerstwo publiczno-prywatne $w$ infrastrukturze drogowej $w$ Polsce, Wydawnictwo Politechniki Poznańskiej, Poznań 2007, s. 92.

${ }^{133}$ Por. Partnerstwo publiczno-prywatne, red. A. Gajewska-Jedwabny, s. 11.

134 Partnerstwo publiczno-prywatne. Poradnik, Urząd Zamówień Publicznych, Warszawa 2010, s. 86 i n. 
Ustawa o partnerstwie publiczno-prywatnym z 2005 r. w art. 3 wyraźnie wskazywała, że partnerstwo publiczno-prywatne znajduje uzasadnienie w sytuacji, „gdy korzyści dla interesu publicznego będą przeważające w stosunku do korzyści wynikających z innych sposobów realizacji tego przedsięwzięcia"135. Ustawodawca nie zdefiniował pojęcia korzyści, ograniczając się jedynie do podania w punkcie 2 art. 3 wspomnianej ustawy przykładu sytuacji, w której wystąpią korzyści: oszczędności w wydatkach podmiotu publicznego, podniesienie standardu świadczonych usług lub obniżenie uciążliwości dla otoczenia.

Obowiązująca ustawa z 2008 r. nie określa warunków wyboru najkorzystniejszej oferty. W interesie podmiotu prywatnego jest wykazanie wyższości i efektywności rozwiązań partnerskich nad pozostałymi rozwiązaniami. W tym celu pomimo faktu, że prawo nie narzuca konieczności przeprowadzenia stosownych analiz będą one przygotowane.

Prawdopodobieństwo osiągnięcia dodatkowej korzyści w formule PPP może być sprawdzone za pomocą dwustopniowej analizy:

- wyliczenie kosztu przeprowadzenia prac przy zastosowaniu metody tradycyjnej,

- porównanie kosztu metody tradycyjnej z potencjalnym kosztem zastosowania $\mathrm{w}$ danym przypadku metody PPP.

Porównania można dokonać wykorzystując następujące narzędzia (komparatory):

- Public Private Scan (PPS),

- Public Private Comparator (PPC),

- Public Sector Comparator (PSC).

Komparatory są metodami analizy porównawczej używanymi na różnych etapach opracowania i przygotowania przedsięwzięcia. Pozwalają one na ocenę korzyści PPP w odniesieniu do innych metod, w szczególności metody tradycyjnej.

Public Private Scan ${ }^{136}$ jest narzędziem wykorzystywanym na etapie opracowania i przygotowania koncepcji przedsięwzięcia (faza wstępna analiz). Celem komparatora jest zbadanie, czy planowana inwestycja potencjalnie może być realizowana $\mathrm{w}$ formule PPP. Pozwala to na wyodrębnienie przedsięwzięć określonych jako: ,atrakcyjny w znaczeniu opłacalności” i „obiecujący w świetle oczekiwanego procesu", które mogą być realizowane w formule PPP ze względu na możliwość osiągnięcia korzyści. Komparator jednoznacznie wklucza te przedsięwzięcia, dla których metoda tradycyjna nie jest metodą optymalną. Rezultatem analizy jest decyzja co do dalszego postępowania, wyznaczająca kierunek rozwoju, jasne sformułowanie celów, metod realizacji oraz określenie

${ }^{135}$ Ustawa z dnia 28 lipca 2005 r. o partnerstwie publiczno-prywatnym, DzU, 2005, nr 169, poz. 1420 , art. 3 pkt 1 .

${ }^{136}$ Public Sector Comparator, Working paper 16, Ecorys, Warszawa, maj 2003, s. 21. 
zapotrzebowania na wiedzę niezbędną do osiągnięcia sukcesu. Narzędzie to „otwiera drogę" do dalszej analizy.

Public Private Comparator ${ }^{137}$ - w ramach tego komparatora bada się opłacalność, jaką przyniesie realizacja zadania w formule PPP $\mathrm{w}$ stosunku do poziomu opłacalności, jaką osiągnie się wykonując to zadanie metodą alternatywną (tradycyjną). Punktem wyjścia $\mathrm{w}$ analizie jest identyfikacja cech konstrukcyjnych modelu publicznego i modelu PPP. Następnie dokonuje się porównania jakościowego i ilościowego obu modeli, sformułowania wniosków wynikających z analizy i wypracowania oceny modelu PPP. Na tym etapie analiz może się jeszcze okazać, że pomimo pozytywnego PPS otrzymujemy negatywny wynik analiz prowadzonych w ramach PPC. Oznacza to, że podmiot publiczny powinien rozważyć opcję zmiany sposobu realizacji zadania na metodę tradycyjną.

Public Sector Comparator ${ }^{138}$ jest narzędziem, które pozwala podmiotowi publicznemu ocenić rzeczywistą opłacalność inwestycji na podstawie ofert przedłożonych $\mathrm{w}$ postępowaniu przetargowym i dokonać porównania $\mathrm{z}$ opłacalnością realizacji inwestycji wyłącznie $\mathrm{w}$ ramach własnych możliwości finansowych, bez udziału prywatnych inwestorów. Komparator umożliwia porównanie szacunkowych kosztów wykonania zadania w formule PPP z metodą tradycyjną przy zachowaniu tych samych standardów wykonania. PSC jest modelem kosztowym świadczenia usługi przez podmiot publiczny, uwzględniającym wszystkie koszty i nakłady występujące w całym cyklu funkcjonowania przedsięwzięcia ${ }^{139}$. Model w swojej konstrukcji uwzględnia szacunek kosztów ryzyk ekonomicznych przyjętych przez podmiot prywatny w ramach wariantu PPP, które w metodzie tradycyjnej poniesione byłyby przez sektor publiczny. Podmiot publiczny za podstawę do oszacowania kosztów wykonania danego zadania przyjmuje dane pochodzące $\mathrm{z}$ tożsamych prac wykonanych $\mathrm{w}$ niedalekiej przeszłości. Ważne jest, aby szacowane wielkości uwzględniały dodatkowe okoliczności, które mogą mieć zasadniczy wpływ na zmianę kosztów w nowych warunkach (np. inflacja, słabsze tempo wzrostu gospodarczego). Obliczony szacunkowy koszt jest przedstawiony jako wartość bieżąca netto i może zostać użyty do porównania $\mathrm{z}$ szacunkowym kosztem wykonania danego zadania w trybie PPP. Jeśli tak skalkulowany koszt wykonania przedsięwzięcia przez podmiot publiczny jest większy niż w przypadku prawidłowo skalkulowanego kosztu w ramach PPP, oznacza to, że koszt świadczenia danej usługi metodą

${ }^{137}$ Ibidem, s. 22.

${ }^{138}$ Ibidem, s. 23.

${ }^{139}$ G. Tryc, Metodyka wykonania Modelu Porównawczego Sektora Publicznego (PSC) dla projektu z zakresu gospodarki odpadami komunalnymi, GT Consulting, Warszawa, grudzień 2010, s. 6 . 
tradycyjną jest wyższy niż przy zastosowaniu $\mathrm{PPP}^{140}$. Taki rezultat analizy stanowi silną przesłankę do zawarcia umowy z prywatnym partnerem (schemat 4.8).

Model PSC, aby być użytecznym narzędziem oceny, powinien spełniać następujące warunki ${ }^{141}$ :

- pozwolić na oszacowanie finansowego wymiaru wartości dodanej, wyrażonego w wartościach pieniężnych,

- być poparty opisem korzyści jakościowych, które będą brane pod uwagę przy określeniu potencjalnej wartości dodanej, jaka powstanie w wyniku zawarcia umowy o PPP,

- pokazać trwałość założeń przedsięwzięcia (ukazanie zakresu i wpływu zmian ujętych w modelu na wynik PSC). Poziom wpływu określa się dzięki przeprowadzeniu testów na wrażliwość podstawowych zmiennych modelu finansowego (analiza scenariuszy),

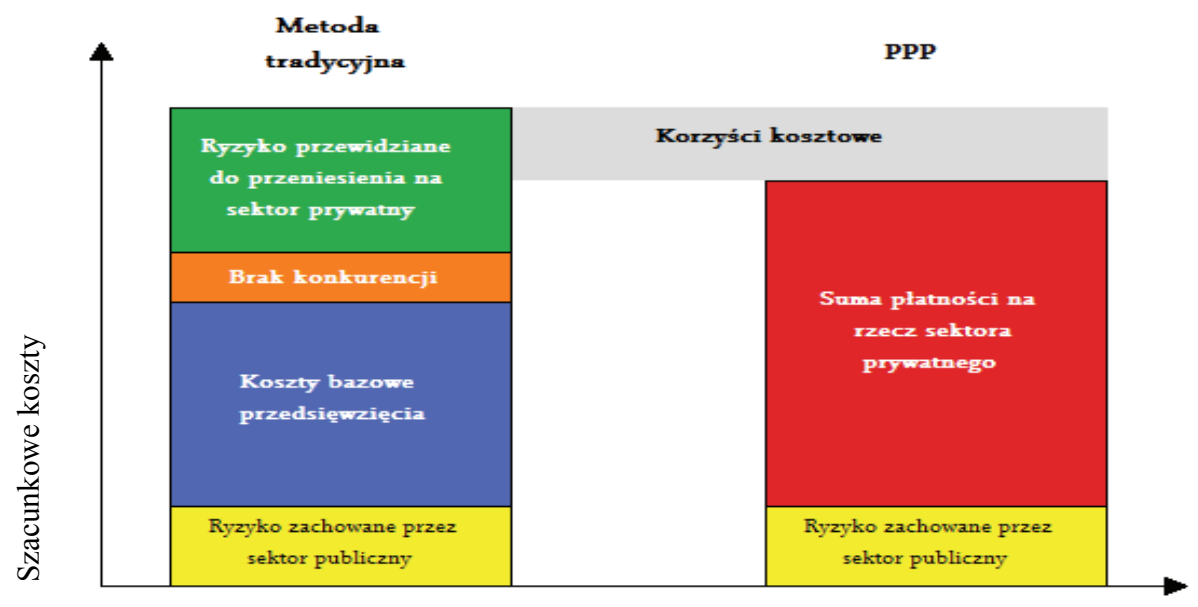

Schemat 4.8. Porównanie kosztów metody tradycyjnej i PPP

Źródło: Partnerstwo publiczno-prywatne jako metoda rozwoju infrastruktury w Polsce, Raport Amerykańskiej Izby Handlowej w Polsce, Warszawa 2002, s. 19

${ }^{140}$ Ministerstwo Skarbu Australii opracowało dokument precyzujący wytyczne dotyczące wykorzystania i obliczenia PSC, skierowany do wszystkich przygotowujących przedsięwzięcia, wykorzystujący do weryfikacji PSC. W dokumencie omówione są elementy wpływające na wynik PSC, szczególnie uwzględniające ryzyko. Public Sektor Comparator. Policy. Government of Western Australia, Departament of Tresury, August 2011.

${ }^{141}$ G. Tryc, Metodyka wykonania Modelu Porównawczego Sektora Publicznego..., s. 6. 
- być elastyczny, aby na bieżąco można było wprowadzać nowe dane, które pojawią się $\mathrm{w}$ trakcie funkcjonowania przedsięwzięcia, np. zmiany $\mathrm{w}$ zakresie kwantyfikacji ryzyka,

- służyć jako benchmark do oceny wartości dodanej alternatywnych metod zapewniających daną usługę, a zwłaszcza do oceny ofert prywatnych inwestorów biorących udział w przetargu.

Model Public Sector Comparator (schemat 4.9) składa się z czterech zasadniczych elementów:

1) podstawowego modelu PSC (koszty operacyjne utrzymania, nakłady inwestycyjne, nakłady odtworzeniowe),

2) neutralności konkurencyjnej,

3) ryzyka zatrzymanego,

4) ryzyka transferowanego.

\section{PSC $=$ podstawowy PSC + neutralność konkurencyjna + ryzyko zatrzymane + ryzyko transferowane}

Schemat 4.9. Elementy Public Sector Comparator

Źródło: oprac. własne

Budowa podstawowego modelu PSC polega na przygotowaniu prognozy finansowej. W tym celu określa się pozycje kosztowe, które obejmują:

1) koszty kapitałowe,

2) koszty operacyjne i utrzymania,

3) koszty odtworzeniowe,

4) koszty finansowe,

5) koszty ponoszone przez sektor publiczny na każdym etapie realizacji projektu.

Neutralność konkurencyjna jest swoistą korektą przewagi, którą może osiągnąć podmiot sektora publicznego nad prywatnym lub partnera prywatnego nad publicznym w procesie realizacji PPP z uwagi na swój status bądź możliwości właścicielskie. Neutralność konkurencyjna może dotyczyć np. zwolnienia lub ulgi w podatku od nieruchomości czy podatku VAT. W pierwszym przypadku określa się, czy nieruchomość objęta PPP ma przyznane zwolnienia lub ulgi. Jeśli tak to, ustala się ich wysokość w sytuacji, gdy płatnikiem miałby być partner prywatny. W przypadku podatku VAT uzasadnieniem dla neutralności jest sytuacja, w której podmiot publiczny nie może dokonać odliczenia kwoty naliczonego podatku VAT. Kwotę taką należy wyeliminować $\mathrm{z}$ analiz, tzn. uwzględnić ją ze znakiem minus. Podmiot prywatny natomiast przygotowuje prognozę w wartościach netto i ma możliwość odliczenia podatku VAT. Bez wprowadzenia neutralności, każdy z sektorów z uwagi na swój status osiągałby 
dodatkową korzyść. Wprowadzenie tego elementu do komparatora neutralizuje położenie stron projektu.

Jak już wskazano, jednym z najważniejszych elementów umowy o PPP jest ryzyko. Jego identyfikacja, wycena i alokacja stanowią najważniejszy element negocjacji pomiędzy stronami. Ryzyko stanowi także ważny element komparatora PSC. Uwzględnia się w nim dwa rodzaje ryzyka: transferowane i zatrzymane. Ryzyko transferowane to takie, które $\mathrm{z}$ uwagi na możliwości, umiejętności zarządcze może być przeniesione na podmiot prywatny, przy założeniu, że strona prywatna je zaakceptuje. Kiedy dokonana zostanie identyfikacja wszystkich rodzajów ryzyka transferowanego, określa się wielkość oraz czas występowania przepływów gotówkowych związanych z pojawieniem się tego ryzyka. $\mathrm{W}$ dalszej kolejności wszystkie rodzaje ryzyka agreguje się w celu określenia zaktualizowanej wartości kosztów ryzyka i ujmuje jako jeden z elementów modelu PSC.

Ryzyko zatrzymane to takie ryzyko, które pozostaje po stronie podmiotu publicznego przez cały okres trwania umowy o partnerstwie. Podobnie jak każdy inny rodzaj ryzyka wymaga ono indywidualnej analizy i oszacowania. Do ryzyk, które pozostają po stronie publicznej zalicza się:

1) ryzyko zmian legislacyjnych,

2) ryzyko zmian związanych z realizacją zamówienia na usługę,

3) ryzyko popytu łączące się ze zmniejszeniem się zapotrzebowania na oferowaną usługę.

Postuluje się, by w celu uniknięcia lub zmniejszenia następstw ryzyka zatrzymanego, podmiot publiczny podjął działania zmierzające do ${ }^{142}$ :

- zmniejszenia prawdopodobieństwa wystąpienia negatywnych zjawisk związanych z pojawieniem się ryzyka,

- wykorzystania sprawdzonych technologii,

- skorzystania z doświadczenia wykonawców,

- stworzenia skutecznego monitoringu ryzyka,

- ubezpieczenia ryzyka.

Public Private Comparator $>$ całkowite koszty projektu Volue for Money

Schemat 4.10. Public Sector Comparator a Value for Money w partnerstwie publiczno-prywatnym Źródło: oprac. własne na podstawie M. Blaiklock, Public sector comparators and value for Money in PPP, European Institute of Public Administration, s. 1-3

Ilościowe elementy komparatora pozwalają na oszacowanie opłacalności wykonania przedsięwzięcia $\mathrm{w}$ formule PPP (schemat 4.10). Komparator powinien być stosowany zarówno na etapie przygotowywania partnerstwa, jak

${ }^{142}$ Public Sector Comparator, Working Paper 16..., s. 23-26. 
i w trakcie otrzymywania ofert od partnerów prywatnych. Umożliwi to wybranie oferty, która będzie generowała największą wartość dodaną przedsięwzięcia.

Można wyróżnić kilka elementów wpływających na wzrost poziomu wskaźnika. Są to, po pierwsze, korzyści wynikające z wartości ekonomicznej związanej z przeniesienia na sektor prywatny poszczególnych ryzyk. Wskaźnik ten wzrasta wraz ze wzrostem poziomu konkurencji pomiędzy inwestorami podczas przetargu. Po drugie, płyną one ze zwiększenia efektywności sektora prywatnego na etapie budowy, eksploatacji, zarządzania kosztami w perspektywie długookresowej (ang. whole-life costing) wdrażania innowacyjnych rozwiązań oraz oparcia specyfikacji prac na oczekiwanych rezultatach i pozostawieniu prywatnemu inwestorowi swobody co do sposobu osiągnięcia tych rezultatów. Po trzecie, źródłem korzyści jest też zestaw zachęt dla prywatnych firm do unikania generowania nadmiernych kosztów i opóźnień na etapie budowy. Przykładowo, w typowym przedsięwzięciu wykonawca przyjmuje ryzyko projektowe i ryzyko opóźnień, które może zminimalizować poprzez właściwy proces projektowania, planowania i zarządzania kosztami. W przypadku powstania opóźnień wykonawca może zostać zmuszony do zapłaty kary, co stanowi silną zachętę do dotrzymania przyjętych terminów.

Doświadczenia Wielkiej Brytanii wskazują, że przedsięwzięcia PPP w porównaniu z metodą tradycyjną mogą dać oszczędności kosztowe rzędu $17 \%$. Poziom oszczędności zależy od specyfiki projektu oraz następujących czynników ${ }^{143}$ :

- ryzyka charakterystycznego dla danego przedsięwzięcia i jego złożoności,

- alokacji ryzyk pomiędzy strony umowy (z doświadczeń państw realizujących zadania w PPP wynika, że korzyści ekonomiczne będące efektem prawidłowego podziału ryzyka mogą sięgać około 60\% łącznych oszczędności kosztowych danego przedsięwzięcia),

- postrzegania ryzyka politycznego,

- długości trwania procesu przetargowego i poziomu konkurencji wśród uczestników przetargu.

Model PSC ${ }^{144}$ :

- oparty jest na najbardziej efektywnym i prawdopodobnym do zastosowania rozwiązaniu dostępnym dla podmiotów publicznych,

- uwzględnia potencjalny wpływ ryzyka na stronę kosztową i przychodową dla całego cyklu życia przedsięwzięcia,

- jest wyrażony jako zaktualizowana wartość kosztów poniesionych przez stronę publiczną w celu zapewnienia usługi w trakcie trwania umowy.

${ }^{143}$ Por. Partnerstwo publiczno-prywatne jako metoda rozwoju infrastruktury w Polsce..., s. 20; Public Sektor Comparator, Supplementary Technical Note, Departament of Tresury and Finance, State Government, July 2003.

${ }^{144}$ G. Tryc, Metodyka wykonania Modelu Porównawczego Sektora Publicznego (PSC)..., s. 6. 
Wykonanie poszczególnych analiz z wykorzystaniem komparatorów trwa średnio od 0,5 miesiąca do 8-12 miesięcy. PPS trwa średnio od 0,5 do 1,5 miesiąca, PPC od 2 do 4 miesięcy, natomiast najbardziej pracochłonny PSC od 4 do 8-12 miesięcy (tab. 4.9).

Tabela 4.9

Szacunkowy czas trwania oceny przedsięwzięcia dla poszczególnych komparatorów

\begin{tabular}{|l|l|l|}
\hline \multicolumn{1}{|c|}{ Komparator } & \multicolumn{1}{|c|}{ Czas trwania oceny } & \multicolumn{1}{|c|}{ Etap przygotowania projektu } \\
\hline PPS & $0,5-1,5$ miesiąca & prace wstępne \\
\hline PPC & $2-4$ miesięcy & $\begin{array}{l}\text { przygotowanie procedur } \\
\text { przetargowych }\end{array}$ \\
\hline PSC & $4-8$ miesięcy & $\begin{array}{l}\text { Wybór partnera prywatnego } \\
\text { w przetargu }\end{array}$ \\
\hline
\end{tabular}

Źródło: oprac.własne na podstawie Tworzenie podstaw dla PPP w Polsce. Wskazówki dotyczace aspektów finansowych PPP, cz. II, ECORYS, Warszawa 2003, s. 20-22.

W celu zapewnienia efektywności wymienionych komparatorów PPP powinny zostać spełnione następujące warunki ${ }^{145}$ :

- zgromadzenie informacji ,wejściowych”, kluczowych z perspektywy procesu planowania,

- określenie jednostek zaangażowanych w stosowanie oceny,

- określenie porozumienia co do faktycznego momentu oceny, w tym osiągnięcie konsensusu w ramach następujących kwestii: statusu narzędzi, metodologii przeprowadzenia szacunków, modelu publicznego poddanego ocenie, wielkości budżetu, obiektywnego charakteru narzędzi oceny PPP.

Wykorzystując komparatory uwzględnia się w nich ryzyko, bez którego nie byłoby możliwe porównanie złożonych ofert w ramach PSC. W wielu przypadkach obok analizy ilościowej wymagana jest analiza jakościowa, dająca pełny obraz warunków, w jakich przedsięwzięcie będzie realizowane.

Przy projektach partnerstwa publiczno-prywatnego należy pamiętać, że $\mathrm{z}$ uwagi na długi horyzont czasowy $\mathrm{w}$ momencie przeprowadzania oceny przedsięwzięcia uzyskują pozytywną ocenę i zostają zakwalifikowane do partnerstwa. Nie jest to jednoznaczne $\mathrm{z}$ tym, że ocena przeprowadzona w przyszłości dałaby pozytywny wynik, co oznacza z kolei że należy uwzględniać wszystkie możliwe do zidentyfikowania czynniki wpływające na przedsięwzięcie.

${ }^{145}$ Partnerstwo publiczno-prywatne jako metoda realizacji zadań publicznych..., s. 10. 


\section{ANALIZA RYNKU SAMORZĄDOWYCH PRZEDSIĘWZIĘĆ PARTNERSTWA PUBLICZNO-PRYWATNEGO W POLSCE W LATACH 2009-2011}

\subsection{Metodyka badań}

Głównym celem badania była identyfikacja i ocena uwarunkowań kształtujących rynek samorządowych przedsięwzięć partnerstwa publiczno-prywatnego w Polsce. Jednostki samorządu terytorialnego są największym inwestorem w sektorze publicznym. Inwestycje realizowane przez nie stanowią i będą stanowić w najbliższych latach siłę napędową rozwoju regionalnego. Za okres badawczy przyjęto lata 2009-2011, co wynika z nowych uregulowań prawnych w zakresie współpracy podmiotów publicznych z sektorem prywatnym, które zaczęły obowiązywać od lutego 2009 r. na podstawie Ustawy z dnia 18 grudnia 2008 r. o partnerstwie publiczno-prywatnym oraz Ustawy z dnia 9 stycznia 2009 r. o koncesji na roboty budowlane lub ustugi. Nowe regulacje zastąpiły wcześniejszą Ustawe o partnerstwie publiczno-prywatnym z 2005 r., której rozwiązania prawne nie znalazły zastosowania w praktyce. Od 2009 r. w polskiej rzeczywistości można zaobserwować pierwsze działania podmiotów publicznych zmierzające do zawarcia umowy o partnerstwo publiczno-prywatne w rozumieniu ustawowym.

Przedmiotem badań była struktura przedsięwzięć partnerstwa publiczno-prywatnego realizowanych przez jednostki samorządu terytorialnego w Polsce w latach 2009-2011. Przeprowadzone badania miały na celu zidentyfikowanie struktury podmiotowo-przedmiotowej samorządowego rynku przedsięwzięć partnerstwa publiczno-prywatnego oraz określenie uwarunkowań wpływających na skłonność władz samorządowych do współdziałania z partnerami prywatnymi.

Głównym źródłem doboru danych do badania na temat samorządowego rynku PPP były ogłoszenia o wybór partnera prywatnego lub koncesjonariusza publikowane w „Biuletynie Zamówień Publicznych” oraz „Suplemencie Europejskiego Dziennika Unii Europejskiej” (TED) w latach 2009-2011, których analiza pozwoliła na wyodrębnienie podmiotów publicznych zainteresowanych partnerstwem publiczno-prywatnym. Spośród wszystkich podmiotów publicz- 
nych wyodrębniono jednostki samorządu terytorialnego. Zidentyfikowano łącznie 70 jednostek samorządu terytorialnego, które w badanym okresie zamieściły w publikatorach ogłoszenie o wybór partnera prywatnego dla PPP. Określono je w pracy jako próbę I. Publikatory stanowią wiarygodne źródło informacji o podmiotach publicznych, które podejmują się współpracy z sektorem prywatnym. Zamieszczenie ogłoszenia jest obligatoryjnym obowiązkiem nałożonym na sektor publiczny w celu zapewnienia konkurencyjności, przejrzystości i jawności działania związanego z wydatkowaniem środków publicznych nałożonym ustawą Prawo zamówień publicznych. W publikatorach ukazały się ogłoszenia samorządów, które planowały realizację inwestycji lub usług publicznych $\mathrm{w}$ formule partnerstwa publiczno-prywatnego. Spośród tej próby badawczej wyodrębniono 16 jednostek samorządu terytorialnego, które zawarły umowę o partnerstwo publiczno-prywatne i stanowią najważniejsze źródło informacji o przebiegu procesu decyzyjnego w odniesieniu do PPP.

W celu weryfikacji stopnia znajomości problematyki partnerstwa publiczno-prywatnego oraz skłonności do realizacji zadań publicznych w formule PPP przez jednostki samorządu terytorialnego celowo poszerzono próbę badawczą o 18 miast będących siedzibami organów stanowiących oraz/lub zarządów województw (II próba badawcza), a także 42 gminy miejskie województwa łódzkiego (III próba badawcza).

Wybór II próby podyktowany był faktem, że miasta te jako stolice regionów wpływają na kształt polityki regionalnej i poziom rozwoju. Działania owe wymagają określonych środków finansowych. Ograniczenia wynikające ze struktury i poziomu dochodów, konieczność zagwarantowania wkładu własnego dla projektów współfinansowanych ze środków unijnych oraz wzrastające zadłużenie powodują, że pomimo ambitnych planów inwestycyjnych niektóre $\mathrm{z}$ nich nie będą podjęte lub zostaną zrealizowane w ograniczonym zakresie. W kontekście wyzwań finansowych i zarządczych, przed jakimi stają duże miasta, uzasadnione było zbadanie skali zainteresowania nowymi formami finansowania zadań publicznych oraz stopnia korelacji pomiędzy sytuacją finansową, poziomem wiedzy $\mathrm{w}$ zakresie partnerstwa publiczno-prywatnego a liczbą planowanych i realizowanych inwestycji w partnerstwie publiczno-prywatnym.

Wybór III próby badawczej miał charakter rozpoznawczo-przeglądowy (niereprezentacyjny), mający na celu weryfikację znajomości problematyki PPP i skłonności do wykorzystania partnerstwa w praktyce jednostek samorządu terytorialnego województwa łódzkiego. Dobór badanych jednostek samorządu terytorialnego miał charakter celowy, ponieważ za jego kryterium przyjęto uwarunkowania ekonomiczne oraz organizacyjne, charakterystyczne dla współpracy sektora publicznego $\mathrm{z}$ sektorem prywatnym $\mathrm{w}$ ramach formuły partnerstwa publiczno-prywatnego. Dodatkowym argumentem przemawiającym za uwzględnieniem tylko tego typu jednostek w województwie łódzkim był fakt, że 
przedstawiciele władz gmin miejskich uczestniczyli w konferencjach i seminariach poświęconych $\mathrm{PPP}^{1}$.

W celu identyfikacji uwarunkowań sprzyjających partnerskiej współpracy autorka opracowała kwestionariusz ankiety ${ }^{2}$ (Aneks 1). Respondentami byli skarbnicy jednostek, z którymi przeprowadzono rozmowę telefoniczną w celu uzyskania zgody na udział $\mathrm{w}$ badaniu. Następnie rozesłano ankietę drogą mailową do wybranych jednostek. Badanie zostało zrealizowane w okresie od lutego do maja $2012 \mathrm{r}$.

Ankietę wysłano łącznie do 130 jednostek, uzyskano zwrot ze 119, natomiast 11 jednostek samorządu terytorialnego, których ogłoszenie o wybór partnera prywatnego ukazały się w publikatorach, nie wzięło udziału w badaniu (tab. 5.1). Wskaźnik response rate wyniósł $91,5 \%{ }^{3}$. Poszczególne etapy badania zaprezentowano na schemacie 5.1.

${ }^{1}$ Informacje pozyskane od organizatorów konferencji i seminariów poświęconych problematyce PPP (konferencja Fundusze Europejskie szansa rozwoju PPP w Polsce, Łódź 2009, cykl konferencji ogólnopolskich Partnerstwo publiczno-prywatne szansa dla sektora prywatnego i publicznego, Łódź [corocznie] marzec 2006-2012; konferencja Partnerstwo publiczno-prywatne $w$ Polsce $w$ świetle nowych rozwiąań legislacyjnych, Łódź 2009; seminaria regionalne projektu systemowego PARP Partnerstwo publiczno-prywatne; I Kongres Finansów Publicznych w Krakowie poświęcony problematyce dlugu publicznego i partnerstwu publiczno-prywatnemu, Kraków 2011.

${ }^{2}$ Ankieta - w języku polskim słowo to rozumiane jest wieloznacznie. Szerokie jego znaczenie odnosi się do wszelkich analiz i badań, w których wykorzystuje się dane pochodzące od osób poinformowanych, różnych instytucji. Należy do grupy technik standaryzowanych, w których badacz otrzymuje materiały $\mathrm{w}$ procesie wzajemnego komunikowania się $\mathrm{z}$ innymi osobami odpowiadającymi pisemnie na jego pytania. Istotną rolę odgrywa formularz, który zawiera pytania jednakowe dla wszystkich respondentów wraz z żądaniem udzielenia odpowiedzi na każde pytanie dotyczące respondenta. Ankietę cechuje także anonimowość. Zdaniem J. Lutyńskiego z metodologicznego punktu widzenia wartość wypowiedzi w technikach komunikowania się (ankiecie) zależy od szczerości, na którą respondentom trudniej jest się zdobyć wówczas, gdy są przekonani o nieanonimowości wypowiedzi. J. Lutyński, Metody badań społecznych. Wybrane zagadnienia, Łódzkie Towarzystwo Naukowe, Societes Scientiarum Lodziensis, Prace Wydziału II Nauk Historycznych i Społecznych nr 96, Łódź 2000, s. 145; Wywiad kwestionariuszowy. Analizy teoretyczne $i$ badania empiryczne, red. K. Lutyńska, A. P. Wejland, PAN, Instytut Filozofii i socjologii, Zakład Narodowy im. Ossolińskich, Wrocław-Warszawa-Kraków-Gdańsk-Lódź 1983, s. 50-53.

${ }^{3}$ Podstawową miarą poziomu realizacji, która pozwala na ogólny ogląd sytuacji i informuje o tym, jaka część potencjalnych respondentów uczestniczy w badaniu, jest odsetek odpowiedzi (response rate), którego terminologiczna wersja anglojęzyczna przyjęła się w badaniach. K. Grzeszkiewicz-Radulska, Respondenci niedostęnni w badaniach sondażowych, [w:] Analizy $i$ próby technik badawczych $w$ socjologii, t. 12, Instytut Socjologii Uniwersytetu Łódzkiego, Wydawnictwo Uniwersytetu Łódzkiego, Łódź 2009, s. 166. 
Tabela 5.1

Struktura respondentów biorących udział w badaniu ankietowym

\begin{tabular}{|c|c|c|c|}
\hline Grupa respondentów & $\begin{array}{c}\text { Liczba JST } \\
\text { objętych } \\
\text { badaniem (w szt.) }\end{array}$ & $\begin{array}{c}\text { Liczba JST, } \\
\text { które zwróciły } \\
\text { ankiety (w szt.) }\end{array}$ & $\begin{array}{c}\text { Udział danej próby } \\
\text { w ogólnej liczbie } \\
\text { JST objętych } \\
\text { badaniem (w \%) }\end{array}$ \\
\hline $\begin{array}{c}\text { JST, które zamieściły ogłoszenie o } \\
\text { planowanym przedsięwzięciu PPP } \\
\text { (próba I) }\end{array}$ & 70 & 59 & 53,8 \\
\hline $\begin{array}{c}\text { Miasta będące siedzibami organów } \\
\text { zarządzających i/bądź stanowiących } \\
\text { województw (próba II) }\end{array}$ & 18 & 18 & 13,8 \\
\hline $\begin{array}{c}\text { Gminy miejskie województwa } \\
\text { łódzkiego (próba III) }\end{array}$ & 42 & 42 & 32,3 \\
\hline Ogółem & 130 & 119 & $\mathrm{x}$ \\
\hline
\end{tabular}

Źródło: oprac. własne na podstawie badań ankietowych.

Argumentem przemawiającym za wyborem ankiety jako narzędzia badawczego były względy ekonomiczne związane z obniżką kosztów wynikających $\mathrm{z}$ dotarcia do respondentów oraz zalety ankiety jako narzędzia badawczego elastyczność i szybkość. Ponadto w opinii autorki ankieta pozwoliła na zweryfikowanie danych liczbowych publikowanych w raportach i zestawieniach instytucji rządowych oraz pozarządowych. Udostępniane dane dotyczące wielkości i wartości przedsięwzięć, rozkładu sektorowego, różnią się między sobą nawet 10-krotnie. Zaobserwowano, że publikowane przez prasę oraz prezentowane na seminariach i konferencjach dane liczbowe mają charakter fragmentaryczny, ogólnikowy i jedynie sygnalizują, że jednostki samorządu terytorialnego podejmują działania zmierzające do ukonstytuowania się partnerstwa publiczno-prywatnego $\mathrm{w}$ praktyce. $\mathrm{Z}$ uwagi na ograniczony dostęp do informacji i brak oficjalnych, rzetelnych statystyk wybrano ankietę jako narzędzie pozyskania danych do analizy.

Rozpiętość danych wymagała od skarbników przygotowania informacji i zestawienia danych $\mathrm{w}$ przedziale czasowym objętym badaniem (np. finansowych), co również przemawiało za ankietą. Gromadzenie danych w formie ankiety pozwoliło na zastosowanie pytań zamkniętych i otwartych. Pytania zamknięte były wielokrotnego wyboru, natomiast otwarte służyły wyrażeniu przez ankietowanych opinii, stanowiących cenny materiał dla osiągnięcia celu badawczego. 


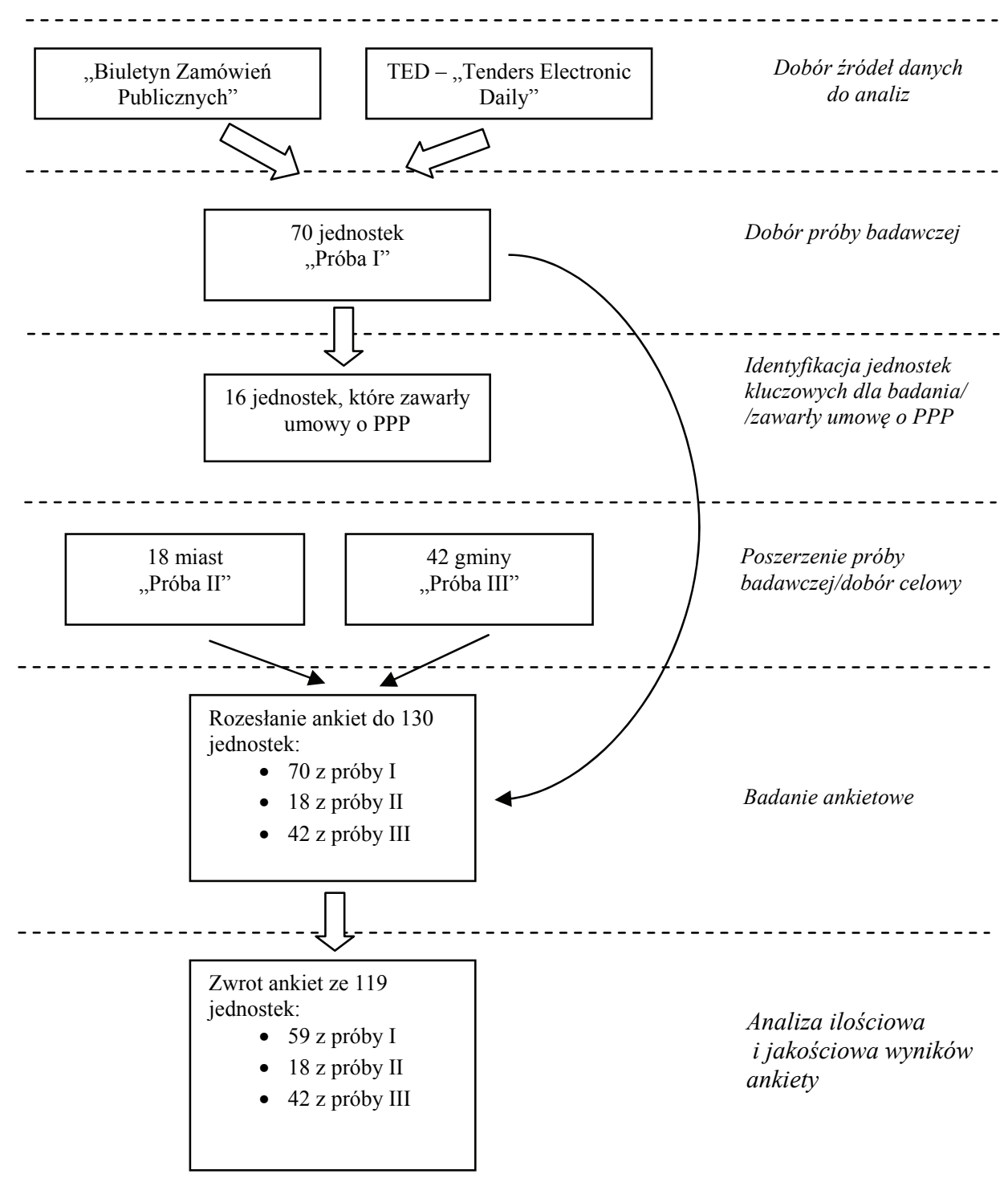

Schemat 5.1. Etapy weryfikujące cel badania Źródło: oprac. własne

Ankieta podzielona została na dwie części. Pierwsza dotyczyła zagadnień finansowych, druga uwarunkowań prawno-organizacyjnych odnoszących się do planowanych i realizowanych projektów PPP. W zakresie finansów samorządu terytorialnego dla każdej jednostki samorządu terytorialnego zgromadzono dane na temat: 
- wydatków zrealizowanych ogółem,

- dochodów zrealizowanych ogółem,

- deficytu lub nadwyżki budżetu,

- przychodów ogółem, w tym kwoty zaciągniętego długu,

- całkowitej wysokości obsługi zadłużenia w ciągu roku,

- kwoty zadłużenia ogółem,

- wskaźnika obsługi zadłużenia,

- wskaźnika zadłużenia ogółem,

- wydatków inwestycyjnych,

- przychodów z prywatyzacji,

- nadwyżki z lat poprzednich,

- wysokości środków na inwestycje z funduszy unijnych.

Układ informacji finansowych ma na celu zweryfikowanie postawionej w pracy hipotezy głównej: Wzrastajacy poziom zadłużenia oraz niski poziom potencjału inwestycyjnego stymuluja władze jednostek samorzadu terytorialnego do zainteresowania formuła partnerstwa publiczno-prywatnego $i$ zawierania umów.

W części dotyczącej prawno-organizacyjnych uwarunkowań projektów PPP zgromadzone informacje uwzględniały:

- zakres merytoryczny niezbędny do przygotowania przedsięwzięcia $\mathrm{w}$ formule partnerstwa publiczno-prywatnego,

- ocenę istniejących rozwiązań prawnych,

- zakres i możliwości wsparcia ze strony administracji centralnej,

- możliwość łączenia PPP z procesem pozyskiwania środków UE,

- rolę doradztwa zewnętrznego: zainteresowanie doradztwem zewnętrznym, zakres usług doradczych, formę wynagrodzenia, kryteria wyboru doradcy,

- prawno-finansową charakterystykę planowanych lub realizowanych przedsięwzięć.

Zmiany $\mathrm{w}$ obowiązującym otoczeniu prawnym związanym $\mathrm{z}$ partnerstwem publiczno-prywatnym oraz jego ewaluacja w ostatnich latach stanowiły przyczynek do zbadania, jak są one postrzegane przez jednostki samorzą$\mathrm{du}$ terytorialnego. Przedmiotem weryfikacji była także ocena sektorów gospodarki, w których rozwiązania partnerskie znajdują zastosowanie, oraz ocena umiejętności i możliwości przedstawicieli samorządów do nawiązania takiej współpracy.

Część pierwsza, finansowa, ankiety wypełniona została przez skarbników badanych jednostek. Natomiast część drugą, zawierającą 14 pytań zamkniętych, dotyczących przedsięwzięć inwestycyjnych PPP, wypełnili koordynatorzy przedsięwzięć, skarbnicy lub osoby przez nich wskazane.

Źródłami uzupełniającymi dla prowadzonych badań były raporty przygotowane przez Instytut Partnerstwa Publiczno-Prywatnego, firmę doradczą Invest- 
ment Support, Centrum PPP oraz portale prowadzone przez Ministerstwo Gospodarki (baza PPP) i Ministerstwo Rozwoju Regionalnego (platforma PPP). Analizy zostały wykonane w programie SPSS.

\subsection{Struktura podmiotowa partnerstwa publiczno-prywatnego w Polsce w latach 2009-2011}

Podmioty publiczne, ze względu na ograniczone zasoby ekonomiczne, techniczne i organizacyjne, coraz częściej poszukują - w związku z koniecznością realizacji powyższych zadań - możliwości współpracy z sektorem prywatnym. Przedmiotowa współpraca stwarza warunki do wykorzystania wiedzy i zasobów kapitałowych sektora prywatnego do realizacji inwestycji w zakresie infrastruktury technicznej, społecznej oraz świadczenia usług publicznych. Pierwszym aktem normatywnym regulującym problematykę PPP w Polsce była uchwalona 28 lipca 2005 r. ustawa. Działo się to więc w okresie, kiedy w praktyce realizowano już przedsięwzięcia $\mathrm{w}$ formule partnerstwa publiczno-prywatnego sensu largo. Pod regulacjami tejże ustawy nie udało się jednak uruchomić żadnego projektu. Wśród przyczyn tego stanu rzeczy wymienia się najczęściej: zbytnią restrykcyjność regulacji, ograniczenia podmiotowe i przedmiotowe PPP, narzucony ustawowo obowiązek sporządzania kosztownych i czasochłonnych analiz przedrealizacyjnych, niesprzyjający klimat, brak wiedzy i umiejętności w zakresie ustawowo pojętej współpracy partnerskiej. Brak sformalizowanych prac nad projektami nie oznaczał jednak, że niektóre jednostki samorządu terytorialnego prac koncepcyjnych nie zaczęły prowadzić ${ }^{4}$. Działaniom tym sprzyjał konkurs Dobre Praktyki $P P P^{5}$. Z chwilą przyjęcia nowych regulacji (uchwalenia ustawy o PPP w grudniu 2008 r. i ustawy o koncesji na roboty budowlane lub usługi w 2009 r.) istniał już pewien zasób wiedzy, analiz

\footnotetext{
${ }^{4}$ Między innymi gmina Wągrowiec przygotowała przedsięwzięcie PPP w zakresie budowy Centrum Rekreacji Wodnej. Nie został on zrealizowany ze względu na brak możliwości spełnienia obowiązku wynikającego z art. 13 ustawy o PPP z 2005 r., tj. ogłoszenia w „Biuletynie Zamówień Publicznych" informacji o planowanej realizacji przedsięwzięcia na zasadach właściwych dla PPP. Naruszenie powyższego obowiązku skutkowało zgodnie z art. 21 pkt 2 nieważnością umowy o partnerstwie publiczno-prywatnym. Brak możliwości zamieszczenia ogłoszenia wynikał z braku odpowiedniego formularza.

${ }^{5}$ Konkurs stanowił swoistego rodzaju platformę współpracy i wymiany doświadczeń pomiędzy podmiotami publicznymi i prywatnymi, które były pionierami w zakresie prac nad wdrożeniem PPP. W latach 2007-2009 zgłoszono do konkursu 93 projekty. W roku 2007 nagrodą dla zwycięzcy były wstępne analizy (z uwagi na fakt, że konieczność ich przygotowania stanowiła jedną z kluczowych barier wdrożenia PPP). W 2008 r. Ministerstwo Gospodarki zwycięzcom sfinansowało analizy wstępne, w 2009 r. nagrodą był zaś wyjazd studyjny do Francji. Na podstawie Dobre Praktyki PPP. Podsumowanie trzech lat konkursu na najlepsze projekty przedsięwzięć publiczno-prywatnych, Investment Support, Warszawa 2009.
} 
i zaplecze organizacyjne pozwalające „poruszać się” w problematyce PPP. Dodatkowo ramowy charakter ustaw o PPP oraz zmiana klimatu wokół formuły spowodowały, że już w pierwszym roku obowiązywania nowych regulacji pojawiło się w „Biuletynie Zamówień Publicznych” oraz „Suplemencie do Dziennika Urzędowego Unii Europejskiej” 41 ogłoszeń o poszukiwaniu partnera prywatnego do wykonywania zadań publicznych. W kolejnym roku liczba ogłoszeń wzrosła do 61. Biorąc pod uwagę czas potrzebny na organizacyjne i merytoryczne przygotowanie prac nad projektem, jest to znacząca liczba, która w efekcie doprowadziła do wzrostu rynku projektów PPP o blisko 50\%. W roku 2011 liczba ogłoszeń zmniejszyła się do 42, skutkując 31\% spadkiem (por. wykres 5.1). Było to wynikiem wyborów z 2010 r., a tym samym wyhamowaniu prac związanych z podejmowaniem decyzji inwestycyjnych. Łącznie w latach 2009-2011 liczba przedsięwzięć partnerstwa publiczno-prywatnego sięgnęła 144. Uwzględniając fakt, że część podmiotów kilkakrotnie publikowała ogłoszenia, rzeczywista ich liczba wyniosła odpowiednio 34, 52 i 37, co w sumie daje123 ogłoszone postępowania.

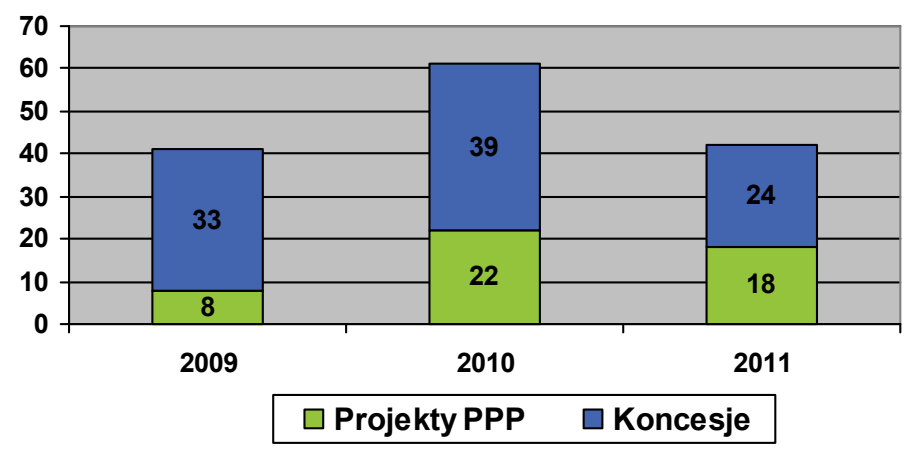

Wykres 5.1. Łączna liczba opublikowanych ogłoszeń o wybór partnera lub koncesjonariusza w latach 2009-2011

Źródło: oprac. własne na podstawie ogłoszeń zamieszczonych w „Biuletynie Zamówień Publicznych” i „Suplemencie do Dziennika Urzędowego Unii Europejskiej”

Biorąc pod uwagę wszystkie zamieszczone ogłoszenia (nawet te pojawiające się kilkakrotnie) najwięcej z nich dotyczyło wyboru koncesjonariusza. Takich łącznie $\mathrm{w}$ analizowanym okresie ukazało się 96. Tylko w jednym przypadku, w 2009 r., posłużono się starymi przepisami koncesji na roboty budowlane, które regulowały przepisy ujęte w Prawie zamówień publicznych ${ }^{6}$. Ogłoszenie

${ }^{6}$ Ustawa z dnia 29 stycznia 2004 r. Prawo zamówień publicznych, DzU, 2006, nr 106, poz. 719 ze zm., rozdz. 4. 
zamieszczone zostało przez Gminę Miasto Gdańsk i dotyczyło zaprojektowania, sfinansowania i budowy zespołu trzech parkingów podziemnych w Gdańsku. Wybór tego trybu procedurowania był efektem wcześniejszych prac nad przedsięwzięciem, prowadzonym jeszcze $\mathrm{w}$ trakcie obowiązywania Ustawy o partnerstwie publiczno-prywatnym z 2005 r. W 48 przypadkach wybór partnera prywatnego opierał się na ustawie o partnerstwie publiczno-prywatnym, przy czym również $\mathrm{w}$ tych postępowaniach korzystano $\mathrm{z}$ dwóch ścieżek postępowania: wyboru partnera na podstawie zapisów Ustawy o koncesji na roboty budowlane lub ustugi - 33 ogłoszenia i Prawa zamówień publicznych - 15 ogłoszeń (tab. 5.2).

Tabela 5.2

Formuły prawno-finansowe przedsięwzięć ogłoszonych dla przedsięwzięć PPP w latach 2009-2011

\begin{tabular}{|l|c|c|c|}
\hline \multirow{2}{*}{$\begin{array}{c}\text { Formuła ogłoszenia postępowania na wybór } \\
\text { partnera prywatnego dla przedsięwzięcia PPP }\end{array}$} & 2009 & 2010 & 2011 \\
\cline { 2 - 4 } & 32 & 34 & 12 \\
\hline Koncesja na roboty budowlane & 0 & 5 & 12 \\
\hline Koncesja na usługi & 1 & 0 & 0 \\
\hline Koncesja na roboty budowlane wg PZP & 4 & 15 & 14 \\
\hline $\begin{array}{l}\text { PPP w trybie koncesji na roboty budowlane lub } \\
\text { usługi }\end{array}$ & 4 & 7 & 4 \\
\hline PPP w trybie PZP & 41 & 61 & 42 \\
\hline Ogółem & & \\
\hline
\end{tabular}

Źródło: oprac. własne na podstawie ogłoszeń zamieszczonych w „Biuletynie Zamówień Publicznych” i „Suplemencie do Dziennika Urzędowego Unii Europejskiej”.

Tabela 5.3

Liczba ogłoszeń według podmiotów ogłaszających postępowanie realizacji PPP w latach 2009-2011

\begin{tabular}{|l|c|c|c|}
\hline \multirow{2}{*}{$\begin{array}{c}\text { Podmioty zamieszczające ogłoszenie o realizacji } \\
\text { PPP }\end{array}$} & \multicolumn{3}{c|}{ Rok } \\
\cline { 2 - 4 } & 2009 & 2010 & 2011 \\
\hline Miasta i Gminy & 22 & 47 & 28 \\
\hline Powiaty & 3 & 3 & 0 \\
\hline Urzędy marszałkowskie & 6 & 0 & 0 \\
\hline Spółki komunalne & 5 & 5 & 5 \\
\hline Jednostki budżetowe & 0 & 4 & 4 \\
\hline Zakłady opieki zdrowotnej & 5 & 1 & 1 \\
\hline Uczelnie wyższe & 0 & 0 & 3 \\
\hline Agencje & 0 & 0 & 1 \\
\hline Ministerstwa & 0 & 1 & 0 \\
\hline Ogółem & 41 & 61 & 42 \\
\hline
\end{tabular}

Źródło: oprac. własne na podstawie ogłoszeń zamieszczonych w „Biuletynie Zamówień Publicznych” i „Suplemencie do Dziennika Urzędowego Unii Europejskiej”. 
Zdecydowana większość ogłoszeń dotycząca projektów partnerstwa publiczno-prywatnego została zamieszczona przez jednostki samorządu terytorialnego. Wśród tych jednostek przeważały gminy i miasta. Nie zabrakło też ogłoszeń powiatów oraz urzędów marszałkowskich. Łącznie JST opublikowały przez trzy lata 109 ogłoszeń. Pozostałe ogłoszenia pochodziły od spółek handlowych, zakładów opieki społecznej, jednostek budżetowych, uczelni publicznych, ministerstwa (tab. 5.3). Część z ogłoszeń publikowana była kilkakrotnie $\mathrm{z}$ uwagi na błędy merytoryczne w ogłoszeniu lub nieprawidłowo wybraną formę realizacji planowanego przedsięwzięcia bądź brak ofert.

Ogłoszenia miast i gmin stanowiły łącznie prawie $68,0 \%$ wszystkich ogłoszeń, jakie zamieszczone zostały w BZP i/lub TED. Dużą grupę podmiotów zainteresowanych współpracą z prywatnym partnerem stanowiły spółki komunalne $(10,0 \%)$. W dalszej kolejności były to jednostki budżetowe, zakłady opieki zdrowotnej, powiaty. Marginalne znaczenie stanowiły ogłoszenia zamieszczone przez państwowe uczelnie (trzy ogłoszenia - 2,0\%), Wojskową Agencję Mieszkaniową oraz Ministerstwo Finansów (po jednym ogłoszeniu - 1,0\%). Strukturę podmiotów publikujących ogłoszenie o wybór partnera prywatnego dla PPP w latach 2009-2011 przedstawia wykres 5.2.

Analizując rozmieszczenie terytorialne podmiotów planujących współpracę z sektorem prywatnym należy wziąc pod uwagę kilka aspektów. Przede wszystkim istnieją regiony, które wykazują dużą aktywność określaną liczbą planowanych inwestycji, co niekoniecznie przekłada się na liczbę zawieranych umów. Istnieją także regiony, gdzie występuje wiele projektów o wysokiej wartości. Nie zawsze liczba projektów przekłada się na wartość inwestycji i odwrotnie. Największa koncentracja projektów partnerstwa publiczno-prywatnego notowana jest $\mathrm{w}$ regionach uważanych za rozwinięte również w innych rankingach gospodarczych, np. dotyczących inwestycji, zatrudnienia czy stopy bezrobocia.

Niekwestionowanym liderem co do liczby planowanych przedsięwzięć PPP na rynku jest województwo małopolskie z miastem Kraków. Dużą liczbą projektów mogą poszczycić się województwa: wielkopolskie, dolnośląskie, mazowieckie, pomorskie, śląskie i warmińsko-mazurskie. Najsłabiej wypadają województwa: świętokrzyskie i zachodniopomorskie z dwoma projektami, podlaskie, łódzkie i podkarpackie $\mathrm{z}$ trzema, pozostałe województwa mają od czterech do ośmiu projektów inwestycyjnych zakwalifikowanych do realizacji $\mathrm{w}$ formule PPP. 


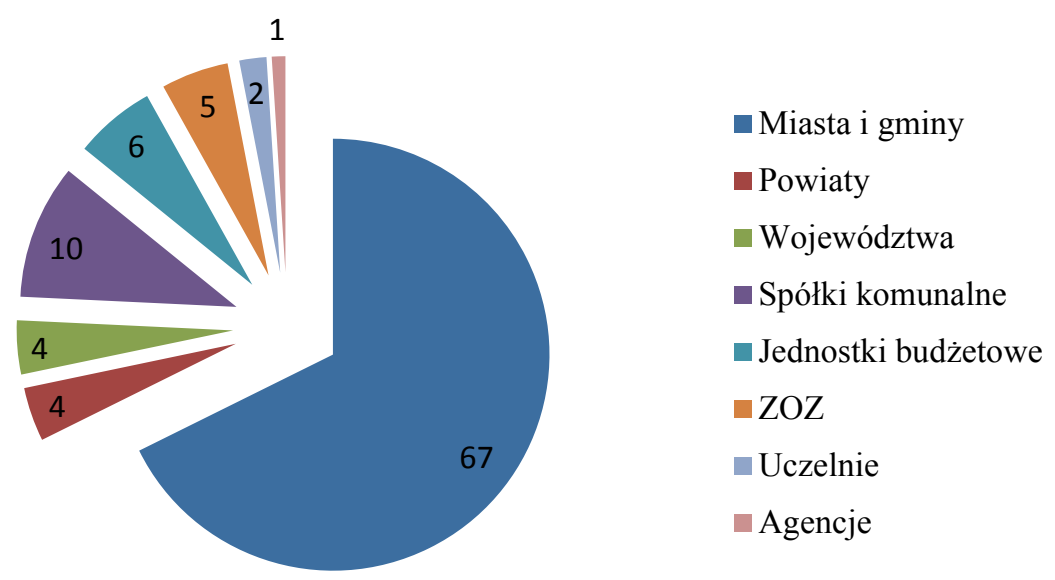

Wykres 5.2. Struktura podmiotów publikujących ogłoszenie o wybór partnera prywatnego dla PPP w latach 2009-2011 (w \%)

Źródło: oprac. własne na podstawie tab. 5.3.

Rozmieszczenie terytorialne i liczbę projektów zgłoszonych w poszczególnych województwach zaprezentowano na mapie 5.1.

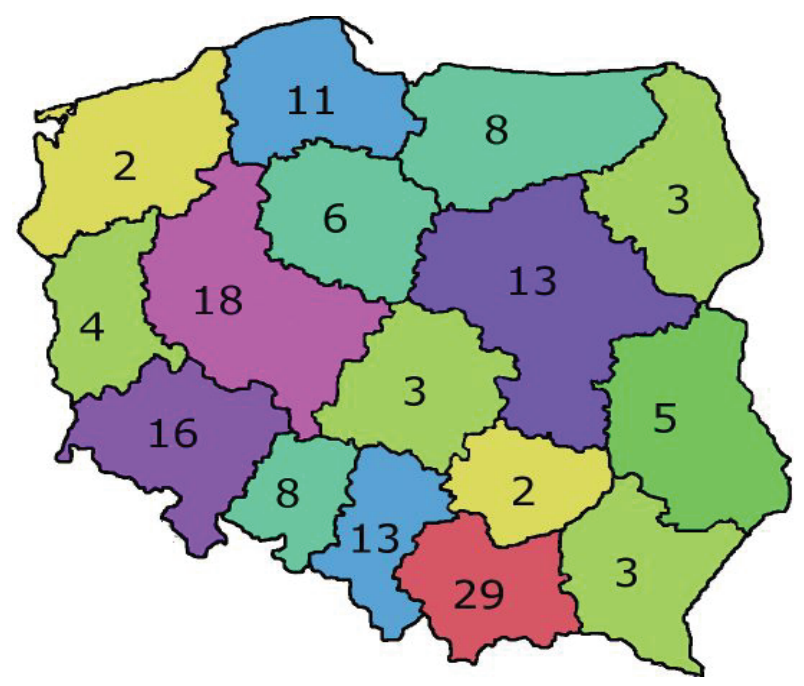

Mapa 5.1. Rozmieszczenie terytorialne przedsięwzięć PPP w latach 2009-2011 (liczba przedsięwzięć)

Źródło: oprac. własne na podstawie danych zamieszczonych w „Biuletynie Zamówień Publicznych” i „Suplemencie do Dziennika Urzędowego Unii Europejskiej” oraz baz projektów PPP, www.pppbaza.pl 
Na tle liczby planowanych przedsięwzięć liczba zawartych umów jest niewielka. Wynika to z faktu małej liczby pozytywnie zakończonych procesów projektowo-przetargowych. W badanym okresie jednostki samorządu terytorialnego zawarły łącznie 20 umów. Realizatorami projektów PPP w 95\% są gminy. Umowy zawarły gminy o charakterze wiejskim, miejsko-wiejskim oraz gminy miejskie. Wśród samorządów, które zawarły umowę o partnerstwie znalazł się także jeden powiat - żywiecki. Liczba poszczególnych typów jednostek samorządu terytorialnego, które zawarły umowę o PPP ukazana została na wykresie 5.3.

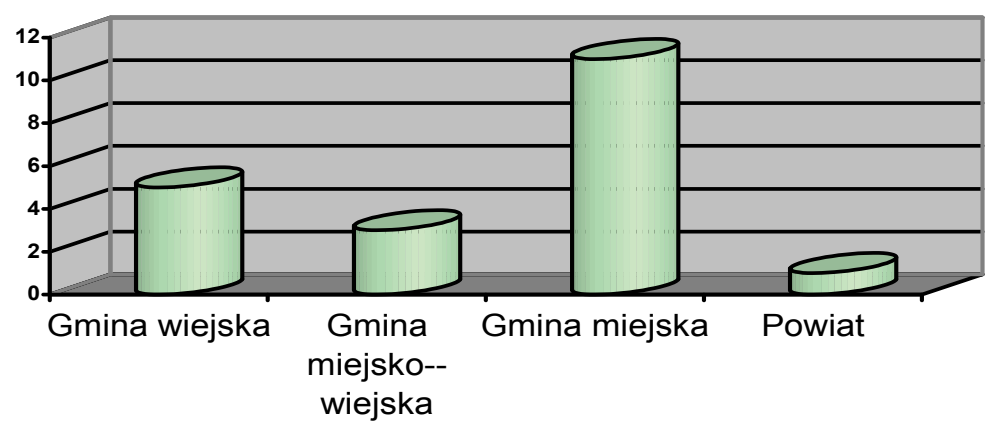

Wykres 5.3. Liczba zawartych umów przez poszczególne typy jednostek samorządu terytorialnego w Polsce w latach 2009-2011

Źródło: oprac. własne na podstawie badania ankietowego

Prawie 55\% zawartych umów przypada na gminy miejskie, gminy wiejskie stanowią $25 \%$, miejsko-wiejskie $15 \%$, powiat zaś $5 \% \mathrm{w}$ strukturze samorządowego partnerstwa. Wśród tych jednostek nie znalazło się żadne województwo. Najwięcej umów zawartych zostało w 2011, co oznacza, że okres przygotowania procedur związanych $\mathrm{z}$ wyborem projektu dla partnerstwa publiczno-pry

Tabela 5.4

Umowy o PPP zawarte przez poszczególne typy jednostek samorządu terytorialnego w latach 2009-2011

\begin{tabular}{|l|c|c|c|}
\hline \multirow{2}{*}{ Typ jednostki samorządu terytorialnego } & \multicolumn{3}{|c|}{ Liczba zawartych umów o PPP w roku } \\
\cline { 2 - 4 } & 2009 & 2010 & 2011 \\
\hline Gmina wiejska & 2 & 2 & 1 \\
\hline Gmina miejsko-wiejska & 0 & 1 & 2 \\
\hline Gmina miejska & 0 & 5 & 6 \\
\hline Powiat & 0 & 0 & 1 \\
\hline Ogółem & 2 & 8 & 10 \\
\hline
\end{tabular}

Źródło: oprac. własne na podstawie badania ankietowego. 
watnego, opublikowania ogłoszenia o wybór partnera prywatnego, procedura przetargowa oraz negocjowanie warunków umowy trwały kilkanaście miesięcy. Osiem umów zawarto w 2010 roku oraz dwie w roku 2009 (tab. 5.4). Tak jak wspomniano, umowy z 2009 r. były efektem postępowań przygotowanych w oparciu na przepisach uchylonej ustawy z $2005 \mathrm{r}$.

Do końca 2011 r. szesnaście jednostek samorządu terytorialnego podpisało łącznie 20 umów o partnerstwie publiczno-prywatnym lub koncesji, co sięga zaledwie $27,1 \%$ łącznej liczby zamieszczonych przez nie ogłoszeń w sprawie PPP. Widać jak niewielki procent podmiotów, które podjęły się trudu przygotowania formuły, zakończyło sukcesem swoje działania. W przypadku realizowanych umów liderami są województwa małopolskie, śląskie i pomorskie z trzema zawartymi umowami. Najsłabiej wypadają województwa: kujawsko-pomorskie, łódzkie, podlaskie, lubelskie i podkarpackie, w których w badanym okresie nie zawarto żadnej umowy o partnerstwie publiczno-prywatnym. Rozmieszczenie terytorialne jednostek, które zawarły taką umowę przedstawiono na mapie 5.2.

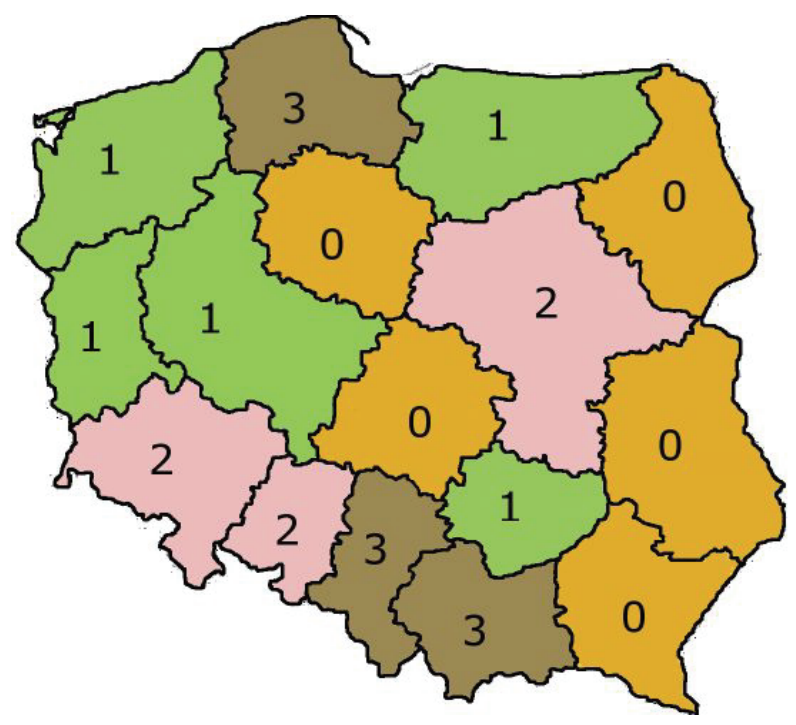

Mapa 5.2. Rozmieszczenie terytorialne umów o PPP lub koncesji w latach 2009-2011 (liczba umów)

Źródło: oprac. własne na podstawie tab. 5.4

Nie wszystkie podpisane umowy mają zapewnione zamknięcie finansowe. Przez zamknięcie finansowe rozumie się uzyskanie przez partnera prywatnego kapitału na finansowanie przedsięwzięć. W większości przypadków w przedsięwzięciach PPP partner prywatny odpowiada za zapewnienie źródła jego finansowania. Nie jest to równoznaczne $\mathrm{z}$ tym, że mają to być jego własne środki 
finansowe. Najczęściej kapitał partnera prywatnego pochodzi ze źródeł zewnętrznych, zwrotnych, w postaci kredytów i pożyczek. W terminologii bankowej związanej z finansowaniem PPP pojawił się termin „bankowalność przedsięwzięć" " Odnosi się on do przedsięwzięć, w których bank udziela wsparcia finansowego prywatnemu partnerowi, przez co możliwe staje się zamknięcie finansowe inwestycji. Bank Gospodarstwa Krajowego jest jednym z najważniejszych na rynku PPP, który wspiera zarówno finansowo, jak i merytorycznie przedsięwzięcia PPP.

W sytuacji, gdy strona prywatna nie dysponuje wystarczającym kapitałem umożliwiającym sfinansowanie przedsięwzięcia, może złożyć zobowiązanie, że w określonym czasie wskaże dodatkowe źródło kapitału. Wówczas podpisuje się tzw. umowy warunkowe.

Obecnie zamknięcie finansowe zostało zapewnione dla 18 z 20 umów. W dwóch przypadkach doszło do podpisania wspomnianych umów warunkowych. Dotychczas takie umowy zawarto dla przedsięwzięć: Centralny Park Rekreacji, Balneologii, Turystyki i Wypoczynku „Termy Gostynińskie” w Gostyninie oraz Budowa i zarządzanie szpitalem powiatowym w Żywcu. W pierwszym przypadku inwestycja miała być finansowana w sposób hybrydowy. Uzupełnieniem środków własnych partnera prywatnego miała być dotacja unijna pozyskana w ramach Europejskiego Funduszu Rozwoju Regionalnego w wysokości $72 \mathrm{mln}$ zł. Przedsięwzięcie do chwili obecnej nie otrzymało wsparcia unijnego, co spowodowało utratę wiarygodności finansowej. W konsekwencji inwestycja została zablokowana. W drugim przypadku zawarcie umowy warunkowej podyktowane zostało stanowiskiem prywatnego partnera InterHealth Canada Ltd., który zobowiązał się, że w ciągu roku przedstawi źródła finansowania inwestycji.

W badanym okresie doszło do rozwiązania dwóch umów. Pierwszej, zawartej w 2010 r. pomiędzy Gminą Łazy a Przedsiębiorstwem Komunikacji Miejskiej Sp. z o.o. w Olkuszu. Ze względu na niską jakość świadczonych usług gmina nie wypłacała koncesjonariuszowi należnego wynagrodzenia. Ostatecznie w grudniu 2010 r. umowa została rozwiązana. Druga umowa koncesyjna zawarta została w 2011 r. przez Gminę Skąpe z prywatnym inwestorem. Przedmiotem koncesji było zagospodarowanie i zarządzanie kąpieliskiem nad jeziorem Niesłysz w Niesulicach. Po trzech miesiącach za porozumieniem stron doszło do rozwiązania umowy. Ostatecznie należy przyjąć, że w okresie objętym badaniem faktycznie realizowanych jest 16 umów o partnerstwo publicznoprywatne.

${ }^{7}$ Sformułowanie używane przez pracowników banków zajmujących się finansowaniem i doradztwem w zakresie PPP, używane również w trakcie szkoleń i konferencji z problematyki partnerstwa. Wplyw odpowiedniego przygotowania projektu PPP na możliwość jego sfinansowania, konferencja pt. PPP szansa na sfinansowanie rozwoju regionalnego, BGK, Toruń 31 maja 2011. 


\subsection{Struktura przedmiotowa partnerstwa publiczno-prywatnego w latach 2009-2011}

Zamieszczone w publikatorach (BZP/TED) przez jednostki samorządu terytorialnego ogłoszenia pozwalają scharakteryzować strukturę przedmiotową przedsięwzięć PPP. Łączna liczba ogłoszeń, jaka się ukazała, wyniosła 109, co nie oddaje rzeczywistej liczby przedsięwzięć przeznaczonych do realizacji z uwagi na kilkukrotne publikacje. Najwięcej ogłoszeń w sprawie wyboru partnera prywatnego dotyczyło przedsięwzięć z obszaru sportu i rekreacji. Wzmożone zainteresowanie tym sektorem należy w znacznej mierze przypisać zbliżaniu się Mistrzostw w Piłce Nożnej EURO 2012. Wiele samorządów chciało poszczycić się zapleczem sportowo-rekreacyjnym. Poza tym sektor ten stwarza wiele możliwości komercyjnych, istotnych z punktu widzenia prywatnego inwestora. Na drugim miejscu znalazły się ogłoszenia dotyczące budowy parkingów. To bardzo piląca potrzeba przy rosnącej liczbie samochodów i od lat tej samej liczby miejsc parkingowych. Władze samorządowe dostrzegają konieczność rozwiązania problemu, który dotyczy w szczególności centrów miast. W dalszej kolejności wymienić trzeba ogłoszenia dotyczące szeroko rozumianej gospodarki komunalnej: sieci wodno-kanalizacyjnej, gospodarki odpadami, gospodarki mieszkaniowej, transportu miejskiego/gminnego, dróg publicznych. Problemy ze służbą zdrowia także znalazły odzwierciedlenie w ogłoszeniach (4). Strukturę opublikowanych ogłoszeń zaprezentowano na wykresie 5.4.
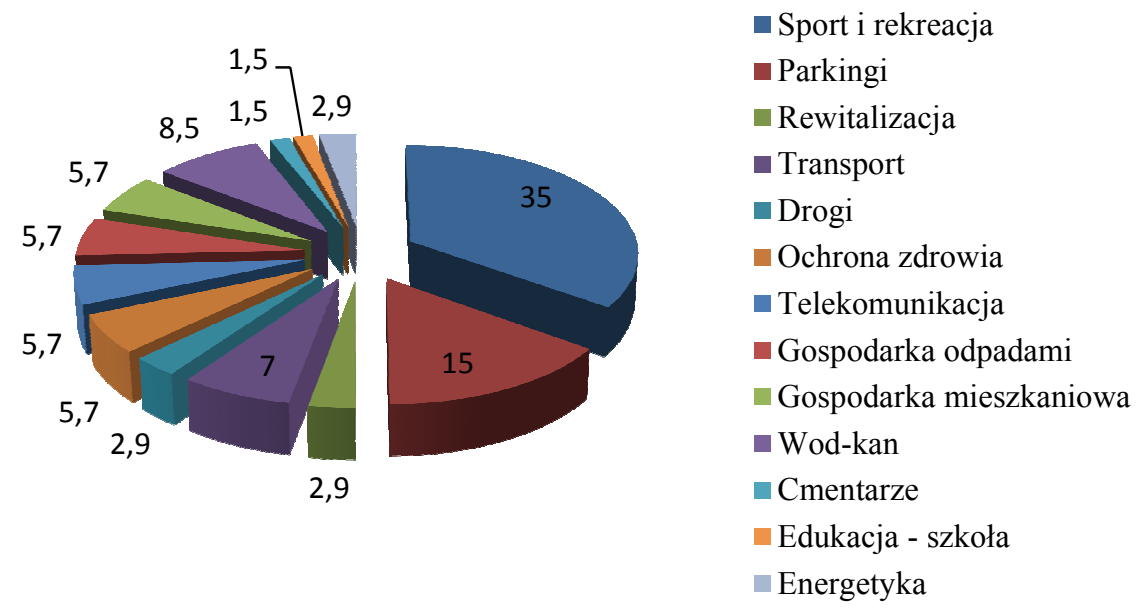

Wykres 5.4. Podział ogłoszeń o wybór partnera prywatnego w poszczególnych sektorach gospodarki w latach 2009-2011 (w \%)

Źródło: oprac. własne na podstawie badania ankietowego 
Struktura przedmiotowa zawartych umów stanowi odzwierciedlenie sektorów gospodarki, gdzie występują największe potrzeby inwestycyjne. Najwięcej zawartych umów - cztery - dotyczy zadań w ramach sportu i rekreacji. Po dwie umowy zawarto $\mathrm{w}$ takich sektorach, jak gospodarka wodno-kanalizacyjna, energetyka, ochrona zdrowia, parkingi, transport publiczny i drogi publiczne, edukacji. Zawarto także po jednej umowie w sprawie wybudowania cmentarza wraz ze spalarnią oraz w zakresie gospodarki odpadami. Strukturę przedmiotową zawartych umów o PPP w latach 2009-2011, uwzględniającą kwestię zamknięcia finansowego, przedstawiono $\mathrm{w}$ tab. 5.5. Wybór takiego przedmiotu umowy podyktowany został $\mathrm{z}$ jednej strony zwiększającymi się potrzebami, $\mathrm{z}$ drugiej zmianami $\mathrm{w}$ przepisach prawnych, zwłaszcza ustawy o utrzymaniu czystości i porządku $\mathrm{w}$ gminach ${ }^{8}$ oraz ustawy o opiece nad dziećmi w wieku do lat trzech, tzw. żłobkowej ${ }^{9}$, które uwypukliły konieczność podjęcia stosownych działań, a także zainteresowanie prywatnych inwestorów tymi sektorami.

Tabela 5.5

Struktura przedmiotowa oraz zamknięcia finansowego zawartych umów o PPP w latach 2009-2011 w Polsce

\begin{tabular}{|c|c|c|c|}
\hline $\begin{array}{l}\text { Nazwa podmiotu } \\
\text { publicznego }\end{array}$ & Nazwa przedsięwzięcia & Sektor & $\begin{array}{c}\text { Zamknięcie } \\
\text { finansowe } \\
\text { przedsięwzięcia }\end{array}$ \\
\hline 1 & 2 & 3 & 4 \\
\hline Gmina Gostynin & $\begin{array}{l}\text { Centralny park Rekreacji, Balneolo- } \\
\text { gii, Turystyki i Wypoczynku Termy } \\
\text { Gostynińskie }\end{array}$ & $\begin{array}{l}\text { sport i re- } \\
\text { kreacja }\end{array}$ & Nie \\
\hline Gmina Gliwice & Zarządzanie krytą pływalnią Neptun & \begin{tabular}{|l|}
$\begin{array}{l}\text { sport i re- } \\
\text { kreacja }\end{array}$ \\
\end{tabular} & Tak \\
\hline Gmina Kiszkowo & $\begin{array}{l}\text { Zbiorowe zaopatrzenie w wodę i od- } \\
\text { prowadzenie ścieków na terenie } \\
\text { gminy }\end{array}$ & \begin{tabular}{|l|} 
gospodarka \\
wodno- \\
kanalizacyjna \\
\end{tabular} & Tak \\
\hline Gmina Kobylnica & $\begin{array}{l}\text { Przebudowa Domu Opieki Społecz- } \\
\text { nej na potrzeby Zakładu Opiekuńczo- } \\
\text { Leczniczego oraz wykonywanie } \\
\text { zadań o charakterze komplementar- } \\
\text { nym }\end{array}$ & $\begin{array}{l}\text { ochrona } \\
\text { zdrowia }\end{array}$ & Tak \\
\hline Gmina Kraków & $\begin{array}{l}\text { Obsługa i administrowanie Zbior- } \\
\text { czym Punktem Gromadzenia } \\
\text { Odpadów }\end{array}$ & $\begin{array}{l}\text { gospodarka } \\
\text { odpadami }\end{array}$ & Tak \\
\hline Gmina Kraków & $\begin{array}{l}\text { Budowa cmentarza wraz z obiektem } \\
\text { ceremonialnym i spopielarnią }\end{array}$ & cmentarze & Tak \\
\hline
\end{tabular}

${ }^{8}$ Ustawa z dnia 1 lipca 2011 r. o zmianie ustawy o utrzymaniu czystości i porządku w gminach oraz niektórych innych ustaw, DzU, 2011, nr 224, poz. 1337.

${ }^{9}$ Ustawa z dnia 4 lutego 2011 r. o opiece nad dziećmi $w$ wieku do lat 3, DzU, 2011, nr 45, poz. 235 . 


\begin{tabular}{|c|c|c|c|}
\hline 1 & 2 & 3 & 4 \\
\hline Gmina Kraków & $\begin{array}{l}\text { Przebudowa przejścia podziemnego } \\
\text { Lubicz-Basztowa wraz z budową } \\
\text { nowych pawilonów handlowych oraz } \\
\text { modernizacją istniejących }\end{array}$ & $\begin{array}{l}\text { drogi } \\
\text { publiczne }\end{array}$ & Tak \\
\hline Gmina Krapkowice & Klub Dziecięcy & edukacja & Tak \\
\hline Gmina Krapkowice & Żłobek & edukacja & Tak \\
\hline Gmina Łazy & $\begin{array}{l}\text { Obsługa przewozów w transporcie } \\
\text { komunalnym na terenie gminy }\end{array}$ & $\begin{array}{l}\text { transport } \\
\text { publiczny }\end{array}$ & Tak \\
\hline Gmina Piecki & Budowa kotłowni na biomasę & energetyka & Tak \\
\hline Gmina Radzionków & $\begin{array}{l}\text { Kompleksowa termomodernizacja } \\
\text { budynków oświatowych }\end{array}$ & energetyka & Tak \\
\hline Gmina Skąpe & \begin{tabular}{|l} 
Zagospodarowanie i zarządzanie \\
kąpieliskiem nad jeziorem Niesłysz \\
w Niesulicach
\end{tabular} & $\begin{array}{l}\text { sport i re- } \\
\text { kreacja }\end{array}$ & Tak \\
\hline Gmina Smołdzino & $\begin{array}{l}\text { Zarządzanie siecią wodno-kana- } \\
\text { lizacyjną }\end{array}$ & $\begin{array}{l}\text { gospodarka } \\
\text { wodno-kana- } \\
\text { lizacyjna }\end{array}$ & Tak \\
\hline Gmina Solec-Zdrój & Kompleks Basenów Mineralnych & $\begin{array}{l}\text { sport i re- } \\
\text { kreacja }\end{array}$ & Tak \\
\hline Gmina Sucha Beskidzka & $\begin{array}{l}\text { Zaprojektowanie, budowa i eksploat- } \\
\text { acja parkingu wraz z myjnią } \\
\text { samochodową }\end{array}$ & parkingi & Tak \\
\hline Gmina Ustka & $\begin{array}{l}\text { Uruchomienie linii przewozów } \\
\text { regularnych dzieci do szkoły i innych } \\
\text { osób }\end{array}$ & $\begin{array}{l}\text { transport } \\
\text { publiczny }\end{array}$ & Tak \\
\hline Gmina Ustka & $\begin{array}{l}\text { Zaprojektowanie i częściowe sfinan- } \\
\text { sowanie przebudowy dróg gminnych } \\
\text { i skrzyżowania z drogą wojewódzką } \\
\text { wraz z budową oświetlenia }\end{array}$ & $\begin{array}{l}\text { drogi } \\
\text { publiczne }\end{array}$ & Tak \\
\hline Gmina Wrocław & $\begin{array}{l}\text { Budowa parkingu podziemnego pod } \\
\text { Placem Nowy Targ, wraz z niezbędną } \\
\text { infrastrukturą }\end{array}$ & parkingi & Tak \\
\hline Powiat Żywiecki & $\begin{array}{l}\text { Zaprojektowanie, budowa i eksploat- } \\
\text { acja parkingu wraz z myjnia } \\
\text { samochodową oraz wyposażenie } \\
\text { wraz z finansowaniem Szpitala } \\
\text { Powiatowego w Żywcu }\end{array}$ & $\begin{array}{l}\text { ochrona } \\
\text { zdrowia }\end{array}$ & $\mathrm{Nie}$ \\
\hline
\end{tabular}

Źródło: oprac. własne na podstawie badania ankietowego.

W ujęciu procentowym strukturę przedmiotową zawartych umów przedstawiono na wykresie 5.5. 


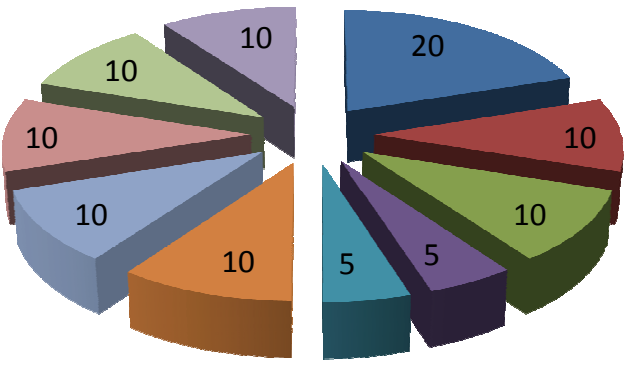

- Sport i rekreacja

- Gospodarka wod-kan

- Ochrona zdrowia

- Gospodarka odpadami

- Cmentarze

Drogi publiczne

Edukacja

- Transport publiczny

Energetyka

Parkingi

Wykres 5.5. Struktura przedmiotowa zawartych umów o partnerstwo publiczno-prywatne w Polsce w latach 2009-2011 (w \%)

Źródło: oprac. własne na podstawie tab. 5.5

W strukturze realizowanych umów PPP dominują przedsięwzięcia związane $\mathrm{z}$ budową basenów wraz z niezbędną infrastrukturą towarzyszącą (20\% rynku umów PPP). Pojedyncze umowy z 5\% udziałem w rynku dotyczyły gospodarki odpadami i wybudowania cmentarza $z$ obiektem ceremonialnym i spopielarnią. Obie umowy zawarte zostały przez Gminę Kraków.

\subsection{Wartość rynku partnerstwa publiczno-prywatnego w Polsce w latach 2009-2011}

Luka finansowa w latach 2011-2022 oszacowana została przez W. M. Orłowskiego $^{10}$ na kwotę 116-197 mld zł. Oznacza to, że takiej kwoty zabraknie w sektorze publicznym, licząc łącznie ze środkami UE, na sfinansowanie potrzeb inwestycyjnych. Gdyby przyjąć, że kwota ta w całości miała być finansowana przedsięwzięciami PPP, to w latach 2011-2022 w Polsce konieczne byłoby ponoszenie rocznych nakładów w tym zakresie na poziomie 4-7 mld zł. Taki też byłby szacunek potencjalnych rocznych wartości rynku PPP w Polsce.

$\mathrm{Na}$ tle zapotrzebowania na PPP analiza wartości rynku przedstawiona będzie w dwóch zbiorach. Pierwszy odnosi się do wartości przedsięwzięć wynikających z zawartych umów, drugi do planowanych przedsięwzięć zgłaszanych przez samorządy. Do wartości rynku PPP w Polsce należy podchodzić ostrożnie, co jest konsekwencją następujących przesłanek:

${ }^{10}$ W. M. Orłowski, Potencjalne makroekonomiczne korzyści stosowania PPP w Polsce, Niezależny Ośrodek Badań Ekonomicznych NOBE, Warszawa 2011, s. 10. 
1) określenie wartości planowanych przedsięwzięć ma jedynie charakter szacunkowy, ponieważ, jak wynika z przeprowadzonego badania, część z nich jest $\mathrm{w}$ fazie projektowania i nie ma pewności, czy zostaną uruchomione procedury zmierzające do wyboru partnera prywatnego,

2) określenie wartości przedsięwzięć objętych umowami nie do końca należy traktować jako ostateczne, ponieważ są one „zamknięte komercyjnie”, ale nie są zamknięte finansowo, a tam gdzie umowa ma charakter warunkowy, wartość przedsięwzięcia nie jest ostatecznie przesądzona.

W latach 2009-2011 samorządy planowały realizację inwestycji na kwotę przeszło $1 \mathrm{mld}$ zł. W odniesieniu do wielu procedura zakończyła się na publikacji ogłoszenia o wybór partnera prywatnego. Dla przedsięwzięć realizowanych łączna wartość, wynikająca z zawartych umów, wyniosła prawie $659 \mathrm{mln}$ zł. Kwota ta obrazuje całkowitą wartość samorządowego rynku PPP w Polsce w latach 2009-2011. W rozbiciu na poszczególne lata wartość umów opiewała odpowiednio: w 2009 r. na kwotę $19 \mathrm{mln}$ zł, w 2010 r. na blisko $345 \mathrm{mln}$ zł, a w $2011 \mathrm{r}$. zawarto umowy w wysokości $295 \mathrm{mln}$ zł.

Wśród zawartych umów przeważają kontrakty dotyczące realizacji przedsięwzięć o małej wartości (do $5 \mathrm{mln}$ zł). W tym przedziale cenowym ogłoszono ich łącznie 11, co stanowi 55\% zawartych umów. Drugą grupę stanowią umowy dla PPP o wartości z przedziału od 5 do $50 \mathrm{mln}$ zł. Zawarto łącznie siedem takich umów (35\%). W latach 2010-2011 zawarto też dwie umowy na duże inwestycje (10\% rynku). W $2010 \mathrm{r}$. umowę warunkową na kwotę $285 \mathrm{mln}$ zł zawarła Gmina Gostynin, a w 2011 r. ten sam typ umowy zawarł powiat żywiecki na kwotę $240 \mathrm{mln}$ zł. Te dwa kontrakty zaważyły w latach 2010-2011 na strukturze wartościowej rynku PPP (wykres 5.6).

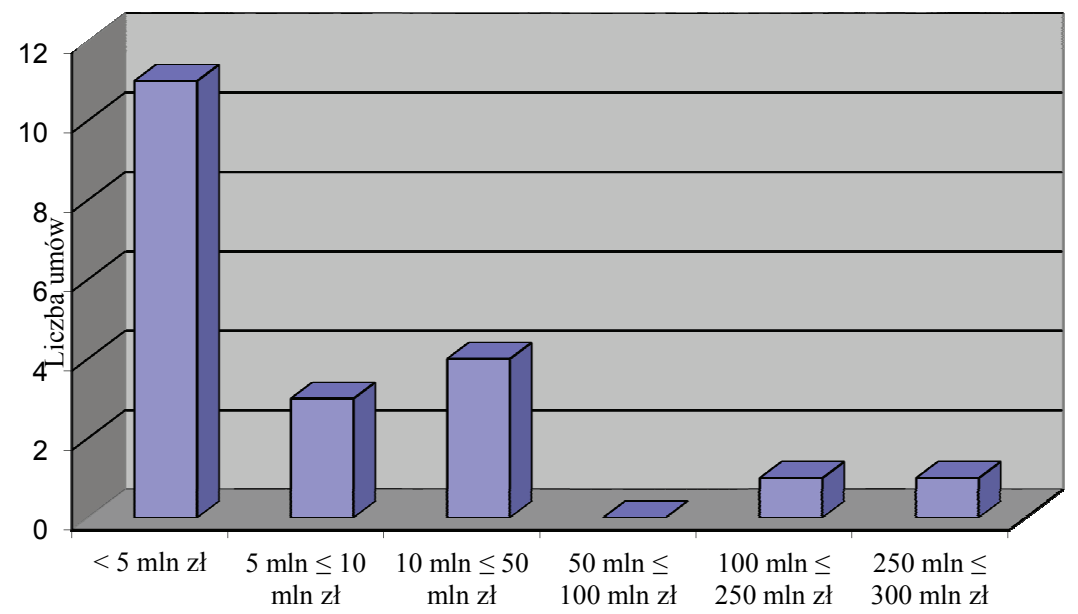

Wykres 5.6. Liczba zawartych umów według wartości przedsięwzięcia w latach 2009-2011 (w mln zł)

Źródło: oprac. własne na podstawie badania ankietowego 
Analiza zamkniętych finansowo umów ujawnia specyfikę polskiego ryn$\mathrm{ku}$, polegającą na tym, że w ramach PPP realizuje się małe zadania inwestycyjne $\mathrm{z}$ dominującą wartością $\mathrm{w}$ przedziale od 1 do $50 \mathrm{mln} \mathrm{zl}$, co nie jest powszechne $\mathrm{w}$ przedsięwzięciach zagranicznych ${ }^{11}$. Biorąc pod uwagę małą liczbę umów i krótki okres analizy, jaki upłynął od pierwszych ogłoszeń i pierwszych zawartych umów, nie jest uzasadnione wyciąganie daleko idących wniosków. Przewaga małych przedsięwzięć może być spowodowana następującymi przesłankami:

1) mniej skomplikowanymi przedsięwzięciami, niepowodzenie w przypadku których nie spowoduje „katastrofalnych” skutków finansowych dla podmiotu publicznego,

2) możliwością ewentualnego wycofania się z umowy,

3) łatwiejszą i szybszą procedurą wyboru wykonawcy przedsięwzięcia,

4) łatwiejszym dostępem do finansowania $z$ uwagi na małe rozmiary przedsięwzięcia,

5) koniecznością tworzenia procedur realizacji formuły PPP $\mathrm{z}$ uwagi na brak polskich rozwiązań w tym obszarze.

Podstawową przyczyną niskiej wartości przedsięwzięć realizowanych w formule PPP jest brak zaangażowania władzy publicznej szczebla centralnego $\mathrm{w}$ ich wykonanie, co powoduje brak wypracowania dobrych praktyk w tym obszarze. Ponadto zaangażowanie samorządów w przedsięwzięcia o wysokiej wartości w przypadku ich niepowodzenia staną się przedmiotem silnej krytyki społeczno-politycznej. Jednocześnie trzeba podkreślić, że w świetle przeprowadzonej analizy optymizmem napawają plany władz samorządowych co do obszaru i wartości planowanych przedsięwzięć w formule PPP. Z badań wynika, że ich wartość będzie rosła $\mathrm{w}$ efekcie nabywania doświadczeń oraz dzięki zaangażowaniu $\mathrm{w}$ przedsięwzięcia infrastrukturalne wymagające wysokich nakładów, np. inwestycje drogowe w województwie dolnośląskim.

${ }^{11}$ W Europie w 2011 r. łączna wartość transakcji PPP wyniosła 17,9 mld euro. Średnia wartość zamkniętego komercyjnie i finansowo projektu PPP w 2011 r. wzrosła do $213 \mathrm{mln}$ euro w porównaniu ze $163 \mathrm{mln}$ euro z $2010 \mathrm{r}$. Jeśli wyłączymy z kwoty $213 \mathrm{mln}$ euro projekt kolejowy Tours-Bordeaux we Francji za 5,4 mld, to wówczas średnia wartość transakcji spadnie do $150 \mathrm{mln}$ euro. Należy podkreślić, że w 2011 r. 84 kontrakty uzyskały zamknięcie finansowe (112 w 2010 r., 118 w 2009 r.); Market Update. Review of the European PPP Market in 2011, European PPP Expertise Centre EPEC, s. 3. 


\subsection{Analiza umów o partnerstwo publiczno-prywatne zawartych przez jednostki samorządu terytorialnego w latach 2009-2011}

\subsubsection{Model współpracy wynikający $z$ umowy o partnerstwie publiczno-prywatnym}

Analiza zawartych przez polskie samorządy umów o partnerstwo publicznoprywatne pozwala określić czas i sektor współpracy pomiędzy stronami umowy. Na szczególną uwagę zasługuje sama struktura i objętość umów. Z uwagi na skomplikowany charakter formuły partnerstwa publiczno-prywatnego, konstrukcja zawartych w latach 2009-2011 umów jest zróżnicowana. Poza oczywistymi różnicami wynikającymi z charakteru inwestycji, tj. ceny, czasu trwania umowy, praw i obowiązków stron, podziału odpowiedzialności za poszczególne ryzyka, uwagę „przykuwa” objętość poszczególnych dokumentów. Z uwagi na przestrzeganie zobowiązania do zachowania tajemnicy zapisów w zakresie wszelkich danych prawnych, finansowych, technologicznych, organizacyjnych analiza musi być przedstawiona w sposób nienaruszający interesu jednostek samorządu terytorialnego i partnerów prywatnych, które $\mathrm{w}$ analizowanym okresie zawarły umowę o partnerstwo publiczno-prywatne.

Idea partnerstwa publiczno-prywatnego wskazuje, że jest to współpraca długookresowa. Od modelu wynagrodzenia partnera prywatnego oraz podziału ryzyka zależy tryb wyboru partnera prywatnego przy wykonaniu przedsięwzięcia w modelu PPP. Może on nastąpić, tak jak to zostało wcześniej wspomniane, na podstawie przepisów Prawa zamówień publicznych bądź przepisów ustawy o koncesji na roboty budowlane lub usługi. Z uwagi na niewielką liczbę zawartych umów wypada stwierdzić, że najbardziej popularnym rodzajem kontraktu jest koncesja. Samorządowcy uważają, że nie wymaga ona złożonych procedur i w stosunkowo krótkim czasie może dojść do jej podpisania. Klasyczne PPP w chwili obecnej stosowane jest sporadycznie (pięć umów). Dodatkowo potwierdzeniem ułomności polskiego rynku, braku doświadczeń i złożoności formuły jest fakt, że do dziś nie powstała jeszcze ani jedna spółka celowa.

Umowy koncesji na usługi stanowią najliczniejszą grupę kontraktów typu PPP. Samorządowcy zawierają te umowy $\mathrm{z}$ uwagi na możliwość poznania specyfiki zarządzania nimi. Przedsięwzięcie PPP zasadniczo różni się od tradycyjnego zamówienia publicznego (opartego na Prawie zamówień publicznych). Przy tradycyjnym zamówieniu publicznym zamawiający kupuje usługę. W partnerstwie ważna jest współpraca, podział zobowiązań, stały monitoring i kontrola podmiotu prywatnego. Poza tym umowy koncesji zawierane są z reguły na krótszy okres, co sprzyja ewentualnemu rozwiązaniu lub niepodejmowaniu w przyszłości takiego rozwiązania przy wykonywaniu usługi publicznej. W latach 2009-2011 łącznie samorządy zawarły osiem umów koncesji na usługi.

Dużym powodzeniem cieszyły się także rozwiązania wynikające z koncesji na roboty budowlane. Łącznie podpisanych zostało siedem takich umów. Wiele 
ogłoszonych postępowań o koncesję na roboty budowlane zakończyło się unieważnieniem. Główną przyczyną była niechęć prywatnych inwestorów do angażowania się w przedsięwzięcia obarczone dużym ryzykiem ekonomicznym, koniecznością przekazania wytworzonej infrastruktury podmiotowi publicznemu po zakończeniu umowy oraz obawą, że okres umowy nie jest wystarczający, aby uzyskać zwrot poniesionych nakładów.

Dla pięciu przedsięwzięć zawarto „klasyczną” umowę partnerstwa publiczno-prywatnego. Podpisanie umowy poprzedzone było postępowaniem przetargowym prowadzonym w tradycyjnej formie zamówienia publicznego. Zapewniło to stronie samorządowej możliwość przestrzegania zasad przejrzystości, niedyskryminacji i konkurencyjności, a także doprecyzowania specyfikacji istotnych warunków zamówienia (SIWZ) dla celów przyszłej umowy (wykres 5.7).

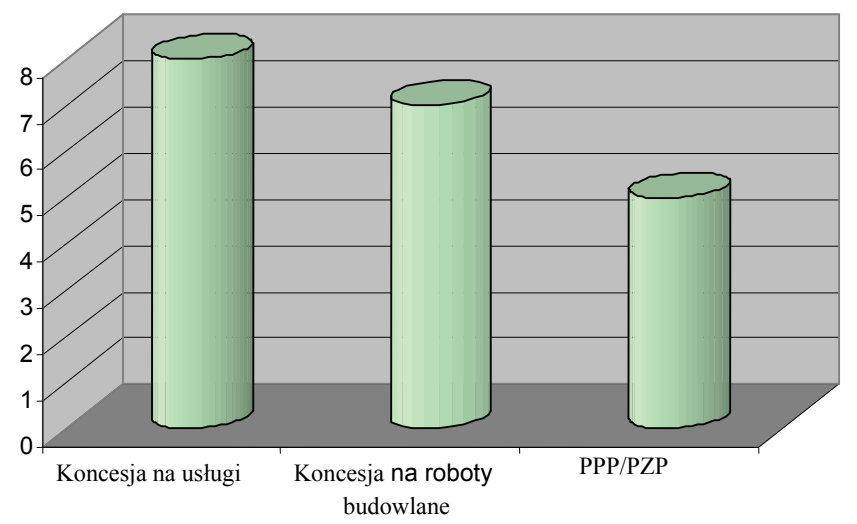

Wykres 5.7. Liczba zawartych umów według modelu współpracy w latach 2009-2011 Źródło: oprac. własne na podstawie badania ankietowego
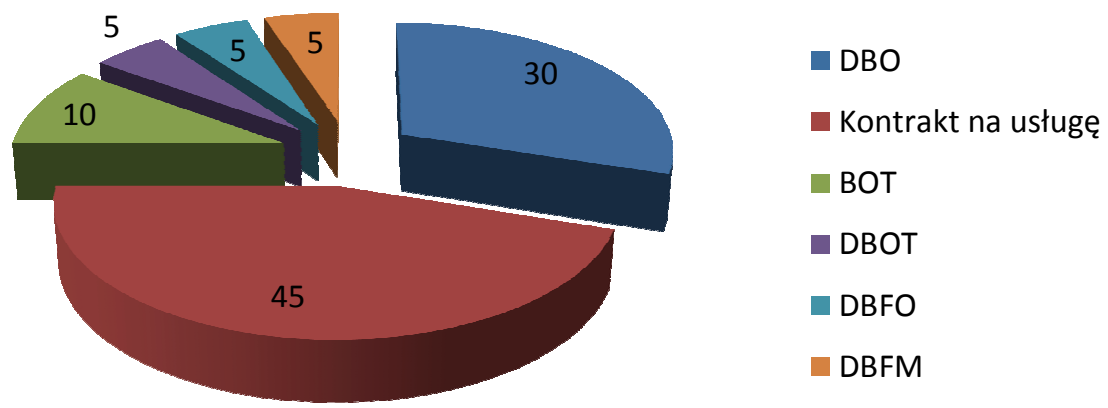

Wykres 5.8. Udział poszczególnych modeli realizacji przedsięwzięć na rynku umów o PPP w Polsce w latach 2009-2011 (w \%)

Źródło: oprac. własne na podstawie badania ankietowego 
Szczegółowa forma modelu współpracy pomiędzy stroną publiczną a partnerem prywatnym każdorazowo dostosowana została do charakteru przedsięwzięcia inwestycyjnego. W teorii wyróżnia się wiele modeli, w praktyce często zostają one dostosowane do potrzeb konkretnej inwestycji. Zawarte umowy w $75 \%$ przyjęly postać koncesji, 25\% umów zawarto zaś o partnerstwo publiczno-prywatne. Struktura kapitału i podział ryzyk pomiędzy strony umowy w praktyce spowodowały, że koncesje przybrały różne formy, co zaprezentowano na wykresie 5.8.

Wśród dominujących były kontrakty na usługi - dziewięć umów, stanowiących 45\% wszystkich form, następnie koncesje typu DBO - sześć umów (30\%), BOT $(10 \%)$ oraz po jednej umowie w ramach koncesji DBOT, DBFO, DBFM odpowiadających 5\% udziałowi spośród zastosowanych form współpracy pomiędzy sektorem publicznym a sektorem prywatnym.

\subsubsection{Czas trwania umowy o partnerstwo publiczno-prywatne}

Jednym z kryteriów wyboru partnera prywatnego jest czas trwania umowy. Nie we wszystkich ogłoszeniach taka informacja została zamieszczona. Tam, gdzie czas określono, nie zawsze pokrywał się on z tym podanym w umowie. Jest to efekt negocjacji w trakcie postępowania przetargowego. Najwięcej umów dotyczyło przedziału od 5 do 15 lat oraz od 15 do 30 lat. Są to umowy koncesji na roboty budowlane lub koncesji na usługi. Cztery przedsięwzięcia będą realizowane $\mathrm{w}$ okresie nie przekraczającym 5 lat. Umowa pomiędzy Wrocławiem a konsorcjum ${ }^{12}$ na wybudowanie parkingu podziemnego zawarta została na 40 lat i jest jak dotychczas najdłuższa. Liczbę przedsięwzięć uwzględniających czas trwania umowy zaprezentowano na wykresie 5.9.

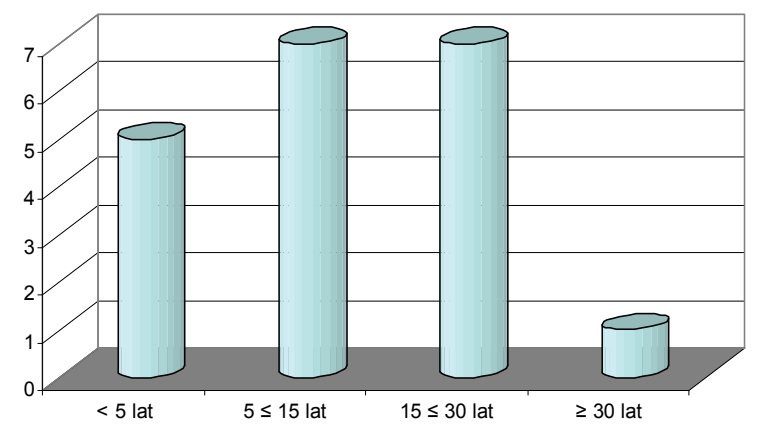

Wykres 5.9. Liczba przedsięwzięć ze względu na czas trwania umowy w latach 2009-2011 Źródło: oprac. własne na podstawie badania ankietowego

${ }^{12}$ Konsorcjum utworzone zostało 15 maja 2009 r. W jego skład wchodzi pięć podmiotów: Mota-Engil Central Europe S.A, Mota-Engil, Engenharia e Construcao S.A, EMSA - EMPREFENDIMENTOS E EXPLORACAO DE ESTACIONAMENTOS, ESLI - Parques de estacionamento S.A, IMMC Park Sp. z o.o. 
Mała liczba umów zawartych oraz krótki czas nie pozwala jednoznacznie stwierdzić, czy istnieje korelacja pomiędzy czasem obowiązywania umowy a modelem współpracy. Na chwilę obecną zauważalna jest tendencja, która wskazuje, że koncesja na usługi wybierana była najczęściej do przedsięwzięć związanych ze świadczeniem usług nie przekraczających pięcioletniego okresu, które jednocześnie nie wymagają wysokiego zaangażowania kapitałowego (por. wykres 5.10). Uwzględniając czas trwania umowy oraz wartość, zauważalna jest korelacja. Kapitałochłonne inwestycje wymagają dłuższego okresu zwrotu poniesionych nakładów. Nieprzypadkowo dwa przedsięwzięcia nie mają jeszcze zamknięcia finansowego, gdyż należą do skomplikowanych i trudnych tematycznie - szpital w Żywcu oraz dużych wartościowo - Termy Gostynińskie. Postępowania przetargowe $\mathrm{w}$ tych dwóch przypadkach także prowadzone były na podstawie innych przepisów. Budowa szpitala powiatowego w Żywcu jest klasyczną umową o PPP uwzględniającą przepisy zamówień publicznych, umowa dotycząca budowy Term jest zaś koncesją na roboty budowlane.

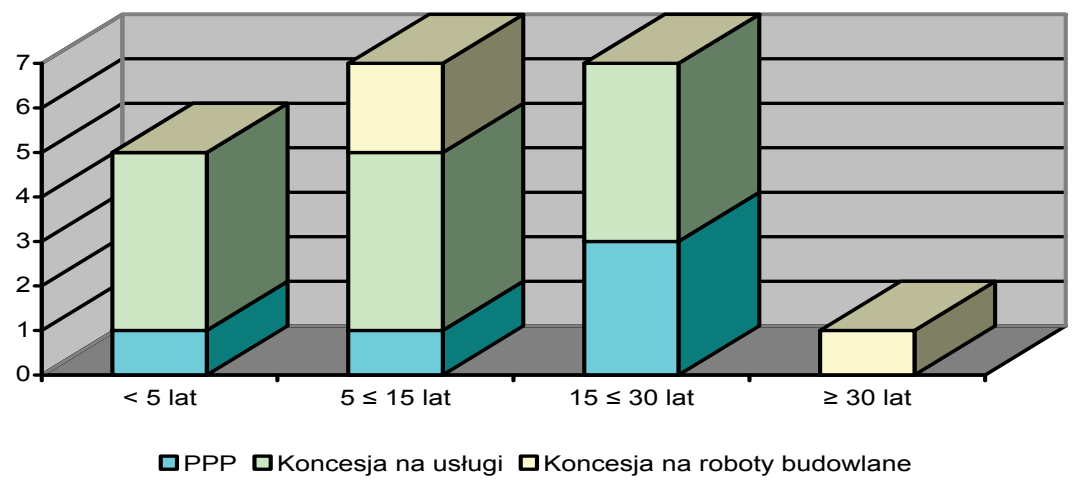

Wykres 5.10. Liczba umów ze względu na czas trwania i model współpracy w latach 2009-2011

Źródło: oprac. własne na podstawie badania ankietowego

Jak wynika z badań, brak ramowych umów powoduje, że każda jednostka samorządu sama wypracowała własne rozwiązania. Ich skuteczność, a nawet uniwersalność, będzie można ocenić dopiero w przyszłości, kiedy będą znane wszystkie prawno-finansowe i organizacyjne efekty, a na to przyjdzie poczekać jeszcze kilkanaście lat. Niemniej jednak są to już pierwsze doświadczenia, które mogą stać się wzorem, a nawet standardem, dla przyszłych przedsięwzięć. Konieczne jednak jest stworzenie centralnej bazy dla umów. Zdaniem autorki taka baza powinna zostać utworzona na szczeblu centralnym, tak jak zorganizowano to np. w Wielkiej Brytanii czy Irlandii. 


\subsubsection{Podzial zadań i ryzyk $w$ umowie o partnerstwo publiczno-prywatne w latach 2009-2011}

Filarem współpracy sektora publicznego z sektorem prywatnym jest takie kształtowanie stosunków, które prowadzi do podziału zadań i ryzyk pomiędzy strony umowy. Każdy proces inwestycyjny obarczony jest możliwością wystąpienia ryzyka. W PPP kluczowy element stanowi jego alokacja. W interesie stron jest takie rozmieszczenie poszczególnych kategorii ryzyk, aby zarządzała nimi ta, która zrobi to najlepiej i jest do zarządzania ryzykiem najlepiej przygotowana. Ta możliwość powoduje, że partnerstwo cechuje unikalność w odróżnieniu od tradycyjnych rozwiązań. Właściwy rozkład ryzyk decyduje o efektywności przedsięwzięcia. Ponadto strona publiczna zainteresowana jest przeniesieniem możliwie jak największej liczby ryzyk na podmiot prywatny. $\mathrm{Z}$ analizy umów jednoznacznie wynika, że podmiot publiczny już w ogłoszeniu zamieszczonym w „Biuletynie Zamówień Publicznych” i/lub „Dzienniku Urzędowym Unii Europejskiej” zamieszczał propozycję podziału ryzyk. W drodze negocjacji kwestie te były doprecyzowywane.

Partnerstwo publiczno-prywatne realizowane w formie koncesji, $\mathrm{z}$ uwagi na możliwość przeniesienia większości ryzyk ekonomicznych na partnera prywatnego, a tym samym odciążenie budżetu, stanowi preferowany sposób wykonania inwestycji lub świadczenia usługi publicznej. Zawarte umowy wyraźnie potwierdzają, że strona publiczna przerzuca większość ryzyk na podmiot prywatny. Analiza zawartych umów pozwala stwierdzić, że w 19 kontraktach ryzyko ekonomiczne w całości lub części przejął na siebie prywatny inwestor. Jest to konsekwencją dążenia strony publicznej do minimalizowania obciążeń budżetowych.

Ryzyko budowy we wszystkich realizowanych przedsięwzięciach budowlanych znalazło się $\mathrm{w}$ zarządzaniu partnera prywatnego. Ryzyko popytu tylko w czterech inwestycjach usytuowano po stronie publicznej, a ryzyko dostępności $\mathrm{w}$ trzech. Ryzyka środowiskowe przejął na siebie sektor publiczny (jedna umowa), natomiast ryzyko uzyskania koniecznych pozwoleń i uzgodnień raz przejął podmiot publiczny, a raz prywatny. Ryzyko polityczne i społeczne w większości zidentyfikowanych przypadków przeniesiono na stronę publiczną. $\mathrm{Z}$ ankiety wynika, że sposobem minimalizacji tych ryzyk była kampania informacyjna przebiegająca $\mathrm{w}$ lokalnych mediach oraz poprzez strony internetowe jednostek samorząa terytorialnego. We wszystkich podpisanych umowach, w których przedsięwzięcie wymagało budowy, modernizacji, zidentyfikowane ryzyko zminimalizowano poprzez konieczność zawarcia ubezpieczenia przez wykonawcę i ewentualnych podwykonawców i przedstawienia go zamawiającemu. Samorządy domagały się także przedstawienia stosownych ubezpieczeń ze strony podwykonawców, w sytuacji gdy główny inwestor będzie zawierał umowy podwykonawcze. 
Ważną kwestię w kontraktach stanowi sposób wynagrodzenia partnera prywatnego. W ustawie o partnerstwie publiczno-prywatnym ustawodawca zdecydował się na prawne usankcjonowanie wynagrodzenia partnera prywatnego. Mechanizm ustalenia wynagrodzenia uzależniony został od rzeczywistego wykonania lub faktycznej dostępności przedmiotu umowy o $\mathrm{PPP}^{13}$.

Zarysowują się trzy zasadnicze tego sposoby:

- pożytki - prawo do wyłącznego pobierania przez podmiot prywatny opłat od użytkowników (odbiorców) za świadczoną usługę, np. czynszu, opłata za dostarczenie usługi;

- opłaty za dostępność - opłaty na rzecz partnera prywatnego pochodzące od podmiotu publicznego, np. miesięczny ryczałt;

- model mieszany - łączy w sobie możliwość pobierania pożytków i wnoszenia opłat przez podmiot publiczny.

Uzależnienie wysokości wynagrodzenia od rzeczywistego wykorzystania lub faktycznej dostępności przedmiotu umowy o PPP stanowi wyraz troski $\mathrm{o}$ interes podmiotu publicznego, a w szerszym sensie o interes publiczny. Zamierzeniem ustawodawcy było wyeliminowanie sytuacji, w której model wynagrodzenia będzie istotnie odbiegał od popytu na świadczone usługi lub od ich jakości, gwarantując jednocześnie partnerowi prywatnemu wynagrodzenie z góry ustalonej wysokości przez okres trwania umowy. Zaletą takiego rozwiązania jest obowiązek zapewnienia przez podmiot prywatny atrakcyjności korzystania z przedmiotu partnerstwa, poprzez np. świadczenie usług o wysokiej jakości, przy równoczesnym utrzymaniu opłat na poziomie akceptowalnym przez odbiorców. Jednocześnie podmiot publiczny musi zagwarantować sobie kontrolę nad kształtowaniem wysokości opłat. Jest to szczególnie istotne w przypadku świadczenia usług $\mathrm{w}$ warunkach monopolu naturalnego.

Praktyka dopuszcza także sytuacje, w których wynagrodzenie będzie miało charakter mieszany. Partner prywatny będzie pobierał niewielkie opłaty od ostatecznego odbiorcy oraz, jednocześnie, uzyskiwał wynagrodzenie za dostępność od podmiotu publicznego. Zastosowanie tego modelu pozwala na wyeliminowanie syndromu free-riding. Każdy korzystający z przedsięwzięcia PPP będzie, choćby w najmniejszym stopniu, musiał zapłacić za usługę ze swoich środków. Wysokość wynagrodzenia uzależniona jest od zapewnienia przez niego dostępności przedmiotu partnerstwa. Kwoty uzyskane od użytkowników są potrącane z płatności podmiotu publicznego. Takie rozwiązanie określane jest jako model dzielenia zysków tzw. profit-sharing. Zestawienie podstawowych elementów umów o PPP zawartych w latach 2009-2011 przez jednostki samorządu, tj. podziału zadań, ryzyk, formę wynagrodzenia partnera prywatnego oraz rodzaj wkładu własnego podmiotu publicznego przedstawiono w tab.5.6.

${ }^{13}$ Uzależnienie to wynika bezpośrednio z zapisu art. 7 ust. 2 Ustawy z dnia 19 grudnia 2008 r. o partnerstwie publiczno-prywatnym, DzU, 2009, nr 19, poz. 100 ze zm., zgodnie z którym „wynagrodzenie partnera prywatnego zależy przede wszystkim od rzeczywistego wykorzystania lub faktycznej dostępności przedmiotu partnerstwa publiczno-prywatnego". 


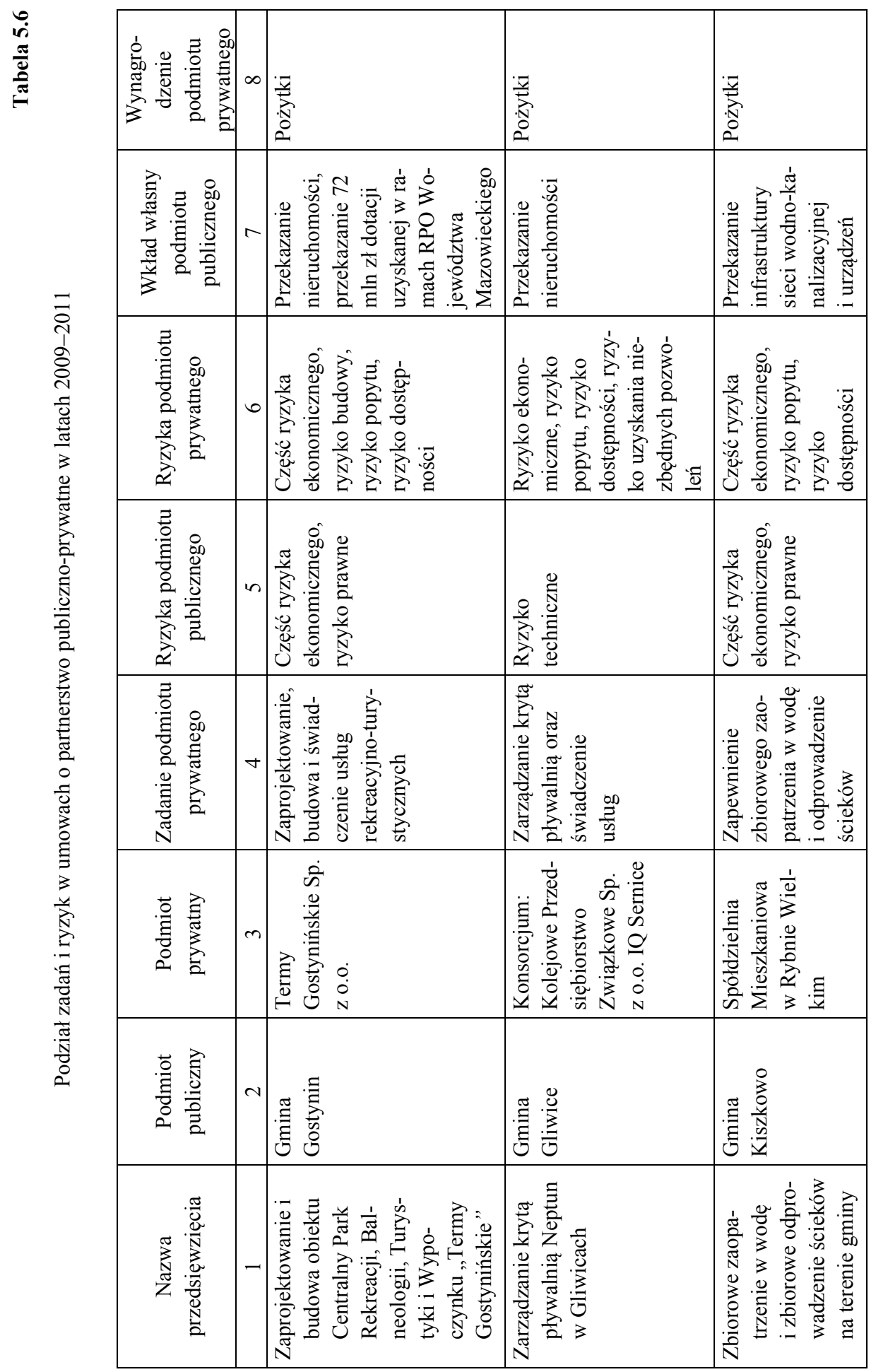




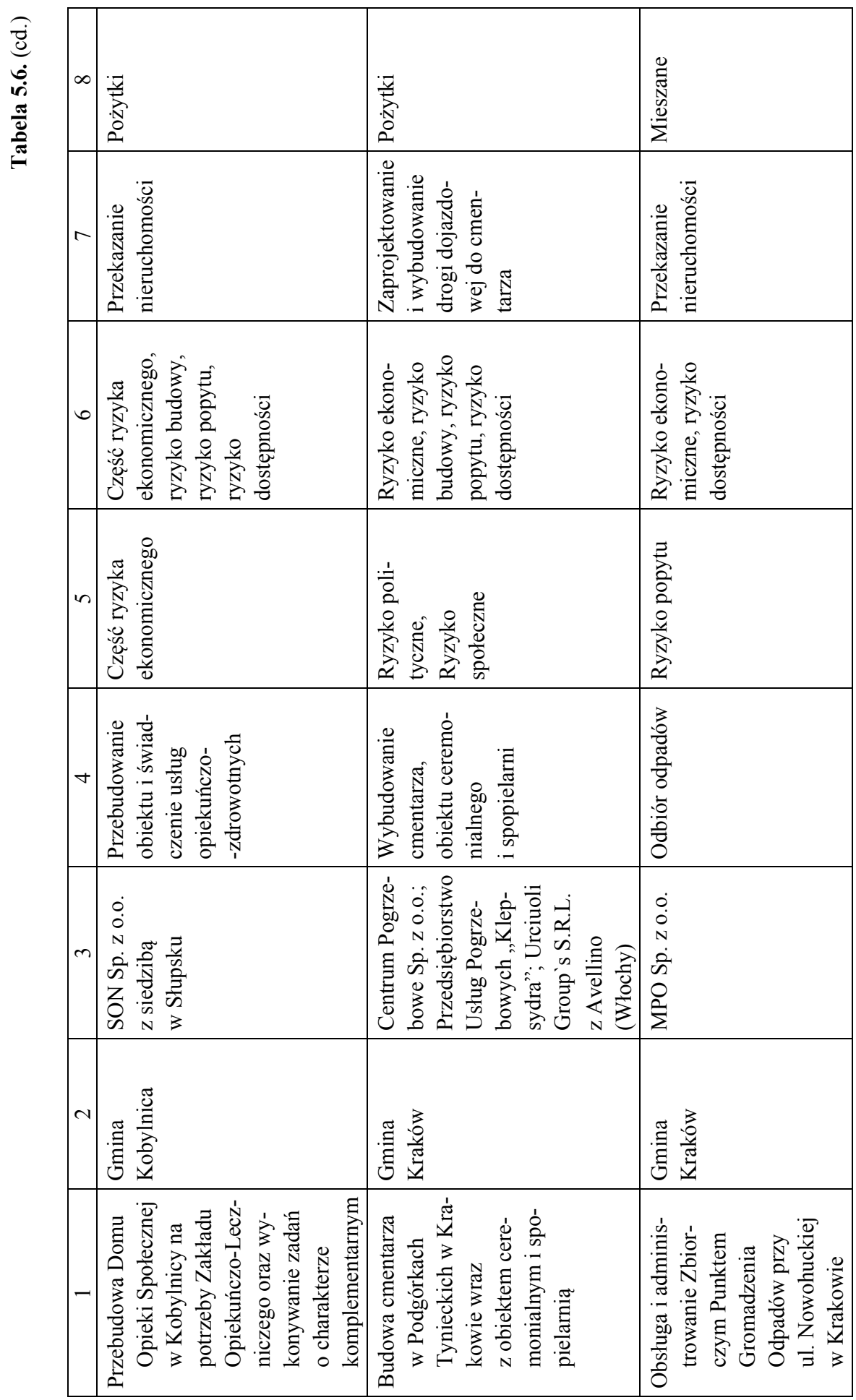




\begin{tabular}{|c|c|c|c|}
\hline$\infty$ & & 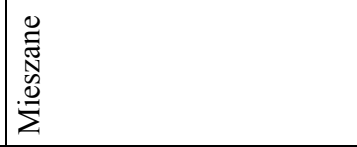 & 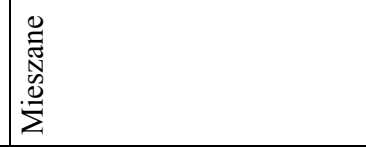 \\
\hline & 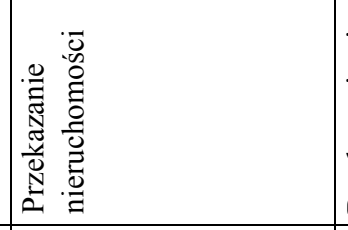 & 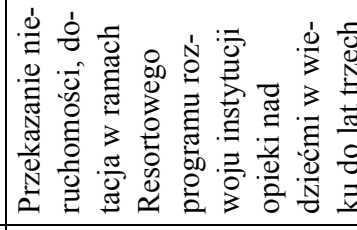 & 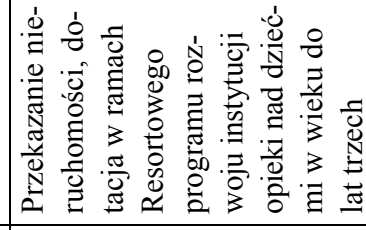 \\
\hline & 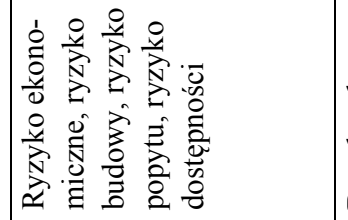 & 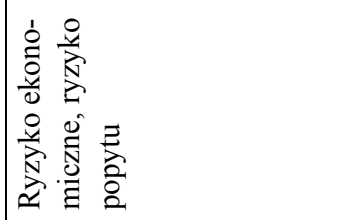 & 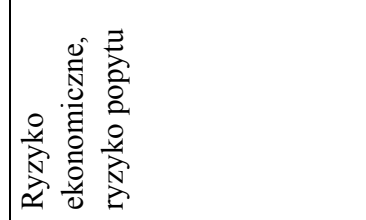 \\
\hline 1 & 离 & 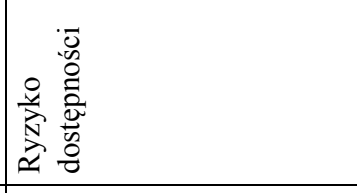 & 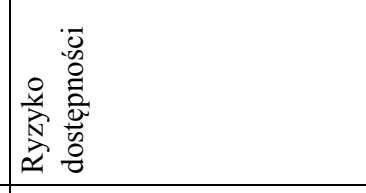 \\
\hline & 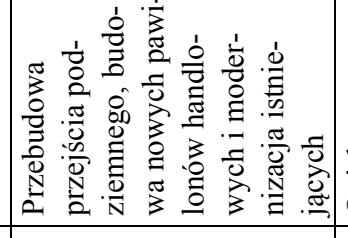 & 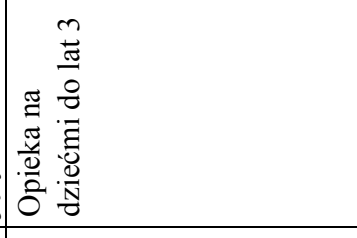 & 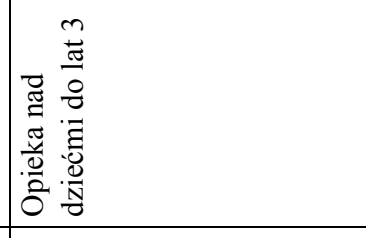 \\
\hline & 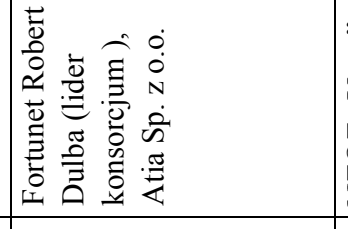 & 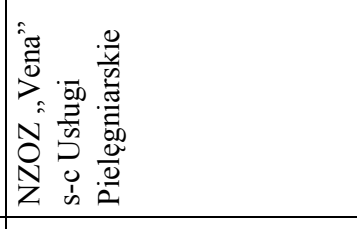 & 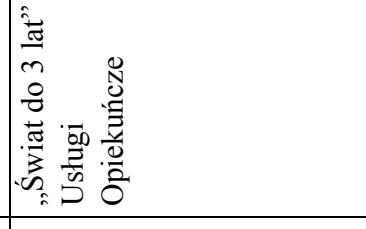 \\
\hline & 畄递 & 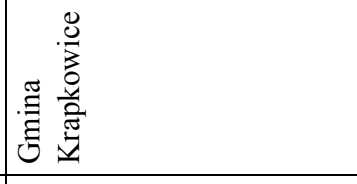 & 总 \\
\hline & 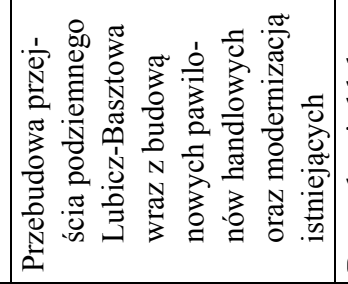 & 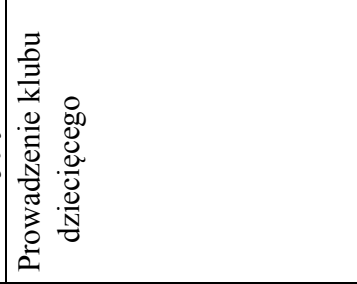 & 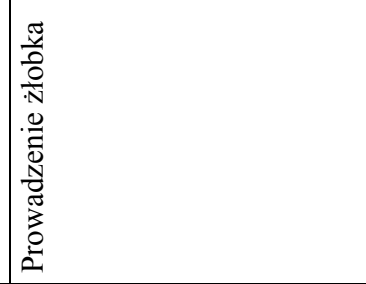 \\
\hline
\end{tabular}




\begin{tabular}{|c|c|c|}
\hline 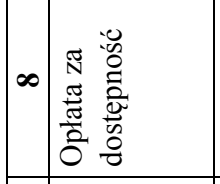 & 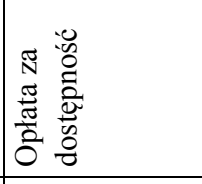 & 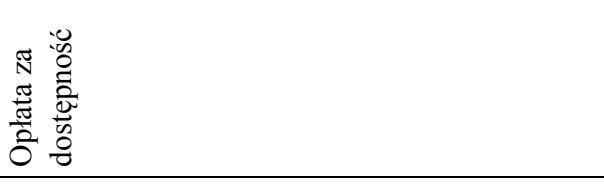 \\
\hline 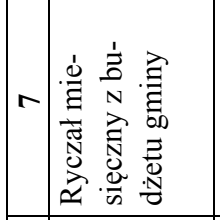 & 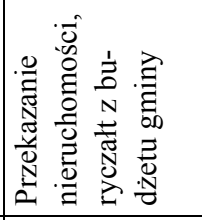 & 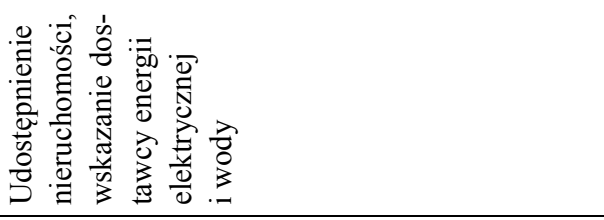 \\
\hline 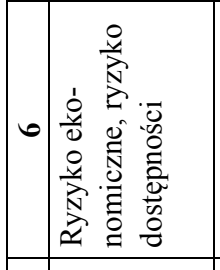 & 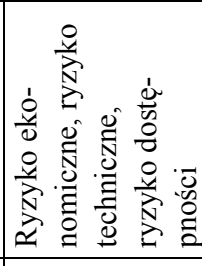 & 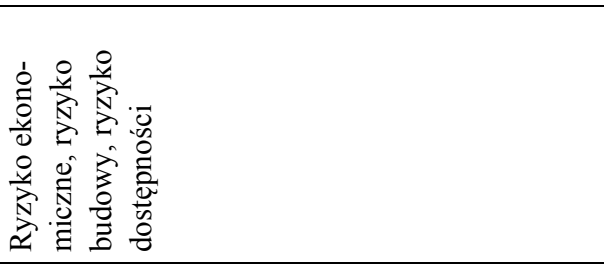 \\
\hline m & 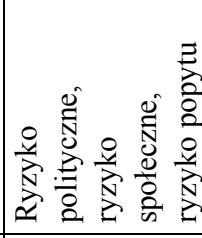 & 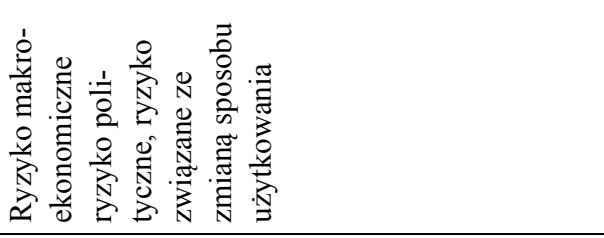 \\
\hline 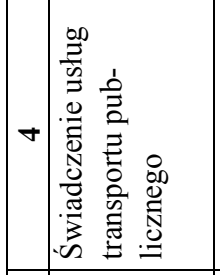 & 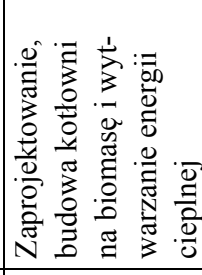 & 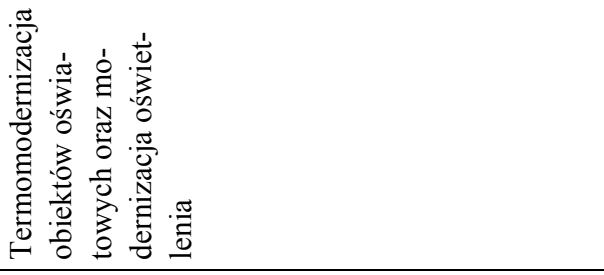 \\
\hline 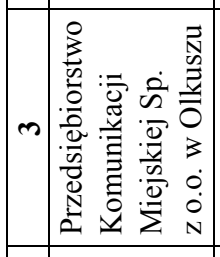 & 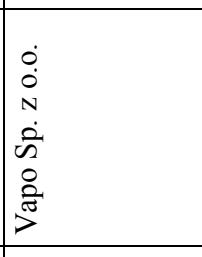 & 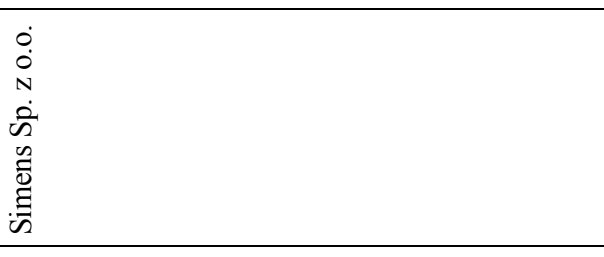 \\
\hline 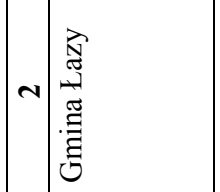 & 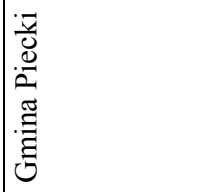 & 莡 \\
\hline 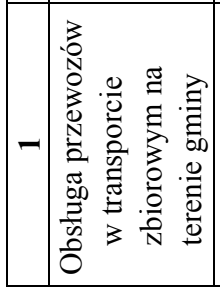 & 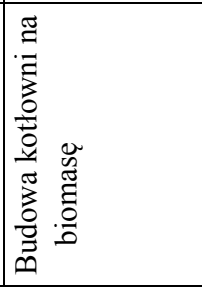 & 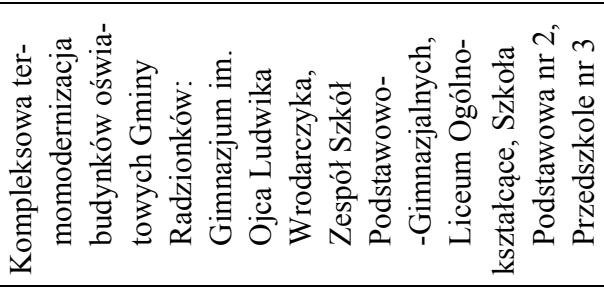 \\
\hline
\end{tabular}




\begin{tabular}{|c|c|c|c|c|}
\hline 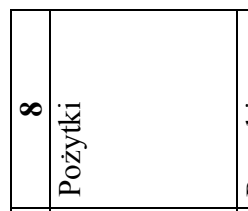 & 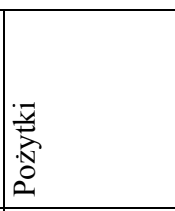 & 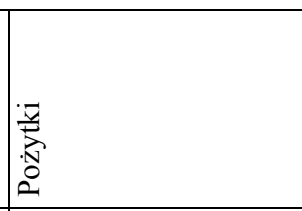 & 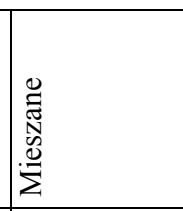 & 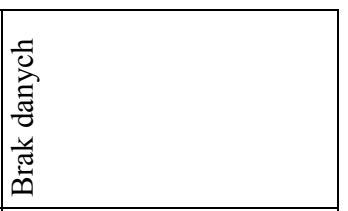 \\
\hline 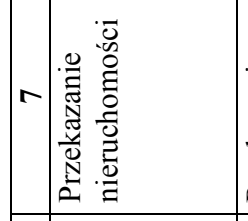 & 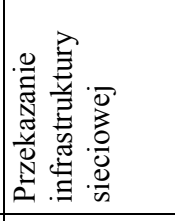 & 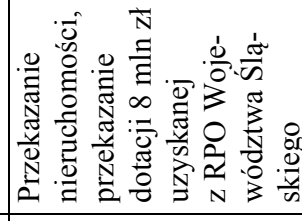 & 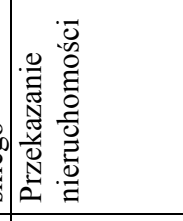 & 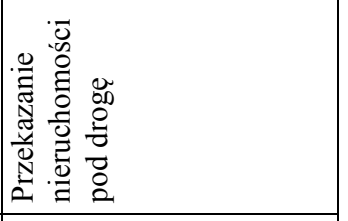 \\
\hline 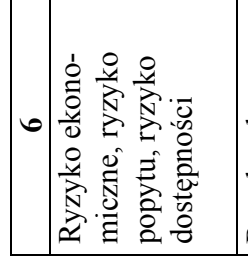 & 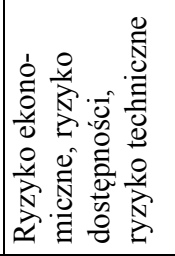 & 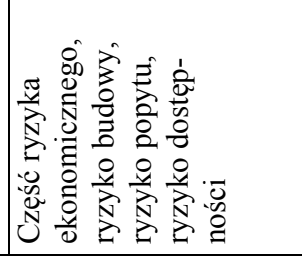 & 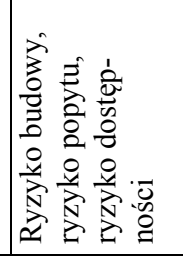 & 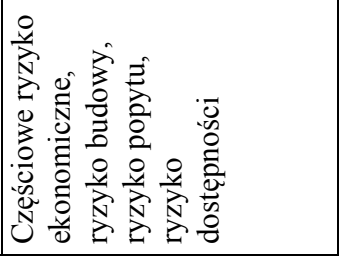 \\
\hline 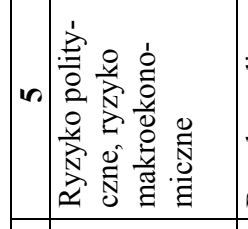 & 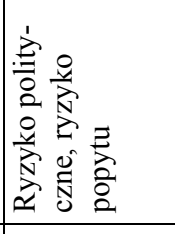 & 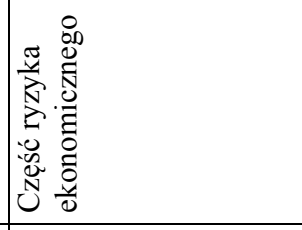 & 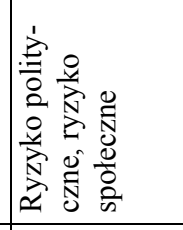 & 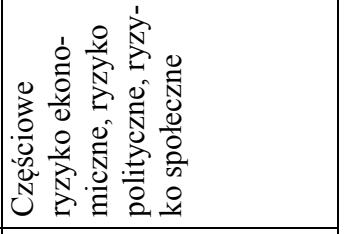 \\
\hline 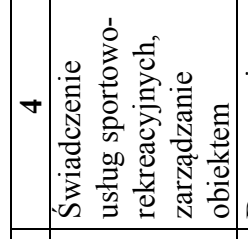 & 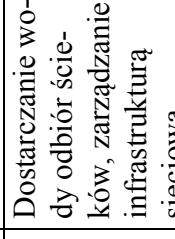 & 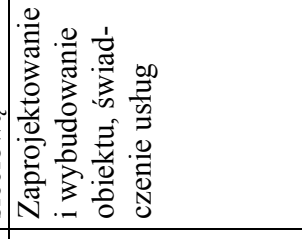 & 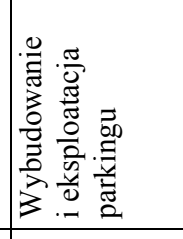 & 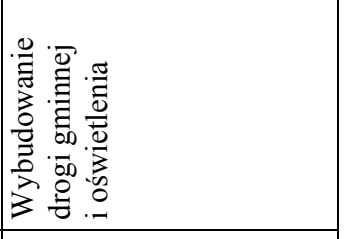 \\
\hline 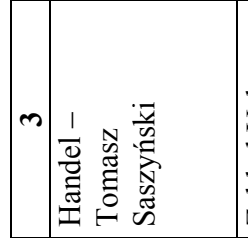 & 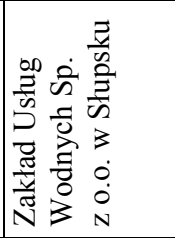 & 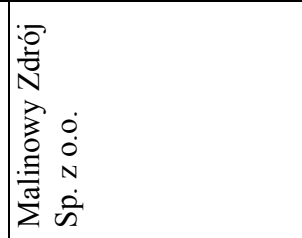 & 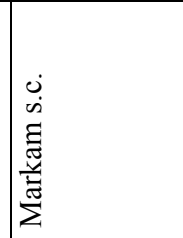 & 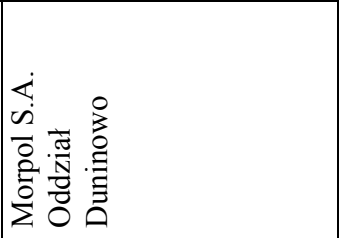 \\
\hline ^ & 音 & 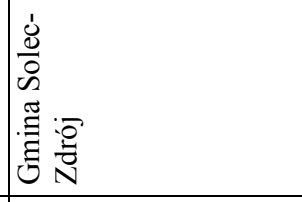 & 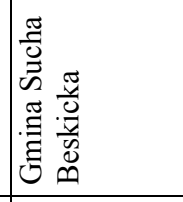 & 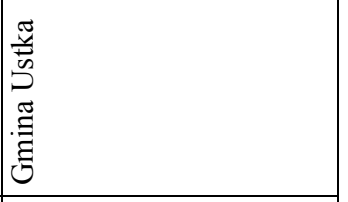 \\
\hline 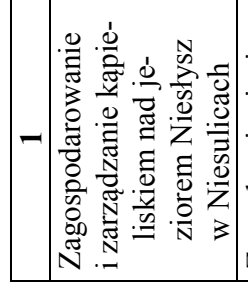 & 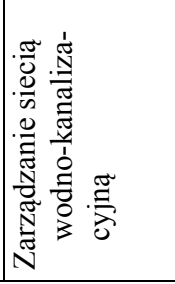 & 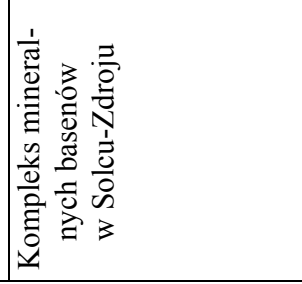 & 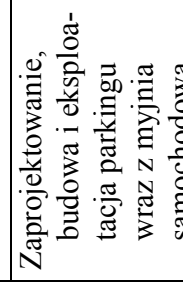 & 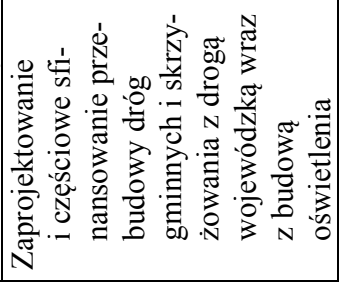 \\
\hline
\end{tabular}




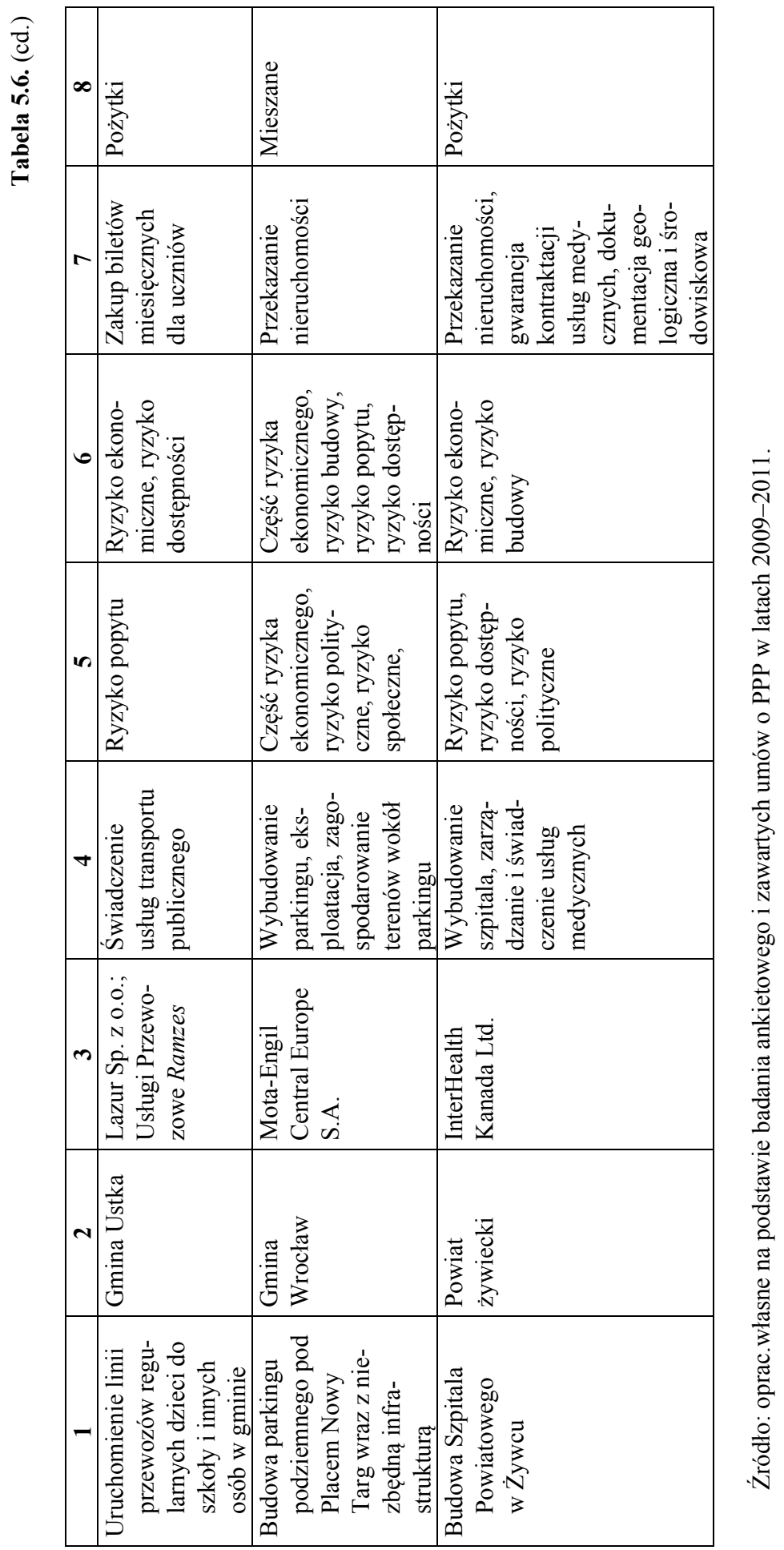


$\mathrm{Z}$ badania wynika, że w większości realizowanych umów przewiduje się pobieranie przez partnera prywatnego pożytków (dziesięć umów). Drugim co do częstotliwości sposobem wynagrodzenia jest model mieszany, co pozwala partnerowi prywatnemu na pobieranie opłat za dostarczanie usług oraz pozyskanie płatności z budżetu gminy. Najczęściej płatność przybiera formy ryczałtowej kwoty płaconej przez samorząd $w$ miesięcznych ratach. Najrzadszą formą wynagrodzenia była opłata za dostępność (tylko w przypadku czterech umów), kiedy to podmiot prywatny uzyskiwał dochód jedynie od strony publicznej. $\mathrm{W}$ odniesieniu do jednej umowy nie podano sposobu wynagrodzenia podmiotu prywatnego. Formy wynagrodzenia partnera prywatnego wynikające $\mathrm{z}$ zawartych umów o PPP w latach 2009-2011 przedstawiono na wykresie 5.11.

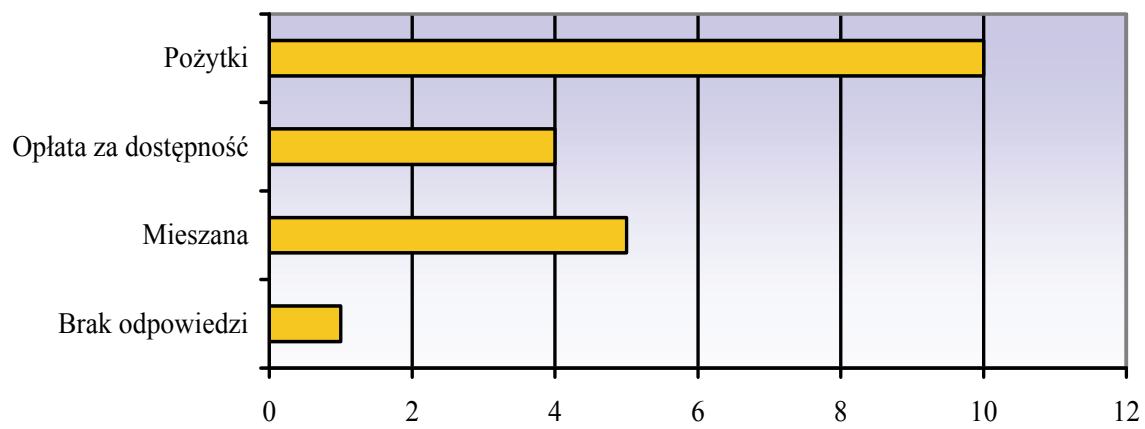

Wykres 5.11. Formy wynagrodzenia partnera prywatnego wynikające z umów o PPP w latach 2009-2011

Źródło: oprac. własne na podstawie badania ankietowego

Partnerska współpraca wymaga zaangażowania obu stron w realizację zadania publicznego. Samorząd odstępując od ustawowego obowiązku wykonywania nałożonych zadań i przekazania ich stronie prywatnej ma prawo do wsparcia poprzez wniesienie wkładu własnego. Przez pojęcie wkładu własnego rozumie się świadczenie strony publicznej polegające na:

1) poniesieniu części wydatków na realizację przedsięwzięcia, w tym sfinansowaniu dopłat do świadczonych usług przez partnera prywatnego,

2) wniesieniu składnika majątkowego, który może wystąpić w postaci nieruchomości, części składowej nieruchomości, przedsiębiorstwa lub prawa majątkowego.

Z zawartych umów o PPP jednoznacznie wynika, że jednostki samorządu terytorialnego aktywnie zaangażowały swój majątek w przedsięwzięcia PPP. W czternastu umowach wkład własny strony publicznej stanowiła nieruchomość, będąca własnością jednostki samorządu terytorialnego. Wniesienie przez stronę samorządową nieruchomości do przedsięwzięcia partnerstwa publiczno-prywatnego następowała poprzez zawarcie umowy dzierżawy na czas trwania 
umowy o PPP. W trzech kontraktach obok nieruchomości strona publiczna zobowiązywała się do przekazania dokumentacji budowlanej. Dla dwóch umów związanych z obiektami sportowo-rekreacyjnymi podmiot publiczny ubiegał się o dofinansowanie ze środków unijnych. Kwota uzyskanej dotacji stanowiła wkład własny samorządu (Gostynin - kwota planowanej dotacji - $72 \mathrm{mln}$ zł, Solec-Zdrój kwota otrzymanej dotacji $8 \mathrm{mln}$ zf). W inwestycjach związanych $\mathrm{z}$ zarządzaniem infrastrukturą sieciową i zaopatrzeniem w wodę oraz odprowadzeniem ścieków wkład własny stanowiła sieć wodno-kanalizacyjna oraz urządzenia (dwa przedsięwzięcia). W umowach dotyczących świadczenia usług $\mathrm{w}$ transporcie publicznym wkład własny występował w formie dopłat do biletów lub gwarancji ich zakupu. Badanie pozwoliło stwierdzić, że nie zawarto umowy, w której strona publiczna nie uczestniczyłaby bez zaangażowania ekonomicznego.

\subsection{Formula partnerstwa publiczno-prywatnego $\mathrm{w}$ opinii ankietowanych jednostek samorządu terytorialnego}

Partnerstwo publiczno-prywatne jako instrument realizacji polityki władz samorządowych w zakresie wykonywania przez nią nałożonych zadań powinno być wprowadzane do praktyki poprzez odpowiednie, świadome działania organizacyjnoprawne. Badania, jakie zostały przeprowadzone wśród jednostek samorządu terytorialnego, pozwoliły na ocenę stanu przygotowania do wdrażania PPP. Ocenie poddano stopień przygotowania organizacyjnego i prawnego, znajomość problematyki PPP oraz ocenę formuły. Pierwsze z pytań ankiety ukierunkowane zostały na zdefiniowanie PPP jako formuły realizacji zadania i wpisanie jej jako jednej z metod do strategicznych dokumentów. Jak wynika $\mathrm{z}$ badań, 78\% postępowań w sprawie PPP było inicjowanych przez jednostki samorządu terytorialnego i spółki komunalne. Większość tych jednostek dopiero rozważa możliwość umieszczenia PPP w swoich długoterminowych planach inwestycyjnych i strategicznych. Zestawienie udzielonych przez ankietowane jednostki odpowiedzi w zakresie umiejscowienia formuly PPP w dokumentach strategicznych przedstawiono w tab. 5.7.

Tabela 5.7

Umiejscowienie formuły PPP w dokumentach strategicznych ankietowanych jednostek samorządu terytorialnego

\begin{tabular}{|c|c|c|}
\hline Wskazania według ankiety & Liczba odpowiedzi & Udział (w \%) \\
\hline 1 & 2 & 3 \\
\hline \multicolumn{3}{|c|}{ Odpowiedzi ankietowanych JST, które zamieścily ogloszenie o PPP } \\
\hline $\begin{array}{l}\text { Nigdy nie rozważaliśmy umieszczenia PPP w dokumen- } \\
\text { tach }\end{array}$ & 1 & 1,7 \\
\hline Rozważaliśmy wprowadzenie PPP do dokumentów & 38 & 64,4 \\
\hline Umieściliśmy PPP $\mathrm{w}$ dokumentach strategicznych & 14 & 23,7 \\
\hline Brak odpowiedzi & 6 & 10,2 \\
\hline Ogótem & 59 & 100,0 \\
\hline
\end{tabular}


Tabela $5.7(\mathrm{~cd}$.

\begin{tabular}{|l|c|c|}
\hline \multicolumn{1}{|c|}{$\mathbf{2}$} & $\mathbf{2}$ & $\mathbf{3}$ \\
\hline \multicolumn{2}{|c|}{$\begin{array}{c}\text { Odpowiedzi ankietowanych JST będących siedzibą władz stanowiących/zarządzających } \\
\text { województw }\end{array}$} \\
\hline Nigdy nie rozważaliśmy umieszczenia PPP w dokumentach & 0 & 0,0 \\
\hline Rozważaliśmy wprowadzenie PPP do dokumentów & 12 & 66,7 \\
\hline Umieściliśmy PPP w dokumentach strategicznych & 4 & 22,2 \\
\hline Brak odpowiedzi & 2 & 11,1 \\
\hline Ogótem Odpowiedzi ankietowanych gmin miejskich województwa lódzkiego \\
\hline \multicolumn{2}{|c|}{$\mathbf{1 0 0 , 0}$} \\
\hline Nigdy nie rozważaliśmy umieszczenia PPP w dokumentach & 9 & 20,9 \\
\hline Rozważaliśmy wprowadzenie PPP do dokumentów & 30 & 69,8 \\
\hline Umieściliśmy PPP w dokumentach strategicznych & 1 & 2,3 \\
\hline Brak odpowiedzi & 3 & 7,0 \\
\hline Ogótem & $\mathbf{4 3}$ & $\mathbf{1 0 0 , 0}$ \\
\hline
\end{tabular}

Źródło: oprac. własne na podstawie badania ankietowego.

Jednostki samorządu terytorialnego, które zamieściły ogłoszenie o wybór partnera prywatnego dla PPP, tylko w jednym przypadku wskazały, że nie zamierzają umieszczać partnerstwa w swoich długoletnich dokumentach strategicznych jako jednej z metod finansowania zadań. Takie stanowisko nie znajduje potwierdzenia $\mathrm{w}$ badaniu przeprowadzonym wśród miast wojewódzkich. Natomiast w miastach województwa łódzkiego spotykamy się z odmienną postawą, aż dziewięć $\mathrm{z}$ nich nie postrzega partnerstwa jako instrumentu pozyskania kapitału na inwestycje. Potwierdza się tendencja stwierdzona w badaniach prowadzonych we wcześniejszych latach przez Instytut PPP. Samorządy coraz częściej rozważają ujęcie PPP w swoich dokumentach strategicznych (przeszło 65\% jednostek). Wskazuje się, że najczęściej informacje o PPP zamieszczone zostałyby w Wieloletnich Planach Inwestycyjnych oraz Strategiach Rozwoju Jednostki. Partnerstwo publiczno-prywatne zostało wpisane do planów strategicznych tych jednostek, które zamieściły ogłoszenie w publikatorach oraz $\mathrm{w}$ przypadku miast wojewódzkich (przeszło $20 \%$ ankietowanych w I i II próbie), w przypadku miast województwa łódzkiego zaś tylko Piotrków Trybunalski wykazał PPP jako źródło finansowania inwestycji w Wieloletnim Planie Inwestycyjnym. Jedenaście ankietowanych jednostek nie udzieliło odpowiedzi. Jedną z przyczyn braku ujmowania rozwiązań PPP $\mathrm{w}$ dokumentach, na jakie wskazywano $\mathrm{w}$ ankiecie, były obawy radnych co do konieczności zastosowania PPP w praktyce i osiągnięcia sukcesu. Ponadto uzależniano odpowiedni zapis od efektu prowadzonego już postępowania (Radom). Sukces ma skutkować umieszczeniem PPP w dokumentach strategicznych, porażka może być przesłanką do dłuższego zaniechania działań w zakresie aplikowania do PPP. 
Partnerstwo publiczno-prywatne z uwagi na swoją skomplikowaną strukturę wymaga odpowiedniego przygotowania organizacyjnego. Ankietowanych zapytano, czy w ich jednostkach instytucjonalnie wyodrębniono stanowiska/komórki do spraw PPP. Odpowiedzi udzielone przez skarbników przedstawiono w tab. 5.8.

Tabela 5.8

Zakres działania na płaszczyźnie instytucjonalnego przygotowania PPP w JST

\begin{tabular}{|c|c|c|c|c|c|c|}
\hline \multirow{2}{*}{$\begin{array}{c}\text { Wskazania według } \\
\text { ankiety }\end{array}$} & \multicolumn{2}{|c|}{ I próba } & \multicolumn{2}{c|}{ II próba } & \multicolumn{2}{c|}{ III próba } \\
\cline { 2 - 7 } & liczba & $\begin{array}{c}\text { udział } \\
(\mathrm{w} \%)\end{array}$ & liczba & $\begin{array}{c}\text { udział } \\
(\mathrm{w} \%)\end{array}$ & liczba & $\begin{array}{c}\text { udział } \\
\text { (w \%) }\end{array}$ \\
\hline $\begin{array}{c}\text { Utworzono odrębne } \\
\text { stanowisko ds. PPP }\end{array}$ & 2 & 4,0 & 1 & 9,1 & 1 & 4,0 \\
\hline $\begin{array}{c}\text { Sprawami PPP zajmuje } \\
\text { się osoba obsługują- } \\
\text { ca inwestorów }\end{array}$ & 32 & 74,4 & 14 & 63,6 & 23 & 92,0 \\
\hline $\begin{array}{c}\text { Powołano właściwe } \\
\text { ciało kolegialne }\end{array}$ & 9 & 20,9 & 6 & 27,3 & 1 & 4,0 \\
\hline
\end{tabular}

Źródło: oprac. własne na podstawie badania ankietowego.

W większości badanych jednostek samorządu terytorialnego działania związane z nawiązaniem partnerskiej współpracy wykonują osoby, które na co dzień mają stały kontakt $\mathrm{z}$ inwestorami wyłonionymi w przetargach realizowanych na podstawie przepisów Prawa zamówień publicznych. Potwierdzają to badania zarówno wśród jednostek, które ogłosiły postępowanie w „Biuletynie Zamówień Publicznych" lub/i TED $(74,4 \%)$ oraz wśród miast wojewódzkich $(63,6 \%)$ i gmin miejskich województwa łódzkiego (92,0\%). Drugim powszechnie praktykowanym rozwiązaniem jest powołanie ciała kolegialnego, składającego się z członków komisji przetargowej oraz pracowników przeszkolonych w zakresie PPP. Natomiast tylko w czterech jednostkach łącznie zdecydowano się na powołanie odrębnego stanowiska (Tychy, Stryków, Olsztyn, Wrocław). Są także jednostki, które nie udzieliły żadnej odpowiedzi, co wynika z braku zainteresowania, a nawet znajomości instrumentu.

Ankietowani zapytani zostali także, czy planują powołanie specjalnej komórki (jeśli taka nie została wcześniej utworzona), która zajmowałaby się problematyką partnerstwa publiczno-prywatnego. Wśród jednostek, które opublikowały ogłoszenie o wyborze partnera prywatnego 29 ankietowanych odpowiedziało „nie”, a zaledwie dziewięciu planuje utworzenie odrębnej komórki, 21 jednostek nie udzieliło odpowiedzi. Wśród przedstawicieli miast wojewódzkich dziesięć jednostek odpowiedziało „nie”, siedem - „tak” oraz jedna nie udzieliła odpowiedzi. Dla potwierdzenia tendencji w miastach województwa łódzkiego rozkład odpowiedzi był podobny 35 - „nie”, sześć - „tak” oraz dwie - „brak odpowiedzi”. Komentarze skarbników pozwalają na sformułowanie kilku 
istotnych wniosków. Po pierwsze, pracownicy nie są zainteresowani PPP, więc nie ma potrzeby tworzenia odrębnego stanowiska, ale gdyby powstał projekt przedsięwzięcia, to władze samorządu są skłonne powołać specjalne stanowisko lub komórkę. Po drugie, część samorządów przygląda się pracom innych jednostek, pozytywne doświadczenia mogą stanowić główną przesłankę i wskazówkę do wdrożenia rozwiązań związanych z partnerstwem. Po trzecie, zagadnienia PPP znajdują się w gestii doradców władz stanowiących gmin lub samych rządzących. Ich działania koncentrują się bardziej na zdobywaniu szczegółowej wiedzy niż na wykorzystaniu PPP jako formy finansowania zadań. Takie podejście jednoznacznie wskazuje na przeciętny stopień znajomości istoty partnerstwa publiczno-prywatnego. Potwierdzeniem tego stwierdzenia są odpowiedzi udzielone przez respondentów dotyczące oceny poziomu wiedzy dotyczącej PPP (por. tab. 5.9).

Tabela 5.9

Samoocena poziomu wiedzy urzędników obsługujących planowane lub realizowane przedsięwzięcia PPP

\begin{tabular}{|l|c|c|}
\hline \multicolumn{1}{|c|}{ Wskazania według ankiety } & Liczba odpowiedzi & Udział (w \%) \\
\hline \multicolumn{1}{|c|}{ Odpowiedzi JST, które zamieścily ogloszenie o PPP } \\
\hline Słaby & 5 & 8,5 \\
\hline Przeciętny & 25 & 42,4 \\
\hline Dobry & 24 & 40,7 \\
\hline Bardzo dobry & 4 & 6,8 \\
\hline Brak odpowiedzi & 1 & 1,7 \\
\hline Ogółem & 59 & 100,0 \\
\hline \multicolumn{1}{|c|}{ Odpowiedzi JST będących siedzibq wladz stanowiących/zarządzających województw } \\
\hline Słaby & 2 & 11,1 \\
\hline Przeciętny & 2 & 11,1 \\
\hline Dobry & 11 & 61,1 \\
\hline Bardzo dobry & 3 & 16,7 \\
\hline Brak odpowiedzi & 0 & 0,0 \\
\hline Ogółem & 18 & 100,0 \\
\hline \multicolumn{3}{|c|}{ Odpowiedzi gmin miejskich województwa tódzkiego } \\
\hline Słaby & 16 & 37,2 \\
\hline Przeciętny & 21 & 48,8 \\
\hline Dobry & 5 & 11,6 \\
\hline Bardzo dobry & 0 & 0,0 \\
\hline Brak odpowiedzi & 1 & 2,3 \\
\hline Ogółem & $\mathbf{4 3}$ & $\mathbf{1 0 0 , 0}$ \\
\hline
\end{tabular}

Źródło: oprac. własne na podstawie badania ankietowego.

Większość ankietowanych ocenia stan wiedzy w zakresie PPP jako przeciętny lub dobry, a w miastach województwa łódzkiego jako słaby. Bardzo 
dobrze swoją wiedzę o PPP ocenili urzędnicy samorządów, które wdrażają PPP, oraz z miast wojewódzkich (odpowiednio 6,8 i 16,7\%). Najwyższy poziom wiedzy deklarują urzędnicy miasta Krakowa, Wrocławia, Poznania, Katowic, Głuchołazów oraz Gostynina.

Badania ankietowe potwierdzają dotychczasowe tendencje, które przedstawione zostały $\mathrm{w}$ raporcie samorządowym PPP przygotowanym przez Instytut Partnerstwa Publiczno-Prywatnego. Samorządowcy nadal nie uzyskują odpowiedniej wiedzy o partnerstwie. Rozwiązaniem problemu powinny być prowadzone na szeroką skalę szkolenia o charakterze warsztatowym, popularyzacja wiedzy poprzez Internet oraz prasę samorządową oraz biuletyny księgowe, które na co dzień są podstawą wiedzy i informacji w samorządach. Bezpośredni dostęp automatycznie może wpłynąć na naturalne zainteresowanie problematyką, co w przyszłości przełoży się na aplikowanie rozwiązania do praktyki. Konieczne są działania, które praktycznie pokażą, jak działa partnerstwo, jak je wdrażać. W opinii samorządowców konferencje nie zapełniają luki, ponieważ ich charakter jest ogólnikowy i schematyczny.

Według badanych, podstawowym źródłem wiedzy o partnerstwie publiczno-prywatnym są szkolenia i konferencje, publikacje - prasa codzienna, czasopisma, ustawy wraz z komentarzami oraz Internet (wykres 5.12).

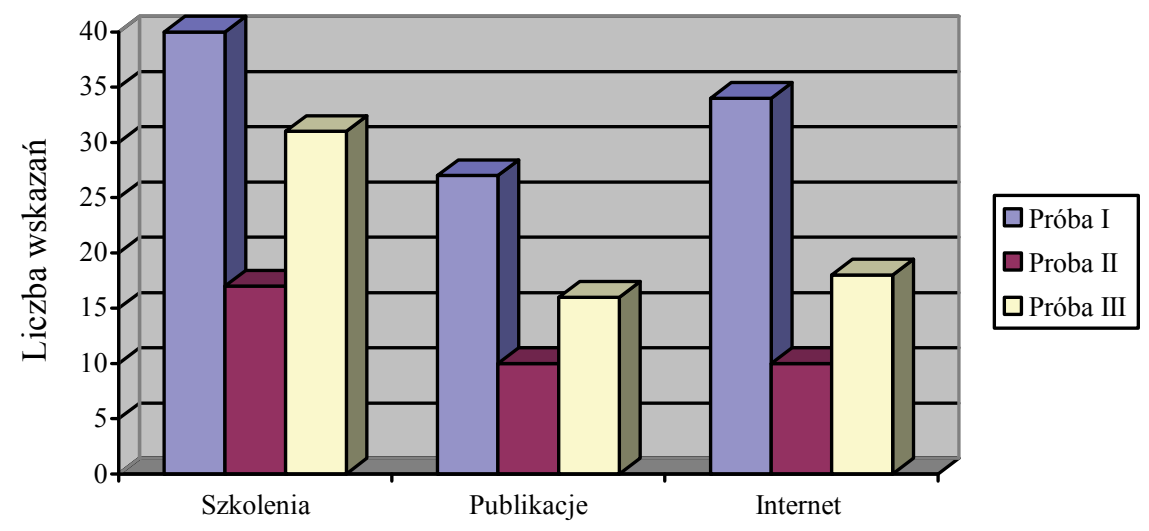

Wykres 5.12. Źródło wiedzy o partnerstwie publiczno-prywatnym w opinii ankietowanych Źródło: oprac. własne na podstawie badania ankietowego

Najczęściej urzędnicy korzystają z bezpłatnych szkoleń i konferencji poświęconych partnerstwu publiczno-prywatnemu. Była to odpowiedź, którą najczęściej zaznaczali ankietowani. W dalszej kolejności wskazywano na informacje pojawiające się w Internecie - około $28 \%$ wszystkich zaznaczonych odpowiedzi w każdej grupie badawczej. Najrzadziej zaznaczano publikacje, co oznacza, że urzędnicy nie mają do nich bezpośredniego dostępu, nie są im oferowane, a w skrajnych przypadkach nie są nimi zainteresowani. Jest to luka, która powinna zostać 
zapełniona przez wydawców broszur poświęconych zagadnieniom księgowo-podatkowym tak, aby jak najszersze grono miało dostęp do informacji.

Dane uzyskane dzięki ankiecie pozwalają także ocenić pomoc, jaka w zakresie PPP oferowana jest samorządom przez administrację rządową. Jak wspomniano, za instytucjonalne wsparcie PPP w Polsce bezpośrednio z mocy ustawy odpowiada minister gospodarki. Dodatkowo w pomoc zaangażowało się Ministerstwo Rozwoju Regionalnego. Ministerstwa utworzyły, każde z osobna, portale, w których można uzyskać podstawowe informacje dotyczące rozwoju PPP w Polsce. Ankietowani zostali poproszeni o ocenę wsparcia oferowaną przez administrację rządową. Wyniki zawiera tab. 5.10.

Tabela 5.10

Ocena wsparcia JST w zakresie PPP przez administrację rządową

\begin{tabular}{|l|c|c|}
\hline \multicolumn{1}{|c|}{ Wskazania według ankiety } & Liczba odpowiedzi & Udział (w \%) \\
\hline \multicolumn{2}{|c|}{ Odpowiedzi JST, które zamieściby ogloszenie o PPP } \\
\hline Słaby & 33 & 55,9 \\
\hline Przeciętny & 16 & 27,1 \\
\hline Dobry & 4 & 6,8 \\
\hline Bardzo dobry & 2 & 3,4 \\
\hline Brak odpowiedzi & 4 & 6,8 \\
\hline Ogółem & 59 & 100,0 \\
\hline \multicolumn{1}{|c|}{ Odpowiedzi JST będących siedzibq wladz stanowiacych/zarządzajacych województw } \\
\hline Słaby & 7 & 38,9 \\
\hline Przeciętny & 6 & 33,2 \\
\hline Dobry & 1 & 5,6 \\
\hline Bardzo dobry & 3 & 16,7 \\
\hline Brak odpowiedzi & 1 & 5,6 \\
\hline Ogółem & 18 & 100,0 \\
\hline \multicolumn{2}{|c|}{ Odpowiedzi gmin miejskich województwa tódzkiego } \\
\hline Słaby & 20 & 46,5 \\
\hline Przeciętny & 17 & 39,5 \\
\hline Dobry & 3 & 7,0 \\
\hline Bardzo dobry & 0 & 0,0 \\
\hline Brak odpowiedzi & 3 & 7,0 \\
\hline Ogółem & 43 & 100,0 \\
\hline
\end{tabular}

Źródło: oprac. własne na podstawie badania ankietowego.

Odpowiedzi uzyskane w każdej próbie pozwalają na jednomyślne sformułowanie wniosku, że samorządy wsparcie otrzymywane ze strony administracji rządowej oceniają jako słabe lub przeciętne. Takie stanowisko reprezentuje $80 \%$ badanych. Zaledwie 3,5\% ankietowanych w próbie I oceniło wsparcie administracji jako bardzo dobre. W próbie drugiej odsetek odpowiedzi „bardzo dobre” wyniósł $16,7 \%$, na co wpływ miało stanowisko przedstawicieli Krakowa, 
Lublina oraz Warszawy. Przedstawiciele gmin miejskich województwa łódzkiego oceny bardzo dobrej nie uwzględnili w swojej opinii.

Tak rygorystyczna ocena jest efektem słabego zaangażowania władz centralnych w promowanie PPP. Samorządy oczekują konkretnego wsparcia merytorycznego rozumianego jako powołanie komórki, która skupiałaby fachowców służących bezpośrednią pomocą w kwestii ekonomiczno-prawnej oceny przedsięwzięcia do realizacji w partnerstwie. Konferencje organizowane przez ministerstwo nie zapełniają luki potrzeb, postrzegane są jedynie jako narzędzie informacji.

Samorządowcy poproszeni zostali o zajęcie stanowiska w sprawie rozwiązań hybrydowych, tzn. połączenia kapitału prywatnego ze środkami unijnymi w celu realizacji zadania publicznego. Zdecydowana większość respondentów opowiedziała się za dwoma wariantami odpowiedzi: po pierwsze, że współpraca $\mathrm{z}$ partnerem prywatnym ma wspomagać finansowo i organizacyjnie proces pozyskania środków UE (odsetek odpowiedzi w kolejny próbach: $32,31,32 \%$ ) oraz że współpraca z partnerem prywatnym ma tylko uzupełniać proces inwestycyjny tam, gdzie nie udało się pozyskać finansowania unijnego (odsetek odpowiedzi odpowiednio w próbach: 35,31,32\%). Zdecydowana większość przedstawicieli samorządów stoi na stanowisku, że najlepszym sposobem na finansowanie inwestycji jest pozyskiwanie środków z funduszy strukturalnych UE, a PPP w stosunku do środków pomocowych Unii stanowią dwie różne drogi pozyskiwania środków i w związku z tym nie mają ze sobą nic wspólnego. W sytuacji, gdy nie ma możliwości skorzystania $\mathrm{z}$ dotacji unijnej kapitał prywatny może stać się jednym ze źródeł kontynuowania inwestycji lub stanowić wkład własny przy ubieganiu się o dotację unijną. Liczbę wskazań dla wariantów odpowiedzi w ramach poszczególnych prób badawczych przedstawiono na wykresie 5.13 .

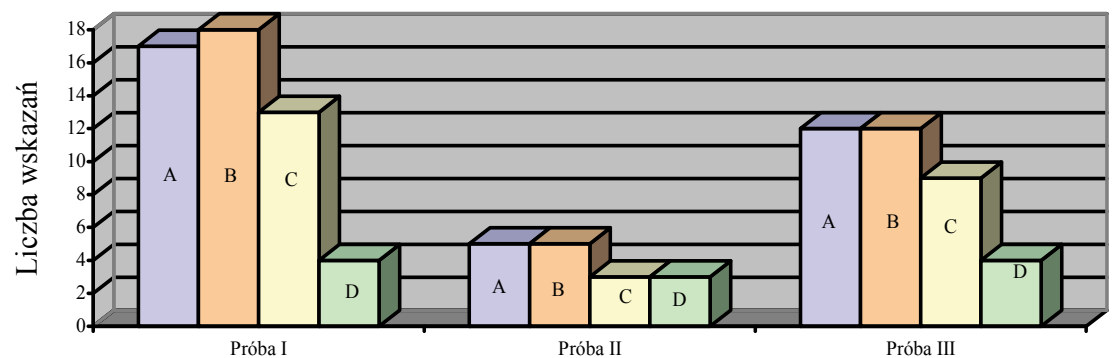

A - współpraca z partnerem prywatnym ma wspomagać finansowo i organizacyjnie proces pozyskiwania środków UE,

B - współpraca z partnerem prywatnym ma uzupełniać proces inwestycyjny tam, gdzie nie udało się pozyskać środków z UE,

C - PPP i środki UE nie mają ze sobą nic wspólnego,

D - PPP powinno być zasadniczym sposobem realizacji zadań inwestycyjnych.

Wykres 5.13. PPP w relacji do środków Unii Europejskiej

Źródło: oprac. własne na podstawie badania ankietowego 
Kolejnym zagadnieniem, jakie zostało poddane opinii ankietowanych, jest ocena regulacji prawnych dotyczących PPP, tj. Ustawy o partnerstwie publiczno-prywatnym i Ustawy o koncesji na roboty budowlane lub ustugi oraz wskazanie wad przyjętych rozwiązań prawnych. Na wykresach 5.14-5.16 zaprezentowano opinie ankietowanych dotyczące uregulowań prawnych w zakresie Ustawy o partnerstwie publiczno-prywatnym.
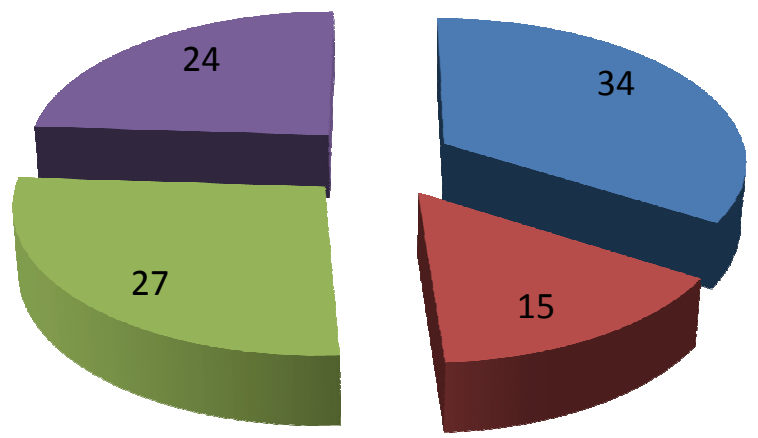

Brak odpowiedzi

- Utrudnia realizację przedsięwzięć PPP

- Jest obojętna dla przedsięwzięć PPP

Ułatwia realizację przedsięwzięć PPP

Wykres 5.14. Ocena Ustawy o partnerstwie publiczno-prywatnym przez samorzady, które opublikowały ogłoszenie o wyborze partnera prywatnego dla PPP (w \%)

Źródło: oprac. własne na podstawie badania ankietowego
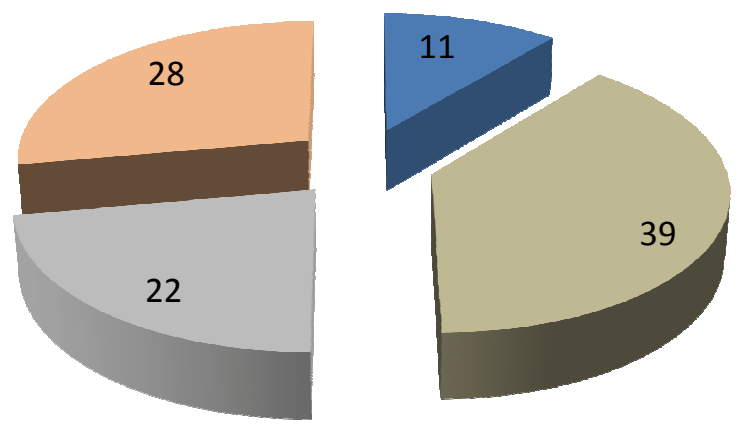

Brak odpowiedzi

Utrudnia realizację przedsięwzięć PPP

Jest obojętna dla przedsięwzięć PPP

Ułatwia realizację przedsięwzięć PPP

Wykres 5.15. Ocena Ustawy o partnerstwie publiczno-prywatnym przez samorządy będące siedzibą organów stanowiących/zarządów województwa (w \%) Źródło: oprac. własne na podstawie badania ankietowego 


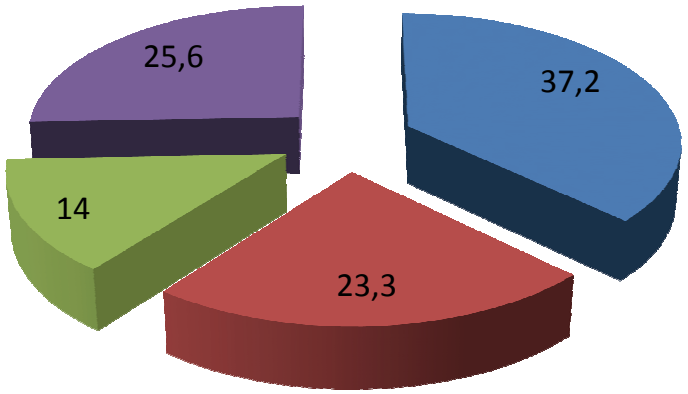

Brak odpowiedzi

Utrudnia realizację przedsięwzięć PPP

Jest obojętna dla przedsięwzięć PPP

Ułatwia realizację przedsięwzięć PPP

Wykres 5.16. Ocena Ustawy o partnerstwie publiczno-prywatnym przez gminy miejskie województwa łódzkiego (w \%)

Źródło: oprac. własne na podstawie badania ankietowego

Jak wynika z powyższych wykresów, zaledwie $25 \%$ samorządowców w poszczególnych grupach badawczych jest zdania, że ustawa o partnerstwie publiczno-prywatnym ułatwia realizację przedsięwzięć w formule PPP. Wskazania kształtują się odpowiednio: dla próby I $23,70 \%$, dla próby II $27,80 \%$ oraz dla próby III $25,57 \%$. Poglądy są podzielone co do tego czy rozwiązania prawne są obojętne, czy też utrudniają wdrożenie przedsięwzięć partnerskich. Wśród samorządów, które przeszły przez wstępny etap prac proceduralnych, dominuje pogląd, że ustawa jest obojętna dla inwestycji (27,1\%), tylko 15,0\% samorządów wskazało, że utrudnia ona działanie. Na uwagę zasługuje fakt, że blisko $34,0 \%$ nie udzieliło odpowiedzi, co oznacza brak sprecyzowanego stanowiska lub nieznajomość przepisów. W drugiej próbie badawczej znajdujemy częściowe potwierdzenie stanowiska samorządowców z próby I. Obojętność przepisów potwierdza 22,0\% respondentów, a 39\% uważa je za blokujące rozwój partnerstwa. Nie udzieliło odpowiedzi $11 \%$ ankietowanych w tej grupie (wykres 5.15). W ostatniej grupie badawczej obojętność ustawy zauważa 14,0\%, 23,3\% określa zaś przepisy jako utrudniające wdrożenie partnerstwa. Podobnie jak w I próbie $37 \%$ ankietowanych nie udzieliło odpowiedzi (wykres 5.16). W komentarzach zwracano uwagę, że sama ustawa ma charakter ramowy, nie zawsze jest to korzystne rozwiązanie, zwłaszcza w sytuacji, gdy w Polsce dopiero rozpoczął się proces wprowadzania długofalowej współpracy międzysektorowej. Akcentowano fakt, że dla urzędników, którzy nie są prawnikami nie wszystkie rozwiązania $\mathrm{w}$ zakresie wyboru partnera prywatnego są jednoznacznie i zrozumiałe. Padały opinie, że powinno nastąpić wyraźne rozgraniczenie ustawy o PPP od ustawy o koncesji na roboty budowlane lub usługi. Obie ustawy mogą być stosowane zamiennie do ustanowienia partnerstwa, lecz urzędnicy widzą w nich źródło konfliktu i ewentualnych kłopotów np. z Regionalną Izbą Obrachunkową. Wysoki odsetek nieudzielonych odpowiedzi jest wynikiem nieznajomości ustawy, co znalazło odbicie w komentarzach do tego pytania. 
Ocenie poddano także Ustawe o koncesji na roboty budowlane lub ustugi. Respondenci z próby I w $29,0 \%$ uznali, że ustawa ta ułatwia realizację PPP. Przeciwnego zdania jest $14,0 \%$ ankietowanych. Dla $22,0 \%$ zapisy ustawy mają obojętny stosunek dla przedsięwzięć PPP, 35,0\% nie udzieliło zaś odpowiedzi (por. wykres 5.17)
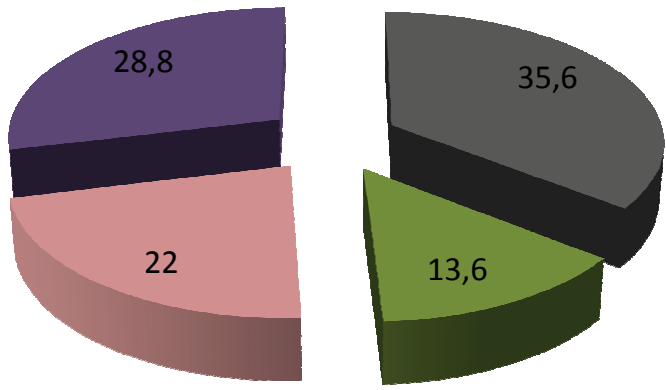

\author{
Brak odpowiedzi \\ - Utrudnia realizację \\ przedsięwzięć PPP \\ - Jest obojętna dla \\ przedsięwzięć PPP \\ - Ułatwia realizację \\ przedsięwzięć PPP
}

Wykres 5.17. Ocena Ustawy o koncesji na roboty budowlane lub ustugi przez samorządy, które opublikowały ogłoszenie o wyborze partnera prywatnego dla PPP (w \%) Źródło: oprac. własne na podstawie badania ankietowego

Dla drugiej próby badawczej rozkład odpowiedzi przedstawiał się następująco: $50,0 \%$ ankietowanych opowiedziało się pozytywnie za regulacjami ustawy, stojąc na stanowisku, że ułatwia ona realizację przedsięwzięć PPP, obojętność przepisów wskazało $28,0 \%$ ankietowanych, rozwiązania ustawowe za utrudniające uznało $11 \%$ ankietowanych i tyle samo nie udzieliło odpowiedzi (wykres 5.18).
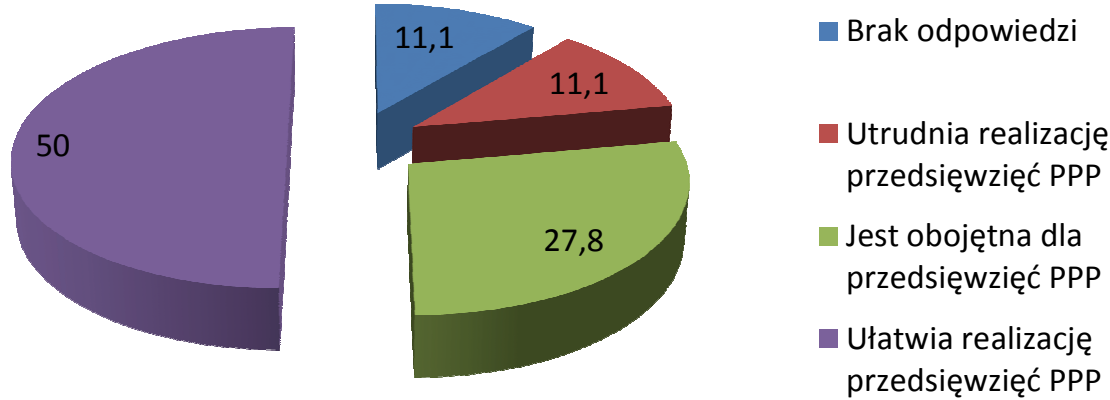

Wykres 5.18. Ocena Ustawy o koncesji na roboty budowlane lub ustugi przez samorządy będące siedzibą organów stanowiących/zarządów województwa (w \%)

Źródło: oprac. własne na podstawie badania ankietowego 
W gminach miejskich województwa łódzkiego 14,0\% ankietowanych uznało Ustawę o koncesji na roboty budowlane lub ustugi za ułatwiającą realizację PPP, taki sam odsetek ankietowanych opowiedział się za wariantem odpowiedzi określającym ustawę jako utrudniającą realizację PPP. Obojętność przepisów wskazało $30 \%$. W tej próbie odnotowano najwyższy odsetek braku odpowiedzi, który wyniósł 42,0\%. Rozkład odpowiedzi przedstawiono na wykresie 5.19.

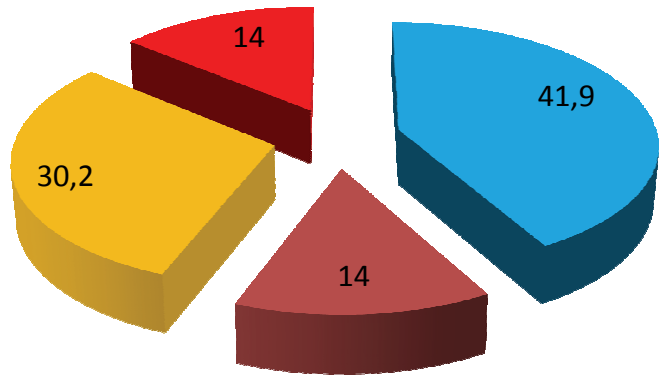

\author{
Brak odpowiedzi \\ - Utrudnia realizację \\ przedsięwzięć PPP \\ Jest obojętna dla \\ przedsięwzięć PPP \\ - Ułatwia realizację \\ przedsięwzięć PPP
}

Wykres 5.19. Ocena Ustawy o koncesji na roboty budowlane lub ustugi przez gminy miejskie województwa łódzkiego (w \%)

Źródło: oprac. własne na podstawie badania ankietowego

Ocena zapisów Ustawy o koncesji na roboty budowlane lub ustugi nie pozwala na jednoznaczne sformułowanie wniosków, ponieważ stanowisko poszczególnych jednostek samorządu terytorialnego jest zróżnicowane. Tylko ankietowani miast wojewódzkich jednoznacznie określili ustawę koncesyjną jako akt prawny ułatwiający nawiązanie partnerskiej współpracy $(50,0 \%)$. Pozostałe samorządy nie potwierdzają tego poglądu. Samorządy prowadzące procedurę, w 29,0\% uznały koncesję za formę sprzyjającą współpracy, w gminach miejskich zaś tylko $14,0 \%$ jest tego zdania. Duża część respondentów w ogóle nie udzieliła odpowiedzi. Kontrowersje budzą zapisy dotyczące wyboru partnera prywatnego, co nie jest jednoznaczne w opinii urzędników nie mających przygotowania prawniczego (powielone zostaje stanowisko odnotowane $\mathrm{w}$ przypadku Ustawy o partnerstwie publiczno-prywatnym). Ponadto zwraca się uwagę na skomplikowany sposób odzyskania nakładów poniesionych przez koncesjonariusza, a związanych z koncesją. Urzędnicy nie do końca potrafią określić granicę, która będzie pozwalała na zastosowanie tychże przepisów. Zwrócono uwagę na konieczność doprecyzowania pojęć m.in. ryzyka ekonomicznego. Stanowisko samorządów dotyczące obydwu ustaw budzi pewne wątpliwości. Z ankiety wyraźnie wynika, że samorządowcy bardziej byliby skłonni prowadzić przedsięwzięcia wykorzystując ustawę o partnerstwie publiczno-prywatnym niż ustawę koncesyjną. W praktyce planowane i realizowane przedsięwzięcia $\mathrm{w}$ większości opierają się na regulacjach ustawy koncesyjnej. Z jednej strony wskazuje się więc na wady tej ustawy, a z drugiej stosuje 
ją w praktyce. Rozbieżność spowodowana jest faktem, że urzędnicy i osoby zaangażowane $\mathrm{w}$ przygotowanie przedsięwzięcia nie do końca samodzielnie podejmowali decyzje o formule realizacji. Duży wpływ na wybór formuły mieli doradcy, którzy wskazywali na korzyści wynikające z proponowanej formuły współpracy. To potwierdza opinię, że brak jest wśród potencjalnych podmiotów publicznych solidnej wiedzy w zakresie możliwości jakie stwarzają poszczególne ustawy dla tworzenia współpracy międzysektorowej. Potwierdzeniem takiego stanowiska są wadliwe zapisy poszczególnych ustaw, jakie zostały wskazane przez ankietowanych. Zestawienie poszczególnych, wadliwych zapisów Ustawy o partnerstwie publiczno-prywatnym i Ustawy o koncesji na roboty budowlane lub ustugi przedstawiono $\mathrm{w}$ tab. 5.11.

Tabela 5.11

Zestawienie wadliwych zapisów ustawy o partnerstwie publiczno-prywatnym i ustawy o koncesji na roboty budowlane lub usługi

\begin{tabular}{|c|c|c|c|c|c|c|}
\hline \multirow[b]{2}{*}{ Rodzaj wady } & \multicolumn{2}{|c|}{ Próba I } & \multicolumn{2}{|c|}{ Próba II } & \multicolumn{2}{|c|}{ Próba III } \\
\hline & \begin{tabular}{|c|} 
liczba \\
wskazań
\end{tabular} & $\begin{array}{l}\text { udział } \\
\text { (w \%) }\end{array}$ & $\begin{array}{c}\text { liczba } \\
\text { wskazań }\end{array}$ & $\begin{array}{l}\text { udział } \\
(\mathrm{w} \%)\end{array}$ & $\begin{array}{c}\text { liczba } \\
\text { wskazań }\end{array}$ & $\begin{array}{l}\text { udział } \\
(\mathrm{w} \%)\end{array}$ \\
\hline 1 & 2 & 3 & 4 & 5 & 6 & 7 \\
\hline \multicolumn{7}{|c|}{ Ustawa o partnerstwie publiczno-prywatnym } \\
\hline $\begin{array}{l}\text { Zbyt liberalne, niepre- } \\
\text { cyzyjne zapisy }\end{array}$ & 12 & 16,0 & 5 & 11,1 & 13 & 21,7 \\
\hline $\begin{array}{l}\text { Niejasne zasady odes- } \\
\text { łania do Prawa zamó- } \\
\text { wien publicznych w zak- } \\
\text { resie procedury wybo- } \\
\text { ru partnera w przypad- } \\
\text { ku pełnej zapłaty od } \\
\text { podmiotu publicznego }\end{array}$ & 17 & 22,7 & 7 & 15,7 & 15 & 25,0 \\
\hline $\begin{array}{l}\text { Niejasne relacje obu } \\
\text { ustaw w zakresie odes- } \\
\text { łania do ustawy konce- } \\
\text { syjnej odnośnie do try- } \\
\text { bu wyboru partnera }\end{array}$ & 9 & 12,0 & 6 & 13,3 & 7 & 11,7 \\
\hline $\begin{array}{l}\text { Wymóg ogłaszania o pla- } \\
\text { nowanym partnerstwie } \\
\text { w BIP }\end{array}$ & 2 & 2,7 & 1 & 2,2 & 2 & 3,3 \\
\hline $\begin{array}{l}\text { Brak należytych zachęt } \\
\text { podatkowych dla pod- } \\
\text { miotów prywatnych }\end{array}$ & 6 & 8,0 & 8 & 17,9 & 7 & 11,7 \\
\hline $\begin{array}{l}\text { Niejasne zasady rozlicza- } \\
\text { nia podatku VAT }\end{array}$ & 16 & 21,3 & 9 & 20,0 & 8 & 13,3 \\
\hline $\begin{array}{l}\text { Brak wskazań co do } \\
\text { zasad podziału ryzyk }\end{array}$ & 13 & 17,3 & 9 & 20,0 & 8 & 13,3 \\
\hline Ogółem liczba wskazań & 75 & 100,0 & 45 & 100,0 & 60 & 100,0 \\
\hline
\end{tabular}




\begin{tabular}{|c|c|c|c|c|c|c|}
\hline 1 & 2 & 3 & 4 & 5 & 6 & 7 \\
\hline \multicolumn{7}{|c|}{ Ustawa o koncesji na roboty budowlane lub uslugi } \\
\hline $\begin{array}{l}\text { Niejasne relacje między } \\
\text { zakresem dopuszczal- } \\
\text { nej płatności ze strony } \\
\text { koncesjodawcy, a zak- } \\
\text { resem ryzyka ekono- } \\
\text { micznego koncesjona- } \\
\text { riusza } \\
\end{array}$ & 16 & 27,1 & 8 & 22,9 & 8 & 21,6 \\
\hline $\begin{array}{c}\text { Zagrożenia związane ze } \\
\text { stosowaniem art. } 8 *\end{array}$ & 4 & 6,8 & 4 & 11,4 & 3 & 8,1 \\
\hline $\begin{array}{l}\text { Wątpliwości co do zgod- } \\
\text { ności z prawem UE } \\
\text { braku wymogu ogła- } \\
\text { szania o koncesji na } \\
\text { usługi w DzUrz. UE } \\
\text { w przypadku dużych } \\
\text { koncesji } \\
\end{array}$ & 4 & 6,8 & 2 & 5,7 & 5 & 13,5 \\
\hline $\begin{array}{l}\text { Zbyt liberalne zasady } \\
\text { ustalania kryteriów } \\
\text { oceny ofert }\end{array}$ & 8 & 13,6 & 2 & 5,7 & 4 & 10,8 \\
\hline $\begin{array}{l}\text { Brak wymogu składania } \\
\text { przez oferentów doku- } \\
\text { mentów potwierdzają- } \\
\text { cych spełnienie wa- } \\
\text { runków udziału w pos- } \\
\text { tępowaniu }\end{array}$ & 7 & 11,9 & 6 & 17,1 & 6 & 16,3 \\
\hline $\begin{array}{l}\text { Zbyt liberalne ujęcie zak- } \\
\text { resu wymaganych } \\
\text { dokumentów (art. } 18 . \\
\text { ust. 2) }\end{array}$ & 8 & 13,6 & 3 & 8,6 & 3 & 8,1 \\
\hline $\begin{array}{l}\text { Zbyt słaba ochrona praw- } \\
\text { na interesu podmiotów } \\
\text { uczestniczących w pos- } \\
\text { tępowaniu }\end{array}$ & 6 & 10,2 & 6 & 17,2 & 3 & 8,1 \\
\hline $\begin{array}{l}\text { Prawdopodobne prob- } \\
\quad \text { lemy orzecznicze } \\
\text { związane z przekaza- } \\
\text { niem jurysdykcji są- } \\
\text { downictwu administra- } \\
\text { cyjnemu }\end{array}$ & 6 & 10,0 & 4 & 11,4 & 5 & 13,5 \\
\hline Ogółem liczba wskazań & 59 & 100,0 & 35 & 100,0 & 37 & 100,0 \\
\hline
\end{tabular}

* Zagrożenie dotyczy rozbieżności pomiędzy opisem przedmiotu koncesji zawartym w specyfikacji technicznej a uzasadnieniem złożonym przez oferenta w ofercie, które zakłada że zaproponowane rozwiązania są równoważne $\mathrm{z}$ określonymi w specyfikacji technicznej. Rozbieżność ta nie powoduje odrzucenia oferty.

Źródło: oprac. własne na podstawie badania ankietowego. 
Wadliwe zapisy, na jakie wskazali ankietowani, obejmują szeroki wachlarz zagadnień przede wszystkim o charakterze prawnym. Stąd często pojawiający się w ankiecie komentarz dotyczący konieczności zaangażowania doradców zewnętrznych, którzy dysponują odpowiednią wiedzą prawnicza niezbędną do prawidłowego interpretowania zapisów. Na szczególną uwagę zasługuje wskazanie uznające za wadę liberalne przepisy Ustawy o partnerstwie publiczno-prywatnym. Liberalizacja przepisów nastąpiła w wyniku wcześniejszych postulatów dotyczących zbyt rygorystycznego podejścia do PPP w ustawie z $2005 \mathrm{r}$. Zmiana przepisów i ramowy charakter ustawy w opinii ankietowanych również zasługuje na krytykę. Krytycznie należy podejść do takiego rozumienia rozwiązań prawnych. W chwili obecnej regulacje te - o charakterze ramowym - mają stworzyć zainteresowanym jak najszersze granice kompromisu i możliwość negocjowania warunków umowy konkretnego przedsięwzięcia inwestycyjnego.

Samorządy zostały poproszone o wskazanie oczekiwań jakie wiążą z zastosowaniem partnerstwa publiczno-prywatnego. Do wyboru postawiono trzy zasadnicze efekty: dodatkowe źródło kapitału, przekazanie części obowiązków na zewnątrz oraz polepszenie jakości infrastruktury. Tabela 5.12 zawiera udzielone odpowiedzi.

Tabela 5.12

Główne oczekiwania samorządowców wobec partnerstwa publiczno-prywatnego

\begin{tabular}{|l|c|c|c|c|c|c|}
\hline \multirow{2}{*}{ Rodzaj oczekiwania } & \multicolumn{2}{|c|}{ Próba I } & \multicolumn{2}{c|}{ Próba II } & \multicolumn{2}{c|}{ Próba III } \\
\cline { 2 - 7 } & $\begin{array}{c}\text { liczba } \\
\text { wskazań }\end{array}$ & $\begin{array}{c}\text { udział } \\
\text { (w \%) }\end{array}$ & $\begin{array}{c}\text { liczba } \\
\text { wskazań }\end{array}$ & $\begin{array}{c}\text { udział } \\
\text { (w \%) }\end{array}$ & $\begin{array}{c}\text { liczba } \\
\text { wskazań }\end{array}$ & $\begin{array}{c}\text { udział } \\
\text { (w \%) }\end{array}$ \\
\hline $\begin{array}{c}\text { Dodatkowe źródło } \\
\text { kapitału }\end{array}$ & 45 & 46,9 & 14 & 40,0 & 31 & 47,7 \\
\hline $\begin{array}{c}\text { Przekazanie części obo- } \\
\text { wiązków na zew- } \\
\text { nątrz }\end{array}$ & 23 & 24,0 & 8 & 22,9 & 15 & 23,1 \\
\hline $\begin{array}{c}\text { Polepszenie jakości } \\
\text { infrastruktury }\end{array}$ & 28 & 29,1 & 13 & 37,1 & 19 & 29,2 \\
\hline Ogółem & 96 & 100,0 & 35 & 100,0 & 65 & 100,0 \\
\hline
\end{tabular}

Źródło: oprac. własne na podstawie badania ankietowego.

Przedstawiciele samorządów są zgodni co do tego, że PPP to jedna z możliwości pozyskania dodatkowego kapitału, odsetek zaznaczonych odpowiedzi wyniósł przeszło $40 \%$. Stanowisko to było jednakowe w każdej z badanych prób. Ankietowani zaznaczali, że PPP umożliwi nie tylko pozyskanie kapitału na inwestycje, ale przede wszystkim odciąży budżet, nie powiększając zarazem limitu zobowiązań. PPP kojarzy się także z możliwością polepszenia jakości infrastruktury. Tutaj wskazuje się na szybszą i terminową realizację inwestycji przy wykorzystaniu wiedzy, doświadczenia i know-how prywatnego przedsię- 
biorcy. Zwrócono także uwagę na fakt, że dzięki współpracy znaczna część obowiązków zostaje przeniesiona na zewnątrz (około 30\% wskazań), prowadzi to do koncentracji całego procesu inwestycyjnego w rękach podmiotu prywatnego, optymalizuje koszty oraz polepsza jakość świadczonych usług. Przedstawiciele gminy Krapkowice wskazali też na ważny aspekt aktywizowania lokalnych przedsiębiorców w lokalne inwestycje, stworzenie silnej więzi biznesowej będącej motorem lokalnego rozwoju.

\section{Próba I}

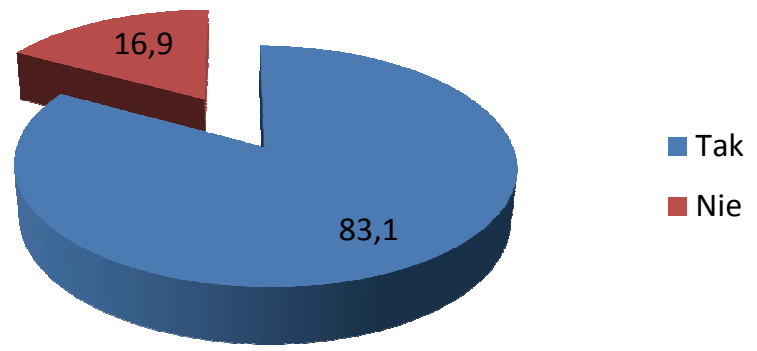

Próba II

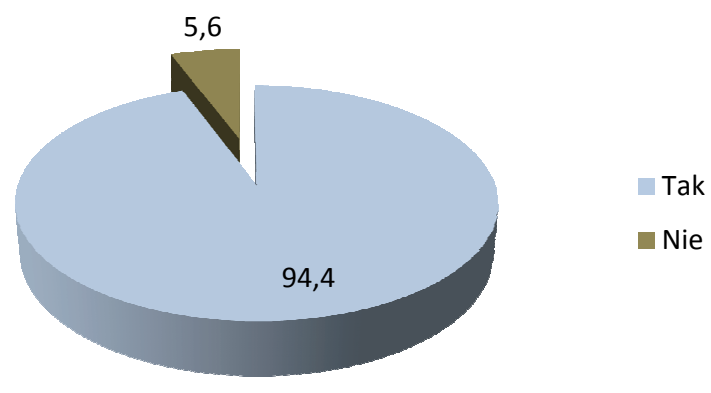

Próba III

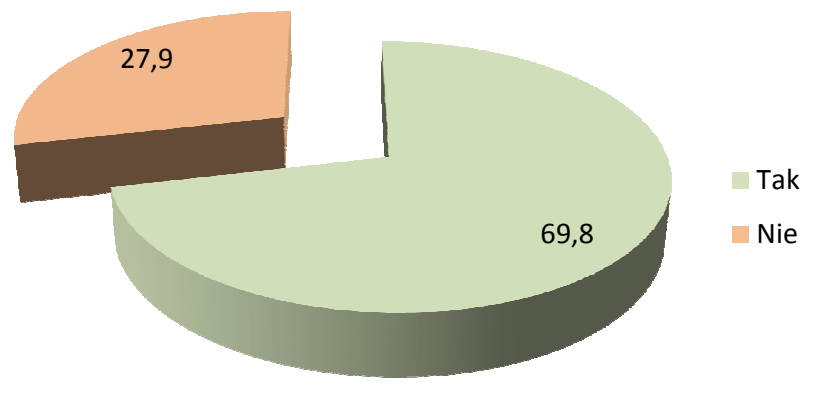

Wykres 5.20. Stopień gotowości JST do korzystania z usług profesjonalnych doradców (w \%) Źródło: oprac. własne na podstawie badania ankietowego 
W analizie rynku partnerstwa publiczno-prywatnego ważna rola spoczywa na doradcach. $Z$ uwagi na to, że jest to rynek dopiero rozwijający się, o czym świadczy skromna liczba zawartych umów, a wysoki stopień skomplikowania procedur przygotowawczych wymaga odpowiedniego przygotowania merytorycznego i wymusza konieczność skorzystania z usług doradców. Brak dobrych praktyk w tym zakresie powoduje, że sukces PPP uzależniony będzie od fachowego wsparcia oferowanego jednostkom samorządu terytorialnego. Mając na uwadze taki stan rzeczy zapytano respondentów, czy są zainteresowani doradztwem zewnętrznych firm, jakiego rodzaju doradztwem, a także, jakie kryteria powinny być stosowane, aby usługi były świadczone na najwyższym poziomie i skutkowały zawarciem umowy oraz jaką formę wynagrodzenia są skłonni zaakceptować za tego typu usługi. Zainteresowanie usługami doradczymi jest duże. Prawie 90\% ankietowanych wśród I i II próby deklaruje chęć skorzystania $\mathrm{z}$ fachowego doradztwa. W gminach miejskich województwa łódzkiego odsetek zainteresowanych doradztwem jest stosunkowo niższy i kształtuje się na poziomie $70 \%$. Odpowiednio niecałe dziesięć procent samorządów z I i II próby nie jest zainteresowanych pomocą doradców, w miastach województwa łódzkiego odsetek ten sięga zaś 30\% (wykres 5.20).

Zakres merytorycznej pomocy został określony szeroko, dostosowując obszar usług do różnorodnych przedsięwzięć. Dzięki pozyskanym z ankiety informacjom wynika, że samorządy oczekują fachowego wsparcia w obrębie doradztwa finansowego, przygotowania analiz przedrealizacyjnych, sklasyfikowania ryzyk i właściwego jego rozdzielenia pomiędzy potencjalne strony umowy (13-16\% wskazań spośród wyodrębnionych usług).

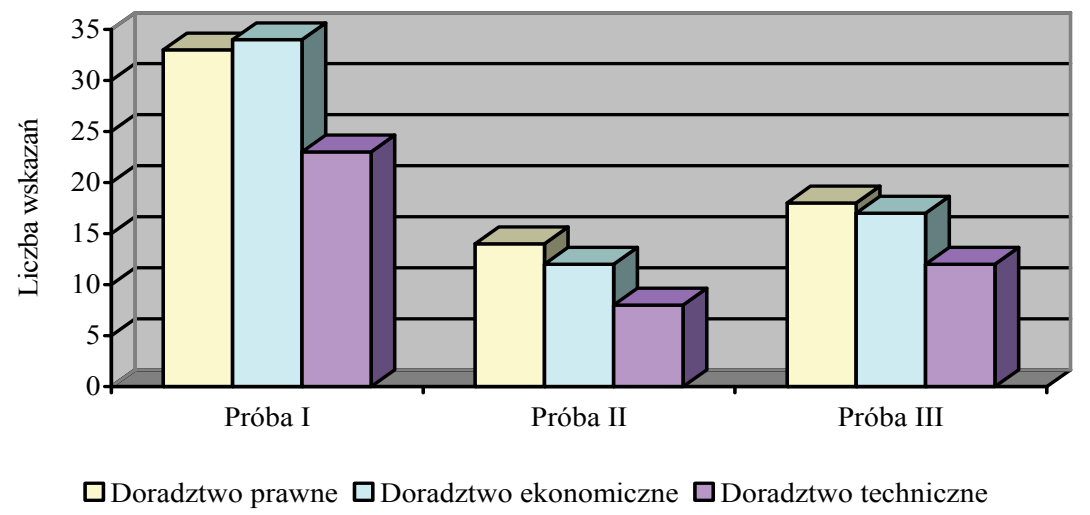

Wykres 5.21. Stopień gotowości wykorzystania poszczególnych kategorii doradztwa PPP Źródło: oprac. własne na podstawie badania ankietowego 
Zainteresowane są także doradztwem w zakresie przygotowania postępowania prowadzącego do wyłonienia prywatnego partnera oraz przygotowania i zawarcia umowy. Są to czynności, których na tym etapie rozwoju rynku PPP w Polsce i przy wykorzystaniu własnego zaplecza organizacyjno-prawnego i ekonomicznego samorządowcy nie są w stanie samodzielnie przygotować dla prawidłowo funkcjonującego, uzasadnionego ekonomicznie przedsięwzięcia partnerstwa publiczno-prywatnego. Dominuje zapotrzebowanie na usługi ekonomiczno-finansowe. Nieznacznie większe oczekiwania dotyczą zagadnień prawnych, w tym określenia formuły współpracy, zasad gospodarowania składnikami majątkowymi, stanu prawnego wkładu własnego wnoszonego do przedsięwzięcia oraz dalszego nad nim nadzoru. Doradztwo techniczne traktowane jest jako uzupełniające (wykres 5.21).

Praktycznie każdy ankietowany wskazywał na kilka grup usług, co w konsekwencji prowadzi do wniosku, że przy korzystnych warunkach finansowych samorządy byłyby zainteresowane kompleksowym doradztwem $\mathrm{w}$ trakcie trwania całego procesu inwestycyjnego i w okresie eksploatacji.

W tabeli 5.13 zestawiono rodzaj usług, jakimi zainteresowane byłyby jednostki samorządu terytorialnego. Najbardziej oczekiwanym wsparciem jest doradztwo finansowe powiązane $\mathrm{z}$ przygotowaniem wstępnych analiz, w tym analizy ryzyka. Istotna jest także pomoc $\mathrm{w}$ zakresie wyboru formy realizacji przedsięwzięcia, przygotowania ogłoszenia o wybór partnera prywatnego, przeprowadzenia postępowania wyłaniającego partnera prywatnego, a także skonstruowania umowy o PPP. Najsłabiej konieczność kontynuowania usług doradczych postrzegano na pozostałych etapach, tj. w fazie realizacji, a następnie $\mathrm{w}$ fazie eksploatacji.

Kwestią zasadniczą przy usługach doradczych jest sformułowanie kryteriów wyboru doradcy oraz forma jego wynagrodzenia. Dane pozyskane $\mathrm{z}$ ankiety wskazują na trzy zasadnicze kryteria wyboru. Są to cena za świadczoną usługę, doświadczenie (liczba przedsięwzięć, w których doradca uczestniczył), zdolność merytoryczna i organizacyjna realizacji doradztwa.

W grupie samorządów, które opublikowały ogłoszenie dotyczące wyboru partnera prywatnego, najważniejszym kryterium przy wyborze doradcy jest doświadczenie (47\%), pozostałe dwa kryteria mają odpowiednio: cena $24 \%$, zdolność merytoryczna i organizacyjna $29 \%$. Wypełniający ankietę wskazywali, że kryterium ceny nie jest istotne przy przedsięwzięciach PPP, ważne jest, aby prawidłowo je zakwalifikować, wskazać jego ekonomiczne uzasadnienie do realizacji w PPP, a następnie tak skonstruować umowę, aby zabezpieczyć interes publiczny przed manipulowaniem, utratą kontroli nad majątkiem oraz ryzykiem ekonomicznym. W opinii tej grupy samorządowców wyraźnie zaznacza się doświadczenie wynikające $\mathrm{z}$ przygotowania przedsięwzięć do partnerstwa. 
Tabela 5.13

Zakres zgłaszanej pomocy merytorycznej przez ankietowane jednostki samorządu terytorialnego

\begin{tabular}{|c|c|c|c|c|c|c|}
\hline \multirow{2}{*}{$\begin{array}{c}\text { Zakres usług doradczych } \\
\text { w ramach PPP }\end{array}$} & \multicolumn{2}{|c|}{ Próba I } & \multicolumn{2}{c|}{ Próba II } & \multicolumn{2}{c|}{ Próba III } \\
\cline { 2 - 7 } & $\begin{array}{c}\text { liczba } \\
\text { wskazań }\end{array}$ & $\begin{array}{c}\text { udział } \\
\text { (w \%) }\end{array}$ & $\begin{array}{c}\text { liczba } \\
\text { wskazań }\end{array}$ & $\begin{array}{c}\text { udział } \\
\text { (w \%) }\end{array}$ & $\begin{array}{c}\text { liczba } \\
\text { wskazań }\end{array}$ & $\begin{array}{c}\text { udział } \\
\text { (w \%) }\end{array}$ \\
\hline $\begin{array}{c}\text { Doradztwo w zakresie identyfika- } \\
\text { cji i przygotowania koncepcyj- } \\
\text { nego przedsięwzięcia }\end{array}$ & 14 & 6,8 & 8 & 8,1 & 11 & 8,1 \\
\hline $\begin{array}{c}\text { Doradztwo w zakresie wykonania } \\
\text { niezbędnych analiz przedreali- } \\
\text { zacyjnych }\end{array}$ & 28 & 13,7 & 12 & 12,1 & 21 & 15,6 \\
\hline $\begin{array}{c}\text { Doradztwo finansowe, w tym } \\
\text { analiza ryzyk }\end{array}$ & 29 & 14,1 & 13 & 13,1 & 22 & 16,3 \\
\hline $\begin{array}{c}\text { Przygotowanie studium wykonal- } \\
\text { ności }\end{array}$ & 29 & 14,1 & 8 & 8,1 & 15 & 11,1 \\
\hline $\begin{array}{c}\text { Doradztwo w zakresie wyboru } \\
\text { formuły PPP }\end{array}$ & 19 & 9,3 & 12 & 12,1 & 14 & 10,4 \\
\hline $\begin{array}{c}\text { Przygotowanie Specyfikacji } \\
\text { Istotnych Warunków Zamówie- } \\
\text { nia i wzoru umowy }\end{array}$ & 18 & 8,8 & 11 & 11,1 & 16 & 11,9 \\
\hline $\begin{array}{c}\text { Doradztwo w zakresie przepro- } \\
\text { wadzenia postępowania wyła- } \\
\text { niającego partnera prywatnego }\end{array}$ & 21 & 10,2 & 11 & 11,1 & 12 & 8,9 \\
\hline $\begin{array}{c}\text { Doradztwo w zakresie przygoto- } \\
\text { wania i zawarcia umowy }\end{array}$ & 24 & 11,7 & 14 & 14,1 & 8 & 5,9 \\
\hline $\begin{array}{c}\text { Konsultacje i doradztwo w zakre- } \\
\text { sie nadzoru nad przedsięwzięciem }\end{array}$ & 14 & 6,8 & 5 & 5,1 & 9 & 6,7 \\
\hline $\begin{array}{c}\text { Doradztwo na pozostałych } \\
\text { etapach cyklu życia przedsię- } \\
\text { wzięcia }\end{array}$ & 9 & 4,4, & 5 & 5,1 & 7 & 5,2 \\
\hline Ogółem liczba wskazań & 205 & 100,0 & 99 & 100,0 & 135 & 100,0 \\
\hline
\end{tabular}

Źródło: oprac. własne na podstawie badania ankietowego.

Odmienną hierarchię kryteriów obserwuje się w samorządach będących siedzibami organów stanowiących/zarządów województw. Odsetek realizowanych w tej grupie umów jest znikomy, co potwierdza się w kontaktach z doradcami ds. PPP. W tej grupie na pierwszym miejscu wskazuje się zdolności merytoryczne i organizacyjne jako podstawowe kryterium wyboru doradcy (40\%), doświadczenie $37 \%$, cena zaś to wybór $23 \%$ respondentów. Przedstawiciele gmin miejskich województwa łódzkiego kryteria wyboru doradcy sklasyfikowali identycznie jak samorządy z pierwszej próby, uznając doświadczenie za najważniejsze kryterium (42,5\%), koleino wskazywano cenę - 31,5\%, i zdolność organizacyjną oraz merytoryczną (na poziomie $26 \%$ ). 
Należy zaznaczyć, że w specyfikacji na wybór doradcy w takiej kolejności przypisywane byłyby wagi stanowiące podstawę wyboru najkorzystniejszej oferty. Dokładny rozkład odpowiedzi zaprezentowano w tab. 5.14.

Tabela 5.14

Kryteria wyboru doradcy dla przedsięwzięć PPP

\begin{tabular}{|l|c|c|c|c|c|c|}
\hline \multirow{2}{*}{ Kryterium } & \multicolumn{2}{|c|}{ Próba I } & \multicolumn{2}{c|}{ Próba II } & \multicolumn{2}{c|}{ Próba III } \\
\cline { 2 - 7 } & $\begin{array}{c}\text { liczba } \\
\text { wskazań }\end{array}$ & $\begin{array}{c}\text { udział } \\
(\mathrm{w} \%)\end{array}$ & $\begin{array}{c}\text { liczba } \\
\text { wskazań }\end{array}$ & $\begin{array}{c}\text { udział } \\
(\mathrm{w} \%)\end{array}$ & $\begin{array}{c}\text { liczba } \\
\text { wskazań }\end{array}$ & $\begin{array}{c}\text { udział } \\
(\mathrm{w} \%)\end{array}$ \\
\hline Cena & 23 & 24,0 & 8 & 22,9 & 23 & 31,5 \\
\hline Doświadczenie & 45 & 46,9 & 13 & 37,1 & 31 & 42,5 \\
\hline $\begin{array}{c}\text { Zdolność merytoryczna } \\
\text { i organizacyjna reali- } \\
\text { zacji doradztwa }\end{array}$ & 28 & 29,2 & 14 & 40,0 & 19 & 26,0 \\
\hline Ogółem & 96 & 100,0 & 35 & 100,0 & 73 & 100,0 \\
\hline
\end{tabular}

Źródło: oprac. własne na podstawie badania ankietowego

Tabela 5.15

Optymalny sposób wynagrodzenia doradcy ds. PPP

\begin{tabular}{|l|c|r|r|r|r|r|}
\hline \multirow{2}{*}{ Kryterium } & \multicolumn{2}{|c|}{ Próba I } & \multicolumn{2}{c|}{ Próba II } & \multicolumn{2}{c|}{ Próba III } \\
\cline { 2 - 7 } & $\begin{array}{c}\text { liczba } \\
\text { wskazań }\end{array}$ & $\begin{array}{c}\text { udział } \\
\text { (w \%) }\end{array}$ & $\begin{array}{c}\text { liczba } \\
\text { wskazań }\end{array}$ & $\begin{array}{c}\text { udział } \\
\text { (w \%) }\end{array}$ & $\begin{array}{c}\text { liczba } \\
\text { wskazań }\end{array}$ & $\begin{array}{r}\text { udział } \\
\text { (w \%) }\end{array}$ \\
\hline Ryczałt & 17 & 28,8 & 7 & 38,9 & 13 & 30,2 \\
\hline $\begin{array}{c}\text { Procent od wartości } \\
\text { inwestycji }\end{array}$ & 11 & 18,6 & 3 & 16,7 & 3 & 7,0 \\
\hline $\begin{array}{c}\text { Premia za osiągnięcie celu } \\
\text { doradztwa (success fee) }\end{array}$ & 26 & 44,1 & 7 & 38,8 & 24 & 55,8 \\
\hline Brak odpowiedzi & 5 & 8,5 & 1 & 5,6 & 3 & 7,0 \\
\hline Ogółem & 59 & 100,0 & 35 & 100,0 & 73 & 100,0 \\
\hline
\end{tabular}

Źródło: oprac. własne na podstawie badania ankietowego.

Samorządy miały także możliwość wypowiedzenia się w kwestii wynagrodzenia doradcy ds. PPP. Zdaniem ankietowanych wynagrodzenie powinno być uzależnione od rodzaju przedsięwzięcia i etapu postępowania, na którym pomoc doradcy byłaby świadczona. Proponuje się, by w fazie wstępnej był to ryczałt, a dopiero $w$ późniejszych fazach, gdy dochodzi do procedur związanych z wyłonieniem partnera prywatnego oraz konstruowania umowy, wynagrodzenie przyjęło formę premii. Rozkład odpowiedzi w poszczególnych próbach przedstawiono w tab. 5.15.

Rozkład odpowiedzi potwierdza, że najchętniej samorządowcy uzależniliby wynagrodzenie doradców od efektów ich pracy, co jednoznacznie przekładają na 
zawarcie umowy z partnerem prywatnym. W drugiej kolejności byłby to ryczałt, choć obawy samorządowców budzi fakt, że doradcy mogą sztucznie „rozdmuchiwać" koszty doradztwa, a nie zawsze przełoży się to na efekt końcowy. Najmniej chętnie zapłaciłyby samorządy doradcy w formie procentu od wartości inwestycji. W całej strukturze odpowiedzi blisko 8\% respondentów nie udzieliło odpowiedzi, co należy odczytać jako brak zdecydowania i poglądu na dany temat.

\subsection{Planowane przedsięwzięcia partnerstwa publiczno-prywatnego w badanych jednostkach samorządu terytorialnego}

Przeprowadzone badania pozwoliły także na oszacowanie liczby i wartości planowanych przedsięwzięć $\mathrm{w}$ formule PPP. Ankietowani poproszeni zostali o podanie informacji, czy w najbliższej przyszłości planują realizować przedsięwzięcia inwestycyjne w formule PPP.

Zestawienie liczby i wartości planowanych przedsięwzięć PPP dla poszczególnych prób badawczych ujęto w tab. 5.16.

Tabela 5.16

Liczba i wartość planowanych przedsięwzięć PPP

\begin{tabular}{|c|c|c|c|}
\hline Grupa badawcza & Liczba JST & $\begin{array}{c}\text { Liczba planowanych } \\
\text { przedsięwzięć }\end{array}$ & $\begin{array}{c}\text { Szacunkowa wartość } \\
\text { planowanych przedsię- } \\
\text { wzięć (mln zł) }\end{array}$ \\
\hline $\begin{array}{c}\text { JST, które zamieściły } \\
\text { ogłoszenie w BZP/TED }\end{array}$ & 1 & 1 & 100 \\
\hline $\begin{array}{c}\text { JST siedziby zarządów/ } \\
\text { władz wojewódzkich }\end{array}$ & 10 & 34 & 3940 \\
\hline $\begin{array}{c}\text { Gminy miejskie wojewódz- } \\
\text { twa łódzkiego }\end{array}$ & 3 & 4 & $14 *$ \\
\hline
\end{tabular}

* szacunkowa wartość podana została dla dwóch z czterech przedsięwzięć. Gmina Konstantynów Łódzki nie podała wartości dla dwu planowanych przedsięwzięć PPP.

Źródło: oprac. własne na podstawie badania ankietowego.

W grupie jednostek samorządu terytorialnego, które zamieściły ogłoszenie w „Biuletynie Zamówień Publicznych” lub „Suplemencie do Dziennika Urzędowego Unii Europejskiej” (TED), znalazła się tylko jedna gmina - Miasto Sopot. Wartość inwestycji opiewa na $100 \mathrm{mln}$ zł i dotyczy zagospodarowania terenów dworca PKP w Sopocie ${ }^{14}$. Pozostałe przedsięwzięcia znajdują się

${ }^{14}$ W dniu 23 stycznia 2012 r. Gmina Sopot zawarła z Bałtycką Grupą Inwestycyjną umowę o partnerstwie publiczno-prywatnym. Przedmiotem umowy jest zagospodarowanie terenów 
w różnych fazach zaawansowania. Na uwagę zasługuje fakt, że jednostki samorządu, które już zawarły umowy, w chwili obecnej nie rozważają możliwości realizowania innych zadań we współpracy z prywatnymi inwestorami. Uzasadniają taką postawę koniecznością ocenienia efektów realizowanej umowy o PPP oraz oceny współpracy z prywatnym inwestorem w długiej perspektywie czasu.

Najwięcej planowanych inwestycji zgłosiły miasta będące siedzibami organów stanowiących i/lub zarządów województw. Na 18 jednostek tylko 10 zadeklarowało chęć realizacji inwestycji w partnerstwie na łączną wartość $3940,17 \mathrm{mln}$ zł.

W grupie gmin miejskich województwa łódzkiego trzy samorządy wskazały, że pracują nad wdrożeniem partnerstwa publiczno-prywatnego. Dwie gminy wskazały po jednym przedsięwzięciu (Aleksandrów Łódzki - o szacunkowej wartości $5 \mathrm{mln}$ oraz Złoczew - szacunkowa wartość przedsięwzięcia $9 \mathrm{mln}$ zł). Gmina Konstantynów Łódzki zgłosiła dwa przedsięwzięcia w fazie koncepcyjnej nie podając wartości inwestycji.

Licząc całkowitą wartość wszystkich zadeklarowanych przedsięwzięć PPP, wartość rynku partnerstwa może wzrosnąć o 4054,17 $\mathrm{mln}$ zł. netto. Podana wartość obarczona jest pewnym marginesem błędu. Nie wszystkie deklarowane przedsięwzięcia mogą wejść w fazę przygotowywania procedur przetargowych, może dojść do weryfikacji wartości zadania inwestycyjnego, nie należy też wykluczyć innej formy realizacji zadania. W konsekwencji można tylko szacować, jak będzie rósł rynek przy sprzyjających warunkach prawnoorganizacyjnych w samorządach. Rozmieszczenie przestrzenne planowanych przedsięwzięć PPP przedstawiono na mapie 5.3.

Większość planów dotyczy przedsięwzięć w sektorze sportu i rekreacji $(36,1)$, budowy parkingów $(23,1)$ oraz mieszkań komunalnych $(18,1 \%)$. W dalszej kolejności zgłoszono zainteresowanie współpracą w takich obszarach, jak transport i rewitalizacja (Miasto Sopot), gospodarka ciepłownicza, edukacja, budowa cmentarza, transport publiczny i drogi, gospodarka odpadami oraz w zakresie administracji samorządowej. Sektorowe ujęcie planowanych PPP ilustruje wykres 5.22. Łącznie w planach znajduje się 39 nowych przedsięwzięć pozostających na różnym etapie realizacji. Dwa zostały zakończone sukcesem w 2012 r. zawarto umowy z prywatnymi inwestorami (inwestycja w Sopocie, związana $\mathrm{z}$ rewitalizacją dworca PKP oraz przyległych terenów, budowa mieszkań komunalnych w Krakowie). Pozostałe znajdują się na etapie wyboru doradcy bądź tuż przed publikacją ogłoszenia na wybór partnera prywatnego.

dworca PKP w Sopocie oraz sąsiadujących z nimi terenów z udziałem podmiotów prywatnych. Powyższa umowa nie jest uwzględniana w badaniach rynku PPP w Polsce $\mathrm{z}$ uwagi na okres objęty badaniem. 


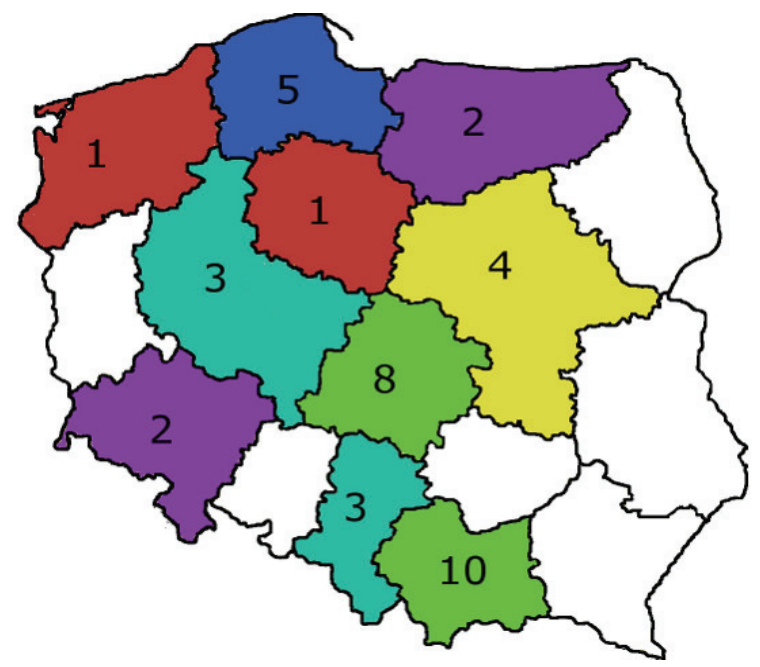

Mapa 5.3. Rozmieszczenie przestrzenne planowanych przedsięwzięć PPP (liczba przedsięwzięć)

Źródło: oprac. własne na podstawie badania ankietowego

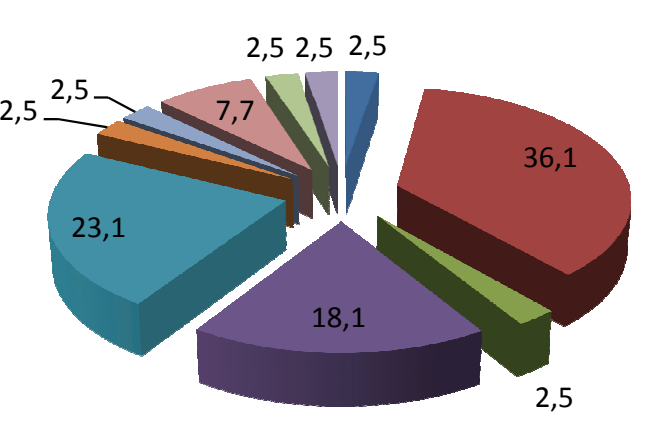

- Transport i reeitalizacja

\author{
- Sport i rekreacja \\ Gospodarka ciepłownicza \\ - Mieszkania komunalne \\ - Parkingi \\ Edukacja \\ Cmentarz \\ Transport publiczny i drogi
}
Wykres 5.22. Sektorowe ujęcie planowanych przedsięwzięć partnerstwa publiczno-prywatnego $(\mathrm{w} \%)$
Źródło: oprac. własne na podstawie badania ankietowego

Dzięki informacjom zawartym w ankiecie możliwe jest określenie, w jakiej formule samorządy planują nowe inwestycje. Podobnie jak przy przedsięwzięciach już realizowanych większość inwestycji planowana jest do realizacji w formule koncesji na roboty (dziewięć zadań) lub koncesji na usługi (pięć 
zadań). W przypadku ośmiu planowanych inwestycji zastosowana ma zostać czysta formuła partnerstwa publiczno-prywatnego, w tym planuje się powołanie jednej spółki celowej. Dla 17 zadeklarowanych przedsięwzięć nie ustalono jeszcze formuly realizacji (wykres 5.23).

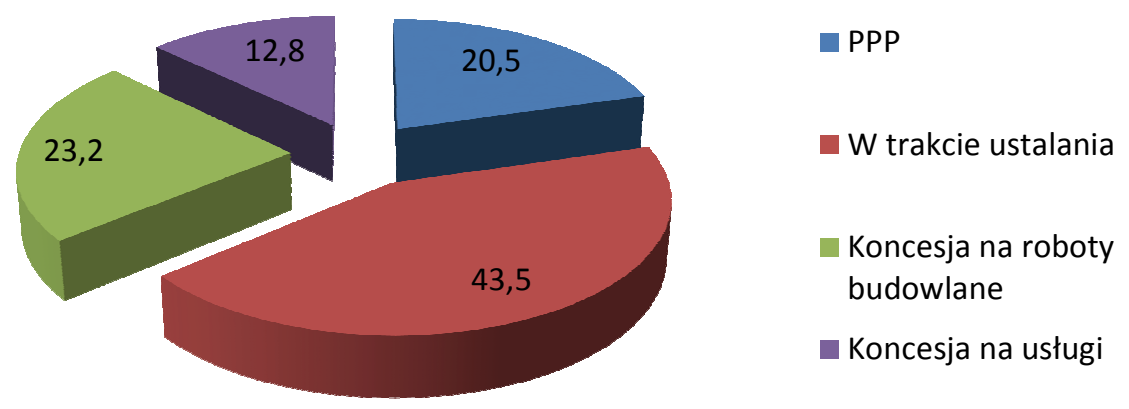

Wykres 5.23. Formuła współpracy dla planowanych przedsięwzięć partnerstwa publiczno-prywatnego

Źródło: oprac. własne na podstawie badania ankietowego

Przeprowadzone badania ankietowe miały na celu ocenę stanu rozwoju ryn$\mathrm{ku}$ przedsięwzięć partnerstwa publiczno-prywatnego oraz poziomu wiedzy merytorycznej $\mathrm{w}$ zakresie stosowania PPP $\mathrm{w}$ praktyce. Weryfikacji poddano także zakres i formę wsparcia instytucjonalnego ze strony administracji rządowej dla podmiotów zainteresowanych partnerską współpracą. Analiza prawno-organizacyjnego przygotowania jednostek samorządu terytorialnego do wdrażania PPP pozwala na sformułowanie następujących wniosków:

1) obowiązujące od 2009 r. regulacje prawne w zakresie partnerstwa publiczno-prywatnego zaowocowały wzrostem zainteresowania współpracą sektora samorządowego z prywatnymi podmiotami, czego wyrazem był wzrost liczby opublikowanych ogłoszeń o wybór partnera prywatnego do realizacji zadań publicznych w formule partnerstwa lub koncesji w „Biuletynie Zamówień Publicznych” i/lub „Europejskim Dzienniku Zamówień Publicznych”;

2) implementacja rozwiązań prawnych dokonuje się „od dołu”, jednostki samorządu terytorialnego są najszerszą grupą beneficjentów rozwiązań PPP;

3) wśród jednostek samorządu terytorialnego najaktywniejsze są gminy miejskie, na które przypada 11 zawartych umów, co stanowi 55\% wszystkich umów zawartych w latach 2009-2011;

4) wśród miast będących siedzibą władz stanowiących/bądź zarządów województw tylko dwa realizują przedsięwzięcia inwestycyjne w formule PPP, co stanowi $11 \%$ zbiorowości; 
5) łączna wartość realizowanych przez miasta stanowiące siedzibę władz organów wojewódzkich przedsięwzięć wynosi $72,3 \mathrm{mln}$ zl, co stanowi $11 \%$ łącznej wartości realizowanych umów, oznacza to, że miasta te, pomimo zgłaszanego dużego zapotrzebowania na środki finansowe na inwestycje angażują się we współpracę z sektorem prywatnym na niskim poziomie;

6) w ramach partnerstwa publiczno-prywatnego dominują inwestycje o niskiej wartości, nieprzekraczającej $5 \mathrm{mln}$ zł, co jest charakterystyczne dla rynków znajdujących się we wstępnej fazie rozwoju, dodatkowo w Polsce brak jest przedsięwzięć pilotażowych na szczeblu centralnych, wypracowanych i skatalogowanych przykładów dobrych praktyk, co powoduje, że samorządy same wyznaczają standardy i procedury dla partnerstwa publiczno-prywatnego;

7) w sferze infrastruktury technicznej zawarto 16 umów (80\%), dominującym sektorem jest tu sport i rekreacja, w sferze infrastruktury socjalnej zawarto cztery umowy odpowiadające 20-procentowemu udziałowi w rynku umów PPP;

8) władze samorządowe wykazują niski lub przeciętny poziom wiedzy w zakresie partnerstwa publiczno-prywatnego, co w konsekwencji przekłada się na brak odpowiednich komórek organizacyjnych w urzędach odpowiedzialnych za inicjowanie współpracy międzysektorowej;

9) urzędnicy uskarżają się na ograniczone możliwości zdobywania wiedzy oraz na charakter prowadzonych konferencji i szkoleń, wskazując na ich szablonowy, wręcz ogólnikowy zakres, co nie służy rozszerzaniu wiedzy oraz zdobywaniu praktycznych umiejętności we wdrażaniu partnerstwa;

10) brak jest umiejętności łączenia funduszy unijnych z prywatnym kapitałem (przykład przedsięwzięcia w Gostyninie) oraz występuje skrajne podejście do rozwiązań hybrydowych, które przejawia się w postrzeganiu PPP jako uzupełniającego źródła kapitału w stosunku do środków unijnych;

11) przedstawiciele samorządów krytycznie odnoszą się do przyjętych rozwiązań prawnych w zakresie partnerstwa oraz koncesji; funkcjonowanie dwóch aktów prawnych przysparza trudności $\mathrm{w}$ zakresie prawidłowego określenia procedury przetargowej na wybór partnera prywatnego, co powoduje konieczność angażowania zewnętrznych doradców ds. PPP; niejasność zapisów zwiększa ryzyko prawne dla potencjalnych wykonawców oraz instytucji finansowych, co może prowadzić do porażki przedsięwzięcia;

12) partnerstwo publiczno-prywatne postrzegane jest przede wszystkim jako źródło dodatkowego kapitału oraz sposób na poprawę jakości zarządzania oraz jakości i liczbie świadczonych usług, co wpisuje się w postulowaną idee New Public Management. Brak wsparcia samorządowych przedsięwzięć partnerstwa publiczno-prywatnego przez administrację rządową, brak systemowych rozwiązań i nisko oceniany stopień wsparcia powodują, że wiele $\mathrm{z}$ nich $\mathrm{w}$ efekcie prawno-ekonomicznych ułomności pozostaje w sferze planów;

13) brak jest praktycznych umiejętności, niejasności prawne dotyczące PPP powodują, że przedstawiciele samorządów są zainteresowani usługami dorad- 
czymi w zakresie PPP ze strony fachowców oraz oczekują kompleksowych usług, uzależniając ich wynagrodzenie od ostatecznych efektów w postaci zawarcia umowy PPP/koncesji.

Przedstawione wnioski składają się na obraz rynku partnerstwa publicznoprywatnego, który znajduje się w początkowym stadium rozwoju. Charakter przedsięwzięć wskazuje, że samorządy dopiero wypracowują rozwiązania i dokonują tego na inwestycjach o niskiej wartości i średnim okresie trwania umowy, co ma sprzyjać ewentualnej zmianie formy realizowania zadania w przypadku niezadowalających rezultatów. Należy wskazać także, że to gminy miejskie są najliczniejszymi podmiotami inicjującymi współpracę. Dostrzegają one korzyści z zaangażowania prywatnego kapitału. W okresie ograniczeń budżetowych, skutków globalnego kryzysu finansowego, negocjacji trwających nad kształtem budżetu Unii Europejskiej w nowej perspektywie finansowej z lat 2014-2020 partnerstwo publiczno-prywatne może okazać się jedynym racjonalnym rozwiązaniem dla każdej ze stron, o czym świadczą zidentyfikowane i planowane przedsięwzięcia jednostek samorządu terytorialnego.

\subsection{Instytucje wspierające przedsięwzięcia partnerstwa publiczno-prywatnego w Polsce w latach 2009-2011}

Rozwiązania prawne przyjęte w polskim ustawodawstwie dotyczącym partnerstwa publiczno-prywatnego nałożyły na ministra gospodarki obowiązek monitorowania funkcjonowania partnerstwa. Artykuł 3 Ustawy o partnerstwie publiczno-prywatnym, stanowiący odpowiednik art. 28 starej ustawy (z 2005 r.), określa zadania, które w szczególności obejmują:

- upowszechnianie i promowanie partnerstwa publiczno-prywatnego,

- dokonywanie analiz,

- ocenę funkcjonowania partnerstwa poprzez ocenę stanu i perspektyw finansowego zaangażowania sektora prywatnego.

W celu realizacji powyższych zadań Ministerstwo Gospodarki utworzyło Bazę Projektów Partnerstwa Publiczno-Prywatnego. Za pośrednictwem bazy mają być gromadzone i powszechnie udostępniane informacje dotyczące planowanych, realizowanych i zakończonych przedsięwzięć $\mathrm{PPP}^{15}$. Obecnie baza zawiera informacje o kilkudziesięciu zadaniach inwestycyjnych przewidzianych do realizacji. Zainteresowane samorządy mogą znaleźć dane dotyczące rozmieszczenia przedsięwzięć planowanych $\mathrm{w}$ formule PPP. Dodatkowo na stronie przewidziano zakładkę $\mathrm{z}$ obowiązującymi regulacjami prawnymi, w której zamieszczono siedem aktów prawnych o zasięgu krajowym powiąza-

$15 \mathrm{Na}$ podstawie informacji zawartych na stronie Bazy PPP, www.bazappp.gov.pl (29.05.2012). 
nych w sposób bezpośredni lub pośredni z partnerstwem oraz dziesięć regulacji obowiązujących w Unii Europejskiej. Ponadto na stronie internetowej Ministerstwa Gospodarki można zapoznać się z wybranymi informacjami dotyczącymi PPP pochodzącymi z konferencji lub szkoleń.

Szczególny nacisk na promocję i edukację w zakresie partnerstwa publiczno-prywatnego kładzie Ministerstwo Rozwoju Regionalnego. W tym celu utworzona została Platforma Partnerstwa Publiczno-Prywatnego (dostępna pod adresem www.ppp.gov.pl/platformaPPP). Platforma powstała $\mathrm{z}$ inicjatywy Ministerstwa Rozwoju Regionalnego w wyniku podpisania 26 stycznia $2011 \mathrm{r}$. Porozumienia $w$ sprawie Platformy wspótpracy $w$ zakresie partnerstwa publiczno-prywatnego, $\mathrm{z}$ wyszczególnionymi $\mathrm{w}$ dokumencie ministrami, przedstawicielami agend rządowych, banków, władz samorządowych. Członkostwo w Platformie jest bezpłatne, a przynależność nabywa się poprzez podpisanie deklaracji.

Misją Platformy jest wzmocnienie potencjału instytucji publicznych do dostarczania wysokiej jakości, efektywnych kosztowo usług publicznych i infrastruktury oraz zwiększenie skuteczności i efektywności samorządów w realizacji inwestycji dzięki partnerstwu publiczno-prywatnemu. Misja ma być realizowana dzięki dążeniu do osiągnięcia pięciu celów ${ }^{16}$ :

1) stworzenia sieci współpracy między członkami Platformy PPP dla wymiany wiedzy, dobrych praktyk i sprawdzonych rozwiązań dotyczących przygotowania i realizacji przedsięwzięć partnerskich, identyfikacji barier oraz tworzenia rozwiązań przyczyniających się do rozwoju partnerstwa;

2) inicjowania i wsparcia przygotowania przedsięwzięć pilotażowych służących identyfikacji barier powstających $\mathrm{w}$ trakcie jego realizacji, przygotowania sektorowych i horyzontalnych analiz, określenia trybu postępowania przy PPP, zapewnienia doradztwa prawnego oraz ekonomiczno-finansowego;

3) wsparcia merytorycznego podmiotów realizujących przedsięwzięcia PPP;

4) zapewnienia podmiotom publicznym szerokiego dostępu do opinii, ekspertyz, analiz, raportów z audytów, wzorów umów dotyczących partnerstwa publiczno-prywatnego;

5) promocji partnerstwa publiczno-prywatnego.

Realizacja tak sformułowanych zadań następuje poprzez stworzenie zespołów sterujących działaniami w zakresie krzewienia wiedzy, doświadczenia oraz grup roboczych, które zapewniają szerokie wsparcie doradcze związane z procesem analitycznym i obsługą procedur wyboru prywatnych partnerów.

Platforma oferuje dostęp do szerokiego katalogu aktów prawnych krajowych i zagranicznych odnoszących się do partnerstwa publiczno-prywatnego oraz publikacji, czasopism, raportów. Ponadto znajduje się tu wykaz planowanych konferencji i szkoleń w zakresie PPP, a także materiały z już odbytych.

${ }^{16}$ Porozumienie $w$ sprawie Platformy wspótpracy $w$ zakresie partnerstwa publiczno-prywatnego, Ministerstwo Rozwoju Regionalnego, www.ppp.gov.pl (29.05.2012). 
Platforma prezentuje także wykaz kilku przedsięwzięć przewidzianych do realizacji w formule PPP wraz z ich metryką (fiszką projektową), co pozwala na zapoznanie się $\mathrm{z}$ dokumentacją i fazą jego realizacji.

Wszelkie wątpliwości, pytania, uwagi można zgłaszać poprzez zakładkę FAQ, co ułatwia kontakt z przedstawicielami Platformy i pozwala na zapoznanie się $\mathrm{z}$ najczęściej zadawanymi pytaniami, zgłaszanymi problemami i wątpliwościami w zakresie PPP.

Utworzenie Platformy należy uznać za inicjatywę niezwykle pożyteczną i faktycznie promującą partnerstwo publiczno-prywatne. Zakres informacji, dostępność umożliwiają zapoznanie się z ideą partnerstwa, a także przyjrzenie się działaniom zmierzającym do upowszechnienia i rozwoju formuły w Polsce.

Polska Agencja Rozwoju Przedsiębiorczości (PARP) wraz z Instytutem Partnerstwa Publiczno-Prywatnego realizuje projekt systemowy pt. Partnerstwo publiczno-prywatne. Realizacja projektu przewidziana jest na okres od maja 2011 r. do grudnia 2014 r. Całkowity budżet projektu wynosi $10047180 \mathrm{zl}$. Celem projektu jest promowanie modelu PPP jako instrumentu współpracy sektora publicznego i prywatnego $\mathrm{w}$ realizacji zadań publicznych, przede wszystkim upowszechnienie wiedzy $\mathrm{z}$ zakresu partnerstwa $\mathrm{w}$ środowisku instytucji publicznych oraz wśród prywatnych przedsiębiorców. Projekt finansowany jest ze środków Europejskiego Funduszu Społecznego w ramach Poddziałania 2.1.3. Wsparcie systemowe na rzecz zwiększenia zdolności adaptacyjnych pracowników i przedsiębiorstw Programu Operacyjnego Kapitał Ludzki. Beneficjentami projektu są przedstawiciele podmiotów publicznych, m.in. administracji rządowej, jednostek samorządu terytorialnego i podległych im jednostek oraz prywatni przedsiębiorcy. W projekcie przewidziano kampanię promocyjno-informacyjną w zakresie PPP, organizację cyklu 16 dwudniowych, regionalnych seminariów poświęconych problematyce partnerstwa, przygotowanie i wydanie licznych publikacji. Realizacja projektu ma przyczynić się do wzrostu świadomości na temat korzyści płynących z podejmowania przedsięwzięć w tej formule wśród beneficjentów programu, podnieść motywację do podejmowania działań $\mathrm{w}$ tej formule oraz zwiększyć poziom praktycznych umiejętności w przygotowaniu projektu PPP. W ramach projektu PARP przeprowadzi dwa ogólnopolskie konkursy dla instytucji publicznych na przedsięwzięcia PPP oraz sfinansuje kompleksowe usługi doradcze dla pięciu pilotażowych przedsięwzięć wyłonionych w drodze tychże konkursów ${ }^{17}$. Realizatorzy projektu PARP zamierzają zbadać potencjał podmiotów publicznych oraz przedsiębiorców do podejmowania przedsięwzięć w formule PPP, co pozwoli na

${ }^{17}$ B. Korbus, M. Wawrzyniak, A. Jędrzejewski, D. Gospodarczyk, Projekt systemowy PARP Partnerstwo publiczno-prywatne, „Biuletyn Partnerstwa Publiczno-Prywatnego” 2011, nr 1 [PARP, Warszawa 2011], s. 12-15. 
oszacowanie możliwości finansowych, organizacyjnych i technicznych oraz zainteresowania przedsięwzięciami możliwymi do realizacji $\mathrm{w}$ formule partnerstwa.

Zaangażowanie PARP-u wraz z Instytutem PPP ma rzeczywisty, praktyczny wymiar. Uczestnicy seminariów mają dostęp do doświadczonych, profesjonalnych praktyków, na co dzień spotykających się z przedsięwzięciami partnerstwa publiczno-prywatnego. Dodatkowym atutem jest możliwość uczestniczenia w praktycznych warsztatach, gdzie potencjalni realizatorzy PPP zapoznają się z zakresem analiz i procedur, jakie są niezbędne do przygotowania PPP. Jest to obecnie jedyny projekt o charakterze publicznym, który stwarza podmiotom zarówno publicznym, jak i prywatnym dostęp do tak szerokiej wiedzy dotyczącej PPP i pozwala nabyć minimalne, ale praktyczne umiejętności oszacowania opłacalności wykonania projektu w formule partnerstwa.

Obok instytucji publicznych zaangażowanych w krzewienie wiedzy z zakresu partnerstwa publiczno-prywatnego, na rynku polskim pojawiło się kilka interesujących inicjatyw prywatnych zaangażowanych w działania edukacyjno-promocyjne na rzecz PPP.

Jako pierwsza w 2003 r. powstała fundacja Instytut Partnerstwa Publiczno-Prywatnego ${ }^{18}$, promująca współpracę pomiędzy podmiotem publicznym i prywatnym. Zespół Instytutu tworzą osoby od lat zaangażowane w działalność doradczo-edukacyjną w zakresie partnerstwa, ściśle współpracujący z jednostkami samorządu terytorialnego oraz agendami rządowymi. Na stronie internetowej Instytutu dostępne są materiały oraz informacje dotyczące rynku PPP w Polsce i za granicą. Instytut systematycznie opracowuje i publikuje raporty dotyczące rozwoju rynku oraz przygotowuje propozycje zmian legislacyjnych w obszarze partnerstwa. Fundacja jest wydawcą magazynu „Forum PPP” poświęconego w całości problematyce partnerstwa publiczno-prywatnego.

Fundacja Centrum Partnerstwa Publiczno-Prywatnego powstała w 2008 r. jako niezależna inicjatywa obywatelska, której zadaniem jest promowanie i upowszechnianie wiedzy na rzecz PPP. Fundatorami jest 41 podmiotów zarówno z sektora publicznego, jak i prywatnego. Centrum udostępnia informacje dotyczące rozwoju PPP w kraju i na świecie, publikacje i raporty z zakresu PPP, przygotowała Kodeks Dobrych Praktyk Doradcy PPP i Ścieżkę dojścia podmiotu publicznego do opracowania przedsięwzięcia PPP.

Poza wymienionymi podmiotami wspierającymi rozwój partnerstwa publiczno-prywatnego w Polsce zwrócić należy także uwagę na Francuską Izbę Przemysłowo-Handlową (CCIFP) w Polsce oraz Brytyjsko-Polską Izbę Handlową (BPCC). Francuska Izba działa w Polsce od 1994 r. i jej działania koncentrują się wokół rozwoju polsko-francuskiej współpracy gospodarczej. Jednym $\mathrm{z}$ zadań jest aktywny udział $\mathrm{w}$ promocji PPP poprzez organizowanie semina-

\footnotetext{
${ }^{18}$ Na podstawie informacji zamieszczonych na stronie www.ippp.pl (29.05.2012).
} 
riów. Brytyjska Izba rozpoczęła działalność w 1992 r. i zajmuje się rozbudową sieci brytyjsko-polskich kontaktów biznesowych. Z uwagi na bogate doświadczenia Wielkiej Brytanii w zakresie realizacji PPP zajmuje się promocją najlepszych praktyk i doświadczeń w tym obszarze w Polsce poprzez cykliczne seminaria.

Wsparcia doradczo-konsultacyjnego w obszarze PPP dostarczają także prywatne kancelarie prawnicze. Działalność tych firm ma charakter komercyjny, co ogranicza dostęp podmiotów publicznych z uwagi na ograniczone możliwości finansowe. Na rynku działa wiele znanych kancelarii, m.in. Investment Support, Kancelaria Doradztwa Gospodarczego C\&K, Collect Consulting, Kancelaria Hogan Lovell.

Złożoność partnerstwa publiczno-prywatnego wymaga prowadzenia ustawicznych działań edukacyjnych, informacyjnych oraz wspomagających wśród potencjalnych beneficjentów PPP. Pomimo barku jednej instytucji organizacyjnej na szczeblu rządowym, która zajmowałaby się wspieraniem prawnoorganizacyjnym potencjalnych realizatorów umów o PPP, została ona zastąpiona szeregiem innych instytucji, w przeważającej mierze o charakterze prywatnym, które wypełniają lukę w tym obszarze. Należy jednak wskazać na istotną wadę takiego rozwiązania. Usługi świadczone przez te instytucje mają charakter komercyjny. Jest to pierwsza zasadnicza bariera dla wielu samorządów, które $\mathrm{z}$ powodów finansowych ograniczają, a nawet $\mathrm{w}$ ogólenie uwzględniają w swoich planach wykorzystania partnerstwa do realizacji zadań.

\subsection{Potencjał inwestycyjny i dług samorządowy jako determinanty przedsięwzięć partnerstwa publiczno-prywatnego}

\subsubsection{Potencjal inwestycyjny a partnerstwo publiczno-prywatne}

Poziom potencjału inwestycyjnego jest kategorią wyznaczającą możliwości inwestycyjne jednostek samorządu terytorialnego. Jego poziom uzależniony jest od dwóch zasadniczych grup: z jednej strony wielkości takich, jak dochody ogółem, nadwyżka operacyjna, wolne środki, z drugiej zaś wielkości wydatków ogółem oraz poziomu zadłużenia. Każda $\mathrm{z}$ tych kategorii wyznacza zakres skłonności inwestycyjnej jednostki samorządu terytorialnego i wpływa na jej poziom.

Metodologia obliczenia potencjału inwestycyjnego sprowadza się do określenia potencjału własnego, rozumianego jako różnica pomiędzy dochodami ogółem jednostki a wydatkami bieżącymi i kosztami związanymi z obsługą zadłużenia, a następnie powiększenia potencjału własnego o nadwyżkę budżetową z lat poprzednich i środki uzyskane z prywatyzacji majątku. W ostateczności uzyskujemy wielkość potencjału inwestycyjnego ${ }^{19}$.

\footnotetext{
${ }^{19}$ Metodologia obliczenia potencjału inwestycyjnego przedstawiona została w podrozdziale 3.3.
} 
$\mathrm{Z}$ danych finansowych jednostek samorządu terytorialnego, przyporządkowanych do poszczególnych prób badawczych, wynika duże zróżnicowanie potencjału inwestycyjnego zarówno wewnątrz poszczególnych prób, jak i pomiędzy nimi. Świadczy o tym rozrzut (różnica pomiędzy poziomem maksymalnym a minimalnym) oraz odchylenie standardowe (tab. 5.17).

Tabela 5.17

Poziom potencjału inwestycyjnego dla poszczególnych prób badawczych w latach 2009-2011 (w tys. zł)

\begin{tabular}{|l|c|c|c|c|c|}
\hline Kategoria & $\begin{array}{c}\text { Minimalny } \\
\text { potencjał } \\
\text { inwestycyjny }\end{array}$ & $\begin{array}{c}\text { Maksymalny } \\
\text { potencjał } \\
\text { inwestycyjny }\end{array}$ & $\begin{array}{c}\text { Średni potencjał } \\
\text { inwestycyjny }\end{array}$ & Mediana & $\begin{array}{c}\text { Odchylenie } \\
\text { standardowe }\end{array}$ \\
\hline Próba I & -61841 & 2089205 & 115695 & 20420 & 302008 \\
\hline Próba II & 14157 & 1648540 & 401988 & 262549 & 382622 \\
\hline Próba III & -12505 & 94003 & 20028 & 13503 & 23368 \\
\hline
\end{tabular}

Źródło: oprac. własne.

Tabela 5.18

Potencjał inwestycyjny dla próby I i III w poszczególnych przedziałach w latach 2009-2011

\begin{tabular}{|c|c|c|c|}
\hline Przedział & Wartość przedziału (w tys. zł) & Liczba JST & Udział (w \%) \\
\hline \multicolumn{4}{|c|}{ Próba I } \\
\hline I & 0 i mniej & 3 & 5,1 \\
\hline II & $(0-50000>$ & 37 & 62,7 \\
\hline III & $(50000-100000>$ & 8 & 13,6 \\
\hline IV & $(100000-150000>$ & 2 & 3,4 \\
\hline $\mathrm{V}$ & Powyżej 150000 & 9 & 1,3 \\
\hline \multicolumn{4}{|c|}{ Próba III } \\
\hline I & 0 i mniej & 7 & 16,3 \\
\hline II & $(0-25000>$ & 23 & 53,5 \\
\hline III & $(25000-50000>$ & 9 & 20,9 \\
\hline IV & $(50000-75000>$ & 2 & 4,7 \\
\hline $\mathrm{V}$ & $(75000-100000>$ & 2 & 4,7 \\
\hline
\end{tabular}

Źródło: oprac. własne.

Ze względu na duże zróżnicowanie wielkości ekonomicznych stworzono przedziały wartościowe dostosowane do wielkości próby. Analiza poziomu potencjału inwestycyjnego została przeprowadzona dla poszczególnych przedziałów. 
Potencjal inwestycyjny próby I

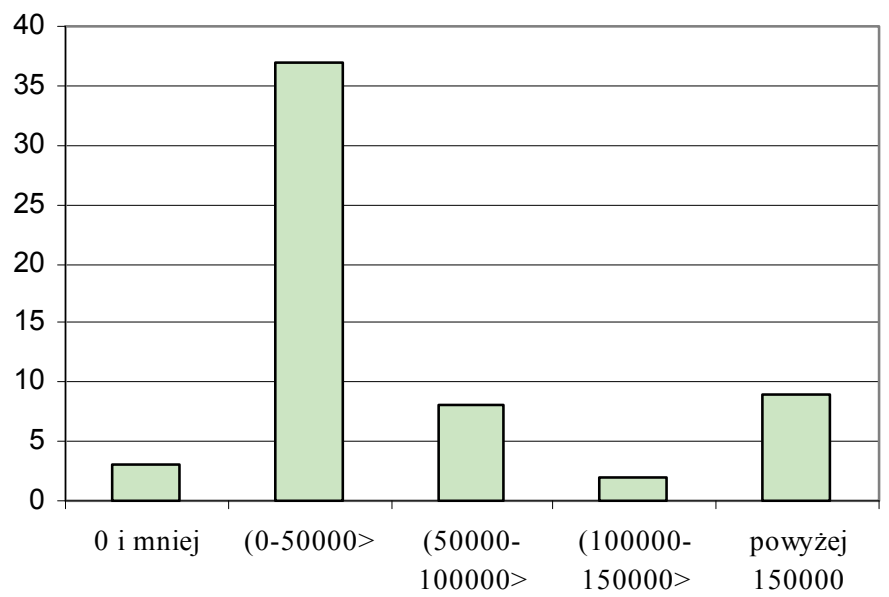

Potencjal inwestycyjny próby III

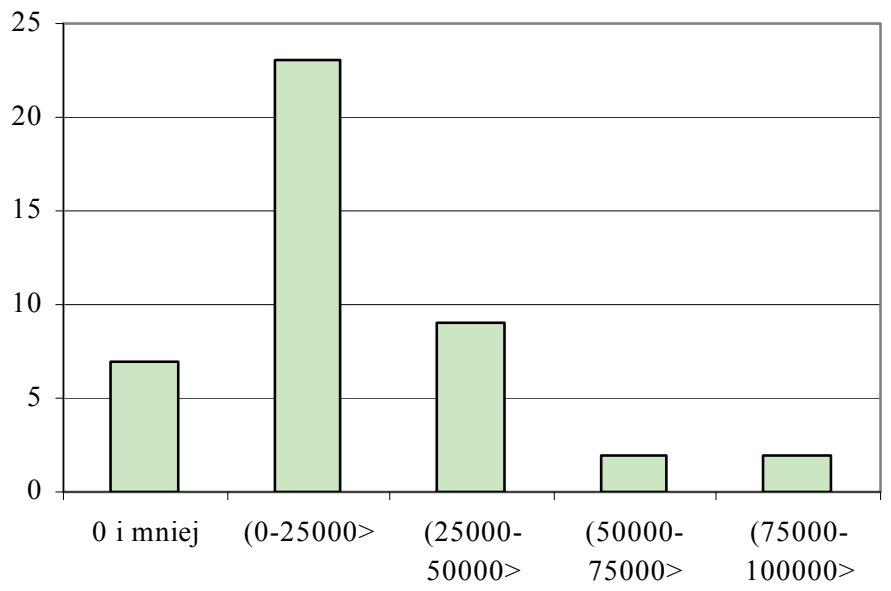

Wykres 5.24. Potencjał inwestycyjny dla próby I i III w latach 2009-2011 (w tys. zł) Źródło: oprac. własne

Najwięcej jednostek samorządu terytorialnego dla I i III próby znajduje się w drugim przedziale, co oznacza, że samorządy dysponują stosunkowo niskim potencjałem inwestycyjnym. W związku z powyższym, ograniczone są możliwości finansowania inwestycji ze środków budżetowych. W samorządach, które zdecydowały się na realizację inwestycji w formule PPP i zamieściły ogłoszenie o wyborze partnera prywatnego znalazły się trzy jednostki, dwie gminy i jeden powiat, których potencjał inwestycyjny był ujemny (Chełm, Zblewo, powiat 
lubiński). Dziewięć samorządów odnotowało potencjał inwestycyjny na poziomie powyżej $150 \mathrm{mln}$ zł.

W gminach miejskich województwa łódzkiego jednostek samorządu terytorialnego z ujemnym poziomem potencjału inwestycyjnego było siedem (Ozorków, Rzgów, Tomaszów Mazowiecki, Tuszyn, Zgierz, Złoczew, Żychlin). Najliczniejszą była grupa samorządów, których poziom potencjału inwestycyjnego oscylował wokół $25 \mathrm{mln}$ zł, tj. należących do drugiego przedziału (tab. 5.18). Na wykresie 5.24 przedstawiono graficzną prezentację rozkładu potencjału inwestycyjnego dla próby I i III.

W grupie samorządów, które podpisały umowę o partnerstwo publicznoprywatne w latach 2009-2011 trzynaście jednostek odnotowało potencjał inwestycyjny w przedziale do $50 \mathrm{mln}$ zł, zaledwie trzy jednostki w przedziale powyżej $150 \mathrm{mln}$ zł.

Stosunkowo niski poziom potencjału inwestycyjnego stanowi istotną determinantę wykorzystania kapitału prywatnego $\mathrm{w}$ formule partnerstwa publiczno-prywatnego do realizacji zadań publicznych. Potwierdzenie znalazło to w determinacji jednostek do zawarcia umowy o PPP, których poziom potencjału inwestycyjnego nie przekroczył $50 \mathrm{mln}$ zł.

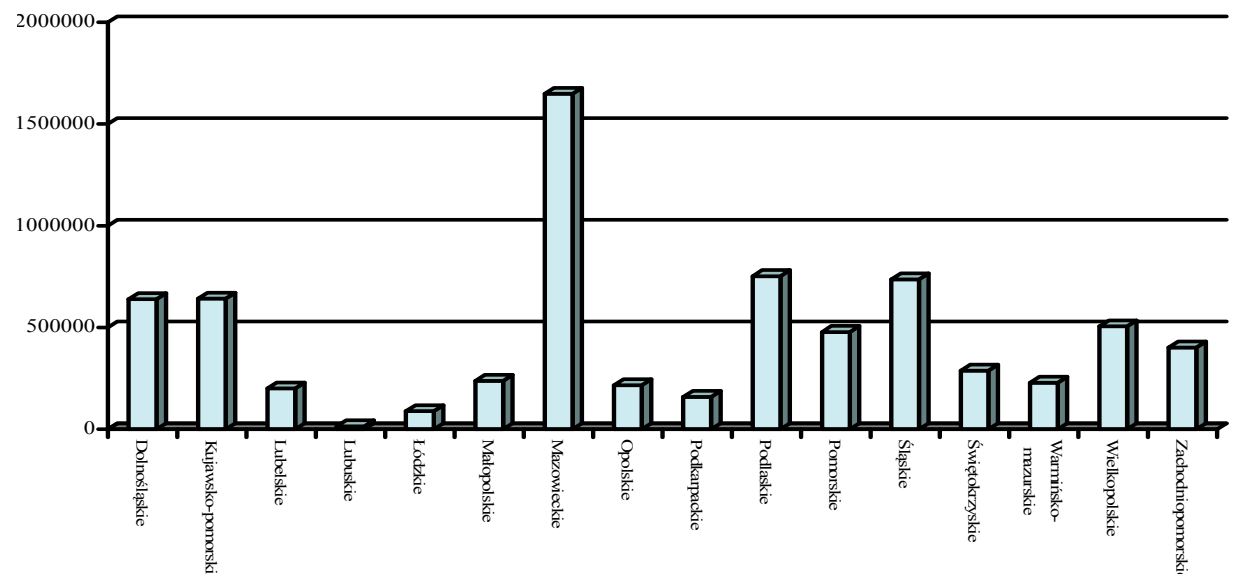

Wykres 5.25. Potencjał inwestycyjny dla próby II w ujęciu wojewódzkim w latach 2009-2011 (w tys. zł)

Źródło: oprac. własne

Analiza miast będących siedzibą organów zarządzających oraz/lub stanowiących województw samorządowych wskazuje, że potencjał ten średnio wyniósł $401 \mathrm{mln}$ zł. Największym dysponowała Warszawa (1648 $\mathrm{mln}$ zł), a najmniejszym Gorzów Wielkopolski (województwo lubuskie - $14 \mathrm{mln}$ zł). Najwięcej miast $\mathrm{z}$ próby II dysponowało potencjałem inwestycyjnym nie przekraczającym $500 \mathrm{mln}$ zł. 
Województwo małopolskie charakteryzuje duża aktywność we wdrażaniu nowych rozwiązań w zakresie finansowania inwestycji. Pionierem jest, jak już wspomniano w rozdziale V, Gmina Miasto Kraków, które planuje, a następnie wdraża nowe rozwiązania ${ }^{20}$. W analizowanym okresie potencjał inwestycyjny miasta kształtował się poniżej $500 \mathrm{mln}$ zł. Niski poziom możliwości inwestycyjnych był jedną z przesłanek (ale także koniecznością) poszukiwania nowych rozwiązań, które pozwoliłyby na kontynuowanie polityki inwestycyjnej, możliwej do prowadzenia w ramach PPP. W porównaniu z miastami województwa małopolskiego odmiennie przedstawia się sytuacja samorządów województwa mazowieckiego. Stosunkowo wysoki poziom potencjału inwestycyjnego nie ogranicza województwa do tradycyjnych form finansowania. Miasto Warszawa aktywnie zabiega o prywatnych inwestorów dla partnerskich inwestycji. W badanym okresie zamieściło 4 ogłoszenia o wybór partnera prywatnego i obecnie postępowania znajdują się w fazie negocjacji. Potencjał inwestycyjny pozostałych miast wojewódzkich pozostaje na poziomie nie przekraczającym $500 \mathrm{mln}$ zł, w tym sześć miast nie planuje wykorzystania PPP przy realizacji inwestycji. Są to miasta będące siedzibą organów zarządzających oraz/lub stanowiących województw: lubelskiego, lubuskiego, opolskiego, podkarpackiego, podlaskiego i śląskiego (wykres 5.25).

Z punktu widzenia możliwości inwestycyjnych samorządu zbadano współzależność pomiędzy potencjałem inwestycyjnym (PI) a poziomem dochodów ogółem (DO). Przyjęto, że o możliwościach inwestycyjnych w jednostce samorządu terytorialnego decydują dwa podstawowe czynniki: skłonność i zdolność do inwestycji. Skłonność do inwestycji określana jest poprzez motywowanie władz samorządowych do podejmowania działań inwestycyjnych. Jej głównym czynnikiem jest dążenie i chęć zaspokajania potrzeb mieszkańców. Zakres podejmowanych działań inwestycyjnych będzie uzależniony od możliwości władz samorządowych w obszarze finansowym, organizacyjno-kadrowym oraz technologicznym. Problem finansowania inwestycji stanowi podstawową barierę. Ograniczenia budżetowe spowodowane brakiem własnych środków oraz utrudnienia w pozyskiwaniu źródeł zwrotnych w znacznym stopniu ograniczają zdolność inwestycyjną samorządów. Z tego wynika, że czynnikiem który bezpośrednio oddziałuje na potencjał inwestycyjny jest poziom dochodów. $\mathrm{W}$ badanych jednostkach samorządu terytorialnego relację pomiędzy potencjałem inwestycyjnym a poziomem dochodów przedstawiono w tab. 5.19.

${ }^{20}$ Miasto Kraków było jednym z pionierów emisji obligacji komunalnych na rynku krajowym oraz euroobligacji I emisji w 1998 r. i II emisji w 2000 r. 
Tabela 5.19

Relacja potencjału inwestycyjnego do dochodów ogółem w latach 2009-2011 dla poszczególnych próbach badawczych

\begin{tabular}{|c|c|c|c|}
\hline Przedział & Rozpiętość procentowa & Liczba JST & Udział (w \%) \\
\hline \multicolumn{4}{|c|}{ Próba I } \\
\hline I & $0 \mathrm{i} \mathrm{mniej}$ & 3 & 5,1 \\
\hline II & $(0-10>$ & 22 & 37,3 \\
\hline III & $(10-20>$ & 22 & 37,3 \\
\hline IV & $(20-30>$ & 8 & 13,6 \\
\hline $\mathrm{V}$ & $(30-40>$ & 1 & 1,7 \\
\hline VI & $(40-50>$ & 3 & 5,1 \\
\hline \multicolumn{4}{|c|}{ Próba II } \\
\hline I & 0 i mniej & 0 & 0,0 \\
\hline II & $(0-10>$ & 9 & 50,0 \\
\hline III & $(10-20>$ & 6 & 33,3 \\
\hline IV & $(20-30>$ & 3 & 16,7 \\
\hline \multicolumn{4}{|c|}{ Próba III } \\
\hline $\mathrm{I}$ & 0 i mniej & 7 & 16,3 \\
\hline II & $(0-10>$ & 7 & 16,3 \\
\hline III & $(10-20>$ & 18 & 41,9 \\
\hline IV & $(20-30>$ & 8 & 18,6 \\
\hline $\mathrm{V}$ & Powyżej 30 & 3 & 7,0 \\
\hline
\end{tabular}

Źródło: oprac. własne.

Z obserwacji zależności wielkości potencjału inwestycyjnego i dochodów ogólem wynika, że w większości jednostek samorządu terytorialnego w próbie I i III zależność ta kształtuje się $\mathrm{w}$ przedziale trzecim, gdzie relacja PI/DO oscyluje w granicy 20,0\%. Oznacza to niską zdolność do finansowania inwestycji z dochodów ogółem. Niedobór środków budżetowych w sposób oczywisty będzie wymuszał na samorządach konieczność poszukiwania i wykorzystywania innych, oferowanych przez rynek instrumentów, w tym analizowanego partnerstwa publiczno-prywatnego. W miastach będących siedzibą władz organów stanowiących i/lub zarządczych województw najwięcej jednostek zanotowało potencjał inwestycyjny na poziomie do $10,0 \%$. Wśród samorządów w próbie III znalazły się także takie samorządy, których relacja PI/DO była powyżej $30 \%$ (Gminy: Kamieńsk, Pabianice, Uniejów). Niepokój budzą także prognozowane wielkości potencjału inwestycyjnego i relacja PI/DO na lata 2012-2016. $\mathrm{Z}$ danych ujętych w Wieloletnich Prognozach Finansowych wynika, że wielkość potencjału inwestycyjnego będzie malała. Przyczyna tego spadku upatrywana 
jest $\mathrm{w}$ spadku dochodów ogółem, braku nadwyżki finansowej z lat ubiegłych oraz środków $\mathrm{z}$ prywatyzacji. Podobny trend występuje $\mathrm{w}$ relacji potencjału inwestycyjnego do dochodów ogółem. Taki stan rzeczy będzie konsekwencją skutków spowolnienia gospodarczego, kryzysu fiskalnego samorządów oraz zmian ustawowych $\mathrm{w}$ zakresie limitu zadłużenia oraz klasyfikowania poszczególnych kategorii zobowiązań do długu. Władze samorządowe zwracają szczególną uwagę na fakt, że w perspektywie może dojść do ograniczenia wydatków inwestycyjnych nawet na poziomie 50,0\% (ograniczenie inwestycji wynika z Programu Konwergencji) ${ }^{21}$.

W odniesieniu do samorządów, które zawarły umowę o PPP, wielkość potencjału inwestycyjnego oraz wskaźnik relacji potencjału inwestycyjnego do dochodów ogółem przedstawiono w tab. 5.20.

Tabela 5.20

Relacja potencjału inwestycyjnego do dochodów ogółem w latach 2009-2011 w jednostkach samorządu terytorialnego, które zawarły umowę o PPP

\begin{tabular}{|l|c|c|}
\hline $\begin{array}{c}\text { JST, które zawarły umowę } \\
\text { o PPP }\end{array}$ & $\begin{array}{c}\text { Poziom potencjału inwesty- } \\
\text { cyjnego (w tys. zł) }\end{array}$ & $\begin{array}{c}\text { Relacja potencjału inwestycyjnego } \\
\text { do } \\
\text { dochodów ogółem (w \%) }\end{array}$ \\
\hline Gmina Gliwice & 499531 & 21,0 \\
\hline Gmina Gostynin & 13645 & 10,0 \\
\hline Gmina Kiszkowo & 10790 & 17,0 \\
\hline Gmina Kobylnica & 23195 & 2,0 \\
\hline Gmina Kraków & 327316 & 1,0 \\
\hline Gmina Krapkowice & 1597 & 23,0 \\
\hline Gmina Lazy & 27661 & 11,0 \\
\hline Gmina Piecki & 6907 & 12,0 \\
\hline Gmina Radzionków & 15093 & 25,0 \\
\hline Gmina Skąpe & 12442 & 1,0 \\
\hline Gmina Smołdzino & 399 & 38,0 \\
\hline Gmina Solec-Zdrój & 25125 & 14,0 \\
\hline Gmina Sucha Beskidzka & 9808 & 14,0 \\
\hline Gmina Ustka & 12809 & 6,0 \\
\hline Gmina Wrocław & 505338 & 10,0 \\
\hline Powiat Żywiecki & 44089 & \\
\hline
\end{tabular}

Źródło: oprac. własne.

Najwięcej samorządów, które realizują umowę o PPP, znajduje się w trzecim przedziale. Relacja potencjału inwestycyjnego do dochodów ogółem kształtuje się na poziomie około $20 \%$, co oznacza, że dochody ogółem mogą

${ }^{21}$ Rząd przyjął w Programie Konwergencji spadek wydatków inwestycyjnych o 50\%, Program Konwergencji. Aktualizacja 2012, Warszawa, kwiecień 2012, s. 20. 
sfinansować zaledwie $20 \%$ zgłaszanych możliwości inwestycyjnych. Ta sytuacja była przesłanką dla poszukiwania prywatnego inwestora, a w konsekwencji zawarcia umowy o PPP. Wart odnotowania jest fakt, że samorządy o bardzo niskiej relacji PI/DO zawarły więcej niż jedną umowę o PPP. Gmina Krapkowice przy relacji PI/DO na poziomie $1,0 \%$ zawarła dwie umowy o PPP, w gminie Kraków relacja PI/DO wyniosła $2,0 \%$, zawarto tu trzy umowy, a dziewięć przedsięwzięć znajduje się $\mathrm{w}$ fazie weryfikowania zasadności wykorzystania PPP. W przypadku gmin Smołdzino oraz Wrocław przy niskiej relacji potencjału inwestycyjnego do dochodów ogółem (na poziomie 1\%) zawarto w badanym okresie po jednej umowie.

Podsumowując, większość samorządów charakteryzowało się niskim potencjałem inwestycyjnym z przedziału $0-50000 \mathrm{mln}$. Niski poziom potencjału inwestycyjnego $\mathrm{W}$ rezultacie przełożył się na niski poziom relacji potencjału inwestycyjnego do dochodów ogółem, co skutkowało zawarciem umów o partnerstwo publiczno-prywatne.

\subsubsection{Poziom zadłużenia a partnerstwo publiczno-prywatne}

W okresie spowolnienia gospodarczego wywołanego ogólnoświatowym kryzysem finansowo-gospodarczym większość poddanych badaniu jednostek samorządu terytorialnego odnotowała deficyt budżetowy. Zrealizowane w trakcie roku budżetowego wydatki nie znalazły pokrycia w będących do dyspozycji dochodach. Samorządy systematycznie zmuszone były do korzystania z finansowania komercyjnego. Dominującym źródłem finansowania deficytu były kredyty i pożyczki, które stanowiły przeszło $80 \%$ całego zadłużenia. W efekcie wskaźnik zadłużenia ogólnego systematycznie wzrastał. W próbie I najwięcej badanych samorządów odnotowało zadłużenie ogólne na poziomie od 35 do $45 \%$, stanowiąc $27,1 \%$ całej próby. W pozostałych jednostkach tej próby wskaźnik ogólnego zadłużenia przedstawiał się następująco: $25,0 \%$ próby odnotowało zadłużenie w przedziale od 25 do $35 \%, 15,0 \% \mathrm{w}$ przedziale od 15 do $25 \%$ zadłużenia. Wśród jednostek znalazła się gmina, w której wskaźnik zadłużenia wyniósł $1,71 \%$ (Nałęczów). W całej próbie poziom zadłużenia nie przekroczył ustawowego limitu $60 \%$. Przeciętny poziom wskaźnika ogólnego dla próby I przedstawiono na wykresie 5.26.

W próbie II wskaźnik ogólnego zadłużenia dla sześciu miast w ciągu trzech badanych lat zbliżył się do granicy $60 \%$. Są to: Bydgoszcz, Poznań, Toruń, Wrocław, Kraków oraz Łódź. Dla pozostałych miast wskaźnik zadłużenia ogólnego oscylował w przedziale od 25 do $55 \%$. Z analizy wynika, że wszystkie miasta w 2010 r. odnotowały wzrost wskaźnika zadłużenia średnio o 7,0\%. W roku 2011 r. sześć miast odnotowało spadek wskaźnika zadłużenia, w pozostałych utrzymana została tendencja wzrostowa. Największy wzrost poziomu wskaźnika odnotowano w Poznaniu (o blisko 25,0\%) oraz we Wrocławiu (o 24,0\%). 


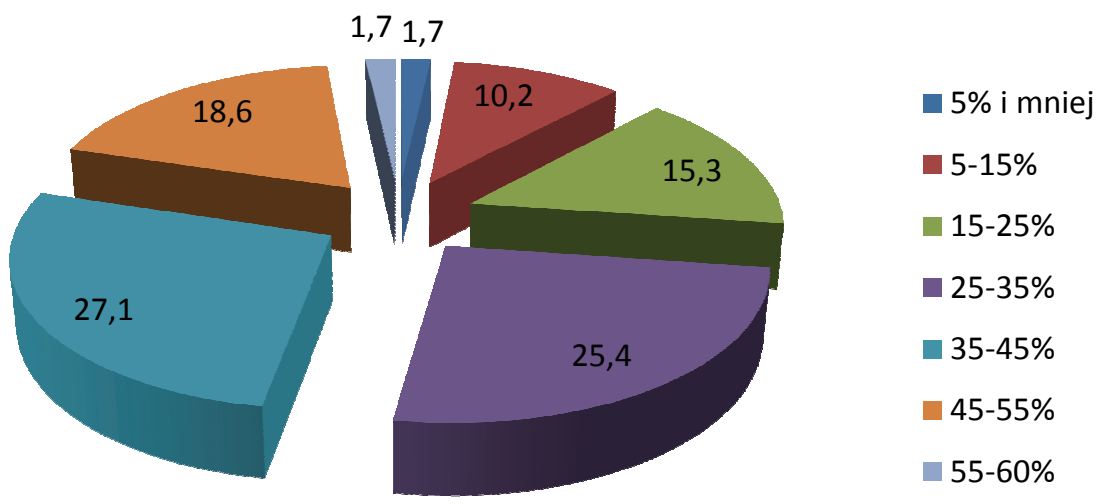

Wykres 5.26. Przeciętny poziom wskaźnika ogólnego zadłużenia dla próby I w latach 2009-2011 (w \%)

Źródło: oprac. własne.

Przeciętny poziom wskaźnika ogólnego zadłużenia dla poszczególnych miast $\mathrm{z}$ próby II $\mathrm{w}$ analizowanym okresie przedstawiono na wykresie 5.27.

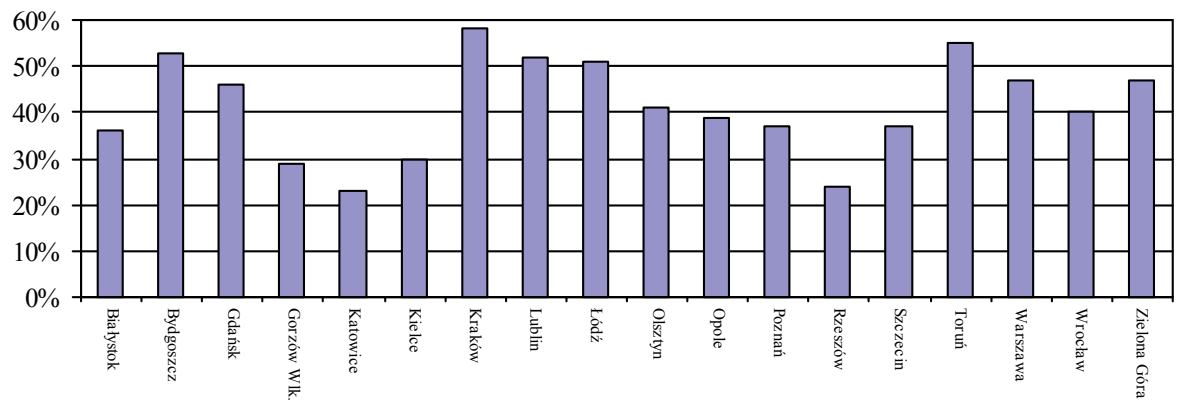

Wykres 5.27. Przeciętny poziom wskaźnika ogólnego zadłużenia dla próby II w latach 2009-2011 (w \%)

Źródło: oprac. własne

W próbie trzeciej łącznie 12 gmin miejskich odnotowało zadłużenie w przedziale $25-35 \%$, co stanowiło blisko $29,0 \%$ próby, w 11 miastach wskaźnik znajdował się w przedziale $35-45 \%$ (26,0\% próby) a w 10 samorządach wskaźnik ogólnego zadłużenia wynosił $15-25 \%$, co stanowiło $23,9 \%$ próby. W dwóch gminach miejskich poziom zadłużenia zbliżył się do $60 \%$, a w sześciu wynosił poniżej 15\% (wykres 5.28). 


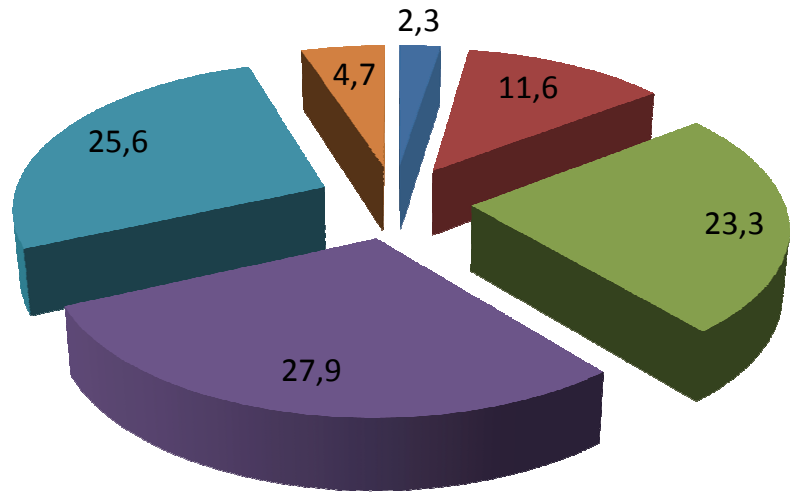

$5 \%$ i mniej

$5-15 \%$

$15-25 \%$

$25-35 \%$

$35-45 \%$

$45-60 \%$

Wykres 5.28. Przeciętny poziom wskaźnika ogólnego zadłużenia dla próby III w latach 2009-2011 (w \%)

Źródło: oprac. własne

Tabela 5.21

Przeciętny wskaźnik obsługi zadłużenia dla próby I i III w latach 2009-2011

\begin{tabular}{|l|c|c|c|}
\hline \multicolumn{1}{|c|}{ Przedział } & Rozpiętość procentowa & Liczba JST & Udział (w \%) \\
\hline \multicolumn{2}{|c|}{ Próba I } \\
\hline I & 1,0 i mniej & 1 & 1,7 \\
\hline II & $(1,0-3,5>$ & 13 & 22,0 \\
\hline III & $(3,5-6,0>$ & 12 & 20,3 \\
\hline IV & $(6,0-8,5>$ & 21 & 35,6 \\
\hline V & $(8,5-11,0>$ & 8 & 13,6 \\
\hline VI & $(11,0-13,5>$ & 4 & 6,8 \\
\hline VII & $(13,5-15>\quad$ & 7 & 0,0 \\
\hline \multicolumn{4}{|c|}{ Próba III } \\
\hline I & 2,0 i mniej & 14 & 16,3 \\
\hline II & $(2,0-6,0>\quad 14$ & 32,6 \\
\hline III & $(6,0-10,0>$ & 5 & 32,6 \\
\hline IV & $(10,0-14,0>$ & 1 & 11,6 \\
\hline V & Powyżej 14,0 & 0 & 2,3 \\
\hline
\end{tabular}

Źródło: oprac. własne.

W badanych jednostkach samorządu terytorialnego stwierdzono tendencję do systematycznego wzrostu poziomu zadłużenia, o czym świadczy relacja zobowiązań ogółem do dochodów ogółem. Intensyfikacja wzrostu zadłużenia nastąpiła w latach 2009-2011, co jest wynikiem pogorszenia się sytuacji finansowej jednostek oraz konieczności zaciągania nowych zobowiązań na finansowanie zadań, w tym także współfinansowanych ze środków unijnych. Wzrost relacji zobowiązań do długu nie wpłynął znacząco na drastyczny wzrost 
kosztów obsługi zadłużenia. Wskaźnik ten w poszczególnych próbach nie przekroczył ustawowego limitu $15 \%$. Jego poziom dla I i III próby badawczej zaprezentowano $\mathrm{w}$ tab. 5.21 oraz na wykresie 5.29.

W pierwszej próbie najniższy wskaźnik obsługi zadłużenia odnotowano w gminie Nałęczów, co wynika z niskiego tu poziomu zadłużenia. W blisko $36 \%$ próby wskaźnik obsługi zadłużenia kształtował się w przedziale od 6 do $8,5 \%$. W miastach będących siedzibami organów zarządczych lub/i stanowiących województw występuje analogiczna sytuacja. W większości wskaźnik obsługi zadłużenia waha się w przedziale od 5 do $10 \%$. Jedynie w Krakowie wskaźnik ten zbliża się do limitu $15 \%$. W gminach miejskich województwa łódzkiego dominują dwie grupy jednostek. Pierwsza z kosztami obsługi zadłużenia na poziomie do $6 \%$ (33\% badanych samorządów) i druga, stanowiąca $33 \%$, ze wskaźnikiem na poziomie od 6 do $10 \%$ kosztów obsługi zadłużenia. W pozostałych samorządach, objętych tą próbą, wskaźnik kosztów obsługi zadłużenia przekroczył 10\%, a w przypadku jednej gminy zbliżył się do ustawowego limitu 15\% (w gminie Kraków).

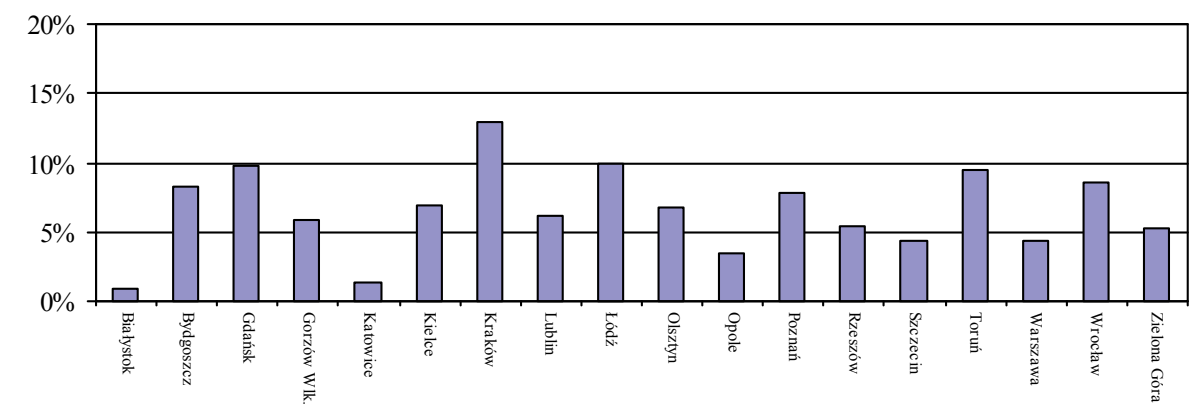

Wykres 5.29. Przeciętny wskaźnik obsługi zadłużenia dla próby II w latach 2009-2011 (w \%) Źródło: oprac. własne

Z informacji objętych Wieloletnią Prognozą Finansową wynikają niekorzystne prognozy dotyczące poziomu zarówno wskaźnika ogólnego zadłużenia, jak i wskaźnika obsługi zadłużenia. Wszystkie jednostki prognozują wzrost wskaźnika zadłużenia ogólnego średnio o $40 \%$, a wskaźnika obsługi zadłużenia analogicznie o $20-25 \%$. Oznacza to, że blisko $20 \%$ poddanych badaniu jednostek osiągnie górną granicę obowiązującego obecnie limitu. Już wiadomo, że przy nowym sposobie liczenia wskaźnika zadłużenia może to oznaczać utratę zdolności do zaciągania nowych zobowiązań, co spowoduje zastój inwestycyjny.

Analiza sytuacji finansowej jednostek samorządu terytorialnego, które zawarły umowę o partnerstwo publiczno-prywatne, potwierdza pogarszającą się sytuację. Na granicy $60 \%$ ogólnego zadłużenia znajdują się Kraków i Gostynin. 
Obecnie podejmowane są tam działania zmierzające do ograniczenia długu (przygotowanie do emisji obligacji restrukturyzacyjnych, przerzucenie długu do spółek komunalnych), mają one przynieść obniżenie wskaźnika zadłużenia do poziomu $50 \%$ w $2016 \mathrm{r}$. W pozostałych samorządach wskaźnik nie przekracza $50 \%$. Poziom przeciętnego wskaźnika ogólnego zadłużenia oraz przeciętnego wskaźnika obsługi zadłużenia przedstawiono w tab. 5.22.

Tabela 5.22

Przeciętny wskaźnik ogólnego zadłużenia i przeciętny wskaźnik obsługi zadłużenia jednostek samorządu terytorialnego, które zawarły umowę o PPP w latach 2009-2011

\begin{tabular}{|l|c|c|}
\hline $\begin{array}{c}\text { JST, które zawarły umowę o } \\
\text { PPP }\end{array}$ & $\begin{array}{c}\text { Przeciętny wskaźnik ogólnego } \\
\text { zadłużenia (w \%) }\end{array}$ & $\begin{array}{c}\text { Przeciętny wskaźnik obsługi } \\
\text { zadłużenia (w \%) }\end{array}$ \\
\hline Gmina Gliwice & 8,0 & 6,9 \\
\hline Gmina Gostynin & 52,0 & 11,2 \\
\hline Gmina Kiszkowo & 9,0 & 2,7 \\
\hline Gmina Kobylnica & 51,0 & 8,5 \\
\hline Gmina Kraków & 58,0 & 13,0 \\
\hline Gmina Krapkowice & 38,0 & 8,2 \\
\hline Gmina Lazy & 48,0 & 7,8 \\
\hline Gmina Piecki & 48,0 & 7,3 \\
\hline Gmina Radzionków & 40,0 & 5,8 \\
\hline Gmina Skąpe & 15,0 & 4,0 \\
\hline Gmina Smołdzino & 29,0 & 3,5 \\
\hline Gmina Solec- Zdrój & 20,0 & 6,2 \\
\hline Gmina Sucha Beskidzka & 29,0 & 6,7 \\
\hline Gmina Ustka & 47,0 & 6,3 \\
\hline Gmina Wrocław & 40,0 & 8,6 \\
\hline Powiat Żywiecki & 35,0 & 6,5 \\
\hline
\end{tabular}

Źródło: oprac. własne.

Bazując na przeciętnym wskaźniku ogólnego zadłużenia, z wyjątkiem trzech jednostek samorządu terytorialnego, jednostki, które zawarły umowę o PPP, nie są w drastycznej sytuacji finansowej, która charakterystyczna jest dla całego podsektora samorządowego. Zdecydowana większość nie przekroczyła $50 \%$ poziomu zadłużenia. Również roczne koszty obsługi długu nie przekraczają ustawowego limitu $15 \%$.

Jeśli przeanalizujemy poszczególne okresy oddzielnie, to zauważymy, że w roku 2011 nastąpił wzrost zarówno wskaźnika zadłużenia, jak i kosztów obsługi długu. Za bezpośrednią przyczynę takiego stanu rzeczy należy uznać zmianę $\mathrm{w}$ sposobie zaliczania poszczególnych tytułów dłużnych do poziomu długu, wynikającą z zapisów Rozporządzenia Ministra Finansów z 23 grudnia $2010 \mathrm{r}$. Rozporządzenie to rozszerzyło zakres kredytów i pożyczek zaliczanych 
do długu, co wpłynęło na wzrost relacji zobowiązań ogółem do dochodów ogółem. Powyższe rozwiązanie prowadzi do poważnego zahamowania rozwoju jednostek samorządu terytorialnego i ograniczenia wydatków inwestycyjnych. Od 2014 r. zacznie obowiązywać nowy, indywidualny wskaźnik. Już w 2011 r. władze samorządowe podjęły działania zmierzające do generowania nadwyżek operacyjnych (dochody - wydatki bieżące), gdyż wyniki budżetowe za lata 2011-2013 będą podstawą do określenia poziomu wydatków na obsługę długu w 2014 r. Ograniczenie możliwości zadłużania drastycznie odbije się na ograniczeniu nie tylko wydatków inwestycyjnych, ale może także prowadzić do braku środków na realizację ustawowych, bieżących zadań własnych. Jest to konsekwencja polityki rządu prowadzonej w ostatnich latach względem JST. Brak jest zachowania konstytucyjnej zasady adekwatności środków finansowych do poziomu delegowanych zadań. Zdaniem skarbnika Krakowa obecnie jednym z głównych obciążeń dla finansów samorządowych są zadania oświatowe i niewystarczający poziom subwencji oświatowej na ich finansowanie. W samym Krakowie w ciągu ostatnich czterech lat dopłaty do zadań oświatowych wzrosły ze 139 do $643 \mathrm{mln} \mathrm{zt}^{22}$. Rozwiązaniem powinny okazać się zmiany systemowe oraz zmiany w Karcie Nauczyciela, które - zdaniem samorządowców - dziś nie przystają do rzeczywistości ${ }^{23}$. Ponadto trwa realizacja inwestycji współfinansowanych ze środków unijnych, gdzie samorządy były zobligowane do zagwarantowania wkładu własnego. W większości pochodził on ze źródeł zwrotnych. Utrzymanie dotychczasowego poziomu inwestycji, przy jednoczesnym utrzymaniu, a nawet zmniejszeniu, zadłużenia wymaga poszukiwania i zastosowania rozwiązań, które podniosą efektywność działania. Tym rozwiązaniem może być sięgnięcie po kapitał prywatny w ramach PPP. W przypadku samorządów, które już realizują umowy o PPP, w chwili obecnej poza Krakowem i Gostyninem samorządy, pomimo że nie zbliżyły się do ustawowego limitu zadłużenia, to zdecydowały się na wykorzystanie formuły PPP do realizacji zadań.

Analiza zjawiska, z uwagi na ograniczone badania wynikające z liczby dotychczasowo zawartych umów o PPP w Polsce, nie pozwala na jednoznaczne stwierdzenie, że poziom zadłużenia ma bezpośredni, a zarazem decydujący wpływ na skłonność do zawarcia umowy o PPP. Duża rozpiętość w poziomie zadłużenia i kosztach jego obsługi może jedynie sugerować, że czynnik ten, przy pogarszającej się sytuacji finansowej jednostki i ograniczonych możliwościach zadłużania, będzie wywierał wpływ na zachowanie władz i wyzwalał w samorządach skłonność do poszukiwania niestandardowych rozwiązań.

${ }^{22}$ A. Gniatkowski, Forum niepokoju i nadziei, „Wspólnota” 2012, nr 41-42, s. 18.

${ }^{23}$ Wnioski z dyskusji w ramach Kongresu Samorządowego Gmina 2012, Poznań 20-23 listopada 2012 r. 
Nie można także jednoznacznie wskazać, które typy jednostek samorządu terytorialnego są bardziej podatne na nowe rozwiązania. Wśród samorządów z podpisaną umową o PPP wysoki poziom zadłużenia mają zarówno gminy miejskie, jak i miejsko-wiejskie oraz wiejskie. Wszystkie posiłkowały się zwrotnymi instrumentami w celu finansowania zadań i wszystkie wykazały skłonność do zawierania umów o PPP. Można pokusić się jedynie o stwierdzenie, że obok aspektu finansowego wpływ na decyzje o zawarciu umowy o PPP wywarły względy pozafinansowe. Decydujące znaczenie miało pokonanie bariery psychologicznej, a także efekt marketingowy, pozyskanie i związanie na dłuższy czas prywatnego inwestora $\mathrm{z}$ samorządem, który w przyszłości może być zainteresowany realizacją kolejnego zadania publicznego. 



\section{TEORETYCZNY MODEL PARTNERSTWA PUBLICZNO-PRYWATNEGO JAKO IMPERATYW DLA FINANSOWANIA INWESTYCJI JEDNOSTEK SAMORZĄDU TERYTORIALNEGO}

\subsection{Zalożenia teoretycznego modelu partnerstwa publiczno-prywatnego}

Zakres działania i związana z nim wielkość sektora publicznego są pochodną przyjętego modelu, który określa rolę państwa w gospodarce i realizowane przez nie funkcje. Niezależnie od różnych poglądów na rolę państwa w gospodarce (od liberalizmu po daleko posunięty interwencjonizm) akceptowane jest tworzenie przez państwo ładu instytucjonalno-prawnego, który ustanawia reguły funkcjonowania gospodarki i społeczeństwa. Powszechnie akceptowana jest także funkcja alokacyjna, która polega na tworzeniu przez państwo warunków sprzyjających możliwie najefektywniejszemu wykorzystaniu czynników produkcji, wspomaga i koryguje rynki w przypadku występowania monopolu.

Powszechnie wyrażana opinia na temat zawodności zarówno mechanizmu rynkowego, jak i roli państwa oraz słabości w zarządzaniu finansami skłaniały i nadal skłaniają do poszukiwania nowych, bardziej skutecznych i efektywniejszych rozwiązań w dostarczaniu dóbr i usług publicznych. W ubiegłym stuleciu nastąpiła zasadnicza transformacja koncepcji państwa. Z „klasycznego państwa minimalnego" (tzw. stróża nocnego) przekształciło się w państwo ukierunkowane na społeczeństwo, co pociągnęło za sobą wzrost wydatków na sferę socjalną. Państwo usiłuje spełniać szeroko pojęte funkcje opiekuńcze, angażując się w zaspokajanie takich potrzeb społecznych, które w liberalnym modelu państwa mieszczą się w sferze indywidualnej konsumpcji dóbr i usług. Odpowiedzią na te dylematy było powstanie koncepcji określanej „nowym zarządzaniem publicznym" (New Public Management - NPM). U jej podstaw stoi założenie o potrzebie zapewnienia gospodarności, efektywności oraz skuteczności zarówno władz publicznych, występujących w charakterze podmiotu zarządzającego całością zadań publicznych, jak i poszczególnych podmiotów występujących w roli bezpośrednich wykonawców tych zadań. $N P M$ postuluje konieczność poprawy jakości dóbr i usług publicznych oraz ich lepsze dostosowanie do zróżnicowanych i ciągle ewaluujących potrzeb społecznych. W koncepcję NPM 
z powodzeniem wpisuje się formuła partnerstwa publiczno-prywatnego. Sprawne i efektywne funkcjonowanie PPP $\mathrm{w}$ gospodarce wymaga zdefiniowania modelowych uwarunkowań, które zdecydują o prawidłowości formuły partnerstwa publiczno-prywatnego.

Konstrukcję Teoretycznego Modelu PPP (Modelu PPP) muszą poprzedzić założenia:

1) współdziałanie międzysektorowe może być prowadzone w ramach istniejącego systemu prawnego obowiązującego w danym państwie lub w drodze przyjęcia nowych, odrębnych aktów prawnych w zakresie PPP,

2) partnerstwo publiczno-prywatne wymaga alokacji zadań i ryzyk,

3) konieczne jest powołanie instytucji ds. PPP i standaryzacji procedur PPP,

4) niezbędne jest przygotowanie administracyjno-organizacyjnego podmiotów publicznych.

Model składa się z trzech filarów PPP: prawnego, finansowego oraz administracyjno-organizacyjnego. Filary tworzą zbiory części składowych (czynników), których istnienie i siła wzajemnego oddziaływania kształtują strukturę współpracy partnerskiej i przesądzają o zasadności wyboru.

Filar prawny PPP zawiera regulacje prawne w zakresie PPP, które obejmują:

- regulacje międzynarodowe,

- prawo krajowe, w ramach którego mogą wystąpić następujące rozwiązania:

○ dotychczasowe akty prawne znajdują zastosowanie dla PPP,

o odrębny akt prawny,

○ odrębny akt prawny wraz z przepisami wykonawczymi,

- umowa o partnerstwo publiczno-prywatne.

W filarze finansowym PPP znajdują się:

- czas finansowania zadania publicznego,

- dywersyfikacja źródeł finansowania zadań publicznych,

- neutralność PPP w relacji do deficytu sektora finansów publicznych i długu publicznego,

- alokacja ryzyk,

- wolumen zadań,

- standard zadań.

W filarze administracyjno-organizacyjnym PPP wyróżnia się:

- rządowe instytucje ds. PPP,

- pozarządowe instytucje wspierające PPP,

- przyjazny klimat wokół PPP,

- standaryzacja procedur.

Siła i zakres oddziaływania głównych filarów (prawnego, finansowego, administracyjno-organizacyjnego) przesądzają o ostatecznym kształcie współpracy i zasadności wyboru PPP jako efektywnym sposobie wykonania zadania publicznego. Spójny system prawny, wypracowane standardy postępowania, zbiory najlepszych praktyk, sprzyjają określeniu podstawy prawnej dla współ- 
pracy podmiotów w formule PPP, prowadząc do oszczędności finansowych, organizacyjnych oraz czasowych. Prawidłowo zastosowane rozwiązania prawne ograniczają ryzyko unieważniania procedur zawarcia PPP.

Prawidłowo przeprowadzona analiza ekonomiczno-finansowa wskazuje na zasadność zastosowania PPP jako źródła finansowania. O neutralności wpływu przedsięwzięcia na deficyt budżetowy i dług publiczny przesądza analiza ryzyk i ich alokacja. Efektem prawidłowo skorelowanych czynników jest wartość, jaką uzyska podmiot z tytułu wyboru PPP (Value for Money). Składa się na nią liczba i jakość oferowanych ostatecznym odbiorcom zadań publicznych i usług użyteczności publicznej oraz racjonalność wydatkowanych środków publicznych, które mogą być przeznaczone na finansowanie innych zadań.

Merytoryczne wsparcie ze strony instytucji rządowych i pozarządowych sprzyja ugruntowaniu PPP na rynku jako nowej formuły realizacji zadań publicznych. Nowe rozwiązania wymuszają konieczność reorganizacji pracy urzędów, powołania nowych struktur (komórek) i wypracowania nowych metod promowania PPP. Oczekuje się wymiernych efektów w postaci oszczędności finansowych i czasowych.

Korzyści wynikające $\mathrm{z}$ zastosowania partnerstwa publiczno-prywatnego muszą być wymierne: rozbudowana infrastruktura bez obciążenia długu publicznego, zastosowane owe rozwiązania techniczne i technologiczne w dostarczaniu dóbr i usług, generowanie korzyści skali wynikających ze świadczenia usług na większym obszarze.

Celem tak skonstruowanego Teoretycznego Modelu PPP jest ocena stopnia skłonności podmiotów publicznych do zawierania umów o partnerstwo publiczno-prywatne. Aby określić ten stopień, każdej z części składowych filaru PPP nadano wartości w skali 0-1 (tab. 6.1).

Tabela 6.1

Proponowana skala wartości dla części składowych filarów Teoretycznego Modelu PPP

\begin{tabular}{|l|c|}
\hline \multicolumn{1}{|c|}{ Filar PPP i jego części składowe } & Skala wartości \\
\hline \multicolumn{1}{|c|}{ Filar prawny PPP } & 2 \\
\hline \multicolumn{1}{|c|}{ Filar finansowy PPP } & $\mathbf{5}$ \\
\hline Regulacje międzynarodowe & $0-1$ \\
\hline Dotychczasowe akty prawne znajdujące zastosowanie dla PPP & $0-1$ \\
\hline Odrębny akt prawny & $0-1$ \\
\hline Odrębny akt prawny z przepisami wykonawczymi & $0-1$ \\
\hline Umowa o partnerstwo publiczno-prywatne & $0-1$ \\
\hline \multicolumn{1}{|c|}{$\mathbf{6}$} \\
\hline Czas finansowania zadania publicznego & $0-1$ \\
\hline Dywersyfikacja źródeł finansowania zadań publicznych & $0-1$ \\
\hline $\begin{array}{c}\text { Neutralność PPP w relacji do deficytu sektora finansów publicznych i } \\
\text { długu publicznego }\end{array}$ & $0-1$ \\
\hline Alokacja ryzyk & $0-1$ \\
\hline
\end{tabular}


Tabela $6.1(\mathrm{~cd}$.

\begin{tabular}{|l|c|}
\hline \multicolumn{1}{|c|}{1} & 2 \\
\hline Wolumen zadań publicznych & $0-1$ \\
\hline Standaryzacja zadań publicznych & $0-1$ \\
\hline \multicolumn{1}{|c|}{ Filar administracyjno-organizacyjny PPP } & $\mathbf{4}$ \\
\hline Rządowe instytucje ds. PPP & $0-1$ \\
\hline Pozarządowe instytucje wspierające PPP & $0-1$ \\
\hline Przyjazny klimat wokół PPP & $0-1$ \\
\hline Standaryzacja procedur PPP & $0-1$ \\
\hline Łączna wartość & $\mathbf{1 5}$ \\
\hline
\end{tabular}

Źródło: oprac. własne.

Wartość 1 przypisano w sytuacji, gdy dany czynnik występuje. Natomiast w przypadku braku zaistnienia danego czynnika wartość wynosi 0 . W sytuacji, kiedy trudno jednoznacznie opowiedzieć się za występowaniem czynnika lub jego brakiem przyjmuje się także wartość 0 . Zastosowanie wartości w skali 0-1 wynika z prostoty i łatwości jej wykorzystania. Trudność w obiektywnym określeniu ważności poszczególnych części w ramach filarów PPP uniemożliwia zastosowanie wartości wagowych.

Kombinacja części składowych poszczególnych filarów PPP pozwala na określenie stopnia skłonności do partnerstwa publiczno-prywatnego (tab. 6.2).

Tabela 6.2

Przyjęte stopnie skłonności do PPP w zależności od poziomu wartości

\begin{tabular}{|l|c|}
\hline \multicolumn{1}{|c|}{ Przedział wartości } & Stopień skłonności \\
\hline $0-5$ & niski \\
\hline $6-10$ & przeciętny \\
\hline $10-15$ & wysoki \\
\hline
\end{tabular}

Źródło: oprac. własne.

Zakładając, że do współpracy międzysektorowej może dojść przy różnorodnej kombinacji części składowych ujętych w poszczególnych filarach PPP, określono trzy stopnie skłonności do partnerstwa publiczno-prywatnego, tj. stopień niski, przeciętny i wysoki. Wysoki stopień skłonności do PPP będzie występował wówczas, gdy wymienione w tab. 6.1 uwarunkowania wystąpią w idealnej, niezakłóconej postaci. Modyfikacja polegająca na braku wystąpienia którejkolwiek z części składowej filaru spowoduje obniżenie maksymalnej punktacji i będzie świadczyła o wystąpieniu zakłóceń w Teoretycznym Modelu $P P P$. Procedurę wzorcowego postępowania przy realizacji inwestycji w formule PPP przedstawiono na schemacie 6.1. 


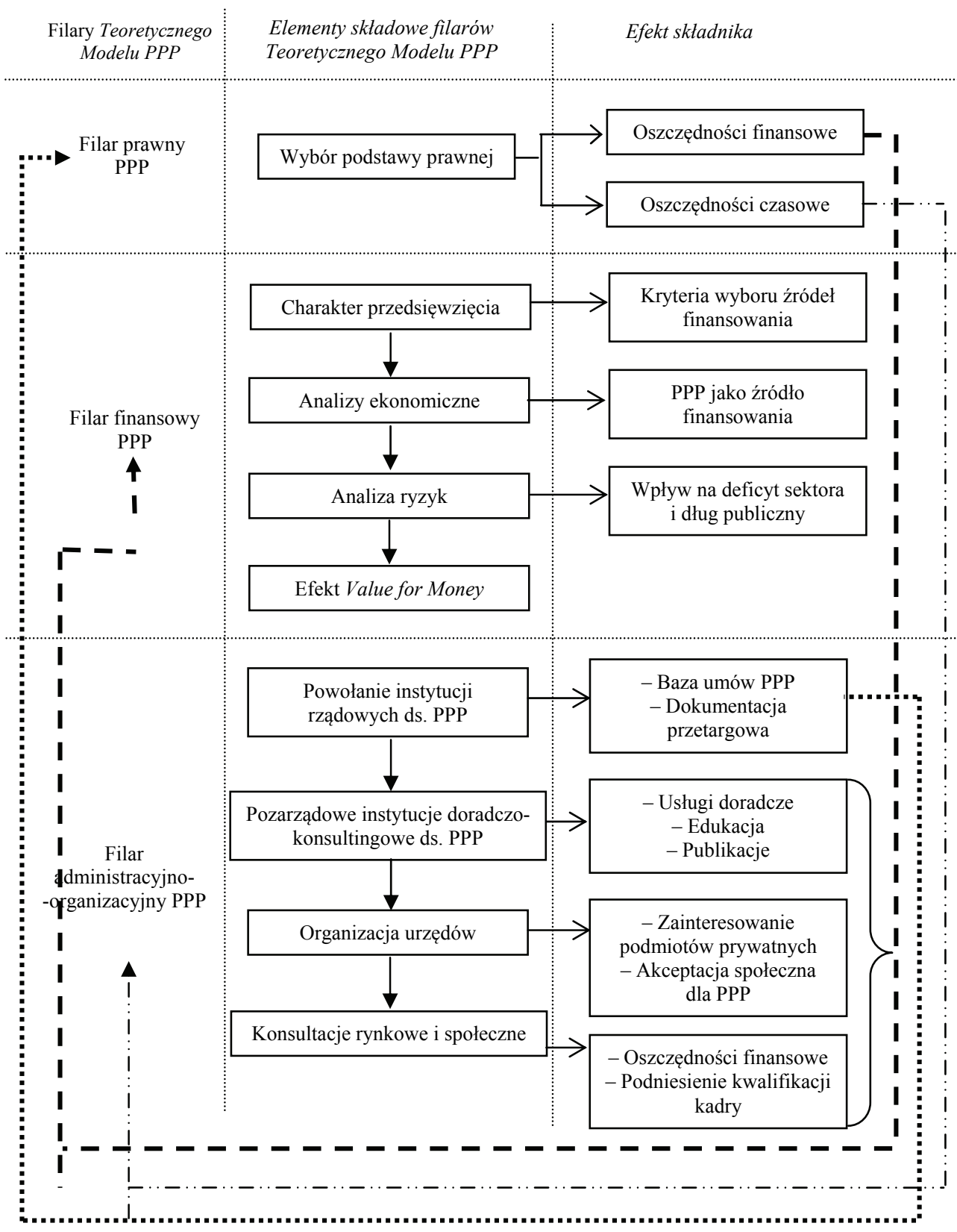

Schemat 6.1. Wzorcowy model przebiegu procesu realizacji inwestycji oparty na formule PPP Źródło: oprac. własne 
Zaproponowany Teoretyczny Model PPP ma charakter wzorcowy i przedstawia sytuację hipotetyczną. W praktyce może dojść do różnych deformacji i odchyleń w zależności od stopnia rozwoju rynku, rekomendowania rozwiązań w zakresie PPP przez centra rządowe i lokalne oraz otoczenia instytucjonalnodoradczego. Zmiana uwarunkowań i siła oddziaływania każdego z wymienionych elementów może doprowadzić do odkształceń w zaproponowanym Teoretycznym Modelu PPP.

\subsection{Model partnerstwa publiczno-prywatnego w sektorze finansów samorządowych}

Nowe zarządzanie publiczne jest koncepcją, która znajduje zastosowanie w zarządzaniu podsektorem samorządowym stwarzając warunki do zwiększania efektywności w wykonywaniu systematycznie rozszerzanego katalogu zadań jednostek samorządu terytorialnego ${ }^{1}$. Procesy decentralizacji sprzyjają przekazaniu władzom samorządowym odpowiedzialności nie tylko za realizację zadań własnych, ale również odpowiedzialność za rozwój lokalny i regionalny. Zadania wykonywane przez jednostki samorządu terytorialnego, zgodnie z zasadą subsydialności, należą do kategorii zadań publicznych. Polegają na zaspokojeniu $\mathrm{w}$ drodze konsumpcji zbiorowej potrzeb społecznych poprzez świadczenie usług oraz wytwarzania dóbr materialnych o charakterze użyteczności publicznej. Dostarczanie usług i dóbr odbywa się w zasadzie nieodpłatnie lub za częściową odpłatnością, która ma na celu nie tyle osiągnięcie rentowności działania, ile regulowanie popytu na oferowane dobra i usługi. Stworzenie odpowiedniej infrastruktury społecznej i technicznej w samorządach sprzyja rozwojowi, poprawie warunków i jakości życia mieszkańców oraz podmiotów gospodarczych ulokowanych na jej terenach. Zwiększenie potencjału rozwojowego wymaga rozbudowy infrastruktury oraz uruchomienia inwestycji generujących nowe miejsca pracy. Realizowane samodzielnie, w sposób tradycyjny (poprzez instytucję zamówień publicznych) inwestycje infrastrukturalne zawsze napotykały i napotykają barierę finansową, tj. brak wystarczających środków finansowych. Inwestycje samorządowe stanowią narzędzie kształtowania ładu przestrzennego i wspomagają przeobrażenia strukturalne na obszarze danej jednostki ${ }^{2}$. Obecnie stanowią podstawową determinantę rozwoju lokalnego, a poziom zagospodarowania infrastrukturalnego ma istotne znaczenie dla inicjowania i przyspieszania wzrostu aktywności gospodarczej jednostki. Dla podmiotów gospodarczych dobrze funkcjonująca infrastruktura jest zachętą,

\footnotetext{
${ }^{1}$ Zob. Partnerstwo publiczno-prywatne w Polsce i jego funkcjonowanie na przykladzie wybranych projektów, red. J. Rutkowski, Wydawnictwo Uniwersytetu Łódzkiego, Łódź 2010, s. 21.

${ }^{2}$ K. Piotrowska-Marczak, T. Uryszek, Zarzadzanie finansami publicznymi, Difin, Warszawa 2009, s. 112-113.
} 
a zarazem niezbędnym warunkiem rozwoju, która w sposób pośredni wpływa na poprawę produktywności, wzrost wydajności pracy oraz przyczynia się do zwiększenia popytu na dobra i usługi. Mieszkańcom inwestycje, w tym $\mathrm{w}$ infrastrukturę, umożliwiają zabezpieczenie na odpowiednim poziomie podstawowych potrzeb, a spirala inwestycyjna oddziałuje na lokalny rynek pracy.

Jednostki samorządu terytorialnego są jednym z największych inwestorów na terenie swojego działania. Poczynania inwestycyjne wymagają nakładów finansowych. Pogarszająca się kondycja finansów publicznych nie pozwala na zapewnienie wystarczających środków budżetowych niezbędnych do zaspokojenia istniejących potrzeb, nie wspominając już o działaniach prorozwojowych. Tradycyjne finansowanie inwestycji komunalnych jest niewystarczające. Wydatki bieżące decydują o poziomie świadczenia codziennych usług komunalnych i społecznych oraz o sprawności funkcjonowania jednostek samorządu terytorialnego, wydatki inwestycyjne mają zaś wpływ na tempo i kierunki rozwoju lokalnego oraz regionalnego, a także na przyszły poziom zaspokojenia potrzeb mieszkańców. Władze lokalne w pierwszej kolejności zobowiązane są do wykonywania zadań służących zapewnieniu odpowiedniego poziomu usług oraz utrzymaniu infrastruktury technicznej. Inwestycje rozwojowe realizowane są dopiero wówczas, gdy samorządy zagwarantują ich finansowanie. Proporcje udziału wydatków bieżących i inwestycyjnych wynikają $\mathrm{z}$ zakresu zadań realizowanych przez samorządy oraz wysokości ich budżetów. Skłonność samorządów do inwestowania jest rezultatem lokalnych potrzeb i możliwości. Rozmiary i tempo procesów rozwojowych są ściśle uzależnione od wysokości osiąganych dochodów budżetowych i posiadanego majątku. Rolą władz samorządowych jest umiejętna i efektywna alokacja zasobów finansowych, która mimo powszechnych w ostatnich latach ograniczeń budżetowych pozwoli na zaspokojenie bieżących i przyszłych potrzeb mieszkańców. Chroniczny brak środków na inwestycje służące szeroko rozumianej realizacji zadań powoduje, że część z nich może i powinna być wykonywana we współdziałaniu z sektorem prywatnym - poprzez tworzenie lokalnych partnerstw, zakładanie spółek specjalnego przeznaczenia, a nawet prywatyzację. Partnerstwo publicznoprywatne pozwala na przełamanie stereotypu, że gospodarka publiczna, w tym samorządowa, jest nieefektywna. Zastosowanie odpowiednich metod implementowanych z sektora prywatnego może sprzyjać efektywności i skuteczności działania. PPP nie jest przy tym koncepcją wynikającą z narzuconych rozwiązań ujętych w jednolitym akcie prawnym lub też formułą współpracy sektorów wynikających z istniejących, ugruntowanych regulacji prawnych. Partnerstwo publiczno-prywatne stanowi alternatywę dla tradycyjnego zarządzania realizacją zadań nakierowaną na wzrost efektywności, skuteczności i jakości. Zaangażowanie sektora prywatnego $\mathrm{w}$ realizację zadań publicznych musi wynikać z przekonania, że zarządzanie jednostkami świadczącymi usługi publiczne jest zbliżone do zarządzania prywatnym przedsiębiorstwem. 
Powierzenie wykonywania usług publicznych podmiotom prywatnym wynika z ogromnego zapotrzebowania na inwestycje infrastrukturalne. Infrastruktura, jej rozmiary, stan techniczny, perspektywy rozbudowy, są czynnikami determinującymi rozwój społeczno-gospodarczy danej jednostki. Jest to równocześnie sfera, w której najwyraźniej ujawniają się niedobory budżetowe sektora samorządowego. Wzrost presji konkurencyjnej powoduje, że władze lokalne zabiegają o prywatnych przedsiębiorców.

Uwzględniając powyższe uwarunkowania działalności jednostek samorządu terytorialnego w obszarze inwestycji można przedstawić profil takiej jednostki realizującej Teoretyczny Model PPP.

Teoretyczny Model PPP dla jednostki samorzadu terytorialnego zawiera następujące elementy:

1) strategiczny plan rozwoju jednostki samorządu terytorialnego,

2) program inwestycyjny,

3) strukturę finansowania ze środków publicznych,

4) strukturę finansowania zwrotnego,

5) politykę zadłużenia jednostki samorządu terytorialnego,

6) katalog parterów prywatnych do zawierania umów o PPP,

7) jednostki odpowiedzialne za PPP,

8) instytucje doradczo-konsultingowe ds. PPP,

9) konsultacje społeczne.

Wdrożenie formuły partnerstwa publiczno-prywatnego do polityki strategicznej jednostki samorządu terytorialnego wyznacza obszary społeczno-gospodarcze objęte współpracą międzysektorową oraz konkretyzuje założenia rozwojowe $\mathrm{z}$ uwzględnieniem PPP jako narzędzia realizacji zadań strategicznych i operacyjnych samorządu.

Strategia rozwoju jest dokumentem, który w perspektywie czasowej wyznacza misję jednostki, docelową wizję rozwoju, wyznacza cele i zadania strategiczne oraz określa sposób ich realizacji. „Kluczowymi elementami strategii rozwoju jest hierarchizacja celów i priorytetów oraz programy służące realizacji najważniejszych celów rozwoju"3. Strategia rozwoju zapewnia samorządowi możliwość realizacji misji i wizji, koncentrację działań na najważniejszych społecznie i gospodarczo problemach, zintegrowanie wokół strategii organizacji pozarządowych i przedsiębiorców, zdywersyfikowanie źródeł finansowania, zwiększenie kreatywności. Włączenie PPP nie ogranicza się jedynie do pozyskania zewnętrznego źródła kapitału, stanowi bowiem szerszy aspekt rozwoju usług publicznych i lokalnej gospodarki.

Uszczegółowienie zapisów strategii rozwoju zapewniają dokumenty szczegółowe odgrywające rolę planów średniookresowych, które w sposób bezpo-

${ }^{3}$ E. Wojciechowski, Zarządzanie w samorzadzie terytorialnym, Difin, Warszawa 2012, s. 226. 
średni kreują strukturę społeczno-gospodarczą jednostki samorządu terytorialnego. Wieloletni plan inwestycyjny (WPI) w kilkuletnim horyzoncie czasowym przedstawia listę kluczowych inwestycji zatwierdzonych do realizacji. Podstawą do opracowania WPI są priorytety inwestycyjne zawarte w strategii rozwoju oraz dane finansowe pochodzące $\mathrm{z}$ dokumentów finansowych. Ustawowy katalog zadań nie stanowi zamkniętego zbioru, zatem w zależności od bieżących potrzeb, planów rozwoju oraz sytuacji społeczno-gospodarczej samorząd może zajmować się wszelkimi sprawami niezastrzeżonymi ustawowo dla innych podmiotów. Duża liczba zadań i ich zakres znajdują się w centrum zainteresowania prywatnych inwestorów. Wiele obszarów wymaga stałego doinwestowania, co otwiera drogę dla PPP. Przeprowadzenie selekcji przedsięwzięć inwestycyjnych w ramach WPI sprzyja rozwiązaniom partnerskim.

Polityka finansowa samorządu zakłada dywersyfikację źródeł finansowania zadań, w tym inwestycyjnych. Wykorzystanie jedynie tradycyjnych źródeł finansowania zadań, takich jak środki własne, kredyty bankowe, pożyczki, obligacje, wpływa na poziom deficytu i długu jednostki. Rozwiązania prawne przyjęte w ustawie o finansach publicznych ograniczają możliwości finansowania inwestycji tradycyjnymi źródłami, gdyż wpływają na poziom deficytu i długu jednostki. Ograniczenia wynikające z ustawowych limitów skutkują zaniechaniem realizacji wielu inwestycji. W związku z powyższymi ograniczeniami jednostki samorządu terytorialnego są $\mathrm{z}$ jednej strony zmuszone do zachowania daleko posuniętej ostrożności w zaciąganiu zobowiązań, a z drugiej do poszukiwania rozwiązań nienaruszających ustawowych limitów zadłużenia. Zmiana polityki inwestycyjnej JST ewoluuje w kierunku dywersyfikacji źródeł finansowania $\mathrm{z}$ naciskiem na pozabudżetowe instrumenty neutralne dla budżetu i długu samorządowego. Jednostka samorządu terytorialnego dysponuje katalogiem podmiotów prywatnych zainteresowanych współpracą. Sprzyja to podejmowaniu wieloaspektowych inicjatyw zarówno przez stronę publiczną, jak i prywatną. Firmy doradczo-konsultingowe ds. PPP, zaangażowane przy przedsięwzięciach PPP, rozszerzają grono lokalnych przedsiębiorców o grupę podmiotów pozostających w bazie firmy doradczej. Pozwala to na prowadzenie szeroko zakrojonych konsultacji rynkowych promujących podmiot publiczny, planowane przedsięwzięcie oraz umożliwiających zweryfikowanie przyjętych ekonomicznych założeń przedsięwzięcia inwestycyjnego.

Umiejscowienie w strukturze organizacyjnej urzędu komórek ds. PPP pozwala na koordynowanie działań związanych z przygotowaniem, przeprowadzeniem prac nad wdrożeniem przedsięwzięcia partnerskiego $\mathrm{w}$ fazę realizacji, a następnie stały monitoring i kontrolę poszczególnych faz realizacji przedsięwzięcia. Komórki ds. PPP składają się z zespołu reprezentującego cztery główne grupy kompetencji:

- zarządcze - przedstawiciele władz samorządu, główny koordynator przedsięwzięcia; 
- finansowe - skarbnik, służby księgowe;

- inwestycyjne - przedstawiciele wydziałów inwestycyjnych, rozwoju, gospodarki komunalnej;

- przetargowe - przedstawiciele zajmujący się zamówieniami publicznymi.

Sprawne działanie zespołu ds. PPP gwarantuje ustawiczne podnoszenie kwalifikacji oraz umiejętności przez poszczególnych członków zespołu, a także wsparcie ze strony profesjonalnych doradców. Profesjonalna pomoc doradcza zapewnia prawidłowy przebieg procedur wdrożeniowych $\mathrm{w}$ zakresie PPP. Umiejętności, wiedza oraz doświadczenie przesądzają o sukcesie bądź porażce przygotowania przedsięwzięcia do realizacji w formule partnerskiej.

Powodzenie przedsięwzięcia, satysfakcję ze sposobu dostarczania zadań publicznych lub świadczenia usług zapewniają szeroko prowadzone konsultacje społeczne. Powszechna niechęć do rozwiązań komercyjnych w zakresie zadań publicznych wynika $\mathrm{z}$ negatywnego odbioru niektórych rodzajów inwestycji infrastrukturalnych oraz obaw społeczności lokalnej związanych z nieuzasadnionym wzrostem cen świadczeń, czy utratą kontroli nad określoną sferą zadań publicznych. Ograniczenie ryzyka braku akceptacji społecznej powinno być wpisane $\mathrm{w}$ strategię wdrażania formuły partnerstwa publiczno-prywatnego w polityce lokalnej.

\subsection{Zweryfikowany model PPP w obszarze inwestycji jednostek samorządu terytorialnego}

Skłonność jednostek samorządu terytorialnego w „obszarze pozyskiwania” prywatnych partnerów do przedsięwzięć partnerstwa publiczno-prywatnego, podyktowana jest czynnikami finansowymi oraz prawno-organizacyjnymi. Podjęcie przez jednostkę samorządu terytorialnego współpracy w formule PPP stwarza szansę zrealizowania zadania, którego w sytuacji ograniczonych możliwości finansowych nie byłaby ona w stanie wykonać samodzielnie.

Trudności finansowe wynikają z niskiego potencjału inwestycyjnego oraz rosnącego zadłużenia, które prowadzą do ograniczeń w zakresie wykorzystania zwrotnych źródeł. Spadkowa tendencja potencjału inwestycyjnego jest konsekwencją braku nadwyżki środków finansowych z lat poprzednich, ograniczonymi działaniami w zakresie sprzedaży majątku komunalnego oraz wzrastającymi kosztami obsługi zadłużenia w trakcie roku. Samorządy w ostatnich latach były najpoważniejszym inwestorem. Jeśli weźmiemy pod uwagę tempo inwestowania w samorządach, które pociągnęło za sobą wzrost zobowiązań, jak również obecne spowolnienie gospodarcze, które spowodowało ograniczenie dochodów samorządów, to poważnym zagrożeniem okazuje się naruszenie ustawowych wskaźników zadłużenia przez poszczególne JST, ale także realna możliwość utraty płynności finansowej przez samorząd. To zaś rzeczywiście stawia pod 
znakiem zapytania poczynania inwestycyjne samorządów w najbliższych latach. W konsekwencji uruchomienie kolejnych inwestycji wymagać będzie wskazania alternatywnego źródła ich finansowania. Potrzeba pozyskania prywatnego kapitału w ramach partnerstwa publiczno-prywatnego wydaje się więc nieunikniona.

Przeprowadzone $\mathrm{w}$ jednostkach samorządu terytorialnego badania dostarczyły informacji pozwalających zidentyfikować i ocenić uwarunkowania kształtujące rynek samorządowych przedsięwzięć partnerstwa publiczno-prywatnego. Szczegółowa analiza danych zawartych w ankietach wypełnionych przez skarbników jednostek samorządu biorących udział w badaniu, a w szczególności tych, które w latach 2009-2011 podpisały umowy o partnerstwo publiczno-prywatne, umożliwiła określenie uwarunkowań prawno-organizacyjnych warunkujących podpisanie tychże umów. Aspekty finansowe nie zostały zweryfikowane $\mathrm{w}$ wystarczającym stopniu $\mathrm{z}$ uwagi na zbyt krótki okres trwania umów o PPP. Bez wątpienia można wskazać warunki, które pozwoliły na uruchomienie przedsięwzięć inwestycyjnych we współpracy $\mathrm{z}$ prywatnym partnerem:

1. System prawny.

Przeprowadzone badania pozwalają jednoznacznie stwierdzić, że na gruncie prawa polskiego wprowadzone ustawami: z dnia 19 grudnia 2008 r. o partnerstwie publiczno-prywatnym i z 9 stycznia 2009 r. o koncesji na roboty budowlane bądź usługi normy prawne regulują zagadnienia dotyczące partnerstwa publiczno-prywatnego. Ustawy te określają zasady współpracy podmiotu publicznego i partnera prywatnego $\mathrm{w}$ ramach PPP oraz wskazują kategorie podmiotów, które mogą w ramach partnerstwa współpracować. Regulują procedury związane z wyborem partnera prywatnego. $Z$ uwagi na fakt, że Polska jest państwem członkowskim Unii Europejskiej powyższe ustawy należy rozpatrywać w kontekście prawa wspólnotowego. Stanowisko Unii Europejskiej $\mathrm{w}$ kwestii związanej z rozwojem i upowszechnieniem partnerstwa publicznoprywatnego przedstawione zostało $\mathrm{w}$ rozdziale pierwszym. Wynika z niego, że każde państwo członkowskie samo podejmuje decyzję w jakiej formie PPP będzie regulowane. Zachowana musi zostać zgodność z przepisami unijnymi w zakresie zasad, które pozwalają na realizowanie zadań publicznych przez podmioty prywatne wybrane $\mathrm{w}$ postępowaniu przetargowym zapewniającym poszanowanie zasad równego traktowania, uczciwej konkurencji, przejrzystości i niedyskryminacji.

W opinii respondentów obowiązujące ustawy rozwiązują kwestie formalnoprawne partnerstwa publiczno-prywatnego, nie stanowiąc bariery dla rozwoju PPP. Ankietowani wyraźnie sygnalizowali trudności w wyborze właściwego aktu prawnego, który miał stanowić podstawę do uruchomienia procedur wyboru partnera prywatnego i skonstruowania umowy. Problemy te wymagały 
zaangażowania zewnętrznych specjalistów (doradców), co prowadziło do wzrostu kosztów przygotowania partnerstwa.

Uwzględniając czynnik prawny należy stwierdzić, że w Polsce istnieją odrębne akty prawne regulujące problematykę partnerstwa publiczno-prywatnego, spójne z prawem wspólnotowym. Jednoznaczne zdiagnozowanie tych dwóch czynników pozwala na uwzględnienie ich w Teoretycznym Modelu PPP i nadanie każdemu z nich wartości 1.

\section{System finansów publicznych.}

Istniejący system finansów publicznych określa katalog dochodów jednostek samorządu terytorialnego i gwarantuje dywersyfikację źródeł finansowania poprzez dostęp do rynku finansowego, kapitałowego, absorpcję środków unijnych oraz zaangażowanie kapitału prywatnego, tym samym prowadzi do zwiększenia strumienia środków finansowych na przedsięwzięcia inwestycyjne.

$\mathrm{Z}$ analizy zawartych przez jednostki samorządu terytorialnego z partnerami prywatnymi umów wynika, że partner prywatny przejął na siebie większość ryzyk. Zgodnie z wytycznymi Eurostatu odnoszącymi się do wpływu ryzyk $\mathrm{z}$ umów o PPP na poziom deficytu i długu publicznego oraz $\mathrm{z}$ regulacjami polskimi $\mathrm{w}$ tym względzie przyjęty $\mathrm{w}$ umowach podział ryzyk zwalnia jednostki samorządu terytorialnego $\mathrm{z}$ ujmowania zobowiązań wynikających $\mathrm{z}$ umowy w swoich sprawozdaniach, tym samym czyniąc umowy o PPP neutralne dla poziomu deficytu i długu samorządu (długu publicznego). Należy jednak wyraźnie zaznaczyć, że polskie regulacje w tym zakresie, takie jak wydane przez ministra finansów rozporządzenia (omówione w podpunkcie 4.2) nie rozstrzygają tej kwestii jednoznacznie, co może prowadzić do różnej interpretacji zapisów. Władze samorządowe postulują uszczegółowienie zapisów w sposób pozwalający jednoznacznie określić wpływ umów o PPP na deficyt i dług publiczny.

Zagadnienie alokacji ryzyka pomiędzy strony umowy o PPP zostało w wyniku badań jasno określone i przypisane stronie prywatnej, co pozwala nadać mu wartość 1. Ankietowani nie wypowiedzieli się co do wpływu umów o PPP na poziom deficytu i długu publicznego, toteż zgodnie z przyjętymi założeniami Teoretycznego Modelu PPP brak zdecydowanego stanowiska skutkuje przyznaniem wartości 0.

Kolejna kwestia to czas trwania umowy. Należy wyraźnie wskazać, że umowy w zależności od przedmiotu mają charakter umów długoterminowych. Zachowana została zasada, według której umowy o świadczenie usług nie przekraczają 15-letniego okresu, umowy zaś które obejmują cały proces inwestycyjny, 30 lat. Wśród zawartych umów tylko jedna przekroczyła rygor czasowy - umowa została zawarta na 40 lat. Czynnik czasowy o charakterze długookresowym został zachowany, tym samym możliwe jest przyznanie mu wartości na poziomie 1 . 
Problemu dywersyfikacji źródeł finansowania zadań publicznych nie udało się do końca zweryfikować. Respondenci różnorodnie oceniali PPP jako źródło finansowania. PPP w stosunku do środków unijnych traktowane było jako źródło uzupełniające, znajdujące zastosowanie dopiero wówczas, gdy niemożliwe jest skorzystanie ze środków pomocowych Unii Europejskiej. W odniesieniu do innych źródeł respondenci stali na stanowisku, że podstawowym źródłem finansowania zadań są tradycyjne instrumenty - kredyty i pożyczki. W związku z powyższym czynnik ten również otrzymał wartość 0 .

Krótki czas obowiązywania umów o PPP nie daje podstaw do dogłębnej analizy czynnika związanego ze standaryzacją zadań realizowanych w formule PPP. Większość umów dopiero została podpisana i efekty w postaci jakości realizowanych zadań lub świadczonych usług będą znane za jakiś czas. Pozytywne efekty można wskazać jedynie w przypadku umowy zawartej przez gminę Radzionków na termomodernizację placówek oświatowych, gdzie odnotowano oszczędności w zużyciu energii na poziomie $40 \%$. Brak kompleksowych danych w zakresie pozostałych umów nie daje podstawy do pozytywnej weryfikacji tego czynnika filaru finansowego PPP (wartość 0). Natomiast jednoznacznie zwiększył się wolumen świadczonych usług, na co wskazują ankietowani, pozwalając na pozytywną weryfikację tego czynnik (wartość 1).

\section{Otoczenie instytucjonalne.}

Obserwacja rynku partnerstwa publiczno-prywatnego w Polsce pokazała, że funkcjonują na nim instytucje rządowe i pozarządowe. Dominują instytucje pozarządowe oferujące usługi doradczo-konsultingowe w zakresie analiz prawnych, finansowych oraz nadzoru i kontroli nad przebiegiem wdrażania PPP. Komercyjny charakter większości instytucji trzeba jednak uznać za ograniczenie, które zawęża dostęp do usług wielu zainteresowanym PPP jednostkom samorządu terytorialnego $\mathrm{z}$ uwagi na ograniczenia budżetowe.

Utworzone przy organach administracji centralnej (Ministerstwie Gospodarki i Ministerstwie Rozwoju Regionalnego) komórki nie gwarantują zadowalającego dostępu do baz dobrych praktyk, analiz, ocen funkcjonowania partnerstw, rejestru umów, co w znacznej mierze wynika z poziomu rozwoju rynku. $\mathrm{W}$ ocenie ankietowanych, zaangażowanie instytucji rządowych w promowanie i pomoc merytoryczną w zakresie PPP jest niewystarczające i oceniane jako słabe (przeciętne). Udokumentowana działalność instytucji rządowych i pozarządowych powołanych ds. PPP pozwala na pozytywne zweryfikowanie czynnika i upoważnia do przyznania każdemu z nich wartości $1 \mathrm{w}$ Teoretycznym Modelu PPP.

\section{Przyjazny klimat wokół PPP.}

Systematycznie wzrastająca oferta edukacyjno-informacyjna dotycząca problematyki partnerstwa publiczno-prywatnego nie spełnia w sposób dostateczny zapotrzebowania na fachową wiedzę w zakresie funkcjonowania partnerstwa, co 
rodzi u potencjalnych stron umowy liczne i naturalne w tej sytuacji wątpliwości. Przeprowadzone badania wskazują, że podstawowym źródłem wiedzy na temat partnerstwa publiczno-prywatnego są dla przedstawicieli władz samorządowych oraz urzędników konferencje i szkolenia oraz Internet, w mniejszym stopniu czasopisma, literatura fachowa. W dokonanej samoocenie poziomu wiedzy ankietowani wskazali, że jest ona przeciętna. Przyczyną tak niskiej oceny był fakt, że urzędnicy mają możliwość korzystania tylko z tych szkoleń lub konferencji, które mają charakter bezpłatny, za czym przemawiają względy finansowe. Respondenci bardzo wyraźnie akcentowali niski poziom merytoryczny bezpłatnych szkoleń, konferencji, które nie poszerzały wiedzy ponad tę już pozyskaną w trakcie wcześniejszych spotkań lub powszechnie dostępną, np. w Internecie.

$\mathrm{Na}$ uwagę zasługują także nieadekwatne rozwiązania kadrowo-organizacyjne jednostek samorządu terytorialnego. Samorządy nie dysponują odpowiednio wykwalifikowaną kadrą $\mathrm{w}$ zakresie zarządzania przedsięwzięciami partnerstwa publiczno-prywatnego, co wymusza konieczność posiłkowania się wyspecjalizowanymi firmami zewnętrznymi, w rezultacie wzrastają koszty przygotowania inwestycji. Brak odpowiedniej kadry nie sprzyja zmianom organizacyjnym samych urzędów, tworzeniu specjalistycznych komórek, czy chociażby zespołów, wdrażających rozwiązania partnerskie. W sposób naturalny ograniczane są warunki wpływające na zainteresowanie formułą PPP.

Powyższe spostrzeżenia, z punktu widzenia rozwiązań zaproponowanych w Teoretycznym Modelu PPP, prowadzą do konkluzji, że pomimo tworzącego się dobrego klimatu wokół PPP, wskazane ograniczenia nie pozwalają ocenić sytuacji pozytywnie, co w konsekwencji prowadzi do przyznania temu czynnikowi wartości 0.

5. Standaryzacja procedur.

Badanie wykazało, że konsultacje społeczne są traktowane pobieżnie. Jednostki samorządu terytorialnego, które zawarły umowy o PPP, wskazały, że takowe zostały przeprowadzone przez firmy doradcze, które świadczyły komercyjne usługi na rzecz samorządów. Przedstawiciele jednostek stali w kwestii konsultacji społecznych na stanowisku, że mają one jedynie charakter zdawkowy. Powierzchowne informowanie mieszkańców o sprawach ważnych, takich jak kierunki rozwoju jednostki, o formie realizacji zadań czy świadczenia usług nie sprzyjają wyjaśnieniu mechanizmów współpracy z prywatnymi inwestorami, porównaniu tradycyjnego zamówienia publicznego z formułą PPP, eksponowaniu korzyści wynikających $\mathrm{z}$ zastosowania PPP, wypracowaniu przejrzystych procedur organizacji przedsięwzięcia PPP w jednostce. Sprawnie prowadzona polityka informacyjna jest niezbędna jeśli chcemy ograniczyć ryzyko braku akceptacji społecznej dla przedsięwzięć PPP czy ewentualnych protestów w przyszłości. Ten czynnik filaru organizacyjno-administracyjnego 
Teoretycznego Modelu PPP należy jednoznacznie uznać za dziś nierealizowany i przyznać mu wartość 0 .

Wyniki weryfikacji Teoretycznego Modelu PPP uzyskane na podstawie przeprowadzonego badania i zgodnie z przyjętymi w podpunkcie 6.1. założeniami ujęto w tab. 6.3.

Tabela 6.3

Wartości weryfikujące Teoretyczny Model PPP dla jednostek samorządu terytorialnego

\begin{tabular}{|c|c|}
\hline Filar PPP i jego części składowe & Skala wartości \\
\hline \multicolumn{2}{|l|}{ Filar prawny PPP } \\
\hline Regulacje międzynarodowe & 1 \\
\hline Dotychczasowe akty prawne znajdujące zastosowanie dla PPP & 0 \\
\hline Odrębny akt prawny & 1 \\
\hline Odrębny akt prawny z przepisami wykonawczymi & 0 \\
\hline Umowa o partnerstwo publiczno-prywatne & 1 \\
\hline \multicolumn{2}{|l|}{ Filar finansowy PPP } \\
\hline Czas trwania zadania publicznego & 1 \\
\hline $\begin{array}{c}\text { Neutralność PPP w relacji do deficytu i długu jednostki samorządu } \\
\text { terytorialnego }\end{array}$ & 0 \\
\hline Alokacja ryzyk & 1 \\
\hline $\begin{array}{l}\text { Dywersyfikacja źródeł finansowania zadań przez jednostkę samorządu } \\
\text { terytorialnego }\end{array}$ & 0 \\
\hline Wolumen zadań publicznych & 1 \\
\hline Standaryzacja zadań publicznych & 0 \\
\hline \multicolumn{2}{|l|}{ Filar administracyjno-organizacyjny PPP } \\
\hline Rządowe instytucje ds. PPP & 1 \\
\hline Pozarządowe instytucje wspierające PPP & 1 \\
\hline Przyjazny klimat wokół PPP & 0 \\
\hline Standaryzacja procedur PPP & 0 \\
\hline Łączna liczba przyznanych punktów & 8 \\
\hline
\end{tabular}

Źródło: oprac. własne.

Przeprowadzona analiza dotycząca jednostek samorządu terytorialnego, które w latach 2009-2011 zawarly umowę o partnerstwo publiczno-prywatne na realizację przedsięwzięć inwestycyjnych pozwala na stwierdzenie, że podmioty te cechuje przeciętny stopień skłonności do PPP, o czym świadczy przyznana im punktacja w ramach poszczególnych filarów (8 punktów), tym samych spełniają one warunki niezbędne dla Teoretycznego Modelu PPP. Jednostki samorządu terytorialnego charakteryzuje zachowawcza polityka inwestycyjna opierająca się na niskim stopniu dywersyfikacji źródeł finansowania. Władze samorządowe oraz kadra samorządowa wykazują przeciętne zainteresowanie innowacyjnymi 
rozwiązaniami w zakresie finansowania inwestycji. Jednocześnie należy uznać, że pomimo średniego zainteresowania stają się jednak na polskim rynku PPP prekursorami we wdrażaniu nowych rozwiązań oraz metod zarządzania przedsięwzięciami. Działania władz ukierunkowane są na podnoszenie atrakcyjności i konkurencyjności jednostki w regionie.

Partnerstwo publiczno-prywatne jest instytucją wielowymiarową. Wymaga powiązania wielu aspektów prawnych, ekonomiczno-finansowych i organizacyjnych. Na tych płaszczyznach dochodzi do porozumienia pomiędzy podmiotami, które funkcjonują, by zrealizować odmienne zadania dla osiągnięcia zgoła odmiennych celów. Sektor prywatny nastawiony jest na osiągnięcie korzyści ekonomicznych $\mathrm{w}$ postaci zysków, celem działania samorządów jest zaś realizacja ustawowo przypisanych zadań $\mathrm{w}$ związku z zaspokojeniem nieograniczonych potrzeb społeczeństwa. Zgoda na zmianę formy wykonania zadania z tradycyjnej na partnerską pociąga za sobą konieczność dostosowania struktur organizacyjnych i kadrowych samorządu do potrzeb przedsięwzięcia. Jak już wspomniano PPP charakteryzuje złożona struktura. Różnorodność procesów i zagadnień, jakie składają się na przedsięwzięcie PPP wymuszają na służbach samorządowych, zaangażowanych $\mathrm{w}$ tego typu przedsięwzięcia, znajomość i umiejętności organizacji i zarządzania PPP. Procesy organizacyjne i zarządcze wymuszą z czasem:

- koordynowanie lokalnej polityki PPP,

- określenie zasad polityki jednostki samorządu terytorialnego w stosunku do prywatnych partnerów,

- powołanie komórek organizacyjnych do spraw PPP,

- przeszkolenie pracowników bezpośrednio zaangażowanych w przedsięwzięcia PPP,

- monitorowanie wykorzystania zasobów i środków zaangażowanych w przedsięwzięcia PPP,

- weryfikowanie efektów działań związanych z realizacją przedsięwzięcia PPP.

Brak wiedzy i doświadczenia służb samorządowych może być czynnikiem decydującym o powodzeniu lub porażce przedsięwzięcia, a także stanowić barierę szybkiej implementacji regulacji prawnych w tym obszarze. Sprostanie tym wyzwaniom wymusza na władzy samorządowej taką organizację urzędu, która pozwala na stworzenie odrębnych komórek do spraw PPP, gdzie znajdują się urzędnicy dysponujący odpowiednią wiedzą. Dlatego właśnie, jak pokazują doświadczenia innych państw, działania o charakterze szkoleniowym, edukacyjnym i informacyjnym mają zasadniczą wagę $\mathrm{w}$ przygotowaniu odpowiedniej kadry do zarządzania inwestycjami w formule PPP. Istotne znaczenie na przebieg procesu wdrażania, a następnie realizację, ma stopień i zakres wsparcia instytucjonalnego. Wskazuje się na potrzebę aktywnego zaangażowania władz rządowych oraz grup eksperckich w sferę doradztwa i wypracowanie przez te gremia wzorów kluczowych dokumentów. Standaryzacja procedur przetargowych i dokumentacji ułatwi organizację procesu wdrażania PPP. 
Modelowe ujęcie skłonności do zawierania umów o PPP będzie ulegać ewolucji wraz z rozwojem rynku. Wymienione cechy, z uwagi na ograniczoną próbę badawczą, nie pozwalają na jednoznaczne wskazanie, czy w trakcie rozwoju rynku cechy te będą ulegać uwypukleniu, czy też inne czynniki zaczną wywierać dominujący wpływ na kształt i charakter organizacji partnerstwa publicznoprywatnego. Ważną rolę $\mathrm{w}$ kształtowaniu struktury organizacyjnej przedsięwzięć odegrają niewątpliwie władze samorządowe, same służby oraz czynniki zewnętrzne związane ze stopniem aktywizacji administracji rządowej i doradców zewnętrznych. Oferta edukacyjna oraz pomoc w obszarze prawnoekonomicznym będą decydującym impulsem do rozwoju rynku i kreowania kształtu formuły partnerstwa publiczno-prywatnego w Polsce.

\subsection{Zakłócenia modelu partnerstwa publiczno-prywatnego w jednostkach samorządu terytorialnego}

Partnerstwo publiczno-prywatne z uwagi na swoją skomplikowaną strukturę wymaga współdziałania różnorodnych czynników w obszarze prawnym, finansowym, organizacyjnym oraz społecznym. Podstawą udanej implementacji sektora prywatnego $\mathrm{w}$ realizację przedsięwzięć publicznych jest stała i spójna polityka państwa dotycząca rozwoju PPP, jasne i przejrzyste regulacje prawne, akceptowalny podział ryzyk pomiędzy uczestników partnerstwa, silne wsparcie instytucjonalne oraz akceptacja społeczna. Sukces PPP zależy od dopasowania elementów składowych i ich „współgrania”. Wypaczenie któregokolwiek z tych czynników prowadzi do zakłóceń i „deformacji” Teoretycznego Modelu PPP.

Czynniki zakłócające prawidłowe funkcjonowanie tego modelu w przypadku jednostek samorządu terytorialnego można podzielić na dwie zasadnicze grupy - prawne i finansowe. Pierwsza grupa czynników zagrażających prawidłowemu funkcjonowaniu Teoretycznego Modelu PPP dla omawianych jednostek będzie dotyczyła zagadnień prawnych. Wśród nich najważniejszą rolę odgrywają regulacje prawne. Zasadniczym czynnikiem warunkującym rozwój partnerstwa publiczno-prywatnego jest skonstruowanie takiego systemu regulacji w systemie prawnym, który ze względu na specyfikę danego państwa uznany zostanie za optymalny. Konsekwencją takiego podejścia jest zróżnicowanie rozwiązań stosowanych $\mathrm{w}$ praktyce. Regulacje dotyczące współpracy mogą odbywać się na mocy obowiązującego ustawodawstwa, które nie zawiera bezpośrednich regulacji odnoszących się do partnerstwa jako takiego. Innym rozwiązaniem jest wprowadzenie odrębnych przepisów uwzględniających specyfikę partnerstwa. Bez względu na charakter regulacji prawnych pożądana jest ich stabilność oraz stworzenie optymalnych warunków rozwoju formuły PPP, które umożliwią prawidłowe funkcjonowanie Teoretycznego Modelu PPP dla JST. 
Podstawowym czynnikiem destabilizującym rozwój PPP, a tym samym deregulującym Teoretyczny Model PPP, są niepożądane zmiany w obrębie prawa. Brak stabilności przepisów bądź wewnętrznej ich spójności, sprzyja błędnej interpretacji prawa. Nadmierne obostrzenia na wczesnym etapie uruchomienia procedur mogą zniechęcić potencjalnie zainteresowane podmioty do stosowania formuły partnerstwa publiczno-prywatnego. W efekcie w praktyce zastosowanie znajdą tradycyjne metody realizacji zadań publicznych (np. zamówienie publiczne), a partnerstwo publiczno-prywatne stanie się ostatnim z możliwych rozwiązań. Przedstawiciele władz samorządowych nie będą zainteresowani przygotowaniem procedur obawiając się, że w wyniku nieprawidłowej interpretacji przepisów zostaną one unieważnione, co pociągnie za sobą wzrost kosztów przygotowania przedsięwzięcia i negatywne nastawienie do partnerstwa publiczno-prywatnego. Nieprawidłowo przeprowadzona procedura może doprowadzić do zawarcia niekorzystnej umowy, w efekcie której nie zostanie osiągnięty zamierzony cel. Skutkiem takiego stanu rzeczy może być rozwiązanie umowy. Brak jasnych ram prawnych $\mathrm{w}$ zakresie realizacji przedsięwzięć przynosi negatywny skutek psychologiczny, polegający na zmniejszeniu zaufania społecznego do inwestycji realizowanych $\mathrm{z}$ udziałem podmiotów prywatnych oraz obniżone zaufanie do kontraktów partnerstwa publicznoprywatnego.

Racjonalna alokacja ryzyka i proces zarządzania nim stanowią kolejne czynniki decydujące o powodzeniu funkcjonowania Teoretycznego Modelu $P P P$. W uproszczeniu oznacza to, że wszystkie zidentyfikowane dla przedsięwzięcia ryzyka i zagrożenia zostały prawidłowo przypisane stronom, które potrafią nimi najlepiej zarządzać. Alokacji ryzyk przyświecała zasada racjonalności, dokonana według możliwości i umiejętności stron przyjmujących poszczególne kategorie ryzyk. Prawidłowy przebieg procesu alokacji ryzyk gwarantuje neutralny wpływ na sytuację finansową jednostki samorządu terytorialnego. Błędnie przeprowadzony proces alokacji ryzyk skutkujący przejęciem przez jednostkę samorządu terytorialnego $\mathrm{w}$ zarząd większości zagrożeń spowoduje, że zobowiązania wynikające z kontraktu PPP zostaną zaliczone do zobowiązań sektora publicznego, tym samym wpłyną na wzrost długu publicznego i deficytu sektora finansów publicznych. Nie zostanie więc spełnione podstawowe założenie partnerstwa publiczno-prywatnego prowadzące nie tylko do poprawy jakości i efektywności wykonania zadania, ale także poprawy sytuacji finansowej sektora publicznego.

Destabilizujący wpływ na funkcjonowanie Modelu PPP będą miały również czynniki społeczne. Brak pełnej, rzetelnej informacji o planowanych do realizacji w PPP, inwestycjach będzie w lokalnych wspólnotach budził podejrzliwość, co do przejrzystości współpracy samorządu z partnerem prywatnym. Zaniechanie działań informacyjnych, edukacyjnych, promocyjnych PPP, mających na celu uświadomienie mieszkańcom, że partnerskie przedsięwzięcie przyczyni się 
do wzrostu liczby świadczonych usług oraz przyniesie wymierne finansowe skutki dla samorządu, ograniczy zaufanie wspólnoty samorządowej do rozwiązań partnerskich. Brak akceptacji dla PPP może skutkować konkretnymi działaniami w postaci protestów, a w skrajnych przypadkach spadkiem popytu na usługi publiczne, co w konsekwencji może doprowadzić do zerwania przez stronę prywatną umowy.

Czynnikiem ograniczającym funkcjonowanie Teoretycznego Modelu PPP dla JST może być też organizacja urzędu oraz niski poziom przygotowania kadry samorządowej. Brak odpowiednich kwalifikacji, znajomości problematyki PPP, może prowadzić do nieprawidłowości na kolejnych etapach wdrażania partnerstwa, skutkujących błędnymi decyzjami w zakresie prowadzenia postępowań negocjacyjnych, konstrukcji umowy czy samego nadzorowania przedsięwzięcia. Niezbędne jest przystosowanie urzędu do koordynowania prac nad przedsięwzięciami PPP poprzez stworzenie odpowiedniego zespołu oraz zagwarantowanie przepływu informacji pomiędzy komórkami planistycznymi, finansowymi i kontrolnymi. Zakłócenia w tym obszarze mogą doprowadzić do nadużyć ze strony prywatnego partnera oraz do zwiększenia oporów społecznych przeciwko przedsięwzięciu, co w ostatecznym rozrachunku przełoży się na wzrost nakładów poniesionych na inwestycję.

Wystąpienie w rzeczywistości wymienionych czynników może skutecznie ograniczyć zainteresowanie formułą PPP, a w skrajnych przypadkach zahamować rozwój partnerstwa publiczno-prywatnego. 



\section{ZAKOŃCZENIE}

Partnerstwo publiczno-prywatne w kontekście wykonywania zadań publicznych przy współudziale sektora prywatnego jest zagadnieniem, które w Polsce od końca lat 90. minionego wieku znajduje się w centrum rozważań zarówno teoretyków, jak i praktyków. Nie oznacza to jednak, że współpraca pomiędzy wymienionymi sektorami na świecie dopiero się kształtuje. Idea koncepcji partnerstwa publiczno-prywatnego sięga czasów starożytnych, rozgłos i rozkwit formuły nastąpił zaś w końcu lat 80 . XX w. Pomimo że na świecie PPP zdobyło już popularność i na stałe zapisało się jako ważny instrument finansowy, to w Polsce nadal pozostaje instrumentem w fazie wczesnego rozwoju.

Aktualnie jednostki samorządu terytorialnego są głównym wykonawcą zadań publicznych. Do dyspozycji mają wiele różnorodnych źródeł finansowania delegowanych im zadań. Obok prawnie zagwarantowanych środków budżetowych mogą korzystać z instrumentów rynku finansowego oraz kapitałowego. Od 2004 r. są największym beneficjentem środków unijnych. Prawo pozwala także na komercjalizację, kontraktację usług publicznych oraz delegowanie wykonania zadań publicznych partnerom społecznym i prywatnym.

Spowolnienie gospodarcze, kryzys finansów publicznych i związany z tym ciągły niedostatek środków inwestycyjnych stanowią ważną przesłankę trwałej współpracy sektora samorządowego $\mathrm{z}$ prywatnymi inwestorami $\mathrm{w}$ ramach formuły partnerstwa publiczno-prywatnego. Sprzyjają temu przyjęte na przełomie lat 2008 i 2009 w Polsce rozwiązania prawne uelastyczniające warunki zawierania umów o partnerstwo publiczno-prywatne. Stworzenie korzystnego klimatu dla rozwiązań międzysektorowych postulowane było od 2005 r., kiedy to w lipcu Sejm przyjął pierwszą ustawę o partnerstwie publiczno-prywatnym. $\mathrm{Z}$ uwagi na jej rygorystyczny charakter oraz obwarowania prawno-ekonomiczne w Polsce nie doczekano się uruchomienia żadnego przedsięwzięcia w postulowanej formule. Ożywiona dyskusja, jaka przetoczyła się przez gremia rządowe, samorządowe, prawnicze oraz organizacje pracodawców, zaowocowała uchwaleniem dwóch odrębnych ustaw: o partnerstwie publiczno-prywatnym (2008) i o koncesji na roboty budowlane lub usługi (2009), regulujących problematykę współdziałania sektora publicznego z sektorem prywatnym. Przyjęte rozwiązania stały się bodźcem do podjęcia przez jednostki samorządu terytorialnego 
działań zmierzających do zaangażowania prywatnych inwestorów w realizację zadań publicznych.

Przeprowadzone badania, przedstawione $\mathrm{w}$ niniejszej pracy potwierdzają pogląd, że stworzenie ram prawnych i przyjaznego otoczenia wokół partnerstwa publiczno-prywatnego przyczyniło się do uruchomienia na polskim rynku pierwszych przedsięwzięć PPP. Zarówno badania ankietowe, jak i analiza dostępnych na polskim rynku raportów i opracowań dotyczących rozwoju PPP umożliwiły osiągnięcie zamierzonych celów oraz weryfikację postawionej hipotezy.

Zidentyfikowanie zbioru uwarunkowań ujętych w trzech filarach: prawnym, finansowym i administracyjno-organizacyjnym, które łącznie kształtują warunki współpracy jednostki samorządu terytorialnego i prywatnego partnera, pozwoliły na wyodrębnienie nieprawidłowości i słabych punktów ograniczających rozwój partnerstwa publiczno-prywatnego w Polsce. Przedstawione w rozprawie rozważania nad wpływem sytuacji finansowej jednostki samorządu na jej potencjał inwestycyjny mają istotne znaczenie w tworzeniu zbioru uwarunkowań sprzyjających realizacji inwestycji we współpracy z prywatnym partnerem, a tym samym w zawarciu umowy o PPP. W literaturze problematyka współdziałania sektora publicznego i prywatnego jest opisywana szeroko, jednak brak było wzorcowego modelu wskazującego na idealne warunki, w jakich PPP powinno funkcjonować. W niniejszej pracy dokonano ich określenia metodą kroczącą, budując oparty na instrumentarium partnerstwa publiczno-prywatnego Teoretyczny Model PPP. Na podstawie listy czynników w ramach trzech, wspomnianych wcześniej, filarów odpowiadających idei PPP określono uwarunkowania, jakie muszą zaistnieć, aby doprowadzić do prawidłowego współdziałania sektorów publicznego i prywatnego w ramach PPP. Realizacja zadań publicznych w formule partnerstwa ma nie tylko umożliwić władzy lokalnej zaspokojenie najważniejszych potrzeb mieszkańców, ale również stworzenie warunków rozwoju społeczno-gospodarczego jednostki i wzrost konkurencyjności w regionie.

Analiza sytuacji finansowej objętych badaniem ankietowym jednostek samorządu terytorialnego pozwoliła na pozytywną weryfikację hipotezy głównej, że poziom zadlużenia oraz niski poziom potencjatu inwestycyjnego determinuja wladze jednostek samorzadu terytorialnego do realizowania inwestycji w formule partnerstwa publiczno-prywatnego.

$\mathrm{W}$ badanych jednostkach samorządu terytorialnego zauważono wzrostową tendencję zadłużenia o czym świadczył wzrastający poziom wskaźnika ogólnego zadłużenia. Intensyfikacja wzrostu zadłużenia nastąpiła $\mathrm{w}$ badanym okresie (tj. w latach 2009-2011), co wynikało z pogarszania się ogólnej sytuacji finansowej jednostek, wywołanego ustawowym rozszerzeniem katalogu zadań oraz koniecznością pozyskania nowych, zwrotnych źródeł w celu zapewnienia wkładu własnego współfinansowanych ze środków unijnych przedsięwzięć inwestycyjnych. 
Niski poziom potencjału inwestycyjnego jednostek samorządu terytorialnego, spowodowany malejącym potencjałem dochodowym, wzrastającymi kosztami obsługi zadłużenia, brakiem nadwyżek budżetowych z lat ubiegłych i wpływów z prywatyzacji, sprzyjał wykorzystaniu alternatywnych źródeł finansowania, w tym partnerstwa publiczno-prywatnego. Postawiona hipoteza główna znajduje potwierdzenie szczególnie w odniesieniu do jednostek, które zawarły umowę o PPP.

W latach 2009-2011 w sektorze samorządowym zawarto w Polsce łącznie 20 umów o partnerstwo publiczno-prywatne na realizację przedsięwzięć inwestycyjnych. Nie jest to satysfakcjonująca liczba w stosunku do zamieszczonych ogłoszeń, ale pozwala już na budowanie bazy doświadczeń i umiejętności w zakresie zarządzania przedsięwzięciami partnerskimi. Obowiązujący w Polsce system prawny $\mathrm{w}$ zakresie rozwiązań partnerskich nadal nie jest pozbawiony nieprawidłowości. Badania pozwalają jednak na stwierdzenie, że samorządy wykazują duże zainteresowanie współpracą z prywatnymi podmiotami. Obowiązujące regulacje prawne nie stanowią bariery do zawierania umów, a występujące w nich nieprawidłowości jedynie osłabiają dynamikę rozwoju samorządowego rynku PPP.

Przedsięwzięcia partnerstwa publiczno-prywatnego, z uwagi na swą strukturę organizacyjną, charakteryzują się wysokim stopniem złożoności. Ocena funkcjonowania PPP zazwyczaj dotyczy formalno-prawnych uwarunkowań związanych z procedurami wyboru form współpracy, zastosowaniem i interpretacją przepisów prawnych $\mathrm{w}$ odniesieniu do PPP, treści i zakresu kontraktu. Zagadnienia ekonomiczno-finansowe stanowią obszar znacznie słabiej rozpoznany. Powstała więc potrzeba zweryfikowania, czy możliwości inwestycyjne jednostek samorządu terytorialnego, wyrażone w potencjale inwestycyjnym i poziomie zadłużenia, stanowią bodźce do inicjowania współpracy międzysektorowej, a tym samym realizacji nowych przedsięwzięć inwestycyjnych.

W ostatnich latach jednostki samorządu terytorialnego były największym inwestorem publicznym, co zrodziło oczekiwania kontynuowania boomu inwestycyjnego zarówno ze strony potencjalnych wykonawców, jak i społeczności lokalnych. Tymczasem, jeśli uwzględnimy sytuację na rynku związaną ze spowolnieniem gospodarczym, spadkiem dochodów oraz wzrostem zobowiązań, to rodzi się poważny problem dotyczący nie tylko naruszenia ustawowych wskaźników zadłużenia przez poszczególne jednostki samorządu terytorialnego, ale także realne zagrożenie utraty płynności finansowej. W tej sytuacji jednostki coraz bardziej odczuwają zaciskający się „gorset” fiskalny. Rozwiązaniem jest pozyskanie kapitału prywatnego w celu wykonania zadań publicznych przez JST w ramach formuły PPP. Głównym motywem zawierania umów o PPP przez jednostki samorządu terytorialnego było dążenie do skonstruowania takiego kontraktu, który pozwoliłby na przejęcie większości ryzyk związanych $\mathrm{z}$ przedsięwzięciem przez podmiot prywatny. Tym samym poziom długu 
publicznego i deficytu sektora finansów publicznych pozostał na niezmienionym poziomie.

Badanie wykazało, że istotnym elementem oddziałującym na rozwój polskiego rynku PPP w ostatnim okresie było powstanie pozarządowych instytucji wspierających podmioty publiczne $\mathrm{w}$ działaniach zmierzających do pozyskania prywatnego partnera. Celem tych instytucji jest szeroko zakrojona działalność doradczo-konsultacyjna i edukacyjna w zakresie wdrażania partnerstwa publiczno-prywatnego. Zasoby kadrowe oraz dostęp do fachowej wiedzy i doradztwa stanowią główne czynniki umożliwiające zastosowanie formuły PPP. Szczególnego znaczenia nabierają one $\mathrm{w}$ procesie zarządzania przedsięwzięciami partnerskimi, które przekładają się na efektywność wykonania zadania publicznego i poziom zadowolenia lokalnych odbiorców usług publicznych. Zweryfikowany poprzez badanie ankietowe stan wiedzy pracowników samorządowych dowodzi, że służby samorządowe korzystają z różnych form edukacji dotyczących partnerstwa, co pozwala na podnoszenie wiedzy w tym obszarze i przyczynia się do skuteczniejszych działań $\mathrm{w}$ procesie pozyskiwania prywatnych inwestorów.

Dynamika rozwoju PPP uzależniona jest także od intensywności i jakości wsparcia rządowego i pozarządowego. Wypracowanie standardowych procedur prowadzenia postępowań o wybór partnera prywatnego oraz stworzenie wystandaryzowanych wzorów dokumentów, pomoc w przeprowadzeniu analiz prawnoekonomicznych i technicznych mogą stanowić istotny przyczynek do uruchamiania nowych przedsięwzięć w ramach formuły partnerskiej.

Przeprowadzone studia literaturowe oraz badania ankietowe pozwoliły na skonstruowanie Teoretycznego Modelu PPP dla jednostek samorządu terytorialnego. Jego konstrukcja oparta została na głównych filarach odpowiadających idei partnerstwa publiczno-prywatnego. W Teoretycznym Modelu PPP uwzględniono czynniki, które w optymalnych warunkach pozwolą na prawidłowe relacje podmiotów publicznego i prywatnego podporządkowane realizacji przedsięwzięć w formule PPP. Zaproponowany Model PPP ma umożliwić zainteresowanym partnerską współpracą jednostkom samorządu terytorialnego identyfikację czynników, które decydują o powodzeniu przedsięwzięcia. Władze samorządowe otrzymują do dyspozycji nowe narzędzie, za pomocą którego mogą dokonać porównania posiadanych i potrzebnych do współpracy czynników, oraz informację, jakich efektów powinny się spodziewać i w jakich obszarach. Zastosowanie w praktyce Modelu PPP może stanowić ważną przesłankę zachęcającą podmioty prywatne do angażowania się w partnerstwo publiczno-prywatne, ponieważ skróceniu ulegnie czas potrzebny na przygotowanie przedsięwzięcia dzięki właściwiej organizacji służb samorządowych.

W chwili obecnej brak jest wystarczającej wiedzy, aby jednoznacznie określić, z uwagi na zbyt krótki okres funkcjonowania nowych regulacji prawnych i niewielką liczbę umów, jaki będzie kierunek rozwoju rynku PPP w Polsce. 
Jakie korelacje i zależności będą stanowić dominującą przesłankę międzysektorowego realizowania przedsięwzięć, tym samym zawierania umów i jaki kształt przyjmie ostatecznie Model PPP dla jednostek samorządu terytorialnego.

Przeprowadzona analiza pozwala na wstępne zdiagnozowanie rynku inwestycji realizowanych $\mathrm{w}$ ramach partnerstwa publiczno-prywatnego i uzależnienia jego rozwoju od sytuacji finansowej. Wyniki badań pozwalają na pozytywne zweryfikowanie postawionych hipotez badawczych oraz osiągnięcie celów badawczych. Zaproponowany Teoretyczny Model PPP może w wyniku rozwoju rynku ulec modyfikacji w zależności od zmiennych politycznych, ekonomicznych i społecznych, jakie będą wpływać na kształtowanie modelu współpracy. $\mathrm{Na}$ obecnym etapie rozwoju rynku stanowi odzwierciedlenie rzeczywistych uwarunkowań finansowych i prawno-organizacyjnych wpływających na skłonność do zawierania umów partnerstwa publiczno-prywatnego. 



\section{BIBLIOGRAFIA}

Aggarwal R., Capital Budgeting Under Uncetainty, Prentice-Hall, Englewood Cliffs 1993.

Andersen J., Public-private partnerships: organizational hybrids as channel for local mobilisation and participation?, „Scandinavian Political Studies” 2004, 27 (1).

Atkinson A. B., Stiglitz J. E., Lectures on Public, Ekonomics, Mc Graw-Hill Book Co. LTD, New York 1980.

Bachor W., Efektywność majątku trwatego w spółkach komunalnych. Wybrane zagadnienia $i$ wyniki badań, Oficyna Wydawnicza SGH, Warszawa 2009.

Bachor W., Ekstowicz B., Grzymała Z., Jeżowski P., Maśloch G., Sadowy M., Zalewski A., Podstawy ekonomiki i zarzadzania w gospodarce komunalnej, Oficyna Wydawnicza SGH, Warszawa 2011.

Bailey S. J., Local government economics principles and practice, Mac Millan, 1999.

Bajoch K., Redeł S., Prawo gospodarki komunalnej, Wydawnictwo Naukowe PWN, Warszawa 2000.

Baron M., Ochojski A., Partnerstwo publiczno-prywatne - próba systematyzacji doświadczeń, [w:] Studia regionalne w Polsce. Teoria, polityka, projektowanie, red. F. Kużnik, Prace Naukowe Akademii Ekonomicznej im. K. Adameckiego w Katowicach, Katowice 2005.

Begg D., Fischer S., Dornbusch R., Makroekonomia, PWE, Warszawa 2007.

Bień W., Zarządzanie finansami przedsiębiorstwa, Difin, Warszawa 1999.

Biernat S., Prywatyzacja zadań publicznych. Problematyka prawna, Wydawnictwo Naukowe PWN, Warszawa-Kraków 1994.

Bitner M., Bariery rozwoju partnerstwa publiczno-prywatnego jako metody wykonywania zadań zwiazanych z realizacją inwestycji lokalnych i regionalnych $w$ Polsce, [w:] Realizacja zadań publicznych przez jednostki samorzq̨du terytorialnego we wspótpracy z sektorem prywatnym, red. E. Kornberger-Sokołowska, Uniwersytet Warszawski, Centrum Studiów Samorządu Terytorialnego i Rozwoju Lokalnego, Warszawa 2008.

Bitner M., Modele partnerstwa publiczno-prywatnego w krajach Unii Europejskiej, „Finanse Komunalne" 2003, nr 2 Ekstra.

Boć J., Blicharz J., Prawo administracyjne, Kolonia Limited, Wrocław 2000.

Borodo A., Samorzad terytorialny. System prawnofinansowy, LexisNexis, Warszawa 2004.

Borodo A., Samorzad terytorialny. System prawnofinansowy, Wydawnictwa Prawne PWN, Warszawa 1997.

Borodo A., System finansowy samorzadu terytorialnego w Polsce, Dom Organizatora TNOiK, Torun 2011.

Brandenburg H., Zarządzanie projektami, Wydawnictwo Politechniki Śląskiej, Gliwice 1999.

Brochocka U., Gajęcki R., Metody oceny projektów inwestycyjnych, Oficyna Wydawnicza SGH, Warszawa 1997.

Brzozowska K., Finansowanie inwestycji infrastrukturalnych przez kapitat prywatny na zasadach Project finance, Wydawnictwa Fachowe CeDeWu, Warszawa 2005.

Brzozowska K., Partnerstwo publiczno-prywatne. Przesłanki, możliwości, bariery, Wydawnictwa Fachowe CeDeWu, Warszawa 2006. 
Brzozowska K., Partnerstwo publiczno-prywatne w Europie, cele, uwarunkowania, efekty, Wydawnictwo Fachowe CeDeWu, Warszawa 2010.

Budżet władz lokalnych. Narzędzie zarządzania, red. S. Owsiak, PWE, Warszawa 2002.

Carson L., Gerber K., Ideas for community consultation: a discussion on principles and procedures for making consultation work, New South Wales. Dept. of Urban Affairs and Planning, 2001.

Cenkier A., Partnerstwo publiczno-prywatne, INFOS, Zagadnienia społeczno-gospodarcze nr 13 (37), Biuro Analiz Sejmowych, Warszawa 2008.

Cenkier A., Partnerstwo publiczno-prywatne jako metoda wykonywania zadań publicznych, Szkoła Główna Handlowa w Warszawie, Warszawa 2009.

Chałas M., Nowoczesne systemy realizacji zadań publicznych, Dom Wydawniczy ELIPSA, Warszawa 2006.

Chojna-Duch E., Podstawy finansów publicznych i prawa finansowego, Lewis Nexis, Warszawa 2012.

Chong Y. Y., Brown E. M., Zarządzanie ryzykiem projektu, Dom Wydawniczy ABC, Kraków 2001.

Cieślak R., Partnerstwo publiczno-prywatne $w$ samorzadzie terytorialnym, Infor Ekspert, Warszawa 2011.

Czempas J., Inwestycje gminne - zakres i pomiar, [w:] Polska samorządność w integrujacej się Europie, I Forum Samorządowe, Fundacja na rzecz Uniwersytetu Szczecińskiego, Szczecin 2004.

The Delhi Metod: Techniques and Applications, eds H. A. Linstrone, M. Juroff, Addison-Wesley, 2002.

Derkacz A. J., Partnerstwo publiczno-prywatne w kontekście nowej ustawy. Funkcjonalna analiza ustawy z dnia 19 grudnia 2008 r. o partnerstwie publiczno-prywatnym, Szkoła Główna Handlowa w Warszawie, Warszawa 2009.

Dębski W., Zarządzanie finansami, t. 1, Centrum Informacji Menedżera, Warszawa 1996.

Dobija M., Rachunkowość zarządcza, Wydawnictwo Naukowe PWN, Warszawa 1994.

Dobrzelecka E., Analiza ryzyka inwestycyjnego, „Wiadomości Statystyczne” 1995, nr 9.

Drobniak A., Ocena projektów publicznych, Wydawnictwo Akademii Ekonomicznej w Katowicach, Katowice 2005.

Drobniak A., Podstawy oceny efektywności projektów publicznych, Wydawnictwo Akademii Ekonomicznej w Katowicach, Katowice 2008.

Drucker P. F., The Age of Discontinuity: Guidelines to our Changing Society, Harper \& Row, New York 1969 [cyt. za:] Zarys ekonomii sektora publicznego, red. M. Brol, Wydawnictwo Uniwersytetu Ekonomicznego we Wrocławiu, Wrocław 2010.

Dylewski M., Analiza ekonomiczna i finansowa projektu europejskiego, [w:] M. Dylewski, B. Filipiak, A. Guranowski, J. Hałub-Iwan, Zarzadzanie finansami projektu europejskiego, Wydawnictwo C.H. Beck, Warszawa 2009.

Dylewski M., Ocena kosztów i korzyści realizacji zadań w jednostkach samorząu terytorialnego na podstawie metody CBA, [w:] Finanse samorzadu terytorialnego. Zagadnienia wybrane, Wydawnictwo Wyższej Szkoły Bankowej w Poznaniu, Poznań-Wrocław 2005.

Dylewski M., Planowanie budżetowe w podsektorze samorzadowym. Uwarunkowania, procedury, modele, Difin, Warszawa 2007.

Dylewski M., Wplyw spowolnienia gospodarczego na zdolność inwestycyjna JST, [w:] Finanse publiczne, red. J. Sokołowski, M. Sosnowski, A. Żabiński, Prace Naukowe Uniwersytetu Ekonomicznego we Wrocławiu nr 112, Wydawnictwo Uniwersytetu Ekonomicznego we Wrocławiu, Wrocław 2010. 
Dylewski M., Filipiak B., Ustugi publiczne, [w:] Wspótczesna ekonomika usług, red. S. Flejterski, A. Panasiuk, J. Perenc, G. Rosa, PWN, Warszawa 2005.

Dylewski M., Filipiak B., Gorzałczyńska-Koczkodaj M., Analiza finansowa $w$ jednostkach samorzadu terytorialnego, Municypium, Warszawa 2004.

Dylewski M., Filipiak B., Gorzałczyńska-Koczkodaj M., Finanse samorządowe. Narzędzia, decyzje, procesy, PWN, Warszawa 2006.

Dylewski M., Filipiak B., Gorzałczyńska-Koczkodaj M., Metody analityczne $w$ działalności jednostek podsektora samorządowego, Difin, Warszawa 2010.

Dylewski M., Filipiak B., Guranowski A., Hołub-Iwan J., Zarzadzanie finansami projektu europejskiego, C.H. Beck, Warszawa 2009.

Dziadyk J., Kyrcz R., Zakres i efekty modernizacji oświetlenia ulicznego Miasta Krakowa, Urząd Miasta Krakowa, Zarząd Dróg i Komunikacji, Kraków 2006.

Dziembowski Z., Pojęcie infrastruktury i jej charakterystyka, „Miasto” 1966, nr 2.

Dziworska K., Inwestycje przedsiębiorstw, Wydawnictwo Uniwersytetu Gdańskiego, Gdańsk 1993.

Dziworska K., Pojęcie i rodzaje inwestycji, [w:] Projekty inwestycyjne. Finansowanie, metody $i$ procedury oceny, red. T. Gostkowska-Drzewicka, Ośrodek Doradztwa i Doskonalenia Kadr, Gdańsk 1996.

The EIB's role in Public-Private Partnerships (PPPS), Europan Investment Bank, 15 July 2004.

Ekonomia, red. W. Caban, Wydawnictwo Wyższej Szkoły Finansów i Informatyki, Łódź 2006.

Encyklopedia Popularna PWN, Wydawnictwo Naukowe PWN, Warszawa 1993.

Epingrad P., Proces inwestowania wobec wyzwań technologicznych i informatycznych, przekład K. Malaga, Wydawnictwo EFP - Francusko-Polskiej Wyższej Szkoły Nowych Technik Informatyczno-Komunikacyjnych, Poznań 1995.

Filipiak B., Finanse samorzadowe. Nowe wyzwania bieżace i perspektywiczne, Difin, Warszawa 2011.

Filipiak B., Finansowanie rozwoju infrastruktury na przykładzie Miasta Szczecin, [w:] Współczesne problemy finansów i gospodarki jednostek samorzadu terytorialnego, red. S. Kańduła, Wydawnictwo Akademii Ekonomicznej w Poznaniu, Poznań 2008.

Filipiak B., Dylewski M., Prognoza dlugu publicznego w jednostkach samorzadu terytorialnego, „Finanse Komunalne” 2005, nr 11.

Finanse przedsiębiorstwa z elementami zarządzania i analizy, red. M. Wypych, Wydawnictwo Absolwent, Łódź 1998.

Flinders M., Splintered logic and political debate, [w:] International Handbook on Public Private Partnerships, ed. by G. A. Hodge, C. Greve, A. E. Bordman, Edgar Elger: a Family Business in International Publishing, UK 2012.

Flynn N., Public Sector Management, Pearson Education Ltd., Essex 2002.

Franek S., Teoretyczne aspekty zarządzania finansami $w$ podmiotach sfery publicznej, [w:] Teoretycznoprawne aspekty zarzadzania finansami w podmiotach publicznych i prywatnych, red. J. Iwin-Garzyńska, Wydawnictwo Uniwersytetu Szczecińskiego, Rozprawy i Studia, t. 690, Szczecin 2008.

Galiński P., Zarzązanie ryzykiem $w$ inwestycjach jednostek samorzadu terytorialnego, [w:] Finanse publiczne, red. J. Sokołowski, M. Sosnowski, A. Żabiński, Prace Naukowe Uniwersytetu Ekonomicznego we Wrocławiu nr 112, Wydawnictwo Uniwersytetu Ekonomicznego we Wrocławiu, Wrocław 2010.

Gałuszka K., Efektywność sektora publicznego a alokacja dóbr publicznych, [w:] Finanse samorząu terytorialnego, red. L. Patrzałek, Zeszyty Naukowe Wyższej Szkoły Bankowej we Wrocławiu nr 21, Wydawnictwo Wyższej Szkoły Bankowej, Poznań 2011. 
Gałuszka K., Efektywność wydatków inwestycyjnych jednostek samorządu terytorialnego, [w:] Polska samorządność w integrującej się Europie, I Forum Samorządowe, Wydział Zarządzania i Ekonomiki Usług Uniwersytetu Szczecińskiego, Szczecin 2004.

Gałuszka K., Ocena efektywności finansowania rozwoju lokalnego, [w:] Finanse samorzadu terytorialnego. Zagadnienia wybrane, red. L. Patrzałek, Wydawnictwo Wyższej Szkoły Bankowej w Poznaniu, Poznań-Wrocław 2005.

Garbarski L., Rutkowski I., Wrzosek W., Marketing. Punkt zwrotny nowoczesnej firmy, PWE, Warszawa 2000.

Gilowska Z., Formułowanie i finansowanie strategii rozwoju jednostki samorzadu terytorialnego, [w:] Księga pamiątkowa dla uczczenia pracy naukowej Profesora Antoniego Agopszowicza, red. R. Mikosz, Prace Naukowe Uniwersytetu Śląskiego nr 1871, Katowice 2000.

Gilowska Z., System ekonomiczny samorzadu terytorialnego w Polsce, Municipium, Warszawa 1998.

Ginsberg-Gebert A., Rudzka-Lorentz Cz., Woźniak M., Zielińska-Kołtyś A., Infrastruktura komunalna a funkcjonowanie systemu osadniczego kraju, Ossolineum, Warszawa 1984.

Glynn J. J., Perrin J., Murphy M. P., Rachunkowość dla menedżerów, Wydawnictwo Naukowe PWN, Warszawa 2003.

Gniatowski A., Forum niepokoju i nadziei, „Wspólnota” 2012, nr 41-42.

Gołębiowski G., Tłaczała A., Analiza ekonomiczno-finansowa w ujęciu praktycznym, Difin, Warszawa 2005.

Gramlich E., Infrastructure investment, „A Review Essay, Journal of Economic Literature” 1994, No. 32 (3), [za:] K. Brzozowska, Finansowanie inwestycji infrastrukturalnych przez kapitat prywatny na zasadach Project Finance, Wydawnictwa Fachowe CeDeWu, Warszawa 2005.

Granosik B., Metody oceny efektywności inwestycji rzeczowych w zarządzaniu przedsiębiorstwem, Wydawnictwo Politechniki Koszalińskiej, Koszalin 2007.

Grynis R., Obligacje komunalne - efektywny instrument finansowy czy promocja miasta, „Bank i Kredyt" 2002, nr 1.

Grzesiok A., Zasady realizacji partnerstwa publiczno-prywatnego, [w:] Partnerstwo publicznoprywatne jako instrument rozwoju zrównoważonego, red. M. Urbaniec, P. Stec, S. Dolata, Wydawnictwo Akademii Polonijnej w Częstochowie „Educator”, Częstochowa 2009.

Grzeszkiewicz-Radulska K., Respondenci niedostępni w badaniach sondażowych, [w:] Analizy i próby technik badawczych $w$ socjologii, t. 12, Instytut Socjologii Uniwersytetu Łódzkiego, Wydawnictwo Uniwersytetu Łódzkiego, Łódź 2009.

Grzybowski W., Komu powierzyć realizacje projektu w ramach partnerstwa, „Gazeta Prawna” 2011, nr 178.

Grzybowski W., Przedpartnerska analiza kosztów i korzyści, „Gazeta Samorządu i Administracji” $2005, \mathrm{nr} 22$.

Grzybowski W., Realizacja inwestycji sportowych $i$ rekreacyjnych $w$ formule partnerstwa publiczno-prywatnego, Łódź 2012.

Grzybowski W., Umowa o partnerstwie publiczno-prywatnym - ramy określające standardowa zawartość, Warszawa 2007.

Grzymała Z., Inwestycje komunalne w miastach, [w:] Inwestycje w mieście. Uwarunkowania ekonomiczne, organizacyjne i przestrzenne, red. M. J. Nowak, T. Skotarczak, CeDeWu Sp. z o.o., Warszawa 2012.

Grzywacz W., Infrastruktura transportu a gospodarka narodowa, „Przegląd Komunikacyjny” 1983, nr 5 [za:] T. Kamińska, Makroekonomiczna ocena efektywności inwestycji infrastrukturalnych na przyktadzie transportu, Wydawnictwo Uniwersytetu Gdańskiego, Gdańsk 1999.

Guidebook on Promoting Good Govermance in Public-Private Partnerships, United Nations, New York-Genewa 2008. 
Gumińska R., Analiza współczynnika beta z uwzględnieniem ryzyka projektów inwestycyjnych, [w:] Finanse, ryzyko i ekologia w procesach inwestycyjnych, red. H. Henzel, Wyd. Śląsk, Katowice 1999.

Guziejewska B., Ograniczenia $w$ zaciaganiu dtugu przez samorzad terytorialny - aspekty teoretyczne a rozwiąania $w$ praktyce, [w:] Podsektor samorządowy $w$ sektorze finansów publicznych $w$ warunkach akcesji Polski do Unii Europejskiej, red. L. Patrzałek, Wydawnictwo Wyższej Szkoły Bankowej w Poznaniu, Poznań-Wrocław 2006.

Guziejewska B., Problemy klasyfikacji źródet finansowania samorządu terytorialnego, „Samorząd Terytorialny" 2003, nr 6.

Guziejewska B., Zewnętrzne źródła finansowania samorządu terytorialnego. Teoria a praktyka, Wydawnictwo Uniwersytetu Łódzkiego, Łódź 2008.

Hajdys D., Formalnoprawne możliwości wspólpracy sektora publicznego i prywatnego w ramach modelu partnerstwa publiczno-prywatnego, „Finanse Komunalne” 2009, nr 9.

Hajdys D., Instytucjonalne wsparcie partnerstwa publiczno-prywatnego, materiał $\mathrm{w}$ druku w ramach Samorządowego Forum Samorządowego w Szczecinie, Szczecin 2012.

Hajdys D., Możliwości i formy zaangażowania sektora prywatnego $w$ realizację inwestycji komunalnych $w$ Polsce, [w:] Realizacja zadań publicznych przez jednostki samorzadu terytorialnego we wspótpracy z sektorem prywatnym, red. E. Kornberger-Sokołowska, Centrum Studiów Samorządu Terytorialnego i Rozwoju Lokalnego UW, Warszawa 2008

Hajdys D., Partnerstwo publiczno-prywatne jako alternatywna forma finansowania działalności inwestycyjnej, [w:] Strukturalne reformy finansów publicznych $w$ Polsce $i$ Europie, red. J. Węcławski, „Studia i Prace Naukowe Polskiego Stowarzyszenia Finansów i Bankowości, Zeszyty Naukowe", nr 1.

Hajdys D., Rozwój rynku obligacji komunalnych w Polsce w latach 1996-2000, Wydawnictwo Uniwersytetu Łódzkiego, Łódź 2003.

Hajdys D., Źródta finansowania inwestycji infrastrukturalnych realizowanych przez jednostki samorzadu terytorialnego, „Finanse Komunalne” 2007, nr 10.

Heilpern S., Podejmowanie decyzji w warunkach ryzyka i niepewności, Wydawnictwo Akademii Ekonomicznej im. O. Langego we Wrocławiu, Wrocław 2001.

Henzel H., Decyzje w działalności inwestycyjnej-uwarunkowania, metody, efekty, Wydawnictwo Akademii Ekonomicznej w Katowicach, Katowice 2007.

Herbst I., Praktyczne aspekty realizacji przedsięwzięć PPP $w$ Polsce, Centrum PPP, prezentacja podczas IX Dorocznego Europejskiego Szczytu PPP, Warszawa 2009.

International Handbook on Public-Private Partnerships, ed. by G. A. Hodge, C. Greve, A. E. Boardman, Edward Elgar: a Family Business in International Publishing, UK 2012.

Jagielski J., Kontrola administracji publicznej, Wydawnictwo Prawnicze PWN, Warszawa 1999.

Jajuga K., Ryzyko w finansach. Ujęcie statystyczne, Instytut Cybernetyki Ekonomicznej, Akademia Ekonomiczna im. O. Langego we Wrocławiu, Wrocław 1996.

Jajuga T., Podejmowanie decyzji inwestycyjnych $w$ warunkach ryzyka, [w:] Budżetowanie kapitałów, red. W. Pluta, PWE, Warszawa 2000.

Janowska H., Leasing jako źródło finansowania inwestycji $w$ zakresie gminnej infrastruktury technicznej, [w:] Finanse przedsiębiorstw. Finanse publiczne i podatki, t. 2, red. K. Znaniecka, Wydawnictwo Akademii Ekonomicznej w Katowicach, Katowice 2002.

Janowska H., Strategie finansowania gminnych inwestycji infrastrukturalnych $w$ Polsce, Wydawnictwo Uniwersytetu Szczecińskiego, Szczecin 2002.

Jarosiński K., Finansowanie inwestycji komunalnych $w$ Polsce $w$ warunkach samorząności lokalnej, Monografie i Opracowania nr 523, Oficyna Wydawnicza SGH, Warszawa 2003.

Jarosiński K., Możliwości i zakres finansowania inwestycji sektora publicznego ze źródet pozabudżetowych, [w:] Gospodarka, społeczeństwo, przestrzeń w tradycji i badaniach Kate- 
dry Samorzadu Terytorialnego i Gospodarki Lokalnej SGH, red. Z. Strzelecki, Kolegium Ekonomiczno-Społeczne, Oficyna Wydawnicza SGH, Warszawa 2008.

Jasiewicz S., Rogowski W., Inwestycje hybrydowe - nowe ujęcie oceny efektywności, Oficyna Wydawnicza SGH, Warszawa 2009.

Jasiewicz S., Rogowski W., Kicińska M., Kapitat intelektualny - spojrzenie z perspektywy interesariuszy, Oficyna Ekonomiczna, Kraków 2006.

Jerzmanowski Z., Partnerstwo publiczno-prywatne a prywatyzacja, „Przegląd Komunalny” 2005, nr 10.

Jerzmanowski Z., Prywatyzacja a partnerstwo, „Wspólnota” 2007, nr 13.

Jeżowski P., Metody szacowania korzyści $i$ strat $w$ dziedzinie ochrony środowiska $i$ zdrowia, Oficyna Wydawnicza SGH, Warszawa 2009.

Jędrzejewski L., Gospodarka finansowa samorządu terytorialnego w Polsce. Wybrane zagadnienia, Oficyna Wydawnicza Branta, Bydgoszcz-Gdańsk 2007.

Kaczor T., Tomalak M., Potencjat inwestycyjny jednostek samorzadu terytorialnego, Instytut Badań nad Gospodarką Rynkową, Warszawa 2000.

Kamińska T., Makroekonomiczna ocena efektywności inwestycji infrastrukturalnych na przyktadzie transportu, Wydawnictwo Uniwersytetu Gdańskiego, Gdańsk 1999.

Kania M., Marquardt P., Partnerstwo publiczno-prywatne. Komentarz do ustawy z 19 grudnia 2008 r., TNOiK, Toruń 2012.

Karst Z., Techniczno-ekonomiczna infrastruktura gospodarki narodowej, Wydawnictwo Naukowe PWN, Warszawa 1986.

Karwińska A., Wiktor D., Przedsiębiorczość i korzyści społeczne: identyfikacja dobrych praktyk w ekonomii społecznej, „Ekonomia Społeczna Teksty” 2008, nr 6.

Kawala J., Modras M., Kalinowska E., Studium wykonalności dla inwestycji komunalnych, to wcale nie trudne, LEMTECH Konsulting, Kraków 2003.

Kietlińska K., Rozwój form powiązań instytucji sektora publicznego i prywatnego w Polsce, [w:] Nauki finansowe wobec wspótczesnych problemów gospodarki polskiej. Finanse publiczne, t. 1, red. S. Owsiak, Akademia Ekonomiczna w Krakowie, Kraków 2004.

Kijowski D. R., Pozwolenia w administracji publicznej, Studium z teorii prawa administracyjnego, Temida 2, Białystok 2000.

Kiljan E. H., Teisman G. R., Teisman institutional and strategic barriers to public-private partnership: an analysis of Dutch cases, „Public Money and Management” 2003, 23 (3)

Knight F. H., Risk, Uncertainty and Profit, Houghton Mifflin, Boston-New York 1921.

Kopaliński W., Stownik wyrazów obcych $i$ zwrotów obcojęzycznych, Wiedza Powszechna, Warszawa 1989.

Kopańska A., Partnerstwo publiczno-prywatne jako sposób realizacji zadań publicznych. Czynniki rozwoju w Polsce, [w:] Finansowanie gminnego samorzadu terytorialnego, red. D. A. Hałaburda, Wydawnictwo Wyższej Szkoły Ekonomicznej w Białymstoku, Białystok 2008.

Kopańska A., Zewnętrzne źródta finansowania inwestycji jednostek samorzadu terytorialnego, Difin, Warszawa 2003.

Kopańska A., Bartczak A., Siwińska-Gorzelak J., Partnerstwo publiczno-prywatne. Podmioty prywatne $w$ realizacji zadań publicznych sektora wodno-kanalizacyjnego, Wydawnictwo Fachowe CeDeWu, Warszawa 2008.

Korbus B., Jak wdrożyć udany projekt PPP, Urząd Komitetu Integracji Europejskiej, Warszawa 2005.

Korbus B., Partnerstwo publiczno-prywatne. Poradnik, Urząd Zamówień Publicznych, Warszawa 2010.

Korbus B., Strawiński M., Partnerstwo publiczno-prywatne. Nowa forma realizacji zadań publicznych, Wydawnictwo Prawnicze LexisNexis, Warszawa 2006. 
Korbus B., Wawrzyniak M., Jędrzejewski A., Gospodarczyk D., Projekt systemowy PARP Partnerstwo publiczno-prywatne, ,, Biuletyn Partnerstwa Publiczno-Prywatnego” 2011, nr 1 [PARP, Warszawa 2011].

Korczyński T., Kozłowska A., Kozłowski K., Mednis A., Nowaczek A., Koncesja na roboty budowlane lub ustugi a inne formy realizacji inwestycji publiczno-prywatnych, $\mathrm{ABC}$ a Wolters Kluwer business, Warszawa 2010.

Kornberger-Sokołowska E., Decentralizacja finansów publicznych a samodzielność finansowa jednostek samorzadu terytorialnego, Liber, Warszawa 2001.

Korombel A., Ryzyko w finansowaniu działalności inwestycyjnej metoda Project finance, Difin, Warszawa 2007.

Kosek-Wojnar M., Dylematy wyznaczania granic zadtużania sie jednostek samorzadu terytorialnego, [w:] Nauki finansowe wobec współczesnych problemów gospodarki polskiej, t. 1, red. S. Owsiak, Akademia Ekonomiczna w Krakowie, Kraków 2004.

Kosek-Wojnar M., Surówka K., Finanse samorządu terytorialnego, Wydawnictwo Akademii Ekonomicznej w Krakowie, Kraków 2002.

Kosikowski C., Polskie publiczne prawo gospodarcze, Wydawnictwa Prawnicze PWN, Warszawa 2000.

Kozera M., Organizowanie i funkcjonowanie partnerstw, [w:] Strategie zarządzania wspótpraca, red. J. Hadyński, Akademia Rolnicza im. A. Cieszkowskiego w Poznaniu, Poznań 2006.

Kozłowska A., Jak wybrać partnera prywatnego, „Gazeta Samorządu i Administracji” 2009, nr 21.

Kozłowska A., Kontrola partnera prywatnego, „Gazeta Samorządu i Administracji” 2006, nr 3.

Kozłowska A., PPP krok po kroku. Podręcznik o partnerstwie publiczno-prywatnym, Dobre Praktyki Samorządowe, Warszawa 2011.

Kozłowski A. J., Czaplicka-Kozłowska I. Z., Samorzad terytorialny w systemie zarzadzania państwem. Zagadnienia wybrane, Pracownia Wydawnicza Elset, Olsztyn 2010.

Kuczborski T., Stańczuk M., Jak zdobyć pieniądze na inwestycje?, „Rzeczpospolita” 1999, nr 142.

Kulesza M., Burmistrz musi mieć prawo do ryzyka, „Gazeta Prawna” 2008, nr 82.

Kulesza M., Partnerstwo publiczno-prywatne. Uwagi wstępne, „Finanse Komunalne” 2003, nr 2 Ekstra.

Kulesza M., Bitner M., Kozłowska A., Ustawa o partnerstwie publiczno-prywatnym, Dom Wydawniczy ABC, Warszawa 2006.

Kulty J., Ryzyko, niepewność i konflikt $w$ działalności gospodarczej, Wydawnictwo Akademii Ekonomicznej w Krakowie, Kraków 1995.

Lange O., Optymalne decyzje, PWN, Warszawa 1964.

Leksykon PWN, Wydawnictwo Naukowe PWN, Warszawa 2004.

Linder S. H., Coming to terms with the public-private partnership, „American Behavioral Scentist" 1999, No 43 (1).

Lintz R. S., An overview of Alternative institutional Arrangements for the Delivery of Urba Sernice: Public/Private Partnerships [opracowanie dla:] Local Government Partnership Program, program USAID, Chemonics International, b. m. w. 1999.

Lisek A., Rozwiazania z zakresu partnerstwa publiczno-prywatnego w krajach Unii Europejskiej $i$ Stanach Zjednoczonych, [w:] Partnerstwo publiczno-prywatne, Wrocławska Agencja Rozwoju Regionalnego, Wrocław-Kudowa-Zdrój 2002.

Lubieniecki W., Koncepcja partnerstwa publiczno-prywatnego na drogach wojewódzkich Dolnego Ślaska, „Inwestycje Sektora Publicznego” 2011, nr 5.

Lubińska T., Będzieszak M., Własny potencjat inwestycyjny jako miara pozycji wydatkowej gmin w latach 2004 i 2005, [w:] Budżet państwa i samorzadów. Decentralizacja - oświata. Studium porównawcze, red. T. Lubińska, Difin, Warszawa 2005. 
Lubińska T., Franek S., Będzieszak M., Koncepcja własnego potencjatu dochodowego i potencjatu inwestycyjnego $w$ ocenie zdolności wydatkowej samorzadów $w$ świetle badań porównawczych, [w:] Podsektor samorządowy $w$ systemie finansów publicznych $w$ warunkach akcesji Polski do Unii Europejskiej, red. L. Patrzałek, Wydawnictwo Wyższej Szkoły Bankowej w Poznaniu, Poznań-Wrocław 2006.

Lutyński J., Metody badań społecznych. Wybrane zagadnienia, Łódzkie Towarzystwo Naukowe, Societes Scientiarum Lodziensis, Prace Wydziału II Nauk Historycznych i Społecznych nr 96, Łódź 2000.

Majkowska M., Jak przygotować się do partnerstwa, „Gazeta Prawna” 2011, nr 178.

Malina A., Pawełek B., Wanat S., Zeliaś A., Statystyczne metody oceny ryzyka $w$ działalności gospodarczej, red. A. Zeliaś, Wydawnictwo Akademii Ekonomicznej W Krakowie, Kraków 1998.

Malinowska E., Misiąg W., Finanse publiczne w Polsce. Przewodnik 2002, Ośrodek Doradztwa i Doskonalenia Kadr, Gdańsk 2002.

Manikowski A., Tarapaty Z., Metody oceny projektów gospodarczych, Wyższa Szkoła Ekonomiczna, Warszawa 2001.

Manikowski A., Tarapaty Z., Ocena projektów gospodarczych. Modele i metody, Difin, Warszawa 2001.

Marchewka-Bartkowiak K., Zarządzanie dlugiem publicznym w krajach Unii Europejskiej, Oficyna Wydawnicza Zarządzanie i Finanse, Warszawa 2003.

Marcinek K., Finansowa ocena przedsięwzięć inwestycyjnych przedsiębiorstw, Akademia Ekonomiczna im. K. Adamieckiego, Katowice 1998.

Marcinek K., Ryzyko projektów inwestycyjnych, Wydawnictwo Akademii Ekonomicznej w Katowicach, Katowice 2001.

Marcinek K., Walica H., Zarys ekonomiki $i$ organizacji procesu inwestycyjnego i polityki inwestycyjnej, Wydawnictwo Akademii Ekonomicznej w Katowicach, Katowice 1998.

Marczak J., W sprawie klasyfikacji dochodów jednostek samorzadu terytorialnego, w: Stan i kierunki rozwoju jednostek samorzadu terytorialnego, red. L. Patrzałek, Wydawnictwo Wyższej Szkoły Bankowej w Poznaniu, Poznań-Wrocław 2007.

Markowska-Bzducha E., Potencjat inwestycyjny jednostek samorzadu terytorialnego w Polsce, [w:] Wspótczesne problemy finansów i gospodarki jednostek samorzadu terytorialnego, Wydawnictwo Akademii Ekonomicznej w Poznaniu, Poznań 2008.

Markowska-Bzducha E., Samodzielność finansowa polskich gmin, Wydawnictwo Politechniki Gdańskiej, Radom 2005.

Maska N., Efektywność gospodarowania środkami publicznymi, [w:] Źródla finansowania i miary oceny finansowej podmiotów publicznych i prywatnych, red. J. Iwin-Garzyńska, „Wydawnictwo Uniwersytetu Szczecińskiego, Studia i Prace, t. 738.

McQuaid R. W., The Role of Partnerships in Urban Economic Regeneration, „International Journal of Public-Private Partnerships". [Sheffield Hallam University Press, Sheffield 1999], vol. 2 (1), s. 3-5 [cyt. za:] M. Baron, A. Ochojski, Partnerstwo publiczno-prywatne - próba systematyzacji doświadczeń, [w:] Studia regionalne w Polsce. Teoria, polityka, projektowanie, red. F. Kużnik, Prace Naukowe Akademii Ekonomicznej im. K. Adameckiego w Katowicach, Katowice 2005.

Mekiński M., Finanse publiczne 2010. Tekst nowej ustawy o finansach publicznych z praktycznym omówieniem, Wydawnictwo Wiedza i Praktyka Sp. z o.o., Warszawa 2010

Metodologia tworzenia analiz ryzyka w projektach PPP $i$ ich podzialu pomiędzy strone publiczna i prywatna w kontekście ich wptywu na klasyfikację projektu pod kątem dtugu i deficytu sektora publicznego, red. Ernst\&Young, Hogan Lovells, Ministerstwo Rozwoju Regionalnego, Warszawa 2012. 
Metodyka kompleksowej oceny gospodarki finansowej jednostki samorzadu terytorialnego, red. B. Filipiak, Difin, Warszawa 2009.

Michalak A., Finansowanie inwestycji $w$ teorii $i$ praktyce, Wydawnictwo Naukowe PWN, Warszawa 2007.

Miemiec W., Prawne gwarancje samodzielności finansowej gminy $w$ zakresie dochodów publicznych, Kolonia Limited, Wrocław 2005.

Milewski R., Elementarne zagadnienia ekonomii, Wydawnictwo Naukowe PWN, Warszawa 2002.

Misterek W., Zewnętrzne źródła finansowania działalności inwestycyjnej jednostek samorządu terytorialnego, Difin, Warszawa 2008.

Miszczuk A., Miszczuk M., Żuk K., Gospodarka samorządu terytorialnego, Wydawnictwo Naukowe PWN, Warszawa 2007.

Młynarczyk A., Zadtużenie jednostek samorządu terytorialnego a państwowy dlug publiczny, „Finanse Komunalne” 2012, nr 1-2.

Moszoro M., Partnerstwo publiczno-prywatne $w$ monopolach naturalnych $w$ sferze użyteczności publicznej, Wydawnictwo Szkoły Głównej Handlowej w Warszawie, Warszawa 2005.

Musgrave R., The theory of public finance, MacGraw-Hill, New York 1959.

Nahotko S., Ryzyko ekonomiczne $w$ działalności gospodarczej, Oficyna Wydawnicza Ośrodka Postępu Organizacyjnego Sp. z o. o., Bydgoszcz 2001.

Najnigier S., Administracja czy biznes, [w:] Administracja publiczna. Wyzwania $w$ dobie integracji europejskiej, red. J. Czaputowicz, Europejski Instytut Administracji Publicznej, Wydawnictwo Naukowe PWN, Warszawa 2008.

Newbery D. M., Privatization, Restructuring and Regulation of Network Utilities, The WalrasPareto Lectures, The MIT press, Cambridge, MA. 2000.

Niechcielski J., Wieloch D., Szybki i tani pieniadz, „Rzeczpospolita” 1999, nr 125.

Nijkamp P., Burch M., Vindigni G., A comparative institutional evaluation of public-private partnerships in Dutch urban land-use and revitalization projects, „Urban Studies” 2002, No 39.

Noga M., Państwo a inwestycje $w$ gospodarce rynkowej z uwzględnieniem procesu transformacji, Dolnośląska Oficyna Wydawnicza, Wrocław 1994.

Norek E., Prawo zamówień publicznych. Komentarz, LexisNexis, Warszawa 2009.

Nowoczesne systemy realizacji zadań publicznych. Poradnik PPP, red. M. Chałas, Dom Wydawniczy ELIPSA, Warszawa 2006.

Nowy stownik języka polskiego, Wydawnictwo Naukowe PWN, Warszawa 2002.

Ofiarski Z., Subwencje i dotacje jednostek samorzadu terytorialnego, Difin, Warszawa 2002.

Orłowski W. M., Potencjalne makroekonomiczne korzyści stosowania PPP w Polsce, Niezależny Ośrodek Badań Ekonomicznych NOBE, Warszawa 2011.

Osborne D., Gaebler T., Rządzić inaczej. Jak duch przedsiębiorczości przenika i przeksztatca administracje publiczna, Media Rodzina, Poznań 1992.

Ostrowska E., Pomiar ryzyka w rzeczowych inwestycjach przedsiębiorstw, „Przegląd Organizacji” 1997, nr 4.

Ostrowska E., Ryzyko projektów inwestycyjnych, PWE, Warszawa 2002.

Ostrzołek G., Finansowanie budowy drogi w mieście na prawach powiatu na zasadach partnerstwa publiczno-prywatnego (ustawowego), „Finanse Komunalne” 2009, nr 12.

Owsiak S., Finanse publiczne, Wydawnictwo Naukowe PWN, Warszawa 2001.

Owsiak S., Finanse publiczne, teoria i praktyka, Wydawnictwo Naukowe PWN, Warszawa 2005.

Panasiuk A., Koncesja na roboty budowlane lub ustugi. Partnerstwo publiczno-prywatne. Komentarz, C.H. Beck, Warszawa 2009.

Partnerstwo publiczno-prywatne, red. A. Gajewska-Jedwabny, Wydawnictwo C.H. Beck, Warszawa 2007. 
Partnerstwo publiczno-prywatne. Poradnik, red. B. Korbus, Urząd Zamówień Publicznych, Warszawa 2010.

Partnerstwo publiczno-prywatne. Zagadnienia teorii i praktyki, red. M. Perkowski, Temida 2, Białystok 2007.

Partnerstwo publiczno-prywatne jako metoda realizacji zadań publicznych, Ministerstwo Gospodarki i Pracy, Departament Polityki Regionalnej, Warszawa 2005.

Partnerstwo publiczno-prywatne $w$ Polsce $i$ jego funkcjonowanie na przykładzie wybranych projektów, red. J. Rutkowski, Wydawnictwo Uniwersytetu Łódzkiego, Łódź 2010.

Patrzałek L., Finanse samorzadu terytorialnego, Wydawnictwo Akademii Ekonomicznej im. O. Langego we Wrocławiu, Wrocław 2004.

Patrzałek L., Kryteria wyboru i uwarunkowania wykorzystania zwrotnych źródet finansowania jednostki samorzadu terytorialnego, [w:] Gospodarka finansowa jednostki samorzadu terytorialnego. Zagadnienia wybrane, red. L. Patrzałek, Wydawnictwo wyższej Szkoły Bankowej w Poznaniu, Poznań 2010.

Pawlak M., Zarządzanie projektami, Wydawnictwo PWN, Warszawa 2011.

Peters B. G., Witch a little help from our friends: public-private partnerships as institutions and instruments, [w:] J. Pierre (ed.), Partnerships in Urban Governance: European and American Experiences, Macmillan, London 1997.

Pietras P., Zarządzanie projektami. Wybrane metody i techniki, Oficyna Księgarsko-Wydawnicza „Horyzont”, Łódź 2003.

Pilarska A., Jak przygotować przedsięwzięcie w formule PPP, „Gazeta Samorządu i Administracji” 2009, nr 15.

Piotrowska-Marczak K., Finanse lokalne w Polsce, Wydawnictwo Naukowe PWN, Warszawa 1997.

Piotrowska-Marczak K., Uryszek T., Zarządzanie finansami publicznymi, Difin, Warszawa 2009.

Piskozub A., Funkcja przemieszczenia jako cecha wspólna infrastruktury, „Problemy Ekonomiki Transportu" [Biuletyn Informacyjny OBET] 1977, nr 2.

Płonka-Bielenin K., Charakter prawny umowy o partnerstwo publiczno-prywatne, „Samorząd Terytorialny" 2010, nr 9.

Płoskonka J., Pojęcie kontroli w ujęciu zarządczym, „Kontrola Państwowa” 2006, nr 2.

Pokrzywiak J., Bagłaj M., Wymóg polisy, „Miesięcznik Ubezpieczeniowy” 2011, nr 4.

Poniatowicz M., Salachna J. M., Perło D., Efektywne zarzadzanie dlugiem $w$ jednostkach samorzadu terytorialnego, Wolters Kluwer, Warszawa 2010.

Prawo cywilne $i$ handlowe $w$ zarysie, red. W. J. Katner, Oficyna a Wolters Kluwer business, Warszawa 2009.

Prawo gospodarcze. Zagadnienia administracyjnoprawne, red. C. Balasiński, M. Wierzbowski, M. Wyrzykowski, WP PWN, Warszawa 1998.

Prawo samorzadu terytorialnego, red. Z. Ofiarski, M. Mokrzyc, WSAP w Szczecinie, Szczecin 1999.

Pritchard C. L., Zarzadzanie ryzykiem $w$ projektach. Teoria i praktyka, WIG-PRESS, Warszawa 2002.

Public Finance Guidelines. PPP Toolkit, European Bank for Reconstruction and Development, 30 January 2004.

Pyziak-Szafnicka M., Płaszczyk P., Działalność gospodarcza gmin a granice w sfery użyteczności publicznej, „Finanse Komunalne” 1997, nr 2.

Rejda G., Principles of Risk Management and Insurance, New York 1995 [cyt. za:] W. RonkaChmielowiec, Wykorzystanie ubezpieczeń do zarządzania ryzykiem w przedsiębiorstwie, [w:] Zarządzanie ryzykiem działalności organizacji, red. J. Monkiewicz, L. Gąsiorkiewicz, Wydawnictwo C.H. Beck, Warszawa 2010. 
Renda A., Schrefler L., Public-Private Partnerships. Models and Trends in the European Union, European Parlament, IP/A/IMCO/SC/2005-161, February 2006.

Rogowski W., Rachunek efektywności inwestycji, Oficyna Wolters Kluwer business, Kraków 2008.

Rogowski W., Rachunek efektywności przedsięwzięć inwestycyjnych, C.H. Beck, Warszawa 2006.

Ronka-Chmielowiec W., Wykorzystanie ubezpieczeń do zarządzania ryzykiem $w$ przedsiębiorstwie, [w:] Zarzadzanie ryzykiem działalności organizacji, red. J. Monkiewicz, L. Gąsiorkiewicz, Wydawnictwo C.H. Beck, Warszawa 2010.

Rose P. S., Money and Capital Markets, The Financial systemie Ekonomy, Bussiness publ. plano, Teras 1986.

Rosińska J., Źródta finansowania inwestycji komunalnych na przyktadzie miast na prawach powiatu $w$ województwie zachodniopomorskim, [w:] Samorzad terytorialny w zintegrowanej Europie, t. 2, red. B. Filipiak, A. Szewczuk, Uniwersytet Szczeciński, Zeszyty Naukowe nr 426, Ekonomiczne Problemy Usług nr 1, Szczecin 2006.

Różański J., Inwestycje rzeczowe $w$ procesach rozwojowych przedsiębiorstw, Wydawnictwo Uniwersytetu Łódzkiego, Łódź, 1998.

Różański J., Czerwiński M., Inwestycje rzeczowe i kapitałowe, Przedsiębiorstwo Specjalistyczne Absolwent, Łódź 1999.

Rudnicki M., Partnerstwo publiczno-prywatne. Wybrane zagadnienia prawno-ustrojowe i prawno-finansowe, ,Samorząd Terytorialny” 2006, nr 7-8.

Rudzka-Lorentz Cz., Sierak J., Zarządzanie finansami jednostek samorzadu terytorialnego, [w:] Nowe zarządzanie publiczne $w$ polskim samorzadzie terytorialnym, red. A. Zalewski, Oficyna Wydawnicza SGH, Warszawa 2005.

Rudzka-Lorentz Cz., Sierak J., Zarządzanie finansami w gminach, w: Zarządzanie gospodarka i finansami gminy, red. H. Sochacka-Krysiak, Oficyna Wydawnicza SGH, Warszawa 2006.

Rybarczyk M., Bon komunalny, „Gazeta Prawnicza” 1999, nr 16-17.

Rynek ustug komunalnych w Polsce, red. T. Aziewicz, Instytut Badań nad Gospodarką Rynkową, Gdańsk-Lublin 1994.

Sadowy M., Ekonomika przedsiębiorstw komunalnych. Zarys problematyki, [w:] Samorząd terytorialny a rozwój lokalny, red. M. Majchrzak, A. Zalewski, Monografie i Opracowania $\mathrm{nr}$ 483, Oficyna Wydawnicza SGH, Warszawa 2000.

Samorzad terytorialny w procesach rozwoju regionalnego i lokalnego, red. W. Kosiedowski, Dom Organizatora TNOiK, Toruń 2005.

Sarnacka A., Partnerstwo publiczno-prywatne - niewykorzystana szansa na rozwój infrastruktury, [w:] Realizacja zadań publicznych przez jednostki samorzadu terytorialnego we wspótpracy z sektorem prywatnym, red. E. Kornberger-Sokołowska, Uniwersytet Warszawski, Centrum Studiów Samorządu Terytorialnego i Rozwoju Lokalnego, Warszawa 2008.

Savas E. S., Prywatyzacja. Klucz do lepszego rządzenia, PWE, Warszawa 1992.

Shackle G. L. S., Expectation Entprise and Profit, George Allen und Unwin, London 1970.

Sierak J., Potrzeby $i$ wydatki inwestycyjne w samorzadzie terytorialnym a możliwości $i$ źródta ich finansowania, [w:] Gospodarka finansowa jednostek samorzadu terytorialnego w warunkach decentralizacji zarządzania sektorem publicznym, red. H. Sochacka-Krysiak, Oficyna Wydawnicza SGH, Warszawa 2008.

Sierak J., Górniak R., Ocena efektywności i finansowania projektów inwestycyjnych jednostek samorządu terytorialnego wspótfinansowanych funduszami Unii Europejskiej, Oficyna Wydawnicza SGH, Warszawa 2011.

Sierpińska M., Jachna T., Ocena przedsiębiorstwa wedtug standardów światowych, Wydawnictwo Naukowe PWN, Warszawa 1994. 
Skoczyński T., Ustawa partnerstwie publiczno-prywatnym. Praktyczny komentarz, Lex Wolters Kluwer business, Warszawa 2011.

Słodowa-Hełpa M., Partnerstwo: pojęcie, przedmiot, cele, [w:] Strategie zarządzania wspótpraca, red. J. Hałdyński, Akademia Rolnicza im. A. Cieszkowskiego w Poznaniu, Centralna Baza Danych, Poznań 2006.

Stownik ekonomiczny przedsiębiorcy, red. Z. Dowgiałło, Wydawnictwo Znicz, Warszawa 2004.

Stownik finansów samorzadowych, red. A. Borodo, Dom Organizatora TNOiK, Torun 2007.

Stownik języka polskiego, PWN, Warszawa 2002.

Sobiech K., Partnerstwo publiczno-prywatne w infrastrukturze drogowej w Polsce, Wydawnictwo Politechniki Poznańskiej, Poznań 2007.

Sobiech-Grabska K., Analiza finansowo-ekonomiczna w PPP, „Biuletyn Partnerstwa Publiczno-Prywatnego" 2012, nr 4.

Sochacka-Krysiak H., Finanse lokalne, Poltext, Warszawa 1995.

Sochacka-Krysiak H., Partnerstwo publiczno-prywatne - szansa czy konieczność?, [w:] Realizacja zadań publicznych przez jednostki samorzadu terytorialnego we wspótpracy z sektorem prywatnym, red. E. Kornberger-Sokołowska, Uniwersytet Warszawski, Centrum Studiów Samorządu Terytorialnego i Rozwoju Lokalnego, Warszawa 2008.

Starościak J., Zarys nauki administracji, Wydawnictwo Prawnicze PWN, Warszawa 1971.

Stasikowski R., Gwarancje samodzielności gminnej w systemie prawnym Republiki Federalnej Niemiec i Rzeczpospolitej Polskiej, Oficyna Wydawnicza Branta, Bydgoszcz-Katowice 2005.

Stiglitz J. E., Ekonomika sektora publicznego, Wydawnictwo Naukowe PWN, Warszawa 2004.

Strąk T., Modele dokonań jednostek sektora finansów publicznych, Difin, Warszawa 2012.

Sulejewicz A., Analiza społecznych kosztów i korzyści. Między ekonomia dobrobytu a planowaniem rozwoju, Wydawnictwo Naukowe PWN, Warszawa 1991.

Swianiewicz P., Finanse lokalne, teoria i praktyka, Municypium S.A., Warszawa 2004.

Szreder J., Współdziałanie sektora publicznego i prywatnego w rozwoju lokalnym, Wyższa Szkoła Zarządzania w Słupsku, Słupsk 2004.

Szymański W., Wykorzystanie środków z funduszy strukturalnych przez jednostki samorzadu terytorialnego - szanse i zagrożenia, [w:] Samorzad terytorialny w zintegrowanej Europie, t. 2, red. B. Filipiak, A. Szewczuk, Uniwersytet Szczeciński, Zeszyty Naukowe nr 426, Szczecin 2006.

Śliwa J., Zarządzanie finansami przedsiębiorstwa, od diagnozy do projekcji, Fundacja Rozwoju Rachunkowości w Polsce, Warszawa 1998.

Śliwiński P., Kryteria wyboru zewnętrznych źródel finansowania deficytu budżetowego jednostki samorzadu terytorialnego, „Finanse Komunalne” 2002, nr 5.

Tasan-Kok T., Załęczna M., Partnerstwo publiczno-prywatne $w$ rozwoju przestrzeni miejskiej. Polska praktyka na tle regulacji unijnych, Sprawne Państwo Program Ernst\&Young, Warszawa 2010.

Tkaczyk T. P., Wybrane problemy konkurencji, WESI, Warszawa 2000.

Tryc G., Metodyka wykonania Modelu Porównawczego Sektora Publicznego (PSC) dla projektu z zakresu gospodarki odpadami komunalnymi, GT Consulting, Warszawa 2010.

Tyszkiewicz-Mazur A., Umowa o partnerstwie publiczno-prywatnym - wybrane zagadnienia, „Samorząd Terytorialny” 2008, nr 11.

Umowa o partnerstwie publiczno-prywatnym - ramy określające standardowa zawartość, Ministerstwo Gospodarki, Warszawa 2007.

Ustawa o partnerstwie publiczno-prywatnym. Komentarz, red. M. Bejm, Wydawnictwo C.H. BECK, Warszawa 2010. 
Użyteczność publiczna w sektorach infrastruktury gospodarczej, red. K. Bobińska, Bellona, Warszawa 2003.

Varian H., Mikroekonomia. Kurs średni - ujęcie nowoczesne, Wydawnictwo Naukowe PWN, Warszawa 2006.

Vaughan E. J., Risk Manegament, New York 1997.

Walica H., Integracja wykonawców przedsięwzięć inwestycyjnych, Wydawnictwo Akademii Ekonomicznej w Katowicach, Katowice 1992.

Waśkiewicz R., Budżet zadaniowy jako narzędzie racjonalizacji wydatków inwestycyjnych w gminie, [w:] Budżet zadaniowy metoda racjonalizacji wydatków, red. B. Woźniak, M. Postuła, Oficyna Wydawnicza SGH, CeDeWu Sp. z o.o., Warszawa 2012.

Wawrzyniak M, Analiza przedrealizacyjna przedsięwzięcia PPP - zagadnienia podstawowe, „Biuletyn Partnerstwa Publiczno-Prywatnego” 2012, nr 3.

Wernik A., Finanse publiczne, PWE, Warszawa 2007.

Wesołowska H., Ubezpieczenie działalności jednostek samorządu terytorialnego, „Gazeta Prawna", z 29 grudnia 2010.

Wilczek M. T., Podstawy zarzadzania projektami inwestycyjnymi, Wydawnictwo Akademii Ekonomicznej w Katowicach, Katowice 2002.

Wilczek M. T., Wybrane zagadnienia podejmowania decyzji w przedsiębiorstwie, Wyższa Szkoła Zarządzania Marketingowego i Języków Obcych w Katowicach, Katowice 2000.

Willet A. H., The Economic Theory of Risk Insurance, University of Pensylvania Press, Philadelphia 1951.

Winiarski J., Analiza procesu zarządzania ryzykiem wedtug standardów PMBOK, [w:] Ryzyko. Zarządzanie ryzykiem w przedsiębiorstwie, red. J. Bizon-Górecka, TNOiK, Bydgoszcz 2007.

Wirth H., Wanielista K., Butra J., Kicki J., Strategiczna i ekonomiczna ocena przemystowych projektów inwestycyjnych. Poradnik praktyczny, Instytut Gospodarki Surowcami Mineralnymi i Energią PAN, Kraków 2000.

Witoszek G., Techniki oceny ryzyka w podejmowaniu przedsięwzięć inwestycyjnych, „Przegląd Organizacji” 2001, nr 3.

Wojarska M., Zabielska I., Partnerstwo publiczno-prywatne jako narzędzie budowy rynkowego modelu gospodarki komunalnej, [w:] Partnerstwo w regionie, red. J. Karwowski, Uniwersytet Szczeciński, Szczecin 2004.

Wojciechowski E., Zarządzanie w samorzadzie terytorialnym, Difin, Warszawa 2012.

Wojciechowski E., Bogus A., Bon komunalny $w$ gospodarce finansowej gminy, [w:] Finanse, banki i ubezpieczenia w Polsce u progu XXI wieku, Wydawnictwo Akademii Ekonomicznej w Poznaniu, Poznań 2000.

Woroniecki P. M., Obligacje przychodowe, „Inwestycje komunalne - Przegląd Zamówień Publicznych" 2004, nr 12.

Woźniak Z., Między rywalizacja a partnerstwem. Bariery wspótpracy władz samorządowych $z$ organizacjami pozarządowymi, [w:] Samoorganizacja społeczeństwa polskiego. Trzeci sektor, red. P. Gliński, B. Lewenstein, A. Siciński, IFiS PAN, Warszawa 2002.

Wróblewski W., Słownik pojęć komunalnych, Włocławskie Towarzystwo Naukowe, Włocławek 2007.

Wspótczesne problemy zarzadzania finansami lokalnymi, red. A. Kożuch, K. Brzozowska, Fundacja Współczesne Zarządzanie, Kraków 2006.

Wywiad kwestionariuszowy. Analizy teoretyczne i badania empiryczne, red. K. Lutyńska, A. P. Wejland, PAN, Instytut Filozofii i Socjologii, Zakład Narodowy im. Ossolińskich, WrocławWarszawa-Kraków-Gdańsk-Łódź 1983.

Yescombe E. R., Partnerstwo publiczno-prywatne. Zasady wdrażania i finansowania, Oficyna a Wolters Kluwer business, Kraków 2008. 
Zalewski A., Metody oceny projektów rozwojowych, [w:] Samorząd terytorialny a rozwój lokalny, red. M. Majchrzak, A. Zalewski, Monografie i Opracowania nr 483, Oficyna Wydawnicza SGH, Warszawa 2000.

Zalewski A., Reformy sektora publicznego w duchu nowego zarzadzania publicznego, [w:] Nowe zarządzanie publiczne $w$ polskim samorzadzie terytorialnym, red. A. Zalewski, Oficyna Wydawnicza SGH, Warszawa 2000.

Zaremba W., Partnerstwo publiczno-prywatne. Nowe możliwości zarządzania usługami publicznymi, [w:] Partnerskie współdziałanie w sektorze publicznym i prywatnym, red. B. Plawgo, W. Zaremba, Fundacja Współczesne Zarządzanie, Białystok 2005.

Zarys ekonomii sektora publicznego, red. M. Brol, Wydawnictwo Uniwersytetu Ekonomicznego we Wrocławiu, Wrocław 2010.

Zarys finansów publicznych i prawa finansowego, wyd. 5, red. A. Gorgol, A. Kuś, A. Niezgoda, P. Smoleń, W. Wojtowicz, Wolter Kluwer, Warszawa 2008.

Zarzadzanie ryzykiem, red. K. Jajuga, Wydawnictwo Naukowe PWN, Warszawa 2009.

Zasilanie finansowe jednostek samorzadu terytorialnego $w$ warunkach integracji europejskiej, red. T. Famulska, Prace Naukowe Uniwersytetu Ekonomicznego w Katowicach, Katowice 2010.

Zawora J., Samodzielność finansowa samorządu gminnego, Wydawnictwo Uniwersytetu Rzeszowskiego, Rzeszów 2008.

Zimny A., Uwarunkowania efektywności inwestycji gminnych w sferze infrastruktury technicznej, Państwowa Wyższa Szkoła Zawodowa w Koninie, Konin 2008.

Zioło M., Zewnętrzne źródła finansowania infrastruktury komunalnej na przykładzie Gminy Miasto Szczecin, [w:] Gospodarka finansowa jednostki samorzadu terytorialnego. Zagadnienia wybrane, red. L. Patrzałek, Wydawnictwo Wyższej Szkoły Bankowej w Poznaniu, Poznań 2010.

Ziółkowska W., Finanse publiczne. Teoria i zastosowanie, Wydawnictwo Wyższej Szkoły Bankowej, Poznań 2005.

Zysnarski J., Partnerstwo publiczno-prywatne. Teoria i praktyka, Ośrodek Doradztwa i Doskonalenia Kadr Sp. z o.o., Gdańsk 2003.

Zysnarski J., Partnerstwo publiczno-prywatne w sferze usług komunalnych, Ośrodek Doradztwa i Doskonalenia Kadr Sp. z o.o., Gdańsk 2007.

Żabińska T., Partnerstwo jako determinanta rozwoju turystyki $w$ regionie, [w:] Turystyka w badaniach naukowych. Prace ekonomiczne, red. A. Nowakowska, M. Przydział, Wydawnictwo Wyższej Szkoły Informatyki i Zarządzania z siedzibą w Rzeszowie, Rzeszów 2006.

\section{Akty prawne}

Decyzja Eurostatu 04/18 z 11 lutego 2004 r. o traktowaniu partnerstwa publiczno-prywatnego i jego wptywie na dlug $i$ deficyt publiczny.

Dyrektywa Rady 92/43/EWG z dnia 21 maja 1992 r. w sprawie ochrony siedlisk przyrodniczych oraz dzikiej fauny i flory.

Dyrektywa 2001/42/WE Parlamentu Europejskiego i Rady z dnia 27 czerwca 2001 r. w sprawie oceny wpływu niektórych planów i programów na środowisko.

Dyrektywa 2003/35/WE Parlamentu Europejskiego i Rady z dnia 26 maja 2003 r. przewidujaca udziat spoteczeństwa $w$ odniesieniu do sporzadzania niektórych planów i programów $w$ zakresie środowiska oraz zmieniająca $w$ odniesieniu do udziału społeczeństwa $i$ dostępu do wymiaru sprawiedliwości dyrektywy Rady 85/337/EWG i 96/61/WE.

Dyrektywa 2003/4/WE Parlamentu Europejskiego i Rady z dnia 28 stycznia 2003 r. w sprawie publicznego dostęu do informacji dotyczacych środowiska i uchylająca. 
Dyrektywa 2004/17/WE Parlamentu Europejskiego i Rady z dnia 31 marca 2004 r. koordynujacej procedury udzielania zamówień przez podmioty działajace $w$ sektorach gospodarki wodnej, energetyki.

Dyrektywa 2004/18/WE Parlamentu Europejskiego i Rady z 31.03.2004 r. w sprawie koordynacji procedur udzielenia zamówień publicznych na roboty budowlane, dostawy i ustugi, DzUrz. UE, L 134/114.

Dyrektywa Parlamentu Europejskiego i Rady 2008/1/WE z dnia 15 stycznia 2008 r. dotyczaca zintegrowanego zapobiegania zanieczyszczeniom $i$ ich kontroli.

Dyrektywa Rady 85/337/EWG z dnia 27 czerwca 1985 r. w sprawie oceny skutków wywieranych przez niektóre przedsięwzięcia publiczne i prywatne na środowisko naturalne.

Konstytucja Rzeczypospolitej Polskiej z 2 kwietnia 1997 r., DzU, 1997, nr 78, poz. 483.

Rozporzadzenie Komisji (WE) nr 1564/2005 z dnia 7 września 2005 r. ustanawiajace standardowe formularze do publikacji ogłoszeń $w$ ramach procedur zamówień publicznych zgodnie z Dyrektywami 2004/17/WE i 2004/18/Deparlamentu Europejskiego i Rady Europy. Rozporządzenie Ministra Finansów z 3 lutego 2010 r. w sprawie sprawozdawczości budżetowej, Dz. U. Nr 20, poz. 103.

Rozporządzenie Ministra Finansów z dnia 4 marca 2010 r.w sprawie sprawozdań jednostek sektora publicznego w zakresie operacji finansowych, DzU, 2010, $\mathrm{nr}$ 43, poz. 247.

Rozporządzenie Ministra Finansów z 23 grudnia 2010 r. w sprawie szczegółowego sposobu klasyfikacji tytułów dluznych zaliczanych do państwowego dlugu publicznego, w tym do dlugu Skarbu Państwa, DzU, 2010, nr 252, poz. 1692.

Rozporządzenie Ministra Finansów z dnia 28 grudnia 2011 r. w sprawie szczegółowego sposobu klasyfikacji tytutów dłużnych zaliczanych do państwowego dlugu publicznego, DzU, 2011, nr 298, poz. 1767.

Rozporządzenie Ministra Infrastruktury z dnia 18 maja 2004 r.w sprawie określenia metod i podstaw sporzadzania kosztorysu inwestorskiego, obliczenia planowanych kosztów prac projektowych oraz planowanych kosztów robót budowlanych określonych w programie funkcjonalno uzytkowym, DzU, 2004, nr 130, poz. 1389 ze zm.

Rozporządzenie Prezesa Rady Ministrów z dnia 3 marca 2009 r. w sprawie wzorów ogłoszenia o koncesji na ustugi zamieszczonego w Biuletynie Zamówień Publicznych, DzU, 2009, nr 39, poz. 311.

Rozporządzeniu Prezesa Rady Ministrów z dnia 23 grudnia 2009 r. w sprawie kwot wartości zamówień oraz konkursów, od których uzależniony jest obowiązek przekazywania ogłoszeń Urzędowi Oficjalnych Publikacji Wspólnot Europejskich, DzU, 2009, nr 224, poz. 1795.

Rozporządzenie Prezesa Rady Ministrów z dnia 30 grudnia 2009 r. w sprawie rodzajów dokumentów, jakich może żąać zamawiający od wykonawcy oraz form, w jakich te dokumenty moga być sktadane, DzU, 2009, nr 226, poz. 1817.

Rozporządzenie Prezesa Rady Ministrów z dnia 28 stycznia 2010 r. w sprawie wzorów ogłoszeń zamieszczonych w Biuletynie Zamówień Publicznych, DzU, 2010, nr 12, poz. 69.

Rozporządzenie Prezydenta RP z dnia 24 października 1934 r. Prawo upadłościowe, DzU, 1991, $\mathrm{nr} 18$, poz. 512 ze zm.

Rozporzadzenie z dnia 21 czerwca $2006 r$. w sprawie ryzyk zwiąanych z realizacja przedsięwzięć w ramach partnerstwa publiczno-prywatnego, DzU, 2006, nr 125, poz. 868.

Rozporzadzenie z dnia 30 czerwca $2006 r$. w sprawie niezbędnych elementów analizy przedsięwzięć w ramach partnerstwa publiczno-prywatnego, DzU, 2006, nr 125, poz. 86.

Rozporządzenie z dnia 30 czerwca 2006 r. w sprawie szczegółowego zakresu, form i zasad sporządzania informacji dotyczacych umów o partnerstwie publiczno-prywatnym, DzU, 2006, nr 125, poz. 867.

Traktat ustanawiająy Wspólnotę Europejska, DzU, 2004, nr 90, poz. 864/2 ze zm. 
Ustawa z dnia 14 października 1921 r. o udzielaniu koncesji na koleje żelazne, DzU, 1921, nr 88, poz. 646.

Ustawa z dnia 23 kwietnia 1964 r. Kodeks cywilny, DzU, 1964, nr 16, poz. 93 ze zm.

Ustawa z dnia 21 marca 1985 r. o drogach publicznych, DzU, 2011, nr 159, poz. 945.

Ustawa z dnia 8 marca 1990 r. o samorzadzie gminnym, DzU, 2001, nr 142, poz. 1591 ze zm.

Ustawa z dnia 13 lipca 1990 r. o prywatyzacji przedsiębiorstw państwowych, DzU, 1990, nr 51, poz. $298 \mathrm{ze} \mathrm{zm}$.

Ustawa z dnia 19 października 1991 r. o gospodarowaniu nieruchomościami rolnymi Skarbu Państwa oraz o zmianie niektórych ustaw, DzU, 1991, nr 107, poz. 464 ze zm.

Ustawa z dnia 7 lipca 1994 r. Prawo budowlane, DzU, 2006, nr 156, poz. 1118 ze zm.

Ustawa z dnia 29 września 1994 r. o rachunkowości, DzU, 2002, nr 76, poz. 694 ze zm.

Ustawa z dnia 27 października 1994 r. o autostradach płatnych i Krajowym Funduszu Drogowym, DzU, 1994, nr 127, poz. 627 ze zm.

Ustawa z dnia 27 października 1994 r. o autostradach płatnych oraz o Krajowym Funduszu Drogowym, DzU, 2009, nr 223, poz. 1776.

Ustawa z dnia 29 czerwca 1995 r. o obligacjach, DzU, 2005, nr 157, poz. 1316 ze zm.

Ustawa z dnia 20 grudnia 1996 r. o gospodarce komunalnej, DzU, 2011, nr 45, poz. 236.

Ustawa z dnia 30 sierpnia 1996 r. o komercjalizacji i prywatyzacji przedsiębiorstw państwowych, DzU, 1996, nr 11, poz. 561 ze zm.

Ustawa z dnia 21 sierpnia 1997 r. o gospodarce nieruchomościami, DzU, 2011, nr 163, poz. 981.

Ustawa z dnia 29 sierpnia 1997 r. Prawo bankowe, DzU, 2011, nr 232, poz. 1378.

Ustawa z dnia 15 września 2000 r. o referendum lokalnym, DzU, 2011, nr 147, poz. 881.

Ustawa z dnia 30 sierpnia 2002 r. o systemie oceny zgodności, DzU, 2004, nr 204, poz. 2087 ze $\mathrm{zm}$.

Ustawa z dnia 28 lutego 2003 r. Prawo upadtościowe i naprawcze, DzU, 2012, nr 173, poz. 578

Ustawa z dnia 13 listopada 2003 r. o dochodach jednostek samorzadu terytorialnego, DzU, 2008, $\mathrm{nr} 88$, poz. 539 ze zm.

Ustawa z dnia 29 stycznia 2004 r. Prawo zamówień publicznych, DzU, 2004, nr 19, poz. 177 ze $\mathrm{zm}$.

Ustawa z dnia 29 stycznia 2004 r. Prawo zamówień publicznych, DzU, 2011, nr 87, poz. 484 ze $\mathrm{zm}$.

Ustawa z dnia 2 lipca 2004 r. o swobodzie działalności gospodarczej, DzU, 2011, nr 232, poz. 1378.

Ustawa z dnia 30 czerwca 2005 r. o finansach publicznych, DzU, 2005, nr 249, poz. 2103 ze zm.

Ustawa z dnia 28 lipca 2005 r. o partnerstwie publiczno-prywatnym, DzU, 2005, $\mathrm{nr} 169$, poz. 1420.

Ustawa z dnia 3 października 2008 r. o udostępnieniu informacji o środowisku i jego ochronie, udziale społeczeństwa $w$ ochronie środowiska oraz o ocenach oddziatywania na środowisko, DzU, 2012, nr 178, poz. 472.

Ustawa z dnia 19 grudnia 2008 r. o partnerstwie publiczno-prywatnym, DzU, 2009, nr 19, poz. $100 \mathrm{ze} \mathrm{zm}$.

Ustawa z dnia 9 stycznia 2009 r. o koncesji na roboty budowlane lub ustugi, DzU, 2009, nr 19, poz. $101 \mathrm{ze} \mathrm{zm}$.

Ustawa z dnia 27 sierpnia 2009 r. o finansach publicznych, DzU, 2009, nr 157, poz. 1240 ze zm.

Ustawa z dnia 29 sierpnia 2009 r. przepisy wprowadzajace ustawe o finansach publicznych, DzU, 2009, nr 157, poz. 1241 ze zm.

Ustawa z dnia 4 lutego 2011 r. o opiece nad dziećmi w wieku do lat 3, DzU, 2011, nr 45, poz. 235.

Ustawa z dnia 1 lipca 2011 r. o zmianie ustawy o utrzymaniu czystości i porządku w gminach oraz niektórych innych ustaw, DzU, 2011, nr 224, poz. 1337. 


\section{Dokumenty}

Akt notarialny Repertorium A nr 6784/2003 umowa spółki z ograniczoną odpowiedzialnością Aqua Park Łódź.

Analiza kosztów i korzyści projektów inwestycyjnych. Przewodnik (Fundusz Strukturalny - EFRR, Fundusz Spójności i ISPA), Jednostka ds. Ewaluacji Dyrekcja Generalna - Polityka Regionalna, Komisja Europejska, Bruksela 1997.

Decyzja Eurostat o traktowaniu partnerstwa publiczno-prywatnego $i$ jego wplywie na dtug i deficyt publiczny, ,Released” 2004, 18, 11 Feb. 2004, www.europa.eu.

Decyzja nr 143/08 Powiatowego Inspektoratu Nadzoru Budowlanego dotycząca pozwolenia na użytkowanie budynku rekreacyjnego, budynku chlorownii, stacji trafo, linii kablowej eNN i SN, przyłącza telefonicznego, przebudowanego przyłącza wodociągowego, kanalizacyjnego i sieci wewnętrznych, wybudowanych na terenie nieruchomości w Łodzi przy al. Unii Lubelskiej 4, informacji uzyskanych w Urzędzie Miasta Łodzi.

Delloite, Closing the Infrastructure Gap: The Role of Public-Private Partnerships.

Dobre Praktyki PPP. Podsumowanie trzech lat konkursu na najlepsze projekty przedsięwzięc publiczno-prywatnych, Investment Support, Warszawa 2009.

Dokument roboczy na temat Zielonej Księgi Komisji w sprawie partnerstw publiczno-prywatnych oraz prawa wspólnotowego dotyczącego zamówień publicznych i koncesji, Komisja Rynku Wewnętrznego i Ochrony Konsumentów, Pe 374.146v01-00.

The EIB's role in Public-Private Partnerships (PPPs), Europan Investment Bank, 15 July 2004.

Infrastruktura komunalna w 2010 r., Główny Urząd Statystyczny, Warszawa 2011.

Market Update. Review of the European PPP Market in 2010, European PPP Expertise Centre EPEC.

Market Update. Review of the European PPP Market in 2011, European PPP Expertise Centre EPEC.

Nadwyżka operacyjna w jednostkach samorzadu terytorialnego w latach 2004-2006, Ministerstwo Finansów, Warszawa 2007.

Orzeczenie z dnia 20 marca 1990 r. w sprawie C-21/88 Du Pont de Nemours Italiana SPA przeciw Unita Sanitaria lokale no 2 di Carrara.

Orzeczenie z 3 czerwca 1992 r. w sprawie C-360/89 Komisja Wspólnot Europejskich przeciw Republice Włoskiej.

Orzeczenie z dnia 22 czerwca 1993 r. w sprawie C-243/89 Komisja Wspólnot Europejskich przeciw Królestwu Danii.

Orzeczenie z 28 października 1999 r. w sprawie C-328/96 Komisja Wspólnot Europejskich przeciwko Austrii.

Orzeczenie z 18 listopada 1999 r. w sprawie C-275/98 Unitron Scadinavia przeciwko Ministeriat for Frdevaret.

Partnerstwo publiczno-prywatne jako metoda rozwoju infrastruktury w Polsce, Raport Amerykańskiej Izby Handlowej w Polsce, Warszawa 2002.

PFI: meeting the investment challenge, HM Treasry, July 2003.

Program Konwergencji. Aktualizacja 2012, Warszawa, kwiecień 2012.

Przewodnik po PPP, Europejski Bank Inwestycyjny, Europejskie Centrum Ekspertyz PPP, Luksemburg.

Public Finance Guidelines. PPP Toolkit, European Bank for Reconstruction and Development, 30 January 2004.

Public Sector Comparator. Policy. Government of Western Australia, Departament of Tresury, August 2011.

Public Sector Comparator, Supplementary Technical Note, Departament of Tresury and Finance, State Government, July 2003. 
Public Sector Comparator, Working Paper 16, European Bank for Reconstruction and Development, Ecorys, Warszawa 2003.

Ranking samorząów 2011, „Rzeczpospolita” z 19.07.2011.

Raport końcowy z badania efektywności mechanizmów konsultacji społecznych, Pracownia Badań i Innowacji Społecznych STOCZNIA, Warszawa 2011.

Sprawozdanie z realizacji uchwaty Rady Miasta Krakowa $\mathrm{nr}$ XXV/244/95 z dnia 5 lipca 1995 r. w sprawie polityki finansowej Gminy Kraków w zakresie oświetlenia ulicznego, Zarząd Infrastruktury Komunalnej i Transportowej w Krakowie.

Standard \& Poor's, A Global Survey Of PPPs: New Legislation Sets Context For Growth, London, October 2005.

Umowa na Modernizację i Eksploatację Oświetlenia Ulicznego w Krakowie zawarta w dniu 17 kwietnia 1998, Kraków 1998.

Umowa o partnerstwie publiczno-prywatnym - ramy określajace standardowa zawartość, Ministerstwo Gospodarki, Warszawa 2007.

Uzasadnienie do projektu ustawy o koncesji na roboty budowlane lub ustugi, Druk Sejmowy nr 834 z 17 lipca 2008.

Uzasadnienie do projektu ustawy o partnerstwie publiczno-prywatnym, Druk Sejmowy nr 3174.

Uzasadnienie do projektu ustawy o partnerstwie publiczno-prywatnym, Druk Sejmowy nr 1180.

Wpływ odpowiedniego przygotowania projektu PPP na możliwość jego sfinansowania, konferencja pt. „PPP szansq na sfinansowanie rozwoju regionalnego” BGK, Toruń 2011.

Wytyczne $w$ zakresie wybranych zagadnień zwiazanych z przygotowaniem projektów inwestycyjnych, w tym projektów generujących dochód, Ministerstwo Rozwoju Regionalnego, Warszawa 2009.

Wytyczne dotyczace udanego partnerstwa publiczno-prywatnego, Komisja Europejska, Bruksela 2003.

Zarzadzanie ryzykiem $w$ sektorze publicznym. Podręcznik wdrażania systemu zarzadzania ryzykiem w administracji publicznej w Polsce, Ministerstwo Finansów, Warszawa 2004.

\section{Źródla internetowe}

Bazy PPP, www.bazappp.gov.pl

Decyzja Eurostat o traktowaniu partnerstwa publiczno-prywatnego i jego wpływie na dług i deficyt publiczny, Released 11 Feb. 2004, www.epp.eurostat

Definicja partnerstwa publiczno-prywatnego podana przez Ministerstwo Finansów Wielkiej Brytanii, www.hm-treasury.gov.uk/ppp

Definicja partnerstwa publiczno-prywatnego według Banku Światowego, www.worldbank.com

Definicja partnerstwa publiczno-prywatnego według Centrum Partnerstwa Publiczno-Prywatnego, www.centrum-ppp.pl

Działalność inwestycyjna jednostek samorządu terytorialnego w latach 1999-2004, www.rio. gov.pl

Kaliskie Linie Autobusowe, www.kla.com.pl

Metodologia tworzenia analiz ryzyk $w$ projektach PPP $i$ ich podziatu pomiędzy strona publiczna i prywatna w kontekście ich wptywu na klasyfikację projektu pod katem dtugu i deficytu sektora publicznego, Platforma Partnerstwa Publiczno-Prywatnego, www.ppp.gov.pl

Molo M., Zasady oceny efektywności ekonomicznej realizowanych przedsięwzięć, www.malopolskie.pl/ pliki/2008/ekspertyza_efektywnosc_ekonomiczna.pdf

Moszoro M., Kapitat prywatny w finansowaniu inwestycji publicznych, www.mikro.uni.szczecin.pl

The National Council for Public-Private Partnerships, www.ncppp.org

Określenie partnerstwa publiczno-prywatnego w publikacjach OECD, www.oecd.org 
Określenie partnerstwa publiczno-prywatnego zamieszczone przez Instytut PPP, www.ippp.pl/ instytut

Opinia General Accounting Office [za:] M. Moszoro, Kapitał prywatny w finansowaniu inwestycji publicznych, www.mikro.uni.szczecin.pl

Penc J., Leksykon biznesu, Wydawnictwo Placet, Warszawa 1997, www.placet.pl

Podręcznik deficytu i długu sektora instytucji rządowych i samorządowych. Implementacja ESA 95, Edycja 2010, www.bazappp.gov.pl

Porozumienie w sprawie Platformy współpracy w zakresie partnerstwa publiczno-prywatnego, Ministerstwo Rozwoju Regionalnego, www.ppp.gov.pl

Poznalski R., Granice partnerstwa publiczno-prywatnego. Zmiany w obowiazujacych przepisach, www.partnerstwopublicznoprywatne.info

Przewodnik po PPP, Europejski Bank Inwestycyjny, Europejskie Centrum Ekspertyz PPP, Luksemburg, www.eib.org/epec

Public Private Partnership, Framework for Public Private Partnerships, „Working together for quality public service", November 2001, www.ppp.gov.ie.files/dokuments

Schnell Ch., Kiedy stosować ustawę o partnerstwie, a kiedy o koncesjach, „Rzeczpospolita” z 15.12.2008 r., www.new-arch.rp.pl

Standardisation of PFI Contracts, wersja 4, Ministerstwo Skarbu Wielkiej Brytanii, marzec 2007, www.hm-treasury.gov.uk

Stefanowicz J. A., Kiedy partnerstwo publiczno-prywatne, www.freepress.org.pl

Swianiewicz P., Kondycja finansowa samorządów? Nadwyżka operacyjna w 2007, www.wspólnota. org.pl

Strona Urzędu Komitetu Integracji Europejskiej, www.polskawue.gov.pl

Wawrzyniak M., Jędrzejewski A., Raport IPPP, Instytut Partnerstwa Publiczno-Prywatnego, www.ippp.pl

Wąsowski K., Rola zasad corporate governance w partnerstwie publiczno-prywatnym, „Przegląd Corporate Governance" 2009, nr 2, www.spolkigieldowe.bdo.pl

Wystąpienie Sekretarza Stanu w Ministerstwie Gospodarki Adama Szejnfelda, 27. posiedzenie Sejmu RP z dnia 28.10.2008; Sejm Rzeczypospolitej Polskiej VI Kadencji, Uzasadnienie do projektu ustawy o partnerstwie publiczno-prywatnym, Druk Sejmowy nr 1180, Warszawa 2008, www.orka,sejm.gov.pl

Zastosowanie graficznego planu produkcji Gantta, [w:] Encyklopedia Zarzadzania, www.mfiles.pl 



\section{SPIS MAP, SCHEMATÓW, TABEL I WYKRESÓW}

Mapa 1.1. Rozwój PPP na świecie w latach 1994-2011 ..................................................... 26

Mapa 5.1. Rozmieszczenie terytorialne przedsięwzięć PPP w latach 2009-2011 (liczba przedsięwzięć) ........................................................................................ 273

Mapa 5.2. Rozmieszczenie terytorialne umów PPP lub koncesji w latach 2009-2011 (liczba umów)

Mapa 5.3. Rozmieszczenie przestrzenne planowanych przedsięwzięć PPP (liczba przedsięwzięć)

Schemat 2.1. Fazy realizacji przedsięwzięcia w formule PPP ............................................... 85

Schemat 2.2. Tryb wyboru partnera prywatnego dla PPP .................................................... 97

Schemat 2.3. Uczestnicy przedsięwzięcia partnerstwa publiczno-prywatnego ....................... 115

Schemat 3.1. Cechy infrastruktury komunalnej .................................................................... 137

Schemat 3.2. Metody oceny efektywności przedsięwzięć inwestycyjnych ............................. 148

Schemat 3.3. Potencjał inwestycyjny jednostki samorządu terytorialnego ............................. 161

Schemat 3.4. Źródła finansowania inwestycji jednostek samorządu terytorialnego ................. 172

Schemat 4.1. Zakres analiz w przedsięwzięciach partnerstwa publiczno-prywatnego ............ 209

Schemat 4.2. Partnerstwo publiczno-prywatne kontraktowe ................................................ 220

Schemat 4.3. Partnerstwo publiczno-prywatne w formie spółki SPV ................................... 221

Schemat 4.4. Ryzyko w przedsięwzięciach partnerstwa publiczno-prywatnego ...................... 223

Schemat 4.5. Pętla ryzyka .................................................................................. 231

Schemat 4.6. Oszacowanie ryzyka w partnerstwie publiczno-prywatnym na podstawie

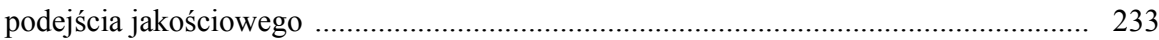

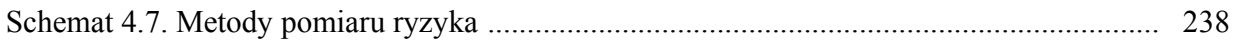

Schemat 4.8. Porównanie kosztów metody tradycyjnej i PPP ............................................ 258

Schemat 4.9. Elementy Public Sector Comparator ................................................................ 259

Schemat 4.10. Public Sector Comparator a Volue for Money w partnerstwie publiczno-

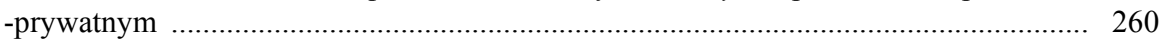

Schemat 5.1. Etapy weryfikujące cel badania ................................................................ 267

Schemat 6.1. Wzorcowy model przebiegu procesu realizacji inwestycji na podstawie formuły PPP ......................................................................................... 343

Tabela 1.1. Aspekty definicji partnerstwa publiczno-prywatnego ...................................... 40

Tabela 1.2. Wybrane akty prawne Komisji Europejskiej w sprawie partnerstwa publiczno-prywatnego

Tabela 1.3. Porównanie ustawy o PPP z 2005 r. i ustawy o PPP z 2008 r. ............................. 54

Tabela 1.4. Porównanie rozwiązań prawnych ustawy o partnerstwie publiczno-prywatnym z 2008 r. z ustawą o koncesji na roboty budowlane lub usługi z 2009 r. ....................... 59

Tabela 1.5. Liczba ogłoszeń dotycząca przedsięwzięć w formie PPP i koncesji w latach 2009-2011 w Polsce 
Tabela 1.6. Zestawienie charakterystycznych cech modeli partnerstwa publiczno-prywatnego

Tabela 1.7. Rodzaje najczęściej realizowanych koncesji

Tabela 1.8. Cechy charakterystyczne modeli/form partnerstwa publiczno-prywatnego .............

Tabela 1.9. Różnice pomiędzy partnerstwem publiczno-prywatnym a prywatyzacją .......... 79

Tabela 2.1. Przykładowy zakres usług doradców w ramach PPP ............................................ 89

Tabela 2.2. Elementy treści ogłoszenia o koncesji ................................................................ 100

Tabela 2.3. Elementy specyfikacji istotnych warunków zamówienia .................................. 107

Tabela 2.4. Ramowa struktura umowy partnerstwa publiczno-prywatnego …....................... 120

Tabela 3.1. Porównanie istoty przedsięwzięcia i projektu ...................................................... 130

Tabela 3.2. Zasady oceny efektywności przedsięwzięć inwestycyjnych ................................. 142

Tabela 3.3. Nadwyżka operacyjna w ujęciu cash flow bieżącego - metoda pierwsza ............ 162

Tabela 3.4. Nadwyżka operacyjna w ujęciu cash flow bieżącego - metoda druga .................. 163

Tabela 3.5. Potencjał inwestycyjny jednostek samorządu terytorialnego ogółem w latach 2005-2011 (w mln zf)

Tabela 3.6. Potencjał inwestycyjny poszczególnych szczebli jednostek samorządu terytorialnego ogółem w latach 2005-2011 (w mln zł)

Tabela 3.7. Wielkość wydatków ogółem i wydatków inwestycyjnych oraz udział wydatków inwestycyjnych poszczególnych szczebli jednostek samorządu terytorialnego w latach 2005-2011

Tabela 3.8. Dynamika wydatków ogółem, wydatków inwestycyjnych i potencjału inwestycyjnego JST w latach 2005-2011

Tabela 4.1. Poziom zadłużenia JST w latach 2005-2011 oraz relacja zadłużenia do poziomu zrealizowanych dochodów budżetowych

Tabela 4.2. Wskaźnik pokrycia wydatków inwestycyjnych długiem i przyrostem długu w JST w latach 2005-2011

Tabela 4.3. Zobowiązania jednostek samorządu terytorialnego w latach 2005-2011 według tytułów dłużnych

Tabela 4.4. Akty prawne regulujące kwestię długu i deficytu publicznego w przedsięwzięciach PPP

Tabela 4.5. Rodzaje ryzyk w partnerstwie publiczno-prywatnym według Komisji Europejskiej

Tabela 4.6. Alokacja podstawowych rodzajów ryzyk w przedsięwzięciach PPP .................... 242

Tabela 4.7. Przykładowe ubezpieczenia zawierane w ramach formuły PPP ........................... 248

Tabela 4.8. Rodzaje gwarancji kontraktowych ............................................................ 250

Tabela 4.9. Szacunkowy czas trwania oceny przedsięwzięcia dla poszczególnych komparatorów

Tabela 5.1. Struktura respondentów biorących udział w badaniu ankietowym ....................... 266

Tabela 5.2. Formuły prawno-finansowe przedsięwzięć ogłoszonych dla przedsięwzięć PPP w latach 2009-2011

Tabela 5.3. Liczba ogłoszeń według podmiotów ogłaszających postępowanie realizacji PPP w latach 2009-2011

Tabela 5.4. Umowy o PPP zawarte przez poszczególne typy jednostek samorządu terytorialnego w latach 2009-2011

Tabela 5.5. Struktura przedmiotowa oraz zamknięcia finansowego zawartych umów o PPP w latach 2009-2011 w Polsce

Tabela 5.6. Podział zadań i ryzyk w umowach o partnerstwie publiczno-prywatnym w latach 2009-2011 
Tabela 5.7. Umiejscowienie formuły PPP $\mathrm{w}$ dokumentach strategicznych ankietowanych jednostek samorządu terytorialnego ...................................................................... 296

Tabela 5.8. Zakres działania na płaszczyźnie instytucjonalnego przygotowania PPP w JST... 298

Tabela 5.9. Samoocena poziomu wiedzy urzędników obsługujących planowane lub realizowane przedsięwzięcia PPP

Tabela 5.10. Ocena wsparcia JST w zakresie PPP przez administrację rządową .................... 301

Tabela 5.11. Zestawienie wadliwych zapisów Ustawy o partnerstwie publiczno-prywatnym i Ustawy o koncesji na roboty budowlane lub ustugi ................................................... 307

Tabela 5.12. Oczekiwania samorządowców wobec partnerstwa publiczno-prywatnego ........ 309

Tabela 5.13. Zakres zgłaszanej pomocy merytorycznej przez ankietowane jednostki samorzadu terytorialnego ....................................................................................... 313

Tabela 5.14. Kryteria wyboru doradcy dla przedsięwzięć PPP ............................................ 314

Tabela 5.15. Optymalny sposób wynagradzania doradcy ds. PPP ....................................... 314

Tabela 5.16. Liczba i wartość planowanych przedsięwzięć PPP ............................................. 315

Tabela 5.17. Poziom potencjału inwestycyjnego dla poszczególnych prób badawczych w latach 2009-2011 (w tys. zł) ................................................................................ 325

Tabela 5.18. Potencjał inwestycyjny dla próby I i III w poszczególnych przedziałach w latach $2009-2011$.................................................................................... 325

Tabela 5.19. Relacja potencjału inwestycyjnego do dochodów ogółem w latach 2009-2011 w poszczególnych próbach badawczych ………...................................................... 329

Tabela 5.20. Relacja potencjału inwestycyjnego do dochodów ogółem w latach 2009-2011 w jednostkach samorządu terytorialnego, które zawarły umowę o PPP ....................... 330

Tabela 5.21. Przeciętny wskaźnik obsługi zadłużenia dla próby I i III w latach 2009-2011 ... 333

Tabela 5.22. Przeciętny wskaźnik ogólnego zadłużenia i przeciętny wskaźnik obsługi zadłużenia jednostek samorządu terytorialnego, które zawarły umowę o PPP w latach 2009-2011

Tabela 6.1. Proponowana skala wartości dla części składowych filarów Teoretycznego

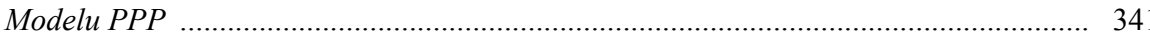

Tabela 6.2. Przyjęte stopnie skłonności do PPP w zależności od poziomu wartości ................ 342

Tabela 6.3. Wartości weryfikujące Teoretyczny Model PPP dla jednostek samorządu terytorialnego

Wykres 1.1. Struktura rozmieszczenia terytorialnego przedsięwzięć PPP na świecie w latach 1994-2011

Wykres 1.2. Wzajemne powiązania w formule partnerstwa publiczno-prywatnego ............... 41

Wykres 1.3. Hierarchia reżimów prawnych w prawodawstwie regulującym przedsięwzięcia

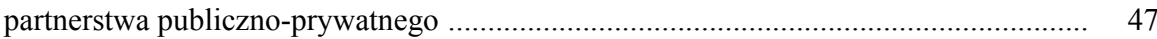

Wykres 3.1. Kryteria klasyfikacji inwestycji .................................................................... 128

Wykres 5.1. Łączna liczba opublikowanych ogłoszeń o wybór partnera lub koncesjonariusza

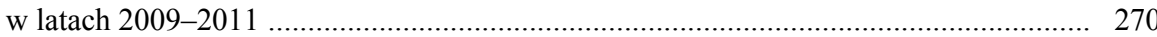

Wykres 5.2. Struktura podmiotów publikujących ogłoszenie o wybór partnera prywatnego dla PPP w latach 2009-2011

Wykres 5.3. Liczba zawartych umów przez poszczególne typy jednostek samorządu terytorialnego w Polsce w latach 2009-2011

Wykres 5.4. Podział ogłoszeń o wybór partnera prywatnego w poszczególnych sektorach gospodarki w latach 2009-2011

Wykres 5.5. Struktura przedmiotowa zawartych umów o partnerstwie publiczno-prywatnym w Polsce w latach 2009-2011 
Wykres 5.6. Liczba zawartych umów według wartości przedsięwzięcia w latach 2009-2011 281

Wykres 5.7. Liczba zawartych umów według modelu współpracy w latach 2009-2011 ........ 284

Wykres 5.8. Udział poszczególnych modeli realizacji przedsięwzięć na rynku umów o PPP w Polsce w latach 2009-2011 ...................................................................... 284

Wykres 5.9. Liczba przedsięwzięć ze względu na czas trwania umowy w latach 2009-2011 . 285

Wykres 5.10. Liczba umów ze względu na czas trwania i model współpracy w latach 20092011

Wykres 5.11. Formy wynagrodzenia partnera prywatnego wynikające z umów o PPP w latach 2009-2011 …..................................................................................... 295

Wykres 5.12. Źródło wiedzy o partnerstwie publiczno-prywatnym w opinii ankietowanych.. 300

Wykres 5.13. PPP w relacji do środków Unii Europejskiej ................................................ 302

Wykres 5.14. Ocena Ustawy o partnerstwie publiczno-prywatnym przez samorzady, które opublikowały ogłoszenie o wyborze partnera prywatnego dla PPP ............................. 303

Wykres 5.15. Ocena Ustawy o partnerstwie publiczno-prywatnym przez samorzady będace siedziba organów stanowiących/zarządów województwa .......................................... 303

Wykres 5.16. Ocena Ustawy o partnerstwie publiczno-prywatnym przez gminy miejskie województwa łódzkiego ....................................................................................... 304

Wykres 5.17. Ocena Ustawy o koncesji na roboty budowlane lub ustugi przez samorzady, które opublikowaty ogloszenie o wyborze partnera prywatnego dla PPP .................... 305

Wykres 5.18. Ocena Ustawy o koncesji na roboty budowlane lub ustugi przez samorzady będace siedziba organów stanowiacych/zarządów województwa ............................... 305

Wykres 5.19. Ocena Ustawy o koncesji na roboty budowlane lub ustugi przez gminy miejskie województwa łódzkiego .................................................................... 306

Wykres 5.20. Stopień gotowości JST do korzystania z usług profesjonalnych doradców ...... 310

Wykres 5.21. Stopień gotowości wykorzystania poszczególnych kategorii doradztwa PPP.... 311

Wykres 5.22. Sektorowe ujęcie planowanych przedsięwzięć partnerstwa publiczno-prywatnego

Wykres 5.23. Formuła współpracy dla planowanych przedsięwzięć partnerstwa publiczno-

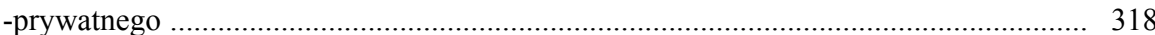

Wykres 5.24. Potencjał inwestycyjny dla próby I i III w latach 2009-2011/w tys. zł) ........... 326

Wykres 5.25. Potencjał inwestycyjny dla próby II w ujęciu wojewódzkim w latach 20092011 (w tys. zł)

Wykres 5.26. Przeciętny poziom wskaźnika ogólnego zadłużenia dla próby I w latach 2009$2011(\mathrm{w} \%)$

Wykres 5.27. Przeciętny poziom wskaźnika ogólnego zadłużenia dla próby II w latach 2009-2011 (w \%)

Wykres 5.28. Przeciętny poziom wskaźnika ogólnego zadłużenia dla próby III w latach 2009-2011 (w \%)

Wykres 5.29. Przeciętny wskaźnik obsługi zadłużenia dla próby II w latach 2009-2011 ....... 334 


\section{ANKIETA \\ UWARUNKOWANIA ROZWOJU PARTNERSTWA PUBLICZNO-PRYWATNEGO (PPP) W PERSPEKTYWIE REALIZACJI ZADAŃ PUBLICZNYCH PRZEZ JEDNOSTKI SAMORZĄDU TERYTORIALNEGO}

\begin{tabular}{|l|l|}
\hline $\begin{array}{l}\text { Nazwa jednostki samorządu terytorialnego } \\
\text { (województwo, gmina miejska, miejsko-wiejska, wiejska) }\end{array}$ & \\
\hline Adres strony WWW & \\
\hline Kontakt & \\
\hline Osoba wypełniająca ankietę (tel., e-mail) & \\
\hline
\end{tabular}

\section{Spis treści:}

Część I Wstępna. Dane makroekonomiczne dotyczące finansów JST

Część II Uwarunkowania organizacyjne i prawne realizacji przedsięwzięć w formule PPP

Część III Dane dotyczące realizowanych i planowanych do realizacji przedsięwzięć w formule PPP (koncesji) w latach 2009-2011 i dalszych

Załącznik 1 do części III ankiety

\section{CZEŚĆ I WSTĘPNA \\ DANE MAKROEKONOMICZNE DOTYCZĄCE FINANSÓW JST}

Proszę o zestawienie danych ujętych w poniższych kategoriach za okres 2009-2012. Dane dotyczące okresów przyszłych (2013-2016) proszę podać na podstawie istniejących analiz, planów (np. WPF, prognoz budżetowych, strategii zarządzania długiem, polityki długu)

\begin{tabular}{|c|l|l|l|l|c|c|c|c|}
\hline & \multicolumn{7}{|c|}{ Rok } \\
\hline Kategorie & 2009 & 2010 & 2011 & 2012 & $\begin{array}{c}2013 \\
\text { (prognoza) }\end{array}$ & $\begin{array}{c}2014 \\
\text { (prognoza) }\end{array}$ & $\begin{array}{c}2015 \\
\text { (prognoza) }\end{array}$ & $\begin{array}{c}2016 \\
\text { (prognoza) }\end{array}$ \\
\hline $\begin{array}{c}\text { Wydatki zrealizowa- } \\
\text { ne ogółem } \\
\text { (w tys. zł) }\end{array}$ & & & & & & & & \\
\hline $\begin{array}{c}\text { Wydatki bieżące } \\
\text { (w tys. zł) }\end{array}$ & & & & & & & & \\
\hline
\end{tabular}




\begin{tabular}{|c|l|l|l|l|l|l|l|l|}
\hline $\begin{array}{c}\text { Dochody zrealizowa- } \\
\text { ne ogółem } \\
\text { (w tys. zł) }\end{array}$ & & & & & & & & \\
\hline $\begin{array}{c}\text { Deficyt/nadwyżka } \\
\text { (w tys. zł) }\end{array}$ & & & & & & & & \\
\hline $\begin{array}{c}\text { Całkowita wysokość } \\
\text { obsługi zadłużenia } \\
\text { w ciągu roku } \\
\text { (w tys. zł) }\end{array}$ & & & & & & & & \\
\hline $\begin{array}{c}\text { Przychody ogółem, w } \\
\text { tym zaciągnięty } \\
\text { dług (w tys. zł) }\end{array}$ & & & & & & & & \\
\hline $\begin{array}{c}\text { Obsługa zadłużenia } \\
\text { do dochodów (\%) }\end{array}$ & & & & & & & & \\
\hline $\begin{array}{c}\text { Kwota zadłużenia } \\
\text { JST (w tys. zł) }\end{array}$ & & & & & & & & \\
\hline $\begin{array}{c}\text { Dług do dochodów } \\
\text { (w \%) }\end{array}$ & & & & & & & & \\
\hline $\begin{array}{c}\text { Wydatki inwestycyj- } \\
\text { ne (w tys. zł) }\end{array}$ & & & & & & & & \\
\hline $\begin{array}{c}\text { Wielkośc nadwyżki } \\
\text { z lat poprzednich } \\
\text { (w tys. zł) }\end{array}$ & & & & & & & & \\
\hline $\begin{array}{c}\text { Wielkość wpływów } \\
\text { z prywatyzacji } \\
\text { (w tys. zł) }\end{array}$ & & & & & & & & \\
\hline $\begin{array}{c}\text { Środki na inwestycje } \\
\text { z funduszy } \\
\text { UE (w tys. zł) }\end{array}$ & & & & & & & & \\
\hline
\end{tabular}

\section{CZĘŚĆ II. UWARUNKOWANIA ORGANIZACYJNE I PRAWNE REALIZACJI PRZEDSIĘWZIĘĆ W FORMULE PPP*}

*przez pojęcie „PPP” w rozumieniu niniejszej ankiety rozumieć należy zarówno przedsięwzięcia realizowane według Ustawy $z$ dnia 19 grudnia $2008 \mathrm{r}$. o partnerstwie publiczno-prywatnym, jak również koncesje w rozumieniu Ustawy z dnia 9 stycznia 2009 r. o koncesji na roboty budowlane lub ustugi.

** Wybrane odpowiedzi proszę zakreślić.

A) Stopień przygotowania JST do realizacji zadań publicznych $\mathbf{w}$ formule PPP (można zaznaczyć więcej niż jedna odpowiedź):

1. Jak oceniacie Państwo swoje przygotowanie do posługiwania się PPP na płaszczyźnie kreowania polityki?

a) umieściliśmy PPP $\mathrm{w}$ naszych dokumentach strategicznych;

b) nigdy nie rozważaliśmy umieszczenia PPP w naszych planach; 
c) rozważamy wprowadzenie PPP do naszych planów;

d) inne (jakie?).

2. Jakie działania w zakresie nawiązywania PPP podjęła JST na płaszczyźnie przygotowania instytucjonalnego?

a) powołano odrębne stanowisko do spraw PPP;

b) obowiązki te wykonuje już funkcjonujący wydział/pracownik;

c) sprawami współpracy z sektorem prywatnym zajmują się osoby obsługujące inwestorów;

d) sprawami współpracy z sektorem prywatnym zajmują się specjaliści od gospodarki nieruchomościami;

e) sprawy z zakresu PPP zastrzeżone są do wyłącznej kompetencji kierownictwa jednostki;

f) powołano właściwe ciało kolegialne;

g) wybrano profesjonalnego doradcę;

h) inne (jakie?)....

3. Jaki jest, w Państwa ocenie, stan wiedzy urzędników obsługujących planowanie i realizację zadań publicznych pracujących w Państwa Jednostce, na temat możliwości, jakie niesie, w zakresie realizacji zadań publicznych, koncepcja PPP?
a) bardzo dobry;
b) dobry;
c) przeciętny;
d) słaby.

Ewentualny komentarz.

4. Jakie jest główne źródło wiedzy na temat możliwości realizacji zadań publicznych we współpracy z sektorem prywatnym:
a) konferencje;
b) szkolenia wewnętrzne;
c) kursy podyplomowe/zawodowe;
d) literatura. (jaka?);
e) prasa (jaka?);
f) Internet (jakie strony?);
g) inne.

5. Jak oceniacie Państwo możliwość otrzymania wsparcia w zakresie realizacji przedsięwzięć PPP ze strony administracji centralnej? Jaki w Państwa ocenie jest poziom pomocy w tym zakresie?
a) bardzo dobry;
b) dobry;
c) przeciętny;
d) słaby.

Ewentualny komentarz

6. Jakie jest zaangażowanie zewnętrznych doradców w obsługę przedsięwzięć typu PPP?
a) doradztwo prawne;
b) doradztwo ekonomiczno-finansowe;
c) doradztwo projektowe (techniczne);
d) inne (jakie?) 
B) Oczekiwania i potrzeby JST wobec wspólpracy opartej na PPP w zakresie zadań służących rozwojowi lokalnemu (proszę o odpowiedź na poniższe pytania).

1. Oczekiwania, co do realizacji konkretnych przedsięwzięć w modelu PPP?

a) dodatkowe źródło kapitału;

b) przekazanie części obowiązków na zewnątrz;

c) polepszenie jakości infrastruktury;

d) inne (jakie?)

2. Jakie są Państwa zdaniem najważniejsze:

Zalety PPP

1. Możliwość pozyskania kapitału

2. Możliwość polepszenia jakości usług

3. Szybsza realizacja inwestycji

4. Możliwość sfinansowania inwestycji bez obciążania limitów zobowiązań

5. Lepsza jakość administracji

6.

\section{Prosimy dodać komentarz.}

\section{Wady PPP}

dodatkowego 1. Niebezpieczeństwo utraty kontroli nad majątkiem zaangażowanym w PPP

2. Obniżenie się jakości usług

3. Ryzyko sporów politycznych

4. Skomplikowana procedura wyboru partnera prywatnego

5. Niebezpieczeństwo wzmożonych kontroli

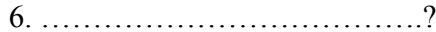

3. Jakie Państwa zdaniem są relacje PPP do procesu pozyskiwania środków UE:

a) współpraca $z$ partnerem prywatnym ma wspomagać finansowo i organizacyjnie proces pozyskiwania środków UE;

b) współpraca z partnerem prywatnym ma tylko uzupełniać proces inwestycyjny tam gdzie nie udało się pozyskać środków UE;

c) PPP i środki UE nie mają ze sobą nic wspólnego i powinny być stosowane niezależnie;

d) PPP powinno być zasadniczym sposobem realizacji zadań inwestycyjnych i wykonywania zadań publicznych.

Ewentualny komentarz.

4. Jakie są zdaniem Państwa główne bariery utrudniające realizowanie przedsięwzięć PPP:

a) brak wiedzy o funkcjonowaniu modelu PPP;

b) brak optymalnych rozwiązań prawnych;

c) brak standardów współpracy (np. wzorów umów, kluczowych dokumentów);

d) brak wsparcia ze strony administracji rządowej;

e) niejasne uregulowanie relacji PPP do funduszy strukturalnych UE i Funduszu Spójności;

f) brak kontaktów samorządów z doświadczonymi doradcami;

g) brak wiarygodności partnerów prywatnych;

h) obawy przed oskarżeniami o niejasne, korupcyjne postępowanie;

i) brak politycznej akceptacji dla PPP;

j) inne

Ewentualny komentarz. 
5. Ustawa z dnia 19 grudnia 2008 r. o PPP:

a) ułatwia realizację przedsięwzięć PPP;

b) jest obojętna dla przedsięwzięć PPP;

c) utrudnia realizację przedsięwzięć PPP.

(dlaczego?)

6. Ustawa z dnia 9 stycznia 2009 r. o koncesji na roboty budowlane lub ustugi:

a) ułatwia realizację przedsięwzięć PPP;

b) jest obojętna dla przedsięwzięć PPP;

c) utrudnia realizację przedsięwzięć PPP.

(dlaczego?)

7. Główne wady ustaw dotyczących PPP, to:

Ustawy o PPP:

a) zbyt liberalne, nieprecyzyjne zapisy;

b) niejasne zasady odesłania do prawa zamówień publicznych w zakresie procedury wyboru partnera, w przypadku pełnej zapłaty od podmiotu publicznego;

c) niejasne relacje obu ustaw w zakresie odesłania do „ustawy koncesyjnej” odnośnie do trybu wyboru partnera;

d) wymóg ogłaszania o planowanym partnerstwie w „Biuletynie Informacji Publicznej”; e) brak należytych zachęt podatkowych dla podmiotów prywatnych;

f) niejasne zasady rozliczania podatku VAT;

g) brak wskazań, co do zasad podziału ryzyk;

h) inne $\ldots ?$
Ustawy o koncesjach:

a) niejasne relacje między zakresem dopuszczalnej płatności ze strony koncesjodawcy a zakresem ryzyka ekonomicznego koncesjonariusza;

b) zagrożenia związane ze stosowaniem art. 8;

c) wątpliwości, co do zgodności z prawem UE braku wymogu ogłaszania o koncesji na usługi w DzUrz. UE w przypadku „dużych” koncesji;

d) zbyt liberalne zasady ustalania kryteriów oceny ofert;

e) brak wymogu składania przez oferentów dokumentów potwierdzających spełnienie warunków udziału w postępowaniu;

f) zbyt liberalne ujęcie zakresu wymaganych dokumentów (art. 18 ust. 2);

g) zbyt słaba ochrona prawna interesu podmiotów uczestniczących w postępowaniu; h) prawdopodobne problemy orzecznicze związane z przekazaniem jurysdykcji sądownictwu administracyjnemu;

i) inne ?

8. Jakie inne problemy prawne, utrudniające zawieranie umów i realizację przedsięwzięć PPP Państwo dostrzegacie? (proszę wskazać) 
9. Czy planowane jest powołanie komórki organizacyjnej zajmującej się PPP?
a) TAK;
b) NIE.

10. Czy chcieliby Państwo otrzymywać informacje o rozwoju rynku PPP?
a) TAK;
b) NIE.

Jeśli tak, to w jakiej formie:
a) konferencje (ile?);
b) szkolenia wewnętrzne (ile?);
c) warsztaty (ile?);
d) kursy podyplomowe/zawodowe;
e) literatura
f) prasa.
g) Internet..................... (jakie portale?)
h) inne........................(proszę wymienić w jakiej formie)?
i)

11. Czy zamierzają Państwo korzystać z pomocy zewnętrznych doradców do obsługi przedsięwzięć typu PPP?
a) TAK;
b) NIE.

12. W jakim zakresie pomocy merytorycznej oczekują Państwo od firm doradczych odnośnie przedsięwzięć PPP:
a) doradztwo w zakresie identyfikacji i przygotowania koncepcyjnego przedsięwzięcia;
b) doradztwo w zakresie wykonania niezbędnych analiz przedrealizacyjncych;
c) doradztwo finansowanie, w tym analiza ryzyk;
d) przygotowanie studium wykonalności;
e) doradztwo w zakresie wyboru modelu PPP;
f) przygotowanie specyfikacji istotnych warunków zamówienia i wzoru umowy;
g) doradztwo w zakresie przeprowadzenia postępowania wyłaniającego partnera prywatnego;
h) doradztwo w zakresie przygotowania i zawarcia umowy;
i) konsultacje i doradztwo w zakresie nadzoru nad przedsięwzięciem;
j) doradztwo na pozostałych etapach cyklu życia przedsięwzięcia;
k) inne (jakie?)

13. Jak Państwo postrzegają optymalny sposób wynagradzania doradcy?
a) ryczałt;
b) procent od wartości inwestycji;
c) premia za osiągnięcie celu doradztwa (success fee);
d) inne (jakie?).

14. Jakie kryterium, zdaniem Państwa, ma główne znaczenie przy wyborze doradcy?
a) cena;
b) doświadczenie;
c) zdolność merytoryczna i organizacyjna realizacji doradztwa;
d) inne (jakie?) 


\section{CZEŚŚĆ III. DANE DOTYCZAC̨E REALIZOWANYCH I PLANOWANYCH DO REALI- ZACJI PRZEDSIĘWZIĘĆ W FORMULE PPP (KOCESJI) w latach 2009-2011 i dalszych}

Ważne!!! Prosimy o dodatkowe wypetnienie załącznika nr 1 do niniejszej części ankiety (dla poszczególnych przedsięwzięć).

A) Zestawienie przedsięwzięć realizowanych (w szeroko rozumianej formule PPP, takich jak PPP, koncesje, itp.) i przygotowywanych do realizacji,

*dotyczy przedsięwzięć realizowanych (już zawarta umowa PPP lub koncesji) i przygotowywanych (tj. ogłoszonych lub przygotowywanych do ogłoszenia na wybór partne$\mathrm{ra} /$ koncesjonariusza) do realizacji.

**1) bardzo satysfakcjonujące

2) satysfakcjonujące

3) średnio satysfakcjonujące

4) słabo satysfakcjonujące

5) niesatysfakcjonujące - wproszę wpisać odpowiednią cyfrę.

\begin{tabular}{|c|c|c|c|c|c|c|c|c|c|}
\hline Lp. & $\begin{array}{l}\text { Nazwa } \\
\text { przedsię- } \\
\text { wzięcia* }\end{array}$ & $\begin{array}{c}\text { Wartość } \\
\text { przedsię- } \\
\text { wzięcia } \\
\text { (w mln } \\
\text { zł) }\end{array}$ & \begin{tabular}{|c|} 
Okres \\
trwania \\
umowy
\end{tabular} & $\begin{array}{l}\text { Sektor } \\
\text { usług } \\
\text { komu- } \\
\text { nalnych }\end{array}$ & $\begin{array}{c}\text { Etap } \\
\text { realizacji } \\
\text { przedsię- } \\
\text { wzięcia } \\
\\
\text { (koncepcja, } \\
\text { ogłoszenie, } \\
\text { negocjacje, } \\
\text { zawarta } \\
\text { umowa, } \\
\text { realizacja) }\end{array}$ & $\begin{array}{c}\text { Model } \\
\text { współpracy } \\
\text { (PPP, spółka } \\
\text { komunalna, } \\
\text { koncesja, } \\
\text { leasing, } \\
\text { dzierżawa, } \\
\text { umowa o } \\
\text { zarządzanie, } \\
\text { inne) }\end{array}$ & $\begin{array}{c}\text { Udział } \\
\text { podmiotu } \\
\text { publicznego } \\
\text { (wniesiony } \\
\text { wkład, udział } \\
\text { kapitałowy, } \\
\text { płatności na } \\
\text { rzecz partnera } \\
\text { prywatnego, } \\
\text { przejęte } \\
\text { ryzyka, udział } \\
\text { w zyskach, } \\
\text { itp.) }\end{array}$ & $\begin{array}{c}\text { Udział } \\
\text { partnera } \\
\text { prywatnego } \\
\text { (zakres } \\
\text { zaangażo- } \\
\text { wania, } \\
\text { wniesiony } \\
\text { wkład, udział } \\
\text { w kosztach, } \\
\text { przejęte ryzy- } \\
\text { ka, forma } \\
\text { wyna- } \\
\text { grodzenia, } \\
\text { itp.) }\end{array}$ & $\begin{array}{c}\text { Ocena } \\
\text { efektów } \\
\text { współpracy** }\end{array}$ \\
\hline & & & & & & & & & \\
\hline
\end{tabular}

B) Kryteria stosowane przy ocenie ofert (prosimy podać jakie zostaty zastosowane $w$ specyfikacji)

C) Kto był doradcą i w jakim zakresie? (proszę podać nazwę firmy doradczej)

D) Czy JST podejmowała dotychczas konsultacje z potencjalnymi partnerami prywatnymi, konsumentami usług przewidzianych do powierzenia sektorowi prywatnemu/obywatelami i ich przedstawicielami oraz lokalnymi masmediami w zakresie PPP (odrębnie dla każdego przedsięwzięcia)? Prosimy opisać te doświadczenia.

E) Czy umowa może być realnie sfinansowana przez instytucje finansujące? Jakie są jego warunki/przeszkody w pozyskaniu? 
F) Z jakich powodów odstąpiono od realizacji p przedsięwzięcia /zawarcia umowy (dotyczy tych przedsięwzięć, których ostatecznie nie zrealizowano)?

G) Ile razy zamieszczano ogłoszenie w BZP i „Dzienniku Urzędowym UE”?

H) Czy w związku z przedsięwzięciem (przedsięwzięciami) korzystano z pomocy lub wsparcia finansowego banków? Czy taka pomoc lub wsparcie było oferowane?

\section{ZALĄCZNIK 1 DO CZĘŚCI III ANKIETY}

1. JST (dane teleadresowe)

2. Nazwa przedsięwzięcia

3. Miejsce realizacji przedsięwzięcia

4. Opis przedsięwzięcia

5. Cel i uzasadnienie przedsięwzięcia

6. Potrzeby, jakie zaspokaja przedsięwzięcie

7. Związek przedsięwzięcia ze strategią rozwoju gminy, polityką władz i/lub innymi dokumentami (prosze podać w jakich dokumentach ujęto wykorzystanie PPP)

8. Inne, oprócz gminy, podmioty zaangażowane w realizację przedsięwzięcia i ich rodzaj zaangażowania (podać przyktady)

9. Koszt realizacji przedsięwzięcia (opisać przedsięwzięcie z rozpisaniem na etapy realizacji)

10. Planowany zysk, generowany przez przedsięwzięcia

11. Źródła finansowania przedsięwzięcia i ich wysokość

12. Forma promocji przedsięwzięcia PPP

13. Czy przedsięwzięcie może Państwa zdaniem ubiegać się o dofinansowanie z funduszu Unii Europejskiej (w jakim zakresie?) 
14. Czy Gmina posiada uzbrojone tereny pod inwestycję (w jakim zakresie?)

15. W jakiej fazie planowania jest pomysł na inwestycję (zaznaczyć właściwa odpowiedź?)

a) pomysł, który powstał ze względu na potrzeby ankiety;

b) pomysł, który powstał w związku z poznaniem metody, jaką jest PPP;

c) pomysł, który został przedyskutowany z organem stanowiącym, mieszkańcami, itp.;

d) pomysł, do którego przygotowano wstępną dokumentację;

e) pomysł, który jest już w postaci gotowego projektu inwestycyjnego (jest przygotowane studium wykonalności, ubiega się o finansowanie, itp.);

16. Jakie widzą Państwo największe przeszkody w realizacji przedsięwzięcia (wymienić i podać powód)?

17. Jaki jest poziom akceptacji dla przedsięwzięcia wśród radnych?

18. Jaki jest poziom akceptacji dla przedsięwzięcia wśród mieszkańców?

19. Czy były prowadzone konsultacje społeczne?

20. Czy gmina dysponuje informacjami na temat ewentualnych partnerów prywatnych?

21. Czy gmina planuje inne przedsięwzięcia PPP (jakie?). 



\section{OD REDAKCJI}

Dagmara Maria Hajdys ukończyła kierunek Finanse i Bankowość na Wydziale Ekonomiczno-Socjologicznym Uniwersytety Łódzkiego w 1994 r.

W latach 1994-1996 była studentką studiów doktoranckich. W roku 1996 została zatrudniona na stanowisku asystenta $\mathrm{w}$ Uniwersytecie Łódzkim na Wydziale Ekonomiczno-Socjologicznym w Katedrze Finansów Publicznych. Obecnie jest pracownikiem Instytutu Finansów w Katedrze Finansów Publicznych. Rozprawę doktorską pt. Rozwój rynku obligacji komunalnych w Polsce w okresie od 1996 do 2000 roku napisaną pod kierunkiem naukowym prof. zw. dr hab. Krystyny Piotrowskiej-Marczak, obroniła w 2002 r.

Zainteresowania naukowe dr Dagmary Marii Hajdys koncentrują się wokół problemów finansów jednostek samorządu terytorialnego. Szczególna jej uwaga skupiona jest wokół alternatywnych form finansowania zadań jednostek samorządu terytorialnego, w tym dłużnych papierów wartościowych i partnerstwa publiczno-prywatnego. Jest autorką dwóch książek i 69 publikacji poświęconych problematyce zarządzania źródłami finansowania samorządu terytorialnego. Od roku 2009 jest opiekunem I roku kierunku Finanse i Rachunkowość oraz specjalności Strategie podatkowe.

Autorka jest doświadczonym wykładowcą z zakresu finansów publicznych i samorządowych, promotorem licznych prac licencjackich i magisterskich. 